\title{
Beginselen van de inkomstenbelasting en de praktijk van de wetgeving
}

Citation for published version (APA):

Weerepas, M. J. G. A. M. (1995). Beginselen van de inkomstenbelasting en de praktijk van de wetgeving. [Doctoral Thesis, Maastricht University]. Gouda Quint. https://doi.org/10.26481/dis.19950623mw

Document status and date:

Published: 01/01/1995

DOI:

10.26481/dis.19950623mw

Document Version:

Publisher's PDF, also known as Version of record

\section{Please check the document version of this publication:}

- A submitted manuscript is the version of the article upon submission and before peer-review. There can be important differences between the submitted version and the official published version of record.

People interested in the research are advised to contact the author for the final version of the publication, or visit the DOI to the publisher's website.

- The final author version and the galley proof are versions of the publication after peer review.

- The final published version features the final layout of the paper including the volume, issue and page numbers.

Link to publication

\footnotetext{
General rights rights.

- You may freely distribute the URL identifying the publication in the public portal. please follow below link for the End User Agreement:

www.umlib.nl/taverne-license

Take down policy

If you believe that this document breaches copyright please contact us at:

repository@maastrichtuniversity.nl

providing details and we will investigate your claim.
}

Copyright and moral rights for the publications made accessible in the public portal are retained by the authors and/or other copyright owners and it is a condition of accessing publications that users recognise and abide by the legal requirements associated with these

- Users may download and print one copy of any publication from the public portal for the purpose of private study or research.

- You may not further distribute the material or use it for any profit-making activity or commercial gain

If the publication is distributed under the terms of Article $25 \mathrm{fa}$ of the Dutch Copyright Act, indicated by the "Taverne" license above, 
Beginselen van de inkomstenbelasting en de praktijk van de wetgeving 


\section{Beginselen van de inkomstenbelasting en de praktijk van de wetgeving}

\section{PROEFSCHRIFT}

ter verkrijging van de graad van doctor aan de Rijksuniversiteit Limburg te

Maastricht, op gezag van de Rector Magnificus, Prof. mr M.J. Cohen, volgens het besluit van het College van Dekanen, in het openbaar te verdedigen op vrijdag 23 juni 1995 om 16.00 uur

door

Maria Johanna Gerarda Antoinette Marjon Weerepas

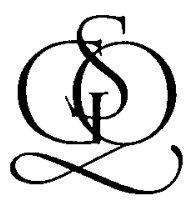

Gouda Quint bv

(S. Gouda Quint - D. Brouwer en Zoon)

Arnhem

1995 
Promotor: Prof. dr R.E.C.M. Niessen

Co-promotor: Dr F. van Dun

Beoordelingscommissie: Prof. mr J.F.M. Giele (voorzitter)

Prof. mr drs H.P.A.M. van Arendonk (Erasmus Universiteit Rotterdam)

DrW.A. Vermeend 


\section{Voorwoord}

Het schrijven van een proefschrift wordt over het algemeen niet als licht ervaren. Toch beginnen mensen om uiteenlopende redenen te schrijven. Deze redenen waren voor ondergetekende naarmate het onderzoek vorderde niet meer zo belangrijk, als wel het feit dat het onderzoek afgerond moest worden. En ik moet zeggen, als uiteindelijk het moment daar is, ervaar ik het als een leuke 'bevrijding' en dan worden de redenen waarom een proefschrift wordt geschreven ook weer duidelijk.

Deze 'bevrijding' kan niet tot stand komen zonder anderen. Daarom wil ik in het bijzonder prof. dr R.E.C.M. Niessen en dr F. van Dun bedanken voor het leveren van commentaar en het begeleiden van het onderzoek. Daarnaast wil ik mw. A. Lankkamp bedanken voor het cameraready maken van het manuscript.

Verder wil ik een ieder bedanken die een positieve bijdrage heeft geleverd aan het totstandkomen van dit proefschrift.

Het onderzoek is eind augustus 1994 afgesloten; daarna zijn slechts marginaal wijzigingen aangebracht.

Marjon Weerepas 


\section{Inhoudsopgave}

Lijst van gebruikte afkortingen

blz.

xi

\section{INLEIDING}

1. Inleiding 3

1.1. Inleiding 3

1.2. Voorlopige omschrijving van het onderzoeksterrein 6

1.3. Theorieën en beginselen van belastingheffing 11

$\begin{array}{lll}\text { 1.4. De Wet op de inkomstenbelasting } 1964 & 17\end{array}$

1.4.1. De totstandkoming van de Wet IB 1964 in vogelvlucht 17

1.4.2. De beginselen genoemd in de parlementaire geschiedenis van de Wet IB 1964

1.5. Probleemstelling 30

1.6. Plan van behandeling 32

DEEL I: PRAKTIJK INZAKE DE INKOMSTENBELASTING

2. De ontwikkeling van de fiscale positie van de gehuwde vrouw 35

2.1. Inleiding 35

2.2. De ontwikkeling van de fiscale positie van de gehuwde vrouw 36

2.2.1. Samenvoegingsstelsel of individueel stelsel 37

2.2.2. Periode vóór $1962 \quad 41$

2.2.3. Periode van 1962 tot 1973

2.2.4. Periode van 1973 tot $1980 \quad 48$

2.2.5. Periode van 1980 tot $1990 \quad 51$

2.3. Samenvatting en conclusies 55

3. De Tweeverdienerswetgeving 57

3.1. Inleiding 57

3.2. Tweeverdienerswetgeving-I 63

3.2.1. Algemene opmerkingen 63 
3.2.2. Het draagkrachtbeginsel

3.2.3. Het gelijkheidsbeginsel 70

$\begin{array}{ll}\text { 3.2.4. } & \text { Budgettaire overwegingen }\end{array}$

$\begin{array}{ll}\text { 3.3. Tweeverdienerswetgeving-II } & 73\end{array}$

$\begin{array}{ll}\text { 3.3.1. Algemene opmerkingen } & 73\end{array}$

$\begin{array}{lll}\text { 3.3.2. Het draagkrachtbeginsel } & 77\end{array}$

3.3.3. Het gelijkheidsbeginsel 82

3.3.4. Budgettaire overwegingen 84

$\begin{array}{ll}\text { 3.4. Tweeverdienerswetgeving-III } & 85\end{array}$

3.4.1. Algemene opmerkingen 85

3.4.2. Het draagkrachtbeginsel $\quad 86$

3.4.3. Het gelijkheidsbeginsel 93

3.4.4. Budgettaire overwegingen 96

3.5. Reparatiewetgeving Tweeverdieners 97

$\begin{array}{ll}\text { 3.5.1. Algemene opmerkingen } & 97\end{array}$

$\begin{array}{ll}\text { 3.5.2. Budgettaire overwegingen } & 101\end{array}$

$\begin{array}{ll}\text { 3.6. Samenvatting en conclusies } & 102\end{array}$

4. OORT-I 105

4.1. Inleiding 105

4.2. De commissie-Oort 115

$\begin{array}{ll}\text { 4.2.1. Algemene opmerkingen } & 115\end{array}$

4.2.2. Concrete voorstellen 118

4.2.3. Het draagkrachtbeginsel 122

4.2.4. Het gelijkheidsbeginsel 124

4.2.5. Doelmatigheid 125

4.2.6. Het vereenvoudigingsstreven 126

4.2.7. Budgettaire overwegingen 127

4.3. OORT-I 128

$\begin{array}{lll}\text { 4.3.1. Inleiding } & 128\end{array}$

4.3.2. Het wetsvoorstel 129

4.3.3. De parlementaire discussie en de kritiek in de literatuur 132

4.3.3.1. Wetgevingsbeginsel(en) 133

4.3.3.2. Het draagkrachtbeginsel in het algemeen 133

4.3.3.3. Het draagkrachtbeginsel in relatie tot de concrete voorstellen 143

$\begin{array}{lll}\text { 4.3.3.4. Het gelijkheidsbeginsel } & 148\end{array}$

4.3.3.5. Het vereenvoudigingsstreven 152

4.3.3.6. Budgettaire overwegingen 156

4.3.3.7. De rol van pressiegroepen 158

$\begin{array}{lll}\text { 4.3.3.8. De aftrekposten } & 160\end{array}$

4.3.3.9. Andere beginselen 162

4.4. Samenvatting en conclusies 163 
5. OORT-II en OORT-III 167

5.1. Inleiding 167

5.2. Het wetsvoorstel OORT-II 169

5.3. De parlementaire discussie en de kritiek in de literatuur 172

5.3.1. Wetgevingsbeginsel(en) 176

$\begin{array}{ll}\text { 5.3.2. Het draagkrachtbeginsel } & 179\end{array}$

5.3.3. Het gelijkheidsbeginsel 184

$\begin{array}{ll}\text { 5.3.4. Het vereenvoudigingsstreven } & 196\end{array}$

5.3.5. Budgettaire overwegingen 200

5.3.6. De rol van pressiegroepen 201

$\begin{array}{ll}\text { 5.3.7. Andere beginselen } & 202\end{array}$

5.4. Het wetsvoorstel OORT-III 203

5.5. De parlementaire discussie en de kritiek in de literatuur 204

5.5.1. Wetgevingsbeginsel(en) 204

5.5.2. Het draagkrachtbeginsel 205

5.5.3. Het gelijkheidsbeginsel 206

5.5.4. Het vereenvoudigingsstreven 207

$\begin{array}{ll}\text { 5.5.5. Budgettaire overwegingen } & 209\end{array}$

5.6. Samenvatting en conclusies 210

DEEL II: THEORIE INZAKE DE BEGINSELEN VAN EEN RECHTVAARDIGE INKOMSTENBELASTING

6. De totstandkoming van belastingwetgeving 215

6.1. Inleiding 215

6.2. Het belang van budgettaire, economische en politieke

6.3. Budgettaire en economische elementen 220

6.4. Politieke elementen 222

6.5. Samenvatting en conclusies 233

$\begin{array}{ll}\text { 7. Rechtvaardigheidsbeginselen tegenover } & \\ \text { doelmatigheid(sbeginsel(en)) } & 235\end{array}$

7.1. Inleiding 235

7.2. Een kort historisch overzicht 242

7.3. Verdelingsbeginselen 253

7.3.1. Het draagkrachtbeginsel 253

7.3.2. Het profijtbeginsel 265

$\begin{array}{lll}\text { 7.4. Het gelijkheidsbeginsel } & 269\end{array}$

7.4.1. Het gelijkheidsbeginsel in het algemeen 269

7.4.2. Het gelijkheidsbeginsel in het belastingrecht 277

7.5. Doelmatigheid 286

7.6. De wetgeving getoetst aan rechtvaardigheid en doelmatigheid 293

$\begin{array}{lll}\text { 7.6.1. De Tweeverdienerswetgeving } & 293\end{array}$ 
7.6.2. OORT-I

7.6.3. OORT-II en OORT-III 295

7.7. Samenvatting en conclusies 295

$\begin{array}{lll}\text { 8. Conclusies } & 299\end{array}$

$\begin{array}{ll}\text { Samenvatting } & 301\end{array}$

$\begin{array}{ll}\text { Summary } & 307\end{array}$

$\begin{array}{ll}\text { Literatuurlijst } & 313\end{array}$

$\begin{array}{ll}\text { Curriculum vitae } & 331\end{array}$ 


\section{Lijst van gebruikte afkortingen}

AAW

A-G

AKW

AOW

AWBZ

AWW

BNB

BuPo

CRvB

EVRM

FED

GW

HR

IVBPR

KG

lk

$\mathrm{mk}$

m.nt.

NJCM

$\mathrm{Pb}$.

rk

Sdu

Stb.

Stcrt.

t.a.p.

TAR

Trb.

UCV
Algemene Arbeidsongeschiktheidswet

advocaat-generaal

Algemene Kinderbijslagwet

Algemene Ouderdomswet

Algemene Wet Bijzondere Ziektekosten

Algemene Weduwen- en Wezenwet

Beslissingen in belastingzaken Nederlandse belastingrechtspraak

Internationaal Verdrag inzake burgerrechten en politieke rechten

Centrale Raad van Beroep

Europees Verdrag tot bescherming van de rechten van de mens en de fundamentele vrijheden

Fiscaal weekblad FED

Grondwet

Hoge Raad der Nederlanden

Internationaal Verdrag inzake burgerrechten en politieke rechten

Kort Geding

linkerkolom

middenkolom

met noot

Nederlands Juristen Comité voor de Mensenrechten

Publicatieblad van de Europese Gemeenschap

rechterkolom

Sdu Juridische en Fiscale Uitgeverij

Staatsblad

Staatscourant

ter aangehaalde plaatse

Tijdschrift voor ambtenarenrecht

Tractatenblad

Bijzondere commissie Wet vereenvoudiging van de loon- en inkomstenbelasting 
$\mathrm{V}-\mathrm{N}$

$\mathrm{Vpb}$

Wet IB 1964

Wet LB 1964

Wet VB 1964

WIR

WW
Vakstudie-Nieuws

Wet op de vennootschapsbelasting 1969

Wet op de inkomstenbelasting 1964

Wet op de loonbelasting 1964

Wet op de vermogensbelasting 1964

Wet investeringsrekening

Werkloosheidswet 
Inleiding 
'There is no country in which the whole system of taxation is one, logically worked out from first principles. Everywhere the accidents of political and commercial consideration in past history are perpetuated, and condition the present system'.'

\subsection{Inleiding}

Een concrete belasting kan worden gedetermineerd aan de hand van het belastingplichtig subject, het belastbaar object en het daarbijbehorende tarief. Zowel het subject als het object met de tarieven variëren in de tijd.

In de middeleeuwen genoten de welgeborenen schotvrijheid. Schot was een ander woord voor belasting. ${ }^{2}$ De schotvrijheid werd gerechtvaardigd door het feit dat de welgeborenen een militaire plicht hadden te vervullen. In de $14 \mathrm{e}$ en 15e eeuw, toen bleek dat de vaste beden, wederom een ander woord voor belasting, niet voldoende opleverden, werd een nieuw soort beden in het leven geroepen. Door de komst van een professioneel leger werd het argument voor de welgeborenen om ontslagen te zijn van de verplichting belasting te betalen, ondergraven. De welgeborenen moesten ook aan de verplichting voldoen de beden te betalen. ${ }^{3}$ Dit voorbeeld kan met legio andere worden aangevuld.

Door de eeuwen heen moest een staat in een aantal behoeften kunnen voorzien en deze behoeften moesten worden gefinancierd. Een van de middelen ter financiering was en is belastingheffing. Alhoewel sommige belastingen enige zogenaamde 'nevendoeleinden' dienden, was de financiering van uitgaven de voornaamste bestaansreden van belastingen. Dit geldt ook voor de tegenwoordige tijd.

Bij de constatering dat de belastingheffing en haar subjecten, objecten en tarieven in de loop van de tijd zijn veranderd, rijst de vraag of de belastingwetgever zich bij de verdeling van de belastingdruk ${ }^{4}$ over de burgers laat leiden door

1. Six Josiah Stamp, Principles of Taxation, blz.25._Ontleend aan A.J. van den Tempel, De belasting als instrument der economische politiek, Samson, 1945, blz. 161 en 162.

2. Zie over de geschiedenis van de belastingterminologie, F.H.M. Grapperhaus, De pelgrimstocht naar het draagkrachtbeginsel, Kluwer, 1993.

3. Zie J.P.H. De Monté Verloren, J.E. Spruit, Hoofdlijnen uit de ontwikkeling der rechterlijke organisatie in de Noordelijke Nederlanden tot de Bataafse omwenteling, 6e druk, Kluwer, 1982, blz. 122, noot 184. Zie ook F.H.M. Grapperhaus, t.a.p., blz. 27 en M.J.H. Smeets, De economische betekenis van de belastingen, 2e druk, Amsterdam, 1954, blz. 37.

4. Smeets onderscheidt de individuele en de macro-economische belastingdruk. Met individuele druk wordt de vermindering van het beschikbare inkomen bedoeld. De vermindering van het 
een aantal regels, of zo men wil, basisprincipes of beginselen. De belastingwetgever legt burgers door middel van belastingheffing immers een aantal lasten op en een belangrijke beginselvraag is hoe deze lasten over de burgers moeten worden verdeeld: het zgn. verdelingsvraagstuk. Een verdeling van de belastingdruk die niet in brede kring als rechtvaardig wordt beschouwd, roept weerstanden op die verstrekkende fiscale en politieke gevolgen kunnen hebben. Ook voor deze stelling biedt de geschiedenis talrijke voorbeelden. ${ }^{5}$ Een goede toepassing van de juiste beginselen kan de belastingheffing meer aanvaardbaar maken voor de burgers.

Een tweede vraag is of de grondslagen thans dezelfde zijn als vroeger. ${ }^{6}$ Nieuwe maatschappelijke ontwikkelingen kunnen het systeem van belastingheffing beïnvloeden. Een gevolg kan zijn dat puur budgettaire en politieke overwegingen meer dan voorheen de aard van de belastingheffing gaan bepalen. ${ }^{7} \mathrm{Nu}$ komt ook het element van de toenemende internationalisering en 'vereuropeanisering' aan de orde. Een typisch Nederlandse belastingheffing moet gaan concurreren met de belastingstelsels van de andere landen. Het lijkt me dat de (verdelings)beginselen een moeilijke periode tegemoet gaan, gezien de verschillende achtergronden van de verscheidene belastingstelsels in Europa. ${ }^{8}$ De twee bovenstaande vragen vormen het kader van mijn onderzoek.

beschikbare inkomen wordt veroorzaakt door het opleggen van de belastingen. Onder macroeconomische belastingdruk wordt de last welke de belastingen op de volkshuishouding leggen verstaan. M.J.H. Smeets, t.a.p., blz. 60 en 61.

5. Denk bij voorbeeld aan Alva's tiende penning. J.P.H. Monté Verloren, J.E. Spruit, t.a.p., blz. 206. Zie verder F.H.M. Grapperhaus, t.a.p., o.a. blz. 34 en 41.

6. H.J. Hofstra m.m.v. C. van Raad, Inleiding tot het Nederlands belastingrecht, Fiscale hand- en studieboeken, no 1, zevende druk, Kluwer, 1992, blz. 117 e.v.

7. De budgettaire functie heeft in ieder geval tot een ingewikkelde belastingheffing geleid. $H . J$. Hofstra, m.m.v. C. van Raad, Inleiding, t.a.p., blz. 21 en 86 . Belastingheffing werd in de zestiende en de zeventiende eeuw als een financiële noodoplossing gezien. F.H.M. Grapperhaus, t.a.p., blz. 65.

Van Arendonk vertaalt het aldus: 'Dat de wetgever met bepaalde bestedingen rekening houdt, zoals buitengewone lasten en giften, is de concrete maatschappelijke invulling van het draagkrachtbeginsel.' H.P.A.M. van Arendonk, De inkomstenbelasting in Nederland: een monumentaal bouwwerk, Maandblad Belastingbeschouwingen, 1993, no 6, blz. 157.

8. Vergelijk L.G.M. Stevens, Ondergang van een draagkrachtheffing in de Europese ruimte, Weekblad voor fiscaal recht, 1992, no 6026, blz. 1344. Denk bij voorbeeld maar aan het al dan niet toepassen van het splitsingsstelsel in de verschillende landen.

Interessant is hetgeen de toenmalige Minister van Financiën, Hofstra, in 1959 in de memorie van toelichting van het wetsontwerp Wet op de Inkomstenbelasting zei over een belastingstelsel in Europa: 'Bij het beschouwen nu van de evolutie van de belastingheffing in de ons omringende landen kan worden geconstateerd, dat voor zover in deze landen een afwijkende structuur van het belastingstelsel valt op te merken, de evolutie daarvan zich, in grote lijnen gezien, eerder beweegt in een richting die dat recht geleidelijk meer in overeenstemming brengt met hetgeen in ons land en vele andere landen als de kern van het belastingstelsel wordt beschouwd, dan in een richting waarbij dat recht zich verder van het onze zou verwijderen.' Hofstra, PvdA, minister van Financiën, Tweede Kamer, vergaderjaar 1958-1959, 5380, no 3, blz. 13. 
Het is niet mijn bedoeling om alle wijzigingen, die zich in de loop van de tijd hebben voorgedaan in de omschrijving van het belastingplichtig subject en het belastbaar object met de daarbijbehorende tarieven te onderzoeken. Ik beperk mij tot de Wet op de inkomstenbelasting 1964 (hierna: Wet IB 1964) en enkele van haar wijzigingswetten. De geschiedenis van deze wetten geeft een mooie illustratie van de ontwikkeling van de gedachten van de belastingwetgever. Ik tracht met behulp van de parlementaire geschiedenis de rechtvaardiging voor deze wijzigingswetten in het bijzonder en de rechtvaardiging voor de inkomstenbelasting in het algemeen te onderzoeken. De inkomstenbelasting tezamen met haar voorheffingen is éen van de belangrijkste bronnen van de overheidsfinanciering. ${ }^{9} \mathrm{Zjj}$ is een persoonlijke belasting, die naar het zuivere inkomen van natuurlijke personen wordt geheven. ${ }^{10}$ De inkomstenbelasting is dan ook het voor de hand liggende object voor een studie van het verdelingsvraagstuk.

Aan mijn onderzoek ligt een aantal algemene vooronderstellingen van politiekfilosofische aard met betrekking tot staat, overheid en belastingen ten grondslag. Visies op belastingheffing hangen samen met visies op staat en overheid.

De realiteit van de staat is overal ter wereld zo manifest dat daaruit ten minste de werkhypothese kan worden afgeleid dat in de huidige fase van de geschiedenis de staat in de samenleving van mensen als onontbeerlijk geldt.

Met het bestaan van de staat en de overheid is de belastingheffing verbonden. Verscheidene taken moeten worden verricht en daarvoor is geld nodig; de financiering wordt onder andere gevonden in de belastingheffing. In de loop van de tijd heeft de staat zich ontwikkeld tot de huidige verzorgingsstaat, waarin het aantal taken dat gefinancierd moet worden, alleen maar toegenomen is. ${ }^{11}$

9. H.J. Hofstra m.m.v. C. van Raad, Inleiding, t.a.p., blz. 124, H.J. Hofstra, De toekomst van de inkomstenbelasting, Weekblad voor fiscaal recht, 1975, no 5248, blz. 1033 en 1034 en L.G.M. Stevens, Elementair belastingrecht voor economen en bedrijfsjuristen, 11e herziene druk, Kluwer, 1993, blz. 14. Zie ook L. Koopmans, A.H.E.M. Wellink, H.J. Woltjer, C.A. de Kam, Overheidsfinanciën, zevende geheel herziene druk, Stenfert Kroese, 1991, blz. 167, 168 en 174. Volgens de Rijksbegroting 1995 bedraagt de raming voor 1994 van de inkomstenbelasting en de loonbelasting $55.035 \mathrm{mln}$. hetgeen neerkomt op $\pm 36,58 \%$ van het totaal van de belastingopbrengsten op kasbasis (150.425 mln.). Weekblad voor fiscaal recht, 1994, no 6119, blz. 1367.

10. Sinds 1892/1893 steunt de inkomstenbelasting te onzent op de bronnentheorie. De bronnentheorie houdt in dat als inkomen wordt beschouwd 'al hetgeen aan de belastingplichtige toevloeit uit de (som van) permanente bronnen.' E.M.G. Creusen, D. Booij, P.M. van Schie, Naar een breder inkomensbegrip? Weekblad voor fiscaal recht, 1979, no 5406, blz. 555. De wet stelt de belastingsubjecten op de voorgrond. Wie naar de daaromtrent gestelde regelen voor het betalen van inkomstenbelasting in aanmerking kan komen, is belastingplichtig. Om tot het betalen van belasting te kunnen worden verplicht, moet bovendien aan de objectieve eis van het genieten van een voldoende inkomen worden voldaan. Zonder belastingplicht kan nooit een belastingschuld ontstaan; maar men kan zeer wel belastingplichtig zijn zonder belastingschuldig te zijn. H.J. Hofstra m.m.v. C. van Raad, Inleiding, t.a.p., blz. 270.

11. Een van de kenmerken van de verzorgingsstaat is een andere (meer egalitaire) invulling van het principe van de verdelende rechtvaardigheid. Deze rechtvaardigheid drukt zich primair uit in de maatschappelijke solidariteit en minder in juridische ideaalbeelden. A.J. Bok, Rechter contra wetgever. toetsing van geschreven aan ongeschreven recht, Hoofdstuk 19, blz. 279. In: De rechtsstaat herdacht, W.E.J. Tjeenk Willink, 1989. 
Ten aanzien van de staat, de overheid en de belastingheffing bestaan vele interpretatiemogelijkheden en visies. In het kader van het onderzoek ga ik ervan uit dat de staat noodzakelijk is en daarmede ook de belastingheffing. Deze vooronderstellingen zijn dermate interessant dat een zelfstandig onderzoek zeker op zijn plaats zou zijn. Maar zo'n onderzoek valt buiten het kader van het onderhavige, t.w. een onderzoek naar de aanwezigheid van de (verdelings)beginselen in de praktijk van de fiscale wetgeving. Concreet: de vraag naar de grondslag van het recht belasting te heffen blijft geheel buiten beschouwing. Het gaat alleen om de vraag naar de behoorlijkheid of de rechtvaardigheid van de belastingheffing als een vorm van een legaal overheidsoptreden.

In § 1.2 geef ik een voorlopige omschrijving van het onderzoeksterrein. In § 1.3 toon ik met behulp van een vooraanstaand Nederlands handboek aan dat de inrichting van de belastingheffing volgens de heersende leer geheel of gedeeltelijk werd beheerst door een aantal 'beginselen'. In $\S 1.4 .1$ geef ik een kort overzicht van de totstandkoming van de Wet IB 1964. In $\S 1.4 .2$ geef ik de in de kamerstukken van de Wet IB 1964 uit de jaren vijftig en zestig genoemde beginselen weer. In $\S 1.5$ formuleer ik de precieze probleemstelling van het onderzoek. In $\S 1.6$ volgt een plan van behandeling.

\subsection{Voorlopige omschrijving van het onderzoeksterrein}

Belastingheffing roept vele vragen op. Voorbeelden van vragen oproepende elementen zijn de mate van afwenteling en het bestaan van politieke meningsverschillen. Gezien de complexiteit van de materie is het niet te vermijden dat over de beantwoording van de vragen verschillend kan worden gedacht. De mate van afwenteling en het bestaan van politieke meningsverschillen zijn, hoe paradoxaal het ook moge klinken, als het ware voorwaarden voor een dynamisch en goed functionerend belastingstelsel; door deze elementen komen de tekorten van de belastingheffing aan het licht.

Om enig idee te geven waar belastingheffing geplaatst moet worden, geef ik enige belangrijke uitgangspunten van het onderzoek weer. Belangrijk zijn de methodologische uitgangspunten en het analytische kader, waarmee de onderzoeker het verschijnsel van de belastingheffing benadert. Een opmerking bij het voorlopig omschrijven van het onderzoeksterrein is, dat ik niet de pretentie heb volledig te zijn.

1. Belastingheffing kan uit vele invalshoeken worden bekeken. Rechten, economie, sociologie en rechtsfilosofie zijn verschillende disciplines die zich met hetzelfde onderwerp, nl. belastingheffing, kunnen bezig houden. ${ }^{12}$ De vragen die

12. Vergelijk H.J. Hofstra, Over belastingbeginselen, Weekblad voor fiscaal recht, 1979, no 5427, blz. 1219. Hofstra beschrijft het verschijnsel van de belastingheffing als een maatschappelijk verschijnsel, met vele kanten, zoals juridische, sociale, ethische en economische. H.J. Hofstra, Het einde der draagkrachttheoric, Weekblad der directe belastingen, invoerrechten en accijnzen, 
vanuit de verschillende disciplines worden gesteld zijn niet altijd dezelfde. $\mathrm{ZO}_{\mathrm{O}}$ zegt men wel dat de juristen de rechtvaardigheid en de economen de doelmatigheid centraal stellen. ${ }^{13} \mathrm{De}$ sociologen trachten de werkelijke feiten te achterhalen, terwijl de rechtsfilosofen de theoretische fundamenten voor het verschijnsel trachten te vinden.

De vragen die in dit onderzoek aan de orde komen, zijn juridisch van aard: Welke zijn de rechtvaardigingsgronden die de fiscale wetgever in enige wijzigingswetteñ van de Wet IB 1964 heeft ingeroepen en worden de gronden consequent gebruikt? Andere invalshoeken, zoals de economische en de politicologische, komen slechts terloops aan bod.

2. In mijn onderzoek behandel ik de problemen die bij de totstandkoming van de belastingwetgeving spelen. Belastingheffing dient een wettelijke grondslag te bezitten. ${ }^{14}$ Bij de wetgevingsprocedure zijn wetgevingsbeginselen belangrijk. ${ }^{15}$ Men zou deze beginselen moeten onderscheiden van de beginselen van de belastingheffing, alhoewel er een onderlinge samenhang is. ${ }^{16}$ Zo wordt het verbod van terugwerkende kracht als een beginsel van behoorlijke wetgeving èn tevens als een beginsel van de belastingheffing beschouwd. ${ }^{17}$

De wetgevingsbeginselen hebben invloed op de legitimiteit van de belastingheffing. Sillevis en De Vries: 'Indien deze fiscale wetgevingsproductie aan die beginselen (wetgevingsbeginselen, $\mathrm{MW}$ ) zou worden getoetst, kan daarvan aanstonds tevens een sanerend effect op de inhoud van de gestelde regels uitgaan, waardoor het maatschappelijk draagvlak van die regelgeving eveneens zou kunnen worden vergroot.' Verder merken zij op: 'De door ons noodzakelijk geachte

1939. In: Tributen aan het recht, 100 jaar Weekblad voor fiscaal recht, 1971, blz. 54, noot 4.

13. Interessant in dit verband is de manier waarop volgens Verloren van Themaat juristen de economische orde bekijken. De kijk van juristen op de economische orde, of liever gezegd de normatieve economische orde, bestaat uit drie groepen van beginselen, t.w.: de vrijheids-, gelijkheids- en solidariteitsbeginselen. Van belang is de onderlinge verhouding tussen de beginselen. Deze kan enorm variëren met alle gevolgen van dien. P. Verioren van Themaat, Economie, gezien door juristen, Koninklijke Nederlandse acadamie van wetenschappen, 1988, blz. 237.

14. Artikel 104 Grondwet luidt: 'Belastingen van het Rijk worden geheven uit kracht van een wet. Andere heffingen van het Rijk worden bij de wet geregeld.'

15. Vergelijk I.C. van der Vlies, Handboek wetgeving, 2e herziene druk, W.E.J. Tjeenk Willink, 1991 en Aanwijzingen voor de regelgeving, vastgesteld bij besluit van 18 november 1992, gepubliceerd in de Staatscourant van 26 november 1992, nr. 230.

16. Vergelijk hetgeen Vermeend (PvdA) op het LOF-congres 'Rechtszekerheid in het belastingrecht' heeft gezegd. '... dat een fiscale wet ontstaat uit een proces van compromissen en beïnvloedingsprocedures en dat in toenemende mate budgettaire overwegingen in de afweging betrokken worden.' 'Omdat het (wetgevingsproces, $M W$ ) een afwegingsproces is, zal optimalisatie van criteria als eenvoud, fiscale logica, rechtszekerheid en doelmatigheid volgens Vermeend niet bereikbaar zijn.' D. van Ledden, E. Veele, Verslag LOF-congres: 'Rechtszekerheid in het belastingrecht', Fiskaal, jaargang 17, nummer 1990-09, blz. 290 en 291.

17. Artikel 4 Wet Algemene Bepalingen luidt: 'De wet verbindt alleen voor het toekomende, en heeft geen terugwerkende kracht.' Zie onder andere J.A.M. van Angeren, Beginselen van behoorlijke wetgeving. In: Kracht van wet, Van Eykeren-bundel, 1984, blz. 70 en P.J.A. Adriani, Het belastingrecht, deel I, 1954, blz. 262. 
legislatieve sanering van de belastingwetgeving vormt ons inziens echter juist een conditio sine qua non voor een vruchtbare gedachtenwisseling over belastingbeginselen, zodat deze metterdaad voor de praktijk van de belastingheffing hanteerbare criteria zal kunnen opleveren., 18

Gezien het bovenstaande zijn de wetgevingsbeginselen van belang, maar deze vormen geen voorwerp van onderzoek.

3. Met name met het oog op verdelingsbeginselen is het (uiteindelijke) karakter van de belastingwet belangrijk. Met dit karakter hangt de mogelijkheid tot afwenteling samen; althans in theorie.

Een belasting kan direct of indirect zijn. Een voorbeeld van een directe belasting vindt men in de Wet IB 1964. De belastingplichtige dient zijn deel van de te dragen belasting, dat wil zeggen een gedeelte van het inkomen, direct aan de fiscus af te dragen. ${ }^{19}$

De indirecte belasting houdt in dat de belastingplichtige de belasting uiteindelijk niet zelf draagt, maar afwentelt op een andere persoon. Een voorbeeld hiervan is te vinden in de Wet op de omzetbelasting 1968.

De theorie luidt dat directe belastingen niet kunnen worden afgewenteld op andere belastingplichtigen dan degenen die de belasting volgens wettelijke voorschriften moeten betalen en indirecte wel. Het hierboven gemaakte onderscheid tussen directe en indirecte belastingen is een onderscheid naar economische begrippen. ${ }^{20}$ Twijfel is gerezen over de zuiverheid van het onderscheid. Het blijkt dat ook de directe belastingen afgewenteld kunnen worden.

Alhoewel de afwenteling een proces is dat plaatsvindt nadat het bedrag van de te betalen belasting is vastgesteld, met andere woorden, in de uitvoeringsfase, heeft de afwenteling gevolgen voor de werking van de (verdelings)beginselen. ${ }^{21}$ Want een slechts in theorie goed functionerend principe heeft geen enkele waarde indien de praktijk anders uitwijst.

18. L.W. Sillevis, N.H. de Vries, Universiteit, belastingbeginselen en samenleving, Weekblad voor fiscaal recht, 1990, no 5943, blz. 1892 en 1893.

19. Hier komt een belangrijk element van de belastingheffing naar voren, namelijk het gedwongen karakter van het afdragen van belastingen. Draagt de belastingplichtige de belasting niet vrijwillig af, dan zorgt een sanctiestelsel ervoor dat de belasting alsnog wordt afgedragen. Deze belastingplicht reikt voor de inkomstenbelasting ook over de staatsgrenzen heen.

20. H.J. Hofstra m.m.v. C. van Raad, Inleiding, t.a.p., blz. 35. Reugebrink stelt dat het onderscheid in economische zin ook niet meer opgaat. Het onderscheidende criterium is het al dan niet aanwezig zijn van het bestemmingslandbeginsel; in tegenstelling tot de directe belastingen geldt voor indirecte belastingen het bestemmingslandbeginsel. J. Reugebrink, Directe en indirecte belastingen: een achterhaalde classificatie? In: Cijns en Dijns, Hofstra-bundel, 1975, blz. 146. Schonis spreekt van een bij de inkomstenbelasting niet meer op te lossen vraag wie de belastingdruk draagt. H.M.N. Schonis, Inkomstenbelasting: ingrijpende verbouwing noodzakelijk, Weekblad voor fiscaal recht, 1992, no 6026, blz. 1348.

21. Voormalig staatssecretaris van Financiën, Koning, VVD verwoordt het aldus: 'Het (afwentelingsproces, MW) ondergraaft niet alleen de draagkrachttheorie, maar ook onze economische positie.' P.C. Goosen en R.N.J. Kamerling, Belastinghervorming, een noodzaak, Kluwer, 1986, blz 98 . 
Daar het moeilijk is om de mate van afwenteling precies te berekenen, is over het verschijnsel weinig bekend. ${ }^{22}$ De mate van afwenteling wordt niet in het onderzoek betrokken.

4. Bovendien is de bestudering van de belastingheffing extra moeilijk omdat deze zwaar beladen is met politieke ideeën en de belastingwetgeving tot stand komt in een politieke context. De invulling van verscheidene kwesties kan daardoor verschillend zijn. Een voorbeeld betreft de gewenste hoogte van het tarief. De beantwoording van deze vraag hangt af van de politieke machtsverhoudingen op een bepaald moment. Het is belangrijk, hoe moeilijk het ook moge zijn, de invloed van de politieke machtsverhoudingen zò veel mogelijk buiten de beschouwingen over de (verdelings)beginselen' te laten. Toegegeven, de nadere invulling van een (verdelings)beginsel is altijd een politieke stellingname, maar het (verdelings)beginsel mag niet worden gebruikt om partijpolitieke of strategische redenen. Het scheiden van de gevolgen van de politieke machtsverhoudingen en de werking van (verdelings)beginselen is niet (geheel) mogelijk, maar een zeker onderscheid moet worden gemaakt ${ }^{23}$; een onderscheid moet worden gemaakt tussen de toepassing van de verdelingsbeginselen en elementen zoals partijpolitiek en pressiegroepen.

5. Naast het financieringsdoel wil de overheid door middel van belastingheffing vaak een reeks wensen ('nevendoelen') verwezenlijken. ${ }^{24}$ De belastingheffing

22. Illustratief is het volgende citaat uit de Miljoenennota 1993: 'Tegen deze achtergrond ligt het in de rede om de opbrengsten c.q. kosten van fiscale maatregelen in beginsel te presenteren zonder in- of uitverdieneffecten. Slechts in die uitzonderlijke gevallen waarin gedragseffecten partieel te berekenen zijn, ondubbelzinnig kwantitatief in kaart kunnen worden gebracht en zich binnen een relatief kort tijdsbestek materialiseren, worden de opbrengsten c.q. kosten van fiscale maatregelen voor gedragseffecten gecorrigeerd.' Miljoenennota 1993, Tweede Kamer, vergaderjaar 1992-1993, 22 800, no 2, bijlage 4, V-N 24 augustus 1992, blz. 2692.

23. Vergelijk Van den Berge, die een onderscheid maakt tussen belastingpolitieke en technischjuridische elementen. Tot de eerste groep behoort de nadere invulling van de belastingdruk; beoogd wordt wijziging te brengen in de belastingdruk. De tweede groep mist dit karakter. W.H. van den Berge, De structuur van het belastingrecht, rede, 1951. In: Tributen aan het recht, 100 jaar Weekblad voor fiscaal recht, 1971, blz. 88 en 89. J.F.M. Giele, Het fiscale rechtstekort, Kluwer, 1977, blz. 19.

24. Volgens Stevens heeft de belastingheffing drie functies, t.w.:

- 1 de budgettaire functie; deze functie betreft de financiering van de overheidsactiviteiten.

- 2 de instrumentele functie; deze functie betreft de nevendoeleinden.

- 3 de steunfunctie; enkele belastingen hebben een steunfunctie ten behoeve van een andere belasting. Een voorbeeld is de vermogensbelasting, die een steunfunctie vervult ten behoeve van de inkomstenbelasting. De vermogensbelasting is een aanvulling op de inkomstenbelasting; de draagkracht die het vermogen verschaft, wordt extra belast. De vennootschapsbelasting heeft ook een ondersteunende functie ten aanzien van de inkomstenbelasting.

Zie L.G.M. Stevens, Elementair, t.a.p., blz. 3-7.

Vergelijk M.J.H. Smeets, die drie functies van belastingheffing weergeeft:

- 1 de traditionele functie: dit betreft het financieren van de overheidsuitgaven;

- 2 de herverdelende functie: dit betreft de verdeling van inkomens en vermogens; 
wordt dan als een beleidsinstrument gebruikt, bij voorbeeld voor het bereiken van economische, sociale of milieudoelstellingen. ${ }^{25}$

In dit verband moet ook de discussie worden gezien rond de belastinguitgaven. Hieronder worden verstaan 'de tegemoetkomingen in de belastingwetgeving, die inbreuk maken op de normale structuur van de wet, welke in de wet zijn opgenomen om een beleidsdoelstelling te realiseren die de overheid ook via directe uitgaven kan nastreven'. ${ }^{26}$

Een voorbeeld is de mogelijkheid buitengewone lasten in mindering te brengen op het belastbaar inkomen. Het voeren van een sociaal beleid wordt in dit geval als nevendoeleinde van de belastingheffing gezien.

Door het gebruik van de belastingheffing als instrument van beleid verandert het karakter van de belastingheffing. Dit geldt nog sterker indien het nevendoeleinde hoofddoeleinde is geworden. ${ }^{27}$

6. De belastingheffing wordt niet alleen beïnvloed door het beleid, maar ook door de partijen die bij het wetgevingsproces zijn betrokken. Dat zijn niet alleen ambtenaren en politici, maar ook pressiegroepen. In de politiek wordt rekening gehouden met eisen van pressiegroepen die niet in het parlement zitting hebben. De nadere definiëring van een pressiegroep en de vragen welke pressiegroepen

- 3 de regulerende functie: dit betreft de conjuncturele of structurele maatregelen ten behoeve van een financieel-economisch goed klimaat.

Economisch beleid en belastingrecht, afscheidsrede, Amsterdam, 1967, blz. 4. En zie ook M.J.H. Smeets, De economische betekenis van de belastingen, 2e druk, Amsterdam, 1954, o.a. blz. 9597.

Zie ook L. Koopmans c.s., t.a.p., blz. 3 en 4.

25. Als doelstellingen van een economische politiek kunnen gelden: een redelijke inkomensverdeling, een aanvaardbare economische groei, volledige werkgelegenheid, evenwicht op de betalingsbalans, stabiel prijsniveau en bescherming van het fysieke leefmilieu. L.G.M. Stevens, Elementair, t.a.p., blz. 1. Zie ook L. Koopmans c.s., t.a.p., blz. 3 en 4.

26. L.M.G. Stevens, Elementair, t.a.p., blz. 5. Vergelijk ook C.A. de Kam, Tax reform in a welfare state: the case of the Netherlands, 1960-1987, Den Haag, 1988, blz. 249. Of in andere bewoordingen: 'Belastinguitgaven kunnen worden gedefinieerd als gederfde belastingopbrengsten als gevolg van speciale voorzieningen in de belastingwetgeving die zijn getroffen met het oog op het bereiken van specifieke doeleinden.' Een voorbeeld is een aftrekpost. Economen zullen meer aftrekposten als belastinguitgave zien dan fiscalisten. Zie L. Koopmans c.s., t.a.p., blz. 12 en 13. Door de toename van het aantal belastinguitgaven wordt het tarief verhoogd, aldus Koopmans c.s.. L. Koopmans c.s., t.a.p., blz. 188.

Of zoals Hofstra en Stevens het zeggen: 'Vele beieidsdoelstellingen, die gelet op de politieke verhoudingen, niet via rechtstreekse maatregelen kunnen worden geëffectueerd, zijn in de loop van de tijd wel op indirecte wijze via het heffingsinstrument (.....) gerealiseerd.' H.J. Hofstra en L.G.M. Stevens, Fiscale hand- en studieboeken, no 2, 4e druk, Kluwer, 1994, blz. 5.

27. Zie bij voorbeeld de verandering van het reiskostenforfait in 1991. En zie L.M.G. Stevens, Elementair, t.a.p., blz. 4. Voorheen was het hoofddoel van de belastingheffing de voorziening in de geldbehoefte van de overheid; later is dat doel ruimer geworden. Zie A.J. van den Tempel, t.a.p., blz. 21 en 22. 
invloed hebben en hoe groot de invloed van deze pressiegroepen is, vallen buiten het onderzoek. ${ }^{28}$

Een interessante vraag is hoe het bestaan van de pressiegroepen democratisch te verantwoorden is. ${ }^{20}$ Interessant is ook de mate waarin pressiegroepen invloed hebben op de verwezenlijking van de (verdelings)beginselen. Zeker is dat tegemoetkomingen aan eisen die het uiteindelijk doel van wetsontwerpen frustreren en alleen het eigen belang dienen, de werking van (verdelings)beginselen ontkrachten.

De conclusie van deze paragraaf is dat een ieder een eigen idee heeft van een nadere invulling van de belastingheffing. De vraag is of enige beginselen hierbij een rol spelen. Met andere woorden, of een gemeenschappelijke noemer aanwezig is.

\subsection{Theorieën en beginselen van belastingheffing}

De rechtvaardiging van de belastingheffing wordt uitgedrukt in de beginselen van belastingheffing. Deze beginselen vinden op hun beurt veelal een plaats in de belastingtheorieën. Theorieën en beginselen van belastingheffing hebben de geleerden lange tijd bezig gehouden.

Belastingtheorieën '... [geven aan] en motiveren waarop het recht van de overheid om belasting te heffen berust, zomede welke beginselen, in het bijzonder ook met betrekking tot de verdeling van de belastingdruk over de verschillende groepen van de bevolking, bij het opbouwen van een verantwoord belastingstelsel behoren te worden gehanteerd'. ${ }^{30}$.

De theorieën lopen nogal uiteen. Hofstra geeft hiervoor drie verklaringen. De eerste reden betreft de maatschappelijke gevolgen van belastingheffing. ${ }^{31} \mathrm{De}$ tweede reden is gelegen in de begrenzing van de theorie door de feitelijke uitvoeringsmogelijkheden. De derde reden is de belangrijkste: de verschillen tussen de achterliggende staatsstructuren en overtuigingen. ${ }^{32}$ Een citaat met een soort-

28. Natuurlijk is het interessant om een empirisch onderzoek hiernaar te doen, maar dit valt buiten . het kader van het onderhavige onderzoek. Wel maak ik, daar waar mogelijk is, opmerkingen over pressiegroepen en hun invloed op het wetgevingsproces.

29. Stevens verwoordt het aldus: 'Op het politiek strijdıneel, ó6k op fiscaal terrein, zijn zowel pressiegroepen actief als politieke partijen en groeperingen die de politieke macht willen aanwenden ten gunste van het groepsbelang, partijbelang of het belang van de (potentiële) achterban.' L.G.M. Stevens; Belastingrecht naar draagkracht, Kluwer, 1980, blz. 103.

30. H.J. Hofstra m.m.v. C. van Raad, Inleiding, t.a.p., blz. 77.

31. Of in andere bewoordingen: 'Het is telkens weer de feitelijke situatie die de problemen stelt waarop het denken een antwoord moet trachten te geven.' Er bestaat blijkbaar een wisselwerking tussen de theorie en de praktijk. H.J. Hofstra m.m.v. C. van Raad, Inleiding, t.a.p., blz. 77.

32. In de vorige druk stond in andere bewoordingen ongeveer hetzelfde, met dien verstande dat de economische redenen duidelijker als onderschcidend criterium voor de verschillende belastingtheorieën naar voren kwam. Met behulp van economische middelen wordt het doel van de staat bereikt. Het economische element moet ook in acht worden genomen. De belastingheffing, als maatschappelijk verschijnsel, is in sterke mate afhankelijk van de actuele, feitelijke om- 
gelijke strekking: 'In de rechtsstaat zijn de belastingtheoretische problemen daarom in laatste instantie problemen van rechtsfilosofische aard, van ethiek, van sociale ethiek (en) van politiek, waarbij een overwegend deel van de beantwoording zich op het algemene staatkundige vlak afspeelt. ${ }^{33}$

Hofstra noemt ten eerste Adam Smith en de zgn. 'klassieken'. De door hen geopperde theorieën hielden in dat de burgers belasting betalen vanwege' het belang dat zij hebben bij hun bescherming door de overheid. De hoogte van de belasting moet worden berekend naar het werkelijke belang, zodat de neutraliteit van de belastingheffing gewaarborgd is. Deze theorieën staan bekend als de belangen, ruil-, equivalentie- of prestatietheorieën. ${ }^{34}$

De tweede categorie theorieën gaat ervan uit dat de Staat een absoluut recht heeft om belasting te heffen. Dit recht vloeit voort uit het feit dat de staat een orgaan is dat zich noodzakelijkerwijze uit de maatschappij heeft ontwikkeld. De plicht om belasting te betalen moet daarentegen wel gelijk aan een ieder worden opgelegd. De druk van het offer van de burger aan de Staat moet voor iedere burger hetzelfde zijn. De betaling van de burger aan de Staat wordt niet gezien als een prijs voor de door de Staat bewezen diensten maar als een offer met een absolute gelding. Deze theorieën kunnen dan ook worden omschreven als de offertheorieën of de theorieën van de absolute belastingplicht. ${ }^{35}$

De derde groep theorieën betreft de moderne belangentheorieën. De theorieën zijn modern omdat niet alleen de inkomstenkant, maar ook de uitgavenkant van de overheid van belang is. Het nut van de collectieve behoeften wordt afgewogen tegen de daarvoor te brengen offers. De wijze van afweging kan verschillend zijn. Zo kan bij deze theorieën de leer van het evenredige genotsoffer een belangrijke rol spelen. Dat wil zeggen, het subjectieve offer moet evenredig zijn aan de totale genotsmogelijkheden van de belastingplichtige. ${ }^{36} \mathrm{De}$ moderne belangentheorieën gaan ervan uit dat de progressie noodzakelijk is. ${ }^{37}$

Als vierde en laatste theorie wordt de draagkrachttheorie genoemd. Met de draagkracht kan de proportionele of de progressieve draagkracht worden bedoeld. De zwakheid van de draagkrachttheorie ligt in het subjectieve element van de maatstaf voor een rechtvaardige belastingheffing; een concreet tarief is niet, of zelfs niet bij benadering, met objectieve criteria vast te stellen. ${ }^{38}$

$\overline{\mathrm{Al}}$ deze theorieën voldoen niet optimaal aan de door hen opgeroepen verwachtingen, aldus Hofstra.

standigheden. H.J. Hofstra m.m.v. C. van Raad, Inleiding, t.a.p., blz. 77 en 78.

33.' Zie H.J. Hofstra m.m.v. C. van Raad, Inleiding, t.a.p., blz. 78, die W.H. van den Berge, Beginselen, blz. 14 en 15, aanhaalt. Opmerkelijk is dat in de vorige druk '(en) van politiek', 'en' niet tussen haakjes stond.

34. H.J. Hofstra m.m.v. C. van Raad, Inleiding, t.a.p., blz. 89. De prestatietheorieën gaan uit van een contract tussen de staat en de samenleving. M.J.H. Smeets, t.a.p., blz. 37 en 38 .

35. H.J. Hofstra m.m.v. C. van Raad, Inleiding, t.a.p., blz. 91 en 92.

36. H.J. Hofstra m.m.v. C. van Raad, Inleiding, t.a.p., blz. 93 en 94.

37. M.J.H. Smeets, t.a.p., blz. 38.

38. H.J. Hofstra m.m.v. C. van Raad, Inleiding, t.a.p., blz. 97 en 98. 
Desondanks leeft nog steeds het idee dat de belastingheffing opgelegd door de overheid een rechtvaardiging behoeft. De belastingheffing wordt rechtvaardig geacht indien de lasten eerlijk worden verdeeld over de burgers. Met andere woorden, een verdeelsleutel dient aanwezig te zijn. Deze wordt gevonden in de verdelingsbeginselen. Voorbeelden van verdelingsbeginselen zijn het draagkrachtbeginsel en het profijtbeginsel. Een aantal parlementsleden en enkele fiscale auteurs zien het draagkrachtbeginsel als richtinggevend voor de Wet IB 1964.9 Een belangrijke vraag is of het draagkracht- en/of het profijtbeginsel in de Wet IB 1964 daadwerkelijk betekenis hebben? Mijns inziens is het belangrijk het begrip draagkracht goed te omschrijven. Belangrijk is dat men weet waarover men praat. ${ }^{40}$ Aan de hand van een vooraanstaand handboek en de parlementaire geschiedenis van de Wet IB 1964 beschrijf ik de (verdelings)beginselen en hun betekenis voor de Wet IB 1964. In dit verband is het volgende van belang: 'Grondslag voor de beslissingen kunnen slechts zijn meer gepreciseerde regelen, die weliswaar uit het grondbeginsel moeten worden afgeleid, doch die, naar mate de verbijzondering voortschrijdt, zwaarder worden belast met de eisen van de, steeds veranderende, situatie, en welker relativiteit dus telkens toeneemt. ${ }^{\text {,41 }} \mathrm{Bij}$ een onderzoek naar de rol van de belastingbeginselen in de wetgevingspraktijk mag men deze 'relativiteit' niet, uit het oog verliezen.

\section{Beginselen genoemd in Hofstra's Inleiding}

In zijn 'Inleiding tot het Nederlands belastingrechy' gaat Hofstra ervan uit dat theoretische richtlijnen aanwezig moeten zijn, wil sprake kunnen zijn van een verantwoord belastingbeleid. ${ }^{42}$

Hofstra is van mening dat ieder rechtsgebied andere beginselen heeft. Derhalve zijn belastingbeginselen aanwezig: '... dat wil zeggen naar welke specifieke belastingbeginselen, de 'normal tax structure' moet worden opgebouwd, waarvan de niet-fiscale doeleinden de 'departures' zijn die het bestaan van een zodanige 'normal tax structure' veronderstellen ${ }^{43}$. Bovendien is Hofstra de mening toegedaan dat de politiek niet zonder belastingtheorie kan werken. Uit deze zin leid

39. Vergelijk Niessen, die stelt dat de collectieve lasten eerlijk moeten kunnen worden verdeeld. 'Een belangrijk richtsnoer daarbij verschaft ons het gelijkheidsbeginsel: het gelijke moet gelijk, maar het ongelijke ongelijk worden belast. De maat voor het meten van gelijk of ongelijk is echter niet de duimstok, maar nu eens draagkracht en dan weer profijt.' Echter hij constateert dat politici het belastingrecht steeds meer enkel en alleen als het instrument voor het voeren van financieel-economisch beleid lijken te beschouwen. De verdelingsbeginselen zijn in die visie een achterhaalde ideologie. R.E.C.M. Niessen, Belastingbeginselen, belastingvlucht en het initiatief-wetsvoorstel van het duo V en V, Column, Forfaitair, 1993, no 34, blz. 62.

40. De nadere concretisering van het draagkrachtbeginsel kent vele invullingen, aldus Niessen. R.E.C.M. Niessen, t.a.p., blz. 62.

41. H.J. Hofstra m.m.v. C. van Raad, Inleiding, t.a.p., blz. 79 en 80.

42. H.J. Hofstra m.m.v. C. van Raad, Inleiding, t.a.p., blz. 77. Een van de redenen zou kunnen zijn dat mensen een rechtvaardiging behoeven voor de verdeling van de belastingdruk. Blijkbaar bestaat de vrees dat indien die rechtvaardiging afwezig zou zijn, de belastingen niet of slechts in beperkte mate worden aanvaard en dat tengevolge daarvan de opbrengst van de belastingen minder dan geraamd zal blijken te zijn.

43. H.J. Hofstra m.m.v. C. van Raad, Inleiding, t.a.p., blz. 83. 
ik af dat politiek en belastingtheorie twee verschillende elementen zijn, die met elkaar verweven zijn. Het mag niet zo zijn dat de politiek dermate opportunistisch is dat de vlag de lading niet meer dekt. Met andere woorden, "kijk wat je pakken kunt, geef aan het wetgevingsprodukt de naam van de theorie en laat de theorie verder voor wat zij is.'

In de literatuur ${ }^{44}$ wordt onderscheiden tussen de volgende beginselen:

a. de rechtvaardigheidsbeginselen;

b. de financiële beginselen, met name inhoudende dat de belastingen voldoende moeten opbrengen voor de financiering van de overheidsuitgaven; ${ }^{45}$

c. de economische beginselen, inhoudende dat schadelijke economische effecten moeten worden yoorkomen.

Mijns inziens kunnen de financiële en de economische beginselen in zekere zin als efficiency-beginselen worden beschouwd. Het streven naar efficiency kan als een streven naar een optimale kosten/batenverhouding worden omschreven. Efficiency is niet gelijk aan effectiviteit. Effectiviteit betreft de berekening van de mate waarin het doel van een regeling wordt bereikt. Efficiency en effectiviteit zijn onder doelmatigheid te scharen.

Volgens Hofstra zijn doelmatigheidsregelen geen rechtsbeginselen. ${ }^{46}$ De doelmatigheid is daarentegen, wel een factor waarmee rekening moet worden gehouden. $\mathrm{Er}$ is geen absolute geldigheid; de doelmatigheid van het recht is net zoals alle beginselen afhankelijk van de tijd. De doelmatigheid beperkt de werking van de belastingbeginselen.

Een compromis moet worden gezocht tussen de doelmatigheid en de rechtvaardigheidsideeën. Het sluiten van dit compromis kan nooit op een zuiver rationele manier plaatsvinden. Aan enige subjectiviteit is bij het sluiten van het compromis niet te ontkomen. Hofstra geeft een zgn. 'vuistregel' voor het vinden van een goed compromis. De vuistregel houdt in, 'dat het gerechtigheidselement voorrang dient te hébben, doch dat een klein belang yan hogere orde mag wijken voor een groot belang van een ander - lager geacht - niveau. ${ }^{.47}$

Ik plaats hierbij een kanttekening. Als het begrip doelmatigheid dezelfde waarde kan aannemen als een rechtsbeginsel, waarom mag de eis van doelmatigheid dan geen beginsel worden genoemd. Bovendien zijn zowel de doelmatigheid als de rechtsbeginselen afhankelijk van de tijd. De afhankelijkheid van de tijd kan mijns inziens dus geen onderscheidend criterium tussen de doelmatigheid en de begin-

44. Zie H.J. Hofstra m.m.v. C. van Raad, Inleiding, t.a.p., blz. 80.

45. In een eerder werk stelt Hofstra dat het financiële aspect bij alle beginselen een rol speelt. Dit is mijns inziens een beperking van de werking van de beginselen. Hofstra zelf geeft nog een andere beperking van de werking van de beginselen, nl. deze: 'De vraag naar de rechtvaardige verdeling van de belastingen is in wezen een politieke vraag'. H.J. Hofstra, Socialistische belastingpolitiek, 1946, blz. 261.

46. H.J. Hofstra m.m.v. C. van Raad, Inleiding, t.a.p., blz. 81 en 84.

47. H.J. Hofstra m.m.v. C. van Raad, Inleiding, t.a.p., blz. 85. Bovendien als "kleiner/groter belang van hoger/lager niveau' zelf een subjectief begrip is, dan is de uitspraak zonder normatief belang. 
selen zijn. Hiermee is niet gezegd dat de doelmatigheidsbeginselen niet van een ander type kunnen zijn dan de verdelingsbeginselen.

In het huidige belastingbeleid spelen in ieder geval de beginselen van de alge-: meenheid van de belastingheffing en het beginsel van de gelijkheid van de belastingdruk een rol. $^{48}$

De literatuur ${ }^{49}$ overziende concludeer ik dat in eerste instantie ervan uit is gegaan dat sprake is van specifieke belastingbeginselen. 'Het doel van de belastingheffing is en blijft ook indien zij bijkomstige hand- en spandiensten aan andere sectoren van het overheidsbeleid verleent, gericht op een verantwoorde toedeling aan de collectieve sector van zijn aandeel in het nationale inkomen, wat een rechtsvraag is die zonder een op dat zelfstandige doel gericht specifiek rechtsbeginsel niet tot oplossing kan worden gebracht. ${ }^{50}$ Maar naarmate het belastingrecht steeds meer een instrument is geworden van het algemeen overheidsbeleid, is de belangstelling voor de specifieke belastingbeginselen afgenomen. Door het gebruik van de belastingheffing voor nevendoeleinden werd en wordt het ook steeds moeilijker de specifieke belastingbeginselen te handhaven. De moeilijkheid neemt zodanig toe dat de vraag rijst of het nog wel mogelijk is om belastingbeginselen hun werking te laten behouden.

Thans kom ik toe aan de beginselen die Hofstra specifiek voor de inkomstenbelasting noemt.

1. Het draagkrachtbeginsel is om zeer uiteenlopende redenen het toonaangevende beginsel. ${ }^{51}$ Het draagkrachtbeginsel houdt in dat de belastingdruk naar de draagkracht van belastingplichtigen wordt verdeeld. 'Zowel historisch als naar de letter genomen betekent een belastingheffing 'naar' draagkracht een zodanige, waarbij van ieders draagkracht een gelijk percentage wordt weggenomen, zodat na de belastingheffing iedereen een eveneens gelijk percentage van zijn oorspronkelijke draagkracht overhoudt. ${ }^{52}$

2. Het andere beginsel is het belangenbeginsel ofwel het profijtbeginsel. ${ }^{53}$ Voor het profijt dat een burger heeft van een overheidsdienst, dient belasting te worden betaald. Hofstra gebruikt de termen profijt- en belangenbeginsel door elkaar. ${ }^{54}$

Menigeen spreekt over hèt draagkrachtbeginsel, maar is de inhoud van het draagkrachtbeginsel wel zo vanzelfsprekend als wordt aangenomen?

48. H.J. Hofstra m.m.v. C. van Raad, Inleiding, t.a.p., blz. 82.

49. Zie H.J. Hofstra m.m.v. C. van Raad, Inleiding, t.a.p., blz. 83.

50. H.J. Hofstra m.m.v. C. van Raad, Inleiding, t.a.p., blz. 83.

51. H.J. Hofstra m.m.v. C. van Raad, Inleiding, t.a.p., blz. 94 e.v. en H.J. Hofstra en L.G.M. Stevens, Inkomstenbelasting, t.a.p., blz. 7.

52. H.J. Hofstra m.m.v. C. van Raad, Inleiding, t.a.p., blz. 95.

53. H.J. Hofstra m.m.v. C. van Raad, Inleiding, t.a.p., blz. 89, 119 en 120 . Het beginsel van de bevoorrechte verkrijging wordt niet expliciet door Hofstra genoemd.

54. Zie voor een nadere uiteenzetting van het profijtbeginsel hoofdstuk 7, § 7.3.2. 
Er moet een onderscheid worden gemaakt tussen het vaststellen van de belastingplichtige subjecten, de belastbare objecten en de vaststelling van de hoogte van hetgeen over het belastbare bedrag aan belasting moet worden betaald.

a. Onder het subject van de draagkracht kan worden verstaan een natuurlijk persoon of een rechtspersoon. In de Wet IB 1964 zijn de natuurlijke personen die in Nederland wonen (binnenlandse belastingplichtigen) en de natuurlijke personen die niet in Nederland wonen en binnenlands inkomen genieten (buitenlandse belastingplichtigen) onderworpen aan de inkomstenbelasting (zie art. 1 Wet IB 1964).

Ten aanzien van het subject kunnen bepaalde draagkrachtvermeerderende en -verminderende factoren een rol spelen. Een voorbeeld is het gehuwd zijn van een belastingplichtige. Het huwelijk kan zowel draagkrachtvermeerderend als -verminderend zijn. Met de bedoelde factoren kan rekening worden gehouden in de belastingheffing.

b. Het object van de draagkracht kan tweeërlei zijn:

- het gerealiseerde inkomen of

- de potentie om inkomen te verwerven. ${ }^{5 s}$

Het moet duidelijk zijn dat er overeenstemming moet zijn welk object van draagkracht als uitgangspunt voor de definiëring van het draagkrachtbeginsel wordt gebruikt. Het maakt voor de definiëring nogal verschil of de eerste of de tweede omschrijving wordt gebruikt. De draagkracht voortvloeiend uit de potentie om inkomen te verwerven is normaal gesproken groter dan de draagkracht voortvloeiend uit het gerealiseerde inkomen. Soms worden beide omschrijvingen door elkaár gebruikt.

Evenals bij het subject kunnen bij het object ook draagkrachtvermeerderende of -verminderende factoren een rol spelen. Ik denk bij het laatste bij voorbeeld aan verwervingskosten.

c. De vaststelling van het tarief is een kwestie van toepassing van het draagkrachtbeginsel. Maar hier spelen politieke factoren. Een voorbeeld van een politieke factor is het voeren van een herverdelingspolitiek. Zoals al is gézegd is de vaststelling van het tarief typisch een voorbeeld van een factor waarbij (verdelings)beginselen en politiek door elkaar lopen. Derhalve is het in casu moeilijk om precies aan te geven waar de werking van het draagkrachtbeginsel ophoudt en waar de herverdelingspolitiek begint.

55. Zie voor het onderscheid Detiger. De samengevoegde inkomens van de gehuwde man en vrouw kan als voorbeeld van het gerealiseerde inkomen als object van draagkracht worden gezien. Het vermogen van mensen om in hun consumptieve behoeften te voorzien kan als voorbeeld van de potentic om inkomen te verwerven worden beschouwd. In: Samenlevingsvormen (2), Geschrift van de Vereniging voor Belastingwetenschap, 1984, no 163, blz. 11. 
Bij het draagkrachtbeginsel moet duidelijk zijn welk aspect van het genoemde beginsel in acht moet worden genomen. ${ }^{56}$ Hierdoor wordt het gevaar vermeden dat een discussie over het beginsel verzandt in een discussie waar langs elkaar heen wordt gepraat.

\subsection{De Wet op de inkomstenbelasting 1964}

\subsubsection{De totstandkoming van de Wet IB 1964 in vogelvlucht}

Eind jaren vijftig, begin jaren zestig, vond in het parlement de langdurige bespreking plaats van wat toen als een grote operatie werd gezien; de invoering van de Wet op de inkomstenbelasting 1964, de Wet op de loonbelasting 1964 en de Wet op de vermogensbelasting 1964. De Wet IB 1964 verving het Besluit van $1941 .^{\text {.7 }}$

De vraag rijst of bij deze bespreking nog enige (verdelings)beginselen werden betrokken? Zo ja, welke opmerkingen werden over deze beginselen gemaakt? In het onderstaande tracht ik door middel van citaten uit de parlementaire geschiedenis de besproken beginselen en de achtergrond waarin deze beginselen werden besproken weer te geven. Ik beperk mij in hoofdzaak tot de parlementaire geschiedenis van de totstandkoming van de Wet IB 1964. Slechts zijdelings komen enige opmerkingen over de andere twee wetten aan de orde.

De Wet IB 1964 is een belangrijk vertrekpunt voor het onderhavige onderzoek, en wel om twee redenen. Op de eerste plaats is de huidige Wet IB 1964 de basis voor de grote wetgevingsoperaties, zoals onder andere de Tweeverdieners- en de OORT-wetgeving, die daarna hebben plaatsgevonden. Op de tweede plaats geeft de parlementaire geschiedenis aardig weer hoe eind jaren vijftig, begin jaren zestig over de al dan niet aanwezige beginselen werd gedacht.

Gezien het aantal opmerkingen over de beginselen in verhouding met opmerkingen over andere onderwerpen betreffende de inkomstenbelasting waren mijns inziens de toenmalige politici ervan overtuigd, dat bepaalde beginselen een zekere werking hadden.'Hieraan doet niet af dat bij de vergelijking van de citaten met die uit de parlementaire geschiedenis van belangrijke wetgevingsoperaties, zoals de Tweeverdieners- en de OORT-wetgeving, blijkt dat deze onderling opmerkelijke overeenkomsten bezitten. ${ }^{58}$

56. Hetzelfde kan worden gezegd van het gelijkheidsbeginsel en de doelmatigheid.

57. De Wet op de inkomstenbelasting 1964 (Stb. 513) is op 16 december 1964 vastgesteld. De wet trad op 1 januari 1965 in werking, met uitzondering van de artikelen 58 en 84 , derde en vierde lid; deze traden op 1 januari 1966 in werking. De Wet op de Vermogensbelasting 1892 en de Wet op de Loonbelasting 1940 werden ook vervangen. De Wet op de vermogensbelasting 1964 trad op 1 januari 1965 in werking en de Wet op de loonbelasting 1964 trad op 1 juli 1965 in werking.

58. Ook in vroegere tijden is een herbezinning over belastingbeginselen nodig geweest, die er nooit echt gekomen is. A.G.J. Haselbekke, Profijtbeginsel en politieke besluitvorming, Stenfert Kroese, 1987, blz. 79 en 80 . 
Het heeft er alles van weg dat de meeste van de toenmalige problemen ook thans nog actueel zijn. ${ }^{39}$

Voordat ik de parlementaire geschiedenis van de Wet IB 1964 bespreek, wil ik graag een zevental opmerkingen maken. Dezé betreffen onderwerpen die een belangrijke rol hebben gespeeld bij de totstandkoming van de Wet IB 1964. Enkele onderwerpen doen nog steeds hun invloed gelden. Veel van het onderstaande hangt samen met datgene wat onder $\S 1.2$ is opgemerkt.

\section{Belastingwetenschap}

Ten eerste werd in die tijd zwaar getild aan het gewicht van hetgeen de belastingwetenschap te berde bracht. 'Voor zover de voortschrijdende belastingwetenschap, die in het bijzonder voor de grondslagen van inkomstenbelasting steeds grote belangstelling heeft getoond, reeds tot afgeronde en algemeen aanvaarde conclusies is gekomen, hebben deze resultaten uiteraard op de samenstelling van het ontwerp een belangrijke invloed gehad. ${ }^{.60}$

\section{Subjectiviteit}

Ten tweede zijn de belastingtheorieën zonder enige subjectiviteit ondenkbaar. 'De geschetste theorieën, uitgezonderd wellicht die van de vermogensvergelijking, hebben dit bezwaar gemeen dat de gestelde criteria zelf een onvoldoend scheidend vermogen hebben en dat daarmede het inkomensbegrip in te sterke mate afhankelijk wordt van subjectieve inzichten. ${ }^{61}$

\section{Gebrek aan tijd}

Ten derde is het opmerkelijk dat de herziening in die tijd niet een fundamentele kon zijn, vanwege het gebrek aan tijd. ${ }^{62}$ 'Vele leden merkten op, dat, wanneer alle ontwerpen van wet in het kader van de algemene belastingherziening tot wet zullen zijn verheven, de ontwikkeling van ons fiscaal recht niet voltooid zal zijn.

59. Zie bij voorbeeld de discussie over de grondslag van de vermogensbelasting.

60. Hofstra, PvdA, minister van Financiën, Tweede Kamer, vergaderjaar 1958-1959, 5380, no 3, blz. 29 en 30 . De Wilde stelde dat de belastingwetenschap in belangrijke mate politiek bepaald is. De Wilde, VVD, kamerlid, Eerste Kamer, vergaderjaar 1964-1965, 12de vergadering, 5380, blz. $193, \mathrm{lk}$.

61. Hofstra, PvdA, minister van Financiën, Tweede Kamer, vergaderjaar 1958-1959, 5380, no 3, blz. 17. Volgens Hofstra kan in het kader van een belasting naar draagkracht in de sector van de zgn. subjectieve belastingen, een vermogensbelasting niet worden gemist. Hofstra, PvdA, minister van Financiën, Tweede Kamer, vergaderjaar 1958-1959, 5380 (vermogensbelasting), no 5, blz. 6 en 7.

62. Hofstra, PudA, minister van Financiën, Tweede Kamer, vergaderjaar 1958-1959, 5380, no 3, blz. 13. De vaste Commissie voor Financiën vindt het onbevredigend dat de uit de vorige eeuw daterende grondslagen van het belastingstelsel, bij de voorgestelde wijze van (partiële) herziening ongewijzigd blijven. De herziening is een technische. Tweede Kamer, vergaderjaar 19611962, 5380, no 16, blz. 1. De regering antwoordt dat dat niet het geval is. Tweede Kamer, vergaderjaar 1962-1963, 5380, no 19, blz. 2. Zie echter ook Tweede Kamer, vergaderjaar 19631964, 5380 (vermogensbelasting), no 30, blz. 2, rk en Handelingen Tweede kamer, vergaderjaar 1963-1964, 5380, blz. 1879, lk. 
Men zal in de toekomst open moeten blijven staan voor moderne theorieën over vraagstukken betreffende het belastingwezen - het vraagstuk van de afwenteling daaronder begrepen - alsmede over die inzake de winstberekening, welke moet worden bezien uit een oogpunt van inkomensverdeling, economische groei en conjunctuurpolitiek. ${ }^{63}$

\section{Gebonden aan tijd en plaats}

De vierde opmerking hangt samen met het laatste citaat. In de parlementaire geschiedenis wordt duidelijk dat de beginselen gebonden zijn aan tijd en plaats. 'De ondergetekenden kunnen dan ook de mening van de Commissie als zouden grondslagen van ons belastingstelsel sedert de vorige eeuw ongewijzigd zijn blijven voortbestaan, niet 'onderschrijven. ${ }^{64}$ En de toenmalige staatssecretaris van Financiën merkt op: 'Maar het aan de orde stellen en overwegen van problemen van belastingheffing kan niet met vrucht geschieden los van de dan actuele situatie en daardoor los van de mogelijkheid tot realisatie. ${ }^{65}$ Hierbij moet in acht moet worden genomen dat de belastingwetgeving de maatschappij volgt en niet zo zeer beïnvloedt. ${ }^{60}$

\section{Politiek}

Een vijfde opmerking betreft de term 'politiek', die veelvuldig in de parlementaire geschiedenis voorkomt, zonder dat duidelijk wordt wat daarmee precies wordt bedoeld. Enige citaten ter illustratie:

1. 'De ondergetekenden zijn van oordeel dat het belastingbeleid in zijn algemeenheid en in zijn wezenlijke onderdelen zo zeer ook politiek geladen is, dat een adviescommissie, die op dit terrein werkzaam zou zijn, zich niet zou kunnen onthouden van in wezen politieke oordeelvellingen. ${ }^{67}$

2. 'Vervolgens mag niet worden vergeten dat de problematiek waaraan de Commissie de studie gewijd zou willen zien, nl. de fundamenten van ons belastingstelsel, de gewenste normale belastingdruk en de verdeling van deze druk over de beide sectoren van de directe en van de indirecte belastingen, een politiek karakter draagt. Zoals de ervaring leert kan men de grondslagen van het fiscale recht, alsmede de totale hoogte en de verdeling van de fiscale lasten niet in ab-

63. Eerste Kamer, vergaderjaar 1964-1965, 5380, no 13, blz. 3.

64. Tweede Kamer, vergaderjaar 1962-1963, 5380, no 19, blz. 2.

65. Tweede Kamer, vergaderjaar 1963-1964, 5380, no 33, blz. 3, rk. Elders werd gerefereerd: '... aan de veranderde betekenis van de draagkrachtgedachte ...' Lucas, KVP, kamerlid, Handelingen Tweede Kamer, vergaderjaar 1963-1964, 54ste vergadering, 5380, blz. 1863, rk.

66. Zie onder andere Kieft, ARP, kamerlid, Handelingen Tweede Kamer, vergaderjaar 1963-1964, 54ste vergadering, 5380, blz. 1873, rk. De Wilde, VVD, kamerlid, Handelingen Eerste Kamer, vergaderjaar 1964-1965, 12de vergadering, 5380, blz. 193. Uit een andere opmerking van hetzelfde kamerlid blijkt dat deze de belastingheffing ook als een sturend instrument wil zien: "De belastingheffing reguleert derhalve de koopkrachtstroom met het doel het maatschappelijk leven in stand te houden en in een bepaalde richting te sturen. De Wilde, VVD, kamerlid, Handelingen Eerste Kamer, vergaderjaar 1964-1965, 12de vergadering, 5380, blz. 194, rk.

67. Commissie van rapporteurs, Eerste Kamer, vergaderjaar 1964-1965, 5380, no 13a, blz. 6 en 7. Het al dan niet instellen van zo'n adviescommissie heeft de gemoederen destijds beziggehouden. 
stracto bepalen. Het zijn in feite steeds concrete, onverbrekelijk met het algemene overheidsbeleid samenhangende politieke beslissingen, welke uiteindelijk aan deze elementen gestalte geven. ${ }^{68}$

3. 'En dat is niet de enige passage van deze memorie van antwoord, waarin de politiek met zoveel woorden wordt genoemd, ja, waar zelfs alles draait om de politiek. ${ }^{\text {, }}$

4. 'De bewindslieden schijnen nu het standpunt te huldigen, dat fiscaal beleid mér en wezenlijker politiek beleid zou zijn dan enig ander beleid. ${ }^{70}$

5. 'Bij tal van onderwerpen en genomen beslissingen speelde niet in de eerste plaats de problematiek, maar de politiek een voorname rol. ${ }^{71}$

Getuige de volgende citaten kan blijkbaar kan een onderscheid worden gemaakt tussen politiek en wetenschap. Hoe dat onderscheid moet worden gemaakt, is echter niet aangegeven.

6. '.. voorstellen, hoe verdienstelijk ook uit wetenschappelijk oogpunt, hebben weinig nut voor de Regering, indien zijn niet kunnen worden ingepast in het kader van de politieke mogelijkheden. ${ }^{, 72}$

7. 'De al of niet bestaande ruimte wordt voorgewend als een al of niet kunnen volgens de wetenschappelijke normen. In feite betreft het merendeels een al of niet willen volgen van zuiver politieke normen. ${ }^{73}$

Politieke ideeën hebben een enorme invloed op de nadere invulling van de belastingheffing. Dit lijkt me onontkoombaar, maar men moet voorkomen dat door het koppelen van de term 'beginsel' aan een partij-politiek belang ten onrechte aan het voeren van een bepaalde politiek een 'gouden randje' wordt gegeven. Anders gezegd, een beginsel is een abstracte opinie voor rechtvaardigheid welke in een maatschappij min of meer algemeen onderschreven wordt.

68. De vaste Commissie voor Financiën, Tweede Kamer, vergaderjaar 1962-1963, 5380, no 19, blz. 2 en Handelingen Eerste Kamer, vergaderjaar 1964-1965, 12de vergadering, 5380, blz. 193, lk.

69. Polak, PvdA, kamerlid, Handelingen Eerste Kamer, vergaderjaar 1964-1965, 12de vergadering, 5380, blz. 1998, lk.

70. Polak, PvdA, kamerlid, Handelingen Eerste Kamer, vergaderjaar 1964-1965, 12de vergadering, 5380, blz. 198, lk.

71. Eerste Kamer, vergaderjaar 1964-1965, 5380, no 13, blz. 4. Deze citaten kunnen met legio worden aangevuld. ' '... waar zij (bewindslieden, $M W$ ) zeggen dat belastingwetenschap in belangrijke mate politiek bepaald is.' De Wilde, VVD, kamerlid, Handelingen Eerste Kamer, vergaderjaar 1964-1965, 12de vergadering, 5380, blz. 193, lk. Vergelijk ook De Geer van Oudegein, CHU, kamerlid, Handelingen Eerste Kamer, vergaderjaar 1964-1965, 12de vergadering, 5380, blz. 209, rk. '... beperken tot enkele hoofdlijnen van het fiscale beleid, alsmede tot enkele algemene politieke aspecten, ...' Eerste Kamer, vergaderjaar 1964-1965, 5380, no 13, blz. 2 en no 13a, blz. 1.

72. Eerste Kamer, vergaderjaar 1964-1965, 5380, no 13a, blz. 7. Er wordt gesproken van zowel wetenschappelijke als politieke criteria. Zijlstra, ARP, kamerlid, Handelingen Eerste kamer, vergaderjaar 1964-1965, 13de vergadering, 5380, blz. 227, lk. De toenmalige staatssecretaris van Financiën, Van den Berge, antwoordt dat de grondslagen van een belastingstelsel politiek bepaald zijn en zich niet lenen voor een wetenschappelijke discussie. Zie onder andere Eerste Kamer, vergaderjaar 1964-1965, 5380, no 13, blz. 4.

73. Polak, PvdA, kamerlid, Handelingen Eerste Kamer, vergaderjaar 1964-1965, 12de vergadering, 5380 , blz. 200 , rk. 
Door ontwikkelingen in de tijd en door afwijkingen in de opinies van de subculturen (partijen) zijn bij de praktische toepassing van die opinie verschillen van opvatting denkbaar. Het beginsel zelf wordt op het hogere abstractieniveau niet aangetast. Maar daarnaast is het denkbaar dat politici standpunten die eigenlijk met het beginsel niet te maken hebben, wel onder het mom van dat beginsel presenteren teneinde daaraan een hogere waarde te doen toekomen. Er moet derhalve onderscheid worden gemaakt tussen een pleidooi dat iemands persoonlijk gekleurde opvatting voor rechtvaardigheid weergeeft en een pleidooi dat bij voorbeeld een klein groepsbelang dient.

\section{Gebruik van nevendoeleinden}

Ten zesde werd het gebruik van nevendoeleinden in de belastingheffing in het algemeen als positief ervaren, zij het dat enige voorzichtigheid in acht moest worden genomen. Zo werd de mogelijkheid van aftrekbaarheid van giften als een buiten de primaire fiscale doeleinden vallend element gezien. ${ }^{74}$ De toenmalige staatssecretaris van Financiën, Van den Berge, zag het gebruik van de belastingheffing voor nevendoeleinden als volgt: 'Ik zie belastingheffing toch in de eerste plaats als een probleem van verdeling van lasten. Als belangrijk facet komt daarbij het facet van economische en conjuncturele politiek. ${ }^{75}$

Dat het gebruik van de belastingheffing voor nevendoeleinden voorzichtig moest worden gehanteerd blijkt uit het volgende: '... versterkt door een verruiming van het oorspronkelijk enige doel van de belastingheffing - het verkrijgen van middelen om van jaar tot jaar de uitgaven te dekken - met andere doelstellingen, verruiming welke het gevolg is van het veld winnen van de gedachte, dat de van het algemeen overheidsbeleid deel uitmakende fiscale politiek steun kan bieden aan het overheidsbeleid op economisch, sociaal en cultureel terrein. Nochtans behoort te worden bedacht, dat de mogelijkheden tot het in de fiscale politiek tot gelding brengen van economische, sociale of culturele doeleinden van algemeen overheidsbeleid niet moeten worden overschat. ${ }^{76}$

74. Tweede Kamer, vergaderjaar 1962-1963, 5380, no 19, blz. 70 en Handelingen Tweede Kamer, vergaderjaar 1963-1964, 58ste vergadering, 5380, blz. 1992, lk.

75. Van den Berge, staatssecretaris van Financiën, partijloos, Handelingen Eerste Kamer, vergaderjaar 1964-1965, 13de vergadering, 5380, blz. 218, lk. Een soortgelijke opmerking van de staatssecretaris: '... belangrijke budgettaire eisen de ideale regelingen en verhoudingen, die men zou willen, doorkruisen, maar ook door de moderne visie op de functie van het belastingrecht telkens belangrijke economische, sociale, soms culturele motieven hun desintegrerende invloed op een dergelijke fiscale constructie zullen uitoefenen.' Van den Berge, staatssecretaris van Financiën, partijloos, Handelingen Tweede Kamer, vergaderjaar 1963-1964, 54ste vergadering, 5380, blz. 1893, rk.

76. Hofstra, PvdA, minister van Financiën, Tweede Kamer, vergaderjaar 1958-1959, 5380, no 3, blz. 12. Ook thans is Hofstra dezelfde mening toegedaan. Gebruik is toegestaan, maar dan moet wel duidelijk zijn dat de belastingheffing het enige, of althans het meest doelmatige, instrument is om het belastingureemde doel te dienen. W.H.C. Zuidgeest, Afscheid Hofstra, Weekblad voor fiscaal recht, 1994, no 6110, blz. 974. 
Een laatste opmerking betreft de rol van pressiegroepen. Het fenomeen van de pressiegroepen kwam voornamelijk tot uitdrukking in de discussie over het al dan niet instellen van een adviesorgaan inzake belastingwetgeving. 'De beraadslagingen in en de adviezen van dat orgaan (destijds gewenst adviesorgaan belastingwetgeving, $M W$ ) zouden aldus meer worden de mening van deze vertegenwoordigende deelbelangen (belangengroeperingen, $M W$ ), zouden veel meer het resultaat worden van een worstelpartij van deze deelbelangen dan een soort objectieve mening, boven de partijen verheven van een beperkt aantal belastingrechtgeleerden.' $\pi$

Dat verscheidene groepen belastingplichtigen wensen hebben, was ook duidelijk. 'Een nog verdergaande tegemoetkoming op dit punt zou tekort doen aan de rechtvaardigheid van de lastenverdeling, die met name bij de zwaar drukkende inkomstenbelasting ongetwijfeld ten aanzien van alle groepen van belastingplichtigen wel enige levende wensen onvervuld moet laten. ${ }^{.78}$

\subsubsection{De beginselen genoemd in de parlementaire geschiedenis van de Wet IB 1964}

De parlementaire geschiedenis van de Wet IB 1964 is wat de beginselen betreft interessant. De volgende indeling kan worden gemaakt:

1. Verdeling van lasten;

2. het draagkrachtbeginsel;

3. het gelijkheidsbeginsel;

4. het. yereenvoudigingsstreven;

5. budgettaire overwegingen.

\section{Verdeling van lasten}

Belastingheffing legt aan burgers lasten op. Zoals in $\S 1.3$ naar voren is gekomen, is door de tijden heen naar een criterium voor een rechtvaardige verdeling van die lasten gezocht. De grondslagen van de inkomstenbelasting hebben de gemoederen geruime tijd beziggehouden. De wetgeving die vervangen diende te worden was niet zonder grondslagen: '... dat de bestaande wetgeving ook niet geheel arbitrair is, dat zij, ondanks historisch bepaalde vorm, veeleer is voortgekomen uit fundamentele structuren en uit fundamentele waardeoordelen. ${ }^{77}$ Desondanks werd het noodzakelijk gevonden de grondslagen te verbeteren. 'Ligt de betekenis van de wetsvoorstellen voor het fiscale regime hier te lande in de verbetering van de grondslagen waarnaar de belastingen van het inkomen, de winst en het vermogen worden geheven, hoogte en verdeling van de belastingdruk vormen

77! Zijlstra, ARP, kamerlid, Handelingen Eerste Kamer, vergaderjaar 1964-1965, 12de vergadering, 5380 , blz. 206, lk en rk.

78. Eerste Kamer, vergaderjaar 1964-1965, 5380, no 13a, blz. 9.

79. Thurlings, KVP, kamerlid, Handelingen Eerste Kamer, vergaderjaar 1964-1965, 12de vergadering, 5380 , blz. 201, rk. 
de complementerende factoren welke het fiscale klimaat te onzent bepalen. ${ }^{80}$ Dit is mijns inziens een belangrijke stellingname. Enerzijds wordt gesproken over grondslagen van belastingen en anderzijds over hoogte en verde-ling van de belastingdruk. Dit blijken twee verschillende elementen te zijn.

De verdelende rechtvaardigheid kan volgens een kamerlid niet op zich zelf staan. 'Als wij alleen zouden kijken naar de verdelende rechtvaardigheid als leidend beginsel in de belastingpolitiek, dan zouden wij alleen een progressieve loon- en inkomstenbelasting kunnen hebben. ${ }^{\text {,1 }}$

Bij de bestudering van de parlementaire geschiedenis wordt duidelijk dat een sociaal aspect - ongeacht wat dit aspect ook verder moge inhouden - van belang is.

'Het sociale aspect van de verdelende rechtvaardigheid, is weliswaar ook naar hun mening van zeer grote betekenis, maar daarnaast moeten tot hun recht koI men de eisen van een innerlijk redelijke en verantwoorde belastingstructuur, alsmede - bij deze ontwerpen - van de economische doelmatigheid., ${ }^{82}$

In dit verband moet ook de discussie rondom het al dan niet invoeren van de vermogenswinstbelasting worden gezien. 'De vermogenswinstbelasting is niet alleen een fiscaal vraagstuk, het is ook een sociaal vraagstuk. Het is een zaak van rechtvaardiger vermogens- en inķomensverdeling. ${ }^{, 83}$

Naast het criterium van de verdelende rechtvaardigheid, dienen andere eisen, zoals doelmatigheid in acht te worden genomen. 'Wij hebben in het voorlopig verslag gezegd, dat wij dit sociale aspect van de verdelende rechtvaardigheid zowel

80. Zijistra, ARP, minister van Financiën, Tweede Kamer, vergaderjaar 1959-1960, 5380, 6000, no 9, blz. 18. Ook bij de vennootschapsbelasting is de gedachtensfeer van algemeenheid en gelijkheid van Jasten van belang. Tweede Kamer, vergaderjaar 1958-1959, 5380, no 3, blz. 16.

81. Zijlstra, ARP, kamerlid, Handelingen Eerste Kamer, vergaderjaar 1964-1965, 12de vergadering, 5380 , blz. 208, rk.

82. Eerste Kamer, vergaderjaar 1964-1965, 5380, no 13, blz. 5 en no 13a, blz. 7. Zie ook Zijlstra, ARP, kamerlid, Handelingen Eerste Kamer, vergaderjaar 1964-1965, 13de vergadering, 5380, blz. 227, rk.

83. Van Urk, PvdA, kamerlid, Handelingen Tweede Kamer, vergaderjaar 1963-1964, 54ste vergadering, 5380, blz. 1860, lk. Over de invoering van deze belasting was niet een ieder het eens. Een soortgelijke opmerking: 'Het laten bestaan van de mogelijkheid, dảı beduidende inkomsten belastingurij kunnen worden genoten, moet naar hun oordeel bepaaldelijk in strijd worden geacht met de opvattingen, die in ons land ten aanzien van een rechtvaardige en billijke belastingwetgeving worden gehuldigd.' Tweede Kamer, vergade rjaar 1961-1962, 5380, no 16, blz. S. Handelingen Tweede Kamer, vergaderjaar 1963-1964, 57ste vergadering, 5380, blz. 1969, ik. 'Afgezien'van de vorenstaande bedenkingen tredtn bij een nadere uitwerking van de idee van een belastingheffing over vermogensvoordelen de daaraan uit het oogpunt van rechtvaardigheid klevende bezwaren duidelijk aan het licht. In haar concrete verschijningsvorm mist deze belasting - en dit achten de ondergetekenden het belangrijkste bezwaar - innerlijke redelijkhęid omdat zij wel een deel van alle positieve vermogenswinsten opeist doch de vermogensverliezen voor rekening van de belastingplichtige zelf laat; een gebrek aan redelijkheid dat scherp naar voren treedt indien men haar zou invoeren in een tijd van algemene teruggang.' Zijlstra, ARP, minister van Financiên;. Van den Berge, partijloos, staatssecretaris van Financiën, Tweede Kamer, vergaderjaar 1959-1960, 5380, 6000, no 9, blz. 2. 
uiterst belangrijk vinden als eenzijdig, wanneer het bij uitsluiting als criterium wordt aanvaard voor de beoordeling van de aanvaardbaarheid van dergelijke wetsontwerpen. Wij hebben gezegd, dat het sociale aspect van de verdelende rechtvaardigheid weliswaar van grote betekenis is, maar dat daarnaast tot hun recht moeten komen de eisen van een innerlijke redelijke en verantwoorde belastingstructuur, alsmede b.v. in deze ontwerpen de vraagstukken en punten van economische doelmatigheid. ${ }^{84}$

Resumerend kan worden gezegd dat de belastingheffing een rechtvaardige verdeling van de lasten dient in te houden. De eis van een rechtvaardige verdeling werd naast doelmatigheid als een belangrijke leidraad gezien voor de inkomstenbelasting.

\section{Het draagkrachtbeginsel}

Aan de rechtvaardige verdeling van lasten wordt een nadere invulling gegeven door het draagkrachtbeginsel. Het inkomen bepaalde de draagkracht. 'Het (inkomensbegrip, MW) heeft zich ontwikkeld als een praktisch, empirisch begrip, dat in de loop der jaren ten behoeve van de heffing van deze draagkrachtbelasting is gevormd. ${ }^{\text {'8 }}$ Vergelijkbare citaten: 'Ervan uitgaande, dat het inkomen in zijn geheel ongeacht de inspanning en het risico, waarmede het is verkregen, en onverschillig welke bestemming daaraan wordt gegeven, een verantwoorde, goed hanteerbare maatstaf is voor de individuele draagkracht, achten de ondergetekenden het in strijd met de draagkrachtgedachte de winsten van persoonlijke ondernemers geheel of gedeeltelijk onder een ander fiscaal regime dan dat van de synthetische inkomstenbelasting te brengen. ${ }^{86}$ ' $B$ ij het heffen van belastingen naar het inkomen wordt gestreefd naar een zoveel mogelijk gelijke verdeling van de lasten naar de draagkracht van de contribuabelen. ${ }^{, 87}$

84. Zijlstra, ARP, kamerlid, Handelingen Eerste Kamer, vergaderjaar 1964-1965, 12de vergadering, 5380 , blz. 208, rk. '... dat het toch wel moeilijk is om op basis hiervan te concluderen, dat uit het oogpunt van het sociale aspect (dat betekent, uit het oogpunt van de verdelende rechtvaardigheid, wat ik ook als een belangrijke zaak zie) hier iets a priori scheef moet worden genoemd.' Zijlstra, ARP, kamerlid, Handelingen Eerste Kamer, vergaderjaar 1964-1965, 12de vergadering, 5380, blz. 207, rk. Vergelijk ook Handelingen Eerste Kamer, vergaderjaar 1964-1965, 13de vergadering, 5380, blz. 226, lk, blz. 227, rk. en Eerste Kamer, vergaderjaar 1964-1965, 5380, no 13a, blz. 8.

85. Hofstra, PvdA, minister van Financiën, Tweede Kamer, vergaderjaar 1958-1959, 5380, no 3, blz. 17.

86. Zijlstra, ARP, minister van Financiën, en Van den Berge, staatssecretaris van Financiën, partijloos, Tweede Kamer, vergaderjaar 1959-1960,5390, 6000, no 9, blz. 16. En zie ook Tweede Kamer, vergaderjaar 1958-1959, 5380, no 3, blz. 20.

87. Tweede Kamer, vergaderjaar 1962-1963, 5380, no 19, blz. 21. Citaten met een soortgelijke strekking: 1. 'Wat de inkomstenbelasting betreft, houdt dit in dat aard en wezen van de bestaande synthetische inkomstenbelasting, welke het totale inkomen ongeacht de herkomst onderwerpt aan een belastingheffing naar draagkracht, in het ontwerp van de nieuwe Wet op de inkomstenbelasting 1958 behouden is.' Hofstra, PvdA, minister van Financiën, Tweede Kamer, vergaderjaar 1958-1959, 5380, no 3, blz. 25. 2. 'Het inkomen vormt dan ook een aanknopingspunt bij uitstek voor belastingheffing en wel voor een jaarlijkse belasting naar een - min of meer bestendige - jaarlijkse financiële draagkracht.' Tweede Kamer, vergaderjaar 1962-1963, 5380, no 19, blz. 7. 3. 'Het inkomen bepaalt zo duidelijk het materieel levensniveau, de weistand en de draag- 
De toenmalige minister van Financiën, Hofstra, constateert dat de term 'draagkracht' in het belastingrecht aanleiding heeft gegeven tot vele discussies. Derhalve wil hij de term alleen taalkundig hanteren; 'de term [geeft] uitdrukking aan de gedachte dat aanwezig is het vermogen tot het dragen van geldelijke - en daarmede dus ook fiscale - lasten. ${ }^{\text {} 88}$

Een inkomstenbelasting naar draagkracht werd belangrijk gevonden. Het inkomen van het individu gedurende het jaar was het uitgangspunt. ${ }^{\$ 2}$

\section{Factoren der draagkracht}

Bij de berekening van de draagkracht moet rekening worden gehouden met de zgn. draagkrachtvermeerderende en -verminderende factoren. 'De inkomstenbelasting wordt jaar voor jaar geheven naar een stelsel dat beoogt de totale last over de belastingplichtigen te verdelen naar evenredigheid van ieders draagkracht in elk jaar. Deze draagkracht wordt in beginsel gemeten naar ieders inkomen over een jaar, terwijl op deze meting correcties worden aangebracht, zowel exacte wegens het aanwezig zijn van persoonlijke verplichtingen, van buitengewone

kracht. Het is dan ook wel het meest aangewezen om te dienen als grondslag voor belastingheffing.' De Geer van Oudegein, CHU, kamerlid, Handelingen Eerste Kamer, vergaderjaar 19641965 , 12de vergadering, 5380, blz. 209, rk. 4. '... om het doel van de belastingheffing, een evenwichtige verdeling van lasten naar draagkracht, ...' Hofstra, PvdA, minister van Financiën, Tweede Kamer, vergaderjaar 1958-1959, 5380, no 3, blz. 17. 5. '... wanneer het gaat om de meest wenselijke constellatie van de belastingen naar inkomen en vermogen in onderling verband en georiënteerd op de draagkracht van het individu.' Dit citaat betreft weliswaar de vermogensbelasting, maar is hier cok van toepassing. Hofstra, PvdA, ministervan Financiën, Tweede Kamer, vergaderjaar 1958-1959, 5380, no 5, blz. 1. Opmerkelijk is hetgeen enige leden van de vaste Commissie voor Financiën opmerken over de betaalde vermogensbelasting; deze zou als persoonlijke verplichting in aanmerking moeten worden genomen. 6 . 'Het deel van het bruto-inkomen, waarop door de fiscus in de vorm van een aanslag in de vermogensbelasting reeds beslag is gelegd, kan toch bezwaarlijk in aanmerking genomen worden voor de berekening van de draagkracht, welke op het inkomen is gebaseerd.' Tweede Kamer, vergaderjaar 1961-1962, 5380, no 16, blz. 31. 7. '... onderworpen aan de inkomstenbelasting, welke op de individuele draagkracht is afgestemd.' Zijlstra, ARP, minister van Financiën en Van den Berge, staatssecretaris van Financiën, partijloos, Tweede Kamer, vergaderjaar 1959-1960, 5380, 6000, no 9, blz. 16. 8. '... maar vooral in verband met het doel van de inkomstenbelasting: een evenwichtige verdeling van lasten naar financiële draagkracht. ' '... tot een inkomstenbelasting te kunnen komen welke in het algemene rechtsbewustzijn voldoende fundament heeft.' Tweede Kamer, vergaderjaar 1962-1963, 5380, no 19, blz. 6. Zie cok Tweede Kamer, vergaderjaar 1958-1959, 5380, no 3, blz. 29 en 45 .

88. Hofstra, PvdA, minister van Financiën, Tweede Kamer, vergaderjaar 1958-1959, 5380 (vermogensbelasting), no 5, blz. 5 en 6.

89. Kieft, ARP, kamerlid, Handelingen Tweede Kamer, vergaderjaar 1963-1964, 59ste vergadering, $5380, \mathrm{blz}$. 2044, lk. Onduidelijk was wat precies onder draagkracht moest worden verstaan en welke factoren uiteindelijk de draagkracht bepalen. Vergelijk de Eerste Kamer, vergaderjaar 1964-1965, 5380, no 13a, blz. 14 inzake de Wet op de vermogensbelasting 1964: 'Deze aan het bezit van vermogen ontleende factor van draagkracht als zodanig zien de ondergetekenden als de ook thans nog geldende rechtsgrond voor de vermogensbelasting.' 
lasten en van charitatieve uitgaven, als forfaitaire op grond van het al of niet gehuwd zijn en het kindertal. .90

De buitengewone lasten vinden hun rechtvaardiging in de extremiteit van bepaalde situaties. 'Dit karakter moeten wij zoeken in een zekere calamiteit voor de belastingplichtige, een calamiteit die zijn draagkracht beïnvloedt. Men komt dan ter rechtvaardiging van de fiscale tegemoetkoming bij het beginsel, dat prof. De Langen heeft gekwalificeerd als het tegenslagbeginsel. ${ }^{.91}$

Af en toe is getracht de draagkracht te meten. Ter illustratie: De drempel van $21 / 2 \%$ van de ziektekosten als buitengewone lasten wordt gezien als afbakening van de min of meer normale uitgaven van ziekte van aftrek wegens buitengewone lasten. De drempel van $4 \%$ is gekozen 'om aan te geven bij welke omvang van de totale als buitengewone lasten aan te merken uitgaven van de belastingplichtige zijn draagkracht geacht wordt zodanig zijn te verminderd, dat de belastingheffing moet terugtreden. ${ }^{92}$

\section{Belastingheffing gehuwden}

Een belangrijk maatschappelijk verschijnsel waarbij het moeilijk was - en dat overigens nog steeds is - de juiste draagkrachtvermeerderende of -verminderende factoren toe te rekenen, was het huwelijk. In de totstandkomingsgeschiedenis van de Wet IB 1964 werd inzake de belastingheffing van gehuwden het samenvoegingsstelsel en het splitsingsstelsel besproken. 'Immers, een splitsingstarief kan slechts gebaseerd zijn op de veronderstelling dat twee gehuwden een even groot gezamenlijk inkomen behoeven als twee alleenstaande ongehuwden om gelijke draagkracht te hebben als die twee ongehuwden te zamen. Deze veronderstelling houdt dus in dat van het huwelijk alleen een draagkrachtverminderende werking zou uitgaan als gevolg van het feit dat van het gezamenlijke inkomen twee per-

90. Tweede Kamer, vergaderjaar 1962-1963, 5380, no 19, blz. 74. Aan de draagkrachtvermeerderende en -verminderende factor wordt niet altijd een constante factor toegerekend. Dit illustreert dat de werking van het draagkrachtbeginsel onderhevig is aan tijd en plaats. Een voorbeeld is het voorstel de drempel van de buitengewone lasten te fixeren op $2 \frac{1}{2} \%$ en het voorstel de verlaging van de drempel niet, zoals voorheen bij het eerste, maar pas bij het derde kind te laten beginnen en de verlaging te laten stoppen bij het zesde kind. Dit betekende een verzwaring voor grote gezinnen, die in die tijd veelvuldig voorkwamen. Tweede Kamer, vergaderjaar 1961-1962, 5380 , no 16, blz. 32 en 36.

91. De Wilde, VVD, kamerlid, Handelingen Eerste Kamer, vergaderjaar 1964-1965, 12de vergadering, 5380 , blz. 194, rk.

92. Tweede kamer, vergaderjaar $1962-1963,5380$, no 19, blz. 68. Het fenomeen van de negatieve buitengewone lasten kwam in die tijd aan de orde. Een dergelijke regeling zou niet beperkt dienen te blijven tot de buitengewone lasten, maar ook de persoonlijke verplichtingen, aldus de toenmalige staatssecretaris. Zie cok de volgende opmerking: '... uit overweging, dat, bij een zich op hoog tariefniveau bevindende heffing, de redelijkheid gebiedt ook deze negatieve inkomensbestanddelen ten volle als componenten van draagkracht te aanvaarden.' Tweede Kamer, vergaderjaar 1958-1959, 5380, no 3, blz. 46. Zie ook Tweede Kamer, vergaderjaar 1961-1962, 5380, no 16, blz. 31. Alleen die belastingplichtigen wiens draagkracht door de buitengewone uitgaven nadelig worden beïnvloed, moet worden tegemoetgekomen. Handelingen Tweede Kamer, vergaderjaar 1963-1964, 58ste vergadering, 5380, blz. 1989, rk.

Vergelijk de discussie in de OORT-wetgeving inzake de negatieve persoonlijke verplichtingen. Tweede Kamer, vergaderjaar 1963-1964, 5380, no 33, blz. 34. 
sonen moeten leven - en niet tevens ook een draagkrachtvermeerderende - t.w. een besparende - werking. ${ }^{.93}$

'Het verwaarlozen van deze progressie bij toenemend loon van de man is duidelijk in strijd met het principe van de inkomstenbelasting, dat de draagkracht van een echtpaar door het gezamenlijke inkomen van man en vrouw wordt bepaald. ${ }^{94}$

Ten aanzien van de belastingheffing van de werkende gehuwde vrouw werd ervan uit gegaan dat een correctie nodig was om rekening te houden met het verlies van een draagkrachtvermeerderende factor van het verrichten van huishoudelijke arbeid door het buitenshuis gaan werken van de gehuwde vrouw. 'Dienaangaande wijst de bewindsman erop dat de regeling voor de werkende gehuwde vrouw een correctie vormt op de in deze gevallen wel zwaar wegende druk van de progressie, veroorzaakt door de samentelling van de inkomens van man en vrouw. Hierbij moet worden bedacht dat de arbeid van de werkende gehuwde vrouw de besparende invloed die van haar huishoudelijke arbeid pleegt uit gaan, vermindert, terwijl zij zich zelf ook vaak geplaatst ziet voor hogere kosten. ${ }^{95}$

Samenvoeging van de inkomens van de gehuwde man en vrouw blijft het uitgangspunt. 'Daarbij stelt hij voorop dat er naar zijn mening geen sprake kan zijn van een inbreuk op het ook in de thans ingediende ontwerpen aanvaarde beginsel van de samenvoeging van inkomens en vermogens van echtgenoten. ${ }^{9 \%}$

\section{Het gelijkheidsbeginsel}

Het gelijkheidsbeginsel stond begin jaren zestig hoog aangeschreven. 'Belangwekkend is de hiervoren geschetste gedachte reeds hierom, omdat zij ertoe komt om met een beroep op het desideratum van een gelijke behandeling van gelijke gevallen - het leidende beginsel'van het belastingrecht en trouwens van alle recht de grondvesten van onze historisch gegroeide belastingheffing naar inkomen en winst aan te tasten. ${ }^{97}$. Een soortgelijk citaat: 'Een belastingheffing echter, welke het rechtsbeginsel van de gelijkheid op het stuk van financiële lasten tot uitdrukking beoogt te brengen, zal zich moeten richten op de materiële werkelijkheid in haar financiële betekenis voor betrokkenen. ${ }^{, 98}$

93. Tweede Kamer, vergaderjaar 1962-1963, 5380, no 19, blz. 77 en Handelingen Tweede Kamer, vergaderjaar 1963-1964, 58ste vergadering, 5380, blz. 1995, tk en blz. 1996, lk.

94. Tweede Kamer, vergaderjaar 1962-1963, 5380, no 19, blz. 79.

95. Tweede Kamer, vergaderjaar 1963-1964, 5380 (loonbelasting), no 31, blz. 7, rk. De aftrekbare kosten inzake arbeid en woon- werkverkeer hebben overigens destijds voor de nodige hoofdbrekens gezorgd. Zie onder andere Tweede Kamer, vergaderjaar 1963-1964, 5380, no 137, blz. 2 en no 119 , blz. 6.

96. Hofstra, PvdA, minister van Financiën, Tweede Kamer, vergaderjaar 1958-1959, 5380, no 3, blz. 27 en 28 . De eis van samenvoeging heeft thans aan betekenis ingeboet, omdat de positie van de gehuwde vrouw zelfstandiger is geworden. Zie ook Eerste Kamer, vergaderjaar 1964-1965, 5380 , no 13 , blz. 5 , waar gesproken wordt van een belastingheffing als onderdeel van de maatschappijstructuur, welk evolueert naar tijd en plaats.

97. Zijlstra, ARP, minister van Financiën, en Van den Berge, staatssecretaris van Financiën, partijloos, Tweede Kamer, vergaderjaar 1959-1960, 5380 en 6000, no 9, blz. 16.

98. Tweede Kamer, vergaderjaar 1962-1963, 5380, no 19, blz. 55 . 
Opmerkelijk is de volgende opmerking over andere samenlevingsvormen dan het huwelijk. 'Het instituut van het huwelijk neemt een zo centrale plaats in de samenleving in, dat sommige feitelijke situaties welke op enkele punten met de maatschappelijke leefwijze van gehuwden te vergelijken zijn, daarmede in genen dele op één lijn gesteld kunnen worden, ook niet in fiscale zaken. ${ }^{99}$

\section{Het vereenvoudigingsstreven}

De ingewikkeldheid van de belastingheffing kan zich op vele terreinen voordoen. Deze kan variëren van het invullen van het aangiftebiljet tot de belastingwet. De wens tot vereenvoudiging kent derhalve ook vele vormen.

De roep om vereenvoudiging is in de loop der tijden regelmatig naar voren gekomen. Uit het volgende valt af te leiden dat al in 1892 werd beoogd de belastingheffing te vereenvoudigen. '... met de door de wetgever van 1892 uitdrukkelijk te kennen gegeven bedoeling - t.w. het vereenvoudigen van de taak van de belastingplichtigen bij de berekening van hun vermogen - .... ${ }^{100}$

In 1948 was de wens de belastingheffing te vereenvoudigen wederom groot. In dat jaar werd door de toenmalige minister van Financiën Lieftinck een zgn. Commissie tot vereenvoudiging van de belastingwetgeving ingesteld. ${ }^{101}$ Aan deze commissie werd opgedragen te onderzoeken welke vereenvoudigingen zowel in de belastingwetgeving zelf, als in de uitvoering daarvan zouden moeten worden tot stand gebracht. Tevens dienden enige voorstellen daartoe te worden gedaan. De voorstellen zijn uitgewerkt in concept-wetsontwerpen. De belastingherziening is begonnen vanuit de voorstellen van de vereenvoudigingscommissie. ${ }^{102}$ Door invoering van de Wet op de inkomstenbelasting 1964 werd geacht een belangrijke stap naar een vooruitgang op het gebied van eenvoud, duidelijkheid en overzichtelijkheid te zijn gezet. ${ }^{103}$

De vereenvoudiging van de belastingwetgeving ging niet geheel vlekkeloos. De vereenvoudiging van het fiscale rechtsgeheel kon slechts worden verwezenlijkt, indien tot een algemene herziening van het belastingrecht werd overgegaan en niet alleen door het tot stand brengen van een vereenvoudiging van bepaalde ingewikkeld geachte onderdelen, aldus de memorie van toelichting. ${ }^{104}$ In ieder geval werd duidelijk dat het uitvoeren van de opdracht tot vereenvoudigen een tijdrovende was. 'De aan de vereenvoudigingscommissie verstrekte opdracht om na te gaan, hoe op korte termijn tot een vereenvoudiging van de fiscale wetgeving ware te komen, was in de praktijk onvervulbaar gebleken. ${ }^{105}$

99. Tweede Kamer, vergaderjaar 1962-1963, 5380, no 19, blz. 83.

100. Tweede Kamer, vergaderjaar 1962-1963, 5380 (vermogensbelasting), no 21, blz. 9.

101. Zie onder andere Eerste Kamer, vergaderjaar 1964-1965, 5380, no 13, biz. 1.

102. Tweede Kamer, vergaderjaar $1958-1959,5380$, no 3, blz. 11 en no 19 , blz. 63 . Handelingen Tweede Kamer, vergaderjaar 1963-1964, 54ste vergadering, 5380, blz. 1868, rk en blz. 1873, lk.

103. Hofstra, PvdA, minister van Financiën, Tweede Kamer, vergaderjaar 1958-1959, 5380, no 3, blz. 25.

104. Tweede Kamer, vergaderjaar 1958-1959, 5380, no 3, blz. 11.

105. Eerste Kamer, vergaderjaar 1964-1965, 5380, no 13, blz. 2. Zie ook de toenmalige staatssecretaris Van den Berge, die pessimistisch was ten aanzien van de vereenvoudiging. Handelingen Tweede Kamer, vergaderjaar 1963-1964, 55ste vergadering, 5380, blz. 1895, lk. 
Eenvoud staat blijkbaar tegenover draagkracht: 'Het is van belang dit bij de beoordeling van de vraag of hier het aspect van de eenvoud op verantwoorde wijze tegenover dat van de heffing naar draagkracht is afgewogen, voor ogen te houden. ${ }^{106}$

Tussen draagkracht, het rechtvaardigheidsbeginsel, enerzijds en het vereenvoudigingsstreven anderzijds dient een evenwicht te worden gevonden. Volgens de vaste Commissie voor Financiën dient met betrekking tot persoonlijke verplichtingen de voorkeur te worden gegeven aan een eenvoudige regeling boven een theoretisch beter verdedigbare, doch ingewikkeldere regeling. ${ }^{107}$

\section{Budgettaire overwegingen}

Budgettaire overwegingen hebben veelal een beperkende functie; de volledige uitvoering van een principe kan door budgettaire overwegingen worden begrensd. Zo werd dan ook gewezen '... op de beperkingen, die uit budgettair oogpunt geboden zijn."108

De vaste Commissie voor Financiën vroeg zich af of naast de progressie budgettaire redenen bij de samenvoeging van het inkomen van man en vrouw een rol hebben gespeeld. ${ }^{109}$

Uit de parlementaire geschiedenis wordt duidelijk dat de budgettaire zijde van voorgestelde wetswijzigingen en amendementen vaak niet precies gegeven kan worden. 'Er zijn nl. onvoldoende gegevens voorhanden om voor elke budgettaire post een uitsplitsing te maken, hetzij naar bepaalde vermogensgroepen, hetzij naar bepaalde inkomensgroepen, hetzij naar een afzonderlijke groep als die der bejaarden. ${ }^{.110}$

Ten aanzien van de loonbelasting: 'In dit verband herhaalt de bewindsman zijn naar aanleiding van punt 3 gedane toezegging de invoering van een vereenvoudigd aangiftebiljet te zullen overwegen.' Tweede Kamer, vergaderjaar 1963-1964, 5380 (loonbelasting), no 31, blz. 9, rk.

106. Tweede Kamer, vergaderjaar 1962-1963, 5380 (vermogensbelasting), no 21, blz. 8. '... die noopt tot een afweging van eenvoud tegenover billijkheid.' Eerste Kamer, vergaderjaar 1964-1965, 5380 , no $13 a$, blz. 2.

107. Tweede Kamer, vergaderjaar 1961-1962, 5380, no 16, blz. 28.

108. Hofstra, PudA, minister van Financiën, Tweede Kamer, vergaderjaar 1958-1959, 5380, no 3, blz. 12. Een kamerlid maakt de volgende opmerking: 'De verhoging van de tarieven in 1951 met terugwerkende kracht kan gebillijkt worden, omdat dit een nasleep was van noodgedwongen verhoging van de defensielasten.' De Wilde, VVD, kamerlid, Handelingen Eerste Kamer, vergaderjaar 1964-1965, 12de vergadering, 5380, blz. 197, rk.

109. Tweede Kamer, vergaderjaar 1961-1962, 5380, no 16, blz. 8. Citaten met een soortgelijke strekking: 1. 'Zoals gezegd, betekent dit dat het voorstel reeds om budgettaire redenen niet kan worden aanvaard.' Tweede Kamer, vergaderjaar 1962-1963, 5380, blz. 23. 2. '... en dat ook de budgettaire zijde van deze zaak een grens stelt.' Tweede Kamer, vergaderjaar 1963-1964, 5380 (vermogensbelasting), no 30 , blz. 1. 3. ‘... - dikwijls ook onder druk van wisselende budgettaire overwegingen -...' Van den Berge, staatssecretaris van Financiën, partijloos, Handelingen Tweede Kamer, vergaderjaar 1963-1964, 55ste vergadering, 5380, blz. 1892, rk.

110. Eerste Kamer, vergaderjaar 1964-1965, 5380, no 13a, blz. 3. Zie ook Handelingen Tweede Kamer, vergaderjaar 1963-1964, 57ste vergadering, 5380, blz. 1955, $1 \mathrm{k}$. 
Opmerkelijk bij de behandeling van de vele amendementen is dat de amendementen die geld kostten, aan het eind van de beraadslaging zouden worden behandeld. Er werd bezien of er nog een budgettaire ruimte over was, alvorens over bepaalde amendementen te beslissen. ${ }^{\text {II }}$

\subsection{Probleemstelling}

De Wet IB 1964 heeft de laatste jaren een aantal, niet altijd onbetwiste wetswijzigingen ondergaan. In dit onderzoek ga ik na of blijkens latere wetswijzigingen de oude beginselen nog gelden. ${ }^{112}$

Voor de zuiverheid van de discussie is het noodzakelijk een onderscheid tussen de motieven te maken. Een eerste groep betreft de motieven inzake de rechtvaardigheidsbeginselen, dat wil zeggen, de ideeën van de wetgever omtrent een eerlijke verdeling van de lasten .over de burger.

Dit blijkt ook uit het volgende statement naar aanleiding van het recente wetsvoorstel inzake de beperking van de mogelijkheden tot overdracht van de basisaftrek in het kader van het streven naar een verdergaande individualisering. De Raad van State begint zijn commentaar met de volgende opmerking: 'De loonen inkomstenbelasting wordt in beginsel naar draagkracht geheven. ${ }^{113}$ Naar alle waarschijnlijkheid is in het belastingrecht het meest voorkomende rechtvaardigheidsbeginsel het draagkrachtbeginsel. Het draagkrachtbeginsel kan als een nadere invulling van het gelijkheidsbeginsel worden gezien. Heffen naar draagkracht impliceert een. zodanige verdeling van lasten dat een ieder een gedeelte van zijn verdiende inkomen naar draàgkracht moet afstaan aan de belastingheffer. ${ }^{114}$

111. Zie o.a. Handelingen Tweede Kamer, vergaderjaar 1963-1964, 57ste vergadering, 5380, blz. 1963, rk en Handelingen Tweede Kamer, vergaderjaar 1963-1964, 58ste vergadering, 5380, blz. 1976 , lk.

112. In dit verband is ook belangrijk hetgeen Wiarda zegt over topica. Deze zijn nauw verwant met rechtsbeginselen en hebben zowel een objectieve als een subjectieve inslag en hebben nooit meer dan relatieve betekenis. Objectief betekent: door alle 'verstandigen' worden bepaalde begrippen voor waar aangezien en waar een zekere consensus wordt verondersteld. Subjectief betekent dat er geen absolute geldigheid aan kan worden toegekend en dat de rechter derhalve naar eigen inzicht uitzonderingen op de topica kan maken. Zie G.J. Wiarda, Drie typen van rechtsvinding, 3e druk, Zwolle, 1988, blz. 114.

Het volgende toont eveneens de relativiteit van de rechtsbeginselen aan: '... dat de kracht waarmede rechtsbeginselen zich doen gelden, een zeer verschillende kan zijn; soms hebben zij bijkans absolute gelding, maar meestal is hun gelding slechts relatief en komen zij voor toepassing buiten het gebied waarop de wetgever er zich duidelijk door liet inspireren, niet of slechts in beperkte mate in aanmerking.' G.J. Wiarda, t.a.p., blz. 111.

113. Voorstel van wet van de leden De Korte en Van Rey tot wijziging van de Wet op de inkomstenbelasting 1964 en de Wet op de loonbelasting 1964 met het oog op een beperking van de mogelijkheden tot overdracht van de basisaftrek in het kader van het streven naar een verdergaande individualisering, Tweede Kamer, vergaderjaar 1993-1994, 23 231, A, biz. 1.

114. In hoofdstuk 7 komt de inhoud van de rechtvaardigheidsbeginselen aan de orde. De rechtvaardigheidsbeginselen worden in dat hoofdstuk geplaatst tegenover de doelmatigheid. 
Daarnaast is er een andere groep motieven die ik zou willen aanduiden als rechtvaardigingsmotieven in ruime zin. Het betreft hier gronden welke voor de wetgever een belangrijke rol spelen bij de totstandkoming van de wet, ten aanzien waarvan echter (nog) niet van een rechtvaardigheidsbeginsel kan worden gesproken. Veelal beperken de hierbedoelde motieven de werking van de rechtvaardigheidsbeginselen. Onder de tweede groep motieven versta ik in ieder geval: de doelmatigheidsmotieven, de budgettaire motieven en de zgn. politieke motieven, waaronder die van pressiegroepen. Bovendien worden met politieke motieven die motieven bedoeld die met partijpolitieke belangen te maken hebben. ${ }^{115}$ Andere van belang zijnde motieven worden, indien ter sprake komend, afzonderlijk genoemd.

In de parlementaire stukken maakt de wetgever melding van zijn motieven voor het in het leven roepen van de betreffende regels. De wetsgeschiedenis fungeert derhalve als de bron bij unitstek van ḍ़it onderzoek.

Ik maak hierbij een kanttekening, Aan het bestuderen van beginselen is de aanwezigheid van subjectieve elementen enigszins inherent. Beginselen kunnen niet met volledig zuiver wetenschappelijke normen worden ingevuld.$^{116}$ De invloed van subjectieve elementen bij het onderzoek naar de door de wetgever gebezigde beginselen kan niet helemaal worden geëlimineerd. Hiermee wil niet gezegd zijn dat de toepassing van beginselen zonder enige objectieve criteria kan geschieden; een zekere mate van consistentie en duidelijkheid moet aanwezig zijn.

Met inachtneming van hetgeen in $\S 1.3$ en $\S 1.4$ over de beginselen reeds is opgemerkt, kan met betrekking tot het verschijnsel van de belastingheffing een tweeledige probleemstelling worden geformuleerd:

1. Welke beginselen worden in de Wet. IB 1964 en in enige wijzigingswetten gebruikt? Zijn deze beginselen inherent aan het belastingrecht, of niet?

2. Hoe gaan de personen en instanties die bij het wetgevingsproces zijn betrokken met de beginselen om? Zijn dezen daarin consequent of niet?

Hierbij komt ook de kwestie betreffende de al dan niet van tijd en plaats afhankelijke werking van de beginselen aan de orde.

Het onderzoek draait om de vraag of de (oude) beginselen (nog) een rol spelen. Mede gezien de ontwikkeling van de nevendoeleinden van de belastingheffing naast de hoofdfunctie als inkomstenbron voor de overheid, is dat een interessante vraag. Aan het eind van het onderzoek beantwoord ik de vraag wat uiteinde-

115. Onder andere kan hier worden gedacht aan de haalbaarheid van een voorstel. Het gewicht van een wetsvoorstel kan variëren. Dit heeft te maken met partijpolitieke verhoudingen. Zo kan het gebeuren dat op het ene moment het wetsvoorstel inzet wordt van een politieke strijd en ingetrokken op een ander moment. Een voorbeeld is de discussie rondom de aftrekbaarheid van de hypotheekrente. De politieke motieven zijn soms moeilijk te achterhalen, maar spelen zeker een rol. Een motief dat misschien tot een beginsel kan leiden, is te vinden in de milieuvriendelijke maatregelen, zoals de milieu-toeslag, de aanpassing van het reiskostenforfait en de reservering van winsten voor bodemsanering.

116. Vergelijk hetgeen in $\S 1.4 .1$ inzake het verschil tussen wetenschappelijke en politieke criteria is gesteld. 
lijk, gezien de huidige praktijk van de wetgeving, over blijft van de (oude) beginselendiscussie.

\subsection{Plan van behandeling}

Het onderzoek is onder te verdelen in twee gedeelten. Het eerste gedeelte betreft de praktijk van wetgeving. Met praktijk bedoel ik de recente wetgeving inzake de Wet IB 1964. Enkele belangrijke wijzigingen in het belastingplichtig subject en het belastbaar object met de daarbij behorende tarieven van de. Wet IB 1964 passeren de revue. In dit onderzoek komen de Wet IB 1964, de zogenaamde Tweeverdienerswetgeving, de daarbij behorende reparatiewetgeving en de OORT-wetgeving aan de orde. ${ }^{117} \mathrm{Ik}$ onderzoek wat wetgever en fiscale auteurs te berde brengen over de gelding van fiscale beginselen daarbij.

Hoofdstuk 2 houdt een beschrijving van de ontwikkeling van de fiscale positie van de gehuwde vrouw in. Dit hoofdstuk vormt een inleiding op hoofdstuk 3. Hoofdstuk 3 betreft de Tweeverdienerswetgeving-I, -II, -III en de reparatiewetgeving die naar aanleiding van de Tweeverdienerswetgeving nodig is geweest.

In hoofdstuk 4 volgt de bespreking van het onderzoek van de commissie-OORT en OORT-I, hèt spraakmakende fiscale wetgevingsprodukt van de laatste jaren. In hoofdstuk 5 worden OORT-II en OORT-III beschreven. OORT-II en OORTIII zijn wat de werking van de beginselen betreft interessante produkten.

Het tweede gedeelte begint in hoofdstuk 6. Hierin wordt de brug geslagen tussen het eerste, meer praktische deel van het onderzoek en het tweede waarin de beginselen aan een nadere beschouwing worden onderworpen. In dit hoofdstuk beschrijf ik welke budgettaire en politieke elementen - waaronder mede begrepen de invloed van pressiegroepen - een rol spelen in besluitvormingsprocessen. De budgettaire en de politieke elementen beïnvloeden de werking van beginselen. $\mathrm{Na}$ dit overgangshoofdstuk worden in hoofdstuk 7 twee te onderscheiden begrippen behandeld, namelijk enerzijds de rechtvaardigheids- of verdelingsbeginselen en anderzijds de doelmatigheid(sbeginselen).

De eisen van rechtvaardigheid en doelmatigheid gelden voor het gehele recht. De rechtvaardigheidsbeginselen kunnen op hun beurt worden onderverdeeld in enerzijds een aantal verdelingsbeginselen, te weten: het draagkrachtbeginsel en het profijtbeginsel, en anderzijds, het gelijkheidsbeginsel. In het kader van dit onderzoek toon ik het speciale belang van deze beginselen voor het belastingrecht aan.

Afsluitend volgen in hoofdstuk 8 enige conclusies.

117. Na de commissie-Oort is er nog een andere commissie geweest, de commissic-Stevens. Deze commissie is ingesteld op 4 april $1990 \mathrm{en}$ had tot taak advies uit brengen over onder andere een verdere vereenvoudiging en verbreding van het draagvlak van de loon-en inkomstenbelasting, een stroomlijning van de ondernemingswinst en een evenwichtige verdeling van de belastingdruk over alleenstaanden, alleenverdieners en tweeverdieners. Aangezien het rapport thans politiek van weinig belang meer is, komen slechts enkele opmerkingen terloops aan de orde. 


\section{Deel I}

Praktijk inzake de inkomstenbelasting 



\section{De ontwikkeling van de fiscale positie van de gehuwde vrouw}

$\therefore$... dat een goede wetgeving, van welke aard ook, alleen maar kan worden verkregen wanneer zij uitgaat van enkele duidelijke, en zowel voor de belanghebbenden als voor de wetsuitvoerder en de rechter begrijpelijke, doelstellingen of beginselen, waaraan dan ook consequent wordt vastgehouden'.

\subsection{Inleiding}

In het eerste gedeelte van het onderzoek ga ik aan de hand van een bestudering van de parlementaire geschiedenis van een aantal wijzigingswetten van de inkomstenbelasting na, welke de motieven van de fiscale wetgever zijn geweest om tot wetswijziging over te gaan. De vraag die hierbij rijst, is welke invloed die motieven hebben op de werking van de beginselen, zo deze al enige werking hebben. Niet alle wetswijzigingen worden bekeken. Van belang zijn dus vooral wetswijzigingen die de omvang van de draagkracht beïnvloeden; derhalve die wetswijzigingen die aanknopen bij de persoonlijke levenssfeer van de belastingplichtigen of die op zijn minst enige invloed op de persoonlijke levenssfeer doen gelden. Ik heb daarom gekozen voor de wijzigingen in de regels aangaande de belastingheffing ten aanzien van alleenstaanden en samenlevingsvormen; de aard van de samenlevingsvorm beïnvloedt de draagkracht. Enige wetsartikelen (zie onder andere artt. 5 en 56 Wet IB 1964) geven aan dat samenlevingsvormen van belang zijn voor de heffing van inkomstenbelasting. Zoals in het vorige hoofdstuk aangetoond, geldt de omvang van de draagkracht als belangrijk uitgangspunt van de huidige inkomstenbelasting.

Voordat ik de wetswijzigingen betreffende de samenlevingsvormen in hoofdstuk 3 bespreek, geef ik de ontwikkeling van de fiscale positie van de gehuwde vrouw weer.

In dit kader komt het gelijkheidsbeginsel op twee manieren aan de orde. Op de eerste plaats komt het gelijkheidsbeginsel bij de bespreking van de ontwikkeling van de fiscale positie van de gehuwde vrouw aan de orde. Dit is de inhoud van dit hoofdstuk. Op de tweede plaats speelt het beginsel een rol in de inkomenspositie waarin de gehuwden en ongehuwde samenlevers verkeren. Dit komt in het volgende hoofdstuk aan de orde. De toepassing van het gelijkheidsbeginsel blijkt in praktijk in de genoemde situaties nogal eens te verschillen.

Hierbij zij opgemerkt dat het onderzoek naar de positie van de gehuwde vrouw

1. H.J. Hofstra, Het splitsingsstelsel. In: Belastingbeschouwingen, Christiaanse-bundel, Kluwer, 1989, blz. 69. 
en het onderzoek naar de tweeverdienerswetgeving enigszins in elkaar overlopen en derhalve is het niet mogelijk een compleet gescheiden behandeling te geven van de twee issues in de opeenvolgende hoofdstukken.

Een voorbeeld van een samenlevingsvorm is het huwelijk. In het fiscale recht speelt de positie van de gehuwde vrouw een belangrijke rol. Dit geldt sterker voor het verleden dan voor het heden.

In de afgelopen decennia is veel gesproken over de veranderde positie van de gehuwde vrouw. Dit heeft te maken met maatschappelijke veranderingen zowel binnen als buiten het huwelijk. Op de eerste plaats doordat veel meer vrouwen dan voorheen, zowel gehuwd als ongehuwd, buitenshuis gaan werken. Op de tweede plaats doordat het ongehuwd samenleven enige maatschappelijke relevantie krijgt. Hoe is het fiscale recht omgegaan met de veranderingen van maatschappelijke opvattingen?

Zeker is dat op fiscaalrechtelijk gebied de wijzigingen veel later dan op civielrechtelijk gebied tot stand zijn gekomen. ${ }^{2}$

Tot in de jaren zeventig acht de belastingwetgever het rechtvaardig dat het inkomen van de gehuwde vrouw aan de man wordt toegerekend. Maar de emancipatie van de vrouw blijkt in deze situatie toch enige verandering te brengen. Derhalve moet gezocht worden naar een beter theoretisch uitgangspunt, zodat de belastingheffing weer aansluit bij de maatschappelijke realiteit. De nadere invulling van de beginselen van belastingheffing, indien aanwezig, blijkt aan tijd en plaats gebonden.

De ontwikkeling van de fiscale positie van de gehuwde vrouw toont aan dat de maatschappelijke realiteit de belastingheffing veelal voor dilemma's stelt wat betreft de uitwerking van haar uitgangspunten, of zo men liever wil, haar (verdelings)beginselen. Vaak moet de belastingheffing zich aan de maatschappelijke realiteit aanpassen. Deze aanpassing roept op zijn minst enige twijfels op over de aanwezigheid van leidende belastingbeginselen. Wellicht moet worden gezegd dat de maatschappelijke ontwikkeling de belastingheffing en haar beginselen 'leidt'.

\subsection{De ontwikkeling van de fiscale positie van de gehuwde vrouw}

Aanvankelijk wordt het door de gehuwde vrouw verdiende inkomen volledig bij dat van de man opgeteld en telt de vrouw, althans de gehuwde vrouw, voor de belastingheffing niet (volledig) mee. Man en vrouw worden geacht een fiscale eenheid te vormen. ${ }^{3}$ Maar zoals gezegd, ook in de belastingwetgeving is de emancipatie enigszins doorgedrongen, zij het dat het nog tot 1973 duurt voordat

2. Zie onder andere H.J. Hofstra en L.G.M. Stevens, Inkomstenbelasting, Fiscale hand- en studieboeken, no 2, 4e druk, KJuwer, 1994, blz. 80 e.v..

3. Zie voor een uitgebreid historische weergave van het samenvoegingsprincipe, F.C. Wijle, Belastingen en gezinseenheid, Een kritische beschouwing inzake verbanden tussen gezinsconnecties en subjectieve belastingheffing, Samson, 1972. Zie ook J.H. Christiaanse, Belastingaftrek voor de gehuwde vrouw, derde druk, Kluwer, 1961, blz. 12. 
er echt verandering in de fiscale positie van de gehuwde vrouw komt. De ontwikkeling van de fiscale positie van de gehuwde vrouw in de Wet IB 1964 is grofweg in de volgende vier perioden in te delen:

1. periode vóor 1962 (2.2.2);

2. periode van 1962 tot 1973 (2.2.3);

3. periode van 1973 tot 1980 (2.2.4);

4. periode van 1980 tot 1990 (2.2.5);

Het genieten van inkomen door de gehuwde vrouw stelt de belastingwetgever voor de vraag hoe en bij wie de desbetreffende inkomsten moeten worden belast. Verschillende opties kunnen ten aanzien van de behandeling van het inkomen van de gehuwde vrouw worden gekozen. Deze opties kunnen variëren van de samenvoegingsstelsels - waaronder het splitsingsstelsel - tot het individuele stelsel. Voor de overzichtelijkheid en duidelijkheid is het gewenst een en ander over de verschillende stelsels uiteen te zetten.

\subsubsection{Samenvoegingsstelsel of individueel stelsel}

Grof weergegeven kunnen voor de toerekening van inkomensbestanddelen van gehuwden en ongehuwd samenlevenden twee stelsels aan de orde komen, nl. het samenvoegingsstelsel en het individuele stelsel. Van belang hierbij is de rol die het draagkrachtbeginsel speelt.

Het samenvoegingsstelsel gaat uit van de veronderstelling dat 'het huwelijk juridisch en maatschappelijk een duurzame verbondenheid tot stand brengt, die niet alleen in ideëel, doch ook in financieel opzicht tot een zodanige eenheid tussen de echtgenoten leidt, dat het totaal hunner inkomsten en vermogens bepalend is voor hun financiële draagkracht, ongeacht van welke zijde zij zijn opgekomen en los van een huwelijksgoederenrechtelijke verhouding. ${ }^{, 4}$ In dit stelsel springt het draagkrachtbeginsel sterk naar voren. Voor draagkracht moet hier gezinsdraagkracht worden gelezen. Samenvoeging wordt gerechtvaardigd door de draagkrachtvermeerderende factoren van het huwelijk. ${ }^{5}$ Dit zogenaamde samenvoegingsstelsel dateert al van $1893 .^{6}$

De ontwikkelingen in de maatschappij, waaronder de emancipatie van de vrouw, maken de toepassing van het draagkrachtbeginsel (lees voor draagkracht: gezinsdraagkracht, $M W$ ) moeilijker. Die verzelfstandiging van de positie van de gehuwde vrouw staat immers de samenvoeging in de weg.

4. F.C. Wijle, t.a.p., blz. 37 .

5. Rapport van de Commissie ter bestudering van de fiscale aspecten van samenlevingsvormen, Geschriften van de Vereniging voor Belastingwetenschap, no 162, Kluwer, 1984, blz. 34.

6. F.C. Wijle, t.a.p., blz. 37. De samenvoeging werd eind jaren vijftig als een beginsel gezien '... van een inbreuk op het ook in de thans ingediende ontwerpen aanvaarde beginsel van de samenvoeging van inkomens en vermogens van echtgenoten.' Tweede Kamer, vergaderjaar 1958-1959, 5380 , no 3 , blz. 28. 
Het samenvoegingsstelsel heeft voor- en nadelen. ${ }^{7}$ Een nadeel van het stelsel uit het oogpunt van gelijkheid is dat het stelsel slechts opgeld kan doen ingeval het samenlevingsverband manifest aanwezig is, zoals bij voorbeeld in geval van een huwelijk, en niet in andere samenlevingsvormen.

Een specifiek voorbeeld van het samenvoegingsstelsel is het splitsingsstelsel. Het splitsingsstelsel brengt de toepassing van het gelijkheidsbeginsel ten aanzien van de gehuwde vrouw het sterkst naar voren. Christiaanse verwoordt het aldus: 'Bij de splitsingsvariant van de samentelling staan man en vrouw als gelijkwaardige individualiteiten sterker op de voorgrond. ${ }^{8}$ Bovendien omzeilt het splitsingsstel-

7. De Commissie ter bestudering van de fiscale aspecten van samenlevingsvormen noemt de volgende voor- en nadelen van het samenvoegingsstelsel.

'Als belangrijkste voordelen van samenvoeging worden genoemd:

a. Het aantal belastingplichtigen dat voor een aanslag in aanmerking komt wordt verlaagd doordat bij samenvoeging van inkomens met én aanslag voor twee natuurlijke personen kan worden volstaan.

b. De toerekening van inkomensbestanddelen aan partners in een samenlevingsvorm kan achterwege blijven.

c. Belastingbesparende constructies tussen partners in een samenlevingsvorm worden vermeden. Daar tegenover staan de volgende nadelen tegen samenvoeging:

a. De loonbelasting dient in vele gevallen niet als eindheffing. Ingeval beide echtgenoten inkomen hebben moet vrijwel steeds een aanslag worden opgelegd. Dit leidt tot een aanzienlijke toename van het aantal aanslagen.

b. Samenvoeging van inkomens vormt voor de niet-verdienende partner een hinderpaal bij de toegankelijkheid van de arbeidsmarkt. Het arbeidsinkomen immers komt bovenop het overige inkomen van beide partners en wordt derhalve zwaar door de progressie getroffen.

c. Samenvoeging kan slechts worden toegepast bij dujdelijk kenbare samenlevingsvormen, zoals het huwelijk. Bij een minder duidelijk kenbare samenlevingsvorm kan in feite dezelfde situatie als in een huwelijk bestaan, zonder dat dit tot samenvoeging van inkomens leidt. Uit een oogpunt van rechtsgelijkheid is dit onbevredigend.'

Zie het rapport van de Commissie ter bestudering van de fiscale aspecten van samenlevingsvormen, Geschriften van de Vereniging voor Belastingwetenschap, no 162, Kluwer, 1984, blz. 34 en 35 .

E.N. Kertzman is het niet eens met het nadeel onder b genoemd. Alleen indien het samenvoegingsstelsel vergeleken wordt met het individuele stelsel, heeft de commissie gelijk; niet indien het samenvoegingsstelsel vergeleken wordt met het huidige stelsel (1984). Zie de bespreking van het rapport van de Commissie bestudering van de fiscale aspecten van samenlevingsvormen, Geschriften van de Vereniging voor Belastingwetenschap, no 163, Kluwer, 1984, blz. 14.

8. J.H. Christiaanse, Christiaanse-bundel, Belastingbeschouwingen, Kluwer, 1989, blz. 63. Andere voorstanders van het splitsingsstelsel: C.P.A. Bakker, Tweeverdieners-derde fase: kruidenierspolitiek, Weekblad voor fiscaal recht, 1984, no 5657, blz. 1352-1355; Hofstra, zij het dat hij een onderscheid maakt tussen gehuwden en ongehuwd samenwonenden. H.J. Hofstra, Het splitsingsstelsel. In: Belastingbeschouwingen, Christiaanse-bundel, Kluwer, 1989, blz. 80 en zie ook P.C. Goosen en R.N.J. Kamerling, Belastinghervorming een noodzaak, Kluwer, 1986, blz. 6. Stevens stelt dat het splitsingsstelsel het beste aansluit bij de belasting naar draagkracht. Bovendien is het splitsingsstelsel neutraal ten opzichte van de rolverdeling en eenvoudiger dan de huidige regeling. L.G.M. Stevens, Belasting naar draagkracht, Kluwer, 1980, blz. 183, L.G.M. Stevens, Solidair en solitair. de relevantie van de leefvorm voor het inkomensbeleid, rede, Kluwer, 1986, blz. 46. Mobach heeft hierop kritiek. Hij stelt dat een keuze voor een behandeling van alleenstaanden om budgettaire redenen niet altijd kan worden gemaakt. Bovendien is het splitsingsstelsel niet altijd neutraal ten opzichte van de rolverdeling binnen het gezin. Ook moeten de 
sel de problematiek van de gelijkstelling van de ongehuwd samenlevenden met de gehuwden. De vorm van het samenlevingsverband heeft geen invloed op de vraag of ongehuwd samenlevenden gelijkgesteld moeten worden met de gehuwden.

Het splitsingsstelsel komt er kort gezegd op neer dat inkomen ingebracht door eén of twee leden van een samenlevingsverband gelijkelijk wordt toegerekend aan ieder der leden.' Veelal wordt in het splitsingsstelsel getracht rekening te houden met draagkrachtvermeerderende factoren ten opzichte van de alleenstaanden en dit geschiedt door het belastbaar inkomen niet te delen door 2, maar door 1,8 of $1,5 .^{10}$ Een nadere motivering van het precieze cijfer wordt vaak niet gegeven, om de eenvoudige reden dat een exacte berekening van de factoren niet mogelijk is. ${ }^{11}$ ( $\mathrm{Zie}$ voor een overzicht van draagkrachtvermeerderende en draagkrachtverminderende factoren hoofdstuk 3.)

Tegenover de verschillende samenvoegingsstelsels staat het stelsel van de individuele belastingheffing. Ieder individu wordt individueel in de belastingheffing betrokken, dat wil zeggen, geen rekening wordt gehouden met een eventuele samenlevingsvorm. ${ }^{12}$

uitvoeringsvoordelen niet worden overschat. $H$. Mobach, Solidair of solitair: een versluierend dilemma. In: Fiscale rechtsbescherming, Leids fiscaal jaarboek, Gouda Quint, 1985, blz. 109-111. Giele is van mening dat de optie betreffende het splitsingsstelsel een louter theoretisch idee is. Zie H.P.A.M. van Arendonk, De Tweeverdienersregeling, Maandblad Belastingbeschouwingen, 1986, no 6, blz. 161. Tot slot J.W. Zwemmer, P.C. Goosen en R.N.J. Kamerling, t.a.p., blz. 48.

9. Bij de behandeling van de OORT-wetgeving wordt het splitsingsstelsel in een noot bij de Handelingen van de Vaste Commissie voor Financiën als volgt omschreven. 'Het (heffings)inkomen wordt eerst verminderd met de toegepaste heffingsvrije som. Op $2 / 3$ factor (factor 1,5 ) respectievelijk $1 / 2$ (factor 2 ) wordt vervolgens het schijventarief - wederom zonder vrije som - toegepast. De aldus verkregen uitkomst wordt dan vermenigvuldigd met 1,5 respectievelijk 2 waaruit het te betalen bedrag resulteert.' De twee verschillende splitsingsfactoren zijn afhankelijk van het aantal personen waaruit een samenlevingsverband bestaat en de omstandigheden waaronder die personen verkeren. Noot 1, Handelingen Tweede Kamer, vergaderjaar 1986-1987, 20 595, blz. $64-20,1 \mathrm{k}$.

10. Een voorbeeld ter illustratie: Stel A, gehuwd met B, heeft een belastbaar inkomen van $f 80.000$; het inkomen van $B$ is nihil. Gedeeld door 2 bedraagt het belastbaar inkomen voor ieder $f 40.000$. Gedeeld door 1,8 bedraagt het belastbaar inkomen $f 44.444,45$. In het verschil van $f 4.444,45$ zijn de draagkrachtvermeerderende factoren verdisconteerd. De keuze voor 1,8 in plaats van 2,0 is gelegen in de waarde van de huishoudelijke arbeid (meestal) verricht door de vrouw èn budgettaire argumenten. Rapport van de Commissie voor de belastingherziening, Graag of niet, Sdu, 1991, blz. 172.

11. H.J. Hofstra en L.G.M. Stevens, Inkomstenbelasting, t.a.p., blz. 82.

12. 'Als belangrijkste voordelen van individuele belastingheffing worden beschouwd:

a. Individuele belastingheffing is in principe neutraal ten aanzien van de beslissing om van een samenlevingsvorm deel te gaan uitmaken.

b. Individuele belastingheffing discrimineert niet tussen de verschillende soorten samenlevingsvormen.

c. De loonbelasting kan bij individuele belastingheffing in vele gevallen eindheffing zijn:

Daartegenover staat als bezwaar tegen individuele belastingheffing dat verschuivingen van inkomensbestanddelen in een stelsel van individuele belastingheffing fiscale voordelen op kunnen leveren.' Rapport van de Commissie ter bestudering van de fiscale aspecten van samenlevings- 
In 1983 zegt de regering het volgende: 'Een nader standpunt ten aanzien van het vraagstuk van individualisering en draagkracht waarnaar van verschillende zijden is gevraagd, is op dit moment echter nog niet mogelijk. De gedachten daarover zijn nog niet voldoende uitgekristalliseerd om op korte termijn tot een afronding te komen. ${ }^{13}$ We schrijven nu 1994 en nog steeds is er geen duidelijk en eenduidig antwoord op de vraag of het wenselijk is over te gaan tot individualisering of niet. ${ }^{14}$ Dit kan ook niet anders omdat het een arbitraire keuze is.

Ter illustratie van het laatste: In de literatuur wordt gesteld dat de keuze voor een bepaalde optie van politieke aard is. ${ }^{35} \mathrm{De}$ vraag rijst of dit betekent dat het noemen van het draagkrachtbeginsel als een etikettering van een politieke beslissing moet worden gezien, daar in het samenvoegingsstelsel in vergelijking tot het individuele stelsel sprake is van een sterkere werking van het draagkrachtbeginsel. In het eerstgenoemde stelsel wordt, in tegenstelling tot het tweede, rekening gehouden met de draagkrachtvermeerderende factor van de samenwoning. Hierbij komt dan ook nog het probleem van het streven naar een gelijke behandeling van de gehuwde man en vrouw. Mijns inziens is het moeilijk het streven naar een gelijke fiscale behandeling van de echtgenoten te combineren met het draagkrachtbeginsel. Aangenomen dat een gehuwde man en zijn vrouw beiden inkomen verdienen, dan kan worden gesteld dat deze twee personen een gezamenlijk inkomen inbrengen. Weliswaar zijn er bij tweeverdieners meer (arbeids)kosten te verwachten dan bij een alleenverdiener, maar hiermee kan toch niet worden ontkend dat hun draagkracht - ook ik weet geen nadere definitie te geven - hoger is dan die van een gezin waarin slechts eén persoon inkomen inbrengt. Immers weinig belastingplichtigen zullen geneigd zijn te gaan werken indien de kosten hoger zijn dan de baten. In geval van een gelijke behandeling zullen zowel man als vrouw voor de draagkrachtvermeerderende factoren van samenwoning en het samen verdienen moeten opdraaien. Indien de inkomens gelijk zijn, is dat nog niet zo'n probleem. Het wordt anders indien de inkomens verschillen, hetgeen gebruikelijk is. Hierbij wordt wel afgezien van eventuele bij-

vormen. Geschriften van de Vereniging voor Belastingwetenschap, no 162, Kluwer, 1984, blz. 44.

Kertzman acht een individueel stelsel in strijd met de gedachte van heffen naar draagkracht. E.N. Kertzman, Belastingheffing van gehuwden en ongehuwden, Fiscale monografieën, no 32, Kluwer, 1979, blz. 146.

Mobach is voorstander van een individueel stelsel werkend met een belastingaftrek. H. Mobach, t.a.p., blz. 110.

13. Tweede Kamer, vergaderjaar 1982-1983, 17 885, no 3, blz. 11, 12.

14. Zie verder het wetsvoorstel van de VVD-kamerleden De Korte en Van Rey tot wijziging van de Wet op de inkomstenbelasting 1964 en de Wet op de loonbelasting 1964 met het oog op een beperking van de mogelijkheden tot overdracht van de basisaftrek in het kader van het streven naar een verdergaande individualisering. Tweede Kamer, vergaderjaar 1992-1993, 23231.

15. Rapport van de Commissie ter bestudering van de fiscale aspecten van samenlevingsvormen, Geschriften van de Vereniging voor Belastingwetenschap, no 162, Kluwer, 1984, blz. 37 en 46. Individualisering- en samenvoegingsidecën gaan niet samen, aldus L.G.M. Stevens in hetzelfde rapport, blz. 17. Zie ook de verschillende meningen van de leden van de commissie. Rapport van de Commissie ter bestudering van de fiscale aspecten van samenlevingsvormen, Geschriften van de Vereniging voor Belastingwetenschap, no 162, KJuwer, 1984, blz. 72 e.v.. 
zondere omstandigheden. Het is mijns inziens moeilijk om een goede keuze te maken. Een regel die bij de keuze van het toepasselijke stelsel in acht moet worden genomen, is dat consistentie van uitgangspunten een vaststaand gegeven moet zijn.

In ieder geval is de keuze voor een bepaald stelsel en daarmee voor de werking van het draagkrachtbeginsel er een van waardeoordelen. Duidelijk is dat een keuze voor het individuele stelsel de werking van het draagkrachtbeginsel beperkt. $^{16}$

\subsubsection{Periode vóór 1962}

De maatschappelijke situatie in de jaren vijftig en zestig is als volgt. De vrouw doet het huishouden. Er zijn in die tijd weinig gehuwde vrouwen die buitenshuis werken. De belastingheffing van die tijd past geheel bij dit beeld en derhalve geldt een volledige heffing over het gezamenlijke inkomen. Het gezamenlijke inkomen is belast bij de man.

Tot 1957 is de gehuwde vrouw handelingsonbekwaam. De handelingsonbekwaamheid is naast de maritale macht van de gehuwde man een goed argument vór samenvoeging van de inkomensbestanddelen. De opheffing van de handelingsonbekwaamheid in 1957 leidt ertoe dat een reden voor samenvoeging wegvalt. Desalniettemin blijft de samenvoegingsregel bestaan.

Uit het bovenstaande valt af te leiden dat de maatschappelijke situatie het politieke denken en daarmee de belastingheffing beïnvloedt. De maatschappelijke situatie kan als een leidende factor voor de nadere invulling van de belastingheffing worden gezien. Ter illustratie kan de volgende zinsnede uit de wetsgeschiedenis worden aangehaald: 'Het door de verschillende leden ter sprake gebrachte vraagstuk van het samenvoegen van de inkomens van echtgenoten moet worden gezien in samenhang met het voor de inkomstenbelasting ter zake gel-

16. Zie ook de commissie-Stevens, die geen duidelijke keuze maakt. De commissie geeft drie visies weer, de individualisering, het splitsingsstelsel en het huidige systeem. Graag of niet, t.a.p., blz. 159. De commissie-Stevens noemt de volgende nadelen van individualisering: ' 1 . Het stelsel is in strijd zowel met de feiten als met het civiele recht en met doel en strekking van de inkomstenbelasting ... 2. De resultaten van het stelsel zijn in strijd met elementaire rechtseisen omdat zij de rechtsgelijkheid op onverantwoorde wijze schenden ... 3. Het stelsel zoekt niet naar een verdeling van de belastingdruk die naar doel en strekking van de belastingwet rechtvaardig kan worden geacht.' Graag of niet, t.a.p., blz. 171.

Het splitsingsstelsel heeft de volgende nadelen: ' 1 . Het splitsingsstelsel sluit niet aan bij het burgerlijk recht omdat dit slechts een wederzijdse verzorgingsplicht kent voor zover de partners niet zelf in hun onderhoud kunnen voorzien ... 2. Het splitsingsstelsel leidt tot een relatief grote belastingverlaging voor hogere inkomens, terwijl er voor inkomens in de eerste schijf niets verandert... 3. Het splitsingsstelsel leidt tot grote uitvoeringsproblemen waarmede of werkgevers of de belastingdienst moeten worden opgezadeld. 4. Het splitsingsstelsel stelt anders dan bij in. dividualisering niet de zorg voor kinderen centraal doch de zorg voor echtgenoten die zich kunnen veroorloven niet te werken. 5 . Het splitsingsstelsel belemmert de arbeidsparticipatie omdat voor de herintredende partner (veelal de vrouw) het marginale tarief van de man gaat gelden. 6. Het splitsingsstelsel beloont schaalvoordelen, terwijl met de extra kosten van tweeverdieners geen rekening wordt gehouden.' Graag of niet, t.a.p., blz. 175. 
dende beginsel (cursivering schrijver dezes) dat alle met het verwerven van inkomen in verband staande aangelegenheden van de gehuwde vrouw geacht worden de man te betreffen. ${ }^{17}$

In 1958 wordt een wetsvoorstel ingediend met de strekking rekening te houden met de extra uitgaven die buitenshuis werken van de gehuwde vrouw met zich brengt. De belastingheffing ten name van de man bleef gehandhaafd. Voor de gehuwde vrouw die betaalde arbeid verrichtte, werd een inkomensaftrek voorgesteld. ${ }^{18}$

In deze periode verschijnen ook enige rapporten die de draagkrachtberekening van het gezin als onderwerp hebben; de draagkrachtberekening van een gezin levert enige problemen op. De rapporten worden geschreven ter verduidelijking van de discussie over de gelijke verdeling van de belastingdruk tussen de gehuwden en de alleenstaanden. Ze schrijven aan een huwelijk enige draagkrachtvermeerderende en -verminderende factoren toe.

In 1958 verschijnt het rapport van de Commissie voor de Statistiek van de Vereniging voor Belastingwetenschap ${ }^{19}$ dat de volgende drie draagkrachtvermeerderende factoren aan het gezin toeschrijft:

1. besparing van uitgaven tengevolge van het voeren van een gezamenlijke huishouding;

2. het verrichten van de huishoudelijke arbeid door de vrouw;

3. de kosten van de voorziening in immateriële behoeften zijn voor ongehuwden hoger dan voor gehuwden.

Als draagkrachtverminderende factor wordt het feit gezien dat in een huwelijk twee personen van eén inkomen moeten leven. ${ }^{20}$ Het inkomen van het gezin is de maatstaf voor draagkracht. ${ }^{21}$ Voor gezin moet de gehuwde man en vrouw worden gelezen.

De compensatie voor de draagkrachtvermeerderende factoren wordt gevonden in de progressie. Een nadere berekening van de progressie wordt echter niet gegeven.22

In 1960 komt een draagkrachtvermeerderende factor, de besparende werking van het huwelijk, in het tarief tot uitdrukking; het tarief voor ongehuwden is ver-

17. Tweede Kamer, vergaderjaar 1953-1954, 3039 , no 5, par. 19, lid 7.

18. De inkomensaftrek bedroeg $f 3$ voor elke dag waarop ten minste 4 uren door de gehuwde vrouw werd gewerkt. Het maximum bedroeg $f 624$ per jaar. In 1960 werd voorgesteld de aftrek te verruimen tot $f 4,50$ voor elke dag waarop ten minste $31 / 2$ uren wordt gewerkt (maximum $f 1.000$ per jaar). Nota Op Weg, Tweede Kamer, vergaderjaar 1979-1980, 15 835, nrs. 1-2, blz. 9.

19. Tarieven inkomstenbelasting voor gehuwden en ongehuwden, Geschrift van de Vereniging voor Belastingwetenschap, no 59, Samson, 1958.

20. Fiscale aspecten van samenlevingsvormen, Rapport van de Commissie ter bestudering van de fiscale aspecten van samenlevingsvormen, Geschriften van de Vereniging voor Belastingwetenschap, no 162, Kluwer, 1984, blz. 19. En zie F.C. Wijle, t.a.p., blz. 32.

21. P. Kavelaars, L.G.M. Stevens, L. Opheikens, Tweeverdieners 1984-1985, Fiscaal- en sociaalrechtelijke aspecten, Kluwer, 1985, blz. 1.

22. Cursus Belastingrecht, Inkomstenbelasting, H. Mobach, L.W. Sillevis, Gouda Quint, blz. 22 (Groene banden). 
laagd. ${ }^{23}$ In 1961 komt een correctie op het tarief voor de gevallen waarin de besparende werking van het huwelijk geheel of gedeeltelijk wegvalt. Het buitenshuis werken van de gehuwde vrouw kan extra uitgaven met zich brengen. De compensatie hiervoor wordt gevonden in de verhoging van de belastingvrije som. Hier wordt de besparende werking van het huwelijk dan wel het wegvallen daarvan gezien als een zodanige draagkrachtvermeerderende dan wel draagkrachtverminderende factor, dat daarmee rekening moet worden gehouden in het tarief. ${ }^{24}$

Resumerend kan worden gezegd dat in deze periode ervan uit wordt gegaan dat het vormen van een gezin per saldo draagkrachtvermeerderend werkt.

Uit de variërende opsommingen van de draagkrachtvermeerderende en draagkrachtverminderende factoren kan worden geconcludeerd dat de invulling van het draagkrachtbeginsel in de loop van de tijd varieert.

Met betrekking tot het gelijkheidsbeginsel merk ik op dat de gelijke behandeling van gehuwden en ongehuwde samenlevers (nog) niet aan de orde komt, als gevolg van de omstandigheid dat ongehuwde samenlevers eenvoudigweg nauwelijks voorkomen.

Op een ander gebied komt het gelijkheidsbeginsel wel ter sprake, maar kent het nog geen toepassing; namelijk ten aanzien van de verhouding tussen gehuwden. Van een gelijke behandeling van de gehuwde man en vrouw is geen sprake, maar de belastingheffing sluit in zoverre aan bij de maatschappelijke realiteit.

\subsubsection{Periode van 1962 tot $1973^{25}$}

De maatschappij verandert en de gehuwde vrouw gaat meer buitenshuis werken. En wederom past de belastingheffing zich daarbij aan.

In 1962 verschijnt de mogelijkheid om een aftrek ten laste van het gezamenlijke inkomen te brengen; deze aftrek dient de kosten die het buitenshuis werken van de vrouw met zich brengt te compenseren. De aftrek bedraagt minimaal $f 500$ en maximaal $f 2.000$ van het inkomen van de man. ${ }^{26}$ De aftrek is gebaseerd op de omvang van het inkomen, niet op de arbeidsduur, hetgeen ook mogelijk zou zijn geweest.

De argumenten voor invoering van de voorgestelde regeling zijn voornamelijk op het draagkrachtbeginsel gebaseerd, t.w.:

'1. het buiten het gezin werken van de gehuwde vrouw kan direct extra uitgaven

23. Nota Op Weg, Tweede Kamer, vergaderjaar 1979-1980, 15 835, nrs. 1-2, blz. 9.

24. Nota Op Weg, Tweede Kamer, vergaderjaar 1979-1980, 15 835, nrs. 1-2, blz. 9.

25. In deze periode wordt het Besluit IB 1941 vervangen door de Wet op de inkomstenbelasting 1964. Deze vervanging heeft geen directe consequenties voor de fiscale positie van de gehuwde vrouw tengevolge gehad.

26. Zie onder andere Tweede Kamer, vergaderjaar 1963-1964, 5380, no 33, bijlage II, blz. 51. Voor de meewerkaftrek werd een bedrag van $f 2.250$ in aanmerking genomen. Bij het ontwerp van de Wet op de inkomstenbelasting 1960 is nog voorgesteld de aftrek te verruimen tot $f 2.750$. Tweede Kamer, vergaderjaar 1963-1964, 5380, no 119, blz. 3. 
voor het gezin met zich meebrengen"7;

2. het verschil in financiële draagkracht tussen een echtpaar, waarvan de vrouw zich geheel aan de huishoudelijke taak kan wijden, en dat waar dat niet het geval is wegens het buiten het gezin werken van de vrouw (de besparende werking van de huishoudelijke arbeid van de vrouw);'

3. wijziging in de privé-sfeer en ten gevolge daarvan in het behoeftenpatroon, waardoor nieuwe of hogere uitgaven van (huishoudelijke) aard kunnen ontstaan. $^{28}$

In deze periode wordt algemeen aanvaard dat het huwelijk een besparende werking heeft. Het wegvallen van de besparende werking door het buitenshuis gaan werken van de gehuwde vrouw dient door middel van de aftrek te worden gecompenseerd. Het gegeven dat het buitenshuis werken van de vrouw inkomensbestedende uitgaven met zich brengt, moet ook in acht worden genomen. ${ }^{x}$

Ten aanzien van de ingebrachte inkomsten blijft de samenvoegingsregel bestaan. De inkomensbestanddelen van de vrouw worden, ondanks dat de gehuwde vrouw in 1965 formeel belastingplichtig wordt, volledig aan de man toegerekend. Formele belastingplicht dient onderscheiden te worden van materiële belastingplicht. Formele belastingplicht stelt voor de gehuwde vrouw materieel niet veel voor. De vraag is of de (gehuwde) vrouw aan dat onderscheid in het dagelijkse leven betekenis toekent.

In 1969 verschijnt een rapport van de commissie-Hofstra over het onderzoek naar mogelijkheden tot vereenvoudiging van de loon- en inkomstenbelasting ${ }^{30}$.

27. Hierbij moet worden gedacht aan kosten voor kinderopvang en voor huishoudelijke hulp. Tweede Kamer, vergaderjaar 1979-1980, 15 835, nrs. 1-2, blz. 9. Zie Hofstra, die van mening is dat de inkomstenbelasting geen rekening moet houden met de mate van inspanning. H.J. Hofstra, Het splitsingsstelsel. In: Belastingbeschouwingen, Christiaanse-bundel, Kluwer, 1989, blz. 73.

28. Nota Op Weg, Tweede Kamer, vergaderjaar 1979-1980, 15 835, nrs. 1-2, blz. 9 en 10. In de parlementaire geschiedenis van de Wet op de inkomstenbelasting 1964 waren enige leden van de vaste Commissie voor Financiën de mening toegedaan dat de extra-kosten van de huishouding in geval de vrouw buitenshuis werkt, in wezen tot het bestedingspatroon behoorden. Tweede Kamer, vergaderjaar 1961-1962, 5380, no 16, blz. 37. Zie ook Tweede Kamer, vergaderjaar 1962-1963, 5380, no 26, blz. 8.

29. Rapport van de Commissie ter bestudering van de fiscale aspecten van samenlevingsvormen, Geschriften van de Vereniging voor Belastingwetenschap, no 162, Kluwer, 1984, blz. 20.

Er wordt uitgegaan van het gegeven dat het buitenshuis werken van de gehuwde vrouw een draagkrachtverminderende werking heeft. Impliciet valt hieruit af te leiden dat de inkomsten van de gehuwde vrouw niet hoog, althans niet hoger dan die van de man, zijn geweest.

Normalerwijze kan mijns inziens worden gezegd dat de gehuwde vrouw die buitenshuis werkt de draagkracht verhoogt, namelijk door het inbrengen van inkomsten in het gezin. Natuurlijk wordt over deze inkomsten $\infty$ kelasting geheven, maar de draagkracht kan groter zijn dan ingeval de vrouw niet buitenshuis werkt, ondanks dat de kosten die het deelnemen aan het arbeidsproces met zich brengt hoger zijn.

Ik ga ervan uit dat de omvang van het inkomen van de man in beide gevallen even groot blifft.

30. Rapport 'Aftrek voor de werkende gehuwde vrouw in de inkomsten- en loonbelasting', Tweede Kamer, vergaderjaar 1968-1969, 10 027. De commissie noemde zes motieven voor een fiscale tegemoetkoming van de gehuwde vrouw, t.w.: 
In deze periode bestaat al de wens tot vereenvoudiging! In dit rapport luidt de conclusie dat samentelling van het inkomen van gehuwde man en vrouw gerechtvaardigd is. Het is niet rechtvaardig om het buitenshuis werken van de vrouw fiscaal te honoreren, terwijl dit voor de man niet gebeurt. In het gehuwdentarief moet wel rekening worden gehouden met het verlies van de in het tarief verwerkte besparingen op de uitgaven door het voeren van een gezamenlijke huishouding als gevolg van het buitenshuis werken van de vrouw. Bovendien moet er een compensatie zijn voor de niet als aftrekbare kosten in aanmerking komende extra uitgaven welke het buitenshuis werken met zich brengt. ${ }^{31}$

Een correctie vindt plaats op basis van de tijdsduur die nodig is voor het verwerven van het inkomen. Deze correctie dient ter compensatie van het verlies van de in het tarief verwerkte extra draagkracht, die niet of slechts ten dele aanwezig is indien de vrouw buitenshuis gaat werken, en ter compensatie van de niet als aftrekbare kosten in aanmerking komende extra-uitgaven, die het werken buitenshuis met zich brengen. ${ }^{32}$ Het inkomensbegrip en de tariefstructuur moeten derhalve niet worden veranderd, aldus de commissie. ${ }^{33}$ In het rapport van de commissie-Hofstra wordt een correctie in het gehuwdentarief voorgesteld.

De door de commissie gedane voorstellen zijn niet uitgevoerd.

Belangrijk is ook de nota van regeringszijde, de zgn. Nota-Grapperhaus (1970) geweest. ${ }^{34}$ In de nota wordt getwijfeld aan de draagkrachtvermeerderende werking van de drie door de commissie-Hofstra genoemde factoren. Deze factoren zijn:

1. een besparing op de uitgaven door een gezamenlijke huishouding;

2. een besparend effect van de huishoudelijke arbeid van de vrouw;

1. de extra-inspanning welke de vrouw zich getroost;

2. het feit dat de inkomsten van de man en vrouw worden samengeteld;

3. in het belang van de nationale welvaart moet de vrouw worden gestimuleerd om aan het arbeidsproces deel te nemen;

4. de remmende werking van de belastingheffing op de zelfstandige inkomensverwerving die voor sommige vrouwen één van de middelen tot haar levensvervulling kan vormen;

5. het draagkrachtvermeerderend element, de huishoudelijke arbeid van de vrouw, valt gedeeltelijk of geheel weg door het buitenshuis werken;

6. de niet als aftrekbare kosten in aanmerking komende extra uitgaven welke het meewerken buiten de gezinshuishouding kan meebrengen.

31. Nota van 22 januari 1970 betreffende de fiscale positie van de werkende gehuwde vrouw (nota Grapperhaus), Tweede Kamer, vergaderjaar 1969-1970, 10 515, no 2, blz. S. De nota van de staatssecretaris (1970) is overigens vrij laat na het ontstaan van de discussie van de fiscale positie van de gehuwde vrouw (1966) verschenen. In die tijd werd geopperd dat de concretisering van de nota op zich zou laten wachten door budgettaire redenen. Tweede Kamer, vergaderjaar 1969-1970, 10 515, no 4, blz. 2. Zie ook het Rapport van de Commissie ter bestudering van de fiscale aspecten van samenlevingsvormen, Geschriften van de Vereniging voor de Belastingwetenschap, no 162, Kluwer, 1984, blz. 21.

32. Nota Grapperhaus, Tweede Kamer, vergaderjaar, 1969-1970, 10 515, no 2, blz. 4 en 5.

33. Nota Grapperhaus, Tweede Kamer, vergaderjaar, 1969-1970, 10 515, no 2, blz. 5.

34. Zie noot 31 . 
3. een besparing op de uitgaven voor immateriële behoeften. ${ }^{35}$

De twijfel over de keuze van de draagkrachtvermeerderende factoren toont aan dat het zeer moeilijk is om het begrip draagkracht precies te definiëren. Daardoor wordt de keuze voor een factor waaraan een draagkrachtvermeerderend of -verminderend karakter kan worden toegekend, enigszins arbitrair. ${ }^{36}$ Indien de arbitraire draagkrachtvermeerderende of -verminderende factor bekend is, kan de berekening van die factor - een element waarmee rekening wordt gehouden in de belastingheffing - ook niet anders dan enigszins arbitrair zijn.

De nota onderschrijft wel de door de commissie-Hofstra geopperde stelling dat de draagkracht van het echtpaar ontbreekt of slechts ten dele aanwezig is indien de vrouw buitenshuis werkt. ${ }^{37}$ 'Met name de onderlinge verbondenheid maakt dat de totale inkomsten van de beide echtgenoten, ongeacht van welke zijde zij zijn opgekomen, bepalend zijn voor hun financiële draagkracht. Dit maakt de totaalsom van de gezamenlijke inkomsten tot de meest geschikte maatstaf voor de heffing van de inkomstenbelasting. ${ }^{33}$

Verder wordt geconcludeerd dat een aftrek van het inkomen bij de man de meest geschikte oplossing was. Toegegeven wordt dat de hoogte van de aftrek arbitrair is. De hoogte van de aftrek wordt op basis van de hoogte van het arbeidsinkomen en niet op basis van de duur van het verwerven van het arbeid berekend. Voor deze keuze worden vier argumenten gegeven, t.w.:

1. De billijkheid ten opzichte van andere groepen belastingplichtigen; met deze groepen worden de ongehuwden en de gehuwden met slechts én verdienende echtgenoot bedoeld.

2. De billijkheid ten opzichte van de groep werkende gehuwde vrouwen; er wordt vanuit gegaan dat de kosten die het buitenshuis werken van de gehuwde vrouw met zich brengt hoger zijn naarmate het inkomen hoger is. Derhalve wordt het billijk geacht indien de aftrek is gebaseerd op het inkomen. Mijns inziens is dit vrij arbitrair. Het lijkt me dat de kosten een plafond bereiken. Zo zullen de kosten van een huishoudelijke hulp niet duurder worden naarmate het inkomen stijgt.

3. De doelmatigheid; met doelmatigheid wordt hier bedoeld dat de regeling eenvoudig te begrijpen en makkelijk toepasbaar zou moeten zijn.

4. Het vierde argument betreft de continuïteit. ${ }^{39}$ Hiermee wordt gedoeld op het feit dat het invoeren van de regeling voor de meeste belastingplichtigen geen nadelen oplevert. Dit is een merkwaardig argument. Deze factor zou bij elke wetswijziging een rol kunnen spelen, maar bij voorstellen tot lastenver-

35. Nota Grapperhaus, Tweede Kamer, vergaderjaar 1969-1970, 10515, no 2, blz. 6. Zie ook Tweede Kamer, vergaderjaar 1969-1970, 10 515, no 4, blz. 6. Volgens Hofstra dienen deze argumenten niet mee te tellen voor de draagkrachtbepaling. H.J. Hofstra, Het splitsingsstelsel. In: Belastingbeschouwingen, Christiaanse-bundel, Kluwer, 1989, blz. 73 .

36. De drie genoemde factoren zijn op geen enkele wijze te kwantificeren. Zie ook Tweede Kamer, vergaderjaar 1969-1970, 10 515, no 4, blz. 6.

37. Nota Grapperhaus, Tweede Kamer, vergaderjaar 1969-1970, 10 515, no 2, blz. 6 en 28.

38. Nota Grapperhaus, Tweede Kamer, vergaderjaar 1969-1970, 10 515, no 2, blz. 4, rk. In: F.C. Wijle, t.a.p., blz. 33.

39. Nota Grapperhaus, Tweede Kamer, vergaderjaar 1969-1970, 10 515, no 2, blz. 18. 
$\mathrm{Na}$ deze nota volgt in 1971 een wetswijziging met als doel verruiming van de aftrek voor de werkende gehuwde vrouw van het gezamenlijke inkomen, belast bij haar man. ${ }^{41}$ De eerste $f 1.000$ van de arbeidsinkomsten van de gehuwde vrouw zijn vrij; van het meerdere is $20 \%$ vrij, een en ander met een maximum van $f 4.000 .6^{42}$

De overwegingen met betrekking tot het draagkrachtbeginsel zijn de volgende:

1. Gezien de draagkrachtgedachte is een echtpaar als eenheid te zien.

2. De draagkrachtvermeerderende factor van het kostenbesparende effect van de huishoudelijke arbeid van de vrouw valt geheel of gedeeltelijk weg indien de vrouw buitenshuis gaat werken. Derhalve is een inkomensaftrek voor de vrouw gerechtvaardigd geacht. ${ }^{43}$

De conclusie is dat het buitenshuis werken van de vrouw per saldo negatief wordt geacht voor de draagkracht.

Kenmerkend voor de periode van 1962 tot 1973 is dat het samenvoegingsstelsel heeft gegolden. ${ }^{4}$ Het gehele inkomen van de vrouw wordt bij de man geteld, zij het dat vanaf 1962 een aftrek van het gezamenlijke inkomen kan plaatsvinden. Toch kan de theorie van de samenvoeging niet volledig worden doorgevoerd in de toenmalige belastingwetgeving. Vooral aan het begin van de jaren zestig wordt hiertegen bezwaar gemaakt. De aftrekregeling moet een tegemoetkoming zijn voor het integrale samenvoegingsleed.

Opmerkelijk is dat eerst geen rekening wordt gehouden met de draagkrachtverminderende factor van de extra kosten die het buitenshuis werken van de gehuwde vrouw met zich brengt. Later wel; dit heeft onder meer te maken met de ontwikkeling van de emancipatie van de vrouw.

Vergelijkt men deze periode met de vorige, dan blijkt dat het karakter van het

40. Interessant in dit verband is ook de volgende redenering. '... toch konden zij (kamerieden, MW) niet aan de indruk ontkomen, dat in de trapsgewijs opgebouwde redenering van de Staatssecretaris, welke ten slotte naar de beide hoofdvarianten leidt, vele veronderstellingen zitten, die, wanneer men geen aftrekrecht of een veel geringer als het thans bestaande wenselijk zou vinden, anders uitgevallen zouden zijn. De Staatssecretaris had immers uit de discussies na het verschijnen van de visie van de commissie-Hofstra begrepen, dat een meerderheid in het parlement zich niet zou kunnen vinden in een voor de werkende gehuwde vrouw ongunstiger maken van de regeling.' Tweede Kamer, vergaderjaar 1969-1970, 10 515, no 4, blz. 10.

Bovendien speelden in die tijd budgettaire overwegingen bij de realisering van wetsvoorstellen een rol. 'Het concretiseren zal dan te zijner tijd wel weer afhangen van de budgettaire situatie in 1971 of wellicht in 1972.' Tweede Kamer, vergaderjaar 1969-1970, 10 515, no 4, blz. 2.

41. Dit is de zgn. Lex-Grapperhaus. Tweede Kamer, vergaderjaar 1979-1980, 15 835, nrs. 1-2, blz. 12.

42. Aanvankelijk is het minimum $f 1.000$ en het maximum $f 3.000$. Voor de meewerkende vrouw in de onderneming van haar man worden de inkomsten bij hele dagen op 35\% van de winst bepaald, bij halve dagen op 221\%\%\%. Nota Op Weg, Tweede Kamer, vergaderjaar 1979-1980, 15835 , nrs. 1-2, blz. 13.

43. Nota Op Weg, Tweede Kamer, vergaderjaar 1979-1980, 15 835, nrs. 1-2, blz. 13.

44. H.J. Hofstra en L.G.M. Stevens, Inkomstenbelasting, t.a.p., blz. 80. 
draagkrachtbeginsel aan verandering onderhevig is. De gezinsdraagkracht wordt gedeeltelijk vervangen door de individuele draagkracht, althans wat betreft de arbeidsinkomsten. Er wordt in 1972 zelfs gesproken van een introductie van een nieuw beginsel, namelijk het beginsel dat de inkomsten uit arbeid in ieder geval worden belast bij degene die ze genoten heeft. Het gaat hier derhalve om het principe van individualisering en niet om het beginsel van de draagkracht. ${ }^{45}$ Of moet worden gezegd dat het draagkrachtbegrip een andere invulling heeft gekregen? Sommige auteurs spreken dan ook van het veranderen van de maatstaf van draagkracht. Deze maatstaf was eerst het gezinsinkomen, later is het individuele inkomen met het gezin als draagkrachtverhogende factor de maatstaf geworden. ${ }^{46}$

\subsubsection{Periode van 1973 tot 1980}

Tegen de zojuist beschreven aftrekregeling worden na verloop van tijd enige bezwaren ingebracht. Die bezwaren zijn de volgende vier:

1. De hoogte van de aftrekbedragen is moeilijk te verdedigen.

2. De belasting over het inkomen van de vrouw wordt bepaald door de hoogte van het inkomen van de man.

3. De doelmatigheidselementen; de loonbelasting kan in vele gevallen geen eindheffing zijn. Dit brengt extra werk mee voor de belastingdienst en de belastingplichtigen. Veelal komen de aanslagen achteraf. Dit brengt onzekerheid met zich.

4. Bovendien laat de oude theoretische conceptie zich steeds moeilijker terugvinden in de vrijgestelde bedragen. ${ }^{47}$

Het gevolg van de aftrekregeling is dat gehuwde vrouwen niet of moeilijker toetreden tot de arbeidsmarkt; een voor de gehuwde vrouwen nadelig effect van de fiscale wetgeving.

Met wijziging van de bestaande wetgeving in 1973, namelijk het afschaffen van de aftrek en het invoeren van de beperkte verzelfstandiging van de fiscale positie van de gehuwde vrouw wordt getracht het bovengenoemde nadelige effect op te heffen. Met andere woorden, de belastingheffing streeft naast e'en rechtvaardige verdeling van de lasten nog een nevendoeleinde na, $\mathrm{nl}$. het wegnemen van de bestaande belemmeringen voor de arbeidsmarktparticipatie van de gehuwde vrouw.

De wijziging van de bestaande wetgeving houdt in dat de gehuwde vrouw met in-

45. J.F.M. Giele, Toerekening inkomensbestanddelen. In: Belastingbeschouwingen, Christiaansebundel, Kluwer, 1989, blz. 83.

46. P. Kavelaars, L.G.M. Stevens, L. Opheikens, t.a.p., blz. 1. Zie ook H. Mobach, Rapport van de Commissie ter bestudering van de fiscale aspecten van samenlevingsvormen, Geschrift van de Vereniging voor Belastingwetenschap, no 163, Kluwer, 1984, blz. 30.

47. J.F.M. Giele, De problematiek van de tweeverdieners, FED Nederlandse Federatie van belastingconsulenten, 1986, blz. 14. 
gang van 1973 voor het fiscale recht beperkt zelfstandig wordt. ${ }^{48}$ Met beperkt zelfstandig wordt bedoeld dat de inkomsten uit tegenwoordige arbeid bij de gehuwde vrouw worden belast. ${ }^{49}$ Andere inkomsten, zoals de inkomsten uit vroegere arbeid worden bij de man belast. Indien deze laatstgenpemde inkomsten in een gescheiden belastingheffing bij de vrouw worden belast, zou dat een aantasting betekenen van het draagkrachtbeginsel. Het draagkrachtbeginsel mag niet aangetast worden aldus de wetgever. ${ }^{50}$ Voor draagkracht moet in dit geval gezinsdraagkracht worden gelezen.

De beperkte verzelfstandiging wordt nader gemotiveerd met het argument dat voor de gezinsdraagkracht rekening moet worden gehouden met het wegvallen van een belangrijk deel van de kostenbesparende effecten van de huishoudelijke arbeid. ${ }^{\text {sl }}$ Bovendien speelt het begrip van doelmatigheid hier een rol. Het beoogde stelsel zal tot een vereenvoudiging leiden, zowel voor de belastingplichtigen als voor de belastingadministratie. ${ }^{52}$

Tijdens de behandeling van het wetsvoorstel wordt via een amendement geijverd voor het belasten van de tijdelijke en blijvende arbeidsongeschiktheidsuitkeringen bij de vrouw. Dit amendement is aangenomen. ${ }^{53}$ Voor het overige wordt uitgegaan van de samenvoeging van de inkomens van de gehuwde man en vrouw.

Het bovenstaande leidt aldus tot een beperkt samenvoegingsstelsel. Dit stelsel wordt gedragen door het draagkrachtbeginsel; de samengevoegde inkomens van man en vrouw moeten het vermogen om belasting te betalen kunnen dragen..$^{54}$

De zelfstandige heffing voor de gehuwde werkende vrouw wordt over het algemeen niet in strijd geacht met het draagkrachtbeginsel.

De belastingwetgever vindt het bij de invoering van de beperkte verzelfstandiging van de gehuwde vrouw belangrijk dat de werking van het draagkrachtbeginsel in stand wordt gehouden. De fiscale zelfstandige positie van de gehuwde vrouw is derhalve aan een principiële, nl. de draagkracht betreffende, overweging onder-

48. Volgens artikel 5, lid 2 Wet IB 1964 (tekst 1973) wordt de gehuwde vrouw zelfstandig belast voor de winst uit een door haar feitelijk gedreven onderneming en de aan de winst toe te rekenen toevoegingen aan en afnemingen van haar oudedagsreserve. Bovendien wordt de gehuwde vrouw zelfstandig belast voor de zuivere inkomsten uit door haar verrichte tegenwoordige arbeid met uitzondering van die inkomsten uit onderverhuring. Ook wordt de gehuwde vrouw zelfstandig belast voor de winst uit een voor rekening van haar man gedreven onderneming die aan haar wordt toegerekend, ingevolge het derde lid. De premies ingevolge AOW, AWW, AWBZ, AAW en de AKW mogen bij de vrouw in mindering worden gebracht.

49. Met inkomsten uit arbeid worden bedoeld: loon uit dienstbetrekking, winst uit een feitelijk geoefende onderneming, een beloning wegens het meewerken in de onderneming van de echtgenoot, arbeidsongeschiktheidsuitkeringen, WW-uitkeringen. Nota Op Weg, Tweede Kamer, vergaderjaar 1979-1980, 15 835, nrs. 1-2, blz. 6.

50. Tweede Kamer, vergaderjaar 1979-1980, 15 835, nrs. 1-2, blz. 40.

51. Tweede Kamer, vergaderjaar 1979-1980, 15 835, nrs. 1-2, blz. 4.

52. Tweede Kamer, vergaderjaar 1979-1980, 15 835, nrs. 1-2, blz. 16.

53. Tweede Kamer, vergaderjaar 1979-1980, 15 835, nrs. 1-2, blz. 17.

54. E.N. Kertzman, Belastingheffing van gehuwden en ongehuwden, proefschrift, 1978. Zie ook Fiscale monografieẽn, no 32, Kluwer, 1979, blz. 16. 
worpen..$^{55}$ Als ik de kamerstukken goed begrijp, moeten voor de verdere verzelfstandiging van de fiscale positie van de vrouw de draagkrachtverhoudingen goed worden afgewogen. Hoe deze overwegingen goed dienen te worden afgewogen, wordt niet aangegeven. Alleen wordt aangegeven welke vergelijkingen in die heroverwegingen moeten worden betrokken, nl. zowel die tussen de gehuwden en ongehuwden als die tussen gehuwden die beiden inkomen verwerven en gehuwden waarvan slechts eén partner het inkomen verwerft. ${ }^{56}$

De maatschappelijke ontwikkeling wordt als rechtvaardigingsgrond voor het voorstel tot wetswijziging aangevoerd. ${ }^{57}$ Dit toont opnieuw aan dat de werking van het draagkrachtbeginsel wordt beïnvloed door de veranderingen die in de maatschappij plaatsvinden, i.c. de deelname van de gehuwde vrouw aan de arbeidsmarkt. Het motief inhoudende de noodzaak tot aanpassing van de belastingheffing aan de maatschappij blijkt over het algemeen een belangrijke rol te spelen. Voor de draagkrachtbepaling worden de huwelijks- en de gezinsband niet terzijde geschoven. Met de invoering van de zelfstandige heffing wordt wel de toepassing van het draagkrachtbeginsel minder scherp, zodat een meer globale inhoud aan het begrip draagkracht wordt gegeven. ${ }^{58} \mathrm{De}$ vraag rijst of het begrip draagkracht ooit goed gedefinieerd was.

Een volgende opmerking met betrekking tot het draagkrachtbeginsel betreft de belastingvrije sommen. De draagkrachtverschillen tussen de verschillende soorten belastingplichtigen worden tot uitdrukking gebracht in de variërende hoogte van de belastingvrije sommen. De gehuwde vrouw heeft een lagere belastingvrije som dan haar man. Dit heeft te maken met het feit dat de gehuwde vrouw voor haar bestedingsruimte niet alleen afhankelijk is van haar eigen inkomen, maar ook afhankelijk is van het inkomen van haar man. In hoeverre en tot welke hoogte de draagkrachtgedachte doorwerkt, wordt niet weergegeven.

De gehuwde vrouw kan derhalve geen hogere belastingvrije som dan de vastgestelde genieten. Door het toekennen van een hogere belastingvrije som, zou de draagkrachtgedachte opzij worden gezet. Dit laatste is zeer zeker het geval ten aanzien van de gehuwde vrouw die niet buitenshuis werkt en ten aanzien van de alleenstaande. ${ }^{9}$

Het onderhavige stelsel levert problemen op indien de gehuwde vrouw meer verdient dan de gehuwde man. In dat geval kan de zgn. rolwisseling worden toegepast; de belastingvrije sommen van man en vrouw kunnen worden gewisseld. In geval van rolwisseling blijven de persoonlijke verplichtingen, de buitengewone

55. J.F.M. Giele, De problematiek van de tweeverdieners, FED Nederlandse Federatie van belastingconsulenten, 1986, blz. 14.

56. Tweede Kamer, vergaderjaar 1979-1980, 15 835, nrs. 1-2, blz. 4.

57. Tweede Kamer, vergaderjaar 1979-1980, 15 835, nrs. 1-2, blz. 14, 16 en 42.

58. Tweede Kamer, vergaderjaar 1979-1980, 15 835, nrs. 1-2, blz. 14.

59. Tweede Kamer, vergaderjaar 1979-1980, 15835 , nrs. 1-2, blz. 15. Hierbij moet niet alleen aan de gehuwde vrouw die niet buitenshuis werkt worden gedacht, maar ook aan de alieenstaande. Rapport van de Commissie ter bestudering van de fiscale aspecten van samenlevingsvormen, Geschriften van de Vereniging voor Belastingwetenschap, no 162, Kluwer, 1984, blz. 23. 
lasten etc. aan de man toegerekend.

Doch aan dit stelsel kleeft een aantal bezwaren; een daarvan is dat het buitenshuis werken van de gehuwde vrouw fiscaal nadeliger is dan thuisblijven. Dit heeft te maken met het betalen van premies voor volksverzekeringen, welke betalingen geen extra rechten meebrengen. ${ }^{60}$

Resumerend kan worden gesteld dat het in het stelsel van 1973 erop neer komt, dat de gezamenlijke draagkracht van de gehuwde man en de vrouw als maatstaf voor de inkomstenbelasting en de loonbelasting in stand moet worden gehouden. Rekening wordt gehouden met de wegvallende besparende werking, met andere woorden, de draagkrachtvermeerderende werking, van de huishoudelijke arbeid indien de gehuwde vrouw buitenshuis gaat werken.

Een vergelijking met de vorige periode leert het volgende. De gehuwde vrouw wordt voor bepaalde inkomsten zelfstandig in de belastingheffing betrokken. Ondanks de invoering van dit stelsel blijven enige bezwaren bestaan, zoals het feit dat het fiscaal gezien nadeliger is om buitenshuis te werken dan om thuis te blijven.

\subsubsection{Periode van 1980 tot 1990}

Werden voorheen alleen de inkomsten uit tegenwoordige arbeid bij de vrouw belast, in het begin van de jaren tachtig wordt de zelfstandige fiscale positie van de gehuwde vrouw uitgebreid tot de pensioenen. In de voorgaande periode wordt nog gesteld dat indien de zelfstandige fiscale positie van de vrouw wordt uitgebreid tot de arbeidsinkomsten genoten uit vroegere dienstbetrekking, zulks een aantasting van het draagkrachtbeginsel zou betekenen. De fiscale wetgever is toch ertoe overgegaan om de arbeidsinkomsten uit vroegere dienstbetrekking bij de vrouw te belasten. Hoe heeft hij dit gemotiveerd?

Er bestaat in de jaren zeventig een bepaalde mate van ongelijkheid tussen de fiscale behandeling van aan gehuwde vrouwen toekomende arbeidsongeschiktheidsuitkeringen en die van pensioenen. De ongelijkheid tussen de gehuwde man en vrouw betreft de belastingdruk; de eerstgenoemde uitkering wordt bij de vrouw belast, terwijl de tweede aan de man wordt toegerekend, waardoor een stijging van de belastingdruk kan worden waargenomen. Voor de opheffing van deze ongelijkheid wordt de volgende keuze geopperd: of de verzelfstandiging van de arbeidsongeschiktheidsuitkeringen terugdraaien, of de verzelfstandiging verder uitbreiden. ${ }^{61}$ De fiscale wetgever spreekt van een ruimer standpunt innemen ten aanzien van de verzelfstandiging. Deze ongelijkheid wordt in de nota ' $\mathrm{Op}$ weg ${ }^{62}$ geconstateerd.

60. E.N. Kertzman, t.a.p., blz. 17.

61. Gekozen is voor de laatste mogelijkheid; dit gebeurt echter pas in 1984, Wet van 30 december 1983, Stb. 1983, 690. Deze wet is in werking getreden op 1 januari 1984.

62. Nota Op weg, Tweede Kamer, vergaderjaar 1979-1980, 15 835. De volledige titel luidt: Gelijke behandeling voor de loon-en inkomstenbelasting van de (werkende) gehuwde vrouw en haar man en van deelgenoten aan vormen van samenleving en samenwonen. 
In deze nota wordt de voorkeur uitgesproken om een gelijk fiscale behandeling van de gehuwde vrouw met haar man en een gelijke behandèlíng van verscheidene samenlevingsvormen te realiseren. In dit hoofdstuk geef ik de relevante elementen met betrekking tot het eerste aspect weer. Het tweede aspect van de nota wordt in hoofdstuk 3 behandeld.

Het gevolg is dat het argument van de draagkracht thans op een andere wijze tot uitdrukking wordt gebracht, hetgeen erop neerkomt dat individuele draagkracht in de plaats van gezinsdraagkracht komt. ${ }^{63}$ Doelmatigheidsoverwegingen voorkomen een verdergaande verzelfstandiging. ${ }^{64}$

Hier speelt de maatschappelijke ontwikkeling wederom een invloedrijke rol. 'Een uitbreiding van de verzelfstandiging kan ook worden verdedigd met een beroep op de voortschrijdende maatschappelijke ontwikkeling (de 'roep' om individualisering). ${ }^{65}$ Het gelijkheidsbeginsel en de maatschappelijke ontwikkeling hebben de werking van het draagkrachtbeginsel opzij kunnen zetten althans doen verminderen. Dit is opmerkelijk. Eerder werd gezegd dat het draagkrachtbeginsel een uitvloeisel is van het gelijkheidsbeginsel en in dit geval zet het gelijkheidsbeginsel het draagkrachtbeginsel opzij. Dit toont des te meer aan dat de werking en de rangorde van de beginselen in de loop van de tijd kunnen variëren.

Moet gezien het bovenstaande worden geconcludeerd dat de verdere verzelfstandiging van de fiscale positie van de gehuwde vrouw in de ogen van de fiscale wetgever een verdere uitholling van het draagkrachtbeginsel met zich heeft gebracht? Of moet worden geconstateerd dat de maatstaf van het draagkrachtbeginsel onder invloed van de maatschappelijke ontwikkeling veranderd is, $\mathrm{nl}$. de vervanging van de gezinsdraagkracht door de individuele draagkracht? ? $^{\infty 6}$ Het laatste moet wel aangenomen worden, wil nog gesproken kunnen worden van een op het draagkrachtbeginsel rustende Wet IB 1964.

In deze periode komt de zgn. Tweeverdienerswetgeving tot stand. In het kader van de Tweeverdienerswetgeving wordt onder andere gestreefd naar een gelijke behandeling van de gehuwde vrouw en haar man. ${ }^{67}$

63. Tweede Kamer, vergaderjaar 1983-1984, 18 121, no 3, blz. 16.

64. Tweede Kamer, vergaderjaar 1983-1984, 18 121, no 3, blz. 16.

65. Tweede Kamer, vergaderjaar 1979-1980, 15 835, nrs. 1-2, blz. 42.

66. De uitbreiding van de belastingplicht van de gehuwde vrouw is een voorbeeld van wetgeving dat onder invloed van grote maatschappelijke druk tot stand is gekomen. Tweede Kamer, vergaderjaar 1982-1983, 17885 , no 5 , blz. 13 (ingetrokken).

67. De uitbreiding van de zelfstandige belastingheffing van de gehuwde vrouw in de tweede fase van de Tweeverdienerswetgeving bestaat uit:

'- inkomsten uit vroegere arbeid (zoals pensioen, wachtgeld en VUT-uitkering), daaronder begrepen de inkomsten die via de fictiebepalingen van de loonbelasting worden gelijkgesteld met arbeidsinkomsten;

- winst uit een onderneming welke niet of niet meer feitelijk door de vrouw wordt gedreven; - termijnen van lijfrente en andere periodieke uitkeringen welke naar hun ontstaan zijn te herleiden tot vroeger ondernemerschap;

- inkomsten in de vorm van ter zake van studie genoten periodieke uitkeringen;

- dotaties aan en afnemingen van een eigen fiscale oudedagsreserve ingeval de vrouw een onderneming drijft als deelgenoot van haar man.' Tweede Kamer, vergaderjaar 1983-1984, 18 
'Het streven naar een gelijke behandeling van individuele belastingplichtigen (zowel gehuwden als ongehuwden die wegens het voeren van een gemeenschappelijke huishouding in vergelijkbare omstandigheden verkeren) zal in financieel opzicht geen wijziging brengen in de positie van gehuwden waarvan één van de partners betaalde arbeid verricht. ${ }^{68}$

De individualisering wordt wat de arbeidsinkomsten betreft ten koste van de draagkracht ingevoerd. Men komt echter niet verder dan de arbeidsinkomsten. Hierover merkt de Raad van State op dat de argumenten om de gelijke behandeling van de gehuwde vrouw en haar man niet verder door te voeren dan ten aanzien van de arbeidsinkomsten, zeer zwaarwegend moeten zijn. Deze argumenten moeten volgens de regering onder andere worden gezocht in de doelmatigheid. De doelmatigheid zou zich tegen een verdergaande verzelfstandiging verzetten. Aan deze redenering dient echter weinig waarde te worden toegekend, aldus de Raad van State. ${ }^{69}$

De ongelijkheid tussen de gehuwde vrouw en haar man bestaat onder andere uit het verschil in de belastingvrije som die man en vrouw genieten en het feit dat de rolwisseling alleen opgeld doet in geval van het toerekenen van het arbeidsinkomen en de beperkte verzelfstandiging van de gehuwde vrouw. ${ }^{70}$ Wat betreft het verschil in de belastingvrije som kan worden opgemerkt dat met ingang van 1984 iedere belastingplichtige een gelijke belastingurije som heeft. Vanaf dit jaar geldt niet meer de regeling dat de niet persoonsgebonden inkomensbestanddelen per definitie aan de man worden toegerekend. De toerekening dient te geschieden aan degene, die het hoogste persoonlijke arbeidsinkomen heeft. In de praktijk zal dat vaak de man zijn.

Niet alleen de gehuwde vrouw ervaart de belastingdruk als zwaar: ook de traditionele gezinnen ervaren de druk als groot. Om deze belastingdruk van gezinnen enigszins te verlichten worden de alleenverdieners- en de bijna-alleenverdienerstoeslag (1984) ingevoerd. Wat is namelijk het geval? De gehuwde man en vrouw krijgen ieder een gelijke belastingvrije som, maar door de maatschappelijke verhoudingen geniet de vrouw vaak (bijna) geen inkomsten, waardoor zij ook haar belastingurije som niet of nauwelijks kan benutten. Hieraan hebben de boven-

121 , no 3 , blz. 4 .

De uitbreiding van de verzelfstandiging gaat niet zo ver dat de winst uit aanmerkelijk belang hier ook onder valt. Hiertegen wordt bezwaar gemaakt. Tweede Kamer, vergaderjaar 1983-1984, 18 121, no 6, blz. 19.

En zie voor wijziging van de inkomstenbelasting en de loonbelasting; derde fase tweeverdieners, Tweede Kamer, vergaderjaar 1983-1984, 18 519, nrs. A-C, blz. 3.

68. Tweede Kamer, vergaderjaar, 1979-1980, 15 835, nrs. 1-2, blz. 8.

69. Tweede Kamer, vergaderjaar 1983-1984, 18 519, A-C, blz. 8.

70. Fiscale encyclopedie de vakstudie, Kluwer, artikel 5 Wet IB 1964, aantekening 4, blz. 66-78. Een andere ongelijkheid bestaat uit het verschil in belastingdruk tussen de alleenverdiener en de zogenaamde tweeverdieners. Zie echter J.H. Detiger, die geen voorstander is van een zelfstandige belastingheffing voor de gehuwde vrouw. Rapport van de Commissie ter bestudering van de fiscale aspecten van samenlevingsvormen, Geschriften van de Vereniging voor Belastingwetenschap, no 162 , Kluwer, 1984, blz. 74 e.v.. 
staande toeslagen getracht tegemoet te komen. ${ }^{71}$

De veranderde fiscale behandeling van de gehuwde vrouw brengt ook wijzigingen in de tweeverdieners-situatie teweeg. Deze komen in hoofdstuk 3 aan de orde.

Voor een bespreking van de relevantie van het draagkrachtbeginsel is het wetsvoorstel $^{72}$ dat als doel heeft de tariefgroepindeling van de gehuwde vrouw en de gehuwde man te wijzigen van belang. Het feit dat het wetsvoorstel is ingetrokken doet hieraan niets af, daar de strekking van het voorstel in de volgende wetsvoorstellen is terug te vinden. Met het wetsvoorstel wordt beoogd een gelijke behandeling tussen de gehuwde man en vrouw en een gelijke behandeling tussen de éen- en de tweeverdieners te bewerkstelligen. Het wetsvoorstel bewerkstelligt daarentegen wel een ongelijke behandeling tussen de gehuwde en de ongehuwde tweeverdieners. $^{73}$

Thans volgen enige opmerkingen die verscheidene politieke partijen over het draagkrachtbeginsel met betrekking tot de gehuwde vrouw bij de behandeling van het onderhavige wetsvoorstel hebben gemaakt.

De leden van de SGP stellen zich op het standpunt dat er geen strijdigheid is tussen de draagkrachtgedachte en de gelijkwaardige behandeling van mannen en vrouwen. Maar even later verkondigen deze leden dat een verdere fiscale verzelfstandiging van de gehuwde vrouw in strijd zou zijn met de draagkrachtgedachte. ${ }^{74}$ Hoe is dit te rijmen met elkaar?

De leden van D66 vragen zich af of de regering kan aangeven wat onder draagkracht kan worden verstaan en welke de draagkrachtverminderende en de -vermeerderende factoren zijn. ${ }^{75}$ De regering geeft het volgende antwoord. Vooropgesteld zij dat de bepaling van de draagkrachtfactoren arbitrair is. Volgens de regering heeft het buitenshuis werken van de gehuwde vrouw een draagkrachtverminderend effect. ${ }^{76} \mathrm{De}$ wijze van besteding met uitzondering van buitengewone lasten is niet belangrijk voor de draagkrachtbepaling. ${ }^{\pi}$

Afgezien van het feit dat bij de definiëring van het begrip draagkracht de partijpolitieke overtuigingen een (verwarrende) rol spelen, blijkt het zeker niet makkelijk te zijn om op één lijn te gaan zitten ten aanzien van het begrip draagkracht. Dit is wel noodzakelijk, daar het hier om een in de inkomstenbelasting

71. Hofstra vermeldt ook de schokeffecten. In 1985 wordt de wetgeving wederom aangepast ter vermijding van schokeffecten. H.J. Hofstra en L.G.M. Stevens, Inkomstenbelasting, t.a.p., blz. 85.

72. Volledig: Wijziging van de inkomstenbelasting en van de loonbelasting voor het jaar 1983 (tariefgroepindeling van de gehuwde vrouw en de gehuwde man) alsmede aanpassing van enkele volksverzekeringen, vergaderjaar 1982-1983, 17 885. Dit wetsvoorstel is weliswaar ingetrokken maar de behandeling van het onderwerp geeft een aardige indicatie hoe wordt gedacht over het draagkrachtbeginsel.

73. Tweede Kamer, vergaderjaar 1982-1983, 17885 , no 5, blz. 12 (ingetrokken).

74. Tweede Kamer, vergaderjaar 1982-1983, 17885 , no 5, blz. 19 en 20 (ingetrokken).

75. Tweede Kamer, vergaderjaar 1982-1983, 17885 , no 5, blz. 14 (ingetrokken).

76. Tweede Kamer, vergaderjaar 1982-1983, 17885 , no 6, blz. 5 (ingetrokken).

77. Tweede Kamer, vergaderjaar 1982-1983, 17 885, no 6, blz. 7 (ingetrokken). 
leidend beginsel gaat. En in geval van een beginsel moet een ieder het toch eens zijn over de fundamentele invulling daarvan.

$\mathrm{Bij}$ de draagkrachtberekening wordt rekening gehouden met de extra uitgaven in geval van buitenshuis werken van de partner.

Was het in de voorgaande drie perioden nog zo dat rekening werd gehouden met de besparende werking van de huishoudelijke arbeid, sinds 1984 wordt met deze factor geen rekening meer gehouden ${ }^{78}$ Dit is opmerkelijk; een factor wordt ontdaan van het etiket draagkrachtvermeerderend.

\subsection{Samenvatting en conclusies}

De vier perioden overziend kunnen we concluderen dat de fiscale positie van de gehuwde vrouw aan verandering onderhevig is geweest. Voorheen had de vrouw niet zo veel in te brengen, zowel civiel- als fiscaalrechtelijk niet. Maar ook hier deed de maatschappelijke situatie haar invloed gelden, en de aanpassing van de fiscale behandeling van de gehuwde vrouw aan haar maatschappelijke situatie kon niet uitblijven. Hierdoor kwam het toenmalige stelsel van de belastingheffing wel in de problemen. Het samenvoegingsstelsel moest meer en meer plaats maken voor een meer individuele belastingheffing met alle gevolgen van dien.

Als een rode draad loopt het beginsel van de draagkracht door de ontwikkeling van de fiscale positie van de gehuwde vrouw heen. Dit beginsel schijnt de Nederlandse belastingheffing wat betreft de inkomstenbelasting in alle tijden en omstandigheden te kunnen èn te moeten dragen. Echter de inhoud van het begrip varieert in de tijd. Opmerkelijk is bij voorbeeld dat draagkrachtvermeerderende en -verminderende elementen van tijd tot tijd wisselen. Zo kreeg het verrichten van de huishoudelijke arbeid van de gehuwde vrouw aanvankelijk het etiket draagkrachtvermeerderend opgeplakt; enige jaren later wordt met de desbetreffende factor geen rekening meer gehouden. De argumentatie ten aanzien van het draagkrachtbeginsel is niet altijd geheel doorzichtig.

De conclusie lijkt gerechtvaardigd dat aan het beginsel van de draagkracht een magisch element niet kan worden ontzegd. Het beginsel wordt vaak aangehaald zonder dat de inhoud echt duidelijk wordt. Het noemen van het draagkrachtbeginsel stemt menigeen schijnbaar tot tevredenheid. Indien uitgegaan wordt van een belastingheffing naar draagkracht, zoals vele auteurs (willen doen) geloven, dan kan het niet anders zijn dan dat met die draagkracht rekening dient te worden gehouden. Er moet aan het beginsel ook niet meer waarde aan worden toegekend dan er in werkelijkheid aan kan worden toegekend. Wenselijkheid en re-

78. In het wetsvoorstel betreffende de wijziging van de inkomstenbelasting en van de loonbelasting voor het jaar 1983 inzake de tariefgroepindeling van de gehuwde vrouw en gehuwde man wordt met de besparende werking in verband met het verrichten van de huishoudelijke arbeid van de vrouw nog rekening gehouden. Tweede Kamer, vergaderjaar 1982-1983, 17 885, no S, blz. 8 (ingetrokken). 
aliteit moeten niet met elkaar worden verward. Zelfs het subject en het object van draagkracht zijn niet duidelijk te definiëren. Geconstateerd kan worden dat er in ieder geval sprake kan zijn van twee soorten draagkracht; de gezinsdraagkracht en de individuele draagkracht. De laatste jaren heeft een verschuiving plaatsgevonden van de gezinsdraagkracht naar de individuele draagkracht. Indien uitgegaan moet worden van de gezinsdraagkracht, kan volgens de literatuur worden geconcludeerd dat er een ongelijke behandeling bestaat tussen de (on)gehuwde énnverdieners en de zgn. 'tweeverdieners'. Nog afgezien van de politieke keuze die gemaakt wordt ten faveure van het samenvoegingsstelsel of het splitsingsstelsel, zal de volgende regel in acht moeten worden genomen. Indien ge-kozen wordt voor een bepaalde invulling van het begrip draagkracht, zal die in-vulling consequent dienen plaats te vinden. Er moet niet op een en hetzelfde tijdstip op twee gedachten worden gehinkt. ${ }^{\text {Ty }}$

79. Zie verder voor het aan de orde stellen van het inconsistent gebruik van het begrip draagkracht Van Arendonk. H.P.A.M. van Arendonk, t.a.p., blz. 162. 


\section{De Tweeverdienerswetgeving}

Maar dan moeten we ook de moed hebben om de grondslagen van onze eigentijdse belastingtheorieën ter discussie te stellen. Zijn die nog op reëel bestaande veronderstellingen gebaseerd? Zo hanteren onze volksvertegenwoordigers nog steeds de draagkrachtgedachte, een gedachte uit de vorige eeuw, ontstaan toen men over een inkomstenbelasting begon na te denken."

\subsection{Inleiding}

Getuige artikel 1 van de Wet IB 1964 wordt de inkomstenbelasting geheven van natuurlijke personen. Hofstra spreekt in dit verband zelfs van een beginsel; een beginsel inhoudende dat inkomstenbelasting wordt geheven van een natuurlijk persoon en niet van een samenlevingsverband. Een uitzondering hierop is het samenlevingsverband tussen gehuwde personen. Dit samenlevingsverband wordt in de belastingheffing betrokken, $\mathrm{nl}$. in die zin dat de niet tot het persoonlijke inkomen behorende positieve en negatieve inkomensbestanddelen van de echtgenote resp. echtgenoot worden opgeteld bij het inkomen van de meestverdienende echtgenoot resp. echtgenote (zie artikel 5, lid 1 Wet IB 1964).

Het doelmatigheidsaspect speelt in een huwelijkssituatie ook een rol. Een gezamenlijke aanslag is in geval van een huwelijkssituatie doelmatiger dan een aanslag voor ieder afzonderlijk. ${ }^{2}$

In de laatste decennia is de positie van de (gehuwde) vrouw aan verandering onderhevig. Zo verricht de (gehuwde) vrouw niet enkel en alleen de huishoudelijke arbeid, maar gaat zij ook meer en meer arbeid buitenshuis verrichten. Naast de man verdient de gehuwde vrouw enig inkomen in de zin van de Wet IB 1964. Er vindt als het ware een ontwikkeling plaats naar een tweeverdienerssituatie. Deze situatie komt naast de vertrouwde alleenverdienerssituatie, waarin de man het inkomen verdient.

Van een tweeverdienerssituatie is sprake als in een min of meer duurzaam samenlevingsverband twee personen ieder inkomen in de zin van de Wet IB 1964 inbrengen.

Behoudens dat de (gehuwde) vrouw meer en meer arbeid buitenshuis gaat verrichten, treedt nog een wijziging op in de bestaande gezinssituatie. Het ver-

1. H. Mobach, Lezing voor de Vereniging Landelijke Werkgroep Vrouw en Recht, Amsterdam, 10 september 1991.

2. H.J. Hofstra en L.G.M. Stevens, Inkomstenbelasting, Fiscale hand- en studieboeken, no 2 , $4 \mathrm{e}$ druk, Kluwer, 1994, blz. 80 en 83 . Zie ook P.C. Wijle, Belastingen en gezinseenheid, Een kritische beschouwing inzake verbanden tussen gezinsconnecties en subjectieve belastingheffing, Fiscaal-Economisch Instituut, Samson, 1972, blz. 5. 
trouwde, traditionele gezin, bestaande uit een gehuwde man en vrouw eventueel met kinderen, blijkt niet meer dè samenlevingsvorm te zijn. Ongehuwd samenleven komt steeds meer voor. Te denken valt aan de ongehuwd samenlevende man en vrouw, en een samenlevende broer en zus. ${ }^{3}$

Het gemeenschappelijke element in de verscheidene samenlevingsverbanden is het voeren van een gemeenschappelijke huishouding. De gemeenschappelijke huishouding heeft invloed op de draagkracht. Bovendien is de draagkracht van de omvang van het ingebrachte inkomen afhankelijk.

In het algemeen onderschrijft men de stelling dat de fiscale wetgever rekening dient te houden met de ontwikkelingen die in de samenleving plaatsvinden. Dat heeft de fiscale wetgever in het verleden met betrekking tot de tweeverdienerssituatie en de verscheidene vormen van ongehuwd samenleven ook gedaan. De ontwikkeling van de tweeverdienerssituatie naast de alleenverdienerssituatie heeft tot wijziging van de inkomstenbelasting genoopt. De wijziging resulteert in de Tweeverdienerswetgeving, die de verscheidenheid van samenlevingsvormen erkent. Deze wetgeving heeft tamelijk veel kritiek ondervonden. ${ }^{5}$ Maar de vraag of de motieven die aan de wetswijziging ten grondslag liggen gerechtvaardigd zijn, is van een andere orde.

\section{Historische beschouwing}

Tot ongeveer 1960 betaalt de ongehuwde belastingplichtige $50 \%$ tot $100 \%$ meer belasting dan de gehuwde man. Een van de voornaamste redenen is van budgettaire aard. ${ }^{6}$ Naar mijn mening behoren budgettaire overwegingen geen dominante rol te spelen wanneer het gaat om een rechtvaardige verdeling van de lasten. Het aanvoeren van budgettaire redenen ontneemt aan de tot stand gebrachte lastenverdeling een groot deel van de daaraan toegedachte rechtvaardiging.

3. Zie het cijfermateriaal van het Centraal Bureau voor de Statistiek. Het aantal éénpersoonshuishoudens is in $1990(29,3 \%)$ ten opzichte van $1980(21,6 \%)$ gestegen met 7,7\%. Het percentage meerpersoonshuishoudens is in $1990(70,6 \%)$ afgenomen ten opzichte van $1980(78,4 \%)$. Onder deze meerpersoonshuishoudens moeten in ieder geval de gehuwde samenlevers worden verstaan. Samenwonen wordt populairder, maar het huwelijk blijft de belangrijkste samenlevingsvorm. Onderzoek gezinsvorming 1988: samenwonen, trouwen, geboortenregeling, werken en kinderen krijgen, Centraal Bureau voor de Statistiek, Sdu, 's-Gravenhage, 1990, blz. 16-18, 23 en 26. Zie ook het rapport van de interdepartementale werkgroep samenlevingsvormen buiten huwelijk, Ministeric van Justitic, Samenlevingsvormen buiten huwelijk, 1986, blz. 8 en Tweede Kamer, vergaderjaar 1992-1993, 22 700, no 3, blz. 2.

4. De draagkracht wordt als randvoorwaarde van de belastingheffing gezien. Handelingen Eerste Kamer, vergaderjaar 1983-1984, 18 121, blz. 352, mk.

5. Zie onder andere H.J. Hofstra en J.W. Zwemmer. Hofstra noemt de wetgeving beginselloos en de uitvoering van de wetgeving is zijns inziens onmogelijk. Zwemmer noemt de wetgeving te ingewikkeld. De wetgeving is een resultaat van het in de politiek hoogste ideaal, nl. de rechtvaardigheid, aldus Zwemmer. P.C. Goosen en R.N.J. Kamerling, Belastinghervorming, een noodzaak, Kluwer, 1986, blz. 4 en 47.

Staatssecretaris Koning daarentegen vindt de Tweeverdienerswet een zeer acceptabele uitwerking van het regeerakkoord. P.C. Goosen en R.N.J. Kamerling, t.a.p., blz. 95.

6. F.C. Wijle, t.a.p., blz. 59 en 60 . 
In de jaren vijftig en zestig wordt erkend dat het moeten leven van een inkomen door twee personen een draagkrachtverminderende factor is. Uit de kamerstukken blijkt dat het leven van én inkomen door twee personen zelfs een zeer belangrijke overweging in dezen is. ${ }^{7}$

In die tijd wordt gezegd dat draagkracht 'een in het rechtsbewustzijn zetelend informatief begrip zou zijn.' De werking van het draagkrachtbeginsel eist, dat ongehuwden een hogere progressie moeten ondervinden, en dit is beleid. ${ }^{8}$ Hier worden mijns inziens twee begrippen door elkaar gebruikt. Op de eerste plaats het draagkrachtbeginsel en op de tweede plaats het herverdelingsmotief. De progressie wordt grotendeels geleid door het herverdelingsmotief. De progressie is een onderdeel van het inkomensbeleid. Hier blijkt dat de partijpolitiek een belangrijke rol speelt en dat belastingbeginselen een politiek karakter niet kan worden ontzegd.?

In 1973 wordt de gehuwde vrouw beperkt zelfstandig in de inkomstenbelasting betrokken. Aan het huwelijk worden enige draagkrachtvermeerderende en -verminderende factoren toegekend. Hierin schuilt ook de kritiek die op het toenmalige stelsel naar voren komt. De fiscale positie van gehuwden is gebouwd op een ingewikkeld samenstel van factoren. Deze factoren kunnen de draagkracht vermeerderen of verminderen. Aan andere samenlevingsvormen worden geen fiscale gevolgen verbonden. ${ }^{10}$ Deze niet-gelijke behandeling zou niet erg consequent zijn.

In 1979 wordt de zelfstandige positie van de gehuwde vrouw uitgebreid. Er is nog steeds geen gelijkstelling van de gehuwden met de ongehuwden die gezamenlijk een duurzame huishouding voeren. Bovendien is ook geen gelijkschakeling mogelijk in de tariefgroepindeling, die toch een globaal onderscheid in draagkrachtcategorieën representeert. ${ }^{11}$

De houding in de maatschappij ten aanzien van de vorm van het samenlevingsverband verandert in de loop van de tijd. ${ }^{12}$ Meer mensen dan voorheen kiezen voor een ongehuwd samenleven en de fiscale wetgever moet naar zijn mening hierop inspringen. Bovendien hebben de ongehuwde samenlevers ${ }^{13}$ een groter netto-inkomen dan de gehuwde samenlevers daar ze in tegenstelling tot de ge-

7. Handelingen Tweede Kamer, vergaderjaar 1983-1984, 18 121, blz. 1128, lk.

8. F.C. Wijle, t.a.p., blz. 61 .

9. Zie voor een voorbeeld waarbij het herverdelingsmotief in het draagkrachtbeginsel is ingesloten, Handelingen Tweede Kamer, vergaderjaar 1983-1984, 18 121, blz. 1119, lk.

10. F.C. Wijle, t.a.p., blz. 81.

11. Tweede Kamer, vergaderjaar 1979-1980, 15835 , nrs. 1-2, blz. 61.

12. Vergelijk ook het rapport Samenlevingsvormen buiten huwelijk. Dat beschrijft de samenlevingsvormen buiten huwelijk als zijnde relaties van zeer uiteenlopende aard die soms verwantschap vertonen met het huwelijk. Rapport van de interdepartementale werkgroep samenlevingsvormen buiten huwelijk, Ministerie van Justitje, 1986, blz. I. Zie verder ook noot 3.

13. De definiëring van ongehuwd samenlevenden is nog een praktisch probleem. J.F.M. Giele stelt voor de ongehuwd samenlevenden op schriftelijk verzoek als fictief gehuwden aan te merken, onder de voorwaarde dat de samenlevenden zich wederzijds schriftelijk verbinden tot voorziening in elkaars levensonderhoud. J.F.M. Giele, De problematiek van de tweeverdieners, FED Nederlandse Federatie van Belastingconsulenten, 1986, blz. 27. 
huwden individueel in de belastingheffing worden betrokken. Deze ongelijkheid moet naar de mening van de fiscale wetgever worden opgeheven.

In de al eerder genoemde nota 'Op weg' wordt een gelijke behandeling van deelgenoten aan vormen van samenleving en samenwonen voorgestaan. 'Naarmate andere vormen van samenleving dan het huwelijk meer gaan voorkomen en het huwelijk bepaald in meer dan voorbijgaande mate een verbintenis blijkt te zijn welke wordt verbroken, klemt de vraag of nog van een evenwichtige behandeling van belastingplichtigen kan worden gesproken. ${ }^{14}$ Aansluiting moet worden gezocht bij de feitelijke situatie; hetgeen geschiedt. De werking van het draagkrachtbeginsel is nog steeds aanwezig, zij het dat de werking van het beginsel afhankelijk is van tijd en plaats.

In de jaren tachtig komt de fiscale wetgever met de beruchte Tweeverdienerswetgeving. Deze is in drie fasen ingevoerd. De Tweeverdienerswetgeving-I, de zgn. eerste fase, betreft de realisering van een gelijke behandeling van de gehuwde man en de vrouw en een gelijktrekking van de gehuwde tweeverdieners met de gehuwde alleenverdieners. De Tweeverdienerswetgeving-II, de tweede fase, betreft de gelijke behandeling van de gehuwden en de ongehuwd samenlevenden op het gebied van de tariefgroepindeling, de verdergaande verzelfstandiging van de gehuwde vrouw en de integrale rolwisseling van gehuwden. En ten slotte, de derde fase regelt de verschillen in belastingdruk tussen de alleenverdieners en de tweeverdieners. ${ }^{15}$ Gezien de intrekking van de eerste fase, gaat de meeste aandacht uit naar de tweede en de derde fase. Desalniettemin geef ik de van belang zijnde elementen van de eerste fase weer.

De invoering van deze wetgeving roept vragen op zoals: Welke motieven liggen aan de invoering van de Tweeverdienerswetgeving ten grondslag? Welke zijn de motieven van de fiscale wetgever geweest om gehuwden en ongehuwd samenlevenden gelijk dan wel ongelijk te behandelen? Is er sprake van een consequent toepassen van beginselen of niet? Of moet gesproken worden van een leidinggevend beleid dat beinnloed wordt door de op een bepaalde tijd heersende maatschappelijke verhoudingen? In het onderstaande tracht ik deze vragen te beantwoorden. Hierbij zij aangetekend dat de wijziging van de gelijke behandeling van de gehuwden en de ongehuwd samenlevenden tengevolge van de OORT-wetgeving apart in hoofdstuk 4 wordt besproken.

\section{Overzicht}

Voordat ik de motieven van de fiscale wetgever inzake de Tweeverdienerswetgeving bespreek, geef ik een overzicht van de in de relevante literatuur en de parlementaire stukken meest genoemde draagkrachtvermeerderende en -verminderende factoren. In het onderstaande overzicht worden de meeste draagkrachtvermeerderende en -verminderende factoren bezien vanuit de gehuwden en de ongehuwd samenlevenden in vergelijking met de alleenstaanden. Bij enkele factoren heeft de factor tijd zijn invloed doen gelden.

14. Tweede Kamer, vergaderjaar 1979-1980, 15 835, nrs. 1-2, blz. 65 .

15. Tweede Kamer, vergaderjaar 1982-1983, 17 885, no S, blz. 2 (ingetrokken). 
A. samenlevers vergeleken met alleenstaanden

-1 besparing op uitgaven in verband met het voeren van een gezamenlijke huishouding

-1 met twee personen van één inkomen leven

-2 minder kosten voor de bevrediging van (im)materië behoeften

-2 kinderen*1

-3 buitenshuis werken van de vrouw*2

-3 kostenbesparend effect van de huis- -4 houdelijke arbeid van de vrouw*3

-4 vrije tijd van de vrouw

B. Andere factoren

-1 inkomsten in natura

-2 eigen huis

-3 bezit van vermogen

-1 aftrekbare giften*4

-2 buitengewone lasten

-3 reizen woon- werkverkeer

-4 arbeidskosten

-5 noodzaak in onderneming te investeren

Toelichting overzicht:

*1 De kosten die betrekking hebben op kinderen, worden dan weer wel, dan weer niet in de Wet IB 1964 betrokken. Bij voorbeeld in 1985 komt de aanvullende arbeidstoeslag in de Wet IB 1964 ter dekking van kinderopvangkosten. $^{16}$

*2 Van 1984 tot 1990 wordt met deze factor rekening gehouden door middel van de arbeidstoeslag.

*3 Sinds 1985 wordt met deze factor geen rekening meer gehouden.

*4 $\mathrm{Bij}$ giften kan ook worden gesproken van een toepassing van een niet-fiscaal doeleinde.

De auteurs die bovenstaande factoren noemen, geven toe dat het toekennen van een draagkrachtvermeerderend of -verminderend karakter aan bepaalde factoren niet altijd even sterk is. De omvang van de factoren kan sterk uiteenlopen doordat deze sterk van allerlei omstandigheden afhangt. Hofstra: 'Aangenomen kan worden dat het samenleven in huwelijksverband inderdaad financiële voordelen kan opleveren al is dat lang niet altijd het geval, en al lijkt wel vast te staan dat de omvang afhankelijk mede van het inkomensniveau en van de leefwijze, sterk uiteenloopt en uiterst onzeker is. ${ }^{17}$

16. Thans (1994) is een wetsvoorstel ingediend, waarin de kinderopvangkosten in de Wet IB worden opgenomen. Zie het op 10 november 1993 ingediende wetsvoorstel tot wijziging van de Wet op de inkomstenbelasting 1964, de Wet op de loonbelasting 1964 en de Coördinatiewet Sociale Verzekering (regelingen met betrekking tot aftrek en belastingvrije vergoeding van kosten van kinderopvang) Tweede Kamer, vergaderjaar 1993-1994, 23483.

17. H.J. Hofstra, Het splitsingsstelsel. In: Belastingbeschouwingen, Christaanse-bundel, Kluwer, 1989, blz. 73. 
Het is evenmin zo vanzelfsprekend als het wordt voorgesteld dat de besparing van de huishoudelijke arbeid in de inkomstenbelasting betrokken wordt. Indien de vrouw buitenshuis gaat werken, kan een eventuele vervanging van de huishoudelijke arbeid mijns inziens zowel als een inkomensbestedend als een inkomensverwervend element worden gezien. Met betrekking tot de draagkracht is het van belang of alleen inkomensverwervende elementen of ook inkomensbestedende elementen in de Wet IB 1964 dienen te worden betrokken. ${ }^{18}$

Waaraan wordt draagkracht toegerekend? Uitgangspunt van de Wet IB 1964 is de zgn. bronnentheorie. ${ }^{19}$ De draagkracht wordt onder andere bepaald door de omvang van de in de wet genoemde bronnen. De bronnentheorie richt zich op de inkomensverwerving. De bronnentheorie bevat drie elementen, t.w.:

1. deelname aan het economisch verkeer;

2. het oogmerk om voordeel te behalen (het subjectieve element);

3. de belastingplichtige kan het voordeel ook redelijkerwijs verwachten (het objectieve element). ${ }^{20}$

Laten we eens uitgaan van de situatie waarin de huishoudelijke arbeid tegen beloning wordt verricht door een gezinslid. Deze situatie is in de jurisprudentie herhaaldelijk aan de orde geweest. Indien de drie criteria worden toegepast op deze situatie kan met name het eerste criterium voor problemen zorgen. Een objectieve grens tussen belastbaarheid en onbelastbaarheid voor het verrichten van huishoudelijke arbeid is niet te trekken. ${ }^{21}$ Maar het gaat hier niet om het belonen van het verrichten van de huishoudelijke arbeid, maar om een besparing van de huishoudelijke arbeid. Het spiegelbeeld van de besparing van de huishoudelijke arbeid is het verrichten van de huishoudelijke arbeid ingeval de vrouw buitenshuis gaat werken. Voorheen werden kosten van huishoudelijke hulp als inkomensbesteding gezien. Deze kosten worden steeds meer als inkomensverwervende kosten beschouwd. Er vindt als het ware een accentverschuiving plaats. ${ }^{22}$

18. Hetzelfde kan worden gezegd over de andere factoren in het overzicht. Zie ook de discussie rond de kinderopvangkosten. Zie ook het recente wetsvoorstel inzake de beperking van de mogelijkheden tot overdracht van basisaftrek in het kader van het streven naar een verdergaande individualisering. In dat voorstel wordt geopperd dat een eventuele draagkrachtvermindering als gevolg van een huwelijk als een vorm van inkomensbesteding kan worden gezien. Tweede Kamer, vergaderjaar 1993-1994, 23 231, A, biz. 1.

19. Vergelijk H.J. Hofstra, Het splitsingsstelsel. In: Belastingbeschouwingen, Christiaanse-bundel, Kluwer, 1989, blz. 73. H. Mobach heeft kritiek op de bronnentheorie, omdat uitsluitend de wet bepaalt wat inkomen is en wat de aftrekposten zijn. Het economisch inkomen wordt niet bepalend geacht voor de bepaling van iemands draagkracht. H. Mobach, t.a.p., blz. 1 en 2.

20. Zie ook de bijdrage van RE.C.M. Niessen in de FED-bundel Fantasie en durf, Voordeel beogen en voordecl verwachten, 1991, blz. 75-80.

21. H. Mobach, t.a.p., blz. 2 en 3 . Is het in de situatie waarin tegen betaling huishoudelijke arbeid wordt verricht vaak al moeilijk om belastbaarheid van de beloning aan te nemen, in de situatie waarin geen beloning wordt gegeven is het nog moeilijker om een bron van inkomen aan te nemen. Vergelijk Tweede Kamer, vergaderjaar 1984-1985, 18 519, no 5, blz. 11.

22. A.C. Rijkers, Tweeverdieners-IIl. Een nabeschouwende vooruitblik, Weekblad voor fiscaal recht, 1984, no 5636, blz. 528. In de kamerstukken wordt het zelfs een beginsel genoemd om de besparende werking van de huishoudelijke arbeid van de vrouw te vergelden. Handelingen Tweede Kamer, vergaderjaar 1984-1985, 18 519, blz. 1119, mk. 
Door de besparing van de huishoudelijke arbeid in de inkomstenbelasting te betrekken wordt een inkomensbestedend element in de belastingheffing betrokken. Het zal duidelijk moeten worden welke reikwijdte het draagkrachtbeginsel heeft of zal moeten hebben. Stevens heeft het in dit kader over het feit dat het draagkrachtbeginsel dan niet beperkt zou zijn tot de inkomensverwerving. ${ }^{23}$

Uit het bovenstaande valt af te leiden dat het gezinsverband een aantal draagkrachtvermeerderende en -verminderende factoren in zich bergt. De toerekening van de draagkrachtvermeerdering of -vermindering kan niet anders dan subjectief zijn. De 'optelsom' van deze factoren kan mijns inziens ook niet anders dan subjectief worden gemaakt. Enige objectivering is daarin wel aan te brengen, maar die zal voor discussie vatbaar kunnen zijn. ${ }^{24}$

Daarbij is het van belang dat de definitie van het draagkrachtbeginsel duidelijk moet vaststaan. Mijns inziens spelen inkomensverwervende elementen bij de bepaling van het belastbaar bedrag een hoofdrol. Daarnaast wordt rekening gehouden met het inkomensbestedend karakter van bepaalde lasten. Denk bij voorbeeld maar eens aan de buitengewone lasten.

Voor de werking van het draagkrachtbeginsel is het van essentieel belang of naast de inkomensverwervende elementen ook de inkomensbestedende elementen in de belastingheffing moeten worden betrokken. Gezien de tekst en de parlementaire geschiedenis van de Wet IB 1964 kan worden geconcludeerd dat beide elementen in de wet aanwezig zijn.

\subsection{Tweeverdienerswetgeving-I}

\subsubsection{Algemene opmerkingen}

De vorm van het samenlevingsverband fluctueert. Indien in het begin van de jaren tachtig in de belastingheffing rekening wordt gehouden met een samenlevingsverband, is het alleen het gehuwde samenlevingsverband. 'Als subjectieve, op het draagkrachtprincipe gebaseerde heffing houdt onze inkomstenbelasting

23. L.G.M. Stevens, Belasting naar draagkracht, Kluwer, 1980, blz. 177. In een later artikel wordt een drietal toeslagen als vergoeding voor inkomensverwervende activiteiten beschouwd, t.w.: de arbeidstoeslag (verrichten van arbeid), de aanvullende arbeidstoeslag (het hebben van kinderen) en de aanvullende alleenstaande-oudertoeslag. L.G.M. Stevens, Wetsontwerp Tweeverdieners, derde fase (18 519), Weekblad voor fiscaal recht, 1984, no 5655, blz. 1233. De kosten van de kinderopvang zijn kosten die aanvankelijk als inkomensbestedende en later als inkomensverwervende kosten worden gezien. Tweede Kamer, vergaderjaar 1983-1984, 18 121, no 5, blz. 27.

Zie in dit verband ook Van der Burght, die van mening is dat in bepaalde gevallen over de huishoudelijke arbeid verricht door een van de partners moet worden afgerekend. Een vergoeding moet worden gegeven ingeval de wederkerigheid ontbreekt. G.R. van der Burght, Vergoeding voor huishoudelijke arbeid?, Weekblad voor fiscaal recht, 1993, no 6043, blz. 219.

24. Zie ook E.N. Kertzman, die de weging van deze factoren zwak vindt, omdat deze niet voor alle inkomensgroepen gelijk behoeft te zijn. E.N. Kertzman, Belastingheffing van gehuwden en ongehuwden, Fiscale monografieën, no 32, Kluwer, 1979, blz. 47. 
o.m. rekening met de burgerlijke staat en met het aantal en de status der kinderen, die iemand tot zijn last heeft."25

Het hebben van een of meer kinderen is blijkens bovenstaande zin van belang voor de bepaling van de draagkracht in verband met de inkomstenbelasting. Het gezinsinkomen wordt door eén of beide ouders binnengebracht. Ouders voorzien in het levensonderhoud van hun kinderen. Hierdoor kan het hebben van kinderen als een draagkrachtverminderende factor worden gezien. Mijns inziens moet worden gezegd, dat het hebben van kinderen meer te maken heeft met inkomensbesteding dan met inkomensverwerving. ${ }^{26}$ In de literatuur lopen de meningen over het al dan niet toekennen van een draagkrachtverminderend karakter aan het hebben van kinderen uiteen. Dit heeft te maken met de al eerder aan de orde gekomen vraag of het draagkrachtbeginsel al dan niet zijn werking moet hebben in de inkomensbestedingssfeer. De burgerlijke staat heeft ook niets te maken met inkomensverwerving. In dit hoofdstuk zal het element van het aantal kinderen slechts zijdelings worden behandeld. De burgerlijke staat daarentegen zal uitvoeriger worden besproken.

In het wetsvoorstel Tweeverdieners-I (1983) gaat het onder andere om een belastingverzwaring alleen voor de gehuwde en niet voor de ongehuwde samenlevers. ${ }^{27}$ De tweeverdieners worden verondersteld een grotere draagkracht te hebben dan de alleenverdieners en derhalve dienen de tweeverdieners zwaarder te worden belast. 'Dit verschil in belastingdruk kan tot grote verschillen in besteedbaar inkomen leiden bij hetzelfde totale gezinsinkomen voor belastingheffing. ${ }^{28}$ De eerste fase van de Tweeverdienerswetgeving is nooit ingevoerd. De

25. F.C. Wijle, t.a.p., blz. 4. Hofstra spreekt van een verandering van het onderscheid gehuwd/ongehuwd in samenlever/alleenstaande. H.J. Hofstra en L.G.M. Stevens, Inkomstenbelasting, t.a.p., blz. 87.

26. Vergelijk A.C. Rijkers, Tweeverdieners-III. Een nabeschouwende vooruitblik, Weekblad voor fiscaal recht, 1984, no 5636 , blz. 518 .

27. Tweeverdieners Eerste Fase, wetsvoorstel 17885 , Wijziging van de inkomstenbelasting en van de loonbelasting voor het jaar 1983 (tariefgroepindeling van de gehuwde vrouw en gehuwde man) alsmede aanpassing van enkele volksverzekeringen. Het voorstel houdt in dat de belastingvrije sommen voor 1983 voor de tweeverdieners naar tijdsgelang worden gewijzigd. De gehuwde vrouw wordt ingedeeld in tariefgroep 2 . De gehuwde man blijft ingedeeld in tariefgroep 4 indien de vrouw in 1983 geen inkomen heeft of een minder arbeidsinkomen dan $f$ 4.842. De gehuwde man wordt ingedeeld in tariefgroep 3 indien het arbeidsinkomen van de vrouw meer dan $f 4.841$ maar minder dan $f 7.382$ bedraagt. De man wordt ingedeeld in tariefgroep 2 indien het arbeidsinkomen van de gehuwde vrouw meer dan $f 7.381$ bedraagt. Tariefgroep 2 (gehuwde vrouw), cen belastingvrije som in 1983 van $f$ 3.757. Tariefgroep 2 (gehuwde man), een belastingvrije som in 1983 van $f$ 11.383. Tariefgroep 3, een belastingurije som in 1983 van $f$ 12.018. Tariefgroep 4, een belastingvrije som van $f$ 12.716. Ned. Stcrt., 19 juli 1983, nr. 137. De Tweeverdienersmaatregel' voor gehuwden treedt op 1 oktober in werking, Weekblad voor fiscaal recht, 1983, no 5600 , blz. 959.

28. Fiscale wetgeving, Belastingmaatregel voor gehuwde tweeverdieners, Weekblad voor fiscaal recht, 1983, no 5584, blz. 382. 
reden ligt juist in de ongelijke behandeling van gehuwde en ongehuwde tweeverdieners. $^{20}$

\subsubsection{Het draagkrachtbeginsel}

In 1979 is de fiscale positie van de ongehuwd samenlevenden in het algemeen gunstiger dan die van de gehuwd samenlevenden. ${ }^{30}$ In de aan de Tweeverdienerswetgeving voorafgaande nota 'Op weg' wordt voorgesteld dat de ongehuwde partners niet gunstiger doch ook niet ongunstiger worden behandeld dan de gehuwde partners. Bij het gunstiger behandelen van ongehuwde samenlevers moet worden gedacht aan maatregelen die getroffen zijn met het oog op de geringere draagkracht van ongehuwden wegens het alleenstaan. De voordelen die uit de maatregelen voortvloeien, zullen moeten verdwijnen.

In de nota wordt belastingheffing naar draagkracht belangrijk gevonden. '... evenmin is een gelijkschakeling mogelijk in de tariefgroepindeling, die toch een globale onderscheiding(sic!) in draagkrachtcategorieën representeert. ${ }^{31}$

De nota gaat verder uit van het kostwinnersprincipe: 'Bij hen doet de behoefte aan gelijkstelling met gehuwden zich vooral gelden in situaties waarin én van hen de kost verdient, met andere woorden in gevallen van traditioneel kostwinnerschap. ${ }^{32}$

In de parlementaire stukken worden met betrekking tot het draagkrachtbeginsel enige opmerkingen gemaakt en vragen gesteld. De opmerkingen en vragen vallen in twee categorieën uiteen. Op de eerste plaats is dat de categorie van opmerkingen over en vragen naar hetgeen onder draagkracht moet worden verstaan. Op de tweede plaats is dat de categorie betreffende het door de regering en het parlement in te nemen standpunt ten opzichte van de gezinsdraagkracht en de individuele draagkracht.

1. Wat moet onder draagkracht worden verstaan?

Met de invoering van de Tweeverdienerswetgeving wordt het begrip 'gezamenlijk voeren van de huishouding' geïntroduceerd. De Raad van State merkt op dat dit begrip een draagkrachtverhogende factor impliceert, en wel een zodanige dat

29. Aldus onder andere de Raad van State. Tweede Kamer, vergaderjaar 1982-1983, 17 885, no 5, blz. 25 (ingetrokken).

30. De situaties waarin de fiscale positie voor de ongehuwd samenlevenden gunstiger is dan voor de gehuwd samenlevenden zijn, aldus de nota:

- de aftrek onvolledig-gezin leidt bij een ongehuwd samenlevende tot een geringer belastingbedrag;

- indien tén of beide ongehuwd samenlevende partners ouder zijn dan 35 jaar,

- ingeval van het hebben van kinderen door de ongehuwd samenlevenden;

- kosten van gezinshulp of kinderdagverblijf kunnen in tegenstelling tot de gehuwden bij de ongehuwd samenlevenden tot een buitengewone-lastenaftrek leiden. Tweede Kamer, vergaderjaar 1979-1980, 15 835, nrs. 1-2, blz. 62-64.

31. Tweede Kamer, vergaderjaar 1979-1980, 15 835, nrs. 1-2, blz. 61.

32. Tweede Kamer, vergaderjaar 1979-1980, 15 835, nrs. 1-2, blz. 61. 
daarmee rekening moet worden gehouden. Hiertegenover staat de draagkrachtverminderende factor inhoudende dat van én inkomen twee mensen moeten leven ${ }^{33}$ De kritiek van de Raad van State op het onderhavige wetsontwerp houdt onder meer het volgende in. 'In de memorie van toelichting wordt voorts onvoldoende duidelijk gemaakt in hoeverre er uit draagkrachtoogpunt dringende redenen zijn voor de wijziging. ${ }^{34}$

De leden van het CDA definiëren solidariteit als het opleggen van offers naar draagkracht. Een voorzichtige definitie van het draagkrachtbeginsel volgt: 'Het draagkrachtbeginsel houdt onder meer in, dat het beleid inzake de sociale zekerheid en de belastingen wordt afgestemd op het samenlevingsverband waarin de uitkeringsgerechtigde en de belastingplichtige woont en leeft..35

De leden van het CDA vragen zich af of met de invoering van het wetsvoorstel niet gezegd moet worden dat de draagkrachtvermeerderende factor van het voeren van een gezamenlijke huishouding hoger gewaardeerd wordt dan voorheen. Indien dit waar is, zou sprake zijn van een opwaardering van de gezinsdraagkracht, aldus de leden. ${ }^{36}$

Leden van de PvdA vragen zich af welke draagkrachtfactoren van belang zijn in vergelijking tussen de éen- en tweeverdieners en welk gewicht daaraan moet worden toegekend. Uiteindelijk moet duidelijk worden welk verschil in behandeling gerechtvaardigd is of niet. ${ }^{37}$

De leden van de VVD vragen zich eveneens af hoe het zit met de weging van de verschillende draagkrachtbepalende factoren. $\mathrm{Zij}$ constateren dat geen grondige weging valt te ontdekken. Gezien het feit dat de tweeverdieners een groter inkomen na de belastingheffing hebben te besteden, vragen de leden van de VVD zich af hoe dit is te verdragen vanuit de draagkrachtfilosofie - wat deze ook moge inhouden - waarbij rekening wordt gehouden met de extra uitgaven die een tweeverdienersgezin heeft en het missen van de besparende werking die verband houdt met de huishoudelijke arbeid. ${ }^{38}$ De leden van de VVD begrijpen hier blijkbaar een vorm van inkomensbesteding onder de werking van het draagkrachtbeginsel.

Ook de leden van D66 vragen zich af of de regering kan aangeven welke de draagkrachtverminderende en de -vermeerderende factoren zijn en wat onder draagkracht kan worden verstaan. ${ }^{39}$

33. Tweede Kamer, vergaderjaar 1982-1983, 17 885, nrs. A-B, blz. 1 (ingetrokken).

34. Tweede Kamer, vergaderjaar 1982-1983, 17885 , nrs. A-B, blz. 2 (ingetrokken). Hierbij moet met name worden gedacht aan het wegvallen van een belangrijk deel van de besparende werking van het huwelijk indien de vrouw buitenshuis werkt en de kinderopvangkosten.

35. Tweede Kamer, vergaderjaar 1982-1983, 17885 , no 5, blz. 4 (ingetrokken).

36. Tweede Kamer, vergaderjaar 1982-1983, 17885 , no S, blz. 6 (ingetrokken).

37. Tweede Kamer, vergaderjaar 1982-1983, 17885 , no 5, blz. 3 (ingetrokken).

38. Tweede Kamer, vergaderjaar 1982-1983, 17 885, no 5, blz. 8 (ingetrokken).

39. Tweede Kamer, vergaderjaar 1982-1983, 17 885, no 5, blz. 14 (ingetrokken). 
De regering antwoordt dat de bepaling van de draagkrachtfactoren vrij arbitrair is. ${ }^{40}$

Een voorbeeld van zo'n arbitrair element is het buitenshuis werken van de gehuwde vrouw; deze factor heeft een draagkrachtverminderend effect. ${ }^{41}$ 'Daartegenover staat dat de inkomstenbelasting als heffing naar draagkracht in het algemeen geen rekening houdt met het ter verkrijging van een bepaald inkomen gewerkte aantal uren of de voor dat inkomen verrichte inspanning, doch slechts aansluit bij de objectief te bepalen inkomsten zelf. ${ }^{, 42}$ De waardering van het buitenshuis werken van de gehuwde vrouw is niet zodanig dat daarmee het verschil in belastingdruk tussen de éen- en de tweeverdieners kan worden verklaard. Het huidige stelsel gaat ervan uit dat pas boven een zeker bedrag (= belastingvrije som) plaats is voor belastingheffing naar draagkracht, aldus de regering. ${ }^{43}$ De wijze van besteding is met uitzondering van buitengewone lasten niet belangrijk voor de draagkrachtbepaling. ${ }^{44}$

Ten slotte volgt nog een opmerking over de ruwheden, de zgn. schokeffecten, die als gevolg van de invoering van Tweeverdieners-I zullen optreden. Deze worden aanvaard ten behoeve van een zo doelmatig mogelijke gelijke behandeling. Dit is onaanvaardbaar gezien vanuit een rechtvaardige belastingheffing, aldus de leden van het CDA en de VVD. ${ }^{45}$

2. De vragen en de opmerkingen in het parlement ten opzichte van de individuele draagkracht en de gezinsdraagkracht laten zich als volgt verwoorden.

$\mathrm{Al}$ in 1976 geeft de staatscommissie Bevolkingsvraagstuk, de commissie-Muntendam, in haar rapport 'Bevolking en Welzijn in Nederland' de aanbeveling, dat gestreefd dient te worden naar een geïndividualiseerd systeem van heffing,

40. De draagkrachtfactoren zijn vrij arbitrair, maar kunnen schijnbaar toch in behoorlijke exacte percentages worden weergegeven. Zie onder andere de latere Tweeverdienerswetgeving, Tweede Kamer, vergaderjaar 1884-1985, 18519 , no 8, blz. 6 en 7.

41. Tweede Kamer, vergaderjaar 1982-1983, 17885 , no 6, blz. 5 (ingetrokken).

42. Tweede Kamer, vergaderjaar 1982-1983, 17885 , no 6, blz. 7 (ingetrokken).

43. Tweede Kamer, vergaderjaar 1982-1983, 17885 , no 5, blz. 3 (ingetrokken). Staatssecretaris Koning: '... niet zal passen in de huidige opzet van inkomstenbelasting, waarbij naast bevoorrechte verkrijging de heffing naar draagkracht de grondslag vormt.' Handelingen Tweede Kamer, 15 december 1982, blz. $1243 \mathrm{lk}$ en mk. In: H. Snijders-Borst, Belasting en leefeenheid, Weekblad voor fiscaal recht 1983, no 5578, blz. 200 en 201.

Hierbij verliest mijns inziens de regering uit het 00 dat de hoogte van de belastingvrije som bij lange niet overeenkomt met hetgeen dat als een minimum-garantie van noodzakelijke levensbehoefte wordt beschouwd.

44. Tweede Kamer, vergaderjaar 1982-1983, 17 885, no 6, blz. 7 (ingetrokken).

45. Bij het genoemde bezwaar komt ook het bezwaar van het op de proef stellen van de fiscale moraliteit tengevolge van de schokeffecten. Tweede Kamer, zitting 1982-1983, 17885 , nrs. A-B, blz. 4 en no 5, blz. 7, 9 en 15 (ingetrokken). Onder het verschijnsel van 'schokeffecten' wordt verstaan het extra te betalen bedrag aan belasting wanneer een partner zijn of haar (bijna-)alleenverdienerstoeslag verliest omdat de andere partner inkomen boven een bepaalde grens verdient. Handelingen Eerste Kamer, vergaderjaar 1983-1984, 18 121, blz. 452, mk. 
waarbij de heffing onafhankelijk is van de draagkrachtveranderingen ten gevolge van keuzehandelingen in de persoonlijke levenssfeer. ${ }^{46}$

De regering volgt die aanbeveling niet. $\mathrm{Zij}$ stelt zich op het standpunt dat een louter individuele belastingheffing onvoldoende maatschappelijk draagvlak heeft. 'Fiscale regelingen mogen naar onze mening niet haaks staan op maatschappelijke ontwikkelingen. ${ }^{947}$

Er zal een synthese moeten worden gevonden tussen het streven naar individualisering en het recht doen aan het aspect van de draagkracht van de leefeenheid. Het regeerakkoord stelt dat het fiscale beleid gebaseerd moet zijn op zowel de individualiseringsgedachte als het draagkrachtbeginsel. ${ }^{48}$ De uiteindelijke beslissing over het invullen van de synthese tussen het streven naar individualisering en gezinsdraagkracht zal in de derde fase duidelijk worden. Opmerkelijk is dat al in de tweede fase vooruitlopend op de uiteindelijke synthese beslissingen worden genomen.

Het standpunt van de SGP ten aanzien van de ongehuwde samenlevers is het volgende: '... hun bezwaren tegen het wettelijk erkennen en gelijkstellen van andere vormen van samenleven van twee mensen met het wettelijke huwelijk. Een verantwoorde en reële toepassing van het draagkrachtprincipe bracht met zich mee, dat financiële gelijke gevallen in ieder geval gelijk worden belast. ${ }^{, 49}$ De leden van het CDA zijn van mening dat er niet éen draagkrachtbeginsel is, maar twee, nl. het beginsel van de gezinsdraagkracht en dat van de individuele draagkracht. Het gaat hierbij om drie zaken, t.w.:

1. Het op een of andere wijze samenstellen van inkomens.

2. Het draagkrachtverminderende effect wanneer twee personen van éen inkomen moeten leven.

3. De draagkrachtvermeerderende factor van het voeren van een gezamenlijke huishouding.

Gekozen is voor een individuele belastingheffing. ${ }^{50}$ Een nadere berekening van de drie hier genoemde factoren wordt niet gegeven.

De leden van de VVD praten niet over twee draagkrachtbeginselen, maar over het draagkrachtbeginsel en de individualiseringsgedachte. Dit valt af te leiden uit de volgende zinsnede: '... dat het fiscale beleid gebaseerd dient te zijn op zowel de individualiseringsgedachte als het draagkrachtbeginsel ...51.

46. Tweede Kamer, vergaderjaar 1982-1983, 17885 , no 5, blz. 9 (ingetrokken).

47. Tweede Kamer, vergaderjaar 1982-1983, 17 885, no 5, blz. 2 (ingetrokken).

48. Tweede Kamer, vergaderjaar 1982-1983, 17885 , no 5, blz. 8 en no 6, blz. 13 (ingetrokken).

49. Het splitsingsstelsel zou meer recht doen aan het draagkrachtbeginsel, aldus de SGP. Tweede Kamer, vergaderjaar 1982-1983, 17 885, no 5, blz. 30 en 31 (ingetrokken).

50. Tweede Kamer, vergaderjaar 1982-1983, 17885 , no 5, blz. 5 en 6 (ingetrokken).

51. Tweede Kamer, vergaderjaar 1982-1983, 17885 , no 5, blz. 8 (ingetrokken). Zie ook het standpunt van D66, dat inhoudt dat een spanning bestaat tussen individualisering en draagkracht. Tweede Kamer, vergaderjaar 1982-1983, 17 885, no 5, blz. 10 (ingetrokken). 
De leden van D66 spreken van een beginsel van individuele fiscale behandeling. ${ }^{52}$

De leden van de PSP constateren dat de regering met de voorgestelde maatregel kiest voor een gezinsdraagkracht, nader gespecificeerd, de gezamenlijke draagkracht van de tweeverdieners. ${ }^{53}$

Stevens vindt het onderhavige wetsontwerp een wetsontwerp met een gemengd karakter; het wetsontwerp heeft zowel elementen van een gezinsbelasting als van een individuele belastingheffing in zich. Dit betekent dat geen gehoor wordt gegeven aan de door de nota 'Op weg' voorgestane individualisering van de inkomstenbelasting. ${ }^{54}$ De keuze voor het gezinsinkomen is er een van maatschappelijke voorkeuren, aldus Stevens. ${ }^{55}$

Ik proef uit de verschillende formuleringen dat het draagkrachtbeginsel nader wordt ingevuld door hetgeen in de maatschappij zich ontwikkelt en de partijpolitieke opvattingen.$^{56}$ Het draagkrachtbeginsel en de verzameling maatschappelijke voorkeuren ten gevolge waarvan op den duur een bepaalde ontwikkeling van het beginsel plaatsvindt, zijn blijkbaar twee begrippen van verschillende orden. Het draagkrachtbeginsel ondergaat de invloed van de maatschappelijke opvattingen. ${ }^{7}$ Dit is niet erg, maar het zegt wel iets over het niveau waarop over het draagkrachtbeginsel wordt besproken. Blijkbaar is er meer dan éen niveau waarop over het draagkrachtbeginsel wordt gesproken. Hiermee bedoel

52. Tweede Kamer, vergaderjaar 1982-1983, 17885 , no 5, blz. 10 (ingetrokken).

53. Tweede Kamer, vergaderjaar 1982-1983, 17885 , no 5, blz. 16 (ingetrokken).

54. L.G.M. Stevens, Wetsontwerp Tweeverdieners, Weekblad voor fiscaal recht, 1983, no 5591, blz. 581. De regering dient een keuze te maken tussen de individuele draagkracht of de gezinsdraagkracht. Uit: H. Mobach, solidair of solitair. een versluierend dilemma, Leids Fiscaal Jaarboek, Gouda Quint, 1986, blz. 107.

55. L.G.M. Stevens, Wetsontwerp Tweeverdieners, Weekblad voor fiscaal recht, 1983, no 5591, blz. 579 en 580 . Vergelijk ook P. Kavelaars, die zegt dat de draagkracht van het samenlevingsverband bepalend is. Het gezamenlijke inkomen is de maatstaf. P. Kavelaars, Tweeverdieners: laatste fase?, Weekblad voor fiscaal recht, 1985, no 5707, blz. 1598. Vergelijk ook de opmerking van J.F.M. Giele, die vindt dat het splitsingsstelsel als vorm van een samenvoegingsstelsel slechts nog een theoretisch element is. J.F.M. Giele, De problematiek van de tweeverdieners, FED Nederlandse Federatie van Belastingconsulenten, 1986, blz. 29. L. Andringa stelt voor gehuwden als ongehuwden te behandelen gezien de ongelijkheid die optreedt. Met andere woorden niet kiezen voor de gezinsdraagkracht, maar voor de individuele draagkracht. $L$. Andringa, Van gezinsdraagkracht naar individuele draagkracht, Nemisis, 1987, blz. 176.

56. A.C. Rijkers, Tweeverdieners-III. Een nabeschouwende vooruitblik, Weekblad voor fiscaal recht, 1984, no 5636, blz. 517. Zo is de ingewikkeldheid van de fiscale wetgeving ook aan 'de politiek' te wijten. L.G.M. Stevens, Wetsontwerp Tweeverdieners, derde fase (nr 18 519), Weekblad voor fiscaal recht, 1984, no 5655, blz. 1225. Vergelijk ook E.N. Kertzman, die al in 1979 tot de conclusie komt dat het heffen naar draagkracht geen politiek neutraal fiscaal doeleinde is, maar een doeleinde waar politieke belangen een zekere rol spelen. E.N. Kertzman, Belastingheffing van gehuwden en ongehuwden, Fiscale monografieën, no 32, Kluwer, 1979, blz. 37.

57. In dit verband past ook het volgende citaat: '... een zeer beperkte betekenis toe, omdat de diverse uitgangspunten die in het verleden ten grondslag zijn gelegd aan de belastingvrije sommen, moeten worden gezien in het licht van de toentertijd geldende maatschappelijke opvattingen en verhoudingen.' Tweede Kamer, vergaderjaar 1984-1985, 18 519, no 5, blz. 9. 
ik te zeggen dat men veelal spreekt over hèt draagkrachtbeginsel, terwijl de concrete invulling van het beginsel niet altijd hetzelfde behoeft te zijn. Op een abstract niveau is men ondanks de verschillende overtuigingen het in het algemeen wel eens over de functie van het draagkrachtbeginsel, maar op een concreet niveau wordt het al moeilijker.

\subsubsection{Het gelijkheidsbeginsel}

Volgens de nota 'Op weg' dienen economisch gelijke situaties fiscaal gelijk behandeld te worden. ${ }^{58}$ Door deze wens komt een materieel criterium, economisch gelijke situaties, in plaats van een formeel criterium, zoals het huwelijk. Het criterium voor een alternatieve samenlevingsvorm houdt in dat twee samenlevers gedurende een zekere tijd een gezamenlijke huishouding voeren. De duurzaamheid van de gezamenlijke huishouding moet worden aangetoond (12 maanden vanaf 18 jaar). ${ }^{59}$ Vermelding verdient het feit dat de verschillende wettelijke regelingen die betrekking kunnen hebben op de gelijke behandeling van gehuwden en ongehuwde samenlevers, niet altijd dezelfde criteria hanteren. Deze onderscheiden zijn een gevolg van de verschillende doelstellingen en rechtsgronden van de verschillende regelingen.$^{60}$ Hierdoor is het mogelijk dat twee ongehuwden voor de ene regeling wel en voor de andere niet als ongehuwd samenlevend worden aangemerkt. ${ }^{61}$ De vraag of dit wenselijk is, is niet gemakkelijk te beantwoorden.

Uit het bovenstaande volgt dat de economische situatie leidend moet zijn voor de nadere invulling van het draagkrachtbeginsel. Laten we aan de hand van de aan het begin van de jaren tachtig geldende fiscale wetgeving de verschillende situaties vergelijken. Onderscheid dient te worden gemaakt tussen de situatie waarin slechts én partner de kost verdient, en die waarin beide partners verdienen.

a. In het geval van traditioneel kostwinnerschap - alleenverdiener - is een ongehuwde partner slechter af dan een gehuwde. De belastingdruk is voor de ongehuwde veel hoger. Bovendien kan de gehuwde belastingplichtige in tegenstelling tot de ongehuwde bepaalde kosten ter bestrijding van ziekte of invaliditeit van de partner in aanmerking nemen.

In geval van kinderen die vallen onder de termen van kinderbijslag of kinderaftrek, maakt het niet uit of beide partners gehuwd of ongehuwd zijn.

58. Tweede Kamer, vergaderjaar 1979-1980, 15 835, nrs. 1-2, blz. 67. Zie ook Tweede Kamer, vergaderjaar 1982-1983, 17 885, no 6, blz. 3 (ingetrokken). Tweede Kamer, vergaderjaar 19851986, 19262 , no 4, blz. 6 waarin wordt gesteld dat de formele zorgplicht niet een verschil in draagkracht veroorzaakt.

59. Tweede Kamer, vergaderjaar 1979-1980, 15 835, nrs. 1-2, blz. 65 en 66 . Onder gehuwden en ongehuwd samenlevenden worden die belastingplichtigen verstaan die een gezamenlijke huishouding voeren.

60. Tweede Kamer, vergaderjaar 1985-1986, 19 262, no 3, blz. 4.

61. Zie voor een overzicht van de diverse regelingen Tweede Kamer, vergaderjaar 1985-1986, 19 262, nrs. 1-2. 
Ingeval sprake is van een toepassing van een 'onvolledig-gezinaftrek', is de ongehuwde voordeliger af.

b. In het geval van tweeverdieners geldt het volgende. Wanneer geen sprake is van kinderen en beide partners jonger zijn dan 35 jaar, maakt het bijna geen verschil of de partners gehuwd zijn of niet. Indien eén van de partners of beiden ouder zijn dan 35 jaar, wordt het verschil in belastingdruk groter. Het ongehuwde stel betaalt veel minder belasting door toepassing van verschillende belastingvrije sommen. Ingeval er kinderen zijn, is het verschil nog groter. Bovendien komt in dat geval ook de 'onvolledig-gezinaftrek' om de hoek kijken, waardoor het verschil in belastingdruk nog groter wordt ten gunste van de ongehuwden. ${ }^{62}$

De ongehuwde partner is over het algemeen in de alleenverdienerssituatie slechter af dan de gehuwde. In een tweeverdienerssituatie zijn de rollen omgekeerd. Twee economisch vergelijkbare situaties moeten gelijk worden behandeld. Deze wens tot gelijkstelling vult als het ware het draagkrachtbeginsel in.

Volgens de nota zullen de volgende regelingen voor de gehuwde en ongehuwde samenlevers gelijkelijk van toepassing zijn:

1. de mogelijkheid tot voetoverheveling;

2. de tariefgroepindeling. Een voorbeeld hiervan is dat de ongehuwde belastingplichtige die voorziet in het levensonderhoud van de andere partner die geen eigen inkomen heeft, evenals de gehuwde in aanmerking komt voor rangschikking in tariefgroep 4 (het kostwinnersprincipe: het voorzien in het levensonderhoud van de gehuwde partner).

De gelijkstelling geldt alleen voor de toepassing van het tarief. De gelijke behandeling met gehuwden omvat niet de inkomenstoerekening, dit zou in strijd zijn met de individualiseringsgedachte. ${ }^{63}$ Ten aanzien van de buitengewone lasten kan geen inbreuk op de individualiseringsgedachte worden gemaakt. ${ }^{64}$

Het uitgangspunt van de voorgestelde regeling houdt een algemene belastingvrije som in, zowel voor de gehuwde man als voor de gehuwde vrouw. Dit wordt als een belangrijke stap op weg naar een fiscale gelijke behandeling van de gehuwde vrouw gezien. Het feit dat een lastenverzwaring optreedt, doet daaraan niets af. In dit geval wijkt het draagkrachtbeginsel voor het gelijkheidsbeginsel. ${ }^{65}$ Opmerkelijk is dat eventuele uitvoeringsmoeilijkheden, die kunnen ontstaan doordat de fiscus een gemeenschappelijke huishouding aanwezig acht doch de belastingplichtige niet, aanvaard moeten worden. Optimistisch wordt van re-

62. Tweede Kamer, vergaderjaar 1979-1980, 15 835, nrs. 1-2, blz. 61-65.

63. Tweede Kamer, vergaderjaar 1979-1980, 15835 , nrs. 1-2, blz. 81. In de nota wordt vastgesteld dat de gelijkstelling een fiscale bate oplevert van $f 75$ min.. Tweede Kamer, vergaderjaar 19791980, 15835 , nrs. 1-2, blz. 68.

64. Tweede Kamer, vergaderjaar 1979-1980, 15835 , nrs. 1-2, blz. 83.

65. Dit is opmerkelijke conclusie, daar het draagkrachtbeginsel kans worden gezien als een nadere invulling van het gelijkheidsbeginsel. Zie verder hoofdstuk 7 . 
geringszijde opgemerkt dat deze uitvoeringsmoeilijkheden in de praktijk mogelijk zullen meevallen. ${ }^{6}$

Een curiositeit is dat in de nota wordt gesproken van een streven naar een gelijke behandeling van de gehuwden en de ongehuwd samenlevenden, terwijl in het wetsvoorstel Tweeverdieners-I alleen de gehuwde tweeverdieners worden aangepakt.

De Raad van State is van mening dat een ongelijke behandeling tussen de gehuwd en de ongehuwd samenlevende tweeverdieners onwenselijk is: 'De grotere draagkracht welke bij tweeverdienersgezinnen in verhouding tot de énverdienersgezinnen aanwezig kan worden geacht, kan immers ook bij tweeverdieners, waarvan de partners niet gehuwd zijn, worden gesignaleerd. ${ }^{67}$

De leden van onder andere D66 menen dat het wetsvoorstel niet neutraal is ten opzichte van de leefvorm, omdat de voorgestelde maatregel niet geldt voor de ongehuwd samenlevenden. ${ }^{68}$

Deze kritiek is uiteindelijk de aanleiding geweest om het wetsvoorstel in te trekken, hetgeen geschiedt op 8 maart 1984.

\subsubsection{Budgettaire overwegingen}

In een laatste deelparagraaf, maar zeker niet de onbelangrijkste, maak ik een aantal opmerkingen over budgettaire overwegingen. De vraag rijst of deze overwegingen een rol spelen? En zo ja, in hoeverre spelen zij een rol of mogen zij een rol spelen?

De eerste vraag kan met enige restrictie bevestigend worden beantwoord. Zo heeft de reden voor de invoering van de Tweeverdienerswetgeving onder andere gelegen in de financiering van de eenmalige uitkering aan de 'minima'. De voorgestelde maatregel dient ter financiering van de koopkrachtbijstellingen voor het jaar $1983^{\oplus 9}$

Opvallend bij het onderzoek naar de beantwoording van de tweede vraag, is dat het verband met het budgettaire vaak wordt verbloemd.

66. Tweede Kamer, vergaderjaar 1979-1980, 15835 , nrs. 1-2, blz. 68 .

67. Tweede Kamer, vergaderjaar 1982-1983, 17 885, nrs. A-B, blz. 2 en 3 en no 5, blz. 12 en 25 (ingetrokken).

68. Tweede Kamer, vergaderjaar 1982-1983, 17 885, no 5, blz. 14 (ingetrokken). Zie ook E.N. Kertzman, die van mening is dat de fiscus niet neutraal kan staan ten opzichte van de samenlevingsvorm, zonder een inbreuk op het privé-leven. E.N. Kertzman, t.a.p., blz. 145 en 146.

69. Fiscale wetgeving, Belastingmaatregel voor gehuwde tweeverdieners, Weekblad voor fiscaal recht, 1983, no 5584, blz. 382. Handelingen Tweede Kamer, vergaderjaar 1983-1984, 18 121, blz. 1058 , lk. Het bestendigen van de tijdelijke maatregel voor gehuwde tweeverdieners, (eerste fase) levert een bate op van ongeveer $f 300 \mathrm{~min}$.. Weekblad voor fiscaal recht, 1983, no 6505, blz. 1152. Tweede Kamer, vergaderjaar 1982-1983, 17885 , no 5, blz. 11 (ingetrokken). De budgettaire bate daait ten gevolge van het later willen invoeren van de voorgestelde maatregel. Tweede Kamer, vergaderjaar 1982-1983, 17 885, no, blz. 1 (ingetrokken). Zie C.P.A. Bakker, die spreekt van een waarschijnlijk tegenvallende opbrengst. C.P.A. Bakker, Gehuwde tweeverdieners: ondoelmatige ingreep!, Weekblad voor fiscaal recht 1983, no 5594, blz. 686. 
De budgettaire overwegingen zijn blijkbaar de drijfveren geweest voor de eerste fase. Hierin ligt ook de kritiek van het parlement. ${ }^{70}$ De leden van bij voorbeeld D66 zijn van mening dat het wetsvoorstel niet steunt op principiële, maar op budgettaire overwegingen. ${ }^{71}$ Belangrijk in dit verband is het volgende citaat: 'De Regering ziet de maatschappelijk(sic!) druk tot deze uitbreiding (uitbreiding van de beperkte verzelfstandiging van de belastingheffing van de gehuwde vrouw, MW) als aanleiding om te overwegen hiertoe per 1 januari 1984 over te gaan, maar acht het van belang dat in totaal een budgettair aanvaardbaar resultaat wordt bereikt. ${ }^{32}$

Hier worden twee dingen gezegd: de maatschappij bepaalt de nadere invulling van de belastingheffing en budgettaire overwegingen zijn hierbij belangrijke richtingsfactoren. Budgettaire overwegingen kunnen zeer belangrijk zijn voor het al dan niet invoeren van een fiscale maatregel.

Het dominante karakter van de budgettaire overwegingen is in sommige gevallen van een zodanig gewicht, dat ik me afvraag of niet in feite sprake is van een beginsel. Althans budgettaire overwegingen zijn zulke zwaarwegende elementen dat zij de werking van het draagkrachtbeginsel en het gelijkheidsbeginsel drastisch kunnen beperken.

\subsection{Tweeverdienerswetgeving-II}

\subsubsection{Algemene opmerkingen}

De tweede fase $(1984)^{73}$ wil een gelijke belastingvrije voet voor zowel man als vrouw invoeren. De indeling van de tariefgroepen verandert. Voorheen was de indeling afhankelijk van de sexe en de burgerlijke staat, en onafhankelijk van het inkomen van de partner. Met de invoering van Tweeverdieners-II is de indeling van de tariefgroepen afhankelijk van het inkomen van de partner geworden. ${ }^{74}$ Een verdere verzelfstandiging van de gehuwde vrouw wordt beoogd. ${ }^{75} \mathrm{De}$ inte-

70. J.W. Zwemmer merkt het volgende op: 'Eerst kostte de tweeverdienerswet $f 500$ miljoen. In de tweede fase leverde ze $f 500$ miljoen op. Het Ministerie van Financiën werkt met gegevens van jaren terug. ... De enige reden waarom het wordt geloofd is dat niemand betere gegevens heeft. Men denkt dat Financiën het heeft uitgerekend. Het heeft helemaal niets uitgerekend, gewoon de natte vinger in de lucht gestoken.' P.C. Goosen en R.N.J. Kamerling, t.a.p., blz. 47.

71. H. Snijders-Borst, Belasting en leefeenheid, Weekblad voor fiscaal recht, 1983, no 5578, blz. 191 en Mondeling overleg over de behandeling van de Nota Op weg, Weekblad Fiscaal Recht, 1983, no 5596, blz. 785 en Tweede Kamer, vergaderjaar 1982-1983, 17 885, no 5, blz. 13, 23, 25 en 42 (ingetrokken). Handelingen Tweede Kamer, vergaderjaar 1983-1984, 18 121, blz. 1197, lk. Zie cok L.G.M. Stevens, Wetsontwerp Tweeverdieners, Weekblad voor fiscaal recht, 1983, no 5591, blz. 577 en 578.

72. Tweede Kamer, vergaderjaar 1982-1983, 17885 , no 5, blz. 13 (ingetrokken).

73. Wet van 30 december 1983, Stb. 1983, 690; inwerkingtreding op 1 januari 1984.

74. E. van Kessel, M. Kuperus, H. Pott-Buter, Hoezo gelijk belast?, Invloed van arbeid, belastingen premieheffing op het leven van vrouwen, 1986, blz. 51.

75. Zie voor de uitbreiding van de fiscale zelfstandige positie van de gehuwde vrouw hoofdstuk 2 , noot 62 . 
grale rolwisseling kan worden toegepast. Dit betekent dat in een huwelijk alle niet tot het persoonlijk arbeidsinkomen behorende inkomensbestanddelen worden toegerekend aan de echtgenoot met het hoogste persoonlijk arbeidsinkomen. ${ }^{76}$ Tweeverdienerswetgeving-II streeft ernaar het verschil in belastingdruk tussen cén- en tweeverdieners te verminderen, alhoewel dit laatste vooral in de derde fase tot uiting zal komen. ${ }^{n}$ Met de invoering van de Tweeverdienerswetgeving-II worden twee toeslagen geïntroduceerd, t.w.: de alleenverdienerstoeslag en de bijna-alleenverdienerstoeslag.

De tweede fase moet zeker niet als een afgerond geheel, maar als een belangrijk onderdeel in het geheel worden beschouwd. ${ }^{78}$ Globaal gezegd gaat het in deze fase om een afweging tussen de individualisering, het draagkrachtbeginsel en het gelijkheidsbeginsel. ${ }^{79}$ Net zoals in de eerste fase, kan mijns inziens deze afweging niet anders dan met partijpolitieke motieven worden gemaakt. De beginselen worden dan als het ware 'aangekleed' door partij-politieke motieven. Bovendien zijn veel beslissingen van compromissoire aard. Dit heeft uiteraard zijn weerslag op de nadere invulling van de beginselen. Ik zal dat proberen aan te tonen.

In het advies van de Raad van State betreffende de tweede fase worden de volgende opmerkingen ten aanzien van de beginselen gemaakt. Ten eerste maakt de Raad van State een opmerking over het tempo waarin het wetsvoorstel moet worden behandeld. De Raad vreest voor een slechte kwaliteit van zowel de voorbereiding als het uiteindelijke wetgevingsprodukt. Dit punt van kritiek betreft een wetgevingsbeginsel, $\mathrm{nl}$. het beginsel van consensus. ${ }^{80}$

Ten tweede maakt de Raad van State opmerkingen betreffende de doelmatigheid. De controle van de fiscus moet na aanvaarding van dit wetsvoorstel verder gaan dan de controle van de in de aangifte vermelde gegevens. De fiscus moet

76. Tweede Kamer, vergaderjaar 1983-1984, 18 121, no 3, blz. S. Het wetsvoorstel: Wijziging van de indeling in tariefgroepen in de inkomsten- en loonbelasting en wijziging van de inkomenstoerekening voor gehuwde belastingplichtigen in de inkomstenbelasting alsmede aanpassing van een aantal wetten, 18 121, Wet van 30 december 1983, Stb. 1983, 690. De wet is inwerking getreden op 1 januari 1984. De horizontale tariefstructuur bestaat uit een algemene belastingvrije som en de volgende toeslagen: de alleenstaandetoeslag, de alleenverdienerstoeslag, de bijna-alleenverdienerstoeslag en de alleenstaande-ouderstoeslag.

77. Handelingen Tweede Kamer, vergaderjaar 1983-1984, 18 121, blz. 1120, lk.

78. Handelingen Tweede Kamer, vergaderjaar 1983-1984, 18 121, blz. 1132, rk.

79. Zie bij voorbeeld Handelingen Tweede Kamer, vergaderjaar 1983-1984, 18 121, blz. 1123, rk. De belastingheffing naar draagkracht kan als volgt worden omschreven: de individuele draagkracht van een zelfstandige belastingplichtige wordt bepaald door het samenwerkingsverband waarin hij zorgt, leeft en werkt. Het beginsel van gezinsdraagkracht dient nadrukkelijk tot uiting te komen. Handelingen Tweede Kamer, vergaderjaar 1983-1984, 18 121, blz. 1190, rk, 1191, ik.

80. Tweede Kamer, vergaderjaar 1983-1984, 18 121, nrs. A-C, blz. 3 en 4. J.C. van der Vlies, Het wetsbegrip en beginselen van behoorlijke regelgeving, 's-Gravenhage, 1984, blz. 199 e.v.. Frappant is echter dat de regering, vooruitlopend op de goedkeuring van het de tweede fase betreffende wetsvoorstel, formulieren met de nieuwe wettekst aan de werkgevers heeft gestuurd. Dit is wel voorbarig. Handelingen Tweede Kamer, vergaderjaar 1983-1984, 18 121, blz. 1134, mk en rk. 
naar aanleiding van de Tweeverdienerswetgeving nu ook de persoonlijke omstandigheden van de belastingplichtigen gaan controleren. Dit kost mankracht en is niet doelmatig. ${ }^{83}$ Bovendien worden de nieuw geïntroduceerde begrippen 'het voeren van een huishouding' en een 'gezamenlijke huishouding' niet nader uitgelegd, hetgeen impliceert dat een verschuiving van begripsinterpretatie plaatsvindt van de wetgever naar de rechter. Het niet nader invullen van de begrippen door de wetgever zal veel conflictstof opleveren tussen de fiscus en de belastingplichtigen. ${ }^{82}$ Hetzelfde geldt ten aanzien van de invoering van de referentieperiode ter vervanging van de peildatum.

Met de doelmatigheid hangt ook de fiscale moraal samen. De Raad van State is bang dat de gevolgen van de verslechterende moraal worden onderschat. ${ }^{83}$

Een ander aspect van doelmatigheid is de mate van ingewikkeldheid van de regeling. De onderhavige wetswijziging is van een bijzonder ingewikkelde aard, aldus de Raad van State. ${ }^{84}$

Ten slotte maakt de Raad van State een opmerking over het gelijkheidsbeginsel in relatie met de doelmatigheid. Hij vraagt zich af waarom doelmatigheidsoverwegingen zich tegen de volledig gelijke behandeling van gehuwden en ongehuwd samenlevers verzetten. De doelstelling van de gelijke behandeling wordt niet ten volle gerealiseerd. ${ }^{85}$ Het ware wellicht mogelijk dat de regering een duidelijker motivering ten aanzien van dit punt kan geven. ${ }^{86}$

Van regeringszijde wordt op hetgeen de Raad van State heeft opgemerkt als volgt gereageerd.

81. Tweede Kamer, vergaderjaar 1983-1984, 18 121, nrs. A-C, blz. 4 en 6. Ook in de literatuur zijn twijfels gerezen over de doelmatigheid van het wetsvoorstel. Gevreesd wordt voor relatief lage en onzekere opbrengsten en hoge uitvoeringskosten. Zie C.P.A. Bakker, Gehuwde tweeverdieners: ondoelmatige ingreep!, Weekblad voor fiscaal recht, 1983, no 5594, blz. 684.

82. Tweede Kamer, vergaderjaar 1983-1984, 18 121, nrs. A-C, blz. 6. Zie voor een uiteenzetting van de inhoud van de begrippen, P.J. van Amersfoort, D. van den Hoeven, De wet tweeverdieners, Enkele begrippen en consequenties nader beschouwd, Weekblad voor fiscaal recht, 1984, no 5625, blz. 189-200. Zie voor een verdere uitkristallisatie van de begrippen, E.P.J. Wasch, Tweeverdienersregeling: gezamenlijke huishouding, commerciële relatic en enkele praktijkproblemen, Weekblad voor fiscaal recht, 1986, no 5742, blz. 1157-1168.

83. Tweede Kamer, vergaderjaar 1983-1984, 18 121, nrs. A-C, blz. 5.

84. Tweede Kamer, vergaderjaar 1983-1984, 18 121, nrs. A-C, blz. 6.

85. De verschillen die blijven bestaan zijn:

- het verschillend formeel criterium voor het verkrijgen van de beide alleenverdienerstoeslagen;

- de fiscale erkenning van het pensioen van de partner;

- de aftrek buitengewone lasten die voor de minst verdienende partner zou kunnen wegvallen;

- verschillen in het erfrecht en de successiebelasting;

- de vermogensinkomsten; ongehuwden kunnen in tegenstelling tot de gehuwden profiteren van twee maal de rente- of dividendvrijstelling;

- verschillen in het sociale zekerheidsstelsel.

Zie voor het laatste punt de notitie 'Leefvormen', Tweede Kamer, vergaderjaar 1985-1986, 19

262. Handelingen Eerste Kamer, vergaderjaar 1983-1984, 18 121, blz. 355, mk.

86. Tweede Kamer, vergaderjaar 1983-1984, 18 121, nrs. A-C, blz. 8. 
Een nadere toelichting op het wetgevingsbeginsel inhoudende een nadere motivering wordt niet nodig geacht. ${ }^{87}$ Indien de voorgestelde regeling niet op tijd kan worden ingevoerd, schroomt de regering niet om in verband met budgettaire overwegingen eventueel tot noodwetgeving over te gaan. ${ }^{88}$ Hier ziet men het grote belang van budgettaire overwegingen in een wetgevingsproces.

Ten aanzien van de controle door de fiscus stelt de regering dat de Raad van State hieraan te zwaar tilt. ${ }^{\$}$ Een nadere motivering van de doelmatigheidsargumenten wordt niet nodig geacht, omdat de wetswijziging alleen een wijziging in de tariefgroepindeling betreft. ${ }^{90}$ Maar in de tariefgroepindeling komen toch de verschillen in draagkracht tot uiting? Dan lijkt een nadere motivering wel degelijk gewenst.

Wat het punt van de invoering van de moeilijke begrippen betreft, stelt de regering zich op het standpunt dat uit het oogpunt van rechtvaardigheid gekozen is voor een beknopte en niet voor een uitvoerige regeling. ${ }^{11}$ Met betrekking tot de referentieperiode wordt medegedeeld dat deze uit het oogpunt van draagkracht rechtvaardiger is dan een peildatum. Het criterium is het voeren van een gezamenlijke huishouding gedurende zes maanden. ${ }^{22}$

Met de fiscale moraal zal het volgens de regering wel meevallen. Maar aan de andere kant wordt wel toegegeven dat de grens van het uiterste wat betreft de uitvoering is bereikt. ${ }^{93}$ Bovendien heeft de tweede fase nogal wat schokeffecten tot gevolg. ${ }^{94}$ Dit bevordert de fiscale moraal ook niet. De praktijk zal een en ander moeten uitwijzen.

Ten aanzien van de ingewikkeldheid van de wetgeving merkt de regering op dat weinig belastingplichtigen de wettekst zullen lezen. Een ieder wordt weliswaar geacht de wet te kennen, maar dit hoeft geenszins te betekenen dat een ieder zich de wet eigen maakt. Het betekent echter wel dat een beroep op de onbekendheid van de wettelijke regels niet kan slagen. Ik vraag me af hoe iemand de inhoud van de wettelijke regels kan kennen zonder zich de wet eigen te maken. Dit kan in dat geval alleen maar door een beroep te doen op fiscale adviseurs.

87. Tweede Kamer, vergaderjaar 1983-1984, 18 121, nrs. A-C, blz. 11.

88. Handelingen Tweede Kamer, vergaderjaar 1983-1984, 18 121, blz. 1133, lk.

89. Tweede Kamer, vergaderjaar 1983-1984, 18 121, nrs. A-C, blz. 12.

90. Tweede Kamer, vergaderjaar 1983-1984, 18 121, nrs. A-C, blz. 16. De regering kiest niet voor formele criteria, zoals de indeling naar burgerlijke staat en sekse, maar voor een materieel criterium, een indeling naar feitelijke omstandigheden, zoals het voeren van een huishouding voor zich alleen of het voeren van een gezamenlijke huishouding. Tweeverdieners 2 , lof en blaam, H. Snijders-Borst, Weekblad voor fiscaal recht, 1983, no 5618, blz. 1605.

91. Tweede Kamer, vergaderjaar 1983-1984, 18 121, nrs. A-C, blz. 13 en Handelingen Tweede Kamer, vergaderjaar 1983-1984, 18 121, blz. 1143, mk.

92. Tweede Kamer, vergaderjaar 1983-1984, 18121 , nrs. A-C, blz. 14 en 16, no 3, blz. 14. Tegenstrijdig is dan wel het feit dat ingeval van de alleenverdienerstoeslag, die een fiscale erkenning is van een draagkrachtverminderende factor, juist geen referentieperiode kent. Zie ook amendement nr. 21 (Kombrink), Weekblad voor fiscaal recht, 1983, no 5616, blz. 1554.

93. Twieede Kamer, vergaderjaar 1983-1984, 18 121, nrs. A-C, blz. 13. Handelingen Tweede Kamer, vergaderjaar 1983-1984, 18 121, blz. 1132, rk.

94. De budgettaire opbrengsten zullen tegenvallen door de schokeffecten. H. Snijders-Borst, Tweeverdieners 2, lof en blaam, Weekblad voor fiscaal recht, 1983, no 5618, blz. 1613. 
Dit kan toch niet de bedoeling van de fiscale wetgeving zijn? Indien zo wordt geredeneerd, lijkt me dat de maatschappelijke aanvaarding van de fiscale wetgeving op den duur wordt ondermijnd.

Ten slotte volgt een opmerking over de werking van de maatschappelijke druk. 'Voor de loon- en de inkomstenbelasting dient naar ons oordeel de (lasten)verdelende rechtvaardigheid niet uit het oog worden verloren. Zou men dit wel doen, dan gaat dit zeker bij de huidige tarieven van de loon- en de inkomstenbelasting te zeer ten koste van de maatschappelijke aanvaarding van deze belastingen. ${ }^{95} \mathrm{De}$ in het maatschappelijk verkeer geldende opvattingen zijn bepalend voor de invulling van de belastingheffing. Dit is ook logisch, daar de aanpassing van de belastingheffing aan de in het maatschappelijk verkeer geldende opvattingen zal leiden tot een grotere maatschappelijke aanvaarding. De regering gaat ervan uit dat de realisering van de (verdelings)beginselen als maatschappelijke wens wordt geopperd. Op zichzelf is het een nobel streven om de wens van de maatschappij te willen realiseren. Maar de vraag rijst of de regering deze wens ook daadwerkelijk uitvoert.

\subsubsection{Het draagkrachtbeginsel}

Bij de bestudering van de parlementaire geschiedenis behorende bij de Tweeverdieners-II valt het op dat net als bij Tweeverdieners-I het begrip draagkracht moeilijk te definiëren is en op vele manieren kan worden ingevuld. Zo is er op de eerste plaats een onderscheid tussen gezinsdraagkracht en individuele draagkracht; anderen spreken van een individuele belastingheffing. ${ }^{96}$ Wat met de begrippen 'gezin' en 'individu' wordt bedoeld, spreekt enigszins voor zichzelf. Alhoewel?

Draagkracht en gezinssamenstelling blijken onderling verband te hebben. Voorstanders van gezinsdraagkracht stellen dat met de gezinsdraagkracht een belangrijk nevendoel van de belastingheffing kan worden gediend, $\mathrm{nl}$. de herverdeling van inkomen. ${ }^{97}$ Elk lid van het gezin profiteert gelijkelijk van het inkomen.

Voorstanders van een individuele belastingheffing daarentegen stellen dat door toepassing van het idee van de individuele belastingheffing aan het draagkrachtbeginsel optimale werking wordt verleend. Persoonlijk inkomen van echtgenoten

95. Tweede Kamer, vergaderjaar 1983-1984, 18 121, no 7, blz. 3. De acceptatie van de belastingheffing in de maatschappij wordt mijns inziens in het parlement als een steeds groter wordend goed gezien. Handelingen Tweede Kamer, 1983-1984, 18 121, blz. 1081, mk.

96. Veelal wordt gesteld dat individualisering en draagkracht niet samen gaan. H. Snijders-Borst stelt zich op het standpunt dat individualisering geen inbreuk op het draagkrachtbeginsel behoeft te betekenen. Bovendien bevordert de individualisering ook de herverdeling van het inkomen, aldus de auteur. Zie H. Snijders-Borst, Belasting en leefeenheid, Weekblad voor fiscaal recht, 1983, no 5578, blz. 203-205.

97. H. Snijders-Borst, Belasting en leefeenheid, Weekblad voor fiscaal recht, 1983, no 5578, blz. 204. Zie C.P.A. Bakker, die spreekt van de meest rechtvaardige heffing naar draagkracht ingeval uitgegaan wordt van het gezinsinkomen. C.P.A. Bakker, Leven met Tweeverdieners 2, Weekblad voor fiscaal recht, 1984, no 5624, blz. 164. 
moet worden geïndividualiseerd en aan belastingplichtigen met kinderen moeten verlichtingen worden toegekend. ${ }^{98}$

\section{Het begrip draagkracht}

Wat voegt de Tweeverdienerswetgeving-II toe aan het begrip draagkracht?

Er wordt een onderscheid gemaakt tussen de objectieve en de subjectieve draagkracht. Objectieve draagkrachtmeting houdt de bepaling van het inkomen in. ${ }^{99}$ Dit wordt zoveel als mogelijk is geindividualiseerd gemeten. Bij de objectieve draagkrachtmeting kan geen rekening worden gehouden met subjectieve draagkrachtverschillen.

De bestedingsruimte die een subject heeft, wordt de subjectieve draagkracht genoemd. Deze subjectieve draagkracht wordt onder andere beïnvloed door het al dan niet voeren van een zelfstandige huishouding. ${ }^{100}$

Stevens heeft kritiek op het gemaakte onderscheid van de subjectieve en de objectieve draagkracht. Hij is de mening toegedaan dat de regering zich niet moet verschuilen achter het draagkrachtbeginsel, maar gewoon ronduit moet zeggen dat het om een partijpolitieke keuze gaat. ${ }^{101}$

De kwalificatie van een draagkrachtvermeerderende of een -verminderende factor is problematisch. ${ }^{102} \mathrm{Na}$ de kwalificatie komt het probleem van de vaststelling van de mate van invloed van de factoren op de draagkracht. ${ }^{103}$ Een van de

98. H. Snijders-Borst, Belasting en leefeenheid, Weekblad voor fiscaal recht, 1983, no 5578, blz. 207. Thans is sprake van cen onbelaste inkomensonafhankclijke Kinderbijslag die buiten de Wet op de inkomstenbelasting 1964 valt.

99. Tweede Kamer, vergaderjaar 1983-1984, 18 121, nrs. A-C, blz. 17.

100. Handelingen Tweede Kamer, vergaderjaar 1983-1984, 18 121, blz. 1050. Tegen deze achtergronden acht de fractie van de VVD het te rechtvaardigen dat de geïndividualiseerd vastgelegde objectieve draagkracht haar subjectieve vertaling vindt in een horizontale tariefstructuur waarbij, uitgaande van een voor iedere belastingplichtige geldende algemene belastingurije som, toeslagen worden gegeven ter erkenning van de draagkrachtbeïnvloeding vanwege persoonlijke omstandigheden.' De tariefstructuur is opgebouwd uit horizontale elementen (= de algemene belastingvrije som en de toeslagen daarop) en verticale elementen ( $=$ de tariefschijven). Tweede Kamer, vergaderjaar 1984-1985, 18 519, no 5, blz. 7.

101. L.G.M. Stevens, Wetsontwerp Tweeverdieners II: schutterputjeswetgeving, Weekblad voor fiscaal recht, 1983, no 5612, blz. 1403. (Zie echter C.P.A. Bakker, die van mening is dat de gezinsdraagkracht niet op herkenbare wijze uit dit wetsontwerp blijkt. C.P.A. Bakker, Wetsontwerp tweeverdieners tweede fase: een kapitale misgreep. Weekblad voor fiscaal recht, 1983, no 5612, blz. 1420.) Stevens stelt echter dat de definiëring van het inkomensbegrip en de vaststelling van de belastingvrije som beleidskeuzen zijn, die aan de meting van de draagkracht vooraf gaan. Dit maakt mijns inziens niet zoveel uit, of moet je zeggen dat de meting van draagkracht ook niets anders is dan beleid.

102. Tekenend is daarentegen dat voor het bepalen van de belastingdruk het noodzakelijk is kennis van draagkrachtverschillen te hebben. Handelingen Eerste Kamer, vergaderjaar 1983-1984, 18 121, blz. 440, rk.

103. Dit blijkt ook hieruit dat naar de mening van de regering bepaalde draagkrachtfactoren moeten worden herwogen. Handelingen Eerste Kamer, vergaderjaar 1983-1984, 18 121, blz. 450 , rk. 
problemen is dat de partijpolitieke overtuiging de nadere invulling van het draagkrachtbeginsel 'kleurt'. ${ }^{104}$

Een argument kan worden gevonden in de kamerstukken. In de Tweede Kamer heeft een discussie plaatsgevonden over de vraag of het hebben van kinderen nu wel of niet onder het begrip draagkracht moest worden gerangschikt. ${ }^{105} \mathrm{De}$ twijfel over het al dan niet toerekenen van een draagkrachtverminderend karakter aan het hebben van kinderen toont aan dat het begrip draagkracht niet met complete zekerheid is vast te stellen. Dat deze toerekening twijfelachtig is, is al eerder geconstateerd.

De onzekerheid betreffende het vaststellen van het begrip draagkracht blijkt ook hieruit dat naar de mening van de regering bepaalde draagkrachtfactoren moeten worden herwogen. ${ }^{106}$

In deze tweede fase wordt door de regering een nader onderzoek naar de volgende draagkrachtbepalende factoren voorgesteld:

1. de extra kosten die kunnen ontstaan bij partners die beiden een (volledige) baan hebben;

2. de waarde van de (wegvallende) huishoudelijke arbeid;

3. het hebben van (kleine) kinderen.

104. Zie bij voorbeeld Handelingen Tweede Kamer, vergaderjaar 1983-1984, 18 121, blz. 1110, mk. Gesproken wordt van een deal tussen de VVD en het CDA. Een citaat van de staatssecretaris: 'Er zal op een gegeven ogenblik politiek gewogen moeten worden, vooral wat het gewicht betreft dat men wil toekennen aan de onderscheiden draagkrachtelementen.' Handelingen Eerste Kamer, vergaderjaar 1983-1984, 181 21, blz. 467, mk.

Zie ook L.G.M. Stevens, Wctsontwerp Tweeverdieners, derde fase (18 519), Weekblad voor fiscaal recht, 1984, no 5655 , blz. 1227.

105. Handelingen Tweede Kamer, vergaderjaar 1983-1984, 18 121, blz. 1123, rk, 1124, lk. De oplossing moet worden gezocht in de subjectieve sfeer. Dit zal in de derde fase plaatsvinden. Handelingen Tweede Kamer, vergaderjaar 1983-1984, 18 121, blz 1150, rk. Zie ook H. SnijdersBorst, Belasting en leefeenheid, Weekblad voor fiscaal recht, 1983, no 5578, blz. 203. Hierin stelt de auteur zich op het standpunt dat het hebben van kinderen naast het inkomen de draagkracht van een belastingplichtige bepaalt. In een ander artikel stelt dezelfde auteur dat de overheid op basis van het profijtbeginsel gehouden is met het hebben van kinderen rekening te houden. H. Snijders-Borst, Tweeverdieners 2; lof en blaam, Weekblad voor fiscaal recht, 1983, no 5618 , blz. 1618.

H. Kombrink spreekt over een maatschappelijk/politieke keuze ingeval van de fiscale behandeling van de samenlevingsvorm en het hebben van kinderen. H. Kombrink, De progressieve druk van H. Mobach, Mobach-bundel, Leids Fiscaal Jaarboek, Gouda Quint, 1985, blz. 79.

106. Handelingen Eerste Kamer, vergaderjaar 1983-1984, 18 121, blz. 450, rk.

De kwalificatic wordt in belangrijke mate bepaald door politieke overwegingen. Zie bij voorbeeld Handelingen Tweede Kamer, vergaderjaar 1983-1984, 18 121, blz. 1110, mk en Handelingen Eerste Kamer, vergaderjaar 1983-1984, 18 121, blz. 467, mk.

Zie ook L.G.M. Stevens, Wetsontwerp Tweeverdieners, derde fase (18 519), Weekblad voor fiscaal recht, 1984, no 5655, blz. 1227. H. Kombrink spreekt over een maatschappelijk/politieke keuze ingeval van de fiscale behandeling van de samenlevingsvorm en het hebben van kinderen. H. Kombrink, De progressieve druk van H. Mobach, Mobach-bundel, Leids Fiscaal Jaarboek, Gouda Quint, 1985, blz. 79. 
Bovendien zal worden onderzocht of het voor ongehuwd samenlevenden mogelijk is onderling de aftrekposten in mindering op het inkomen te brengen. ${ }^{107}$ De resultaten van dit onderzoek zullen ter voldoening aan de rechtvaardigheidseisen in de derde fase moeten worden verwerkt. Frappant is wel dat de tweede fase ook te maken heeft met de waardering van bepaalde draagkrachtfactoren, maar daarover wordt nu niets gezegd, wel geregeld. In de tweede fase kan worden geconstateerd, dat hetgeen in de derde fase zal worden geregeld niet altijd even duidelijk is. ${ }^{108}$

In de parlementaire stukken komen we op verscheidene plaatsen het kostwinnersbeginsel tegen. ${ }^{109}$ In de alleenverdienerssituatie wordt gesproken van een kostwinnersbeginsel. De huidige wetgeving (1983) schijnt geënt te zijn op het principe van de alleenverdienende kostwinner met een gezin. De definitie van kostwinner luidt: meest verdienende partner. ${ }^{110}$ Dit strookt niet geheel meer met de maatschappelijke realiteit, althans de huidige draagkrachtverhoudingen wordt geweld aangedaan. ${ }^{111}$ Getuige de kamerstukken moet het kostwinnersbeginsel als een species van het begrip draagkracht worden gezien; het gezinsinkomen is de maatstaf voor de draagkracht. ${ }^{112}$

Het kostwinnersbeginsel moet worden verstaan als een produkt van een tijd waarin er naast de alleenverdienerssituatie nauwelijks andere voorkwamen. Ten slotte volgt een opmerking over de (bijna-)alleenverdienerstoeslag. De (bijna-)alleenverdienerstoeslag is een fiscale erkenning van een draagkrachtverminderende factor. Deze factor houdt in dat een belastingplichtige in belangrijke mate feitelijk voorziet in het levensonderhoud van een andere belastingplichtige waarmee een duurzame huishouding wordt gevoerd; het gaat hier om de zorgplicht die de ene partner tegenover de andere heeft. ${ }^{113}$

De invulling van het begrip draagkracht verandert. ${ }^{114}$ "Aan de in het verleden aangevoerde argumentatie voor het beperken van de verzelfstandiging van de

107. Handelingen Tweede Kamer, vergaderjaar 1983-1984, 18 121, blz. 1132, mk. De VVD is van mening dat deze factoren de draagkracht bepalen. Handelingen Tweede Kamer, vergaderjaar 1983-1984, 18 121, blz. 1057, lk. D66 vindt het opmerkelijk dat niets gezegd wordt over de grotere draagkracht van een alleenverdiener omdat deze iemand thuis heeft die huishoudelijke arbeid verricht. Handelingen Tweede Kamer, vergaderjaar 1983-1984, 18 121, blz. 1063, lk.

108. Vergelijk Handelingen Eerste Kamer, vergaderjaar 1983-1984, 18 121, blz. 372, lk.

109. Zie bij voorbeeld Tweede Kamer, vergaderjaar 1983-1984, 18 121, no 5, blz. 5 en 6, no 6, blz. 5. Handelingen Tweede Kamer, vergaderjaar 1983-1984, 18 121, blz. 1111, lk en 1122, mk.

110. Tweede Kamer, vergaderjaar 1983-1984, 18 121, no 5Si, blz. 33.

111. Handelingen Tweede Kamer, vergaderjaar 1983-1984, 18 121, blz. 1122, mk.

112. Tweede Kamer, vergaderjaar 1983-1984, 18121 , no 4, blz. 8.

113. Tweede Kamer, vergaderjaar 1983-1984, 18 121, no 5 , blz. 3 en no 6, blz. 5. Handelingen Berste Kamer, vergaderjaar 1983-1983, 18 121, blz. 440, rk.

114. Zie H. Snijders-Borst, die stelt dat de term draagkracht door velen zelfs op een zodanige manier wordt ingevuld dat ze niet eens draagkracht bedoelen. $H$. Snijders-Borst, Tweeverdieners 2, lof en blaam, Weekblad voor fiscaal recht, 1983, no 5618, blz. 1624. Voor Stevens is de ideale maatstaf van draagkracht het gezinsinkomen, L.G.M. Stevens, Wetsontwerp tweeverdieners, derde fase (nr 18 519), Weekblad voor fiscaal recht, 1984, no 5655, blz. 1229. 
gehuwde vrouw tot inkomsten uit tegenwoordige arbeid, te weten die van de gezinsdraagkracht, kan naar onze mening niet meer op goede wijze inhoud worden gegeven door samentelling van inkomensbestanddelen van de gehuwde vrouw en die van haar man.' Een ander citaat: 'Ten aanzien van ongehuwden vindt de meting van de objectieve draagkracht thans plaats op volstrekt individuele basis en het laat zich moeilijk indenken daarin wijziging te brengen', aldus de regering. ${ }^{115}$

Aangetoond is dat aan het begrip draagkracht niet steeds dezelfde betekenis wordt gegeven. In de kamerstukken wordt niet altijd duidelijk welk begrip wordt gehanteerd. Dit maakt het geheel onoverzichtelijk en onduidelijk. ${ }^{116}$

Maar hoe dan ook, ik constateer dat in het algemeen het draagkrachtbeginsel als leidend beginsel voor de inkomstenbelasting wordt gezien. ${ }^{117}$ Illustratief is in dit verband een opmerking van de toenmalige staatssecretaris van Financiën, Koning. Een belastingstelsel waarin slechts één belastingvrije som zonder toeslagen is, is een stelsel waarin op geen enkele wijze rekening zou worden gehouden met reële draagkrachtverschillen. Dit stelsel is onaanvaardbaar, aldus Koning. ${ }^{118}$

\section{Synthese}

Volgens de regering dient tussen de objectieve en de subjectieve draagkracht een synthese tot stand te komen. De mate waarin dit gebeurt, is een keuze van politieke aard." $\mathrm{De}$ drie onderwerpen (tariefgroepindeling, verdergaande ver-

115. Tweede Kamer, vergaderjaar 1983-1984, 18 121, no 3, blz. 16

116. Handelingen Tweede Kamer, vergaderjaar 1983-1984, 18 121, blz. 1135, mk. Hier komt nog bij dat vaak een beroep wordt gedaan op draagkrachtvermeerderende en -verminderende factoren terwijl exacte cijfers ontbreken.

'In feite hebben wij er echter helemaal geen gegevens over hoe men de hoogte van de draagkracht kan onderbouwen. Wij weten dus niet waar wij het over hebben.' Handelingen Tweede Kamer, vergaderjaar 1983-1984, 18 121, blz. 1123, rk, 1173, lk. Een ander argument dat pleit voor het feit dat het begrip draagkracht niet duidelijk kan worden omschreven is het volgende. Renaud en Siegers(1984) komen via een economisch onderzoek tot de conclusie dat tweeverdieners een geringere draagkracht hebben dan éénverdieners. Hagenaar, Homan en van Praag(1984) komen via een subjectieve bepaling tot de conclusie dat é́nverdieners een grotere draagkracht hebben dan tweeverdieners. Dronkers en Bakker(1981) komen via een sociologisch onderzoek tot de conclusie dat tweeverdieners een grotere draagkracht hebben dan éenverdieners. CBS: De leefsituatie en de Nederlandse bevolking 1983, De draagkracht van éenen tweeverdieners, 1983, blz. 7.

117. Tweede Kamer, vergaderjaar 1985-1986, 19 262, no 4, blz. 34: 'Omdat het uitsluitend gaat om belasting naar draagkracht en niet om inkomensvoorziening naar behoefte, speelt de relatie tussen personen in een gezamenlijke huishouding geen rol.' Handelingen Tweede Kamer, 1983 1984, 18 121, blz. 1049, rk, 1055, lk, en 1067, mk.

118. Tweede Kamer, vergaderjaar 1983-1984, 18 121, nrs. A-C, blz. 12.

119. Voor politiek dient in dit geval de partijpolitieke idecën en belangen en het sluiten van compromissen te worden gelezen. Tweede Kamer, vergaderjaar 1983-1984, 18 121, no 3, blz. 47. Zie ook het feit dat de erkenning van de relevantie van de draagkrachtbenadering per leefeenheid als een uitvloeisel wordt beschouwd van de inkomenspolitieke invalshoek (althans door de socialisten). Handelingen Tweede Kamer, vergaderjaar 1983-1984, 18 121, blz. 1081, rk. 
zelfstandiging en integrale rolwisseling, MW) zijn zowel fiscaal theoretisch als politiek nauw met elkaar verbonden., ${ }^{120}$

De synthese moet als volgt plaatsvinden. De inkomensbepaling (objectieve draagkracht, $\mathrm{MW}$ ) moet zo veel mogelijk verzelfstandigd worden. In de tariefstructuur (subjectieve draagkracht, MW) moet rekening worden gehouden met de draagkrachtelementen. In de tweede fase gaat het vooral om het vereffenen van de draagkrachtverschillen die voortvloeien uit de zorgrelatie en uit de alleenstaande-situatie. ${ }^{121}$

\subsubsection{Het gelijkheidsbeginsel}

Tweeverdieners-II bewerkstelligt dat gehuwden en ongehuwde samenlevers gelijk worden behandeld ten aanzien van de tariefgroepindeling. De economische situatie wordt als uitgangspunt van de gelijke behandeling van de gehuwden en de ongehuwd samenlevenden genomen. De behandeling is echter niet in alle opzichten gelijk.

Met betrekking tot de werking van het gelijkheidsbeginsel betreffende de gehuwden en de ongehuwde samenlevers kan het volgende worden opgemerkt. De regering streeft ernaar om materieel vergelijkbare situaties zoveel mogelijk gelijk te behandelen. ${ }^{122}$ 'Hiervoren hebben wij al opgemerkt dat het voorgestelde systeem beoogt op neutrale wijze aan te sluiten bij in het maatschappelijke verkeer zich voordoende situaties. ${ }^{123}$

De economische positie en niet de civielrechtelijke positie, is het uitgangspunt voor een gelijke behandeling van de ongehuwd samenlevenden met de gehuwden. Staatssecretaris Koning merkt op: 'Voorziet, indien twee personen ongehuwd samenwonen, éen van hen feitelijk in het levensonderhoud van de ander, dan acht ik het gerechtvaardigd dat deze feitelijke verzorging fiscaal wordt gehonoreerd naar analogie van de onderlinge zorgplicht van echtgenoten. ${ }^{124}$

120. Aldus de regering, Tweede Kamer, vergaderjaar 1983-1984, 18 121, no 5, blz. 4.

Volgens J.H. Christiaanse is bij de totstandkoming van de Tweeverdienerswetgeving sprake geweest van een enorme politieke druk en een compromis tussen het CDA en de VVD. P.C. Goosen, R.P.J. Kamerling, t.a.p., blz 54.

121. Tweede Kamer, vergaderjaar 1983-1984, 18 519, no 3, blz. 2.

122. Tweede Kamer, vergaderjaar 1983-1984, 18121 , no 5, blz. 42.

123. Tweede Kamer, vergaderjaar 1983-1984, 18 121, no 5, blz. 6 . Het commentaar uit de Eerste Kamer stelt onder andere dat de fiscaliteit het gedragspatroon wel degelijk beïnvloedt. Handelingen Eerste Kamer, vergaderjaar 1983-1984, 18 121, blz. 460, mk. Later geeft de staatssecretaris ook toe dat de neutraliteit niet helemaal is realiseren. Handelingen Tweede Kamer, vergaderjaar 1984-1985, 18 519, blz. 1089, rk.

124. Tweede Kamer, vergaderjaar 1983-1984, 18 121, nrs. A-C, blz. 15. Curieus is dat de staatssecretaris even later deze stelling terugtrekt. '... volstaan met de opmerking dat naar mijn cordeel een andere betekenis kan en moet worden toegekend aan de uit de wet voortvloeiende verplichtingen tussen echtgenoten dan aan het feit van samenwoning van twee ongehuwde niet-verwanten.' Handelingen Tweede Kamer, vergaderjaar 1983-1984, 18 121, blz. 1136, rk. Zie ook de leden van de GPV die stellen dat de morele zorgplicht een omstandigheid is, die de draagkracht beïnvloedt. Tweede Kamer, vergaderjaar 1983-1984, 18 121, no 4, blz. 9. 
De gelijke behandeling voor ongehuwd samenwonenden wordt niet alleen door het gelijkheidsbeginsel, maar ook door het draagkrachtbeginsel gerechtvaardigd. ${ }^{125}$ Het draagkrachtbeginsel komt meer tot zijn recht door het invoeren van materiële in plaats van formele criteria bij de bepaling van de hoogte van de belastingvrije som, aldus de regering. ${ }^{126} \mathrm{Om}$ doelmatigheidsredenen wordt, in tegenstelling tot de gehuwden, voor de ongehuwd samenlevenden een leeftijdscriterium gehanteerd. Dit is niet in strijd met het gelijkheidsbeginsel, aldus de regering. ${ }^{127}$

Bij de hier bedoelde gelijkstelling moet in acht worden genomen dat het regime voor ongehuwden wordt bijgesteld in de richting van dat voor gehuwden. Het systeem voor gehuwden is in belangrijke mate op practische gronden ingegeven, terwijl het invoeren van hetzelfde systeem voor ongehuwden op een meer principiële grond zou moeten plaatsvinden. ${ }^{128}$ De gelijkstelling gaat echter niet zover dat de integrale rolwisseling ook voor de ongehuwde samenlevenden geldt, terwijl toch de gezamenlijke huishouding een centrale rol speelt in de tariefgroepindeling. ${ }^{129}$

Zowel de gehuwden als de ongehuwd samenlevenden kunnen onder voorwaarden de alleenverdienerstoeslag en de bijna-alleenverdienerstoeslag bij de belastingvrije som optellen; dit vloeit voort uit het gelijkheidsbeginsel. ${ }^{130}$

125. Tweede Kamer, vergaderjaar 1983-1984, 18 121, no 3, blz. 14. Zie ook E.N. Kertzman, Belastingheffing van gehuwden en ongehuwden, Fiscale monografieën, no 32, KJuwer, 1979, blz. 42 waarin wordt gesteld dat 'een zodanige inhoud aan het begrip 'gelijke draagkracht' gegeven kan worden, dat het mogelijk wordt aan te geven hoe de gehuwden en de ongehuwden naar draagkracht belast moeten worden'. Dit impliceert een andere invulling van het huidige (1979) begrip 'draagkracht'.

Zie cok Handelingen Eerste Kamer, vergaderjaar 1983-1984, blz. 444, lk, waarin wordt gezegd dat een gelijke behandeling van de gehuwden en ongehuwden leidt tot een betere werking van het draagkrachtbeginsel.

126. Tweede Kamer, vergaderjaar 1983-1984, 18 121, nrs. A-C, blz. 14 en 16 en Handelingen Tweede Kamer, vergaderjaar 1983-1984, 18 121, blz. 1121, rk.

127. Handelingen Tweede Kamer, vergaderjaar 1983-1984, 18 121, blz. 1197, mk.

Zie L.G.M. Stevens, die stelt dat bij de hoogte van het leeftijdscriterium zowel budgettaire als doelmatigheidsredenen een aanzienlijke rol hebben gespeeld. Wetsontwerp Tweeverdieners II: schutterputjeswetgeving, Weekblad voor fiscaal recht, 1983, no 5612, blz. 1405 en 1406.

128. Tweede Kamer, vergaderjaar 1983-1984, 18 121, no 5, blz. 41. De PvdA constateert dat hierdoor de gelijkstelling alleen in de richting van de gehuwden werkt en niet andersom. Tweede Kamer, vergaderjaar 1983-1984, 18 121, no 6, blz. 21. Ook de Emancipatieraad heeft hierop kritiek. Tweede Kamer, vergaderjaar 1983-1984, 18 121, no 5Si, biz. 34. Zie ook H. Snijders-Borst, Tweeverdieners 2, lof en blaam, Weekblad voor fiscaal recht, 1983, no S618, blz. 1617.

129. Tweede Kamer, vergaderjaar 1983-1984, 18 121, no 6, blz. 21. Het niet voeren van een gezamenlijke huishouding is een rechtvaardigheidsgrond van de alleenstaande-toeslag. Handelingen Eerste Kamer, vergaderjaar 1983-1984, 18 121, blz. 440, mk, rk.

130. Tweede Kamer, vergaderjaar 1983-1984, 18 121, no 7, blz. 4. 


\subsubsection{Budgettaire overwegingen}

De budgettaire opbrengst van de eerste en de tweede fase is $565 \mathrm{mln}$. op transactiebasis. ${ }^{131}$ De kosten van de uitbreiding van de zelfstandige positie van de gehuwde vrouw en de integrale rolwisseling worden gecompenseerd door de wijziging van de fiscale behandeling van ongehuwd samenwonenden en alleenstaanden. ${ }^{132}$ Verder doorvoeren van de verzelfstandiging waarbij ook de inkomsten uit vermogen zouden worden betrokken, wordt verhinderd door budgettaire overwegingen. ${ }^{133}$ Een bijkomend argument om de desbetreffende regeling niet verder te laten gaan dan wordt voorgesteld, is de eis dat de uitvoering van de fiscale wetgeving budgettair neutraal dient te verlopen. De regering geeft toe dat in deze tweede fase budgettaire overwegingen verhinderen de leeftijdsgrens voor de alleenstaande-toeslag te verlagen van 34 tot 27 jaar. ${ }^{134}$

De Raad van State verwoordt het budgettaire element in Tweeverdieners-II aldus: 'De vraag moet worden gesteld of de fiscus, door de geldnood van de staat gedwongen, zich niet langzamerhand op gebieden gaat begeven waar hij niet thuishoort. ${ }^{, 135}$ Een ander voorbeeld uit de parlementaire geschiedenis ter illustratie is het volgende citaat uit de memorie van antwoord: '... in casu de financiële nood van de overheid «de wet» breekt. ${ }^{\text {.136 }}$

De regering geeft wel toe dat de financiële nood van de overheid een bespoediging van het aannemen van de wetgeving bewerkstelligt. ${ }^{137}$ 'Het tijdstip van invoering van de voorgestelde regeling moge zijn beïnvloed door budgettaire overwegingen, de regeling op zichzelf niet. ${ }^{138}$

Voorts merkt zij op: 'Inmiddels heeft de gecombineerde eerste en tweede fase wel belangrijke budgettaire aspecten, maar dat mag naar onze mening het zicht op fiscaal-theoretische en maatschappelijke aspecten van dit voorstel niet vertroebelen.'139

131. Opbrengst tweede fase wet tweeverdieners, Weekblad voor fiscaal recht, 1985 , no 5690 , blz. 890. De opbrengst van de tweede fase is $f 210 \mathrm{mln}$. Tweede Kamer, vergaderjaar 1983-1984, 18121 , no $55 \mathrm{~g}$, blz. 22.

132. 'Tweeverdienersmaatregel' voor gehuwden treedt 1 oktober in werking, Weekblad voor fiscaal recht, 1982, no 5600 , blz. 958 en 959.

133. C.P.A. Bakker, Leven met Tweeverdieners 2, Weekblad voor fiscaal recht, 1984, no 5624, blz. 163.

134. Handelingen Tweede Kamer, vergaderjaar 1983-1984, 18 121, blz. 1197, rk. Ook wordt vaak toegegeven dat een stuk, bij voorbeeld een amendement, theoretisch beter kan zijn, maar dat budgettaire redenen de invoering verhinderen. Handelingen Tweede Kamer, vergaderjaar 1983-1984, 18 121, blz. 1209, rk.

135. Tweede Kamer, vergaderjaar 1983-1984, 18 121, nrs. A-C, blz. 4.

136. Tweede Kamer, vergaderjaar 1983-1984, 18 121, no S, blz. 4.

137. Zie Tweede Kamer, vergaderjaar 1983-1984, 18 121, no 4, blz. 4, no 5, blz. 3, 4 en no $55 i$, blz. 32. C.P.A. Bakker, Leven met Tweeverdieners 2, Weekblad voor fiscaal recht, 1984, no 5624, blz. 161.

138. Tweede Kamer, vergaderjaar 1983-1984, 18 121, nrs. A-C, blz. 12, no 5, blz. 3.

139. Tweede Kamer, vergaderjaar 1983-1984, 18 121, no 7, blz. 3 en no $55 g$, blz. 4. Een soortgelijke redenering. Redenen van rechtvaardigheid en billijkheid hebben de overhand in de tweede fase, aldus de regering. Tweede Kamer, vergaderjaar 1983-1984, 18 121, no 6, blz. 7. Handelin- 
Het beroep op rechtvaardigheid en billijkheid lijkt, evenals in Tweeverdieners-I, enigszins willen maskeren dat budgettaire overwegingen hier een dominante rol spelen. ${ }^{140}$

\subsection{Tweeverdienerswetgeving-III}

\subsubsection{Algemene opmerkingen}

De derde fase is de afrondende fase van de Tweeverdienerswetgeving. ${ }^{141} \mathrm{De}$ gehele procedure van de Tweeverdieners kan thans worden overzien. Het betreft een afronding van de wetgeving inhoudende de gelijke behandeling van de gehuwde vrouw en haar man, een evenwichtiger behandeling van gehuwden en ongehuwd samenlevenden, en een evenwichtiger behandeling van zogenaamde tweeverdieners ten opzichte van alleenverdieners. Daarnaast beoogt de derde fase nog twee doelen te verwezenlijken, t.w.:

1. het voorkomen van schokeffecten door invoering van integrale en zuivere voetoverheveling;

2. de introductie van de (aanvullende) arbeidstoeslag. Hiermee komt het aantal toeslagen op de belastingvrije som door het vervallen van de (aanvullende) alleenverdienerstoeslag op vijf. ${ }^{142}$

Voor een verdergaande verzelfstandiging van de fiscale positie van de gehuwde vrouw dan in de tweede fase is geschied, wordt geen aanleiding gezien. ${ }^{143}$ Daarom kan worden verwezen naar hetgeen hierover in hoofdstuk 2 is gezegd. De uitkomst van het in de tweede fase door de regering toegezegde onderzoek naar een drietal draagkrachtbepalende factoren is als volgt.

1. De extra kosten die kunnen ontstaan bij partners die beiden een (volledige) baan hebben; deze draagkrachtverminderende factor is verwerkt in de arbeidstoeslag.

gen Eerste Kamer, vergaderjaar 1983-1984, 18 121, blz. 450, lk.

Zie de kritiek van Hofstra op de tweeverdienerswetgeving, die is ingegeven door budgettaire belangen. Het al vaker misbruikte draagkrachtbeginsel kan de regeling ook niet dragen. H.J. Hofstra, Van recht naar wet, Scheltens-bundel Van wet naar recht, Kluwer, 1984, blz. 59 en 61.

140. Tweede Kamer, vergaderjaar 1983-1984, 18 121, no 6. Handelingen Eerste Kamer, vergaderjaar 1983-1984, 18 121, blz. 373, mk. Zie ook L.G.M. Stevens, Wetsontwerp Tweeverdieners II: schutterputjeswetgeving, Weekblad voor fiscaal recht, 1983, no 5612, blz. 1401.

141. Wijziging van de inkomstenbeiasting en de loonbelasting: derde fase. Stb. 1984, 649; inwerkingtreding op 1 januari 1985 en L.W. Sillevis, De opmars van de samenwoners in de inkomstenbelasting, Leids Fiscaal jaarboek, Gouda Quint, 1985, blz. 161-176.

142. Uitgangspunten voor de derde fase tweeverdieners, Weekblad voor fiscaal recht, 1984, no 5642, blz. 698.

143. Tweede Kamer, vergaderjaar 1983-1984, 18 519, nrs. A-C, blz. 3, lk en blz. 8, lk en rk, no 3, blz. 21. 
2. De waarde van de (wegvallende) huishoudelijke arbeid; met deze factor wordt geen rekening meer gehouden. ${ }^{144}$

3. Het hebben van (kleine) kinderen; deze factor komt, zij het minimaal, tot uitdrukking in de aanvullende arbeidstoeslag.

Door de nieuwe regeling voor de tariefgroepindeling zal de belastingdruk voor de tweeverdieners ten opzichte van die voor de énverdieners verzwaard worden. Het verschil in belastingdruk tussen de eén- en de tweeverdieners met een gelijk inkomen wordt veroorzaakt door de horizontale en de verticale tariefstructuur. De verzwaring van de belastingdruk impliceert een benadrukking van het kostwinnersbeginsel. ${ }^{145}$ Dit beginsel heeft echter door de toenemende individualisering die in de maatschappij plaatsvindt, niet meer zo'n sterke werking als voorheen. Bovendien is het toegenomen aantal tweeverdienershuishoudens mijns inziens ook een indicatie dat het kostwinnersbeginsel meer op de achtergrond moet worden geplaatst. Dit toont opnieuw aan dat de werking van beginselen aan invloed van tijd onderhevig is.

Reeds bij de behandeling van de derde fase blijkt dat de invoering van de tweede fase niet geheel vlekkeloos verloopt. Bij de belastingdienst is twijfel gerezen over de mogelijkheid van een sluitende controle op het bestaan van een gezamenlijke huishouding dan wel een huishouding voor zich alleen. Een hoge mate van fraudebestrijding is niet doelmatig. ${ }^{146} \mathrm{De}$ fiscale wetgever zal met deze wetenschap rekening moeten houden in zijn verdere wetgeving; anders komt zijn produkt in gevaarlijk drijfzand terecht.

\subsubsection{Het draagkrachtbeginsel}

\section{Het begrip draagkracht}

Het draagkrachtbeginsel is een belangrijk element dat in de gehele kwestie van de Tweeverdieners een rol speelt, al was het maar om de simpele reden dat het begrip getuige het boven- èn onderstaande vaak voor onduidelijkheid zorgt. In paragraaf 3.3.2 hebben we gezien wat de Tweeverdienerswetgeving-II aan het begrip draagkracht toevoegt. Voegt deze derde fase nog nieuwe elementen toe aan het draagkrachtbeginsel?

In ieder geval moeten in een beschouwing van het begrip draagkracht de maatschappelijke, economische, budgettaire, uitvoeringstechnische, fiscale en politieke overwegingen worden bekeken, aldus de regering. ${ }^{147} \mathrm{De}$ staatssecretaris is duidelijk genoeg: 'Naar mijn mening is niemand gediend met geconstrueerde theoretische beschouwingen die moeten verhullen, dat de keuze voor een tarief-

144. Zie onder andere C.P.A. Bakker, Tweeverdieners-derde fase: kruidenierspolitiek, Weekblad voor fiscaal recht 1984 , no 5657 , biz. 1254.

145. Tweede Kamer, vergaderjaar 1983-1984, 18 121, no 6, blz. 5 .

146. Tweede Kamer, vergaderjaar 1983-1984, 18 519, nrs. A-C, blz. 4.

147. Tweede Kamer, vergaderjaar 1983-1984, 18 121, no 5, blz. 40. 
structuur en een verdeling van de belastingdruk tussen alleen- en tweeverdieners uiteindelijk een politieke en niet een wetenschappelijke keuze is. ${ }^{\text {,48 }}$

In de tweede fase wordt een onderscheid gemaakt tussen objectieve en subjectieve draagkracht; ook in deze derde fase wordt dat onderscheid gemaakt. ${ }^{149}$ De regering tracht de verzelfstandiging, de zgn. objectieve draagkracht, door te voeren. Ze gaat ervan uit dat alleenstaanden, alleenverdieners en alleenstaande ouders bij een bepaald inkomen een geringere draagkracht hebben dan twee partners, die een individueel gelijk inkomen hebben. ${ }^{150}$

Uit de kamerstukken blijkt dat fiscale wetgever het draagkrachtbeginsel als leidend beginsel van de Wet IB 1964 wil beschouwen. Maar of dit beginsel in alle gevallen leidend is, is te betwijfelen. Ter illustratie van die twijfel geef ik een aantal passages weer uit de kamerstukken.

1. Toegegeven wordt dat het niet mogelijk is om de draagkracht in absolute zin te meten. Maar het draagkrachtbeginsel is in de maatschappij zo ingeworteld dat acceptatie van de wetgeving niet meer plaatsvindt indien aan dit beginsel getornd zou worden. In de maatschappij heerst de opvatting dat het begrip draagkracht niet alleen maar als draagkracht per individu moet worden opgevat, aldus de regering. Gezien deze diepe wortels in de maatschappij moet een synthese worden bereikt tussen de draagkracht die tot uitdrukking komt in de tariefstructuur, de subjectieve draagkracht, en de zgn. verzelfstandiging, de objectieve draagkracht genoemd. ${ }^{151}$

2. 'Het verminderen van deze verschillen (tussen de alleen- en de tweeverdieners, MW) is niet alleen uit draagkrachtoverwegingen een goede zaak. Maatschappelijk wordt de (subjectieve) draagkracht van het persoonlijke inkomen vaak bezien in samenhang met een even groot gezamenlijk inkomen van een leefeenheid. ${ }^{152}$

3. Interessant is de discussie tussen de PvdA en de regering over de al dan niet vermeende toepassing van de draagkrachttheorie. 'De leden van de P.v.d.A.fractie constateerden, dat evenals bij de tweede fase, ook bij de derde fase de motivering voor de wijziging van de tariefstructuur berust op de draagkrachttheorie en daarvan afgeleide draagkrachtfactoren. ${ }^{2153}$ Verder vraagt deze fractie zich af of het door de regering gehanteerde draagkrachtbeginsel

148. Handelingen Tweede Kamer, vergaderjaar 1984-1985, 18 519, blz. 1088, mk. Zie cok M.K. Kamperman, Enige beschouwingen over de opbouw van het tarief der inkomstenbelasting. In: Fiscaal-economische opstellen, Schendstok-bundel, Samson, 1966, blz. 136.

149. Tweede Kamer, vergaderjaar 1983-1984, 18519 , no 3, blz. 2 . In de derde fase wordt meer dan in de tweede fase rekening gehouden met het hebben van een zorgrelatie; een zgn. draagkrachtverminderende factor. Daarnaast wordt rekening gehouden met het voor zich alleen voeren van een huishouding. Handelingen Tweede Kamer, vergaderjaar 1984-1985, 18 519, blz. 1316, rk.

150. Tweede Kamer, vergaderjaar 1984-1985, 18 519, no 5, blz. 10.

151. Tweede Kamer, vergaderjaar 1983-1984, 18 121, no 3, blz. 47. De draagkracht wordt niet bepaald door de sekse of door de burgerlijke staat, aldus de staatssecretaris. Handelingen Eerste Kamer, vergaderjaar 1984-1985, 18 519, blz. 397, rk.

152. Tweede Kamer, vergaderjaar 1983-1984, 18 121, no 3, blz. 48.

153. Tweede Kamer, vergaderjaar 1984-1985, 18 519, no 4, blz. 2. 
voldoende concreet is om een rechtvaardig geachte belastingdruk te bewerkstelligen. De betekenis van de draagkracht blijft gering omdat het begrip vaag blijft in haar concrete vertaling in een belastingdruk, aldus de fractie. ${ }^{154}$

De regering antwoordt als volgt: 'Anders dan de leden van de P.v.d.A.-fractie veronderstellen, berust ons voorstel niet rechtstreeks op de draagkrachttheorie of op het draagkrachtbeginsel. We menen dan ook te mogen afzien van algemene beschouwingen over deze theorie en dit beginsel, te meer nu over de inhoud, wellicht zelfs over het bestaan ervan, geen eenduidige opvattingen bestaan. Dit neemt niet weg dat ook het onderhavige wetsvoorstel berust op de gedachten over draagkracht, die wij zo nodig verder zullen uiteenzetten. ${ }^{155}$ Naar mijn mening is deze passage innerlijk tegenstrijdig; enerzijds wordt het bestaan van de draagkrachttheorie ontkend, anderzijds wordt het begrip draagkracht toch bij het wetsvoorstel betrokken.

Twee opmerkingen zou ik bij deze discussie willen maken. Ten eerste kom ik hier terug op het eerder gemaakte onderscheid tussen het abstract en het concreet niveau waarop over het draagkrachtbeginsel wordt gesproken. Op het abstract niveau is het blijkbaar niet moeilijk het bestaan van het draagkrachtbeginsel aan te nemen; op concreet niveau wordt dat anders.

Het is op zijn zachtst gezegd opmerkelijk indien een discussie moet plaatsvinden over de vraag of het draagkrachtbeginsel al dan niet in een wetsvoorstel aanwezig is. Enige duidelijkheid over het tocpassen van het draagkrachtbeginsel zou gewenst zijn.

Ten tweede merk ik dat als een deel van de fiscale wetgever - in dit geval de regering - vaststelt dat het voorstel niet gebaseerd is op het draagkrachtbeginsel, de vraag rijst hoe naar de mening van de regering het voorstel maatschappelijk dan moet worden aanvaard, daar zij getuige hetgeen onder 1 is gesteld zelf uitgaat van de stelling dat het draagkrachtbeginsel diep geworteld is in de maatschappij.

4. Het wetsvoorstel is niet gebaseerd op het draagkrachtbeginsel. De derde fase is gebaseerd op drie andere elementen, t.w.:

a. de noodzaak tot een compromissoir stelsel;

b. de uitvoerbaarheid;

c. de beperkte ruimte voor koopkrachtmutatie.

Deze drie elementen zijn in de ogen van de regering belangrijker dan het draagkrachtbeginsel. ${ }^{156}$ De regering spreekt ook van een timmermansoog,

154. Tweede Kamer, vergaderjaar 1984-1985, 18 519. no 4, blz. 2.

155. Tweede Kamer, vergaderjaar 1984-1985, 18 519, no 5, blz. 7 .

156. Tweede Kamer, vergaderjaar 1984-1985, 18 519, no 5, blz. 7. Verderop in het kamerstuk wordt gesteld dat de diverse uitgangspunten die aan de verschillende belastingvrije sommen ten grondslag zijn gelegd, moeten worden gezien in het licht van de toen geldende maatschappelijke opvattingen en verhoudingen. Tweede Kamer, vergaderjaar 1984-1985, 18 519, no 5, blz. 9. De GPV-fractie is de mening toegedaan dat de regering verantwoordelijk is voor een rechtvaardige belastingheffing en zich niet moeten leiden door de grootste gemene deler van de maatschappelijke opvatting. De PvdA vindt het eveneens opmerkelijk dat gezegd wordt dat de Wet IB 1964 niet rust op het draagkrachtbeginsel, maar dat vervolgens verschillende draagkrachtelementen worden besproken. Tweede Kamer, vergaderjaar 1984-1985, 18 519, no 
de ervaring en het gevoel. Deze elementen bepalen blijkbaar het rechtvaardigheidsgehalte van de inkomstenbelasting.

Wat deze 'elementen' ook mogen inhouden, in ieder geval zouden zij een belangrijker rol spelen dan het wetenschappelijke draagkrachtbeginsel. ${ }^{157}$ De vraag rijst wat de maatstaf van een rechtvaardige drukverdeling is. Hierop antwoordt de regering dat deze maatstaf geen andere is dan een politiek waardeoordeel dat in tijd verschilt. ${ }^{158}$ Ik geef toe dat dit laatste waar is, maar men mag niet te licht een beroep doen op de verandering in de tijd. Met andere woorden, er dient voor te worden gewaakt dat met het draagkrachtbeginsel te lichtvaardig wordt omgesprongen.

5. 'Die omstandigheid (het toekennen van het arbeidskostenforfait aan het individuele geval waarin geen draagkrachtverminderende factor is aan te wijzen, $M W$ ) kan echter niet dienen als argument tegen de regeling als zodanig, omdat het een essentieel onderdeel is van de loon- en inkomstenbelasting dat met verschillende draagkrachtbepalende factoren rekening wordt gehouden op globale en forfaitaire wijze.139

Ik mag hieruit afleiden dat het begrip draagkrachtbeginsel toch een rol speelt. Ik ben dan ook van mening dat ik gerechtigd ben de vraag te stellen wat hier precies wordt bedoeld.

Uit het bovenstaande wordt mij niet duidelijk wat de regering met het draagkrachtbeginsel bedoelt. Bedoelt zij te zeggen dat dat beginsel weliswaar in dit wetsontwerp geen rol speelt, maar dat uiteindelijk de Wet IB 1964 wel op dit beginsel steunt? Het gevaar dat hierin schuilt, is dat de Wet IB 1964 wel gebaseerd is geweest op het draagkrachtbeginsel, maar dat latere wetswijzigingen het grotendeels uithollen of oprekken of er een andere betekenis aan geven. In ieder geval is de discussie niet helemaal duidelijk en het gevaar voor foute interpretatie van het begrip wordt groter. ${ }^{160}$ Het lijkt me overbodig op te merken dat hetgeen gesteld is ten aanzien van het gebruik van vele definities van draagkracht in de tweede fase, ook in de derde fase geldt. ${ }^{161}$

7, blz. 6 en 7. Handelingen Eerste Kamer, vergaderjaar 1983-1984, 18 121, blz. 363, lk.

157. Tweede Kamer, vergaderjaar 1984-1985, 18519 , no 8, blz. 4 en 5.

158. Tweede Kamer, vergaderjaar 1984-1985, 18519 , no 8, blz. 5 . Ook in de literatuur is men van mening dat draagkracht politiek bepaald is. Zie bij voorbeeld L.G.M. Stevens, Rapport van de Commissie ter bestudering van de fiscale aspecten van samenlevingsvormen, Geschrift van de Vereniging voor Belastingwetenschap, no 163, Kluwer, 1984, blz. 16. Dit feit wordt ook duidelijk in het gehele rapport van de Commissie ter bestudering van de fiscale aspecten van samenlevingsvormen, Geschrift van de Vereniging voor Belastingwetenschap, no 163, Kluwer, 1984.

159. Tweede Kamer, vergaderjaar 1984-1985, 18 519, no 8, blz. 8.

160. Tweede Kamer, vergaderjaar 1983-1984, 18 121, no 3, blz. 49. Handelingen Eerste Kamer, vergaderjaar 1983-1984, 18 121, blz. 363, rk. Handelingen Tweede Kamer, vergaderjaar 19841985,18519, blz. 1078, mk, rk. Zie ook het geopperd idee dat in het draagkrachtbeginsel rekening moet worden gehouden met de geleverde inspanning. Handelingen Tweede Kamer, vergaderjaar 1984-1985, 18519 , blz. 1103, mk.

161. Tweede Kamer, vergaderjaar 1984-1985, 18 S19, no 5, blz. 8. 
Interessant in dit verband is nog het volgende. De regering betoogt dat de verschuldigde inkomstenbelasting bij een volgens het empirisch inkomensbegrip vastgesteld inkomen, samen dient te hangen met de 'draagkracht' welke de belastingplichtige aan dat inkomen ontleent. Dit ziet volgens mij op de bestedingsruimte die een belastingplichtige heeft en niet op de inkomensverwerving. Hieruit leid ik af dat ten aanzien van de 'draagkracht die aan het inkomen wordt ontleend, blijkbaar rekening moet worden gehouden met hetgeen aan inkomstenbelasting moet worden betaald. De vraag is of het draagkrachtbeginsel een rol dient te spelen na het betalen van de belasting of enkel en alleen vór dat moment.

Een terrein waar de etikettering van inkomensverwervend of -bestedend eveneens een rol speelt, is dat van de kinderopvangkosten. In het parlement is getracht een zodanige redenering op te zetten, dat de kosten voor kinderopvang als verwervingskosten kunnen worden aangemerkt. ${ }^{162}$ De redenering dat de kinderopvangkosten weliswaar inkomensbestedend zijn, maar dat deze in die mate draagkrachtverminderend zijn dat met deze kosten toch rekening in de Wet IB 1964 moet worden gehouden, komt men ook wel tegen in de kamerstukken. ${ }^{163}$ Zoals al eerder aangegeven rijst de vraag of hierdoor de inkomstenbelasting niet onzuiver wordt? Moet het inkomensbegrip niet aan een nadere beschouwing worden onderworpen? ${ }^{164}$

\section{Draagkracht en arbeidstoeslagen}

Het invoeren van de arbeidstoeslag berust op de gedachte dat een tegemoetkoming moet worden gegeven voor de lasten die het buitenshuis werken met zich

162. Zie onder andere Tweede Kamer, vergaderjaar 1984-1985, 18519 , no 5, blz. 16, no 7 en blz. 15 en Handelingen Tweede Kamer, vergaderjaar 1984-1985, 18 519, blz. 1046, Ik. L.G.M. Stevens, die stelt dat kosten voor kinderopvang een causaal verband hebben met de inkomensverwerving. Derhalve zou een kostenaftrek op zijn plaats zijn geweest. L.G.M. Stevens, Nota Tweeverdieners derde fase, Weekblad voor fiscaal recht, 1984, no 5645, blz. 806 en 817 . In datzelfde artikel wordt ook een andersluidende mening aangevoerd, nl. de mening van de Hoge Raad, HR 27 januari 1982, BNB 1982/75. A.C. Rijkers is van mening dat het hebben van kinderen een uiting van draagkracht is. A.C. Rijkers, Tweeverdieners-III, Een nabeschouwende vooruitblik, Weekblad voor fiscaal recht, 1984, no 5636, blz. 529.

163. Tweede Kamer, vergaderjaar 1984-1985, 18 519, no 7, blz. 12. Zie de Commissie ter bestudering van de fiscale aspecten van samenlevingsvormen, die ondanks het inkomensbestedend karakter van de kosten besluit tot een mogelijkheid tot aftrekbaarheid van deze kosten. Rapport van de Commissie ter bestudering van de fiscale aspecten van samenlevingsvormen Geschriften van de Vereniging voor Belastingwetenschap, no 162, Kluwer, 1984, blz. 45.

164. Voor een herziening van het inkomensbegrip pleit ook het feit dat in 1984 in artikel 56 Wet IB 1964 een ander inkomensbegrip wordt gehanteerd dan bedoeld in artikel 3 Wet IB 1964. Dit is niet erg consequent. P.J. van Amersfoort en D. van den Hoeven, De wet tweeverdieners, Enkele begrippen en consequenties nader beschouwd, Weckblad voor fiscaal recht, 1984, no 5625, blz. 192 en 193. Zie ook Handelingen Eerste Kamer, vergaderjaar 1984-1985, blz. 386, $\mathrm{lk}$, waar gesproken wordt van een bijstelling van het inkomensbegrip door een verruiming van het begrip 'aftrekbare kosten'. 
brengt. Opgemerkt zij dat deze toeslag volgens de Raad van State haaks staat op het beleid om de aftrekbare kosten te beperken. ${ }^{165}$

Opmerkelijk is hetgeen de regering met betrekking tot de arbeidstoeslag stelt. Een negatieve draagkrachtfactor waarmee geen positieve draagkrachtfactor, zoals inkomen, is verbonden, hoeft niet in aanmerking te worden genomen. ${ }^{166}$ Getuige het feit dat in het verleden een andere negatieve draagkrachtfactor - het verlies van het kostenbesparend effect van de huishoudelijke arbeid door het buitenshuis werken van de gehuwde vrouw - waarmee ook geen directe positieve draagkrachtfactor was verbonden, wel in aanmerking werd genomen, moge duidelijk zijn dat deze redenering niet altijd opgeld heeft gedaan. Het bereiken van een politiek compromis heeft in de formulering van de arbeidstoeslag een grote rol gespeeld. ${ }^{167}$

De Raad van State twijfelt aan de ratio die de bewindslieden toekennen aan de aanvullende arbeidstoeslag. De Raad stelt de vraag of de aanvullende arbeidstoeslag wel op de veronderstelde draagkrachtgedachte steunt. ${ }^{168}$ De aanvullende arbeidstoeslag steunt op de gedachte dat in kosten van kinderopvang tegemoet wordt gekomen. Echter de hoogte van de toeslag is zo gering dat van een verrekening van een draagkrachtvermindering nauwelijks kan worden gesproken. De vraag rijst of hier de budgettaire overwegingen de grens bepalen van de werking van het draagkrachtbeginsel.

De regering antwoordt dat met de fiscale faciliteit niet alleen een tegemoetkoming wordt geboden voor de draagkrachtverschillen tussen de tweeverdieners met en zonder jonge kinderen. Deze faciliteit laat de ouders vrij te voorzien in de wijze waarop de kinderen worden opgevangen. De doelmatigheid heeft een ook belangrijke rol gespeeld bij de voorgestelde voorziening van kinderop-

165. Tweede Kamer, vergaderjaar 1983-1984, 18519 , nrs. A-C, blz. 6. Onder andere de PvdA-fractie vraagt zich af of met het invoeren van de arbeidstoeslag niet via een omweg de factor huishoudelijke arbeid binnen de Wet IB 1964 wordt gehaald. Tweede Kamer, vergaderjaar 1984-1985, 18 519, no 7, blz. 8.

166. Tweede Kamer, vergaderjaar 1984-1985, 18 519, no 5, blz. 12.

167. Handelingen Tweede Kamer, vergaderjaar 1984-1985, 18519 , blz. 1108, 1k, 1110, rk. De hoogte van de arbeidstoeslag is een resultaat dat voortvloeit uit een compromis tussen de regeringspartijen. Handelingen Tweede Kamer, vergaderjaar 1984-1985, 18 519, blz. 1080, lk. Ministerpresident Lubbers praat over een inschatting maken van de aanvaardbaarheid van het wetsontwerp in de Tweede Kamer. Handelingen Tweede Kamer, vergaderjaar 1984-1985, 18 519, blz. 1326, rk.

168. Tweede Kamer, vergaderjaar 1983-1984, 18 519, nrs. A-C, blz. 7. De kritiek in de Tweede Kamer ten aanzien van de arbeidstoeslag is niet mis. Zie bij voorbeeld Handelingen Tweede Kamer, vergaderjaar 1984-1985, 18 519, blz. 1071, lk, 1080, lk, en 1081, rk. 
vang. ${ }^{199}$ Bij deze aanvullende arbeidstoeslag komt het al eerder ter sprake gebrachte element van de inkomensbesteding naar voren. ${ }^{170}$

\section{Synthese}

Met de invoering van de derde fase moet een aanvaardbare synthese worden bereikt tussen verzelfstandiging en draagkracht. Met de synthese hangt het al dan niet toekennen van een draagkrachtvermeerderend of -verminderend karakter aan een factor samen. De draagkrachtvermeerderende of -verminderende factoren zijn elementen van de zgn. subjectieve draagkracht.

Over de motivering van de synthese door de regering heeft de Raad van State zijn twijfels. Het gezamenlijk voeren van een huishouden is in de regel een draagkrachtvermeerderende factor, waarmee rekening moet worden gehouden. Hiernaast moet volgens de Raad van State evenzeer rekening worden gehouden met de situatie waarin de alleenverdiener het inkomen inbrengt waarvan twee mensen moeten rondkomen; deze situatie kan als een draagkrachtverminderende factor worden gezien. ${ }^{171}$ Dit element is zo in de maatschappij geworteld dat er niet aan kan worden ontkomen om er in de inkomstenbelasting rekening mee te houden. De berekening van de mate waarin met de desbetreffende factoren rekening moet worden gehouden, wordt door de regering niet aangegeven.

Er wordt geen aanleiding meer gezien om de waarde van huishoudelijke arbeid als min of meer zelfstandige draagkrachtfactor te doen vergelden in de horizontale of verticale tariefstructuur. ${ }^{172}$ Op zeer indirecte wijze wordt rekening gehouden met de ruimte in de tijdsbesteding; dit gebeurt via de arbeidstoeslag. ${ }^{173}$ Maar het gaat de regering te ver om te stellen dat de huishoudelijke arbeid als draagkrachtfactor een rol van betekenis speelt; het gaat hier om een zgn. 'tijdbeslagcomponent ${ }^{3}{ }^{174}$

169. Tweede Kamer, vergaderjaar 1984-1985, 18 519, no 5, blz. 14 en 15 . Daarnaast heeft een eenmalige uitkering plaatsgevonden. Een tegemoetkoming in de inkomstenbelasting voor kosten van kinderopvang van tweeverdieners voor het kalenderjaar 1984 (18 643). Deze tegemoetkoming heeft terugwerkende kracht. Deze terugwerkende kracht is gelegen in het feit dat het alleen mogelijk was in het kader van de inkomstenbelasting naar een oplossing te streven, aldus de staatssecretaris. Handelingen Eerste Kamer, vergaderjaar 1984-1985, 18 643, blz. 4443, mk.

170. Tweede Kamer, vergaderjaar 1984-1985, 18 519, no 5, blz. 17. Van de arbeidstoeslag wordt ook gezegd dat deze een inkomensbestedend karakter niet kan worden ontzegd. Deze toeslag zou een onzuiver element zijn de Wet IB 1964. Tweede Kamer, vergaderjaar 1984-1985, 18 519, no 7, blz. 12.

171. Tweede Kamer, vergaderjaar 1983-1984, 18 519, nrs. A-C, blz. 4 en S. De PvdA-fractie spreekt dat de synthese een produkt is van een politiek compromis tussen de beide regeringsfracties. Tweede Kamer, vergaderjaar 1984-1985, 18 519, no 8, blz. 4.

172. Tweede Kamer, vergaderjaar 1984-1985, 18 519, no 5, blz. 11.

173. Tweede Kamer, vergaderjaar 1984-1985, 18 519, no 5, blz. 11.

174. Zie echter de commissie-Stevens die stelt dat de druk voor alleenverdieners in de tweede en derde schijf hoger is dan voor tweeverdieners. Dit komt omdat tweeverdieners minder schaalvoordelen ontlenen aan de gezamenlijke huishouding dan alleenverdieners. Moet ik hieruit afleiden dat via een achterdeur toch rekening wordt gehouden met de huishoudelijke arbeid? Rapport van de Commissie voor de Belastingherziening, Graag of niet, Sdu, 1991, blz. 162. 
Duidelijk is dat de concrete invulling van de synthese nog niet zo'n gemakkelijke opgave is. Zeker niet waar het erom gaat te bepalen welke factoren draagkrachtvermeerderend en welke draagkrachtverminderend zijn. Daarna komt de moeilijke weging van de verschillende draagkrachtfactoren.

De synthese is mijns inziens een mooi woord voor een compromis dat ontstaan is tussen de regeringspartijen. Hierbij moet men denken aan termen zoals politieke haalbaarheid etc.. ${ }^{175}$ Het draagkrachtbeginsel ondergaat de invloed van partijpolitieke ideeën en het sluiten van compromissen.

\subsubsection{Het gelijkheidsbeginsel}

Door invoering van Tweeverdieners-III hebben de ongehuwde samenlevers, indien zij daarom verzoeken, een mogelijkheid tot samenvoeging. Deze samenvoeging geschiedt op basis van het gelijkheidsbeginsel. De inkomens van de gehuwden worden al sedert geruime tijd samengevoegd. Er wordt derhalve geen betekenis toegekend aan de civielrechtelijke en de inhoudelijke verschillen tussen de samenlevingsvormen.

Als rechtvaardigheidsgrond voor samenvoeging werd aanvankelijk de handelingsonbekwaamheid van de vrouw aangevoerd. Maar toen deze opgeheven was, moest een nieuwe rechtvaardigheidsgrond worden gezocht. Deze werd gevonden in de economische eenheid van duurzame aard, die man en vrouw zouden voeren. ${ }^{176}$ Het veranderen van de rechtvaardigheidsgrond bevestigt de stelling dat de invulling van het draagkrachtbeginsel aan de invloed van tijd en plaats onderhevig is. ${ }^{17}$

In de derde fase zijn de voornaamste elementen die het gelijkheidsbeginsel betreffen, de volgende:

1. De regeling inzake de buitengewone lasten;

2. De regeling van de rente- en dividendvrijstelling;

3. De regeling van de bevoegdheid inzake het aanwijzen van bepaalde voorzieningen voor nagelaten betrekkingen als pensioenregeling in de zin van de Wet IB 1964. ${ }^{178}$

4. De regeling inzake de meewerkaftrek en de reële beloning.

5. De regeling inzake de stamrechtvrijstelling.

6. De regeling inzake de oudedagsreserve.

\section{ad 1. Buitengewone lasten}

De ongehuwd samenlevenden moeten materieel zoveel mogelijk in een gelijke positie kunnen komen te verkeren als de gehuwden. De drempel die beide groe-

175. Zie onder andere Handelingen Tweede Kamer, vergaderjaar 1984-1985, 18 519, blz. 1034, 1k, en 1041, lk.

176. Rapport van de Commissie ter bestudering van de fiscale aspecten van samenlevingsvormen, Geschrift van de Vereniging voor Belastingwetenschap, no 162, Kluwer, 1984, blz. 33 en 34.

177. Vergelijk Handelingen Eerste Kamer, vergaderjaar 1983-1984, 18 121, blz. 356, lk.

178. Tweede Kamer, vergaderjaar 1983-1984, 18 519, no 3, blz. 21. 
pen belastingplichtigen in acht moeten nemen, is dezelfde. Deze drempel is voor de gehuwden in de richting van de regeling voor ongehuwden bijgesteld. ${ }^{179} \mathrm{De}$ ongehuwde samenlevers hebben in tegenstelling tot de gehuwden een keuzemogelijkheid. De reden waarom de gehuwden niet kunnen kiezen, is gelegen in uitvoeringstechnische problemen. ${ }^{180}$ Het een en ander brengt wel een inbreuk op de volstrekt individuele heffing met zich, maar wordt door de maatschappelijke realiteit gerechtvaardigd. ${ }^{181}$ Hier zie je weer dat de regering zich laat leiden door het maatschappelijk gebeuren. ${ }^{182}$

\section{ad 2. Rente-en dividendvrijstelling}

$\mathrm{Bij}$ de rente- en dividendvrijstelling wordt gelijkstelling in de richting van de ongehuwden doorgetrokken. De gehuwden kunnen ook een beroep doen op de dubbele rente- en dividendvrijstelling. ${ }^{183} \mathrm{Om}$ redenen van doelmatigheid kan niet worden bewerkstelligd dat de ongelijkheid volledig wordt opgeheven, daar de vrijstelling bij de gehuwden niet individueel wordt toegepast. Dit gebeurt wel bij de ongehuwd samenlevenden. Derhalve wordt niet gekozen voor een verdere verzelfstandiging doch voor de oplossing dat de bedragen worden verdubbeld. ${ }^{184}$

\section{ad 3. Partnerpensioen}

Voor de ongehuwden bestaat de mogelijkheid om een pensioen ten behoeve van hun partner op te bouwen, het zgn. partnerpensioen. Deze gelijkstelling met de gehuwden tracht de blokkade, die voor de ongehuwd samenlevenden in de wettelijke bepaling bestaat, weg te nemen. Een nadere invulling van het begrip partnerpensioen zal door de pensioenfondsen moeten worden ontwikkeld. ${ }^{125}$

Gestreefd wordt derhalve naar een zo gelijk mogelijke behandeling van vergelijkbare gevallen. Dit streven leidt echter niet tot een verdergaande verzelfstandiging. De verdergaande verzelfstandiging zou niet door de maatschappij worden

179. L.W. Sillevis vindt het toevallig dat een voor de ongehuwd samenlevenden ongunstige regeling thans ook voor de gehuwden geldt. L.W. Sillevis, De opmars van de samenwoners in de inkomstenbelasting, H. Mobach-bundel, Leids Fiscaal Jaarboek, Gouda Quint, 1985, blz. 167.

180. Tweede Kamer, vergaderjaar 1984-1985, 18 519, no 5, blz. 37.

181. Tweede Kamer, vergaderjaar 1983-1984, 18 519, no 3, blz. 23.

182. Een citaat, weliswaar gedateerd na de invoering van de Tweeverdienerswetgeving maar toch van belang, is het volgende: 'Dat is echter ook onvermijdelijk wanneer althans, zoals bij de tweeverdienerswetgeving het geval is, gepoogd wordt zoveel mogelijk recht te doen aan de veelkleurige maatschappelijke werkelijkheid, waarbij tevens recht moet worden gedaan aan het beginsel van een rechtvaardige verdeling van de belastingdruk over de verschiliende belastingplichtigen.' Staatssecretaris van Financiën, Koning, Uit het parlement, Weekblad voor fiscaal recht, 1986, no 5734, blz. 854.

183. Tweede Kamer, vergaderjaar 1983-1984, 18519 , nrs. A-C, blz. 8. Wel wordt hier gerealiseerd dat een volledige gelijkstelling niet kan worden bewerkstelligd. Tweede Kamer, vergaderjaar 1983-1984, 18 519, no 3, blz. 24.

184. Tweede Kamer, vergaderjaar 1984-1985, 18 519, no 5, blz. 38.

185. Tweede Kamer, vergaderjaar 1983-1984, 18 519, no 3, blz. 24 en 25. 
aanvaard en de fiscale wetgever dient, naar zijn eigen woorden ${ }^{186}$, ook niet te proberen om de maatschappij te veranderen. De fiscale wetgever volgt de maatschappij daarentegen wel. Dit is ook wenselijk in verband met de aanvaarding van de belastingheffing.

\section{ad 4. Meewerkaftrek of reële beloning}

Zowel de gehuwden als de ongehuwde samenlevers kunnen ter zake van het verrichten van werkzaamheden door de partner een zgn. meewerkaftrek ten laste van de winst brengen. ${ }^{187}$ In plaats van een meewerkaftrek kan een zelfstandige beloning ten laste van de winst worden gebracht.

\section{ad 5. Stamrechtvrijstelling}

De stamrechtvrijstelling is onder vigeur van Tweeverdieners-III ook van toepassing op de ongehuwd samenlevenden onder de voorwaarde dat ten minste vijf jaren een gezamenlijke huishouding is gevoerd.

\section{ad 6. Oudedagsreserve}

De gehuwde vrouw heeft ook recht op een oudedagsreserve. Hier vindt een gelijkstelling plaats van de gehuwden in de richting van de ongehuwd samenlevenden. Voor de ongehuwd samenlevenden geldt de voorwaarde dat de gezamenlijke huishouding ten minste vijf jaren is gevoerd.

$\mathrm{Nu}$ is het met de invoering van de derde fase van de Tweeverdienerswetgeving niet zo dat alle regelingen die voor de gehuwden gelden, ook van toepassing zijn op de ongehuwd samenlevenden. Dit is bij voorbeeld niet het geval bij de aftrekbaarheid van de hypothecaire renteschuld. Bij de ongehuwde samenlevers is de hypothecaire renteschuld fiscaal aftrekbaar bij de partner die de rente draagt, ongeacht de civielrechtelijke schuld. Met andere woorden, de partners kunnen de renteschuld naar eigen goeddunken verdelen. Dit is niet juist, aldus de Raad van State. ${ }^{188}$

Op het punt van de alleenverdienerstoeslag en de voetoverheveling is ook geen volledige gelijke behandeling van de gehuwden en ongehuwd samenlevenden. ${ }^{189}$

186. Tweede Kamer, vergaderjaar 1984-1985, 18 519, no 5, blz. 34 en 35. Aansluiten bij de maatschappij geschiedt daarentegen wel. Handelingen Eerste Kamer, vergaderjaar 1984-1985, 18 519 , blz. $436, \mathrm{mk}$.

187. Aanvankelijk constateerde de Raad van State aanmerkelijke verschillen met betrekking tot de meewerkaftrek, die door gehuwde paren - in tegenstelling tot ongehuwde - kon worden toegepast. Tweede Kamer, vergaderjaar 1983-1984, 18 519, nrs. A-C, blz. 8.

188. Tweede Kamer, vergaderjaar 1983-1984, 18 519, nrs. A-C, biz. 8 en 9 . Later komt een resolutie tot stand waarin wordt toegestaan dat de rente in aftrek kan worden gebracht die de partner die de rente betaald heeft. Dit kan niet indien met de verdeling van de rentelast slechts een fiscaal voordeel is beoogd. Resolutie van 25 maart 1985, BNB 1985/12.

189. D. van den Hoeven, Nog wat vraagpunten bij de toepassing van de wet tweeverdieners, Weekblad voor fiscaal recht, 1985, no 5692, blz. 971-978. 
De vraag of de gehuwden en ongehuwd samenlevenden gelijk behandeld moeten worden, loopt als een rode draad door de discussie tussen de voor- en tegenstanders van het samenvoegingsstelsel en het individuele stelsel heen (zie hoofdstuk 2). De keuze voor het ene of het andere stelsel heeft derhalve gevolgen voor de fiscale behandeling van de gehuwden en ongehuwd samenlevenden. Dat betekent dat of een volledige gelijke behandeling plaats moet vinden of juist niet. Maar dan gebeurt het niet op de wijze zoals in de Tweeverdienerswetgeving is geschied.

De kamerstukken betreffende de derde fase Tweeverdieners geheel overziende concludeer ik dat weliswaar ernaar gestreefd is het vijfledige doel van de Tweeverdienerswetgeving - gelijke behandeling tussen groepen belastingplichtigen - te realiseren, maar dat doelmatigheidsredenen een algehele gelijke behandeling frustreerden. In sommige gevallen is weliswaar een optieregeling in het leven geroepen, zoals bij voorbeeld bij de meewerkaftrek, maar hiermee is de gelijkheid niet optimaal gediend. ${ }^{190}$ Wil de gelijkheid gediend zijn, dan zal een gelijke behandeling op alle gebieden mogelijk moeten zijn.

In de literatuur is eveneens de kritiek met betrekking tot het gelijkheidsbeginsel niet van de lucht. De kritiek houdt onder andere in dat de gelijke behandeling ten aanzien van sommige onderdelen in de Wet IB 1964 voor zowel de gehuwden als de ongehuwden enigszins willekeurig aandoet. ${ }^{191}$

\subsubsection{Budgettaire overwegingen}

In tegenstelling tot de eerste en tweede fase, die geld opleverden, leidt de derde fase tot een belastingmiddelenderving van $f 485 \mathrm{mln}$. op transactiebasis. ${ }^{192}$

190. H.P.A.M. van Arendonk, De Tweeverdienersregeling, Maandblad Belastingbeschouwingen, 1986, no 6, blz. 159. Zie ook de commissie-Stevens, die zich afvraagt of het verschil in behandeling van niet-arbeidsinkomensbestanddelen niet leidt tot een schending van artikel 26 BuPo. De gelijke behandeling van gehuwden met ongehuwd samenlevenden brengt wel uitvoeringsproblemen met zich. Graag of niet, t.a.p., blz. 175 en 176.

191. Zie onder andere H.P.A.M. van Arendonk, De Tweeverdienersregeling, Maandblad Belastingbeschouwingen, 1986, no 6, blz. 158-162. In dit artikel wordt de 33e Belastingconsulentendag betreffende de gelijke behandeling van gehuwden en ongehuwd samenlevenden besproken. L.W. Sillevis spreekt van het ontbreken van een theoretisch gefundeerde basis met betrekking tot de gelijkstelling. L.W. Sillevis, De opmars van samenwoners in de inkomstenbelasting, Leids Fiscaal jaarboek, Gouda Quint, 1985, blz. 162. L.W. Sillevis vermeldt ook de elementen die niet zijn gelijksteld voor de ongehuwd samenlevenden, t.w.: de doorschuiving bij overdracht van de onderneming, de aanmerkelijk belang regeling, de zelfstandigenaftrek, de regeling inzake de lijfrentepremies voor kinderen. L.W. Sillevis, t.a.p., blz. 168-170.

Vergelijk L.G.M. Stevens, die meent dat de gelijkstelling van de gehuwden met de ongehuwde samenlevers te weinig fundamenteel is. L.G.M. Stevens, Wetsontwerp Tweeverdieners derde fase (nr 18 519), Weekblad voor fiscaal recht, 1984, no 5655, blz. 1242.

192. De Tweeverdienersoperatie is neutraal verlopen; de eerste en tweede fase leveren in tegenstelling tot de derde een opbrengst. Evaluatierapport Tweeverdienerswetgeving, Ministerie van Sociale Zaken en Ministerie van Financiën, 1987, błz. 6. 
In deze fase spelen de rechtvaardigheidsbeginselen wederom een verbloemende rol voor budgettaire overwegingen. Hiermee bedoel ik dat in enkele gevallen budgettaire overwegingen niet alleen de grens bepalen van hetgeen mogelijk is, maar ook de inhoud van de rechtvaardigingsgronden. Onder het mom van bij voorbeeld het draagkrachtbeginsel spelen in dat geval budgettaire overwegingen een dominante rol. 'Het uitgangspunt was, zoals Giele reeds vermeldde, dat er aan de samenlevende tweeverdieners voor de schatkist wat te verdienen viel. ${ }^{193}$ De budgettaire overwegingen zijn richtinggevend voor de rechtvaardiging van een wet(swijziging). Zoals gezegd bepalen zij in sommige gevallen niet alleen de grenzen van hetgeen mogelijk is, maar bepalen zij tevens de nadere inhoud van de rechtvaardigingsgronden. Soms blijven met een beroep op budgettaire overwegingen bepaalde overgangsregelingen achterwege. ${ }^{194}$ In de Tweeverdienerswetgeving is de hoogte van de toeslagen bepaald door de budgettaire ruimte. Een voorbeeld is de vaststelling van de uiteindelijke hoogte van de arbeidstoeslag. ${ }^{195}$

\subsection{Reparatiewetgeving Tweeverdieners}

Alvorens in te gaan op de reparatiewetgeving, wil ik eerst de titel van deze paragraaf toelichten. Deze is enigszins misleidend. Hij suggereert dat de reparatiewetgeving noodzakelijk is geweest $n a$ de invoering van de Tweeverdienerswetgeving. Niets is minder waar; reeds in de derde fase is enige reparatiewetgeving nodig. ${ }^{196}$

\subsubsection{Algemene opmerkingen}

Op de Tweeverdienerswetgeving is veel kritiek geleverd. ${ }^{197}$ Uit de kamerstukken van 1984 blijkt dat er tal van uitvoeringsmoeilijkheden zijn met betrekking tot de tweede fase. Deze betreffen voornamelijk de begripsafbakening. Bij de belastingdienst blijken twijfels te bestaan met betrekking tot de controlemogelijkheden. ${ }^{198}$ Bovendien is de Tweeverdienerswetgeving een vrij ingewikkelde

193. Discussiebijdrage C.J. Visser, in J.F.M. Giele, De problematiek van de tweeverdieners, FED Nederlandse Federatie van Belastingconsulenten, 1986, blz. 31. Zie verder § 3.3.4.

194. Zie voor een voorbeeld, Tweede Kamer, vergaderjaar 1983-1984, 18 121, nrs. A-C, blz. 16.

195. Fiscale wetgeving, Wetsontwerp derde fase tweeverdieners bij de Tweede Kamer ingediend, Weekblad voor fiscaal recht, 1984, no 5551, blz. 1098. Tweede Kamer, vergaderjaar 1984-1985, 18519 , no 9 , blz. 8.

196. Handelingen Eerste Kamer, vergaderjaar 1983-1984, 18 121, blz. 462, lk.

197. Een greep uit de vele plaatsen in de wetgevingsstukken waaruit de kritiek blijkt: Handelingen Eerste Kamer, vergaderjaar 1983-1984, 18 121, blz. 359, rk en 369, mk. Zie onder andere J.F.M. Giele, De problematick van de tweeverdieners, FED Nederlandse Federatie van Belastingconsulenten, 1986, blz. 49. H.J. Hofstra spreekt zelfs van een beginselloosheid die de Tweeverdienerswetgeving kenmerkt. De Tweeverdienerswetgeving is mede tot stand gekomen onder invloed van pressiegroepen. H.J. Hofstra, De lof van de Tweeverdienersregeling, Mobach-bundel, Leids Fiscaal Jaarboek, Gouda Quint, 1985, blz. 40.

198. Tweede Kamer, vergaderjaar 1983-1984, 18 519, no 3, blz. 33. 
regeling. De kritiek op de tweede fase betreft derhalve voornamelijk de doelmatigheid; de uitvoering verloopt allesbehalve vlekkeloos.

De regeling betreffende de teruggave van de voetoverheveling kan als een voorbeeld van een ondoelmatige regeling worden gezien. Zo zal een groter aantal belastingplichtigen ( 75.000 meer) bij de inkomstenbelasting moeten worden betrokken, daar een partiële voetoverheveling in de loonbelasting niet mogelijk is. ${ }^{199}$

$\mathrm{Na}$ de invoering van de derde fase verschijnen met betrekking tot de tweeverdienerswetgeving enkele nota's. Het betreft hier de nota 'Leefvormen' ${ }^{200}$ en de nota '(kleine) Tweeverdieners'201.

De nota 'Leefvormen' gaat uit van twee draagkrachtbeïnvloedende elementen, t.w.:

1. het samenwonen met éen of meer anderen, al dan niet zonder een eigen inkomen; en

2. het voeren van een eigen huishouding of een huishouding voor zich alleen. De draagkrachtverschillen worden in de belastingheffing zuiver economisch benaderd, aldus de nota. ${ }^{202}$ 'Het gaat immers om inkomensvoorziening en inkomstenbelasting naar behoefte en draagkracht op grond van de feitelijke woonen leefsituatie, waarvoor de burgerrechtelijke relatie niet beslissend is. ${ }^{203}$

In de andere nota wordt geconstateerd dat ten gevolge van de invoering van de derde fase van de Tweeverdienerswetgeving enige onrust op de arbeidsmarkt is ontstaan. Naar aanleiding hiervan wordt overgegaan tot een wetswijziging.

Tijdens de behandeling van het wetsvoorstel betreffende de derde fase is de regering nog van mening dat de maatschappij niet zover verfiscaliseerd is dat de fiscale gevolgen van de derde fase een beperkende invloed zullen hebben op de toetreding tot de arbeidsmarkt. ${ }^{204} \mathrm{Bij}$ de behandeling in de derde fase van een vraag of een evaluatie naar de effecten op de arbeidsmarkt zal plaatsvinden, stelt de regering zich op het standpunt dat de inhoudelijke evaluatie van de gevolgen

199. Tweede Kamer, vergaderjaar 1983-1984, 18 519, nrs. A-C, blz. 6. Bovendien ervaren de belastingplichtigen de systematiek van de voetoverheveling als complex. Evaluatierapport Tweeverdienerswetgeving, t.a.p., blz. 50.

200. Tweede Kamer, vergaderjaar 1985-1986, 19 262. In de nota 'Leefvormen' wordt onder andere aangetoond dat de leefsituatie van invloed is op toepassing van een wettelijke regeling. De nota wordt zover hier van belang weergegeven.

Fiscaal zag de situatie als volgt uit. Allereerst is de objectieve draagkracht van belang. Deze objectieve draagkracht betreft het inkomensniveau. Hierbij zijn de persoonlijke omstandigheden (subjectieve draagkracht, $M W$ ) van belang. Met andere woorden: een ieder heeft recht op de belastingvrije som en de persoonlijke omstandigheden rechtvaardigen een eventuele toeslag daarop.

De draagkracht wordt fiscaal gezien berekend naar zuiver economische factoren; de vraag moet worden beantwoord of er sprake is van éen of meer inkomens in het huishouden.

201. Nota '(kleine) tweeverdieners', Tweede Kamer, vergaderjaar 1985-1986, 19039.

202. Tweede Kamer, vergaderjaar 1985-1986, 19 262, nrs. 1-2, blz. 14.

203. Tweede Kamer, vergaderjaar 1985-1986, 19 262, nrs. 1-2, blz. 19.

204. Tweede Kamer, vergaderjaar 1984-1985, 18 519, no 5, blz. 19. Tweede Kamer, vergaderjaar 1983-1984, 18 121, no 5, blz. 41. Handelingen Eerste Kamer, vergaderjaar 1984-1985, 18 519, blz. 432 , mk. 
voor de arbeidsmarkt geen taak voor de belastingdienst zou zijn. ${ }^{205}$ Maar toch wel voor de overheid, welke instantie dan ook, zou ik willen stellen. De gevolgen van de belastingheffing dienen wel degelijk in ogenschouw te worden genomen, daar dit uiteindelijk voor de opbrengst van de belastingheffing van evident belang is. Dit is een kwestie van doelmatig handelen. ${ }^{206}$

De toenmalige staatssecretaris Koning heeft wel toegezegd dat een onderzoek naar de effecten op de arbeidsmarkt zal worden ingesteld. De resultaten, benevens de budgettaire effecten en de politieke beoordeling, zullen bepalend zijn voor de eventuele bijstelling van de wettelijke regeling. ${ }^{27} \mathrm{De}$ evaluatie volgt en wijziging blijkt nodig te zijn. ${ }^{208}$ 'Mooie' principes worden teniet gedaan door feitelijke omstandigheden. In een reactie op hetgeen te berde wordt gebracht als kritiek, zoals bij voorbeeld de enorme fraudegevoeligheid van de Tweeverdienerswetgeving, stelt de staatssecretaris vast dat ernaar gestreefd is zoveel mogelijk recht te doen aan de vele maatschappelijke verhoudingen met in het achterhoofd een rechtvaardige verdeling van de lasten, waarbij geen onderscheid naar geslacht of burgerlijke staat wordt gemaakt en waarbij rekening wordt gehouden met feitelijke omstandigheden zoals het voeren van een huishouding voor zich alleen. Met de fraudegevoeligheid valt het mee, aldus de staatssecretaris. ${ }^{209}$

Maar de maatschappij reageert op een min of meer in de literatuur voorspelde wijze, en fiscale maatregelen moeten worden genomen; al in 1985 moet enige reparatiewetgeving op de Tweeverdienerswetgeving plaatsvinden. ${ }^{210} \mathrm{De}$ genomen maatregel betreft een financiële tegemoetkoming voor belastingplichtigen die wel de arbeidstoeslag, doch geen aanvullende arbeidstoeslag genieten: de tweeverdieners zonder jonge kinderen. De maatregel komt er kort gezegd op

205. Tweede Kamer, vergaderjaar 1984-1985, 18 519, no 5, blz. 45. Zie ook Weekblad voor fiscaal recht, 1984, no 5636, blz. 545 en 546, waarin wordt gesteld dat naar aanleiding van de schokeffecten die een gevolg waren van de invoering van de tweede fase meer vrouwen zwart zijn gaan werken. Dit heeft uiteindelijk een frustrerend effect op de opbrengst van de belastingheffing.

206. Zie ook Tweede Kamer, vergaderjaar 1984-1985, 18 519, no 7, blz. 27.

207. Weekblad voor fiscaal recht, 1985 , no 5669 , blz. 166 . Tienduizend ontslagnames door kleine tweeverdieners is een gevolg van de invoering van de Tweeverdienerswetgeving. Nota inzake (kleine) tweeverdieners, Weekblad voor fiscaal recht, 1985, no 5689, blz. 841.

208. Een van de redenen waarom tot wetswijziging is overgegaan is de door de derde fase van de Tweeverdienerswetgeving ontstane onrust op de arbeidsmarkt weg te nemen. Tweede Kamer, vergaderjaar 1985-1986, 19 293, A-C, blz. 5.

Een van de wettelijke wijzigingen die het gevolg zijn van de evaluatie is het wetsvoorstel 19 279 , inhoudende een wijziging van de inkomstenbelasting en de loonbelasting (verruiming mogelijkheden voor vermindering van loonbelasting). Deze wijziging wordt hier niet behandeld.

209. Weekblad voor fiscaal recht, 1986, no 5734 , blz. 853 en 854 . Zie echter het Evaluatierapport Tweeverdienerswetgeving: het niet duurzaam voor zich alleen voeren van een huishouding is in $30 \%$ van de belastingverhogende correcties (LB-plichtigen) de reden voor wijziging. Evaluatierapport Tweeverdienerswetgeving, t.a.p., blz. 28 en 29.

210. Zie onder andere de Wet van 18 december 1985 tot wijziging van de inkomstenbelasting (verruiming voetoverheveling) Stb. 1985, 699; inwerkingtreding op 1 januari 1986. Bijbehorende kamerstukken, Tweede Kamer, vergaderjaar 1985-1986, 19 293. Zie ook het Evaluatierapport Tweeverdienerswetgeving, t.a.p., blz. 74. 
neer dat het inkomen van de echtgenoot dat minder dan de belastingurije som bedraagt, voor $85 \%$ in aanmerking wordt genomen. Dit kan worden gezien als een verkapte verhoging van de belastingvrije som. In de literatuur wordt het voorstel gedaan om de arbeidstoeslag naar de verwervingskosten over te brengen. Dit zal een meer gelijke behandeling van eén- en tweeverdieners bewerkstelligen. ${ }^{211}$

Met de invoering van de wetswijziging wordt beoogd een nevendoeleinde der belastingheffing te bereiken, $n$ l. het wegnemen van de onrust op de arbeidsmarkt.

Allereerst kan hier een opmerking met betrekking tot de wetgevingsbeginselen worden gemaakt. Ik wijs op de brief van de Vaste commissie voor Financiën d.d. 13 november 1985. Deze commissie komt tot de conclusie dat de invoering van het hier bedoelde wetsvoorstel niet echt in een ordelijk wetgevingsproces past. ${ }^{212}$ Geconstateerd wordt dat gedurende de behandeling van de gehele Tweeverdienerswetgeving een enorme tijdsdruk aanwezig is geweest. Hiermee is de eis van consistentie van wetgeving niet gediend.

Ik wil nog een opmerking maken over de vanzelfsprekendheid van feiten waarvan de fiscale wetgever zich bedient. Ter illustratie: De regering stelt dat de omvang van de uitgaven voor de kinderopvang bij kleine tweeverdieners wel beperkter zal zijn dan bij de grotere tweeverdieners. Dit hangt samen met de periode waarin kinderopvang nodig wordt geacht; de perioden zouden voor de grotere tweeverdieners langer duren dan voor de kleinere. ${ }^{213}$ Moet hieruit afgeleid worden dat met de categorie kleinere tweeverdieners belastingplichtigen worden bedoeld die minder uren werkzaam zijn dan de belastingplichtigen die het etiket 'grote tweeverdiener' opgeplakt krijgen? De karakterisering van 'groot' en 'klein' slaat blijkbaar op de omvang van het inkomen. Hiermee wil ik zeggen dat feiten soms als vanzelfsprekend worden aangenomen, terwijl niet duidelijk is wat precies wordt bedoeld. Indien dat wel het geval is, is het de vraag of deze feiten voldoende geverifieerd zijn. Het is als vanzelfsprekend dat de fiscale wetgever van goed voorziene informatie moet uitgaan, wil de fiscale wetgeving in de maatschappij voldoende worden aanvaard. ${ }^{214}$

211. P. Kavelaars, Tweeverdieners: laatste fase?, Weekblad voor fiscaal recht, 1985, no 5707, blz. 1597. De auteur kan overigens geen enkele rechtvaardiging voor invoering van de onderhavige wetswijziging vinden. P. Kavelaars, Tweeverdieners: laatste fase?, Weekblad voor fiscaal recht, 1985, no 5707, blz. 1606.

212. Tweede Kamer, vergaderjaar 1985-1986, 19279 en 19 293, no 6, blz. 1. Zie ook de notitie die wordt gegeven. Tweede Kamer, vergaderjaar 1985-1986, 19279 en 19 293, no 10-11.

213. Tweede Kamer, vergaderjaar 1985-1986, 19 293, no 3, blz. 3. Een ander voorbeeld: 'De kosten van levensonderhoud van oudere ongehuwden zullen in het algemeen hoger liggen dan die van jongere ongehuwden'. Ontleend aan A.C. Rijkers, Tweeverdieners-III. Een nabeschouwende vooruitblik, Weekblad voor fiscaal recht, 1984, no 5636, blz. 532.

214. Dit wordt ook aangetoond door de vermelding door de regering dat niet bekend is hoeveel kleine tweeverdieners die ontslag namen weer opnieuw aan de slag zijn gekomen. Tweede Kamer, vergaderjaar 1985-1986, 19 293, no 6, blz. 5. Vergelijk ook hetgeen de leden van de PSPfractic over de maatschappelijke aanvaardbaarheid van de belastingheffing zeggen. Tweede Kamer, vergaderjaar 1984-1985, 18 519, no 7, blz. 6. Een ander voorbeeld is het gegeven dat de draagkracht van tweeverdieners groter is dan van alleenverdieners. Handelingen Tweede Ka- 
De rechtvaardigheid wordt door de hierboven genoemde maatregel voldoende bereikt, aldus de regering. ${ }^{215}$ Met het invoeren van deze maatregel is echter de uitvoeringslast verzwaard. Dit toont aan dat de invoering van de tweeverdienerswetgeving niet erg doelmatig is, en zeker niet de deregulering dient. ${ }^{216}$ De regering maakt de volgende belangenafweging: 'Hoewel niet kan worden ontkend dat er een verzwaring en complicering van regelgeving optreedt, is het belang van de voorgestelde regeling voor de belastingplichtigen wie het aangaat zodanig dat dit naar het oordeel van de regering zwaarder moet wegen dan de bezwaren die uit het oogpunt van terughoudendheid van regelgeving tegen het voorstel kunnen worden aangevoerd. ${ }^{217}$ Op een andere plaats merkt de regering op: 'dat telkenmale een afweging moet wor-den gemaakt tussen de met het oog op de belangen van individuele belastingplichtigen c.q. de rechtvaardigheid van het stelsel gewenste verfijningen en de met het oog op de belangen van het geheel der belastingplichtigen en de hanteerbaarheid van het stelsel gewenste eenvoud. ${ }^{218}$

Uit de citaten blijkt dat een voorkeur voor de rechtvaardigheid ten nadele van de doelmatigheid wordt uitgesproken. Maar of en hoe deze voorkeur in de praktijk wordt gebracht, is blijkbaar een vraag van een andere orde.

Rest nog te vermelden dat de twijfels die over de hoogte van de kosten van de kinderopvang bij de Raad van State en het parlement zijn ontstaan, door de regering ontzenuwd zijn door op het forfaitaire karakter van de regeling te wijzen. Bij de beoordeling van deze forfaitaire regeling moet het criterium van de verdelende rechtvaardigheid een grotere rol spelen dan de individuele rechtvaardigheid. ${ }^{219}$

\subsubsection{Budgettaire overwegingen}

Spelen budgettaire overwegingen ook bij de reparatiewetgeving een rol? Jazeker. Tekenend is de volgende discussie. De vaste commissie voor Financiën richt het volgende verzoek tot de regering: 'Ter bevordering van een vruchtbare gedach-

mer, vergaderjaar 1984-1985, 18 519, blz. 1042, rk. Gesproken wordt ook wel van een rechtvaardiger verdeling van de belastingdruk gebaseerd op een 'politieke rechtvaardigheid' en niet op duidelijke onderzoeken. Handelingen Eerste Kamer, vergaderjaar 1984-1985, 18 519, blz. 393, mk.

215. Tweede Kamer, vergaderjaar 1985-1986, 19 293, no 3, blz. 6 en no 7, blz. 2. Echter het voordeel van de regeling neemt toe naarmate de inkomens stijgen. P. Kavelaars, Tweeverdieners: laatste fase?, Weekblad voor fiscaal recht, 1985, no 5707, blz. 1599. De belastingplichtigen zijn niet van mening dat met de Tweeverdienerswetgeving de rechtvaardigheid gediend is. Evaluatierapport Tweeverdienerswetgeving, t.a.p., blz. 20.

216. Tweede Kamer, vergaderjaar 1985-1986, 19 293, no 3, blz. 6. Zie ook H.P.A.M. van Arendonk, P. Kavelaars, L.G.M. Stevens, Eenvoud in praktijk, OORT-wetgeving, $2 e$ herziene druk, Kluwer, 1991, blz. 22.

217. Tweede Kamer, vergaderjaar 1985-1986, 19 293, no 3, blz. 6.

218. Tweede Kamer, vergaderjaar 1985-1986, 19 293, no 6, blz. 2.

219. Tweede Kamer, vergaderjaar 1985-1986, 19 293, no 6, blz. 8. 
tenwisseling over deze materie verzoekt de commissie u een notitie op te stellen, waarin wordt geanalyseerd waardoor het komt dat wetsvoorstellen met budgettaire gevolgen voor het volgende begrotingsjaar (in de regel wetsvoorstellen in het kader van het dekkingsplan) al sinds jaren zo laat bij de Kamer worden ingediend dat hun behandeling in Tweede en Eerste Kamer telkenmale onder een zware tijdsdruk moet plaatsvinden. ${ }^{220}$

Het antwoord van de regering luidt: 'Het moge duidelijk zijn dat de spanning die bestaat tussen de voor het wetgevingsproces wenselijke ruimte en de daarvoor feitelijk beschikbare tijd nauw is verbonden met de bestaande politieke processen, zeker wanneer de desbetreffende wetsontwerpen deel uitmaken van de besluitvorming over de begroting van het volgende jaar. ${ }^{, 221}$

Op de vraag naar een onderzoek van de arbeidsmarkteffecten van de tweeverdienerswetgeving antwoordt de staatssecretaris als volgt: 'Of het onderzoek zal leiden tot bijstelling van de wetgeving hangt vanzelfsprekend af van het resultaat van het onderzoek, met inbegrip van de budgettaire effecten en de politieke beoordeling daarvan., 222

Een ander voorbeeld waarin de budgettaire belangen voorop staan, is de bepaling van het percentage van het inkomen dat kan worden overgeheveld naar de partner. Het inkomen van de overhevelende partner wordt voor $85 \%$ in aanmerking genomen. Ter motivering van het percentage van 15 (100\%-85\%) geeft de regering toe dat daaraan 'geen diepzinnige gedachten ten grondslag hebben gelegen.' De uitkomst is afhankelijk van het budget. ${ }^{223}$ Bovendien is vanwege de beperkte budgettaire ruimte de regeling van de verruimde voetoverheveling niet van toepassing op degenen die geen recht hebben op de aanvullende arbeidstoeslag. ${ }^{24}$ Het budgettaire belang èn het partij-politieke belangen bepalen hier het uiteindelijke wetgevingsprodukt.

Kortom, onrechtvaardigheden moeten worden opgeheven. Maar de grens van het opheffen van de onrechtvaardigheden wordt gevonden in de budgettaire ruimte.

\subsection{Samenvatting en conclusies}

Met de invoering van de Tweeverdienerswetgeving tracht de wetgever een compromis te bereiken tussen de individuele draagkracht en de gezinsdraagkracht.

220. Tweede Kamer, vergaderjaar 1985-1986, 19279 en 19 293, no 6, blz. 2.

221. Tweede Kamer, vergaderjaar 1985-1986, 19279 en 19 293, nrs. 10-11, blz. 5.

222. Nota inzake (kleine) tweeverdieners, Weekblad voor fiscaal recht, 1985, no 5689 , blz. 841. Gesproken wordt van het gegeven dat 8.000 à 10.000 (naar gelang van de verschillende onderzoeken) gehuwde vrouwen hun baan opzegden. Evaluatierapport Tweeverdienerswetgeving, t.a.p., blz. 62 en 67.

223. Tweede Kamer, vergaderjaar 1985-1986, 19 293, no 6, blz. 5. Verderop wordt gesproken van 'een gegeven budgettaire ruimte'. Tweede Kamer, vergaderjaar 1985-1986, 19 293, no 6, blz. 7.

224. P. Kavelaars, Tweeverdieners: laatste fase?, Wcekblad voor fiscaal recht, 1985, no 5707, blz. 1600. 
Hierdoor hinkt de wetgeving op twee gedachten, hetgeen resulteert in een niet uitmuntend wetgevingsprodukt.

Bovendien is de Tweeverdienerswetgeving door haar compromissoir karakter een bijzonder ingewikkeld wetgevingsprodukt. Hier komt nog bij dat aanzienlijke reparatiewetgeving nodig is gebleken. Maar volgens de staatssecretaris is de ingewikkeldheid niet erg, want de gemiddelde belastingplichtige kan de wet toch niet lezen. Ik denk niet dat dit de juiste weg is. Zeker niet als de regering uitgaat van de maatschappelijke aanvaarding. Dit is op zijn zachtst gezegd opmerkelijk.

\section{Het draagkrachtbeginsel}

Uit de kamerstukken valt af te leiden dat het begrip draagkracht zeker geen eenduidig begrip is. Nu is dit vanwege het politieke karakter van het draagkrachtbeginsel al lange tijd bekend, maar onjuist gebruik van het beginsel moet toch worden voorkomen. Onder politiek dient hier te worden verstaan het bestaan van partij-politieke ideeën en belangen enerzijds en het sluiten van compromissen anderzijds. Een conclusie is dat het draagkrachtbeginsel een begrip is dat onder invloed van tijd en omstandigheden verandert.

Een andere conclusie is mijns inziens de volgende. De fiscale wetgever heeft het draagkrachtbeginsel wederom veelvuldig als rechtvaardigingsgrond gebruikt, met het gevolg dat het beginsel een andere, ruimere invulling heeft gekregen. Daardoor bestaat het gevaar dat het draagkrachtbeginsel zijn waarde verliest; het draagkrachtbeginsel fungeert als paraplu voor de vele partijpolitieke invullingen die aan het beginsel worden gegeven. De fiscale wetgever dient ervoor te waken geen produkten te verkopen onder het mom dat de Wet IB 1964 een belastingheffing naar draagkracht is.

\section{Het gelijkheidsbeginsel}

Wat het gelijkheidsbeginsel betreft, is de voornaamste gelijke behandeling die de Tweeverdienerswetgeving voorstaat die van de gehuwden en de ongehuwde samenlevers geweest. Dit streven naar een gelijke behandeling is echter niet op alle punten gelukt. Een reden hiervoor is onder andere gelegen in de beperkende werking van de doelmatigheid.

Is daardoor de wetgeving mislukt? Volgens de fiscale wetgever niet; de uiteindelijke Tweeverdienerswetgeving wordt als het maximaal haalbare resultaat gezien.

Het klinkt wellicht overbodig, maar mijns inziens wordt de mate van de maatschappelijke aanvaarding van de belastingheffing vergroot door een algehele gelijke behandeling. Voor een ongehuwd samenlevende belastingplichtige is het moeilijk te begrijpen dat de ene regeling, die voor gehuwden geldt, wel op hem en zijn partner van toepassing is, en een andere, voor gehuwden geldende, regeling niet. Dit geldt natuurlijk ook omgekeerd. 


\section{Budgettaire overwegingen}

Uit de kritiek, die in het parlement en de literatuur op de voorgestane gelijke behandeling naar voren komt, valt het vermoeden af te leiden dat budgettaire overwegingen een aanzienlijke rol hebben gespeeld.

Getuige de parlementaire geschiedenis wordt enerzijds verbloemd dat de budgettaire overwegingen een vooraanstaande rol spelen. De verbloeming geschiedt door het simpelweg noemen van rechtvaardigheidsbeginselen. Anderzijds wordt openlijk toegegeven dat budgettaire overwegingen wel degelijk een rol spelen. De vraag in welke mate zulks het geval is, valt echter niet in het algemeen te beantwoorden. Dit zal per regeling moeten worden nagegaan. De budgettaire overwegingen beperken de werking van het gelijkheidsbeginsel en het draagkrachtbeginsel; een bepaalde regeling kan niet verder worden doorgevoerd daar de budgettaire ruimte beperkt is.

Geconstateerd kan worden dat in het algemeen een zekere terughoudendheid valt te bespeuren ten aanzien van het gebruik van het argument budgettair belang. Dit gebruik zou de maatschappelijke aanvaardbaarheid en naleving van de belastingwet in gevaar brengen. Maar indien de budgettaire overwegingen daadwerkelijk een aanzienlijke rol spelen, verdient het aanbeveling deze duidelijk te doen uitkomen. Met een deugdelijke motivering van een wetgevingsprodukt is de maatschappelijke aanvaarding groter en zal de regeling waarschijnlijk een langer leven beschoren zijn dan een wetgevingsprodukt met een ondeugdelijke motivering. 
OORT-I 'Zolang een duidelijke visie op de grondbeginselen en
de structuren ontbreekt kan men niet spreken van een
inbreuk op de rechtvaardigheid door maatregelen van
vereenvoudiging die nodig zijn.'

\subsection{Inleiding}

De belastingheffing is zeker de laatste decennia zeer complex geworden. Dit wil niet zeggen dat de complexiteit van de belastingheffing niet al eerder speelde. Zo wordt al in 1947 de (onnodige) ingewikkeldheid van de belastingheffing aan de orde gesteld. ${ }^{2}$ Deels moeten de redenen daarvoor worden gezocht in de plotselinge werking van de maatregelen die de toenmalige bezetter zonder overleg had ingevoerd, deels liggen zij in de steeds sterkere roep om rechtsverfijning. ${ }^{3}$

Ook na 1947 blijft de roep om rechtsverfijning hoorbaar. Ten gevolge daarvan is de ingewikkeldheid van de belastingheffing alleen maar toegenomen. De invoering van de Tweeverdienerswetgeving in de jaren tachtig is een bewijs daarvan.

Zoals iedere actie een reactie teweeg brengt, komt er ook een reactie op de rechtsverfijning. De reactie houdt het verlangen in om het belastingstelsel te

1. H.J. Hofstra, Verslag forumdiscussie, Weekblad voor fiscaal recht, 1986, no 5750, blz. 1473 en 1474.

2. Zie verder hoofdstuk $1, \S 1.4 .2$.

3. K.V. Antal, Eenvoud in het belastingrecht in Nederland, Openbare les, 1947. Zie ook B. Schendstok, Ontwikkelingsfactoren van het belastingrecht, rede, Samsom, 1946, blz. 16. 
vereenvoudigen. ${ }^{4}$ Rechtsverfijning en vereenvoudiging blijken begrippen te zijn die elkaar bijten. ${ }^{5}$.

Zeker na de invoering van de desastreuze Tweeverdienerswetgeving wordt de roep om een eenvoudige belastingheffing zodanig sterk dat uiteindelijk in 1985 een commissie wordt ingesteld die de mogelijkheden voor vereenvoudiging dient na te gaan. ${ }^{6}$

4. Volgens Koopmans c.s. dient men - voordat kan worden beslist of dat een belasting(stelsel) aan herziening toe is - dit te toetsen aan bepaalde kwaliteitseisen, waarvan er zes worden genoemd, t.w.:

1. de regels waarmee belastingplichtigen te maken hebben, moeten begrijpelijk zijn, dat wil zeggen, hun rechten en plichten moet ondubbelzinnig zijn vastgelegd, met loegang tot de onafhankelijke rechter ingeval van discussie (doorzichtigheid);

2. de regelgeving mag zowel belastingplichtigen als de fiscus niet onnodig veel kosten, dat wil zeggen, de belastingwetgeving mag geen fraude uitlokken en niet slechts tegen hoge kosten uit te voeren zijn (eenvoud);

3. het belastingstelsel mag economische beslissingen niet (te veel) verstoren (neutraliteit);

4. belastingen dienen een vangnet voor de armen te spannen. De overige belastingplichtigen dienen een met het inkomen toenemend deel bij te dragen in de financiering van de publieke uitgaven (herverdeling); deze eis lijkt mij een partijpolitieke stellingname;

5. de economische motieven mogen niet (te zeer) worden ontmoedigd (scherpte van prikkels); 6. belastingheffende instanties moeten aan de kiezers verantwoording afleggen (publieke verantwoording).

Het Nederlandse belastingstelsel is ondoorzichtig, erg ingewikkeld en niet neutraal. Bovendien zijn de wettelijke tariefpercentages hoger dan nodig zou zijn en is de publicke verantwoording van de belastingen onvolledig, aldus Koopmans c.s..

Zie L. Koopmans, A.H.E.M. Wellink, H.J. Woltjer, C.A. de Kam, Overheidsfinanciën, zevende geheel herziene druk, Stenfert Kroese, 1991, biz. 169-171.

5. De rechtvaardigheid en doelmatigheid tezamen is én geheel. De volgende som kan worden gemaakt: rechtvaardigheid en doelmatigheid $=1$. Het bevorderen van het eerste element kan ten koste gaan van het andere en andersom.

6. Op 20 september 1985 wordt een commissie tot vereenvoudiging van de loonbelasting en de inkomstenbelasting ingesteld. De commissie wordt genoemd naar de voorzitter, C.J. Oort. Verder nemen deel aan de commissie: H. Burger, H.P.A.M. van Arendonk, P. den Boer, H.J. Hofstra, C.A. de Kam, H. Mobach, W.F.C. Stevens, N. Vogelaar, H. Baron van Lawick. Op 15 mei 1986 dient een tussentijdse aanbieding van hoofdlijnen plaats te vinden. Op 1 januari 1987 dient het eindrapport te worden aangeboden aan de Minister van Financiën.

In artikel 2 van het Instellingsbesluit is de volgende taak te lezen: 'De commissie heeft tot taak uitgaande van het bestaan van de loonbelasting en de inkomstenbelasting, voorstellen te doen ter vereenvoudiging van deze belastingen.

Daarbij dient zij mede:

a. aandacht te schenken aan de verhouding tussen de loonbelasting en de inkomstenbelasting en meer in het bijzonder aan de positie die de loonbelasting in een nieuwe structuur moet innemen;

b. de mogelijkheden te bezien die voortgaande automatisering voor de belastingheffing kan bieden;

c. de samenhang met andere regelingen in de secundaire sfeer en met inkomensafhankelijke regelingen in de tertiaire sfeer in de beschouwing te betrekken;

d. de mogelijkheden te onderzoeken van een integratie van de heffing van de premies voor de volksverzekeringen en die van de loonbelasting en de inkomstenbelasting;

e. van de door haar ontwikkelde voorstellen de gevolgen voor de inkomens aan te geven.'

De commissie geeft haar voorstellen zodanig vorm dat budgettaire neutraliteit zo veel mogelijk wordt gewaarborgd. Voor zover voorstellen aan deze voorwaarden niet voldoen, worden de 
De commissie motiveert de roep om vereenvoudiging met drie redenen, t.w.: de ingewikkeldheid van de regelgeving, de daarmee samenhangende uitvoeringsproblemen en de hoge tarieven. Hierbij dient te worden bedacht dat er in die tijd een internationale tendens tot vereenvoudiging en verlaging van de tarieven viel te bespeuren?

Hierbij rijzen twee vragen. Ten eerste de vraag hoe de geschiedenis rond de instelling van de commissie is geweest, mocht nog getwijfeld worden aan de wens tot vereenvoudiging. En, ten tweede de vraag wat onder vereenvoudiging wordt verstaan en in hoeverre de loon- en inkomstenbelasting moeten worden vereenvoudigd.

Aan de hand van de parlementaire geschiedenis van de instelling van de commissie tracht ik beide vragen te beantwoorden.

\section{Wens tot vereenvoudiging}

De geschiedenis rondom de instelling van de commissie begint met de motie van Vermeend (PvdA, kamerlid). ${ }^{8}$ In deze motie wordt om vereenvoudiging verzocht. Aanvankelijk kende de motie-Vermeend een beperkte opzet. ${ }^{9}$ De motie behelsde een opdracht aan de regering om een commissie in te stellen 'met als opdracht het formuleren van concrete voorstellen voor één inkomensbegrip dat zowel voor de loon- en inkomstenbelasting als voor de premieheffing als grondslag kan dienen'. ${ }^{10}$ Later deelde Vermeend mede dat de motie te beperkt van opzet was en uitgebreid diende te worden. ${ }^{11}$

mogelijkheden van dekking aangeduid.

7. Zicht op eenvoud, Rapport van de commissie tot vereenvoudiging van de loonbelasting en de inkomstenbelasting, Distributiecentrum Overheidspublikaties (DOP), 's-Gravenhage, mei 1986, blz. 16.

Zie ook een bijlage bij de kamerstukken: Internationale vergelijking van de marginale tarieven van de inkomstenbelasting. Tweede Kamer, vergaderjaar 1986-1987, 19 567, nrs. 4-5, bijlage 7, blz. 70 (kabinetsstandpunt) en no 7, blz. 10. Handelingen Tweede Kamer, vergaderjaar 19861987, 19 567, UCV, blz. 63-26, mk en blz. 63-43, rk. Zie L. Koopmans c.s., t.a.p., blz. 194 en 195.

8. Tweede Kamer, vergaderjaar 1984-1985, 18600 hoofdstuk IXB, no 39 (motie-Vermeend).

9. D66-kamerlid Engwirda had eerder een soortgelijke motie als de uitgebreide motie-Vermeend ingediend, maar deze werd destijds niet ondersteund (Tweede Kamer, vergaderjaar 1984-1985, 18600 hoofdstuk IXB, no 43). Tweede Kamer, vergaderjaar 1984-1985, 18600 hoofdstuk IXB, no 63 , blz. 2.

10. De redenen moeten worden gezocht in de ingewikkeldere en ondoorzichtigere geworden wetgeving op het terrein van de loon- en de inkomstenbelasting en de premieheffing volksverzekeringen, in het feit dat veel belastingplichtigen niet of nauwelijks hun aangiftebiljet kunnen invullen en er geen optimale afstemming van het inkomensbegrip is in de belasting- en premiewetgeving. Tweede Kamer, vergaderjaar 1984-1985, 18600 hoofdstuk IXB, no 39.

11. De commissie zou niet alleen belast worden tot het doen van voorstellen voor één inkonensbegrip voor de loon- en inkomstenbelasting. Ook zou volgens Vermeend aan de commissie kunnen worden opgedragen:

'- een inventarisatie van de kritiek op de bestaande heffingen naar inkomen (de complexiteit; aftrekposten), en op het inkomensbegrip zelf (de bruikbaarheid; de veelheid van begrippen); zulks tegen de achtergrond van een mogelijke integratie van de heffingen loon-en inkomstenbelasting en premies AOW/AWW in de vorm van één tarief; 
De Grave (VVD) en Engwirda (D66) stelden zich uitdrukkelijk achter de motieVermeend op. ${ }^{12}$ Woltjer (CDA) was het eens met de vereenvoudigingsgedachte, maar niet met het voorgestelde instrument, de instelling van een commissie. ${ }^{13}$ De toenmalige staatssecretaris van Financiën, Koning, maakte de opmerking: 'Wat de Kamer (meerderheid) precies wil dient wel goed vast te staan. ${ }^{14}$

De ministerraad is uiteindelijk akkoord gegaan met de instelling van een vereenvoudigingscommissie. ${ }^{15}$

Op 20 september 1985 is de commissie-Oort geïnstalleerd. ${ }^{16}$ Uit enige citaten uit de installatierede van Koning blijkt dat de wens tot vereenvoudiging aanwezig was:

1. 'Dat er alle aanleiding is voor het uitvoeren van een studie naar de mogelijkheden van vereenvoudiging van de loon- en inkomstenbelasting zal u duidelijk zijn. Allerwegen verheffen zich stemmen ...'

2. '... 'voor de kast zal gaan werken'. Ik acht dat gevaar gering, al was het alleen al omdat de instelling van deze commissie berust op een vrijwel kamerbrede wens daartoe en ook de samenstelling van de commissie in belangrijke mate uit die hoek is beïnvloed.'

3. 'Daarmee, kan naar ik verwacht, worden bereikt, dat de vereenvoudiging van de loon- en inkomstenbelasting op een zodanige wijze ter hand wordt genomen, dat verschillen in politieke visie wellicht zullen kunnen worden geëgaliseerd. ${ }^{17}$

- onderzock naar de mogelijkheden tot verbreding van het inkomensbegrip, dat wil zeggen een ruimere opzet van de grondslag;

- onderzoek naar de budgettaire en verdelings-(inkomens-)effecten van een geïntegreerd tarief, waarbij wat betreft het tweede aspect gebruik zou kunnen worden gemaakt van het door het Sociaal Cultureel Planbureau ontwikkelde micromodel op simulatiebasis;

- onderzoek naar de mogelijkheden die het automatiseringsproces bij de belastingdienst biedt tot vereenvoudiging van de belastingheffing.' Tweede Kamer, vergaderjaar 1984-1985, 18600 hoofdstuk IXB, no 63, blz. 1. Een soortgelijke mening is De Grave (VVD) toegedaan. Tweede Kamer, vergaderjaar 1984-1985, 18600 hoofdstuk IXB, no 63, blz. 2.

Het D66-lid Engwirda spreekt van een goede stap in de richting van een grondige vereenvoudiging van het belastingstelsel. Tweede Kamer, vergaderjaar 1984-1985, 18600 hoofdstuk IXB, no 63 , blz. 2.

12. Tweede Kamer, vergaderjaar 1984-1985, 18600 hoofdstuk IXB, no 63, blz. 1 en 2.

13. Tweede Kamer, vergaderjaar 1984-1985, 18600 hoofdstuk IXB, no 63, blz. 3.

14. Tweede Kamer, vergaderjaar 1984-1985, 18600 hoofdstuk IXB, no 63, blz. 3.

15. Staatscourant 4 mei 1985, no 86 . Tweede Kamer, vergaderjaar 1984-1985, 18600 hoofdstuk IXB, no 65 (brief van staatssecretaris van Financiën, Koning).

16. Staatscourant 25 september 1985 , no 186 , blz. 3.

17. Grapperhaus legt het egaliseren van verschillen in politieke visie uit als het sluiten van politieke compromissen. F.H.M. Grapperhaus, Column, Weekblad voor fiscaal recht, 1985, no 5705, blz. 1506. 
4. 'Deze bereidheid tot een gezamenlijke aanpak is heel duidelijk aanwezig, zoals onder meer is gebleken uit het overleg met de Vaste Commissie voor Financiën uit de Tweede Kamer. ${ }^{18}$

Overigens is Koning van mening dat de installatierede van de in 1948 ingestelde vereenvoudigingscommissie door de toenmalige minister van Financiën, Lieftinck, ook bij de installatie van de commissie-Oort had kunnen worden uitgesproken. De voorzitter van de commissie, Oort, spreekt zich bij de installatie van de commissie aldus uit over de wens tot vereenvoudiging:

1. 'Drukverlichting en vereenvoudiging zijn vrijwel algemeen gevoelde wensen.'

2. 'De commissie voelt zich echter gesteund door uw duidelijke opdracht, die gedragen wordt door alle grote politieke partijen en door een algemeen in de maatschappij levend onbehagen met de huidige situatie. ${ }^{19}$

De toenmalige minister van Financiën, Ruding, spreekt van een vergroting van de rechtvaardigheid en de daarmee samenhangende acceptatie in de maatschappij. $^{20}$

18. Staatscourant 25 september 1985 , no 186 , blz. 3. 'Politieke druk' is volgens de staatssecretaris een belangrijke factor voor de mate van de ingewikkeldheid. 'Wij kunnen er namelijk niet aan voorbijgaan dat de ingewikkeldheid van de wetgeving mede door politieke druk wordt veroorzaakt.' Staatscourant 25 september 1985 , no 186 , blz. 3 .

19. Voorzitter Oort in zijn rede bij de installatie van de commissie, Staatscourant 25 september 1985, no 186, blz. 3. Zie ook het dagblad De Gelderlander, 25 februari 1989. Interview met C.J. Oort over het rapport-Oort: 'Om een unaniem advies, gedragen door vertegenwoordigers van de drie grote partijen, kan men moeilijk heen. In de Kamer is ook herhaalde malen op dat unanieme voorstel gewezen. Daarom heeft de politiek er ook geen gaten in geschoten.'

Interessant met betrekking tot de wens tot vereenvoudiging is $\infty$ ketgeen Grapperhaus stelt: 'Een gelegenheidscombinatie van VVD en PvdA in de personen van de Tweede Kamerleden mr. F.H. de Grave en dr. W.A. Vermeend slaagde er dit voorjaar in een flink tegenstribbelende staatssecretaris Koning te dwingen tot de instelling van een commissie voor vereenvoudiging van de inkomstenbelasting.' De staatssecretaris was blijkbaar tegen, maar ging overstag. Het CDA was ook geen voorstander, maar ging toch met het initiatief mee omdat anders handelen politiek onverstandig zou zijn geweest. F.H.M. Grapperhaus, t.a.p., blz. 1505. Een tweede citaat van Grapperhaus: '... fiscaal Nederland heeft zo vaak en in zo indringende bewoordingen ach en wee geroepen over het fiscale stelsel, inzonderheid dat van de inkomstenbelasting, dat elke poging daarin verbetering te brengen op waardering en ondersteuning moet kunnen rekenen.' F.H.M. Grapperhaus, t.a.p., blz. 1506.

Het CDA is voor eenvoud en wel om de volgende redenen: '1. eenvoud geeft inzicht; 2 . eenvoud dient de waarheid; 3 . iedereen met een inkomen binnen de lange eerste schijf, weet waaraan hij toe is; 4. de loonbelasting is in een groot aantal gevallen eindheffing; 5 . de inkomens worden onderling beter vergelijkbaar.' Handelingen Tweede Kamer, vergaderjaar 1986-1987, 19 567, blz. 63-2, mk en rk en blz. 63-3, lk.

20. Handelingen Tweede Kamer, vergaderjaar 1986-1987, 19 567, UCV, blz. 63-42, lk. De maatschappelijke aanvaardbaarheid is een belangrijke toetsing. Tweede Kamer, vergaderjaar 19861987, 19 567, no 3, blz. 7. L.G.M. Stevens stelt dat de unanimiteit en de algemene waardering die voor de rapportage van de commissie-Oort tot uitdrukking zijn gebracht, een belangrijke aanwijzing vormen voor de aanvaarding door grote groepen van de samenleving. Tweede Kamer, vergaderjaar 1986-1987, 19 567, no 3, blz. 42. Zo wordt de keuze voor vereenvoudiging toegejuicht door de Federatie van verenigingen voor inspecteurs en adjunct-inspecteurs van rijksbelastingen, de Nederlandse orde van belastingadviseurs, de Nederlandse federatie van belastingconsulenten en de Raad van de centrale ondernemingsorganisaties. Tweede Kamer, vergaderjaar 1986-1987, 19 567, no 3, blz. 4, 7 en 12. De Raad voor het midden- en kleinbedrijf 
Interessant is nog de opmerking van Kombrink (PvdA, kamerlid): 'Mijn fractie constateert een niet gemakkelijk hanteerbare spanning tussen het waarmaken van onze eigen politieke verantwoordelijkheid enerzijds en het besef dat een zeer ingrijpende tijdrovende vereenvoudigingsoperatie gemakkelijk mislukt als daarover niet een zekere consensus is te voeren tussen de politieke hoofdstromingen in dit land. Dit geldt temeer, nu door de Kamer het initiatief is genomen. Al bij de instelling van de commissie-Oort pleitten wij daarom voor het hanteren van twee centrale uitgangspunten. Ten eerste het betrachten - binnen zekere marges - van inkomenspolitieke neutraliteit per inkomensgroep. Dat wil zeggen: vermijden dat de vereenvoudiging vermengt raakt met politieke controverses over de inkomensherverdeling in nivellerende of denivellerende zin .... Ten tweede moest budgettaire neutraliteit worden nagestreefd. ${ }^{21}$ Hier worden twee randvoorwaarden genoemd voor het slagen van de vereenvoudigingsoperatie. Politieke controverses en budgettaire overwegingen kunnen het proces gemakkelijk verstoren; dit moet, hoe moeilijk het ook is, worden vermeden.

$\mathrm{Na}$ de commissie-Oort is nog een commissie ter vereenvoudiging ingesteld, de commissie-Stevens ${ }^{22}$. Daar slechts enige voorstellen gedaan door deze commissie door de regering zijn overgenomen en uitgevoerd, valt het rapport van deze commissie buiten het kader van het onderzoek. ${ }^{23}$ Maar voor de beantwoording van de vraag of de wens tot vereenvoudiging aanwezig is, is de instelling van deze commissie wel degelijk van belang. Blijkens het volgende citaat uit de installatie-rede van de toenmalige staatssecretaris van Financiën, Koning, kan worden geconstateerd dat de wens tot vereenvoudiging ook in 1990 aanwezig is. 'Met de belastingherziening van 1990 is een eerste noodzakelijke en fundamentele stap gezet in de richting van het begeerde einddoel. ${ }^{24}$

spreekt van een worsteling met de noodzaak tot vereenvoudiging. Tweede Kamer, vergaderjaar 1986-1987, 19 567, no 3, blz. 28. Belastingdeskundigen roepen dat indien nu (1987, MW) niet wordt vereenvoudigd, men het jaren kan vergeten. Tweede Kamer vergaderjaar 1987-1988, 19 567, no 10, blz. 4 en Handelingen Tweede Kamer, vergaderjaar 1986-1987, 19567, UCV, blz. 63$61,1 \mathrm{k}$.

21. Handelingen Tweede Kamer, vergaderjaar 1986-1987, 19 567, UCV, blz. 63-11, lk en mk. De Sociaal-Economische Raad twijfelt aan de neutraliteit van de voorstellen van de commissieOort. Advies belastingvereenvoudiging, Sociaal-Economische Raad, 87/17, 16 oktober 1987, blz. 42.

22. De commissie-Stevens bestaat uit de volgende leden: W.F.C. Stevens (voorzitter), C.W.M. van Ballegooijen, J.C.K.W. Bartel, H.J. Hofstra, C.A. de Kam, E.J.J.E. van Leeuwen-Schut, A. Overbosch, H. Smit, G. Zoutendijk.

23. $\mathrm{Er}$ is geen regeringsstandpunt ingenomen inzake de voorstellen van de commissie-Stevens. Op hoofdlijnen worden de voorstellen van de commissie gevolgd, waarbij onder andere een relatie wordt gelegd met de fiscale concurrentiepositie en het milieu. Bij de hoofdlijnen moet worden gedacht aan de verlaging van tarieven, het wijzigen van de schijflengtes, de heffingskortingen en een eventuele afschaffing van de overhevelingstoeslag in combinatie met de brutering van lonen. Tweede Kamer, vergaderjaar 1992-1993, 22 800, no 3, antwoorden op de vragen 62 en 63. Zie voor de afschaffing van de overhevelingstoeslag, Stb. 1993, 743.

24. Met dat einddoel wordt aanpassing in de fiscale regelgeving bedoeld. Staatscourant 5 april 1990, no 68 , blz. 7. 
Een andere aanwijzing dat de wens tot vereenvoudiging aanwezig is geweest, is artikel 2 van het instellingsbesluit van de commissie-Stevens: '... advies uit brengen over verdere vereenvoudiging en verbreding van het draagvlak van de loon- en inkomstenbelasting en ter stroomlijning van de belasting op de ondernemingswinst. ${ }^{25}$ In een bijlage van het instellingsbesluit staat een passage van het Regeerakkoord betrekking hebbende op de vereenvoudiging: 'Daarom zal een Commissie worden ingesteld, die tot taak krijgt advies uit te brengen over verdere vereenvoudiging en verbreding van het draagvlak van de loon- en inkomstenbelasting .... ${ }^{26}$ Uit het woord verder leid ik af dat het hier gaat om een op de commissie-Oort voortbouwende commissie. ${ }^{27}$

Uit het rapport van de commissie-Stevens, 'Graag of niet' blijkt ook dat deze commissie als een voortzetting van de commissie-Oort moet worden gezien. Enige citaten ter illustratie: 'Deze commissie treedt met die vereenvoudigingsopdracht in de voetsporen van de commissie Oort. ${ }^{28}$ en 'Ik zie als einddoel, globaal omschreven, een fiscaal systeem, en dan met name in de loonbelasting, de inkomstenbelasting, en de vennootschapsbelasting, waarvan eenvoud en maatschappelijk aanvaarde tarieven de hoofdkenmerken zijn. ${ }^{29}$

Duidelijk wordt dat de wens tot vereenvoudiging door een grote kamermeerderheid wordt gedragen. ${ }^{30}$ Blijkbaar is de wens tot vereenvoudiging aanwezig. Thans kom ik toe aan de beantwoording van de tweede vraag. Wat moet in casu onder vereenvoudiging worden verstaan en in hoeverre moet de loon- en inkomstenbelasting worden vereenvoudigd?

25. Staatscourant 4 april 1990 , no 67 , blz. 11.

26. Bijlage Paragraaf 1, punt 24 van het Regeerakkoord (Tweede Kamer, vergaderjaar 1989-1990, 21 132, no 9, blz. 13 en 14). Zie Staatscourant 4 april 1990, no 67, blz. 11.

27. Van Arendonk c.s. spreekt over een boven het hoofd groeien van de ingewikkeldheid. Deswege werd een commissie ingesteld. H.P.A.M. van Arendonk, L.M.G. Stevens, P. Kavelaars, Eenvoud in praktijk, OORT-wetgeving, 1991, blz. 13.

28. Graag of niet, Rapport van de Commissie voor Belastingherziening, Sdu, 1991, blz. 13.

29. Voorzitter Stevens in zijn rede bij de installatie van de commissic, Staatscourant 4 april 1990, no 67, blz. 8.

30. Dit blijkt ook uit de kamerstukken betreffende de openbare hoorzitting over de voorstellen van de commissie-Oort:

1. 'Het belang van een vereenvoudiging van het belastingstelsel wordt alom erkend.' Tweede Kamer, vergaderjaar 1986-1987, 19 576, nrs. 4-5, blz. 4 (kabinetsstandpunt). Zie ook Tweede Kamer, vergaderjaar 1986-1987, 19 567, nrs. 4-5, blz. 31 (kabinetsstandpunt).

2. 'Er was voldoende politieke steun voor een kabinetsvoorstel te verwachten, want de roep om vereenvoudiging onder politici was algemeen.' Van Amelsvoort, CDA, kamerlid, Handelingen Tweede Kamer, vergaderjaar 1986-1987, 19 567, UCV, blz. 63-2, lk.

3. 'Die zeer brede kamermeerderheid liet in de loop van 1985 merken dat zij nu werkelijk wilde komen tot een fundamentele vereenvoudiging van de loon- en inkomstenbelasting.' Engwirda, D66, kamerlid, Handelingen Tweede kamer, vergaderjaar 1986-1987, 19 567, UCV, blz. 63-33, 1k. Zie ook Handelingen Tweede Kamer, vergaderjaar 1986-1987, 19567 , UCV blz. 63-41, rk en blz. $63-50,1 \mathrm{k}$. 
De wens tot vereenvoudiging is aanwezig, maar is er ook consensus over de inhoud van het begrip vereenvoudiging?

De geschiedenis van de instelling van de commissie zal wederom uitkomst moeten bieden. Met betrekking tot het begrip vereenvoudiging kan een onderscheid worden gemaakt tussen vereenvoudiging op abstract niveau en vereenvoudiging op concreet niveau. ${ }^{31}$ Duidelijk is dat ten aanzien van vereenvoudiging op abstract niveau een grotere consensus aanwezig zal zijn dan ten aanzien van vereenvoudiging op concreet niveau.

Opmerkingen gemaakt over vereenvoudiging op abstract niveau zijn de volgende. Voormalig staatssecretaris Koning refereert aan de installatietoespraak van de in 1948 door Lieftinck ingestelde vereenvoudigingscommissie. Lieftinck maakte een onderscheid tussen nodeloze ingewikkeldheid en de ingewikkeldheid die het gevolg is van financiële, economische en sociale eisen van de belastingheffing. Aan dit laatste element mag volgens Koning door de commissie niet stilzwijgend worden voorbijgegaan. Indien de laatstgenoemde ingewikkeldheid weggenomen dient te worden, betekent dat een grondige herziening van de belastingheffing.

Voorzitter Oort: 'Evenmin kunnen u en wij genoegen nemen met een beperkt aantal voorstellen tot incidentele vereenvoudigingen, die weliswaar op zichzelf genomen zinvol kunnen zijn, doch geen wezenlijke bijdrage leveren tot een meer rationeel en doorzichtig heffingenstelsel. ${ }^{32}$

Grapperhaus spreekt van een toetsing van de vereenvoudigingswaarde aan de hand van twee criteria. Dat wil zeggen, ten eerste of het voorstel een bijdrage vormt aan meer zuiverheid in de inkomstenbelasting, met name tot het inkomensbegrip, en, ten tweede, of het voorstel een bijdrage vormt aan de vermindering van de administratieve werkzaamheden. ${ }^{33}$

Indien de Raad van State de vereenvoudiging toetst, vraagt deze zich af welke vereenvoudigingen worden bereikt en wie met name de vruchten plukken van deze vereenvoudigingen. Bovendien wordt gekeken naar de prijs die voor de vereenvoudigingen moet worden betaald. ${ }^{34}$

31. Van Ameisvoort, CDA, kamerlid, verwoordt het aldus: 'Of omdat zij bang waren dat de politici weliswaar eenstemmig waren in hun roep om vereenvoudiging in abstracto, maar dat er allerminst eenstemmigheid over een voorstel in concreto te verwachten viel.' Handelingen Tweede Kamer, vergaderjaar 1986-1987, 19 567, UCV, blz. 63-2, lk.

32. Voorzitter Oort in zijn rede bij de installatie van de commissie, Staatscourant 25 september 1985 , no 186, blz. 3.

33. Tweede Kamer, vergaderjaar 1986-1987, 19 567, no 3, blz. 50.

34. Tweede Kamer, vergaderjaar 1987-1988, 20 595, B, blz. 2 en 3. De Raad van State twijfelt ten zeerste of voor de belastingplichtigen en voor de inhoudingsplichtigen de beoogde vereenvoudiging wordt bereikt. Tweede Kamer, vergaderjaar 1987-1988, 20 595, B, blz. 9-12.

De SER verstaat onder vereenvoudiging: meer inzichtelijkheid voor de burger en een grotere mate van uitvoerbaarheid voor inhoudingsplichtigen en de belastingdienst. Advies belastingvereenvoudiging, SER, nr. 87/17, 1987, blz. 117. 
Over vereenvoudiging op concreet niveau zijn de volgende opmerkingen gemaakt. De regering verstaat onder vereenvoudiging het afschaffen van vrijwel alle toeslagen voor de heffingsplichtigen, inhoudingsplichtigen en de belastingdienst. $^{35}$ Bovendien is het terugdringen van het aantal aanslagen inkomstenbelasting en premieheffing een bijdrage aan het streven naar vereenvoudiging. ${ }^{36}$

Geconcludeerd kan worden dat enerzijds de belastingheffing betreffende de inkomstenbelasting eenvoudiger moet worden, en dat anderzijds gestreefd wordt naar een vermindering van de administratieve lasten door het aangiftebiljet te vereenvoudigen en het aantal aangiftebiljetten te verminderen. Dit betekent dat de wetgeving aangepast moet worden. Naar mijn mening hangt de vereenvoudiging van het aangiftebiljet samen met de vereenvoudiging van de belastingheffing. Een vereenvoudiging van het aangiftebiljet kan niet geheel zonder vereenvoudiging van de belastingheffing.

\section{Rapport en wetgeving}

In mei 1986 verschijnt het rapport van de commissie-Oort, getiteld 'Zicht op eenvoud ${ }^{37}$. Zoals de titel al doet vermoeden, houdt het rapport enige vereenvoudigingsvoorstellen in. In de Wet IB 1964 zijn inmiddels zo veel gedetailleerde elementen ingeslopen, dat de vraag rijst of nog sprake is van een goed wetgevingsprodukt. Immers een goed wetgevingsprodukt impliceert dat de wetgeving duidelijk en begrijpelijk is. Een goed wetgevingsprodukt verhoogt de maatschappelijke aanvaarding. ${ }^{38}$ Een hoog gehalte van de maatschappelijke aanvaarding

35. Tweede Kamer, vergaderjaar 1986-1987, 19 S67, nrs. 4-5, blz. 15 (kabinetsstandpunt).

36. Tweede Kamer, vergaderjaar 1986-1987, 19 567, nrs. 4-5, blz. 18 (kabinetsstandpunt).

37. De commissie-Oort zou, gezien haar opdracht, tevens een eindrapport moeten uitbrengen, maar ziet daar om de volgende redenen vanaf. De eerste reden is dat wetteksten, administratieve bepalingen, uitvoeringsvoorschriften en het aangifteformulier op het terrein van regelgeving en uitvoering liggen. De tweede reden is dat een enigszins verantwoorde analyse van de vraagstukken, die een fundamentele herbezinning op de grondslagen van het belastingstelsel vereist, een (te) groot tijdsbeslag kent. De fundamentele herbezinning heeft onder andere betrekking op het fiscale inkomens- en vermogensbegrip en de draagkracht. Een dergelijke taak is onuitvoerbaar, aldus de commissie. Zicht op eenvoud, t.a.p., blz. 12 en 13. Zie ook de aanbiedingsbrief van het rapport door de commissie-Oort aan de minister van Financiën en de staatssecretaris van Financiën, Zicht op eenvoud, t.a.p., bijlage 2, blz. 150.

De commissie wordt op 30 mei 1986 van haar opdracht ontslagen. Tweede Kamer, vergaderjaar 1985-1986, 19 567, no 1, blz. 1.

Zie ook de SER. 'Daarbij onderkent de Raad, met het kabinet en de commissie-Oort, dat het streven naar vereenvoudiging niet op zich zelf kan staan, maar dient te zijn ingebed in doelstellingen en beginselen van de belasting-en premiewetgeving, waarbij de heffing naar draagkracht als instrument van verdelende rechtvaardigheid een belangrijke plaats inneemt.' '... en dat de roep om eenvoud en de roep om verfijning en precisering gelijktijdig zijn te beluisteren en met elkaar in harmonie zullen moeten worden gebracht.' Advies belastingvereenvoudiging, SER, t.a.p., blz. 115.

38. Zie H.P.A.M. van Arendonk, die de term 'maatschappelijke aanvaardbaarheid' als een voorwaarde van de regering beschrijft om een wetsvoorstel aan te nemen. Op zichzelf staand is dat een juiste eis, maar onder 'maatschappelijke aanvaardbaarheid' wordt de goedkeuring van de sociale partners verstaan. Met Van Arendonk ben ik het eens dat deze definitie te beperkt is. 
heeft een gunstige werking op de hoogte van de uitvoeringskosten; en hiermee is de cirkel rond.

In 1989 komt uiteindelijk de vereenvoudiging in OORT-I $\mathrm{I}^{39}$ tot stand. Deze moet echter gefinancierd worden. OORT-I blijft daardoor niet het enige wetgevingsprodukt dat in het kader van deze operatie wordt vervaardigd. Door middel van OORT-II en OORT-III ${ }^{40}$ wordt de vereenvoudigingsoperatie mogelijk gemaakt. Het verbinden van de naam 'OORT' aan deze wetgeving is niet helemaal terecht en werkt verwarrend. ${ }^{41}$ De inhoud van deze nadere wetgevingsprodukten betreft kort gezegd de beperking van de aftrekbaarheid van gemengde kosten, zowel in de prive-sfeer als in de ondernemingssfeer. Het paradoxale van de gehele vereenvoudigingsoperatie is dat het hier gaat om bijzonder gedetailleerde regelingen. De algemene kritiek is dat het stelsel van de belastingheffing in het geheel niet wordt vereenvoudigd. ${ }^{42}$ Twijfel rijst over de vraag of nog sprake is van een positieve opbrengst van de vereenvoudigingsoperatie.

In dit hoofdstuk bespreek ik het rapport 'Zicht op eenvoud' van de commissieOort en OORT-I aan de hand van de nader te vermelden beginselen.

Door de nadruk die ligt op het aspect van vereenvoudiging, wordt duidelijk dat in de OORT-wetgeving een nieuw evenwicht moet worden gevonden tussen de rechtvaardigheid en de doelmatigheid. ${ }^{43}$ Interessant is de vraag hoe, en in hoeverre, de (verdelings)beginselen in deze wetgeving tot uiting komen. Belangrijk hierbij is in hoeverre budgettaire overwegingen en pressiegroepen een rol van betekenis spelen. ${ }^{44}$

De vereenvoudigingsoperatie heeft ook consequenties gehad voor de Tweeverdienerswetgeving. De significante verschillen met betrekking tot de in hoofdstuk 3

H.P.A.M. van Arendonk, OORT-I en OORT-II, Maandblad Belastingbeschouwingen, 1988, no 9, blz. 222 en 224.

39. Het wetsvoorstel OORT-I (Wetsvoorstel vereenvoudiging tariefstructuur in de loon- en inkomstenbelasting) is op 17 juni 1988 ingediend.

40. Op 10 oktober 1988 is OORT-II (Wetsvoorstel invoering en aanvulling van de vereenvoudiging van de tariefstructuur in de loon-en inkomstenbelasting en wijziging van de regeling betreffende aftrekposten) ingediend. OORT-III (Wetsvoorstel beperking van de aftrekbaarheid van gemengde kosten in de winstsfeer) is eveneens op 10 oktober 1988 ingediend.

41. L.G.M. Stevens prefereert te spreken van Koning-I in plaats van OORT-II.

42. Onder andere Stevens verwoordt het resultaat van de vereenvoudigingswetgeving aldus: 'Het zou echter een illusie zijn te denken dat daardoor (het invoeren van de vereenvoudigingswetgeving, MW) de inkomstenbelasting ècht eenvoudiger is geworden.' L.G.M. Stevens, Elementair belastingrecht voor economen en bedrijfsfiscalisten, 11e herziene druk, Kluwer, 1993, blz. 108.

43. Grapperhaus vertaalt het als volgt: '... worden vertaald voor de belastingheffer: rekening houdend met zijn schaarse middelen en met de noodzaak die economisch, effectief en efficiënt aan te wenden, moet hij een antwoord geven op de vraag van de vereenvoudiging van de belastingwetgeving tegenover de rechtvaardigheid die eist dat met relevante verschillen rekening wordt gehouden en voorts tegenover de introductie in het fiscale recht van niet-fiscale doeleinden.' F.H.M. Grapperhaus, Vereenvoudiging van de belastingheffing een vraagstuk voor managers, Weekblad voor fiscaal recht, 1986, no 5750, blz. 1436.

44. Zie voor de druk van de pressiegroepen bij de volksvertegenwoordigers onder andere C.A. de Kam, Big rat is eating you!, Weekblad voor fiscaal recht, 1986, no 5750, blz. 1463 en 1464. 
behandelde materie worden weergegeven. In het algemeen kan er geen eenduidige conclusie worden getrokken dat de voorstellen van de commissie-Oort de effecten van de Tweeverdienerswetgeving versterken dan wel verzwakken. ${ }^{45}$

\subsection{De commissie-Oort}

De commissie-Oort heeft in haar rapport 'Zicht op eenvoud' een aantal suggesties betreffende de vereenvoudiging gedaan. In het navolgende maak ik een onderscheid tussen algemene opmerkingen, concrete voorstellen van de commissie-Oort enerzijds, en opmerkingen met betrekking tot het draagkrachtbeginsel, het gelijkheidsbeginsel, de doelmatigheid en het vereenvoudigingsstreven anderzijds. $^{46}$

\subsubsection{Algemene opmerkingen}

De belastingheffing heeft tot voornaamste doel middelen te verzamelen ter dekking van de overheidsuitgaven. Daarnaast wordt de belastingheffing ook ter bevordering van andere doeleinden, de zgn. nevendoeleinden, gebruikt. Door het gebruik van nevendoeleinden in de belastingheffing wordt de mate van complexiteit van de belastingwetgeving vanzelfsprekend groter ${ }^{47} \mathrm{Na}$ verloop van tijd is duidelijk geworden dat het gebruik van de belastingheffing als instrument ter realisering van nevendoeleinden niet zo geschikt is als door de beleidsmakers aanvankelijk werd gedacht. ${ }^{48}$

Een effect van een ingewikkelde belastingheffing kan zijn, dat een ongelijke behandeling van belastingplichtigen optreedt. ${ }^{49} \mathrm{De}$ belastingheffing kan zo ingewikkeld worden dat een miniem verschil in de positie van belastingplichtigen leidt tot een groot verschil in fiscale behandeling.

Bovendien kunnen belastingplichtigen met een hoog inkomen zich gemakkelijker deskundige hulp veroorloven voor het invullen van het aangiftebiljet en voor het inrichten van een verstandige (tax-)planning van hun handelen dan belastingplichtigen met een laag inkomen. Hierdoor kunnen belastingplichtigen met een hoog inkomen gemakkelijker hun belastingverplichtingen verkleinen; zij betalen derhalve in verhouding minder belasting dan belastingplichtigen met een laag inkomen. Uiteindelijk ontstaat een ongelijkheid in de betalingsverplichtingen.

45. Tweede Kamer, vergaderjaar 1986-1987, 19 567, nrs. 4-5, blz. 33 (kabinetsstandpunt).

46. De commissie-Oort gaat nauwelijks in op mogelijke sociaal-economische gevolgen. Advies belastingvereenvoudiging, SER, t.a.p., blz. 41.

47. De commissie-Oort: 'Daarnaast is de wetgeving echter ingewikkelder geworden doordat de overheid steeds meer nevendoeleinden (mede) met fiscale maatregelen wilde verwezenlijken. Het gaat daarbij om nevendoeleinden op het economische, maatschappelijke en inkomenspolitieke vlak.' Zicht op eenvoud, t.a.p., blz. 16.

48. Eerste Kamer, vergaderjaar 1988-1989, 20 595, no 131a, blz. 3.

49. Zicht op eenvoud, t.a.p., blz. 16. 
Zoals al duidelijk is geworden is de ingewikkeldheid van de regelgeving een van de voornaamste kritiekpunten die in de loop van de laatste decennia tegen de huidige belastingheffing zijn opgekomen. Twee andere kritiekpunten betreffen de uitvoeringsproblemen en de hoge tarieven..$^{50}$ Kortom, het is de hoogste tijd dat in die situatie verbetering wordt gebracht.

De commissie-Oort heeft opdracht te zoeken naar oplossingen voor deze problemen. In hoofdlijnen komt de commissie-Oort tot de volgende vier voorstellen:

'1. één vast tarief over een lang inkomenstraject;

2. samenvoeging van inkomstenbelasting en premies voor de volksverzekeringen;

3. loonbelasting zoveel mogelijk eindheffing;

4. stroomlijnen van aftrekposten- en andere vereenvoudigingsvoorstellen. ${ }^{51}$

De legitimatie van de commissie-Oort is gelegen in het feit dat in de Wet IB 1964 de rechtsverfijning ten koste van de doelmatigheid is gegaan. Derhalve dient in de voorstellen van de commissie-Oort een nieuw evenwicht te worden gevonden tussen de rechtvaardigheid en de doelmatigheid; aan de doelmatigheid (lees: o.a. eenvoud) moet een grotere betekenis dan voorheen worden toegekend. ${ }^{52}$

De rechtvaardigheid en de doelmatigheid spelen een grote rol bij het primaire doel van de belastingheffing, het verzamelen van middelen. Deze stelling lijkt een open deur te zijn, maar gezien het grote belang dat in deze operatie aan het streven naar vereenvoudiging wordt gehecht, is het niet overbodig melding te maken van de eisen van rechtvaardigheid en doelmatigheid. Immers vereenvoudiging moet tot een grotere doelmatigheid leiden. Een gegeven is dat het streven naar meer doelmatigheid ten koste kan gaan van de rechtvaardigheid. En andersom geldt de regel dat het streven naar meer rechtvaardigheid kan leiden tot een inbreuk op doelmatigheid. Sommige auteurs zijn een andere mening toegedaan. Hofstra is van mening dat doelmatige wetgeving tot rechtvaardige

50. Zicht op eenvoud, t.a.p., blz. 16.

51. Zicht op eenvoud, t.a.p., blz. 18.

52. Zie bij voorbeeld het verslag van de forumdiscussie dat op 24 oktober 1986 heeft plaatsgevonden. In deze discussie komt de vraag naar voren of de vraag in hoeverre de doelmatigheid de werking van de rechtvaardigheid kan beperken in abstracto kan worden beantwoord. Antwoord: nee, enkel vaag. Zie Verslag forumdiscussie, Weekblad voor fiscaal recht, 1986, no 5750, blz. 1473.

De Voorzitter van de commissie is van mening dat de balans de laatste jaren ten ongunste van de doelmatigheid is doorgeslagen en dat de politici een te grote werking toekennen aan de zgn. koopkrachtplaatjes. C.J. Oort, Belastinghervorming, Weekblad voor fiscaal recht, 1988, no 5808, blz. 151 en 152. C.J. Oort, Belastinghervorming, rede 5 februari 1988.

Ook de commissie-Stevens heeft vereenvoudiging hoog in haar vaandel staan. Daarnaast spelen verlaging van de tarieven van de loon-en inkomstenbelasting, en verbreding van de grondslag (de zgn. drie v's) een belangrijke rol. Rapport commissie-Stevens, Graag of niet, t.a.p., blz. 13. L.G.M. Stevens zou hieraan graag een vierde ' $v$ ' toevoegen, $n$ l. de ' $v$ ' van verloedering. Het draagkrachtbeginsel wordt meer en meer geweld aangedaan. Zie verslag van het congres Rapport commissie Stevens, 4 juli 1991, Kluwer, blz. 8. 
wetgeving leidt. Hier wordt een samenhangend verband geconstateerd. ${ }^{53}$ Een kanttekening zou ik hierbij willen maken.

Onder rechtvaardigheid versta ik iets anders dan Hofstra. Rechtvaardigheid kan mijn inziens doelmatigheid impliceren, maar omvat tevens een restcategorie. Doelmatigheid ziet op uitvoeringstechnische zaken. Het is mogelijk dat de rechtvaardigheid wordt bevorderd, maar dat hoeft niet. Integendeel een grote doelmatigheid kan een grote onrechtvaardigheid voor vele belastingplichtigen met zich brengen. Met andere woorden, rechtvaardigheid omvat meer dan alleen doelmatigheid. Ter illustratie: de invoering van de alleenstaandetoeslag wordt rechtvaardig, doch niet doelmatig geoordeeld.

Opmerkelijk is hetgeen de commissie-Oort stelt ten aanzien van haar opdracht. De commissie-Oort heeft alleen maar vereenvoudigingen aangebracht in het huidige stelsel, ongeacht de vraag of het huidige stelsel rechtvaardig is of niet. ${ }^{54}$ De commissie-Oort is van mening dat heroverwegingen van de grondslagen van het stelsel, van de rechtvaardiging van de wijze van uitwerken en van ongewenste nevengevolgen niet aan de orde komen. . $^{s s}$

$\mathrm{Bij}$ het lezen van het voorgaande ontkomt men niet aan de indruk dat er een tegenstelling is. Mijns inziens is het bij een vereenvoudigingsoperatie evident dat de voorstellen gevolgen zullen hebben voor de werking van de grondslagen van het belastingstelsel, de rechtvaardiging van de wijze van uitwerken en de ongewenste nevengevolgen. Wijzigingen ten opzichte van de doelmatigheid hebben gevolgen voor de rechtvaardigheid. Het is dan ook geen toeval dat in een naar

53. H.J. Hofstra stelt dat 'Goed recht is recht dat doelmatig is, dat kan werken'. Verslag forumdiscussie, Weekblad voor fiscaal recht, 1986, no 5750, blz. 1473. 'De eisen van doelmatigheid kunnen de wetgever daarom tot inbreuken op de rechtvaardigheid noodzaken.' H.J. Hofstra, Van recht naar wet, Scheltens-bundel Van wet naar recht, Kluwer, 1984, blz. 53. In de kamerstukken wordt daar over het algemeen anders gedacht. 'Dat is het dilemma: ofwel een rechtvaardige regeling die oncontroleerbaar is of een - ik wil niet zeggen onrechtvaardige, maar laat ik een zachte uitdrukking zoeken - 'weinig' rechtvaardige regeling die wel controleerbaar is.' Handelingen Tweede Kamer, vergaderjaar 1988-1989, 20 595, blz. 26-25, rk en 26-26, lk.

54. Verslag forumdiscussie, Weekblad voor fiscaal recht, 1986, no 5750, blz. 1474. Opmerkelijk in het verslag is ook de vermelding van de volgende opmerking van H.J. Hofstra: 'Zolang een duidelijke visie op de grondbeginselen en de structuren ontbreekt kan men niet spreken van een inbreuk op de rechtvaardigheid door maatregelen van vereenvoudiging die nodig zijn.' Verslag forumdiscussie, Weekblad voor fiscaal recht, 1986, no 5750, blz. 1473-1474.

De commissie-Oort gaat zelf voorbij aan de fundamentele, filosofische grondslagen van de belastingheffing. Tweede Kamer, vergaderjaar 1986-1987, 19 567, no 3, blz. 38. De voorzitter van de commissie-Oort is daarentegen wel van mening dat er een fundamentele herbezinning nodig is omtrent de grondslagen van de loonbelasting en de inkomstenbelasting. Een fundamentele herbezinning betreft ook de vraag naar de rechtvaardigheid.

55. Tweede Kamer, vergaderjaar 1987-1988, 20 595, no 3, bijlage 3, blz. 108. In de literatuur wordt desondanks over de grondslagen van de belastingheffing geschreven. Stevens verwoordt het aldus: 'Liever een wat hoger tariefpercentage en een als draagkrachtmaatstaf verantwoorde heffingsgrondslag dan een lager percentage en vergroving van de heffingsgrondslag.' L.G.M. Stevens, Benvoudig belasten is lastig, Weekblad voor fiscaal recht, 1988, no 5844, blz. 1409. Overigens hanteert de commissie-Oort een benedengrens van $\min 5$ en een bovengrens van plus 5\% koopkrachtverlies c.q. koopkrachtwinst. Zicht op eenvoud, t.a.p., blz. 19. 
aanleiding van het rapport van de commissie-Oort georganiseerd symposium, ondanks dat in het rapport geen specifieke aandacht is geschonken aan de grondslagen, toch een discussie over die grondslagen heeft plaatsgevonden. Deze discussie betrof voornamelijk het draagkrachtbeginsel; het werd onverteerbaar geacht dat een verschil wordt gemaakt tussen alleenstaanden en alleenverdieners, terwijl de twee groepen belastingplichtigen toch dezelfde draagkrachtgrondslag hebben. ${ }^{56}$ Het draagkrachtbeginsel wordt gezien als een principe waaraan moet worden vastgehouden. ${ }^{5}$

\subsubsection{Concrete voorstellen}

De commissie-Oort doet de volgende voorstellen (1986):

\section{Algemeen}

1. Uniformering van de grondslag.

De grondslag voor de Wet LB 1964 en de Wet IB 1964 wordt het premieinkomen plus de opslagpremies AWBZ, AKW en AAW ( = heffingsinkomen). Het heffingsinkomen is hoger dan het belastbaar inkomen. De premies voor volksverzekeringen zijn niet langer aftrekbaar. Deze niet-aftrekbaarheid vormt een inbreuk op de regel: premies niet aftrekbaar, uitkering onbelast; premies aftrekbaar, uitkering belast. Maar de commissie-Oort stelt dat de aftrekbaarheid min of meer is versleuteld in de concrete tariefstelling van de belasting en de premies samen. ${ }^{58}$

De drie opslagpremies komen ten laste van de werknemers c.q. ontvangers van uitkeringen. Er vindt een loonsverhoging plaats overeenkomstig de hoogte van de opslagpremies.

56. H. Kombrink, Verslag forumdiscussie, Weekblad voor fiscaal recht, 1986, no 5750, blz. 1478. Zie ook het Platform van organisaties voor alleenstaanden: In de alleenstaande-toeslag komt tot uitdrukking dat het voeren van een huishouding als een alleenstaande een factor is, die de draagkracht vermindert, zoals het onderhoud van een echtgenote $00 \mathrm{k}$ als een draagkrachtverminderende factor geldt. Tweede Kamer, vergaderjaar 1986-1987, 19 567, no 3, blz. 39.

57. De Grave, VVD, kamerlid: 'Als het gaat om uitgangspunten van ons belastingrecht, is het draagkrachtbegrip, het rechtvaardigheidsbegrip, een term die onder ons belastingrecht is geschoven, naast een aantal andere begrippen.' Tweede Kamer, vergaderjaar 1986-1987, 19567 , no 3, blz. 44. Zie ook Aardema, Tweede Kamer, vergaderjaar 1986-1987, 19 567, no 3, blz. 53.

58. Zicht op eenvoud, t.a.p., blz. 30.

59. De SER concludeert dat de voorstellen in het algemeen negatieve gevolgen hebben voor het functioneren van de arbeidsmarkt. Tegen de wens van de SER in leiden de overheveling en brutering tot een langer bruto-netto-traject. Bovendien leiden de voorstellen tot een verkleining van de netto-inkomensafstand tussen actieven en niet-actieven en een versterking van de progressie, althans voor de hogere inkomens. Advies belastingvereenvoudiging, SER, t.a.p., blz. 137. De Stichting van de Arbeid constateert dat de commissie-Oort de bruteringsoperatie te eenvoudig heeft voorgesteld. Advies belastingvereenvoudiging, SER, t.a.p., blz. B-75. De Stichting concludeert dat de commissie-Oort van een individuele brutering is uitgegaan en dat deze vorm van brutering tot een lastenverzwaring van de werkgevers leidt. Advies belastingvereenvoudiging, SER, t.a.p., blz. B-80 en B-83. 


\section{Tarief.}

Eén tarief zal er zijn voor de loonbelasting en de inkomstenbelasting. De combinatie van de belasting en premies tezamen is de inkomensheffing.

De commissie-Oort stelt twee tarieven voor. Het eerste bestaat uit vier schijven, met een toptarief van $70 \%$ en het tweede uit drie schijven, met een toptarief van $65 \% .^{60}$

Het variabele bijzondere tarief vervalt. Het vaste bijzondere tarief van $20 \%$ blijft. $^{61}$

\section{Basisaftrek.}

De toeslagen op de belastingvrije som vervallen. ${ }^{62} \mathrm{De}$ alleenstaande-oudertoeslag blijft gehandhaafd, maar in een andere vorm. De toeslag wordt in de sfeer van de buitengewone lasten geregeld. In plaats van de belastingvrije som komt een basisaftrek van $f 4.250 .^{63}$ Stevens, een commissielid: 'De basisaftrek mag onder bepaalde voorwaarden worden overgedragen tussen (on)gehuwde partners en vormt daarmee de enige vrijwillige inbreuk op het principe (een gelijke som voor iedereen), waarbij rekening wordt gehouden met de huishouddraagkracht. ${ }^{.64}$

60. Zicht op eenvoud, t.a.p., blz. 139. De commissie noemt twee voorstellen met betrekking tot het tarief.

1. vier schijven, met een toptarief van $70 \%$ (opbouw heffingspercentage: $40-55-65-70$ ).

2. drie schijven met een toptarief van 65\% (opbouw heffingspercentage: $40-55-65$ ).

Het heffingspercentage bestaat uit een belasting- en premiepercentage.

Het tweede voorstel heeft meer dan beperkte inkomensgevolgen tot gevolg. Zicht op eenvoud, t.a.p., blz. 40. Een deel van de SER stelt voor het toptarief te verlagen tot $60 \%$ in verband met de ontwikkeling in de omringende landen. Advies belastingvereenvoudiging, SER, t.a.p., biz. 146.

61. Zicht op eenvoud, t.a.p., blz. 103 en 143. Het variabele bijzonder tarief wordt vervangen door het $3 / 4$ belasten van de desbetreffende inkomsten tegen het gewone tarief. De commissieStevens stelt een tarief met twee schijven voor. Het tarief van de eerste schijf $(f 57.000)$ is $33,6 \%$ en het tarief van de tweede schijf is $55 \%$. Graag of niet, t.a.p., blz. 48. Oort stelt één belastingtarief voor met een percentage van 50. Zie NRC Handelsblad van 22 mei 1993, blz. 14. De SER heeft twijfels over de te behalen eenvoud. Advies belastingvereenvoudiging, SER, t.a.p., blz. 70.

62. Door het vervallen van de toeslagen, wordt de Tweeverdienersproblematiek teruggedraaid. W.F.C. Stevens, Zicht op eenvoud!, Weekblad voor fiscaal recht, 1986, no 5733, blz. 804.

De Emancipatieraad vindt de afschaffing van de toeslagen een goede stap in de richting van individualisering. Emancipatieraad, Advies eenvoud in de loon- en inkomstenbelasting, juni 1987, nr. II $/ 38 / 87$, blz. 8.

63. De alleenstaande-oudertoeslag wordt vervangen door een buitengewone-lastenaftrek van $f \mathbf{3 . 2 0 0}$.

De aanvullende alleenstaande-oudertoeslag wordt vervangen door een variabele buitengewone lastenaftrek van $6 \%$ van de netto arbeidsinkomsten met een maximum van $f 4.200$. Zicht op eenvoud, t.a.p., blz. 63 en 64. De inkomensgevolgen van de (aanvullende) alleenstaandeoudertoeslag komen boven de limiet van $5 \%$; extra compenserende maatregelen zijn nodig. Zicht op cenvoud, t.a.p., blz. 51. De qómmissie-Stevens stelt voor om deze toeslagen te laten vervallen. De alleenstaande ouder dient gelijkgesteld te worden met de alleenverdiener. Graag of niet, t.a.p., blz. 53.

De toerekening van inkomensbestanddelen van gehuwden blijft op dezelfde wijze gehandhaafd. Zicht op eenvoud, t.a.p., blz. 52.

64. W.F.C. Stevens, t.a.p., blz. 803. 
Overdracht van de gehele basisaftrek tussen gehuwden is mogelijk. ${ }^{65}$ Voor ongehuwd samenlevenden geldt een overeenkomstige regeling, mits voldaan is aan een aantal bijkomende voorwaarden, inhoudende dat de beide partners een jaar of langer op een adres ingeschreven zijn, en dat beide partners ouder dan 18 jaar zijn..$^{\infty}$

4. Voorstellen tot vereenvoudiging en stroomlijning van aftrekposten.

De functie van de aftrekposten kan tweeledig zijn. Een aantal aftrekposten heeft de functie de draagkracht van een belastingplichtige zo zuiver mogelijk te benaderen. Andere aftrekposten dienen een niet-fiscaal doeleinde. De beide categorieën aftrekposten hebben twee eigenschappen gemeen, t.w.: door de invoering van de aftrekposten wordt de wetgeving ingewikkelder en de mogelijkheid om aftrekposten te gebruiken leidt tot een lagere belastingopbrengst. ${ }^{67}$

De commissie-Oort zegt het volgende over de afschaffing van de aftrekposten: 'Het ligt derhalve voor de hand om te trachten deze vicieuze cirkel (de verfijning van de inkomstenbelasting verhoogt het aantal aftrekposten en de tarieven etc., MW) te doorbreken door een radicale beperking van aftrekposten'.68 De beperking van de aftrekposten levert $f$ 1,5 mrd op. ${ }^{69}$

Een beperking van de aftrekposten betekent een aanzienlijke vereenvoudiging. Bovendien wordt ruimte geschapen voor een tariefverlaging; ook de bezwaren tegen het schrappen van aftrekposten zullen wegvallen doordat een flinke tariefverlaging heeft plaatsgevonden. Opgemerkt zij dat bij het onderzoek van de commissie-Oort naar de vraag welke aftrekposten zouden kunnen wegvallen, niet is gelet op de maatschappelijke aanvaarding van het schrappen van een aantal aftrekposten. ${ }^{70}$ Ondanks de voorgestelde tariefverlaging is het voor de commis-

65. De Emancipatieraad is van mening dat door de overdracht van de basisaftrek de eenvoud van het systeem van geïndividualiseerde belastingheffing wordt verstoord. Bovendien zou de overdracht de toetreding van vrouwen op de arbeidsmarkt remmen, zij het in mindere mate als in het geval van de alleenverdienerstoeslag en de voetoverheveling. Emancipatieraad, t.a.p., blz. 10.

Derhalve stelt de raad voor niet de basisaftrek, maar het voordeel dat de basisaftrek oplevert, over te dragen. Emancipatieraad, t.a.p., blz. 11 en 20.

66. Zicht op eenvoud, t.a.p., blz. 51 en 52 .

67. Zicht op eenvoud, t.a.p., blz. 89. Afschaffing van de cerste categorie betekent een vereenvoudiging, maar ook een vergroving van de draagkrachtmeting. Zicht op eenvoud, t.a.p., blz. 90. De SER komt tot dezelfde conclusie. Advies belastingvereenvoudiging, SER, t.a.p, blz. 139.

68. Brochure Zicht op eenvoud, Verkorte weergave van de hoofdpunten van het rapport 'Zicht op eenvoud' van de commissie tot vereenvoudiging van de loonbelasting en de inkomstenbelasting, ingesteld op 20 september 1985 door de Minister en de Staatssecretaris van Financiën, 1986, blz. 19.

Het afschaffen van de aftrekposten wordt niet als reëel beschouwd. Brochure, t.a.p., blz. 2. In de literatuur is weinig aandacht besteed aan de overwegingen van de commissie-Oort. Albregtse doet het wel en constateert dat met betrekking tot de aftrekposten de bezuinigingsoverwegingen een grote rol hebben gespeeld. D.A. Albregtse, De commissie-Oort en de aftrekposten: Vereenvoudigen èn bezuinigen!, Maandblad Belastingbeschouwingen, 1986, no 9, blz. 222.

69. Zicht op eenvoud, t.a.p., blz. 94.

70. Zicht op eenvoud, t.a.p., bijlage 11, blz. 175 . 
sie-Oort duidelijk dat de afschaffing niet op een grote maatschappelijke en politieke aanvaarding hoeft te rekenen. ${ }^{71}$

In de bespreking van de Tweeverdienerswetgeving hebben we gezien dat de maatschappelijke aanvaarding wel degelijk een rol speelt bij de vaststelling van de vorm van de belastingheffing. De mate van maatschappelijke aanvaarding is mijns inziens van belang voor de uiteindelijke belastingopbrengst. Met andere woorden, een grote mate van maatschappelijke aanvaarding bevordert de doelmatigheid. Gezien de opdracht van de commissie-Oort, het opnieuw vinden van een compromis tussen de rechtvaardigheid en doelmatigheid, is het op zijn minst opmerkelijk dat de mate van de maatschappelijke aanvaarding niet is meegenomen in de afweging.

In dit verband is de volgende opmerking relevant: 'Los daarvan wordt over de fiscaal-theoretische merites van een dergelijke vergaande ingreep (afschaffen aftrekposten, MW) zeer verschillend gedacht. ${ }^{72}$ Dit is een aardige opmerking, maar wat precies met fiscaal-theoretische merites wordt bedoeld, is niet aangegeven. Nog afgezien van het feit dat een uitspraak over de al dan niet aftrekbaarheid van een bepaalde post impliciet een uitspraak inhoudt over de zgn. fiscaaltheoretische merites.

\section{Specifieke aftrekposten}

5. Reiskosten.

De vergoedings- en aftrekmogelijkheid van kosten van regelmatig woon- werkverkeer voor de eerste 10 kilometer wordt afgeschaft. De hogere forfaitaire bedragen worden met $f 200$ gekort. De aftrekbare bedragen en de normbedragen voor onbelaste vergoedingen worden gelijk gesteld. ${ }^{3}$

6. De aftrek voor groot onderhoud en de aftrek voor onderhoud aan monumentenwoningen.

De mogelijkheden van aftrek voor groot onderhoud en onderhoud aan monumentenwoningen worden afgeschaft. ${ }^{74}$

7. Meewerkaftrek.

De meewerkaftrek verdwijnt. Alleen de mogelijkheid voor een reële arbeidsbeloning blijft over. ${ }^{75}$ Dit geldt ook voor de ongehuwd samenlevenden.

8. Negatieve persoonlijke verplichtingen.

71. Brochure Zicht op eenvoud, Verkorte weergave van de hoofdpunten van het rapport 'Zicht op eenvoud' van de commissie tot vereenvoudiging van de loonbelasting en de inkomstenbelasting, ingesteld op 20 september 1985 door de Minister en de Staatssecretaris van Financiën, 1986, blz. 20. Kort na de bekendmaking van het rapport van de commissie-Oort werd nog weerstand van politieke aard verwacht. L.G.M. Stevens, Gezicht op eenvoud, Weekblad voor fiscaai recht, 1986, no 5733 , blz. 780.

72. Zicht op eenvoud, t.a.p., biz. 95.

73. Zicht op eenvoud, t.a.p., blz. 96 . De commissie-Stevens wil het reiskostenforfait afschaffen en de vergoedingen belasten. Graag of niet, t.a.p., blz. 61-63.

74. Zicht op eenvoud, t.a.p., blz. 97.

75. Zicht op eenvoud, t.a.p., blz. 97. De SER is van mening dat in het kader van de vereenvoudiging beter de reële arbeidsbeloning geschrapt had kunnen worden. Advies belastingvereenvoudiging, SER, t.a.p., blz. 71. 
De negatieve persoonlijke verplichtingen dienen geheel in de inkomstenbelasting te worden betrokken en tot het inkomen te worden gerekend. ${ }^{76}$

9. Buitengewone lasten.

Ten aanzien van de buitengewone lasten stelt de commissie-Oort de volgende maatregelen voor:

a. De aftrek van ziektekosten moet het gaan stellen zonder de vermenigvuldigheidsfactoren. De drempel kan worden vereenvoudigd. Premies voor een ziektekostenverzekering zijn niet meer aftrekbaar. ${ }^{n}$

b. De aftrek van studiekosten wordt beperkt tot les-, cursus- en collegegelden. ${ }^{78}$

c. De lasten van gezinshulp of kinderopvang worden niet meer in de inkomstenbelasting betrokken. Maatregelen in de zin van directe uitkeringen of subsidies komen hiervoor in de plaats.

d. De bedragen voor aftrekbare dieetkosten worden met $f 1.000$ verminderd.

e. Voor de aftrek voor kosten wegens ouderdom of arbeidsongeschiktheid wordt éen bedrag gehanteerd. Eventueel kunnen gehuwden twee maal gebruik maken van de aftrek. ${ }^{7}$

Met betrekking tot de buitengewone lastenaftrek kunnen de ongehuwd samenlevenden niet meer als gehuwden worden aangemerkt. ${ }^{80}$

Zie voor een uitgebreidere bespreking van de aftrekposten hoofdstuk 5 .

\section{Restcategorie}

10. Verder doet de commissie-Oort nog enige voorstellen met betrekking tot bijzondere regelingen, zoals het autokostenforfait, dat nu ook gaat gelden voor de loonbelasting. Vakantiebonnen worden voor $100 \%$ in de heffing betrokken. De fiscale oudedagsvoorziening voor zelfstandigen wordt vervangen door een pensioenreserve. De middelingsregeling vervalt. ${ }^{81}$

\subsubsection{Het draagkrachtbeginsel}

Welke gevolgen hebben de voorstellen van de commissie-Oort voor de werking van het draagkrachtbeginsel?

Een van de voorstellen van de commissie-Oort betreft de introductie van de basisaftrek. De basisaftrek komt in plaats van de belastingurije som. Ten aanzien

76. Zicht op eenvoud, t.a.p., blz. 98.

77. Bij de SER rijst de volgende vraag. 'De vraag kan dan ook worden gesteld of de voorstellen passen binnen de draagkrachtgedachte van de belastingheffing, te meer daar de vereenvoudiging door de voorstellen meer bereikt lijkt te worden door uitsluiting van de regeling dan door een vereenvoudiging van de regeling op zich.' Advies belastingvereenvoudiging, SER, t.a.p., blz. 74.

78. De commissie-Stevens wil de aftrek van de ziektekosten en studiekosten beperken. Daarnaast wil zij dat de mogelijkheid tot aftrek van de consumptieve rente vervalt. Graag of niet, t.a.p., blz. 76-78.

79. Zicht op eenvoud, t.a.p., blz. 98-100 en 143.

80. De Raad van State mist hier een beschouwing waaruit blijkt dat het voorstel past in de fiscale rechtsbeginselen, met name het draagkrachtbeginsel. Tweede Kamer, vergaderjaar 1987-1988, 20 595, B, blz. 36.

81. Zicht op eenvoud, t.a.p., blz. 100, 101 en 143. 
van de relatie van de basisaftrek tot het draagkrachtbeginsel merkt de commissie-Oort op, dat de lage basisaftrek niet de functie kan vervullen die in de gangbare draagkrachttheorie aan de belastingvrije som wordt toegekend. Ik lees uit deze zin, dat nog altijd ervan uit wordt gegaan dat de draagkrachttheorie opgeld doet. Maar de commissie-Oort geeft toe dat de praktijk anders is dan de theorie. Zo ligt de hoogte van de belastingurije sommen (1986) beneden de hoogte van het sociale minimum; in zoverre klopt de theorie niet. De basisaftrek heeft de functie te voorkomen dat de achteruitgang voor de lagere inkomens te groot zou zijn. Deze preventie zou dan niet met het draagkrachtbeginsel te maken hebben. ${ }^{82}$ Met deze redenering van de commissie-Oort wordt de werking van het draagkrachtbeginsel in de Wet IB 1964 beperkter. $^{83}$

De legitimatie van de toeslagen is gelegen in het verschil in draagkracht dat bepaalde groepen belastingplichtigen hebben in vergelijking met andere groepen. In de door de commissie-Oort gedane voorstellen worden bepaalde draagkrachtbeïnvloedende factoren niet meer erkend. Moet in die gevallen ervan uit worden gegaan dat de verschillen in draagkracht kleiner zijn geworden, en wel op een zodanige wijze dat daardoor de noodzaak wegvalt om via de verschillende toeslagen rekening te houden met de verschillen in draagkracht? Legitimeert het kleiner worden van de draagkrachtverschillen dat het draagkrachtbeginsel in deze geen werking meer heeft? Met andere woorden, als het verschil in draagkracht maar klein genoeg is, behoeft ook niet meer met het draagkrachtbeginsel gewerkt te worden. Mocht dit waar zijn, waar ligt dan de grens waar het draagkrachtbeginsel weer opgeld doet? In ieder geval is duidelijk dat de werking van het draagkrachtbeginsel door de afschaffing van de toeslagen op het gebied van leefomstandigheden wordt beperkt.

Inzake de beperking van de reiskosten stelt de commissie zich op het standpunt dat de reiskosten voor de eerste 10 kilometer als een vorm van inkomensbesteding kunnen worden gezien. De reden is dat deze kosten door vrijwel alle burgers, al dan niet in verband met werk, worden gemaakt. Albregtse merkt op dat kosten ter verwerving van inkomen en kosten met een bestedingskarakter,

82. Zicht op eenvoud, t.a.p., blz. 46 en 47 .

83. Van de totale belastingverlichting viel $22 \%$ bij de inkomens boven de $f 90.000$. Deze inkomensgroep bedraagt $5 \%$ van het totaal aantal inkomensontvangers. De inkomensgroep van $f 40.000$ tot $f 90.000$ neemt $63 \%$ van de verlichting voor haar rekening; de inkomensgroep van $f 0$ tot $f 40.00016 \%$. L. Koopmans c.s., t.a.p., blz. 199.

Zie ook De Kam en Sturm, die concluderen dat zowel in absolute als in relatieve zin de grootste voordelen aan belastingplichtigen met een inkomen van meer dan $f 200.000$ zijn toegevallen. C.A. de Kam en J.E. Sturm, De effectieve druk van inkomensheffingen en vermogensbelasting, voor en na de operatie-'OORT', Weekblad voor fiscaal recht, 1994, no 6117, blz. 1261 en 1265.

'Het blijkt dat slechts een derde van de ondervraagde particulieren een goed beeld had van de financiële gevolgen van de Oort-wetgeving voor hen persoonlijk.' Eindrapport over de evaluatie OORT-wetgeving, Ministerie van Financiën, Directoraat-Generaal der Belastingen, DirectoraatGeneraal voor Fiscale Zaken, juli 1994, blz. 13. 
zoals de buitengewone lasten, door elkaar worden gegooid. De verwervingskosten mogen niet bovenmatig zijn, terwijl de buitengewone lasten juist te maken hebben met een extremiteit. De buitengewone lasten zijn een tegemoetkoming voor een aantal extreem draagkrachtverminderende factoren. Het vertroebelen van de karakters maakt de systematiek onduidelijk. ${ }^{84}$

Een laatste opmerking betreffende de draagkracht gaat over de meewerkaftrek. Met het schrappen van de meewerkaftrek wordt de draagkrachtgedachte uit het oog verloren, aldus Grapperhaus. Door het meewerken van de partner neemt de draagkracht in de gezinssfeer af. Met de draagkrachtverminderende factor van het buitenshuis werken van de gehuwde vrouw, zij het in casu in de onderneming, moet volgens Grapperhaus rekening worden gehouden ${ }^{85}$ Dit betekent dat de factor opnieuw in de Wet IB 1964 zou moeten worden geïntroduceerd. Het laatste toont opnieuw aan dat er geen eenduidige definitie van het begrip draagkracht is. De weging van verschillende factoren varieert naar tijd en plaats. Bovendien is de persoon die de draagkracht definieert ook belangrijk.

\subsubsection{Het gelijkheidsbeginsel}

Een van de duidelijk in het oog springende kwesties waarbij het gelijkheidsbeginsel in de Wet IB 1964 een rol speelt, is wel het onderscheid tussen gehuwden en ongehuwd samenlevenden. Deze kwestie is in de Tweeverdienerswetgeving, met alle gevolgen van dien, uitdrukkelijk aan de orde geweest.

Wat het onderscheid gehuwden/ongehuwd samenlevenden betreft, kiest de commissie-Oort in geval van de basisaftrek voor een individuele, voor een ieder gelijke basisaftrek, die eventueel in zijn geheel kan worden overgedragen. Deze mogelijkheid tot overdracht geldt zowel voor gehuwden als voor ongehuwd samenlevenden, zij het dat voor de laatste categorie extra voorwaarden gelden. De commissie-Oort spreekt zich niet uit over de wenselijkheid van een splitsingsstelsel. ${ }^{86} \mathrm{Zij}$ is ook geen voorstander van optieregelingen, zoals bij de meewerkaftrek. ${ }^{87}$ De commissie-Oort is van oordeel dat met de door haar voorgestelde maatregelen de malaise van de Tweeverdienerswetgeving wordt teruggedraaid. ${ }^{88}$

84. Zie onder andere D.A. Albregtse, De commissie-Oort en de aftrekposten: Vereenvoudigen èn bezuinigen!, Maandblad Belastingbeschouwingen, 1986, no 9, blz. 222.

85. F.H.M. Grapperhaus, Vereenvoudiging van de belastingheffing een vraagstuk voor managers, Weekblad voor fiscaal recht, 1986, no 5750 , blz. 1445 .

86. De Emancipatieraad is verheugd dat de commissie-Oort niet heeft gekozen voor het splitsingsstelsel. Emancipatieraad, t.a.p., blz. 8.

87. Zicht op eenvoud, t.a.p., blz. 53.

88. Zicht op eenvoud, t.a.p., blz. 49. Zie echter C.P.A. Bakker, de auteur gaat uit van het feit dat de commissie-Oort zich heeft neergelegd bij de bestaande regeling voor tweeverdieners. Een splitsingsstelsel zou in de ogen van de auteur een belangrijke aanvulling en een verdere vereenvoudiging betekenen. Door de voorstellen van de commissie-OORT gaan de tweeverdieners ten opzichte van de alleenverdieners in het algemeen erop vooruit. C.P.A. Bakker, Herziening loon- en inkomstenbelasting, Weekblad voor fiscaal recht, 1987, no 5779, blz. 772 en Eenvoud voor gehuwden en ongehuwden en voor één- en tweeverdieners, Maandblad Belastingbeschouwingen, 1986, no 9, blz. 212 en 213 . Later blijkt dat de verschilien tussen de alleen- en tweeverdieners onder het bruto-inkomen van $f 50.000-f 70.000$ verkleinen en daarboven vergroten. 
Een maatregel van de commissie-Oort, die zowel met het gelijkheidsbeginsel als met het draagkrachtbeginsel te maken heeft, betreft de afschaffing van de toeslagen. Slechts de alleenstaande-oudertoeslag blijft bestaan, zij het in een andere vorm. ${ }^{99} \mathrm{De}$ alleenstaande-oudertoeslag wordt niet meer in de sfeer van het tarief, maar in de sfeer van de buitengewone lasten geregeld.

\subsubsection{Doelmatigheid}

Wat de doelmatigheid betreft, kan ik kort zijn. Op de eerste plaats leveren de voorstellen een arbeidsjaren-besparing op van 1.100 tot $1.375 .^{90}$ Op de tweede plaats neemt het aantal aanslagen met 620.000 af. ${ }^{91}$ Deze twee elementen bevorderen de doelmatigheid.

De doelmatigheid hangt samen met het vereenvoudigingsstreven; een vereenvoudigd belastingstelsel bevordert de doelmatigheid. Deze doelmatigheid werkt in twee richtingen, zowel in de richting van de belastingplichtigen als in die van de belastingdienst. De belastingplichtigen weten eerder waaraan ze toe zijn; de bedoeling van de wetgever is voor de belastingplichtigen sneller duidelijk dan in een ingewikkeld belastingstelsel. Daardoor mag je aannemen dat de belastingplichtigen eerder geneigd zullen zijn de verschuldigde belasting te betalen. De toepassing van het belastingstelsel bevordert door het gebruik van die vaststaande, zekere gegevens een gelijke behandeling van belastingplichtigen.

Voor de belastingdienst werkt een vereenvoudiging ook doelmatiger. Minder mankracht is nodig om het bedrag van de verschuldigde belasting vast te stellen en te innen. ${ }^{92}$

H.P.A.M. van Arendonk, De 'oortse-wijzigingen' en de Tweeverdienerswetgeving, Maandblad Belastingbeschouwingen, 1989, no 4, blz. 87. Zie ook het interessante artikel van Van Herwaarden en De Kam, die tot de conclusie komen dat veel tweeverdieners een lastenverlichting ondervinden ten gevolge van de Oort-wetgeving. F.G. van Herwaarden, C.A. de Kam, De fiscale behandeling van leefvormen, 1970-1990, Weekblad voor fiscaal recht, 1990, no 5905, blz. 321. De minister van Financiën geeft ook toe dat de tweeverdieners met hoge inkomens met alleen standaardaftrekposten erop vooruit gaan. Tweeverdieners met een inkomen van $f 75.000$ gaan er $7 \%$ op vooruit, terwijl de alleenverdiener met hetzelfde inkomen, er slechts $4 \%$ op vooruit gaan. Weekblad voor fiscaal recht, 1991, no 5944, blz. 38 en 39 . Zie ook Advies Belastingvereenvoudiging, SER, t.a.p., blz. 37.

89. Zicht op cenvoud, t.a.p., blz. 47-51. De toeslagen die worden afgeschaft zijn: de alleenstaandetoeslag, de arbeidstoeslag, de aanvullende arbeidstoeslag, de alleenverdienerstoeslag, de aanvullende alleenstaande-oudertoeslag.

90. De gevolgen van enige andere voorstellen konden niet worden berekend, maar worden geraamd op een besparing van 300 arbeidsjaren. Zicht op eenvoud, t.a.p., blz. 137.

91. In de premiesfeer vervallen ongeveer 3.000 .000 aanslagen. Zicht op eenvoud, t.a.p., blz. 137 en Advies belastingvereenvoudiging, SER, t.a.p., blz. 14.

92. Opmerkelijk is dat uit de OORT-evaluatie blijkt dat door de onderzoeksgroepen, inhoudingsplichtigen, landelijke organisaties van belastingconsulenten, niet-commerciële hulpverleningsorganisaties en de Belastingdienst geklaagd wordt over de toegenomen werklast. Eindrapport over de evaluatie OORT-wetgeving, t.a.p., blz. 15. 
Wat onder vereenvoudiging dient te worden verstaan, is in $\S 4.1$ besproken. De commissie-Oort is van mening dat een eenvoudiger belastingstelsel een belangrijke voorwaarde is om de verplichtingen die voortvloeien uit zo'n stelsel beter begrijpelijk en hopelijk daardoor ook meer aanvaardbaar te maken. ${ }^{93}$ Verder meent de commissie dat de door haar gedane voorstellen het een en ander aan vereenvoudigingen zullen opleveren, ondanks het feit dat zij moeilijk kwantificeerbaar zijn." Belangrijk in dit verband is de volgende opmerking. 'Aan de objectieve gegevens kan nog als gevoelsmatig argument worden toegevoegd dat een eenvoudiger en doorzichtig systeem, ook al kent het zekere vergrovingen, het rechtvaardigheidsgevoel eerder zal bevredigen dan het huidige zeer fijnmazige stelsel, waarvan velen het onbestem de gevoel hebben dat vergaande theoretische rechtvaardigheid enerzijds en maatschappelijke realiteit anderzijds soms wel erg ver uit elkaar lijken te liggen. ${ }^{.95}$

Bij deze opmerkingen passen enige kanttekeningen. Op de eerste plaats bedoelt de commissie-Oort mijns inziens te zeggen dat de doelmatigheid en de rechtvaardigheid juist elkaar niet hoeven te bijten. Ik vat het gestelde aldus op dat een doelmatig systeem een rechtvaardig systeem kan zijn. ${ }^{96}$ Wellicht ten overvloede merk ik op dat stellingen met betrekking tot doelmatigheid altijd impliciet een uitspraak inhouden over rechtvaardigheid, alleen al vanwege de onverbrekelijke samenhang tussen de twee elementen.

Ten tweede plaats ik een kanttekening bij het gebruik van een gevoelsmatig argument. Een gevoelsmatig argument is nu eenmaal moeilijk met objectieve maatstaven te achterhalen. Natuurlijk hoeft niet alles met objectieve maatstaven achterhaald te worden, maar enige zekerheid moet toch wel gegeven worden. $\mathrm{Ik}$ voeg aan het bovenstaande nog toe dat indien geconstateerd wordt dat de theoretische rechtvaardigheid en de maatschappelijke realiteit uit elkaar liggen, tevens een uitspraak wordt gedaan over de waarde van de theoretische rechtvaardigheid en over de maatschappelijke realiteit. De conclusie kan dan geen andere zijn dan dat of de theorie niet goed is opgebouwd, althans niet goed werkt of de maatschappelijke realiteit te wensen overlaat.

De toeslagen verzwaren de taak van de inhoudingsplichtigen. Derhalve is afschaffing vereist. De commissie-Oort is van mening dat hiermee een aanmerkelijke vereenvoudiging wordt bereikt. ${ }^{97}$

93. Zicht op eenvoud, t.a.p., blz. 129.

94. Zicht op eenvoud, t.a.p., blz. 131.

95. Brochure Zicht op eenvoud, Verkorte weergave van de hoofdpunten van het rapport 'Zicht op eenvoud' van de commissie tot vereenvoudiging van de loonbelasting en de inkomstenbelasting, ingesteld op 20 september 1985 door de Minister en de Staatssecretaris van Financiën, 1986, blz. 22.

96. Zie noot 5 .

97. Bovendien is het bedrag van de basisaftrek zo gering, dat verbijzondering naar leefvorm onwenselijk voorkomt. Zicht op eenvoud, t.a.p., blz. 49 en 50 . Daarnaast is onder andere belangrijk dat met de afschaffing van de tocslagen een belangrijke inbreuk op de persoonlijke 
Een laatste vraag rest. Is het vereenvoudigingsstreven een beginsel of niet? In de literatuur kan een aanwijzing worden gevonden dat het vereenvoudigingsstreven een beginsel is. ${ }^{98}$

Het vereenvoudigingsstreven kan mijns inziens als een onderdeel van de doelmatigheid worden beschouwd. ${ }^{99}$ Het oordeel of het vereenvoudigingsstreven als een beginsel moet worden gezien, hangt in dat geval samen met het oordeel of de doelmatigheid als een beginsel wordt gezien. In het onderstaande zal ik aangeven hoe het parlement het karakter van de doelmatigheid en daarmee het vereenvoudigingsstreven bestempelt.

\subsubsection{Budgettaire overwegingen}

Uit de formulering van de opdracht van de commissie-Oort wordt duidelijk dat de operatie budgettair neutraal dient te verlopen. De passage uit het instellingsbesluit luidt als volgt: 'De commissie geeft haar voorstellen zodanig vorm dat budgettaire neutraliteit zo veel mogelijk wordt gewaarborgd. Voor zover voorstellen aan deze voorwaarde niet voldoen worden de mogelijkheden van dekking aangeduid. ${ }^{100}$

De commissie maakt bij de berekening van de budgettaire gevolgen van de voorstellen gebruik van micromodel-simulatie. Dat wil zeggen dat de gevolgen van de overheidsmaatregelen worden onderzocht door simulatie met een microeconomisch model. ${ }^{101}$

levenssfeer wordt verijdeld. Zicht op eenvoud, t.a.p., blz. 50.

98. Zie onder andere Albregtse. Hij spreekt van een vereenvoudigingsbeginsel. Hij van mening dat de wetgeving is opgesierd met een aantal elementen die niets uit te staan hebben met het vereenvoudigingsstreven. Belastingbeginselen zijn omwille van de politieke haalbaarheid buiten beschouwing gelaten, aldus Albregste. D.A. Albregtse, Oort I + II en de aftrekposten: minder eenvoud en meer bezuiniging, Maandblad Belastingbeschouwingen, 1988, no 11, blz. 322.

99. Zie onder andere Keekstra, die onder vereenvoudiging het volgende verstaat:

'- verbetering van de uitvoerbaarheid;

- verbetering van de relatie tussen contribuabele en belastingdienst;

- verbetering van de belastingmoraal.' P.E. Keekstra, Vereenvoudiging: het moet, het kan!, Weekblad voor fiscaal recht, 1986, no 5733, blz. 798.

100. Zicht op eenvoud, t.a.p., bijlage 1, blz. 147. Duidelijk wordt ook dat de budgettaire overwegingen inzake oplossingen van knelpunten zwaarwegend zullen zijn. Tweede Kamer, vergaderjaar 1986-987, 19 567, nrs. 4-5, blz. 29 (kabinetsstandpunt).

De SER concludeert dat grosso modo sprake is van neutraliteit. 'De budgettaire neutraliteit impliceert dat er bezien vanuit de bestedingskant van de economie geen belangrijke macroeconomische effecten zijn te verwachten. Indien naar de aanbodkant van de economie wordt gekeken, wordt de conclusic anders.' Advies belastingvereenvoudiging, SER, t.a.p., blz. 56.

101. 'Daarbij wordt gebruik gemaakt van gegevens over huishoudens uit een representatieve, landelijke steekproef van meer dan een kwart miljoen belastingplichtigen uit 1981. Die gegevens betreffen bij voorbeeld de samenstelling van huishoudens, hun inkomensposten, aftrekposten, enzovoort.' Zicht op eenvoud, t.a.p., blz. 105. De inkomensgevolgen worden met behulp van koopkrachtoverzichten en empirische micromodel-simulatie aangetoond. Zicht op eenvoud, t.a.p., blz. 109 e.v.. 
De voorstellen inzake de basisaftrek, het tarief en de afschaffing van alle toeslagen leveren een verlies op. Dit verlies wordt gecompenseerd door het beperken van de aftrekposten en het wijzigen van andere regelingen. ${ }^{102}$

Indien gedachten over de grondslagen niet aan de orde zijn geweest, kan men zich afvragen in hoeverre budgettaire overwegingen de leidende gedachten van de voorstellen zijn geweest. Met andere woorden, in hoeverre hebben budgettaire overwegingen de werking van het draagkrachtbeginsel beperkt? In samenhang met door de regering gedane voorstellen zal ik deze vraag beantwoorden. ${ }^{103}$

\subsection{OORT-I}

\subsubsection{Inleiding}

Op 23 december 1986 heeft de regering kenbaar gemaakt dat de voorstellen van de commissie-Oort in hoofdlijnen zullen worden gevolgd, mits de financiering en de budgettaire neutraliteit verzekerd zijn. ${ }^{104}$ Achttien maanden later, om precies te zijn op 17 juni 1988, wordt het desbetreffende wetsvoorstel ingediend. Als datum van inwerkingtreding wordt gestreefd naar 1 januari 1990.

In het navolgende geef ik in hoofdlijnen het wetsvoorstel weer. Daarna volgen de parlementaire discussie en de kritiek van de literatuur.

102. Zicht op eenvoud, t.a.p., blz. 105. De invoering van de basisaftrek, de schijven en de tariefpercentages (inclusief voor bejaarden het tariefpercentage van $23,6 \%$ ) en de afschaffing van alle toeslagen met instandhouding van de alleenstaande-oudertoeslag in de vorm van een buitengewone last levert een verlies op van $f 1.675 \mathrm{mln}$.. Dit verlies wordt gecompenseerd door de volgende maatregelen: beperking van de T-biljetten in gevallen van tijdelijke werkzaamheden, bij het reiskostenforfait zijn de eerste $f 200$ niet aftrekbaar, de hoogte van onbelaste reiskostenvergoeding wordt aangepast aan de aftrekmogelijkheid, de ziekenfondspremies en premies ziektekostenverzekering worden niet meer in de buitengewone lastenregeling betrokken. Bovendien vindt een verandering van de drempel plaats. De aftrek van studiekosten in de buitengewone lastenregeling wordt beperkt. Het autokostenforfait wordt betrokken in de loonheffing, de vakantiebonnen worden voor $100 \%$ belast, het bijzonder tarief wordt vervangen door het $3 / 4$ belasten van de desbetreffende inkomsten tegen het gewone tarief, de middelingsregeling wordt afgeschaft. Deze maatregelen leveren een bate op van $f 1.575$ mln.. Zicht op eenvoud, t.a.p., blz. 107 en 108.

103. De SER kan zich niet aan de indruk onttrekken dat een aantal voorstellen op grond van budgettaire overwegingen is gedaan, 'met het oog op het verlies aan inkomsten van het rijk en de sociale fondsen bij realisering van de voorstellen ter zake van de tariefstructuur.' Advies belastingvereenvoudiging, SER, t.a.p., blz, 77.

104. Het wetsvoorstel: 'Herziening van de belastingheffing naar aanleiding van de voorstellen van de commissie tot vereenvoudiging van de loonbelasting en de inkomstenbelasting' (Wet vereenvoudiging tariefstructuur en aftrekposten in de loon-en inkomstensfeer). 
Welke voorstellen heeft de regering van de commissie-Oort overgenomen? In het onderstaande wordt een vergelijking gemaakt tussen de voorstellen van de commissie-Oort en het wetsvoorstel OORT-I. Bij deze vergelijking dient men zich te realiseren dat de regering in tegenstelling tot de commissie-Oort heeft kunnen werken met een financiële ruimte. ${ }^{105}$

\section{Algemeen}

1. Uniformering van de grondslag.

De regering stelt voor de premieheffing volksverzekeringen in de belastingheffing op te laten gaan. ${ }^{106} \mathrm{De}$ premies volksverzekeringen zijn niet meer aftrekbaar. ${ }^{107}$ Ter compensatie van deze niet-aftrekbaarheid is het tarief verlaagd. Tot zover is het regeringsvoorstel conform het voorstel van de commissie-Oort. Een van de problemen daarbij is de zgn. bruteringsoperatie. ${ }^{108}$ De regering stelt de bruteringsoperatie als eis voor het doorgang laten vinden van de operatie-Oort. De maatschappelijke pressiegroepen zoals de vakbonden zijn het hiermee niet eens. ${ }^{109} \mathrm{Na}$ een discussie is deze materie uiteindelijk in een compromis geresulteerd, nl. de overhevelingstoeslag. Dit resultaat is een gevolg van het

105. Een vergelijking is gemaakt met de memorie van toelichting, Tweede Kamer, vergaderjaar 1988-1989, 20 595, no 3. Daarna zijn er nog enige veranderingen opgetreden. Zie voor een vergelijking van de voorstellen van de commissie en het kabinetsstandpunt ook: Het kabinetsstandpunt inzake de voorstellen van de commissie-Oort, Weekblad voor fiscaal recht, 1987 , no 5758 , biz. $67-81$.

106. Zie onder andere Handelingen Eerste Kamer, vergaderjaar 1988-1989, 20 595, blz. 26-998. De Raad van State is bang dat het karakter van de premieheffing en belastingheffing vervaagt. Zie onder andere Tweede Kamer, vergaderjaar 1987-1988, 20 595, B, blz. 42.

107. De discussie rondom het karakter van de volksverzekeringen is min of meer verstomd. Dit is geschied door de samenvoeging van de belasting over het inkomen en de premieheffing voor de volksverzekeringen tot én heffingsgrondslag. Zie onder andere Handelingen Tweede Kamer, vergaderjaar 1988-1989, 20595 enz., blz. 40-2492, mk.

108. Het kamerlid Kombrink (PvdA) heeft een alternatief aangedragen. Hij stelde voor de overheveling van de opslagpremies niet te compenseren met een verhoging van het brutoloon, maar een afzonderlijke vergoeding te geven. Advies belastingvereenvoudiging, SER, t.a.p., blz. 79 .

109. Zie onder andere Tweede Kamer, vergaderjaar 1987-1988, 20 595, B, blz. 15 en 16. De Raad van State vindt het bezwaarlijk indien een belastingvereenvoudiging wordt doorgevoerd, welke niet wordt gedragen door zowel de werkgevers als de werknemers. Tweede Kamer, vergaderjaar 1987-1988, 20 595, B, blz. 16.

De SER is van mening dat de bruteringsoperatie veel risico's met betrekking tot de loonkosten in zich heeft. Advies belastingvereenvoudiging, SER, t.a.p., blz. 47 en 121. De Stichting van de Arbeid vindt de operatie onaanvaardbaar, daar geen enkele bruteringsmethode kan voldoen aan het uitgangspunt van kosten- en inkomensneutraliteit. Advies belastingvereenvoudiging, SER, t.a.p., blz. B-97. 
niet geaccepteerd worden door de maatschappij. ${ }^{110}$ Eind 1993 is een wetsvoorstel inzake de brutering van de overhevelingstoeslag aangenomen. ${ }^{11}$

\section{Tarief.}

In het wetsvoorstel OORT-I wordt een tariefsverlaging voorgesteld. De veel-heid van de tariefgroepen dient te verdwijnen. De regering heeft gekozen voor een drie-schijventarief. De percentages variëren met de hoogten van de belastbare sommen. De eerste schijf is lang en kent een percentage van $35,2^{112}$; de tweede schijf kent een percentage van 50; het toptarief is $60 .{ }^{113}$

Voor zover de bijzondere baten uitgaan boven het einde van de eerste schijf plus de heffingvrije som, wordt het variabele bijzondere tarief vervangen door een vast bijzonder tarief, nl. driekwart van het tabeltarief. ${ }^{114}$ Het vaste bijzondere tarief van $20 \%$ blijft gehandhaafd.

110. Brutering levert administratieve uitvoeringsproblemen op. Tweede Kamer, vergaderjaar 19861987, 19 567, no 10, blz. 3. Aanvankelijk moet binnen twee jaar tot een brutering worden gekomen. In deze twee jaar moet de werkgever een overhevelingstoeslag aan de werknemer betalen. Hierdoor vindt een uniformering van de grondslag van belastingen en premies plaats. Persbericht no 87/369. Later is gekozen voor een periode van vijf jaar (1994). De reden hiervoor moet worden gezocht in het bemoeilijken van de loononderhandelingen en de vaststelling van de pensioengrondslag. Verschillende voorstellen zijn gedaan. Zie voor een overzicht van de voorstellen, H.P.A.M. van Arendonk, Zicht op eenvoud gloort en er is bereidheid tot verandering, Maandblad Belastingbeschouwingen, 1988, no 1, blz. 3 en 4. Brutering betekent dat de premies volksverzekeringen door de werknemers worden betaald. De werkgever verhoogt de bruto-lonen met het bedrag dat de werknemers extra moeten betalen aan premies. De nu bestaande overhevelingstoeslag (OHT) is een tussenfase. Persbericht Financiën 21 juli 1988, no 88/185. Tweede Kamer, vergaderjaar 1987-1988, 20 595, B, blz. 15. Handelingen Tweede Kamer, vergaderjaar 1988-1989, 20 595, blz. 39-2394.

Volgens de commissie-Stevens dient de overhevelingstoeslag te verdwijnen. Graag of niet, t.a.p., blz. 101.

111. Wet van 22 december 1993, houdende vaststelling van de Wet brutering overhevelingstoeslag lonen, Stb. 1993, 743. Op 1 januari 1996 wordt de overhevelingstoeslag afgeschaft. Brutering moet op de eerste plaats vorm krijgen door het overleg tussen de werkgevers en werknemers. Is er niets geregeld, dan is er een zogenaamde vangnetbepaling, waarin de verhoging van het per betalingstermijn uit te betalen loon plaatsvindt met een percentage van het (bruto)loon dat voor iedereen gelijk is, het algemene wettelijke bruteringspercentage. Brutering wordt als een op termijn onvermijdelijke maatregel gezien. Tweede Kamer, vergaderjaar 1992-1993, 23 269, no 3 , blz. 3 en 5 .

112. Een lange eerste schijf heeft consequenties voor de toetreding van vrouwen op de arbeidsmarkt. Minder schokkeffecten kunnen optreden. Tweede Kamer, vergaderjaar 1987-1988, 20 595, no 3, blz. 19 en 20. Bovendien wordt door een lange cerste schijf de discussie over het samenvoegings- en het splitsingsstelsel minder interessant.

De SER deelt de optimistische mening van de regering over de arbeidsparticipatie van de gehuwde vrouwen niet. Advies belastingvereenvoudiging, SER, t.a.p., blz. 56.

113. De andere optie betreft een vier-schijventabel met corresponderende tarieven. Aanvankelijk was een vier-schijventabel ook de keuze van de regering. Persbericht $87 / 369$, blz. 2 .

114. Tweede Kamer, vergaderjaar 1987-1988, 20 595, no 3, blz. 9. 


\section{Basisaftrek.}

In het wetsvoorstel kan de basisaftrek worden overgedragen. Het wetsvoorstel is tot zover conform de voorstellen van de commissie-Oort. Voor de ongehuwd samenlevenden gelden bijkomende eisen. In deze eisen wijkt het voorstel van de regering af van het voorstel van de commissie-Oort; er is geen keuze vooraf, de referentie-periode is langer dan zes maanden, en de niet of weinig verdienende partner die jonger is dan 27 jaar mag niet in belangrijke mate door zijn of haar ouders worden onderhouden. ${ }^{115} \mathrm{De}$ alleenstaande-oudertoeslag en de aanvullende alleenstaande-oudertoeslag blijven bestaan. Bij de commissie-Oort worden deze toeslagen in de buitengewone-lastensfeer betrokken. In het wetsvoorstel blijven deze toeslagen in de horizontale tariefstructuur. ${ }^{116}$

Ten tijde van de Tweeverdienerswetgeving heeft de wetgever ten aanzien van de belastingvrije som een ander standpunt ingenomen. De belastingvrije som heeft een persoonlijk karakter; de basisaftrek daarentegen niet. ${ }^{117}$

\section{Aftrekposten.}

De regering heeft het advies tot de afschaffing van een aantal aftrekposten zeer ter harte genomen. De voorgestelde wijzigingen en de overwegingen laten zich als volgt vertalen (zie voor een uitgebreidere weergave hoofdstuk 5).

\section{Specifieke aftrekposten}

\section{Reiskosten.}

De vergoedings- en aftrekmogelijkheid van reiskosten woon-werkverkeer voor de eerste 10 kilometer wordt afgeschaft. Dit is geheel conform het voorstel van de commissie-Oort. ${ }^{118}$

6. De aftrek voor groot onderhoud en de aftrek voor onderhoud aan monumentenwoningen.

De mogelijkheid van aftrek voor groot onderhoud van woningen vervalt. In tegenstelling tot het voorstel van de commissie-Oort vervalt de mogelijkheid tot aftrek voor onderhoud aan monumentenwoningen niet.

\section{Meewerkaftrek.}

De keuze-mogelijkheid tussen de meewerkaftrek en de reële arbeidsbeloning blijft voor de gehuwden bestaan. Dit is afwijkend van hetgeen de commissie-Oort voorstelt. ${ }^{119}$ De ongehuwd samenlevenden hebben geen keuzemogelijkheid meer.

115. Persbericht Financiën, 87/369, blz. 3. Tweede Kamer, vergaderjaar 1987-1988, 20 595, no 3, blz. 22 en 23.

116. Dit zou vooral voor de loonbelasting doelmatiger zijn. Tweede Kamer, vergaderjaar 19871988, 20 595, B, blz. 39.

117. L.G.M. Stevens, Eenvoudig belasten is lastig, Weekblad voor fiscaal recht, 1988, no 5844, blz. 1407.

118. De Raad van State vraagt zich af of met deze voorstellen een goede weg is ingeslagen. Tweede Kamer, vergaderjaar 1987-1988, 20 595, B, blz. 33.

119. De Emancipatieraad is het hier niet mee eens; de meewerkaftrek dient vanuit emancipatoir oogpunt te vervallen. Emancipatieraad, t.a.p., blz. 14. 
8. Negatieve persoonlijke verplichtingen.

Conform het voorstel van de commissie-Oort dienen de negatieve persoonlijke verplichtingen in de inkomstenbelasting te worden betrokken en tot het inkomen te worden gerekend.

9. Buitengewone lasten.

Ten aanzien van de buitengewone lasten stelt de regering de volgende maatregelen voor:

a. De vermenigvuldigingsfactoren vervallen.

b. De studeerkamerkosten zijn niet meer aftrekbaar. De vergoeding van de studiekosten door de werkgever aan de werknemer is belastingvrij. ${ }^{120}$ Uitgezonderd zijn de kosten van de studeerkamer.

c. De lasten van gezinshulp of kinderopvang worden niet meer in de inkomstenbelasting betrokken. Maatregelen in de zin van directe uitkeringen of subsidies komen hiervoor in de plaats. ${ }^{121}$

De voorstellen van de regering inzake de buitengewone-lastenregeling zijn grotendeels overeenkomstig de voorstellen van de commissie-Oort.

De ongehuwde samenlevenden kunnen met betrekking tot de buitengewonelastenregeling niet meer als gehuwden worden aangemerkt.

\section{Restcategorie}

10. Het autokostenforfait wordt ook in de loonbelasting betrokken. Vakantiebonnen komen voor $100 \%$ in aanmerking voor de heffing van de loon- en inkomstenbelasting. De fiscale oudedagsreserve blijft gehandhaafd. Maar in tegenstelling tot het voorstel van de commissie-Oort blijft de vermogenstoets gehandhaafd. De middelingsregeling blijft in vereenvoudigde vorm gehandhaafd; dit is in tegenstelling tot hetgeen de commissie-Oort voorstelt.

\subsubsection{De parlementaire discussie en de kritiek in de literatuur}

Bij de weergave van de discussie die in het parlement en in de literatuur plaatsgevonden heeft, zal worden onderscheiden naar de volgende beginselen: de wetgevingsbeginsel(en), het draagkrachtbeginsel en het gelijkheidsbeginsel. Natuurlijk wordt het vereenvoudigingsstreven niet vergeten. Naast de budgettaire overwegingen zal het element van de pressiegroepen aan een beschouwing worden onderworpen. De aftrekposten komen in een aparte paragraaf aan de orde. In een laatste sub-paragraaf komt een aantal 'elementen' aan de orde

120. De Emancipatieraad is van mening dat de aftrekbaarheid van studiekosten mogelijk moet blijven, daar dit een positieve uitwerking zou hebben op de toetreding van vrouwen op de arbeidsmarkt. Emancipatieraad, t.a.p., blz. 16.

121. De Grave (VVD) vindt dat de budgettaire opbrengst van $f 125 \mathrm{mln}$. van het vervallen van de aanvullende arbeidstoeslag moet worden aangewend voor de financiering het kinderopvangbeleid. Tweede Kamer, vergaderjaar 1986-1987, 19 567, no 9. Dezelfde mening is de SER toegedaan. Advies belastingvereenvoudiging, SER, t.a.p., blz. 129. 
waarvan in het parlement gezegd wordt dat het fiscale beginselen zijn. Hierbij zij aangetekend dat een strikt gescheiden behandeling van bovengenoemde elementen vanwege de onderlinge samenhang niet mogelijk is.

\subsubsection{Wetgevingsbeginsel(en)}

Waarom worden de wetgevingsbeginselen naast de zgn. verdelingsbeginselen behandeld? De reden moet mijns inziens worden gezocht in de eis dat een goed wetgevingsprodukt maatschappelijk beter aanvaard wordt dan een slecht. En een beter maatschappelijk aanvaard wetgevingsprodukt leidt tot minder fraude en ontduiking, waardoor de verdelingsbeginselen - ervan uitgaande dat deze enige werking hebben - beter tot hun recht komen.

De Raad van State is eveneens van mening dat een goed afgewogen presentatie van de voorstellen een betere acceptatie van de belastingheffing te weeg zal brengen. ${ }^{122}$ Net als bij de Tweeverdienerswetgeving wordt door de Raad van State en verschillende auteurs bij de invoering van de OORT-wetgeving getwijfeld aan de kwaliteit van het wetgevingsprodukt. ${ }^{123}$ De Raad van State beschouwt de memorie van toelichting meer als een samenvatting van de besluitvorming dan als een stuk waarin de voor de beoordeling van het wetsvoorstel nodige gegevens, overwegingen en achtergronden zijn vermeld. Dit is uit het oogpunt van de wetgevingstechniek niet zo fraai. ${ }^{124}$

De Eerste Kamer heeft ook kritiek op het wetgevingsproces. De kritiek betreft de snelheid waarmee de wetsvoorstellen moeten worden ingevoerd. Deze kritiek viel de Tweeverdienerswetgeving ook al ten deel. Hierdoor komt de geschiedenis van de wet als bron van de rechtsvinding in gevaar. ${ }^{125}$ Als gevolg daarvan komt te veel gewicht op de schouders van de rechter te liggen, met alle gevolgen van dien. ${ }^{126}$

\subsubsection{Het draagkrachtbeginsel in het algemeen}

De Raad van State vraagt zich af of het voorstel OORT-I in overeenstemming is 'met fiscale rechtsbeginselen (cursivering schrijver dezes), met name dat van belastingheffing naar draagkracht'. ${ }^{127}$ Voordat ik op de hier gemaakte opmer-

122. Tweede Kamer, vergaderjaar 1987-1988, 20 595, B, blz. 6 .

123. Zie de discussie die hierover heeft plaatsgevonden in het Weekblad voor fiscaal recht, 1985, no 5671, blz. 212 en 213, en no 5672, blz. 262 en 263.

124. Tweede Kamer, vergaderjaar 1987-1988, 20 595, B, blz. 5 .

125. H.P.A.M. van Arendonk spreekt van ontkrachting van de belangrijkste rechtvindingsmethode, inhoudende de doel en strekking van de wet. H.P.A.M. van Arendonk, 1990?, Maandblad Belastingbeschouwingen, 1990, no 1, blz. 1.

126. Hiermee ben ik weer bij de discussie betreffende hét toetsingsrecht van de rechter aangeland. Wetten in formele zin mogen niet worden getoetst door de rechter. Maar in dat geval moet de formele wetgever er zorg voor dragen dat een goed wetgevingsprodukt tot stand komt.

127. Tweede Kamer, vergaderjaar 1987-1988, 20 595, B, blz. 3. 
king in ga, ben ik een verklaring verschuldigd over de cursivering van 'fiscale rechtsbeginselen'.

Wanneer gesproken wordt over fiscale rechtsbeginselen, betekent zulks dan dat deze rechtsbeginselen van een andere aard zijn dan de rechtsbeginselen van andere rechtsgebieden en dat daarnaast geen andere rechtsbeginselen hun werking kunnen hebben?

Dit lijkt me niet helemaal juist. In het algemeen worden rechtsbeginselen geacht zo'n universele gelding te hebben, dat geen sprake kan zijn van een toepassing enkel en alleen voor een bepaald rechtsgebied. Deze rechtsbeginselen zou ik de algemene rechtsbeginselen willen noemen. De algemene rechtsbeginselen gelden voor alle rechtsgebieden; deze mogen niet ter zijde worden geschoven. Maar daarnaast zijn er specifieke rechtsbeginselen geldend voor een rechtsgebied afzonderlijk.

Het bovenstaande leidt mijns inziens tot de conclusie dat de rechtsbeginselen dienen te worden onderscheiden in algemene en specifieke rechtsbeginselen. Met andere woorden, naast algemene rechtsbeginselen geldend voor alle rechtsgebieden zijn er mijns inziens specifieke rechtsbeginselen geldend voor de te onderscheiden rechtsgebieden. Een voorbeeld van een rechtsbeginsel voor alle rechtsgebieden is het gelijkheidsbeginsel en een voorbeeld van een rechtsbeginsel voor een bepaald rechtsgebied is het draagkrachtbeginsel voor het fiscale recht. ${ }^{128}$ Terugkomend op hetgeen de Raad van State heeft opgemerkt over het draagkrachtbeginsel kan ik niets anders zeggen dan dat steeds maar weer wordt gepoogd het draagkrachtbeginsel als leidend beginsel van de inkomstenbelasting te zien. De Raad van State vraagt zich af of op het draagkrachtbeginsel niet een zodanige inbreuk wordt gemaakt, dat nauwelijks meer van een werking van het draagkrachtbeginsel kan worden gesproken. De inbreuk wordt veroorzaakt door de uniformering van de grondslag voor premieheffing en belasting, het snijden in de aftrekposten en in de toeslagen op de basisaftrek. ${ }^{120}$

De regering antwoordt dat zij de draagkrachtgedachte als leidend beginsel zou willen blijven zien. ${ }^{130}$ 'Ter voorkoming van misverstanden moeten wij echter opmerken dat er geen theoretische draagkrachtconceptie is die zou kunnen leiden tot een eenduidige, als het ware wetenschappelijke tariefstructuur, horizontaal, noch yerticaal..$^{131}$

128. Belastingbeginselen zijn specifiek geldende rechtsbeginselen, aldus L.W. Sillevis, N.H. De Vries, Universiteit, belastingbeginselen en samenleving, Weekblad voor fiscaal recht, 1990, no 5943 , blz. 1887.

129. Tweede Kamer, vergaderjaar 1987-1988, 20 595, B, blz. 14 en Tweede Kamer, vergaderjaar 1988-1989, 20 595, no 7, blz. 8.

130. De Raad van State constateert dat uit de memorie van toelichting blijkt dat de bewindsslieden de draagkrachtgedachte nog steeds een levende zaak achten. Tweede Kamer, vergaderjaar 1987-1988, 20 595, B, blz. 23.

131. Tweede Kamer, vergaderjaar 1987-1988, 20 595, B, blz. 22. En verder: 'Dat zij (de voorstellen, MW) ten principale een inbreuk zouden vormen op enig draagkrachtbeginsel vermogen wij niet in te zien.' Tweede Kamer, vergaderjaar 1987-1988, 20 595, B, blz. 23. 
De Raad van State is van mening dat het verschil tussen de eerste en tweede schijf geen kenmerk is van een belastingtarief dat gebaseerd is op de draagkrachtgedachte.

Over de basisaftrek merkt de Raad van State op dat de basisaftrek nauwelijks te maken heeft met de draagkrachtgedachte. ${ }^{132}$ Het college merkt dan ook op dat de draagkrachtgedachte door essentiële elementen uit de voorstellen in belang vermindert. ${ }^{133}$

De regering antwoordt dat het vereenvoudigingsstreven een belangrijker overweging is dan de overwegingen die in het verleden hebben geleid tot bepaalde regelingen in de belastingheffing. ${ }^{134}$ Mijns inziens moet bij de hierbedoelde overwegingen zeker aan het draagkrachtbeginsel worden gedacht. ${ }^{135}$ In dit kader passen ook de volgende opmerkingen. De staatssecretaris acht het een verouderd denken indien gesproken wordt van draagkracht en het herverdelingsbeginsel. Dit denken moet opzij kunnen worden gezet. ${ }^{136} \mathrm{De}$ regering verwoordt het als volgt: 'Zoals wij in het nader rapport hebben opgemerkt, achten wij het niet zinvol - gelet op de rode draad van het vereenvoudigingsstreven - als het ware achteraf een fiscaal theoretisch kader te construeren. ${ }^{137}$ Ik vrees dat het achteraf construeren van een fiscaal theoretisch kader toch vaak, zij het min of meer impliciet, gebeurt. Ondanks bovenstaande ontkenning van het toevoegen van een fiscaal theoretisch kader poogt de staatssecretaris ondertussen wel een theoretische conceptie aan de wetsvoorstellen toe te voegen. In de Tweede Kamer zijn vragen gesteld over het niet betrekken van de algemene fiscale beginselen in de desbetreffende wetsvoorstellen. ${ }^{138}$ In antwoord hierop pakt de staatssecretaris het boek van De Langen, spreekt zijn twijfel uit over de door De Langen gebruikte analytisch-empirisch methode, maar gaat vervolgens aan de hand van enige door De Langen genoemde beginselen de wetsvoorstellen toetsen. De staatssecretaris noemt het welvaartbeginsel, het draagkrachtbeginsel, het beginsel van de bevoorrechte verkrijging, het beginsel van de minste pijn en het beginsel van de maximale realisatie. Gemakshalve wordt dit laatste beginsel vertaald als het beginsel van de doelmatigheid. Hiermee is blijkbaar de doelma-

132. Tweede Kamer, vergaderjaar 1987-1988, 20 595, B, blz. 22. Vergelijk hetgeen de commissieOort hierover heeft gezegd.

133. Tweede Kamer, vergaderjaar 1987-1988, 20 595, B, blz. 23.

134. Ook in latere wetgeving stelt de regering zich op het standpunt dat het streven gericht moet zijn op vereenvoudiging. 'Voortdurend zal het streven gericht moeten zijn op verdere vereenvoudiging en lastenvermindering.' Tweede Kamer vergaderjaar 1992-1993, 23 269, B, blz. 3. Eenvoud kan worden bereikt zowel in de wetstechniek als in de uitvoering: 'Uit het oogpunt van cenvoud, zowel wetstechnisch als uitvoeringstechnisch ...' Tweede Kamer, vergaderjaar 1993-1994, 23 269, no 5, blz. 13.

135. Tweede Kamer, vergaderjaar 1987-1988, 20 595, B, blz. 5.

136. Handelingen Tweede Kamer, vergaderjaar 1988-1989 enz., 20 595, blz. 40-2531, mk.

137. Tweede Kamer, vergaderjaar 1988-1989, 20 595, no 8, blz. 6.

138. Vooral Schutte (GPV) heeft hieromtrent vragen gesteld. Zie bij voorbeeld Handelingen Tweede Kamer, vergaderjaar 1988-1989, 20595 enz., blz. 42-2622. 
tigheid een beginsel geworden. ${ }^{139}$ Het welvaartsbeginsel wordt genoemd in verband met de tariefverlaging. Het draagkrachtbeginsel alleen is onvoldoende om de progressie in het huidige systeem te verklaren. Volgens dat beginsel verdraagt het huidige systeem (het systeem vór 'OORT', MW) slechts een bescheiden progressie. ${ }^{140}$ Voor een sterkere progressie is het zgn. 'herverdelingsbeginsel' nodig. ${ }^{141}$ Het door de staatssecretaris aangehaalde beginsel van de bevoorrechte verkrijging komt in het verdere verhaal als het herverdelingsbeginsel voor. Door de verminderde progressie heeft het herverdelingsbeginsel een minder sterke werking gekregen, zou je kunnen zeggen.

Het beginsel van de minste pijn en het beginsel van de maximale realisatie zijn te vinden in de lange eerste schijf, waardoor voor vele belastingplichtigen de loonheffing eindheffing is. ${ }^{142}$ Het door De Langen genoemde profijtbeginsel noemt de staatssecretaris niet.

Een en ander illustreert dat de wijze waarop een theoretisch kader aan de wetsvoorstellen wordt gegeven, enigszins willekeurig geschiedt.

\section{Het begrip draagkracht}

Vooropgesteld zij dat het begrip draagkracht niet met objectieve maatstaven is vast te stellen. ${ }^{143}$ Net als in de Tweeverdienerswetgeving wordt soms met feiten en gegevens gewerkt die niet geheel en voor een ieder duidelijk zijn. ${ }^{144}$

In OORT-I wordt een onderscheid gemaakt tussen subjectieve en objectieve draagkracht. Dit onderscheid kwam al aan de orde bij de Tweeverdienerswetge-

139. Zie ook Th.D.F. Somsen. In: H.P.J. Goossen, Eenvoud kan niet méér, Symposiumverslag, Weekblad voor fiscaal recht, 1986 , no 5733 , blz. 811 .

140. Het draagkrachtbeginsel speelt met name een rol in de horizontale draagkrachtverschillen. Deze verschillen worden in het systeem onder OORT kleiner. Advies belastingvereenvoudiging, SER, t.a.p., blz. 27.

141. De staatssecretaris haalt hiervoor Hofstra aan. Handelingen Tweede Kamer, vergaderjaar 1988-1989, 20595 enz., blz. 42-2622. In dit verband moet ook de omschrijving van het solidariteitsbeginsel door Ter Veld (PvdA) gezien. Zij omschrijft het solidariteitsbeginsel als een beginsel dat een belastingheffing naar draagkracht veroorlooft. Handelingen Tweede Kamer, vergaderjaar 1988-1989, 20595 enz., blz. 39-2438, mk.

Oort spreekt als volgt over de progressie: 'Progressie is een politieke uitvinding die door fiscaal-juristen met argumenten is onderbouwd.' NRC Handelsblad, 22 mei 1993, blz. 13.

142. Handelingen Tweede Kamer, vergaderjaar 1988-1989, 20595 enz., blz. 42-2622. Minister van Financiën, Ruding, noemt het tijdgebrek als argument om niet in te gaan op de grondslagen van de belastingpolitiek. Handelingen Tweede Kamer, vergaderjaar 1988-1989, 20595 enz., blz. 42-2621, mk en rk.

143. De draagkrachtverschillen tussen alleenstaande verzorgende ouders en alleenverdieners met kinderen, alleenstaanden, alleen- en tweeverdieners zijn moeilijk te berekenen. Tweede Kamer, vergaderjaar 1988-1989, 20 595, no 8, blz. 24, no 13, blz. 4. Handelingen Tweede Kamer, vergaderjaar 1988-1989, 20595 enz., blz. 26-29, lk, en 42-2590. lk. Handelingen Eerste Kamer, vergaderjaar 1988-1989, 20595 enz., blz. 26-992, mk.

144. Handelingen Tweede Kamer, vergaderjaar 1987-1988, 20595 enz., blz. 26-16, mk, 26-34, rk. Een voorbeeld is de materie inzake de beperking van de aftrek van de ziektekosten. Ten tijde van de behandeling van het wetsvoorstel is nog niet geheel duidelijk hoe de Dekker-voorstellen zullen uitpakken. Handelingen Tweede Kamer vergaderjaar 1988-1989, 20595 enz., blz. 39-2456, rk. 
ving. Ik val in herhaling maar voor de overzichtelijkheid geef ik de beide begrippen weer.

Met subjectieve draagkracht wordt bedoeld de bestedingsruimte, die een individu heeft. De bestedingsruimte wordt bepaald door persoonlijke omstandigheden van het belastingsubject. ${ }^{145}$ Subjectief draagkrachtbepalende factoren komen forfaitair tot uitdrukking in de belastingvrije sommen ${ }^{146} \mathrm{De}$ economische, maatschappelijke, politieke, budgettaire, fiscale en uitvoeringstechnische overwegingen spelen de grootste rol bij de subjectieve draagkracht. ${ }^{147}$

Valt het aanwezig zijn van gezinsleden ook onder de persoonlijke omstandigheden? In ieder geval wordt daarmee geen rekening gehouden bij het bepalen van de objectieve draagkracht.

Objectief de draagkracht berekenen houdt in het, met uitsluiting van de inkomensbestanddelen van gezinsleden, bepalen van het inkomen van een belastingplichtige. Met andere woorden, er vindt een volledige verzelfstandiging plaats. ${ }^{148}$ Het empirische inkomensbegrip moet als uitgangspunt dienen voor de bepaling van de objectieve draagkracht. Toch spelen draagkrachtbepalende factoren een rol bij het vaststellen van het objectieve inkomen. Van regeringszijde wordt toegegeven dat bij de inkomensvaststelling arbitraire elementen aanwezig zijn. ${ }^{149}$

De regering is de mening toegedaan dat de overheid gehouden is om eerst zo goed mogelijk alle draagkrachtvermeerderende en -verminderende factoren te bepalen, voordat het tarief op een eventueel positief saldo kan worden toegepast. Dit brengt het draagkrachtbeginsel met zich. Op deze manier worden de draagkrachtwijzigingen gelijk behandeld. ${ }^{150}$ Door deze redenering is ook het taxcreditsysteem van de baan, omdat dit systeem zou leiden tot een niet te verdedigen gescheiden behandeling van positieve en negatieve draagkrachtwijzigingen. ${ }^{151}$

145. Tweede Kamer, vergaderjaar 1988-1989, 20 595, no 8, blz. 4.

146. Tweede Kamer, vergaderjaar 1983-1984, 18 121, no 3, blz. 46.

147. Tweede Kamer, vergaderjaar 1983-1984, 18 121, no 5, blz. 40. Zie ook L.G.M. Stevens, die stelt dat het onderscheid tussen subjectieve en objectieve draagkracht een camouflagestunt is. De inconsistentie van de Tweeverdienerswetgeving wordt hiermee gecamoufleerd. L.G.M. Stevens, Nota Tweeverdieners derde fase, Weekblad voor fiscaal recht, 1984, no 5645, blz. 803.

148. Dit werd ten tijde van de Tweeverdienerswetgeving niet voorgesteld, daar het toenmalige(1983/1984) patroon nog bestond uit het inbrengen van het inkomen door één persoon. Tweede Kamer, vergaderjaar 1983-1984, 18 121, nrs. A-C, blz. 17.

149. Tweede Kamer, vergaderjaar 1983-1984, 18 121, no 5, blz. 39. De Kamer is kritisch ten aanzien van het draagkrachtbeginsel en de drukverdeling tussen de alleen- en tweeverdieners. Tweede Kamer, vergaderjaar 1988-1989, 20 595, no 7, blz. 57. Maar het CDA laat vanwege het vereenvoudigingsstreven de verschillen in draagkracht tussen de bijna-alleenverdiener en de alleenverdiener vallen. Handelingen Tweede Kamer, vergaderjaar 1988-1989, 20595 enz., blz. 39-2416.

150. Tweede Kamer, vergaderjaar 1988-1989, 20 595, no 13, blz. 47.

151. Het tax-creditsysteem houdt in dat na de vaststelling van de te betalen belasting een korting wordt toegepast. Tweede Kamer, vergaderjaar 1988-1989, 20 595, no 13, blz. 47. Een ander gevolg is dat met de introductie van het tax-creditsysteem de progressie steiler wordt. Stevens is voorstander van de tax-creditmethode wat betreft de tariefstructuur. L.G.M. Stevens, Eenvoudig belasten is lastig, Weekblad voor fiscaal recht, 1988, no 5844, blz. 1403. Een tax- 
Naast de indeling in een subjectieve en een objectieve draagkrachtberekening kan het begrip draagkracht hetzij vanuit een algemene invalshoek, hetzij vanuit het gezinsverband worden bekeken. ${ }^{152}$ Hier wordt het onderscheid tussen de individuele draagkracht en de gezinsdraagkracht bedoeld.

Levensovertuiging speelt hier een belangrijke rol. Ik citeer de RPF: 'Draagkracht per huishouding en rechtvaardigheid moeten de pijlers zijn van het belastingstelsel.' Maar de RPF stelt zich ook op het standpunt dat het fiscaal aantrekkelijker moet zijn voor hen die wettig gehuwd zijn. ${ }^{153}$ Deze twee standpunten zijn verenigbaar indien uitgegaan wordt van de visie dat alleen gehuwden een huishouding vormen. Dit laatste valt mijns inziens te betwijfelen.

Thans volgen enige opmerkingen over de draagkracht met betrekking tot de volgende onderwerpen, t.w.:

1. de verticale tariefstructuur;

2. de synthese tussen individualisering en de gezinsbenadering;

3. de vergelding van individuele draagkrachtverschillen door aftrekposten en dergelijke.

ad 1. Het tarief (1988) is alleen maar uit historische beschouwingen te begrijpen, niet vanuit een theoretisch idee. 'Bij het beschouwen van de opbouw van het thans geldende (schijven)tarief zou men in ernstige moeilijkheden komen als men zou proberen vanuit een eenduidige theoretische conceptie tot een verklaring van het feitelijke tarief te komen. ${ }^{154}$ Toegegeven wordt dat niet alleen de theoretische conceptie een rol heeft gespeeld, maar zeker ook de budgettaire aspecten en politieke opvattingen. Met andere woorden, de motieven die aan de verscheidene wetsvoorstellen ten grondslag liggen, kunnen enorm variëren. Zeker het element van de politiek - dat blijkens de zojuist geciteerde zin toch iets anders is dan een theoretische conceptie - mag niet worden uitgevlakt.

credit zou wat meer afbreuk doen aan de wat meer traditionele draagkrachtgedachte. L.G.M. Stevens, Tweede Kamer, vergaderjaar 1985-1986, 19 567, no 3, blz. 48. Zie ook commissieStevens, die een tax-credit voorstelt. Er is én basiskorting voor tweeverdieners en alleenstaanden, een dubbele basiskorting voor alleenverdieners en alleenstaande ouders en geen basiskorting voor de partner die de basiskorting heeft overgedragen. Graag of niet, t.a.p., blz. 50 en 53.

De SER is van mening dat de invoering van een tax-credit een positieve invloed heeft op de toetreding van vrouwen op de arbeidsmarkt. Interessant is nog de volgende opmerking. 'Introductie van belastingkortingsbedragen zal geïsoleerd beschouwd leiden tot een versterking van de progressie. Daarnaast kunnen belastingkortingsbedragen leiden tot een verhoogde belastingopbrengst bij gegeven tarieven. Aldus ontstaat er budgettaire ruimte om de tarieven aan te passen en de mate van progressie bij te stellen.' Advies belastingvereenvoudiging, SER, t.a.p., blz. 113 en 114.

152. Tweede Kamer, vergaderjaar 1988-1989, 20 S95, no 8, blz. 4. Het CDA ziet het leven door twee personen van én inkomen als' een draagkrachtverminderende factor. Handelingen Tweede Kamer, vergaderjaar 1988-1989, 20595 enz., blz. 39-2398, lk.

153. Handelingen Tweede Kamer, vergaderjaar 1988-1989, 20595 enz., blz. 39-2444, rk en 39-2445, lk.

154. Tweede Kamer, vergaderjaar 1988-1989, 20 595, no 13, blz. 2. 
Men kan zich afvragen of het draagkrachtbeginsel dan wel zo'n leidend beginsel is als door velen wordt beweerd. In ieder geval moet omtrent de vanzelfsprekendheid van het 'leiderschap' van het draagkrachtbeginsel voorzichtigheid worden betracht. Ter illustratie hiervan citeer ik de regering: 'De eerder weergeven overwegingen over het tot stand komen van tariefmaatregelen zijn voor ons steeds aanleiding geweest zeer terughoudend te zijn, zowel waar het gaat om het onzerzijds in het geding brengen van als fundamenteel aan te duiden uitgangspunten in de afweging van de voorgestelde maatregelen als in het beantwoorden van vragen ter zake.'155

ad 2. Zoals al in hoofdstuk 3 is vermeld, is de Tweeverdienerswetgeving een compromis tussen een volstrekt geindividualiseerde heffing en een heffing naar (gezins)draagkracht. ${ }^{156} \mathrm{Het}$ wetsvoorstel OORT-I moet wat betreft de behandeling van gehuwden en ongehuwden als een verlenging van de lijn van de Tweeverdienerswetgeving worden gezien. ${ }^{157}$ Opmerkelijk, dit staat haaks op hetgeen de commissie-Oort wilde. Deze wilde de malaise van de Tweeverdienerswetgeving juist terugdraaien.

Een echte fundamentele keuze wordt niet gemaakt; de synthese is het resul-taat van een politiek compromis. Tijdens de behandeling van OORT-I heeft de discussie over splitsing en individualisering slechts zijdelings plaatsgevonden. Opvallend bij deze discussie is dat dikwijls ter wille van de vereenvoudiging geen voorkeur voor het een of het ander wordt uitgesproken. In ieder geval mag het uitspreken van een voorkeur niet worden nagelaten ter wille van de budgettaire redenen. ${ }^{158}$

Aan de synthese dient niet gemorreld te worden. Hiervoor worden de volgende argumenten aangevoerd:

1. de synthese is pas een paar jaar oud;

2. de belastingheffing dient volgend en voorwaardenscheppend te zijn;

3. bij wijziging komt het vereenvoudigingsstreven in gevaar. ${ }^{159}$

Op zich is het heel opmerkelijk dat aan die synthese waarover verschil van mening bestaat, niet mag worden gemorreld. Het eerste argument zou betekenen dat, ook al is een wettelijke regeling niet goed, daaraan omwille van de factor tijd niet mag worden getornd. Impliciet lees ik hierin de eis dat ongeacht de kwaliteit van een wettelijke regeling een nieuwe regeling enige tijd moet hebben om te gelden. Bedenk hierbij ook dat de leidraad voor de Tweeverdienerswetgeving was dat gehuwden en ongehuwde samenlevers zo veel mogelijk

155. Tweede Kamer, vergaderjaar 1988-1989, 20 595, no 13, biz. 3.

156. Tweede Kamer, vergaderjaar 1988-1989, 20 595, no 8, blz. 4.

157. Handelingen Tweede Kamer, vergaderjaar 1988-1989, 20595 enz., blz. 26-4. Handelingen Eerste Kamer, vergaderjaar 1988-1989, 20595 enz., blz. 27-1043, lk.

158. Zie bij voorbeeld L.G.M. Stevens, Eenvoudig belasten is lastig, Weekblad voor fiscaal recht, 1988 , no 5844 , blz. 1400 en 1401.

159. Tweede Kamer, vergaderjaar 1988-1989, 20 595, no 13, blz. 9, Handelingen Tweede Kamer, vergaderjaar 1988-1989, 20595 enz., blz. 42-2616 en Handelingen Eerste Kamer, vergaderjaar 1988-1989, 20595 enz., blz. 26-1017. Handelingen Tweede Kamer, vergaderjaar 1988-1989, 20 595 enz., blz. 40-2511, rk. 
gelijk moesten worden gesteld. Onder de OORT-wetgeving wordt de gelijke behandeling enigszins teruggedraaid. De regering beredeneert dit aldus: '... dat in dit kader (geen) sprake is van ongelijke behandeling van gelijke gevallen aangezien een willekeurige samenwonersrelatie niet gelijk kan worden geacht aan de huwelijksrelatie. ${ }^{.160}$

Het bovenstaande toont aan dat de mate van de werking van de verdelingsbeginselen vaak van het moment afhankelijk is. Hiervan getuigt ook het volgende citaat: 'Wij hebben bij de tweeverdienerswetgeving herhaaldelijk te verstaan gegeven dat het ook bij het huidige stelsel gaat om een momentopname, in het bijzonder wat betreft de drukverdeling tussen de verschillende groepen' ${ }^{161}$

Er zijn geen absolute gegevens beschikbaar over draagkrachtverhoudingen bij de te onderscheiden groepen, zoals bij voorbeeld alleenverdieners, alleenstaanden

160. Tweede Kamer, vergaderjaar 1988-1989, 20 595, no 13, blz. 43. De latere gelijkstelling van de gehuwden en de ongehuwd samenlevenden wat betreft de ziektekosten wordt als inconsequent ervaren. Enerzijds is er sprake van een inbreuk op de individualiseringsgedachte en de oorspronkelijke OORT-voorstellen en anderzijds is er sprake van een zekere sympathie voor de gelijkstelling. Handelingen Tweede Kamer, vergaderjaar 1988-1989, 20595 enz., 26-13. In de kamerstukken wordt opgemerkt dat door de eis van financiële neutraliteit die aan de commissie-Oort was gesteld de commissie geen oordeel kan geven over het splitsingsstelsel. Handelingen Eerste Kamer, vergaderjaar 1988-1989, 20595 enz., 27-1075. Handelingen Tweede Kamer, vergaderjaar 1988-1989, 20595 enz., blz. 26-4.

161. Tweede Kamer, vergaderjaar 1988-1989, 20 595, no 13, biz. 10. Opmerkelijk is dat de inkomenseffecten van de voorstellen van de commissie-Oort vaak tegengesteld zijn aan de Tweeverdienerswetgeving. ' $\mathrm{De}$ voorstellen van de commissie hebben een verschillende uitwerking op alleen- en tweeverdieners. Zij brengen niet een eenzijdig voordeel voor één bepaalde groep. Bij de middeninkomens is de alleenverdiener in het voordeel, bij de hogere inkomens de tweeverdiener.' Tweede Kamer, vergaderjaar 1986-1987, 19 567, nrs. 4-5, blz. 5557 (kabinetsstandpunt).

De SER is van mening dat de inkomenseffecten zowel van de commissie-Oort als van de regering te simpel en te gunstig worden weergegeven. Advies belastingvereenvoudiging, SER, t.a.p., blz. 33.

Uit de eerste tussenrapportage van de OORT-evaluatie blijkt dat een meerderheid van de onderzochte heffingsplichtigen van mening is dat de hogere inkomens meer financieel voordeel van de OORT-operatie zullen hebben dan de lagere. OORT en de heffingsplichtigen, Verslag van een onderzoek door het Erasmus Centre for sociolegal tax research, Faculteit der Rechtsgeleerdheid Erasmus Universiteit, in opdracht van het Ministerie van Financiën, M. Goejer, maart 1991, blz. 41. Dit blijkt ook uit de tweede tussenrapportage. Tweede Kamer, vergaderjaar 1992-1993, 22 374, no 2, blz. 4. OORT en de heffingsplichtigen, De Tweede Meting, Verslag van een onderzoek door het Erasmus Centre for sociolegal tax research, Faculteit der Rechtsgeleerdheid Erasmus Universiteit, in opdracht van het Ministerie van Financiën, M. Goejer, oktober 1992, blz. 51. Zie ook OORT en de inhoudingsplichtigen, De Tweede Meting, Verslag van een onderzoek door het Erasmus Centre for sociolegal tax research, Faculteit der Rechtsgeleerdheid Erasmus Universiteit, in opdracht van het Ministerie van Financiën, E.M. Eling, oktober 1992, blz. 40 en Evaluatie OORT-wetgeving, Deelonderzoek, Belastingconsulenten, W. van Dijk, mei 1992, rapportnr. 19, blz. 4.

Zie verder over de inkomenseffecten noot 83. 
e.d.. Toch wordt met verschillen in persoonlijke omstandigheden die schuil gaan achter die groepsbenamingen rekening gehouden. ${ }^{162}$

Er worden twee wegen weergegeven waarlangs draagkrachtaspecten worden gekwantificeerd. De eerste weg voert langs de regels welke uiteindelijk de nettoinkomens bepalen. De regering is van mening dat indien op grond van draagkrachtoverwegingen verschillen in belastingheffing worden gemaakt, de correcties plaatsvinden naar gelang van de persoonlijke omstandigheden waarin een particulier verkeert. Dit gebeurt door het toepassen van een toeslag op de belastingvrije som.

De volgende opmerking over de alleenstaande-oudertoeslag is interessant. De alleenstaande-oudertoeslag van $90 \%$ is een erkenning van het feit dat een huishouding met één volwassene goedkoper is dan een huishouding met twee volwassenen. De fiscale behandeling van de alleenstaande ouder hangt samen met de inkomenseffecten en niet met de theoretische meest wenselijke opzet. ${ }^{163}$ Ik lees hieruit dat de alleenstaande-oudertoeslag niet te maken heeft met het draagkrachtbeginsel, maar met de gewenste inkomenseffecten.

De tweede weg probeert de schaalvoordelen te kwantificeren. Hierbij wordt opgemerkt dat kwantificeren nagenoeg onmogelijk is. Bovendien horen persoonlijke omstandigheden niet thuis in de huidige belastingheffing, aldus de regering. ${ }^{164}$

Het zij nogmaals gezegd, dat aan het meten van draagkrachtverschillen een relatief belang dient te worden toegekend. ${ }^{165}$ Een ander argument op grond waarvan de draagkrachtmeting niet geheel zuiver kan geschieden, is dat indien allerlei verfijningen in de grondslag worden aangebracht, deze desondanks niet kunnen verhinderen dat zuivere draagkrachtverschillen niet kunnen worden aangegeven. ${ }^{166}$

162. Tweede Kamer, vergaderjaar 1988-1989, 20 595, no 13, blz. S. Van Amelsvoort (kamerlid, CDA) vertaalt het als volgt: 'In het onderhavige wetsvoorstel worden naar onze mening de draagkrachtverschillen tussen alleenstaanden, alleenverdieners en tweeverdieners niet op de juiste wijze weerspiegeld ... Wij nemen er toch genoegen mee, omdat er nu eenmaal grenzen zijn aan datgene wat de fiscale wetgever op dit terrein kan bereiken.' Handelingen Tweede Kamer, vergaderjaar 1988-1989, 20595 enz., blz. 26-19, mk. Van Amelsvoort besteedt in tegenstelling tot de behandeling van de Tweeverdienerswetgeving geen aandacht meer aan het verschil in de draagkrachtverhoudingen met als argument dat in de loop van de tijden tot andere conclusies kan worden gekomen. Handelingen Tweede Kamer, vergaderjaar 1988-1989, 20595 enz., blz. 42-2569, lk en mk.

163. Tweede Kamer, vergaderjaar 1988-1989, 20 595, no 13, blz. 8.

164. Tweede Kamer, vergaderjaar 1988-1989, 20 595, no 13, blz. 5, 6 en 7.

165. Tweede Kamer, vergaderjaar 1988-1989, 20595 , no 13, blz. 8.

166. Tweede Kamer, vergaderjaar 1988-1989, 20 595, no 13, biz. 14. Gesteld wordt dat het aanbrengen van draagkrachtbepalende factoren nooit tot een harmonieuze belastingheffing leidt. Ter illustratie van het feit dat het draagkrachtbeginsel nooit helemaal zuiver is aan te geven kan het volgende worden aangevoerd. Vanuit het oogpunt van draagkracht wordt de verhouding nettoloon-werknemer-alleenverdiener tot nettoloon-alleenstaande 100:92 als redelijk gezien. Voorheen was de verhouding 100:97 nog redelijk. Handelingen Tweede Kamer, vergaderjaar 1988-1989, 20595 enz., blz. 26-20, mk, Handelingen Eerste Kamer, vergaderjaar 1988-1989, 20595 enz., blz. 26-995. 
ad 3. Uit de kamerstukken blijkt dat in OORT-II de grondslagbepalende factoren in samenhang met de draagkracht aan de orde zullen komen. ${ }^{167} \mathrm{De}$ commissie-Oort wordt niet geacht een mening te geven over de grondslagen van het belastingstelsel. De hier bedoelde wetsvoorstellen zijn gebaseerd op dat advies van de commissie-Oort maar toch komt hierin een beschouwing over de grondslagen voor. In OORT-II zal een evenwicht moeten worden gevonden tussen de verfijningen (rechtvaardigheid, $\mathrm{MW}$ ) en de doelmatigheid. Dit toont aan dat een voorstel met betrekking tot vereenvoudiging impliciet een uitspraak inhoudt over de rechtvaardigheid.

Een laatste opmerking van regeringszijde is bijzonder tekenend en spreekt voor zichzelf: 'Wij willen onze beschouwingen over de draagkracht dan ook afronden met de veronderstelling dat een loon- en inkomstenbelasting vol met individuele draagkrachtbepalende factoren die er soms als toeters en bellen zijn bijgebracht weliswaar een luide kakofonie, zelden echter een harmonisch geluid kan voortbrengen. ${ }^{.168}$

Het bovenstaande overziende rijst bij mij de vraag of het draagkrachtbeginsel nog enige werking heeft? Ik denk dat het antwoord niet volmondig ja of nee kan zijn. Mijns inziens heeft het draagkrachtbeginsel blijkens de parlementaire geschiedenis nog wel enige werking, maar het betreft hier wel een bijzondere werking. In ieder geval is er iets voor te zeggen dat het draagkrachtbeginsel niet meer dezelfde werking als voorheen heeft.

Van regeringszijde wordt gesteld dat het begrip draagkracht niet beduidend aan gewicht verloren heeft. ${ }^{169}$ Ik lees deze zin aldus dat de werking aanwezig was doch gedeeltelijk verloren is gegaan. Er wordt echter niet aangegeven in hoeverre. Het geheel krijgt een ondoorzichtiger karakter en wederom moet de vraag worden gesteld of het wel duidelijk is waarover wordt gesproken. Met name is het vaak onduidelijk of het draagkrachtbeginsel op het subject of het object van toepassing is.

Door de bewindslieden wordt toegegeven dat het draagkrachtbeginsel enige zwakte kent. Draagkrachtfactoren kunnen blijkbaar niet altijd zuiver tot uitdrukking worden gebracht in belastbaar inkomen.

De algemene indruk is dat het draagkrachtbeginsel niet ten volle is gerealiseerd en ook niet ten volle gerealiseerd kan worden. Ondanks deze erkenning van de tekortkoming van het draagkrachtbeginsel, bestaat kennelijk toch een zekere behoefte om de belastingheffing, althans wat betreft de inkomstenbelasting, een theoretisch kader te geven. Dit laatste gebeurt dan door het draagkrachtbeginsel als uitgangspunt te hanteren. Interessant is natuurlijk de vraag waarom het draagkrachtbeginsel als uitgangspunt wordt gehanteerd. Een reden zou kunnen zijn dat de angst bestaat dat anders de belastingplichtigen de aan hen opgelegde lasten niet zouden accepteren.

167. Tweede Kamer, vergaderjaar 1988-1989, 20 595, no 13, blz. 13 en 14.

168. Tweede Kamer, vergaderjaar 1988-1989, 20 595, no 8, blz. 14.

169. Tweede Kamer, vergaderjaar 1988-1989, 20 595, no 8, blz. 4. 
Het draagkrachtbeginsel wordt in sterkere of in minder sterke mate, als een leidend beginsel gezien. Is dit beginsel niet meer leidend, dan zou de maatschappelijke aanvaarding wel eens in gevaar kunnen komen, aldus enige kamerleden. ${ }^{170}$

Met de wetenschap dat het draagkrachtbeginsel enigszins leidend moet zijn, moet de belastingheffing, althans de nadere invulling van de inkomstenbelasting worden begrepen.

De Toetsingscommissie wetgevingsprojecten is van mening dat de werking van het draagkrachtbeginsel niet als ideaal moet worden gezien. 'Beknotting van de voorstellen door toch weer iedere belastingplichtige in de wet een juk naar ieders draagkracht te willen aanmeten, zou een terugvallen betekenen in de oude fout'. ${ }^{171}$ Betekent dit dat de werking van het draagkrachtbeginsel opzij moet worden gezet? Blijkbaar wel.

\subsubsection{Het draagkrachtbeginsel in relatie tot de concrete voorstellen}

\section{Premies volksverzekeringen.}

Eén van de voorstellen is dat de premies volksverzekeringen niet meer aftrekbaar zijn. Deze maatregel wordt niet gedragen door het draagkrachtbeginsel maar door de wens van de vereenvoudiging, aldus constateert de Raad van State. ${ }^{172}$

De regering geeft als antwoord dat noch het inkomensbegrip noch de opvattingen over draagkracht de vereenvoudiging door de uniformering van de grondslag voor de heffing van premies en belasting frustreren. ${ }^{173}$

Deze discussie onderstreept de stelling dat het wetgevingsproces een soort welles-nietes-spelletje aan het worden is.

\section{Alleenstaanden.}

Met betrekking tot de alleenstaanden komt de draagkracht niet langer in de horizontale tariefstructuur tot uitdrukking. ${ }^{174}$ Dat wil zeggen dat het zijn van

170. Tweede Kamer, vergaderjaar 1988-1989, 20 595, no 7, blz. 4.

171. Tweede Kamer, vergaderjaar 1987-1988, 20 595, no 3, bijlage 3, blz. 110.

172. Tweede Kamer, vergaderjaar 1987-1988, 20 595, B, blz. 8.

173. Tweede Kamer, vergaderjaar 1987-1988, 20 595, B, blz. 9.

174. De horizontale tariefstructuur wordt gevormd door de belastingurije sommen en de toeslagen. De persoonlijke omstandigheden komen hier tot uitdrukking. De verticale tariefstructuur wordt gevormd door de tariefschijven en de basisaftrek (tussen inkomensgroepen). Met de verticale tariefstructuur wordt bedoeld dat een tarieflijn geacht wordt de geobjectiveerde draagkracht van het individuele inkomen te benaderen met voorbijgaan van de persoonlijke omstandigheden (Handelingen Eerste Kamer, vergaderjaar 1988-1989, 20 595, blz. 26-992). Bij de horizontale tariefstructuur gaat het om een ongelijk belasten van belastingplichtigen met een gelijk inkomen. Deze ongelijke behandeling wordt gerechtvaardigd door persoonlijke omstandigheden.

Daarnaast wordt gesproken van de horizontale en verticale gelijkheid.

Horizontale gelijkheid betekent dat er gelijke belastingbedragen zijn voor belastingplichtigen in gelijke omstandigheden. 
alleenstaande geen omstandigheid meer is waarmee in een toeslag op de belastingvrije som rekening wordt gehouden. De draagkrachtverminderende factor van het voor zich alleen voeren van de huishouding wordt niet meer gehonoreerd; de alleenstaande mist de schaalvoordelen van een gezamenlijke huishouding. Deze voordelen worden thans niet meer vergolden. ${ }^{175}$ De regering erkent in 1984 met betrekking tot de afschaffing van de alleenstaande-toeslag nog het volgende. 'Naar onze mening zou daarmee miskend worden dat de ongehuwde belastingplichtige die voor zich alleen een huishouding voert bij een bepaald inkomen daarvan minder draagkracht ondervindt dan een ongehuwde belastingplichtige met een zelfde inkomen die een gezamenlijke huishouding voert met een niet van hem afhankelijke partner. ${ }^{176}$

De vraag rijst of met de afschaffing van de toeslag niet in strijd met de draagkrachtgedachte wordt gehandeld. Over de afschaffing van de alleenstaande-

Verticale gelijkheid betekent dat er een herverdeling plaatsvindt van inkomen. Zie C.A. de Kam en F.G. van Herwaarden, Belastingherziening in Nederland: problemen en perspectieven, Preadviezen van de Koninklijke Vereniging voor de Staathuishoudkunde, 1988, blz. 26.

De Raad van State is van mening dat de inkomensgevolgen op individueel niveau zwaar moeten wegen. Tweede Kamer, vergaderjaar 1987-1988, 20 595, B, blz. 20.

Handelingen Tweede Kamer, vergaderjaar 1988-1989, 20 595, blz. 2590, mk.

175. Hierdoor neemt de druk om andere draagkrachtelementen uit de inkomstenbelasting te weren toe, aldus een Kamerlid. Handelingen Tweede Kamer, vergaderjaar 1988-1989, 20595 , 26-26, rk. Een ander voorbeeld is dat ter wille van de vereenvoudiging de draagkrachtverminderende factor inhoudende dat meerdere personen van éen inkomen moeten leven terzijde wordt gesteld. Handelingen Tweede Kamer, vergaderjaar 1988-1989, 20 595, blz. 39-2400, mk. Tweede Kamer, vergaderjaar 1988-1989, 20 595, no 11, blz. 4, Handelingen Tweede Kamer, vergaderjaar 1988-1989, 20595 , blz. 39-2432, lk.

De SER is het er niet mee eens dat de alleenstaande-toeslag wordt afgeschaft; in de fiscale sfeer zal een oplossing voor het koopkrachtverlies moeten worden gevonden. Advies belastingvereenvoudiging, SER, t.a.p., blz. 124.

176. Tweede Kamer, vergaderjaar 1983-1984, 18 121, no 7, blz. 7. Zie voor een interessante uiteenzetting aan de hand van de jurisprudentie over het begrip 'gezamenlijke huishouding', $P$. Kavelaars, Alleenstaande samenwoners of samenwonende alleenstaanden?, Weekblad voor fiscaal recht, 1990, no 5920 , blz. 955 e.v.. Het behalen van schaalvoordelen is het criterium bij de beoordeling van de al dan niet aanwezige gezamenlijke huishouding. 'De beoordeling of er sprake is van een gezamenlijke huishouding verloopt langs een dubbeltoets:

1 is er sprake van gezamenlijke huisvesting:

- zo nee, dan geen gezamenlijke huishouding, tenzij de dubbele huisvesting geen praktische betekenis heeft, doordat er bijvoorbeeld van de tweede huisvesting geen gebruik kan worden gemaakt, dan wel de tweede huisvesting niet volwaardig is, doordat elementaire woonvoorzieningen ontbreken,

- zo ja, dan toets 2;

2 is er sprake van een gezamenlijk gebruik van de maaltijden:

- zo nee, dan is er evenmin sprake van een gezamenlijke huishouding;

- zo ja, dan is er sprake van een gezamenlijke huishouding, tenzij een commerciële prijs wordt betaald, die - zo blijkt althans uit de rechtspraak - aan de lage kant kan zijn indien er geen sprake is van schaalvoordelen. In dat geval is het voldoende als reeds een reële prijs wordt overeengekomen.' 
toeslag is in het parlement en in de literatuur een uitgebreide discussie gevoerd. ${ }^{17}$ Typerend in de gehele discussie is dat de oorspronkelijke argumenten waarom de alleenstaande-toeslag moet worden afgeschaft, op een gegeven moment niet meer plausibel zijn. ${ }^{178}$ 'Dit alles overziende en een afweging makende tussen rechtvaardigheid en doelmatigheid slaat voor ons de balans door naar de meer doelmatige oplossing waarvoor in het wetsvoorstel is gekozen overeenkomstig het voorstel dat de commissie OORT heeft gedaan op dit punt'. ${ }^{179}$ Hoe de afweging tussen rechtvaardigheid en doelmatigheid precies wordt gemaakt, wordt mij niet duidelijk. De alleenstaande-toeslag wordt ten gunste van de doelmatigheid afgeschaft. De Raad van State stelt in dit verband dat het voor de belastingplichtigen niet duidelijk [is], waarom hun in het verleden door de wetgever vanuit de basisgedachte van de inkomstenbelasting, zijnde heffing naar draagkracht, erkende belang thans voor dat van de vereenvoudiging, waarvan de voordelen in belangrijke mate aan de belastingdienst toevallen, moet wijken'. ${ }^{180}$

De vereenvoudiging, de menskrachtbesparing en het budgettaire aspect zijn de argumenten voor het afschaffen van de alleenstaande-toeslag. ${ }^{181}$ Politieke, fiscale, zakelijke en inhoudelijke overwegingen zijn tegen de invoering van de alleenstaande-toeslag, aldus de regering. Wat precies met deze overwegingen wordt bedoeld, wordt niet duidelijk. Wellicht zijn de uitvoering, de controle, het gelijkheidsbeginsel, de willekeurige opdeling van de totale groep alleenstaanden, de dekking en de horizontale draagkracht in de belasting, waardoor het niet meer nodig is om rekening te houden met het zijn van alleenstaande, de nadere inhoud van deze overwegingen. ${ }^{182}$

Het laten vallen van de alleenstaande-toeslag schijnt net zoals het geval was met de bruteringsoperatie het resultaat te zijn van een compromis. Het kabinet dreigde met intrekking van alle wetsvoorstellen indien de alleenstaande-toeslag

177. De regering antwoordt dat het draagkrachtbeginsel nog steeds van toepassing is indien de alleenstaande-toeslag vervalt. Tweede Kamer, vergaderjaar 1986-1987, 19 567, no 6, blz. 6, vraag 42 en blz. 17. Tweede Kamer, vergaderjaar 1988-1989, 20 595, no 7, biz. 32, 35. Handelingen Tweede Kamer, vergaderjaar 1988-1989, 20 595, blz. 26-26, rk, 42-2590.

178. Handelingen Tweede Kamer, vergaderjaar 1988-1989, 20 595, blz. 42-2591. Zie ook noot 176.

179. Tweede Kamer, vergaderjaar 1988-1989, 20 595, no 8, blz. 29.

180. Tweede Kamer, vergaderjaar 1987-1988, 20 595, B, biz. 21.

181. Tweede Kamer, vergaderjaar 1987-1988, 20 595, no 3, blz. 8. De argumenten die volgens de regering tegen de alleenstaande-toeslag pleiten zijn:

-1 . in de oude situatie was de progressie hoog; in de nieuwe (na invoering van "OORT", MW) minder;

-2. in de oude situatie was er een hoge basisaftrek; in de nieuwe is deze minder. In de nieuwe situatie worden de verschillen tussen alleenstaanden en alleenverdieners minder. De verticale tariefstructuur wordt minder progressief. Handelingen Tweede Kamer, vergaderjaar 19881989, 20 595, blz. 43-2642.

L.G.M. Stevens, Eenvoudig belasten is lastig, Weekblad voor fiscaal recht, 1988, no 5844, blz. 1404.

182. De doelmatigheid speelt een grotere rol dan het budgettaire aspect. Handelingen Tweede Kamer, vergaderjaar 1988-1989, 20 595, blz. 26-18, lk, en 45-2688. 
gehandhaafd zou blijven. Het was kiezen of delen. De VVD zou afzien van de problematiek rondom de alleenstaanden indien het CDA zou afzien van voordelen voor de alleenverdieners. Uiteindelijk wordt genoegen genomen met afschaffing van de alleenstaande-toeslag, zij het dat in een overgangsregeling wordt voorzien. ${ }^{183}$ Het element van het bedrijven van politiek ${ }^{184}$ is ook hier heel sterk aanwezig. ${ }^{185}$ Politiek speelt in dit geval een belangrijkere rol dan de fiscale beginselen. ${ }^{186}$ Interessant in dit verband is de discussie die naar aanleiding van een artikel van Caanen heeft plaatsgevonden. Caanen stelt zich op het standpunt dat het Oortse tariefgroepenstelsel onevenwichtig is in de zin van de individualiseringsgedachte en in de zienswijze van de economische eenheid. Geredeneerd vanuit de individualiseringsgedachte kan alleen het inkomen zelf in aanmerking worden genomen bij de bepaling van de hoogte van de te betalen belasting. Beziet men de kwestie vanuit de economische eenheid, dan spelen eventuele schaalvoordelen, het aantal van het te belasten inkomen afhankelijke personen, de waarde van de huishoudelijke arbeid en de waarde van de vrije tijd ook een rol. Bij een consequente toepassing van een zienswijze moet de conclusie zijn dat of de overdracht van de basisaftrek wordt afgeschaft of de alleenstaande-toeslag wordt herïntroduceerd, aldus Caanen. ${ }^{187}$ Bakker heeft hierop kritiek en stelt zich op het standpunt dat het splitsingsstelsel moet worden toegepast, daar het stelsel rekening houdt met de gezamenlijke draagkracht van de partners. ${ }^{188}$ Het huishoudinkomen is de bepalende draagkrachtfactor, aldus Bakker. ${ }^{189}$

Aan het draagkrachtbeginsel kan een andere werking worden toegekend dan voorheen. Zoals al eerder gezegd wordt het principe van de draagkracht door menig parlementariër nog steeds als een belangrijk politiek streven gezien. Volgens dezelfde parlementariërs moet onder verdelende rechtvaardigheid de

183. Handelingen Tweede Kamer, vergaderjaar 1988-1989, 20 595, blz. 42-2687.

184. Voor politiek moet hier partijpoliticke ideeën en belangen enerzijds en het sluiten van compromissen anderzijds worden gelezen.

185. Zie onder andere Handelingen Tweede Kamer, vergaderjaar 1988-1989, 20 595, blz. 43-2636 e.v.. Acht van de negen fracties in de Tweede Kamer zijn voor handhaving van de alleenstaande-toeslag.

186. Eerste Kamer, vergaderjaar 1988-1989, 20 595, no 131a, blz. 6. Handelingen Tweede Kamer, vergaderjaar 1988-1989, 20 595, blz. 40-2514, lk, 26-23, rk, Handelingen Eerste Kamer, vergaderjaar 1988-1989, 20 595, blz. 26-1019.

187. Caanen maakt een onderscheid tussen een economische en een fiscale benadering van belasting. Daarbij zijn twee factoren van belang, nl. de inkomstencomponenten en de draagkrachtfactoren. Ch. Caanen, Ceterum censeo non esse dividendum of de oortste tariefgroepen en het splitsingsstelsel, Weekblad voor fiscaal recht, 1990, no 5913, blz. 649-651. Zie ook de reactie van Hartman, die van mening is dat Caanen ook de maatschappelijke aanvaardbaarheid en politieke haalbaarheid van het stelsel bij zijn beschouwing had moeten betrekken. A. Hartman, De 'Oortste' tariefgroepen en het splitsingsstelsel, Weekblad voor fiscaal recht, 1990, no 5934, blz. 1498 en 1501.

188. C.P.A. Bakker, Nogmaals: de oortse tariefgroepen en het splitsingsstelsel, Weekblad voor fiscaal recht, 1991, no 5949, blz. 228.

189. De waarde van de huishoudelijke arbeid en de vrije tijd zijn geen factoren waarmee rekening kan worden gehouden bij de bepaling van draagkracht. C.P.A. Bakker, t.a.p., blz. 225 en 227. 
toepassing van het draagkrachtprincipe worden verstaan. ${ }^{190}$ Uit de discussie rondom de afschaffing van de alleenstaande-toeslag kan worden afgeleid dat de toepassing van het draagkrachtbeginsel wordt beperkt.

Overigens zij hierbij opgemerkt dat de huidige tariefstructuur niet is af te leiden uit de theoretische conceptie van draagkracht. 'De tariefstructuur is een synthese tussen de theoretische conceptie draagkracht en het politiek denken in een bepaalde tijd'. ${ }^{191}$ Mijns inziens moet alleen maar worden gesproken van een politiek denken in een bepaalde tijd. ${ }^{192}$

\section{Alleenstaande ouders.}

Ondanks dat de draagkrachtverhoudingen tussen de verschillende groepen niet kunnen worden gekwantificeerd, maakt de regering inzake de alleenstaande ouders toch een opmerking daarover. 'Het is in dit verband opmerkelijk dat de regering lijkt uit te gaan van een lagere draagkracht voor alleenstaande ouders in vergelijking tot alleenverdieners met kinderen', aldus de leden van de CDAfractie. ${ }^{193}$ Het antwoord van de regering hierop luidt dat 'het veeleer [gaat] om globale noties die slechts marginaal kunnen worden getoetst aan voor verschillende doelen vervaardigde berekeningen en analyses. ${ }^{194}$

190. De draagkracht wordt bepaald door het gezinsinkomen. Tweede Kamer, vergaderjaar 19881989, 20 595, no 7, blz. 8 en 9. 'Politiek' bepaalt veelal of een bepaalde operatie doorgaat; zo zijn inkomenseffecten voor bepaalde categorieën belastingplichtigen belangrijk. Handelingen Eerste Kamer, vergaderjaar 1988-1989, 20 595, blz. 26-993, mk.

191. Ruding, minister van Financiën, Handelingen Eerste Kamer, vergaderjaar 1988-1989, 20595 , blz. 27-1034, mk. Er is een onderscheid tussen draagkracht en politiek. '... niet alleen in de theoretische bespiegelingen, maar ook in de politiek', aldus Ruding. Handelingen Eerste Kamer, vergaderjaar 1988-1989, 20 595, blz. 27-1034, rk. De beslissing over de tariefstructuur is een politieke. Kombrink, PvdA, Handelingen Tweede Kamer, vergaderjaar 1988-1989, 20 595, blz. 39-2424.

Zie ook L.G.M. Stevens, Tweede Kamer, vergaderjaar 1986-1987, 19 S67, no 3, blz. 44. En zie ook Koopmans c.s.: 'De feitelijke drukverdeling is de resultante van politieke besluitvorming.' L. Koopmans c.s., t.a.p., blz. 162.

192. Deze stelling wordt ondersteund door het volgende citaat: 'Wij (regering, $M W$ ) beseffen zeer wel dat de bestaande drukverdeling geen vaststaand gegeven is, en dat de waardering van de uitkomsten niet zozeer wetenschappelijke als wel politieke opvattingen weerspiegelt.' Eerste Kamer, vergaderjaar 1988-1989, 20 595, no 131b, blz. 6. Handelingen Tweede Kamer, vergaderjaar 1988-1989, 20595 , blz. 39-2417, $\mathrm{mk}$. Zie voor het onderscheid politiek/wetenschappelijk hoofdstuk 1 .

$\mathrm{Zo}$ is de lastenverlaging een politiek weinig omstreden issue. Handelingen Tweede Kamer, vergaderjaar 1988-1989, 20595 , blz. 39-2418, lk. Een ander citaat van de toenmalige minister van Financiën, Ruding: '... echter de politieke realiteit gebiedt mij om te herhalen wat ik al eerder hier heb gezegd: naar onze taxatic zijn zulke plannen niet voldoende haalbaar of geloofwaardig. Wij zitten nu eenmaal in de jaren met verkiezingen, met kabinetsvorming en met een onbedwingbare neiging tot korte-termijndenken. ... politiek niet haalbaar is.' Handelingen Eerste Kamer, vergaderjaar 1988-1989, 20 595, blz. 27-1033, Ik en mk. Handelingen Eerste Kamer, vergaderjaar 1988-1989, 20 595, blz. 27-1076, mk.

193. Tweede Kamer, vergaderjaar 1988-1989, 20 595, no 11, blz. 3.

194. In theorie zijn er twee lijnen om de draagkrachtaspecten te kwantificeren. 'De ene lijn is om in beeld te brengen welke netto inkomens resulteren als, bij gegeven bruto inkomens de belastingheffing wordt toegepast die voor de onderscheiden groepen in de huidige structuur 
Wordt hier dan toch rekening gehouden met de draagkrachtverhogende werking van de huishoudelijke arbeid die door de partner wordt verricht? Zoals al eerder aan de orde is geweest, wordt met dit element geen rekening meer gehouden. ${ }^{195}$

\section{Referentieperiode.}

Ten aanzien van de referentieperiode voert de regering aan dat het voor de draagkrachtmeting juister is om de meting afhankelijk te laten zijn van de toestand die gedurende meer dan zes maanden heeft bestaan. ${ }^{196}$ Dit lijkt me ook een moeilijk te kwantificeren uitgangspunt.

\section{Buitengewone lasten.}

De premies ziektekostenverzekering, zowel voor de Ziekenfondswet als particulier, zijn niet meer aftrekbaar. Dit wordt gemotiveerd met een beroep op het vereenvoudigingsstreven en budgettaire belangen. Met de regeling van de buitengewone lasten komt juist het draagkrachtkarakter van de inkomstenbelasting tot uiting. Deswege dient de motivering goed te gebeuren, aldus de Raad van State. ${ }^{197}$

\subsubsection{Het gelijkheidsbeginsel}

Onder het regime van de Tweeverdienerswetgeving is het nog zo dat een gelijke behandeling van gehuwden en ongehuwd samenlevenden bewerkstelligd zou moeten worden. De doelstelling van de Tweeverdienerswetgeving was juist een gelijke behandeling voor materieel vergelijkbare situaties tot stand te brengen. Door het loslaten van de formele criteria in de Tweeverdienerswetgeving zou de aanvaardbaarheid van de regelgeving worden vergroot '... omdat daardoor het aantal gevallen vermindert waarbij in materieel vergelijkbare situaties een verschillende belastingdruk ontstaat. ${ }^{, 198}$

In OORT-I daarentegen verhindert de vereenvoudigingsdrift dat ongehuwd samenlevenden als gehuwden worden aangemerkt. De Raad van State mist een verwijzing naar artikel $26 \mathrm{BuPo}{ }^{199}$ Het antwoord van de regering luidt: 'Het gaat hierbij immers niet om een niet geoorloofd onderscheid op irrelevante

geldt dan wel in de voorgestelde structuur is voorzien. De andere lijn zou zijn een indicatieve opstelling te maken van met schaalvoordelen samenhangende welvaartsverschillen.' Tweede Kamer, vergaderjaar 1988-1989, 20 595, no 13, blz. 5 e.v.

195. In de verhouding alleenverdiener-alleenstaande heeft een CDA-kamerlid het over het volgende. Iemand die meer personen moet onderhouden heeft minder te besteden dan degene die voor zichzelf moet zorgen. Handelingen Tweede Kamer, vergaderjaar 1988-1989, 20 595, blz. 42-2568. Een ander kamerlid spreekt juist van een lagere draagkracht van een alleenstaande ten opzichte van de alleen- en tweeverdiener, Handelingen Tweede Kamer, vergaderjaar 1988-1989, 20 595, blz. 42-2603.

196. Tweede Kamer, vergaderjaar 1988-1989, 20 595, no 8, blz. 87.

197. Tweede Kamer, vergaderjaar 1987-1988, 20 595, B, blz. 37 en 38.

198. Tweede Kamer, vergaderjaar 1988-1989, 20 595, no 8, blz. 5.

199. Tweede Kamer, vergaderjaar 19870-1988, 20 595, B, biz. 26. 
gronden, doch om een onderscheid dat zijn grond vindt in de feitelijke, en juridische verschillen die nu eenmaal bestaan tussen (ex-)gehuwden enerzijds en (ex-)samenlevenden anderzijds en de gevolgen die deze verschillen hebben voor de vormgeving van een zoveel mogelijk op eenvoud en een doelmatige uitvoering toegesneden belastingheffing. ${ }^{200}$ ' $\mathrm{De}$ vermogensrechtelijke relatie die ongehuwd samenwonenden ten opzichte van elkaar kunnen hebben is, anders dan bij gehuwde belastingplichtigen zo divers dat wij het onwenselijk en onjuist achten hen in de fiscale sfeer verplicht aan elkaar te koppelen. ${ }^{201}$

Het beleid wordt teruggedraaid. Dit geldt in ieder geval voor de buitengewonelastenregeling en voor de optiemogelijkheid van ongehuwd samenlevenden betreffende de reële beloning of de meewerkaftrek. ${ }^{202}$

De Raad van State wil dat een nadere motivering volgt, zowel voor het onderscheid man-vrouw als voor het onderscheid (ex-)gehuwden-(ex-)samenlevenden. ${ }^{203}$ Blijkens de twee citaten vindt de regering het onderscheid dat wordt gemaakt ten aanzien van de gehuwden en de ongehuwd samenlevenden, daarentegen niet ongeoorloofd. De regering stelt zich op het standpunt dat de bestaande verschillen aansluiten bij de mate van ongelijkheid. De verschillen zijn derhalve billijk. ${ }^{204}$

In de kamerstukken wordt het volgend overzicht getoond van de verschillen tussen gelijke en ongelijke behandeling van gehuwde en ongehuwde samenlevers. ${ }^{205}$ Opgemerkt zij dat dit een overzicht betreft dat uitgaat van de situatie zoals deze is ten tijde van het indienen van het oorspronkelijke wetsvoorstel (1989).

200. Tweede Kamer, vergaderjaar 1987-1988, 20 595, B, blz. 25. Tweede Kamer, vergaderjaar 1987 1988, no 3, blz. 13 en Tweede Kamcr, vergaderjaar 1988-1989, no 13, blz. 43.

201. Tweede Kamer, vergaderjaar 1988-1989, 20 595, no 8, blz. 82 en no 13, blz. 45 en 79.

202. Tweede Kamer, vergaderjaar 1987-1988, 20 595, no 3, blz. 13 en 15. Hiermee komt ook de kwestie aan de orde inhoudende dat een aantal ongehuwde samenlevenden in 1989 wel als samenlevenden wordt erkend en in 1990 niet meer. Dit komt door de verlengde referentieperiode. Dit is opmerkelijk en zeker niet bevorderend voor de rechtszekerheid. Handelingen Eerste Kamer, vergaderjaar 1988-1989, 20 595, blz. 27-1069, rk.

203. Tweede Kamer, vergaderjaar 1987-1988, 20 595, B, blz. 26. Groenman (D66) vindt het niet onmogelijk om een ongelijkheid op basis van artikel $26 \mathrm{BuPo}$ te constateren. Handelingen Tweede Kamer, vergaderjaar 1988-1989, 20 595, biz. 39-2464, mk, rk.

204. Tweede Kamer, vergaderjaar 1987-1988, 20 595, B, blz. 25. Tweede Kamer, vergaderjaar 19881989,20 595, no 13, blz. 42-45.

205. Overzicht ontleend aan Tweede Kamer, vergaderjaar 1988-1989, 20 595, no 11, blz. 26. 


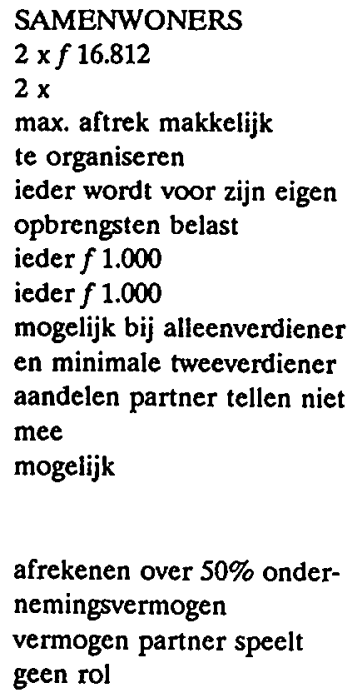

afrekenen over $50 \%$ ondernemingsvermogen vermogen partner speelt geen rol

aandelen partner tellen niet aanmerkelijk belang

overdracht niet mogelijk

giftenaftrek

hypotheekrente verdienende partner

rentevrijstelling

dividendvrijstelling

partner

buitengewone lasten lijfrentepremie-aftrek

vermogensinkomsten laagst belast bij hoogst verdienende

overdracht basisaftrek

geruisloze overdracht on-

derneming aan echtgenoot/

afrekening bij overlijden partner/mede-ondernemer invorderingsvrijstelling
GEHUWDEN

$1 \times f 16.812$

$1 \mathrm{x}$

aftrek bij hoogst verdienende gehuwden $2 \times f 2.000$

gehuwden $2 \times f 2.000$

mogelijk bij alleenverdiener en minimale tweeverdiener aandelen echtgenoot tellen mee

mogelijk

afrekenen over $75 \%$ onder-

nemingsvermogen

vermogen echtgenoot

beïnvloedt vrijstelling

negatief

overdracht verplicht

Ik kan me gezien het bovenstaande niet helemaal aan de indruk onttrekken dat de regering wel eens gebruik maakt van doelredeneringen. Een voorbeeld: in de Tweeverdienerswetgeving is geen volledige gelijkstelling mogelijk wat betreft de verdubbeling van de rente- en dividendvrijstelling voor gehuwden en ongehuwd samenlevenden. De oorzaak is een uitvoeringstechnisch probleem. Thans redeneert de regering dat de weg die bij de dubbele rente- en dividendvrijstelling is gevolgd, niet de richting is voor de andere terreinen. ${ }^{206}$

De gelijkstelling van de gehuwden met de ongehuwd samenlevenden komt blijkbaar nu niet goed uit. ${ }^{207}$

206. Tweede Kamer, vergaderjaar 1988-1989, 20 595, no 13, blz. 43. Kombrink (PvdA) is van mening dat ten aanzien van de gehuwden en de ongehuwd samenlevenden maar eens een fundamentele keuze moet worden gemaakt. Handelingen Tweede Kamer, vergaderjaar 19881989,20595 , blz. 26 , mk.

207. In dit verband is een belangrijk arrest gewezen (HR 27 september 1989, BNB 1990/61). Belanghebbende stelt zich op het standpunt dat het toenmalige artikel 5, leden 1 en 2 Wet IB 1964 (tekst 1981) een ongelijkheid oplevert voor de gehuwde man en de vrouw en voor de gehuwden en de ongehuwd samenlevenden. Ten aanzien van de vermeende ongelijkheid tussen man en vrouw is de Hoge Raad deze mening niet toegedaan. Wel is het onderscheid ter zake van het recht van bezwaar en beroep niet te rechtvaardigen. Ten aanzien van het onderscheid tussen gehuwden en ongehuwde samenlevenden zegt de Hoge Raad het volgende: 'De wetgever kan voor wat betreft de niet tot het persoonlijk arbeidsinkomen behorende inkomensbestanddelen in redelijkheid het beginsel van samentelling handhaven op grond van de overweging dat, gelet op de hiervoor aangeduide verschillen in juridische positie, gehuwden een hechtere economische eenheid vormen dan niet met elkaar gehuwde personen die een gezamenlijke huishouding voeren, zodat zij niet in alle opzichten met laatstbedoelde categorie op énn lijn behoeven te worden gesteld.' (overweging 7.2) 
De geschiedenis van de Tweeverdienerswetgeving en de OORT-wetgeving overziende blijkt dat er een verandering in de houding van de overheid ten opzichte van de behandeling van de ongehuwde samenlevers optreedt. Het moge duidelijk zijn dat OORT-I van een andere strekking is dan de Tweeverdienerswetgeving. Ten tijde van de Tweeverdienerswetgeving wordt gekozen voor gelijke behandeling van de ongehuwden met de gehuwden. Aanvankelijk wil men in de OORTwetgeving helemaal niets weten van een gelijke behandeling. Later is men daar op teruggekomen. Op het ene moment moeten de ongehuwd samenlevenden individueel in de belastingheffing worden betrokken, maar op het andere moment komt het verlangen om belasting te heffen naar draagkracht naar boven, met als gevolg dat de ongehuwd samenlevenden met de gehuwden worden gelijkgesteld. Ten gevolge van de OORT-wetgeving geeft de gelijke behandeling het volgende beeld. Met betrekking tot de buitengewone lasten hebben de ongehuwd samenlevenden de mogelijkheid onder bepaalde voorwaarden in aanmerking te komen voor de regeling die voor de gehuwd samenlevenden geldt. ${ }^{208}$

De ongehuwd samenlevenden kunnen in tegenstelling tot het wetsvoorstel blijven kiezen voor de meewerkaftrek of de reële beloning in geval van het meewerken van de partner in de onderneming.

Wat de overdracht van de basisaftrek betreft, krijgen de ongehuwd samenlevenden onder bepaalde voorwaarden dezelfde fiscale behandeling als de gehuwden. ${ }^{209}$

In de literatuur is met verbazing gereageerd op het feit dat de behandeling soms gelijk, soms ongelijk is. ${ }^{210}$ Een duidelijke keuze moet worden gemaakt. Waarom kan er geen onderzoek naar de motieven van het gaan samenleven of huwen plaatsvinden? Op de resultaten van dat onderzoek kan dan de belastingheffing worden gebaseerd. ${ }^{211}$

208. Amendement Kombrink (PvdA), Vreugdenhil (CDA) en De Grave (VVD), Tweede Kamer, vergaderjaar 1988-1989, 20 595, no 26. Uit de discussie die in de Kamer over de gelijkstelling volgt zijn tegengestelde geluiden laat horen. Handelingen Tweede Kamer, vergaderjaar 19881989, 20 595, UCV, blz. 26-2 e.v.. Door L.G.M. Stevens wordt de reikwijdte van het amendement zeer gering geschat, daar een zeer strenge inkomenseis geldt. L.G.M. Stevens, De vereenvoudiging wordt duur betaald, Weekblad voor fiscaal recht, 5857, blz. 211.

209. Amendement Vreugdenhil (CDA), Van Amelsvoort (CDA) en De Leeuw (CDA), Tweede Kamer, vergaderjaar 1988-1989, 20 595, no 32. De term 'gezamenlijke huishouding' blijft bestaan. H.P.A.M. van Arendonk, De 'Oortse-wijzigingen' en de Tweeverdienerswetgeving, Maandblad Belastingbeschouwingen, 1989, no 4, blz. 85.

210. Zie bij voorbeeld L.G.M. Stevens, Eenvoudig belasten is lastig, Weekblad voor fiscaal recht, 1988, no 5844, blz. 1406.

211. Vergelijk Vreugdenhil (CDA), Handelingen Tweede Kamer, vergaderjaar 1988-1989, 20595 , blz. 42-2573. 


\subsubsection{Het vereenvoudigingsstreven}

Vooropgesteld zij dat de beoogde vermindering van het aantal aanslagen met 620.000 niet zal worden gehaald. Door de terugdraaiing van een aantal maatregelen stijgt het aantal aangiftebiljetten. ${ }^{212}$

De geschiedenis van de inkomstenbelasting van de laatste jaren maakt duidelijk dat de verfijningen steeds maar weer toegenomen zijn. De wetgeving wordt daardoor dermate ingewikkeld dat wel een reactie moet komen; een volledig rechtvaardige heffing op basis van de draagkracht maakt de wetgeving onuitvoerbaar. ${ }^{213}$ De reactie houdt een streven naar doelmatigheid in. Net als op andere rechtsgebieden is derhalve ook op het gebied van het belastingrecht de eis van doelmatigheid in opmars. ${ }^{214}$

Voor het belastingrecht betekent het streven naar doelmatigheid onder meer een streven naar vereenvoudiging. ${ }^{215}$ Onder vereenvoudiging wordt verstaan een

212. Aanvankelijk blijken ongeveer 500.000 belastingplichtigen geen aangifte meer te hoeven doen. Hierbij moet met name worden gedacht aan de $20 \%$-bijtelling van de auto van de zaak alleen in de inkomstenbelasting en niet in de loonbelasting, de verruiming van de ziektekostenaftrek en de verlaging van de teruggavegrens voor $T$-biljetten. Het aantal ambtenaren is verminderd met 1.500. H.P.A.M. van Arendonk, De 'Oortse-wijzigingen' en de Tweeverdienerswetgeving, Maandblad Belastingbeschouwingen, 1989, no 4, blz. 82 en 83 en L. Koopmans c.s., t.a.p., blz. 198.

Uit de tweede tussenrapportage van de Oort-evaluatie blijkt dat niet méér mensen hun aangiftebiljet zelf zijn gaan invullen. Een meerderheid van de particuliere belastingplichtigen vindt de Oort-wetgeving er niet eenvoudiger op geworden. Zie onder andere Tweede Kamer, vergaderjaar 1992-1993, 22 374, no 2, blz. 4 en 8. Zie ook Evaluatie OORT-wetgeving, Deelonderzoek, Belastingconsulenten, t.a.p., blz. 3. Evaluatie OORT-wetgeving, Deelproject, Nietcommerciële hulpverleningsinstanties, W. van Dijk, mei 1992, rapportnr. 20, blz. 4.

Uit het eindrapport van de OORT-evaluatie blijkt dat een daling van het aantal beschreven belastingplichtigen is opgetreden met 265.000 . Hierbij zij aangetekend dat de verwachte daling niet zichtbaar is in de ontwikkeling van het aantal beschrevenen vanaf 1988 tot 1992. 'Andere factoren, zoals een autonome groei, niet-Oort maatregelen en een samenloop van verschillende Oort-maatregelen hebben er toe geleid dat het aantal beschreven belastingplichtigen in 1990 en 1991 per saldo aanzienlijk is toegenomen.' Eindrapport over de evaluatie OORT-wetgeving, t.a.p., blz. 17. Eindrapport over de evaluatie OORT-wetgeving, Bijlagen, Onderdeel Formatieve nacalculatie, Ministerie van Financiën, Directoraat-Generaal der Belastingen, Directie Planning, Financiën en Control, juli 1994, blz. 1 en 10.

213. Tweede Kamer, vergaderjaar 1988-1989, 20 595, no 7, blz. 11. Handelingen Tweede Kamer, vergaderjaar 1988-1989, 20595 , blz. 39-2376, lk.

Uit het eindrapport over de evaluatie OORT-wetgeving blijkt dat ten gevolge van de toegenomen ingewikkeldheid van de fiscale wetgeving een groei in het cliëntenbestand is geconstateerd door de landelijke organisaties van belastingconsulenten. Eindrapport over de evaluatic OORT-wetgeving, t.a.p., blz. 16.

214. Tweede Kamer, vergaderjaar 1987-1988, 20 595, no 3, blz. 2 en Tweede Kamer, vergaderjaar, 1988-1989, no 7, blz. 13.

215. Tweede Kamer, vergaderjaar 1988-1989, 20 595, no 7, blz. 10. Gewaakt moet worden dat de doelmatigheid niet de boventoon gaat voeren. Handelingen Tweede Kamer, vergaderjaar 1988-1989, 20 595, blz. 39-2377, mk. Hofstra zou voor vereenvoudiging juist rechtvaardigheid lezen. Vergelijk Kombrink (PvdA), die onder vereenvoudigen vergroven verstaat. Handelingen Tweede Kamer, vergaderjaar 1988-1989, 20 595, blz. 39-2421, rk. 
verbetering voor de burger, een toevloeien van de collectieve lasten naar de staatskas met zo min mogelijk maatschappelijke kosten en een beperking op menskracht bij de belastingdienst.

Door een vereenvoudiging zal een nieuw evenwicht moeten worden gevonden tussen de rechtvaardigheid en de doelmatigheid. ${ }^{216}$ Via de maatschappelijke kosten kan een link worden gelegd met de rechtvaardigheidseisen. Een rechtvaardigheidsgrond, die bovendien door de maatschappij ook nog geaccepteerd wordt, levert een hoge opbrengst op in verhouding met de kosten. Te veel vereenvoudiging werkt vergroving van de rechtvaardigheid in de hand. Deze grond kan dan in mindere mate door de maatschappij worden geaccepteerd, met alle gevolgen voor een verminderende opbrengst. Uiteindelijk wordt de grens van het mogelijke bereikt en zal een nieuw evenwicht moeten worden gevonden tussen de rechtvaardigheid en de doelmatigheid.

De doelstellingen van de Oort-wetgeving zijn: vereenvoudiging van het belastingstelsel, integratie belasting en premieheffing volksverzekeringen, nieuwe tariefgroepindeling, vermindering van het aantal schijven, tariefverlaging, en het stroomlijnen van aftrekposten en andere regelingen. Eindrapport over de evaluatie OORT-wetgeving, t.a.p., blz. 1.

De eerste tussenrapportage van de OORT-evaluatie leert dat een grote meerderheid van de respondenten weet dat vereenvoudiging een doelstelling is van de belastinghervorming. Opmerkelijk is dat de tariefverlaging, hetgeen ook een belangrijk element in de OORToperatie is geweest, minder wordt erkend als doelstelling. Bovendien zijn zowel particulieren als inhoudingsplichtigen de mening toegedaan dat een eenvoudiger aangiftebiljet ook een Oort-doelstelling is. OORT en de heffingsplichtingen, maart 1991, t.a.p., blz. 15 en Eindrapport over de evaluatie OORT-wetgeving, t.a.p., blz. 10 en 11 . Hetzelfde geldt voor de inhoudingsplichtigen. OORT en de inhoudingsplichtigen, Verslag van een onderzoek door het Erasmus Centre for sociolegal tax research, Faculteit der Rechtsgeleerdheid Erasmus Universiteit, in opdracht van het Ministerie van Financiën, A.M. Eling, maart 1991, blz. 14 en 35. De respondenten zijn van mening dat de gevolgen van de OORT-wetgeving voor de administratieve lasten negatief zijn. Ze zijn wel te spreken over de geïntegreerde heffing van loonbelasting en premies volksverzekeringen. OORT en de inhoudingsplichtigen, maart 1991, blz. 13, 14 en 35. Zie cok Tweede Kamer, vergaderjaar 1991-1992, 22 374, no 1, blz. 7-9 ten aanzien van de particulieren en blz. 12-13, Tweede Kamer, vergaderjaar 1992-1993, 22 374, no 2, blz. 9 en 10 ten aanzien van de inhoudingsplichtigen. Een meerderheid van de respondenten is voor brutering van de lonen. OORT en de inhoudingsplichtigen, De Tweede Meting, t.a.p., blz. 13,14 en 45.

Uit de tweede tussenrapportage van de OORT-evaluatie blijkt een groter percentage van de inhoudingsplichtigen negatief te oordelen over de eenvoud en de begrijpelijkheid. Tweede Kamer, vergaderjaar 1992-1993, 22 374, no 2, blz. 5. OORT en de inhoudingsplichtigen, De Tweede Meting, t.a.p., blz. 43.

216. Uit de eerste tussenrapportage van de OORT-evaluatie blijkt dat $25 \%$ van de respondenten van mening is dat het herziene belastingstelsel rechtvaardiger is geworden; een derde gedeelte denkt juist dat het stelsel onrechtvaardiger is geworden. Tweede Kamer, vergaderjaar 19911992, 22 374, no 1, blz. 8 en OORT en de heffingsplichtigen, De Tweede Meting, t.a.p., blz. 18. Blijkens de tweede tussenrapportage van de OORT-evaluatie zijn meer respondenten de mening toegedaan dat de OORT-wetgeving onrechtvaardig en onaanvaardbaar is. OORT en de heffingsplichtigen, De Tweede Meting, t.a.p., blz. 18 en 50. Voor de inhoudingsplichtigen ligt dat anders. Bijna de helft van de respondenten denkt dat de OORT-wetgeving de rechtvaardigheid niet aantast. OORT en de inhoudingsplichtigen, De Tweede Meting, t.a.p., blz. 43 en 46. 
In het wetsvoorstel OORT-I wordt de maatschappelijke aanvaarding van de belastingheffing als een groot goed gezien. Een rechtvaardigheidsgrond voor het maatschappelijk draagvlak wordt volgens de kamerstukken gevonden in het aanvaarden van de draagkrachtgedachte. Enige werking van het draagkrachtbeginsel moet volgens enige kamerleden aanwezig zijn. ${ }^{217}$ Hier ben ik terug bij hetgeen ik al eerder heb geconstateerd; het met de haren erbij slepen van het draagkrachtbeginsel.

Alleen is nu het draagkrachtbeginsel niet de enige invulling van die acceptatie, maar ook het streven naar vereenvoudiging. Uit de kamerstukken blijkt dat eenvoud een van de criteria is waaraan de belastingheffing moet voldoen. De andere zijn: wie zijn degenen die de vruchten plukken van deze vereenvoudiging; wat is de prijs voor vereenvoudiging; hoe zit het met de draagkracht?

De vereenvoudiging wordt in de Kamer als een eis van een goede belastingheffing gezien. ${ }^{218}$ Interessant in dit kader is het pre-advies van Prast voor de Nederlandse Orde van Belastingadviseurs. Deze stelt dat belastingvereenvoudiging een middel en geen doel is. De belastingvereenvoudiging is geen eis, maar een wijze waarop een rechtvaardige belastingheffing kan worden verkregen. Het doel is te voldoen aan een aantal kwaliteitseisen, zoals bij voorbeeld de kenbaarheid van het belastingrecht, de rechtszekerheid, de rechtvaardigheid en de uitvoerbaarheid. ${ }^{219}$

Ingeval de vereenvoudiging een doel is, staat zij op én lijn met de eis van rechtvaardigheid; de vereenvoudiging is als het ware verheven tot een beginsel. Ingeval de vereenvoudiging een middel is, is zij ondergeschikt aan onder andere de rechtvaardigheid. Dit is een nuanceverschil dat in zoverre belangrijk is, dat in het eerste geval de vereenvoudiging de rechtvaardigheid opzij kan zetten en in het tweede geval niet. ${ }^{220}$

217. Tweede Kamer, vergaderjaar 1988-1989, 20 595, no 7, blz. 4.

218. Het vereenvoudigingsstreven wordt door de Raad van State ondersteund. Tweede Kamer, vergaderjaar 1987-1988, 20 595, B, blz. 2.

219. H. Prast, Belastingadviseur en vereenvoudiging van de wetgeving, Pre-advies no. 6 en debat voor de drieëndertigste jaarvergadering van de Nederlandse Orde van Belastingadviseurs, Kluwer, 1987, blz. 11. In dit pre-advies wordt een onderscheid gemaakt tussen vereenvoudigingen in engere zin en andere maatregelen. Tot de eerste categorie behoren:

1. materiële vereenvoudigingen;

2. het vereenvoudigen van de tekst;

3. het streven om de tekst van de wet en de bedoeling van de wetgever volledig in overeenstemming met elkaar te doen zijn;

Tot de tweede categorie behoren:

1. een rustiger wetgeving, d.w.z.: minder wijzigingen en het vermijden van tijdelijke maatregelen met een niet-fiscaal doel;

2. geen terugwerkende kracht;

3. geen overhaaste wetgeving;

4. een goede overweging van het gebruik van het recht van amendement.

220. De eerste mogelijkheid wordt ook voorgestaan door de commissie-Oort. Die spreekt over het gegeven dat de vereenvoudiging niet kan wachten op een fundamentele herbezinning op de grondslagen van het belastingstelsel, zoals onder andere het inkomens- en vermogensbegrip. Tweede Kamer, vergaderjaar 1988-1989, 20 595, no 8, blz. 12. 
Opmerkelijk bij de vereenvoudigingsdrift is het gegeven dat er zo gestrooid kan worden met getallen betreffende de besparing op mensjaren. In tegenstelling tot de draagkracht schijnt het element van de doelmatigheid (lees gemakshalve: vereenvoudiging) wel gemakkelijk te berekenen te zijn. ${ }^{221}$ In het algemeen wordt in OORT-I het begrip vereenvoudiging alleen maar naar menskrachtbesparing vertaald. De parameter voor vereenvoudiging is de menskrachtbesparing c.q. de extra mankracht die nodig is. ${ }^{22}$ Dit terwijl, zoals aan het begin van de paragraaf is vermeld, onder vereenvoudiging wordt verstaan: een verbetering voor de burger, een toevloeien van de collectieve lasten naar de staatskas met zo min mogelijk maatschappelijke kosten en een beperking op menskracht bij de belastingdienst. ${ }^{223}$

Wat kan na de bestudering van de wetsgeschiedenis worden gezegd over het streven naar vereenvoudiging? Er kan worden geconstateerd dat van de vereenvoudigingsdrift weinig terecht is gekomen, aldus de Raad van State. ${ }^{224}$ De Eerste Kamer twijfelt ook of het vereenvoudigingsstreven wel gerealiseerd is of kan worden. ${ }^{225}$ De vraag is of het voor de burger wel zoveel eenvoudiger is geworden.

221. Vergelijk J.W. Zwemmer, Deregulering en afslanking, Weekblad voor fiscaal recht, 1988, no 5848, blz. 1581 en 1582.

De besparing van de menskrachten is geraamd op 1.705 per jaar. Advies belastingvereenvoudiging, SER, t.a.p., blz. 25 .

222. De operatie-OORT levert een mensjarenbesparing op van 1.610 mensjaren. Tweede Kamer, vergaderjaar 1987-1988, 20 595, no 3, blz. 17. Handelingen Tweede Kamer, vergaderjaar 19881989, blz. 26-60. Later zal blijken dat de menskrachtbesparing met een nadere realisering van de amendementen zal teruglopen tot \pm 1.150 . Handelingen Tweede Kamer, vergaderjaar 1988-1989, 20595 enz., blz. 40-502, mk.

Uit de OORT-evaluatie blijkt dat de menskrachtbesparing 1.140 mensjaren is. Eindrapport over de evaluatie OORT-wetgeving, t.a.p., blz. 17 en Eindrapport over de evaluatie OORTwetgeving, Bijlagen, Onderdeel Formatieve nacalculatie, t.a.p., blz. 10.

223. Vergelijk Minister Ruđing, die onder vereenvoudiging verstaat dat de collectieve lasten met zo min mogelijke maatschappelijke kosten hun weg vinden naar de staatskas. Handelingen Eerste Kamer, vergaderjaar 1988-1989, 20595 enz., blz. 27-1031, rk.

224. Tweede Kamer, vergaderjaar 1987-1988, 20 595, B, blz. 9 en 10. Zie ook Oort in het NRC Handelsblad van 22 mei 1993, blz. 14.

225. Eerste Kamer, vergaderjaar 1988-1989, 20 595, no 131a, blz. 1 en Handelingen Eerste Kamer, vergaderjaar 1988-1989, 20595 enz., blz. 26-998 en 26-1011.

Met betrekking tot de overhevelingstoeslagoperatie is duidelijk geworden dat lang niet in alle opzichten de gewenste vereenvoudiging is bereikt. Tweede Kamer, vergaderjaar 1992-1993, 23 269, no 4, blz. 4. Zie ook Eindrapport over de evaluatie OORT-wetgeving, t.a.p., blz. 6. 


\subsubsection{Budgettaire overwegingen}

De precieze budgettaire cijfers zijn aanvankelijk bij de behandeling van het wetsvoorstel OORT-I nog niet helemaal bekend. ${ }^{206} \mathrm{De}$ regering verwijst naar de behandeling van het wetsvoorstel OORT-II. ${ }^{27}$

In hoeverre hebben budgettaire overwegingen een rol gespeeld bij de concrete voorstellen? Puur budgettaire redenen hebben de lengte van de eerste schijf bepaald. ${ }^{228}$ 'Naast nobele fiscale principes, zat er (bij de indiening van OORT-I, OORT-II en OORT-III, MW) een heel praktisch standpunt bij: er moest voldoende geld worden gevonden.,220

Ten gevolge van budgettaire overwegingen is de alleenstaande-toeslag afgeschaft. ${ }^{230}$ Het element van de doelmatigheid (lees: vereenvoudiging) is ook gebruikt als argument voor afschaffing van de toeslag, zij het dat budgettaire redenen de boventoon voerden. ${ }^{231}$

226. Achteraf blijkt het ook niet mogelijk te zijn de precieze cijfers te kunnen geven. Een reden daarvoor is onder andere dat andere fiscale maatregelen met budgettaire gevolgen zijn doorgevoerd. Eindrapport over de evaluatie OORT-wetgeving, t.a.p., blz. 2.

227. Tweede Kamer, vergaderjaar 1987-1988, 20 595, no 3, blz. 17. De totale lasten (exclusief uitvoeringskosten) bedragen $f 4.995 \mathrm{mln}$.. Er is $f 4.925 \mathrm{mln}$. beschikbaar, $f 70 \mathrm{mln}$. is nog niet gefinancierd. Tweede Kamer, vergaderjaar 1988-1989, 20 595, no 6, blz. 7. Zie ook Eerste Kamer, vergaderjaar 1988-1989, 20 595, no 131b, blz. 9.

Uit de OORT-evaluatie blijkt het volgende: 'De kosten van het onderdeel tariefverlaging in combinatie met de uniformering van de heffingsgrondslag zijn (exclusief mutaties in de uitgavensfeer) circa $60 \mathrm{mln}$, ofwel $0,8 \%$ lager uitgevallen dan het bedrag aan bruto lastenverlichting van ruim 7 miljard gulden dat op de grond van de raming destijds mocht worden verwacht. De verbreding van de heffingsgrondslag door beperking van aftrekposten en vrijstellingen (Oort I en Oort II) heeft circa $115 \mathrm{mln}$, ofwel ruim $6 \%$ meer opgeleverd dan op basis van de in 1988 opgestelde raming mocht worden verwacht.' De dekkingsmaatregelen die geen onderdeel vormen van de OORT-voorstellen leveren structureel $75 \mathrm{mln}$., ofwel $5 \%$ minder op dan destijds was beraamd. Per saldo heeft de OORT-operatie geleid tot een belastingderving die ongeveer $100 \mathrm{mln}$. kleiner is dan de raming. Eindrapport over de evaluatie OORT-wetgeving, t.a.p., blz. 17 en Eindrapport over de evaluatie OORT-wetgeving, Bijlagen, Onderdeel Budgettaire nacalculatie, Ministerie van Financiën, Directoraat-Generaal voor Fiscale Zaken, Directie Algemene Fiscale Politiek, juli 1994, blz. 3.

228. Zie onder andere Handelingen Eerste Kamer, vergaderjaar 1988-1989, 20 595, enz., blz. 271077 , mk.

229. Handelingen Eerste Kamer, vergaderjaar 1988-1989, 20595 enz., blz. 27-1079, lk.

230. Tweede Kamer, vergaderjaar 1988-1989, 20 595, no 7, blz. 31, no 8, blz. 26. Handelingen Tweede Kamer, vergaderjaar 1988-1989, 20595 enz, blz. 40-2525, mk. Handelingen Eerste Kamer, vergaderjaar 1988-1989, 20595 enz., blz. 27-1081, lk. Zie kritiek van Stevens, inhoudende dat in een draagkrachtheffing waarin de bestaanskosten van invloed zijn op de belastingvrije voet, een verschil in de bestaanskosten moet worden gehonoreerd, tenzij de uitvoerbaarheid hier een stokje voor steekt. 'Het budgettaire element is niet een kwestie van niet kunnen, maar van niet willen.' L.G.M. Stevens, Vereenvoudigen is niet eenvoudig, Weekblad voor fiscaal recht, 1988, no 5833, blz. 1004.

231. Handelingen Tweede Kamer, vergaderjaar 1988-1989, 20595 enz., blz. 39-2378, rk, blz. 392379 , rk, blz. 39-2432, lk, rk. Ook hebben redenen van controle en uitvoerbaarheid een grote rol gespeeld bij de afschaffing van de alleenstaande-toeslag. 
Inzake de buitengewone lasten zijn de premies Ziekenfondswet en ziektekostenverzekering niet meer aftrekbaar. Dit wordt deels gemotiveerd met een beroep op budgettaire belangen.

Twee regelingen waarbij bij uitstek de budgettaire overwegingen de hoofdrol spelen, zijn de wetsvoorstellen OORT-II en OORT-III. ${ }^{232}$ Deze wettelijke regelingen komen in hoofdstuk 5 aan de orde.

Ondanks het streven van de politici om principiële zaken te doen voorgaan, spelen budgettaire overwegingen wel degelijk een rol. Zo stelt het Ministerie van Financiën zich op het standpunt dat budgettaire overwegingen een voldoende rechtvaardigingsgrond zijn om tot een ongelijke behandeling van gelijke gevallen over te gaan. ${ }^{233}$ '... op onderdelen heeft echter een nadere toetsing plaatsgevonden binnen het kader van die hoofdlijnen en binnen de randvoorwaarde van budgettaire neutraliteit. ${ }^{234}$ Tekenend is ook een opmerking van het kamerlid Van Amelsvoort (CDA): 'Ik wil niet zo ver gaan, te zeggen dat het toevallig is dat zij (amendementen, MW) dekking leveren voor de budgettaire schade van bepaalde amendementen, maar het komt de heren Kombrink en Engwirda wel goed uit dat zij op totaal andere gronden opbrengst leverende amendementen kunnen indienen en dan kunnen zeggen: nu leveren wij ook dekking voor amendementen die geld kosten'. 235

Budgettaire overwegingen worden derhalve vaak ter verdediging van standpunten gebruikt. Na deze constatering rijst de vraag welke rol budgettaire overwegingen mogen spelen? Is dat een rol van een aan de rechtvaardigheid ondergeschikte betekenis of een dominante rol? In geval van een rol van ondergeschikte betekenis, zijn budgettaire overwegingen niet meer dan randvoorwaarden. In geval van een dominante rol kunnen budgettaire overwegingen naast de rechtvaardigheidseisen staan, en in een onderling conflict deze rechtvaardigheidseisen opzij zetten. Het antwoord is niet met zekerheid te geven. Ik ben geneigd te opteren voor een niet dominante rol. Budgettaire overwegingen kunnen de werking van de (verdelings)beginselen, ik denk hierbij voornamelijk aan het draagkrachtbeginsel, in belangrijke mate beperken. Het kamerlid Vermeend (PvdA) merkt op: 'Wie niet gehinderd wordt door budgettaire beperkingen - ik spreek over de fiscale vakpers - heeft inderdaad meer ruimte om een fiscaal-theoretisch zeer verantwoord stelsel op papier te zetten. ${ }^{236}$

232. Tweede Kamer, vergaderjaar 1988-1989, 20 595, no 8, blz. 40.

233. J. van Elk is van mening dat budgettaire elementen geen reden mogen zijn voor een ongelijke behandeling van gelijke gevallen. $W$. Timmer, Belastingadviseur en de vereenvoudiging van de uitvoering, Weekblad voor fiscaal recht, 1988, no 5827, blz. 740. Een ander voorbeeld is het beroep op de budgettaire elementen in de splitsingkwestie en de drempelbepaling van $f 200$ van de teruggaafgrens. Zie L.G.M. Stevens, Eenvoudig belasten is lastig, Weekblad voor fiscaal recht, 1988, no 5844, blz. 1400 en 1409.

234. Persbericht Financiën, no $87 / 369$, blz. 1 .

235. Handelingen Tweede Kamer, vergaderjaar 1988-1989, 20595 enz., blz. 26, mk.

236. Handelingen Tweede Kamer, vergaderjaar 1988-1989, 20595 enz., biz. 39-2435, mk. Minister Ruding verwoordt het als volgt: 'Je hebt niet alleen principiële of theoretisch-fiscale overwegingen, maar ook puur budgettaire; helaas kan niet alles tegelijk.' Handelingen Eerste Kamer, 
Zeker dient ervoor gewaakt te worden dat budgettaire overwegingen in die mate de hoofdrol gaan spelen, dat er als het ware naar de verdelingsbeginselen 'toe wordt geredeneerd'. Met het laatste bedoel ik te zeggen dat de verdelingsbeginselen erbij worden gesleept om toch vooral enige rechtvaardiging aan de belastingheffing te geven.

\subsubsection{De rol van pressiegroepen}

Een belangrijk punt betreft de aanwezigheid van pressiegroepen. L. Koopmans schrijft in 1975: 'De laatste tijd komt in toenemende mate de gedachte naar voren, dat de verdeling van de belastingdruk zoals die in de verschillende belastingwetten is neergelegd, niet het resultaat is van consequente toepassing van belastingbeginselen, maar in feite tot stand komt onder invloed van de machtsverhoudingen in het parlement en pressie van belangengroepen ${ }^{237}$. Dit punt mag in het kader van de toepassing van de beginselen niet worden veronachtzaamd. Het element van de pressiegroepen kan doorslaggevend zijn in geval van twijfel bij politieke issues.

Veelal zijn er veel commentaren van allerlei organisaties op wetsontwerpen. Dit is ook niet verkeerd. Door het geven van commentaar wordt het voor de wetgever duidelijk of hij veel of weinig weerstand kan verwachten bij de invoering van een wetsontwerp. Maar het geven van commentaar moet mijns inziens wel worden onderscheiden van eisen van pressiegroepen, die geen rekening houden met het belastingstelsel in zijn geheel.

Het is een gegeven dat pressiegroepen een rol spelen. Alleen in hoeverre en waar is moeilijk te achterhalen. ${ }^{238}$ Alleen in de instanties waar de pressiegroepen officieel zijn vertegenwoordigd, kan de mening of de voorkeur en de mate van invloed van een pressiegroep enigszins worden achterhaald. Met officieel bedoel ik dat de aanwezigheid van pressiegroepen of wettelijk is vastgelegd of dat de pressiegroepen op uitnodiging aan een overleg deelnemen en eventueel een beslissing nemen. In deze zin zijn de pressiegroepen enigszins controleerbaar. Als voorbeelden kunnen dienen de leden van de Stichting van de Arbeid en van de Sociaal-Economische Raad. Dezen kunnen vertegenwoordigers van pressiegroepen zijn.

Daarnaast moet worden verondersteld dat de lobby van de pressiegroepen veelal niet open en onduidelijk plaatsvindt. In deze gevallen is het moeilijk te achterhalen wat de meningen en de mate van invloed op de uiteindelijke beslissingen zijn.

vergaderjaar 198-1989, 20595 enz., blz. 27-1035, lk.

237. Koopmans spreekt al in 1975 over de toenemende druk van onder andere pressiegroepen. Verder spreekt hij van een toenemende druk van de overheidsuitgaven en de stijgende belastingdruk. Hij heeft het weliswaar over de uitgavenkant, maar mijns inziens kan hetzelfde worden gesteld ten aanzien van de vaststelling van de inkomsten van de overheid, zoals het instrument van de belastingheffing. L. Koopmans, Overheidsfinanciën, Stenfert Kroese, derde druk, 1975, blz. 51. Zie ook F.H.M. Grapperhaus, Vereenvoudiging van de belastingheffing een vraagstuk voor managers, Weekblad voor fiscaal recht, 1986, no 5750, blz. 1438.

238. Hiervoor zou een empirisch onderzoek moeten worden gestart. 
In het element van de pressiegroepen schuilt het gevaar dat aan de verdelingsbeginselen geen werking (meer) kan worden toegekend, omdat andere belangen op het spel staan. Of het toeval wil dat de werking van de verdelingsbeginselen overeenkomt met de belangen die worden behartigd. ${ }^{239}$

In het element van de pressiegroepen schuilt een dilemma. Wetsvoorstellen moeten een behoorlijke mate van maatschappelijke acceptatie hebben, willen zij de voorgestane werking hebben. In een pressiegroep kan de maatschappelijke aanvaarding tot uitdrukking komen. Mits de pressiegroep een breed draagvlak heeft, zal de maatschappelijke aanvaarding van een wetsvoorstel ook groot zijn. En hiermee is dan ook voldaan aan het principe van de democratie. Maar indien een pressiegroep niet een breed draagvlak heeft en toch een grote invloed op de totstandkoming van de uiteindelijke wet heeft, komt het principe van de democratie in gevaar (zie verder hoofdstuk 6).

Bij het rapport van de commissie-Oort en het wetsvoorstel OORT-I spelen de pressiegroepen ook een rol. $\mathrm{Na}$ de aanbieding van het rapport van de commissieOort wordt het duidelijk dat bepaalde pressiegroepen een aanzienlijk aandeel willen hebben in de operatie. ${ }^{240}$ Hierdoor zijn bepaalde voorstellen weer teruggedraaid of niet zo aangescherpt als aanvankelijk de bedoeling is geweest. Deze praktijk heeft weinig te maken met de beginselenproblematiek. Ik kan zelfs stellen dat door de praktijk de werking van beginselen in belangrijke mate wordt ondergraven. Dit komt met name doordat pressiegroepen het eigen belang nastreven zonder dat het geheel in het oog wordt gehouden. ${ }^{241}$

Een spraakmakend item is de discussie rond afschaffing van de alleenstaandetoeslag geweest. Pressiegroepen hebben geijverd voor handhaving van de alleenstaande-toeslag met een beroep op het rechtvaardigheidsbeginsel. Ik moet toegeven dat het hier wel een beginsel-kwestie betreft; afschaffing zou een onduldbare inbreuk op de het beginsel van de rechtvaardige verdeling van de lasten betekenen. ${ }^{242}$ Weliswaar is met betrekking tot de alleenstaande-toeslag een overgangsregeling getroffen, maar de druk van de pressiegroepen is toch niet voldoende groot geweest, om de afschaffing van de toeslag tegen te houden.

239. Pressiegroepen opperen het idee om het fiscale instrument voor nevendoeleinden te hanteren. Handelingen Eerste Kamer, vergaderjaar 1988-1989, 20595 enz., blz. 27-1034, mk. Een rechtsongelijkheid kan ook ontstaan. L.G.M. Stevens, Vereenvoudigen is niet eenvoudig, Weekblad voor fiscaal recht, 1988, no 5833, blz. 1001. Zie ook onder andere Handelingen Eerste Kamer, vergaderjaar 1988-1989, 20595 enz., blz. 26-1011, rk, 27-1031, lk, en E. Aardema, Rapport van de commissie-Oort; een voorlopig oordeel, Weekblad voor fiscaal recht, 1986, no 5733, blz. 764.

240. Zie C.P.A. Bakker, Weerstanden tegen vereenvoudiging, Weekblad voor fiscaal recht, 1988, no 5844, blz. 1372-1376.

241. Het fenomeen van de pressiegroepen is met name voor de staatsrechtelijke verhoudingen interessant. Vroeger kende men een vorm van ruggespraak. Nu lijkt de weg omgekeerd. De achterban gaat zelf naar zijn of haar vertegenwoordiger(s) toe.

242. L.G.M. Stevens, Eenvoudig belasten is lastig, Weekblad voor fiscaal recht, 1988, no 5844, blz. 1404 en C.C.H.J. Driessen, Vereenvoudigen in rechtvaardig perspectief, Weekblad voor fiscaal recht, 1988, no 5844 , blz. 1475. 
Een ander voorbeeld betreft de door de sociale partners geëiste inbreuken op het loonbegrip. De vakantie-bonnen moeten voor $75 \%$ in plaats van de voorgestelde $100 \%$ nominale waarde in aanmerking worden genomen. ${ }^{243} \mathrm{Zo}$ niet, dan gaat de vereenvoudigingsoperatie niet door. Met betrekking tot de overhevelingstoeslag is een compromis bereikt met het bedrijfsleven. ${ }^{244}$ Het volgende voorbeeld betreft een regeling, waarin de regering 'omgaat' zonder een echte deugdelijke motivering; het betreft het verschil in normbedragen van de reiskostenvergoedingen en de reiskosten-aftrek. De regering 'gaat om' met een beroep op de doelmatigheid. Zowel de commissie-Oort als de regering waren van mening dat het verschil opgeheven moest worden. Onder druk van de sociale partners wordt het verschil echter getolereerd. ${ }^{245}$

Het bovenstaande leert dat het element van de pressiegroepen niet is uit te bannen uit het proces van de belastingwetgeving. In hoeverre verdelingsbeginselen een bepalende rol spelen, is dus eens te meer de vraag. ${ }^{246}$

\subsubsection{De aftrekposten}

De wetgever is ertoe overgegaan een aantal aftrekposten te schrappen of te beperken. De voorstellen van de commissie-Oort worden volledig gevolgd. Bovendien gaat de wetgever veel verder. Zoals de commissie-Oort reeds verwachtte, wordt de beperking van de aftrekposten niet met groot enthousiasme aanvaard. ${ }^{247}$ Hiermee komt de acceptatie van de belastingheffing in gevaar. De

243. L.G.M. Stevens, Eenvoudig belasten is lastig, Weekblad voor fiscaal recht, 1988, no 5844, blz. 1398. Een ander voorbeeld waarin de pressiegroepen een rol spelen, is het volgende. De commissie-Oort stelde ten aanzien van voor de kleinschaligheidstoeslag te verrekenen met de belasting. Onder druk van het midden- en kleinbedrijf kan thans de kleinschaligheidstoeslag worden verrekend met de belasting en de premies. H.P.A.M. van Arendonk, OORT-I en OORT-II, Maandblad Belasting Beschouwingen, 1988, no 9, blz. 223. Tweede Kamer, vergaderjaar 1988-1989, 20 595, no 8, blz. 48.

De commissie-Stevens stelt weer voor de vakantiebonnen voor $100 \%$ te belasten. Graag of niet, t.a.p., blz. 65 .

244. Handelingen Tweede Kamer, vergaderjaar 1988-1989, 20595 enz., blz. 40-2544, 42-2630, lk. De prijs die de werkgevers hebben moeten betalen voor het compromis is de afschaffing van het voordeel van de opslagpremies volksverzekeringen (AWBZ en AAW). De voorgestelde tariefstructuur daarentegen kan door het bereiken van het compromis worden ingevoerd. H.P.A.M. van Arendonk, De 'Oortse-wijzigingen' en de Tweeverdienerswetgeving, Maandblad Belastingbeschouwingen, 1989, no 4, blz. 81.

245. H.P.A.M. van Arendonk, OORT-I en OORT-II, Maandblad Belastingbeschouwingen, 1988, no 9, blz. 224. Van Arendonk beschrijft in dit artikel nog meer voorbeelden waarin pressiegroepen een doorslaggevende rol spelen. Een ander punt dat aan het bovenstaande verwant is het feit dat de concurrentiepositie van Nederland ten opzichte van het buitenland ook een rol heeft gespeeld. Zie bij voorbeeld Handelingen Tweede Kamer, vergaderjaar 1988-1989, 20595 enz., blz. 39-2457, mk en Handelingen Eerste Kamer, vergaderjaar 1988-1989, 20595 enz., blz. 26-1008.

246. Handelingen Eerste Kamer, vergaderjaar 1988-1989, 20595 enz., biz. 26-1000, 27-1057.

247. Uit een onderzoek blijkt dat een meerderheid van de heffingsplichtigen die te maken krijgen met de inkomstenbelasting het wenselijk vinden dat in de toekomst meer aftrekposten worden geschrapt in ruil voor een verlaging van het tarief. Tweede Kamer, vergaderjaar 1992-1993, 
literatuur tekent bezwaar aan tegen de gang van zaken. Somsen: Wetgeving die geen rekening houdt met herkenbare beginselen, transparantheid, uitvoerbaarheid en acceptatie, wetgeving die bovendien tracht een veelheid van doelstellingen te realiseren, díe wetgeving ondermijnt het respect voor de wet en bevordert anti-fiscaal gedrag. 248

De Kamer eist een nadere motivering voor het schrappen van bepaalde posten. ${ }^{249}$

De materie inzake de aftrekposten hangt voor een groot deel samen met de budgettaire overwegingen. De regering stelt zich op het standpunt dat de wetsvoorstellen OORT-I, OORT-II en OORT-III een zodanige samenhang hebben dat deze niet afzonderlijk kunnen worden bezien.

Het gelijkheidsbeginsel speelt een aanzienlijke rol op het punt van de aftrekposten, in het bijzonder bij de kwestie van de zgn. asymmetrie. ${ }^{250}$ Belangrijk in dit verband zijn het Koffiegeld-arrest en het Kinderopvang-arrest. ${ }^{251}$ Blijkens het eerste arrest moet de volgende regel in acht worden genomen: indien de vergoedingen niet als inkomen worden beschouwd, dienen de kosten aftrekbaar te zijn voor degene die geen vergoeding krijgt. Dit wordt door het gelijkheidsbeginsel geëist. Maar volgens de Hoge Raad kan de ongelijkheid bestaande in een hogere belastingvrije vergoeding dan het bedrag dat aftrekbaar is, worden gerechtvaardigd door de doelmatigheid èn de uitdrukkelijke vermelding in de wet. ${ }^{252}$

In het Koffiegeld-arrest gaat het om een gedogen in de uitvoeringssfeer en een door de wetgever gecreëerde ongelijkheid; in het Kinderopvang-arrest bewerkstelligt de wetgever de ongelijkheid.

Geredeneerd zou kunnen worden dat een belastingplichtige die een onbelaste vergoeding heeft voor een bepaalde aftrekpost, een grotere draagkracht heeft dan de belastingplichtige die geen vergoeding heeft en de aftrekpost ook niet kan aftrekken.

Een verdere uitwerking van deze en andere arresten, de aftrekposten en een nadere bespreking van de rol van het gelijkheidsbeginsel en het draagkrachtbeginsel wordt in hoofdstuk 5 gegeven.

22374 , no 2 , blz. 4. De beperking van de onbelastbaarheid van kostenvergoedingen kent daarentegen enige weerstand. OORT en de heffingsplichtigen, maart 1991, t.a.p., blz. $16 \mathrm{en}$ 54. De inhoudingsplichtigen hebben weinig waardering voor de beperkingen in de aftrekposten. OORT en de inhoudingsplichtigen, maart 1991, t.a.p., blz. 14.

248. Th.D.F. Somsen, Ein Mädchen für alles?, Weekblad voor fiscaal recht, 1985, no 5672, blz. 262.

249. Tweede Kamer, vergaderjaar 1987-1988, 20 595, no 7, blz. 40.

250. Uit de tweede tussenrapportage van de OORT-evaluatie blijkt dat de Belastingdienst moeite heeft met de inconsequente behandeling van vergoedingen en aftrekposten. Tweede Kamer, vergaderjaar 1992-1993, 22 374, no 2, blz. 17. Evaluatie OORT-wetgeving, Deelproject Inkomstenbelasting Particulieren, Ervaringen van de Belastingdienst, Ministerie van Financiën, Directoraat-Generaal der Belastingen, J.M. Haring-Lohman, rapportno 26, oktober 1992, blz. 6.

251. HR 22 juni 1988, nr 24 592, BNB 1988/259 m.nt. Van Dijck. Een soortgelijk arrest is HR 12 december 1990, BNB 1991/76 m.nt. P. den Boer inzake de kosten voor kinderopvang. Inmiddels zijn enige resoluties en wetsontwerpen gevolgd.

252. Tweede Kamer, vergaderjaar 1988-1989, 20 595, no 8, blz. 38, no 13, blz. 46. 


\subsubsection{Andere beginselen}

In de wetsgeschiedenis is een aantal nader te noemen 'elementen' als fiscaal beginsel bestempeld. Een daarvan is 'het niet twee keer belasting heffen'. Het doel van de OORT-operatie is dat de premies niet meer aftrekbaar zijn en dat de tarieven worden verlaagd. In dit doel moet een rechtvaardiging worden gezien voor het niet twee maal heffen van belasting. Het beginsel van niet twee maal belasting heffen wordt naar de mening van enige parlementariërs geschonden doordat de premiebetalingen volksverzekeringen niet meer aftrekbaar zijn. Het tweemaal heffen van belastingen schuilt hierin dat de premies niet meer aftrekbaar zijn, maar dat daarentegen de uitkeringen wel worden belast. De vraag hierbij is of het betalen van premies als een verkapte belastingheffing moet worden gezien. Hierover wordt verschillend gedacht. ${ }^{253}$ Opgemerkt zij dat het opzij zetten van de principiële gedachten over het verzekeringskarakter van de volksverzekeringen met minder commotie gepaard is gegaan dan is vermoed. ${ }^{254}$

Een ander beginsel dat in het kader van de OORT-wetgeving is gebruikt, is het beginsel van de minste pijn (zie hoofdstuk 7). Dit beginsel wordt afgezet tegenover de duidelijkheid van de burger over zijn publieke verplichtingen. Het feit dat de loonbelasting vaak eindheffing zal zijn (beginsel van de minste pijn, $M W$ ), moet belangrijker worden geacht dan de duidelijkheid. ${ }^{255}$

Een derde 'element' dat als fiscaal beginsel wordt bestempeld, is het beginsel van de fiscaliteit. 'Je kunt immers constateren dat het beginsel van de fiscaliteit leidend is en wordt en dat dat van de sociale zekerheid een afgeleide zal zijn, bij voorbeeld wanneer vanuit de fiscaliteit bepaalde vergoedingen geheel of gedeeltelijk onderworpen zijn aan loonbelasting en premieheffing. ${ }^{, 256} \mathrm{Er}$ wordt niet omschreven wat onder het beginsel van de fiscaliteit moet worden verstaan.

Een vierde beginsel is dat van de economische zelfstandigheid. Dit beginsel moet in de belastingheffing tot uiting komen, aldus enige kamerleden. ${ }^{257}$ Ook hier wordt niet precies aangegeven wat onder het beginsel moet worden verstaan. Het gevaar van het benoemen van een element als beginsel is, dat het element een soort verheven functie krijgt. Hierdoor kan het zicht op het werkelijke belang van een element worden vertroebeld.

253. Tweede Kamer, vergaderjaar 1988-1989, 20 595, no 8, blz. 10.

254. In de Eerste Kamer is een motie ingediend door Christiaanse en Van Graafeiland inhoudende een bevestiging van een afzonderlijke herkenbaarheid van de belastingen en premies. Eerste Kamer, vergaderjaar 1988-1989, 20595 enz., no 190d.

255. Verslag forumdiscussie, Weekblad voor fiscaal recht, 1986, no 5750, blz. 1475.

256. De Leeuw (CDA), Handelingen Tweede Kamer, vergaderjaar 1988-1989, 20595 enz., blz. 42$2580, \mathrm{mk}$.

257. De regering vindt dat het beginsel van de economische zelfstandigheid voldoende tot uitdrukking komt in het fiscale stelsel. Tweede Kamer, vergaderjaar 1988-1989, 20 595, no 8, blz. 31. 
Het vijfde beginsel is het kostwinnersbeginsel. Dit beginsel speelt bij de overdracht van de basisaftrek; deze komt ten goede aan de kostwinners, in hoofdzaak mannen. De vraag is of dit geen indirecte discriminatie is in de zin van de derde richtlijn (79/7 EEG) inzake de gelijke behandeling van mannen en vrouwen op het gebied van de sociale zekerheid ( $\mathrm{Pb}$. 1979, L6/24). In het algemeen wordt geconcludeerd wordt dat er geen strijd is met het gelijkheidsbeginsel. ${ }^{258}$

\subsection{Samenvatting en conclusies}

\section{Algemeen}

De OORT-wetgeving is in werking getreden. Aanvankelijk zijn de voorstellen van de commissie-Oort met veel gejuich ontvangen.

In hoeverre kan de OORT-wetgeving als afspiegeling van het rapport van de commissie-Oort worden gezien? Het wetsvoorstel inzake OORT-I is via allerlei amendementen allengs ingewikkelder geworden. Geconcludeerd kan worden dat de regering het voorstel van de commissie-Oort in hoofdlijnen heeft gevolgd. Maar daarmee is ook alles gezegd. Hetgeen in de considerans ${ }^{259}$ staat, is beperkt opgevat; de mededeling dat naar aanleiding van het rapport van de commissie-Oort de belastingheffing wordt herzien, heeft een enigszins marginale betekenis.

Voorzitter Oort is niet helemaal gelukkig met het uiteindelijke resultaat: 'Gevreesd moet echter worden dat het 'statische gemillimeter' met verdelingseffecten en de bijna onaantastbaarheid van de status quo ons voorlopig veroordeelt tot het in stand houden van een inefficiënte en demotiverende 'rondpompmachine". 260

258. Zie onder andere Handelingen Tweede Kamer, vergaderjaar 1988-1989, 20595 enz., blz. 392393, 1k, mk. Groenman (D66) denkt er anders over. Handelingen Tweede Kamer, vergaderjaar 1988-1989, 20595 enz., blz, 39-2462, lk, mk.

De Emancipatieraad is een andere mening toegedaan. Deze redeneert aldus, dat kostwinners in de premieheffing worden bevoordeeld boven niet-kostwinners. De groep kostwinners bestaat voor het overgrote deel uit mannen. Derhalve roept het kostwinnerscriterium een vermoeden op van indirecte discriminatie. Er moet bewezen worden dat er sprake is van een objectieve en redelijke rechtvaardigingsgrond, aldus de raad. Emancipatieraad, t.a.p., blz. 19. De regering vindt de grond in het vereenvoudigingsstreven. Emancipatieraad, t.a.p., blz. 20.

259. 'Alzo $\mathrm{W}_{\mathrm{ij}}$ in overweging genomen hebben, dat het wenselijk is de belastingheffing te herzien naar aanleiding van (cursivering schrijver dezes) het rapport van de commissie tot vereenvoudiging van de loonbelasting en de inkomstenbelasting; $\mathrm{Zo}$ is het, dat $\mathrm{Wij}_{\mathrm{ij}}$ de Raad van State gehoord, en met gemeen overleg der Staten-Generaal, hebben goedgevonden en verstaan, gelijk Wij goedvinden en verstaan bij deze: ...' Stb. 1989, 122, blz. 1.

260. C.J. Oort, Belastingherziening in de jaren negentig, Maandblad Belastingbeschouwingen 1990 , no 10, blz. 262. 


\section{Het draagkrachtbeginsel}

Wat de verdelingsbeginselen in het algemeen betreft, kan geconstateerd worden dat zij bij de totstandkoming van de Oort-wetgeving een bescheiden rol hebben gespeeld. ${ }^{261}$

Uit de bestudering van de kamerstukken blijkt dat aan het draagkrachtbeginsel minder gewicht wordt toegekend dan voorheen. Dit geldt zeker ten aanzien van bepaalde onderdelen van het wetsvoorstel. De door de regering gevolgde redenering met betrekking tot het draagkrachtbeginsel is niet altijd even helder en sterk. Een voorbeeld is de afschaffing van de alleenstaande-toeslag. De argumenten tegen handhaving van de alleenstaande-toeslag wisselen nogal eens. Het geheel heeft meer het karakter van 'het naar een resultaat toewerken' gekregen, te weten naar het afschaffen van de alleenstaande-toeslag.

Een verminderde werking van het draagkrachtbeginsel kan ook worden waargenomen in de ingevoerde asymmetrie betreffende de aftrekbaarheid van bepaalde posten als kosten en de belastbaarheid van op die posten betrekking hebbende vergoedingen. In geval van niet-aftrekbare kosten tegenover onbelaste vergoedingen, kan worden gesteld dat in het eerste geval de draagkracht van de belastingplichtige kleiner is dan in het tweede.

Uit de geschiedenis van de wetgeving inzake OORT-I valt wellicht af te leiden dat aan het draagkrachtbeginsel in het verleden een 'overdreven' werking is toegekend. Ik bedoel hiermee dat velen hardnekkige pogingen doen om te doen geloven dat de Nederlandse inkomstenbelasting een belastingheffing naar draagkracht is, terwijl in werkelijkheid het belang van het draagkrachtbeginsel is verminderd.

\section{Het gelijkheidsbeginsel}

Het in de Tweeverdienerswetgeving voorgestane streven naar gelijke behandeling van de gehuwden met de ongehuwd samenlevenden wordt in het regeringsvoorstel gedeeltelijk teniet gedaan. Echter onder parlementaire druk worden de voorstellen te dien aanzien grotendeels teruggedraaid. Duidelijk is dat inzake deze materie in die jaren geen consistent beleid is gevoerd.

Bovendien speelt het gelijkheidsbeginsel ook in de al eerder genoemde asymmetrie tussen de kostenvergoedingen en de aftrekbare kosten. Deze materie komt in hoofdstuk 5 uitvoerig aan de orde.

\section{Het vereenvoudigingsstreven}

Aan het streven naar vereenvoudiging wordt een groter gewicht toegekend dan voorheen. De vereenvoudiging is datgene waar alles mee begonnen is. Of uiteindelijk de vereenvoudiging ook wordt bereikt, is blijkbaar een vraag van een andere orde. In het parlement zijn na indiening van de wetsvoorstellen, mede naar aanleiding van hetgeen in de literatuur wordt opgemerkt, verscheidene

261. Vergelijk D.A. Albregtse, die een onderscheid maakt tussen de politieke haalbaarheid en de belastingbeginselen. 'De politieke haalbaarheid heeft het voorzover het er nu bij staat, gewonnen van de belastingbeginselen'. D.A. Albregtse, Oort I + II en de aftrekposten: minder eenvoud en meer bezuiniging, Maandblad Belastingbeschouwingen, 1988, no 11, blz. 322. 
discussies gevoerd die tot een zekere rechtsverfijning hebben geleid. Die verfijning heeft afbreuk gedaan aan de oorspronkelijk beoogde vereenvoudiging; maar in deze fase stond het vereenvoudigingsbelang bij de wetgever inmiddels lager op de prioriteitenlijst. Hier komt nog bij dat onder vereenvoudiging vaak alleen maar de menskrachtbesparing wordt verstaan. En niet de verbetering voor de burger en het toevloeien van de collectieve lasten naar de staatskas met zo min mogelijke maatschappelijke kosten, welke blijkens de kamerstukken ook onder de vereenvoudiging zou moeten worden verstaan. Door vereenvoudiging te verengen tot menskrachtbesparing komt zij erg dicht bij de doelmatigheid te liggen. Mijns inziens moet onder vereenvoudiging toch iets anders worden verstaan dan onder doelmatigheid. Zeker, meer eenvoud leidt tot meer doelmatigheid. Maar te veel vereenvoudiging gaat ten koste van de rechtvaardigheid. Ondermijning van de rechtvaardigheid leidt uiteindelijk tot minder doelmatigheid, daar de acceptatie van de belastingheffing door de maatschappij in gevaar zal komen. Daardoor worden de kosten van de belastingopbrengst hoger.

\section{Budgettaire overwegingen}

Budgettaire overwegingen zijn in deze wetgevingsoperatie van groot belang geweest. Dit is zeker waar wat betreft de afschaffing van de alleenstaandetoeslag. Bovendien is de beperking of afschaffing van een groot aantal aftrekposten hoofdzakelijk ingegeven door financieringsproblemen.

Opmerkelijk is ook geweest dat de regering al ervan uit ging dat de wetsvoorstellen goedgekeurd zouden worden. Budgettaire overwegingen beperken de werking van de verdelingsbeginselen. In de Wet IB 1964 betekent dat voornamelijk een beperking van de werking van het draagkrachtbeginsel.

\section{De rol van pressiegroepen}

Wat voor de ene pressiegroep rechtvaardig is, is dat nog niet voor de andere. Vaak nemen pressiegroepen een klein deel van hetgeen in een wetsvoorstel wordt beoogd op de korrel. Door deze beperkte zienswijze kan het wetsvoorstel in zijn geheel in gevaar komen; door het al dan niet weglaten van bepaalde onderdelen kan de zgn. 'grote lijn' grote schade worden toegebracht. Hierdoor kan ook de werking van fiscale beginselen in het gedrang komen.

De conclusie van dit hoofdstuk kan tweeledig zijn, t.w.:

1. In vergelijking met voorgaande jaren komen bepaalde beginselen sterker naar voren en andere minder.

2. Een bepaald belang wordt in tegenstelling tot voorheen de status van een beginsel toegedicht, met andere woorden, het 'etiket' van beginsel opgeplakt. 



\section{OORT-II en OORT-III}

'Hoofdregelen der geregtigheid bij alle belastingen zijn: ... 3. gelijkmatigheid in de verdeeling. Elk behoort in die mate te worden belast, als hij deelneemt aan het gemeene welzijn, tot welks teweegbrenging de belastingen strekken. Iedere individu neemt daaraan deel volgens de mate van zijner krachten en zijner goederen, welke den weldadige invloed van de bescherming des staats en deszelfs inrigtingen ondervinden ..."

\subsection{Inleiding}

Op 10 oktober 1988 zijn de wetsvoorstellen OORT-II en OORT-III ingediend. ${ }^{2}$ In OORT-II wordt naast wijziging en aanvulling van het tarief de aftrek van bepaalde kosten, die een natuurlijk persoon in de niet-winstsfeer maakt te beperken of af te schaffen voorgesteld. De datum van inwerkingtreding van OORT-II is 1 januari 1990.

Het wetsvoorstel OORT-III beoogt een beperking of afschaffing van de in de winstsfeer gemaakte kosten. Dit wetsvoorstel wordt gedeeltelijk op 1 juli 1989 en gedeeltelijk op 1 januari 1990 ingevoerd.

OORT-II en OORT-III hebben als functie OORT-I te financieren. De opbrengst dient ter financiering van de verlaging van het tarief. De uiteindelijke lastenverlichting tengevolge van OORT-I moet 4,15 miljard bedragen. ${ }^{3}$ Opmerkelijk is dat

1. J.R. Thorbecke, bewerkt door J.P. Duyverman, Staatsinrigting en staatsbestuur, Gouda Quint, 1968 , blz. 79.

2. OORT-II is de Wet van 27 april 1989, houdende inwerkingtreding van de Wet vereenvoudiging tariefstructuur en aftrekposten in de loon- en inkomstenbelasting en in aanvulling op die wet wijzigingen van de loonbelasting en inkomstenbelasting inzake vaststelling van het tarief en beperking van de aftrekbaarheid gemengde kosten (Wet invoering en aanvulling van de vereenvoudiging van de tariefstructuur in de loon-en inkomstenbelasting en wijziging van de regeling betreffende aftrekposten), Stb. 1989, 123. Het wetsvoorstel is het resultaat van een compromis tussen het CDA en de VVD. H.P.A.M. van Arendonk, De operatie Oort: de vereenvoudiging weggesneden?, Maandblad Belastingbeschouwingen, 1988, no 11, blz. 302. De invoering van de OORT-wetgeving is over het algemeen goed verlopen. Onderscheid dient wel gemaakt te worden tussen het grote bedrijfsleven en het midden- en kleinbedrijf. Het eerstgenoemde heeft deskundigheid in huis, het tweede niet. H.P.A.M. van Arendonk, Oort en de ondernemer, de eerste ervaringen, Maandblad Belastingbeschouwingen, 1990, no 10, blz. 248. A. Timmermans, Oort en de ondernemer ofwel de caravan en de kroket, Maandblad Belastingbeschouwingen, 1990, no 10 , blz. 256.

OORT-III is de Wet van 27 april 1989, houdende wijziging van de inkomstenbelasting en de vennootschapsbelasting (beperking van de aftrekbaarheid van gemengde kosten in de winstsfeer), Stb. 1989, 124.

3. De lastenverlichting is als volgt samengesteld. Aanvankelijk was de lastenverlichting geraamd op 5,55 miljard. Hierop kwamen de volgende lastenverzwaringen in mindering: 1. 250 miljoen gulden voor verhoging van het huurwaardeforfait. 2 . De beperking van de aftrek gemengde kos- 
een deel van de opbrengst van OORT-II al is aangewend vó́r de goedkeuring van het wetsvoorstel.

Of de samenhang van OORT-II met OORT-I een gelukkige is, moet nog worden bezien. Van Elk verwoordt de samenhang aldus: 'Tenslotte, wat er ook zij van de omvang van de door de afschaffing van de WIR ontstane budgettaire ruimte, het feit dat de voorstellen van Oort-II in de winstsfeer reeds zouden moeten ingaan per 1 juli 1989, terwijl de maatregelen in de niet-winstsfeer pas ingaan op 1 januari 1990 tegelijk met de belastingverlichting die in beginsel voor iedereen voortvloeit uit Oort-I, miskent de onderlinge samenhang, zoals hierboven opgemerkt, hun enige theoretische rechtvaardiging - hoe aanvechtbaar ook - en is daarmee niet aanvaardbaar. ${ }^{4}$

Bij de bespreking van het wetsvoorstel OORT-II ligt de nadruk op het tweede onderdeel van het wetsvoorstel, t.w.: de beperking en de afschaffing van bepaalde kosten. De door een natuurlijk persoon gemaakte kosten in de niet-winstsfeer kunnen een zgn. gemengd karakter hebben. Simpel gezegd houdt een gemengd karakter in dat een privé-aspect verbonden is aan het maken van de kosten. Op grond van principiële fiscale overwegingen wordt het juist geacht om de gemeng-

ten niet-winstsfeer ad 375 miljoen. 3. Opbrengsten van het wetsvoorstel inzake mantels ad $\mathbf{1 7 5}$ miljoen. 4. Deel van de opbrengst Brede herwaardering ad 375 miljoen. 5 . Deel van de opbrengst van de beperking van de aftrek gemengde kosten in de winstsfeer ad 300 miljoen. Tweede Kamer, vergaderjaar 1988-1989, 20 873, no 5, blz. 16 en 17 en no 7, blz. 2.

Zie ook de Bijlagen bij het Eindrapport OORT-evaluatie. De totale kosten van de 'OORT-I en OORT-II'-operatie bedragen $6.845 \mathrm{mln}$. Het totaal van de dekkingsmaatregelen ( $3.140 \mathrm{mln}$.) en de belastingmeevaller $(3.350 \mathrm{mln}$.) bedraagt $6.490 \mathrm{mln}$. Het tekort bedraagt derhalve $355 \mathrm{~m} / \mathrm{n}$. (cijfers 1988). Eindrapport over de evaluatie OORT-wetgeving, Bijlagen, Onderdeel Budgettaire nacalculatie, Ministerie van Financiën, Directoraat-Generaal voor Fiscale Zaken, Directie Algemene Fiscale Politiek, juli 1994, blz. 7 en 8.

'Na verwerking van de tijdens de parlementaire behandeling aangebrachte amendementen en rekening houdend met de endogene ontwikkeling 1988-1990 conform de in de belastingramingen aangebrachte correctie op de oorspronkelijke ramingen zou de lastenverlichting voor burgers in cijfers 1990 zijn uitgekomen op ruim 5 mrd.' De nacalculatie leert dat de uiteindelijke lastenverlichting 4,8 mrd. bedraagt. Dit is 0,2 mrd. lager dan beoogd was. Bijlagen, t.a.p., blz. 20.

Zie echter De Kam en Sturm die concluderen dat de lastenverlichting 4,2 mrd. heeft bedragen. Bovendien tonen de auteurs aan dat de verdeling van de lastenverlichting tussen verschillende inkomensgroepen anders uitvalt dan door het Ministerie van Financiën berekend is. Een nader onderzoek achten zij dan ook gewenst. C.A. de Kam en J.E. Sturm, De effectieve druk van inkomensheffingen en vermogensbelasting, voor en na de operatie-'OORT', Weekblad voor fiscaal recht, 1994, no 6117, blz. 1272-1274 en Eindrapport over de evaluatic OORT-wetgeving, Bijlagen, Onderdeel Budgettaire nacalculatic, t.a.p., blz. 22.

4. A.J.M. van Elk, Commentaar van de Nederlandse Orde van Belastingadviseurs op wetsvoorstel 'OORT II', Weekblad voor fiscaal recht, 1988, no 5844, blz. 1463, zoals gewijzigd op blz. 1545. Feteris en Brouwer verwoorden het aldus: 'Van recht kan verder pas sprake zijn als de regeling na de herziening een consistent systeem vormt, waarin hoofdregels bestaan en gemotiveerde uitzonderingen voor afwijkende gevallen.' M.W.C. Feteris, J.Th.L. Brouwer, De vereenvoudiging ontspOort(2), fiscaal weekblad FED, 1988, no 714, blz. 2235. 
de kosten niet meer of althans niet meer voor $100 \%$ in aftrek toe te laten resp. te vergoeden. ${ }^{s}$ De tariefstructuur komt globaal aan de orde.

Aan de hand van wetsvoorstel OORT-II, de parlementaire geschiedenis en de kritiek in de literatuur bespreek ik achtereenvolgens de wetgevingsbeginselen, het draagkrachtbeginsel, het gelijkheidsbeginsel, het vereenvoudigingsstreven en de budgettaire overwegingen. Daarnaast bespreek ik de vraag of, en in hoeverre, pressiegroepen een rol hebben gespeeld. Ten slotte bespreek ik in een aparte paragraaf de in de parlementaire geschiedenis en in de literatuur genoemde andere dan bovengenoemde beginselen.

\subsection{Het wetsvoorstel OORT-II}

Het wetsvoorstel is opgebouwd uit twee elementen, $\mathrm{nl}$. de tariefstructuur en de kwestie van de gemengde kosten.

\section{Tariefstructuur.}

Bij de bespreking van het wetsvoorstel OORT-I is de tariefstructuur grotendeels aan de orde geweest. Voor de volledigheid volgen enige aanvullende opmerkingen. Hierbij zij aangetekend dat uitgegaan is van getallen en percentages zoals deze golden ten tijde van de invoering van OORT-II.

$\mathrm{Er}$ is een basisaftrek van $f 4.500$. De verticale tariefstructuur is in drie schijven verdeeld. De eerste schijf loopt tot $f 41.500$ en het percentage bedraagt inclusief de premieheffing volksverzekeringen $35,2 \%$. Voor bejaarden geldt een percentage van $18 \% .{ }^{6}$ Het tarief in de eerste schijf bedraagt voor de buitenlandse belastingplichtigen $25 \%$. De tweede schijf loopt van $f 41.500$ tot $f 83.000$. Het percentage bedraagt $50 \%$. De derde en tevens laatste schijf loopt vanaf $f 83.000$ en het

5. Handelingen Eerste Kamer, vergaderjaar 1988-1989, 20595 enz., blz. 27-1080. Internationaal gezien wordt in het begin van de jaren tachtig de aftrekbaarheid van gemengde kosten aangepakt. L. Koopmans, A.H.E.M. Wellink, H.J. Woltjer, C.A. de Kam, Overheidsfinanciën, zevende geheel herziene druk, Stenfert Kroese, 1991, blz. 195.

6. In 199 bedraagt het percentage 16,80 . Belastingplichtigen boven 65 jaar betalen thans ook premie voor de AWW dan wel voor de Algemene nabestaandenwet, Wet van 22 december 1993 , Stb. 736.

7. Dit taricf geldt voor de buitenlands belastingplichtige die geen of nagenoeg geen binnenlands belastbaar inkomen heeft. Interessant is dat de Hoge Raad een uitspraak van het Hof van Justitie van de Europese Gemeenschappen te Luxemburg ex artikel 177 EEG-verdrag heeft gevraagd omtrent de eventucle strijdigheid van artikel 53b Wet IB 1964 met artikel 48 Verdrag tot oprichting van de EG. HR 23 maart 1994, BNB 1994/154, V-N 1994, blz. 1381. Vergelijk ook de uitspraak van Hof 's-Gravenhage 11 december 1992, V-N 1992, blz. 470, waarin wordt geoordeeld dat artikel 20b Wet LB 1964 geen discriminatie inhoudt. Het hogere buitenlandtarief is ingevoerd om misbruik te voorkomen; dit vormt een objectieve en redelijke rechtvaardiging voor het onderscheid, aldus het hof. 
percentage bedraagt $60 \% .{ }^{8}$ Het variabele bijzondere tarief wordt vervangen door een vast tarief van $45 \%$.

Alle toeslagen, behalve de (aanvullende) alleenstaande-oudertoeslag, verdwijnen. Met betrekking tot de alleenstaande-toeslag is een overgangsregeling getroffen die inmiddels is uitgewerkt.

\section{Gemengde kosten.}

Gemengde kosten zijn: 'Uitgaven, ... die vaak naast het zakelijke doel tevens het persoonlijke leven van de belastingplichtige dienen en waarvan het beloop in de praktijk, gezien het karakter van de uitgave, in veel gevallen mede afhankelijk is van de mate waarin de fiscale systematiek leidt tot relatief lage netto-kosten."9 Het criterium van een gemengde-kostenpost is volgens de regering dat uiteindelijk iemand een privé-genot heeft van de gedane uitgave. ${ }^{10}$ De gemengde kosten zijn aftrekbaar op grond van artikel 35 Wet IB $1964 .{ }^{11}$ Het veronderstelde privéaspect wordt door het wetsvoorstel geëlimineerd; de gemengde kosten zijn of geheel of gedeeltelijk niet meer aftrekbaar.

\section{Aftrekbare kosten.}

Belangrijk in het wetsvoorstel zijn de wijzigingen en vernieuwingen van de artikelen 35 en 36 Wet IB 1964. Artikel 35 Wet IB 1964 is het algemene artikel betreffende de aftrekbare kosten en artikel 36 Wet IB 1964 bevat een negatieve lijst van niet (meer) aftrekbare kosten en een lijst met beperkt aftrekbare kosten. Eerst moet voldaan zijn aan de criteria van artikel 35 Wet IB 1964, wil sprake kunnen zijn van een toepassing van artikel 36 Wet IB $1964 .{ }^{12}$

Het bestaande systeem van de aftrekbare kosten blijft naast de wetsvoorstellen OORT-II en OORT-III gehandhaafd. Artikel 35 Wet IB 1964 en de desbetref-

8. Persbericht ministerie van Financiën, 21 juli 1988, no 88, 183. Tweede Kamer, vergaderjaar 19881989,20873 , no 1-2. Thans bedraagt de basisaftrek $f 6.074$. De eerste schijf beloopt tot $f 44.349$ (tariefpercentage 6,15, volksverzekeringspremiepercentage 31,5); de tweede tot $f 88.696$ (tariefpercentage 50); de derde kent een tariefpercentage van 60.

9. Tweede Kamer, vergaderjaar 1988-1989, 20873 , no 3, blz. 11 en no 5, blz. 27.

10. De Raad van State verstaat onder privé-sfeer: alle werkzaamheden buiten de ondernemingssfeer. De Raad van State is van mening dat alleen ingeval van kosten die de ondernemer zelf betreffen, gesproken moet worden van gemengde kosten. Tweede Kamer, vergaderjaar 19881989,20874 , no B, blz. 2 en 4.

11. Bink en Wasch spreken van een 'maatmancritcrium'. N. Bink, E, Wasch, Aftrekbare kosten en vergoedingen, Kluwer Belastingwijzers 7, 4e herziene druk, 1991, blz. 11 en Handelingen Tweede Kamer, vergaderjaar 1988-1989, 20595 enz., blz. 26-49 (Vermeend, PvdA). Tweede Kamer, vergaderjaar 1988-1989, 20 873, no 5, blz. 27.

12. De kosten genoend in artikel 36 Wet IB 1964 hoeven niet meer aan het omvangs- en vergelijkingscriterium te worden getoetst. Dit heeft de wetgever al gedaan. Zie onder andere Handelingen Tweede Kamer, vergaderjaar 1988-1989, 20595 enz., blz. 26-49, rk, 26-51, lk en 39-2435, rk, Handelingen Eerste Kamer, vergaderjaar 1988-1989, 20595 enz., blz. 27-1081, rk. Hoe moeilijk deze materie is, blijkt wel uit het feit dat tijdens de behandeling van de reparatiewetgeving(!) nog steeds door het parlement de vraag wordt gesteld hoe het nu precies zit met de relatie tussen artikel 35 en artikel 36 Wet IB 1964. Eerste Kamer, vergaderjaar 1989-1990, 21 184, no $60 a, b l z .1$. 
fende jurisprudentie blijven van toepassing. ${ }^{13}$ Het systeem draait om een marginale toetsing van 'onredelijkheid'. De 'onredelijkheid' bepaalt de grens tussen de inkomensverwerving en inkomstenbesteding. ${ }^{14}$

Uniek in het wetsvoorstel is de doorbreking van de symmetrie tussen de aftrekbaarheid van bepaalde kosten en, indien een vergoeding wordt gegeven, de onbelastbaarheid van de vergoedingen van de desbetreffende kosten. In het wetsvoorstel kan een tweedeling worden gemaakt in de niet (meer) aftrekbare kos$\operatorname{ten}^{15}$, t.w.:

1. de kosten die niet (meer) aftrekbaar zijn en waarvoor de vergoeding door de werkgever belast is;

2. de kosten die niet (meer) aftrekbaar zijn en waarvoor de door de werkgever gegeven vergoeding onbelast is. ${ }^{16}$

Het volgende schema inzake de (niet) aftrekbare kosten en (on)belaste vergoedingen ontstaat:

KOSTEN

1. aftrekbaar

2. niet aftrekbaar

3. niet aftrekken

\section{VERGOEDING}

onbelast;

belast; onbelast (nieuwe mogelijkheid).

13. J. Hoogendoorn, Enkele opmerkingen naar aanleiding van wetsontwerpen 'Oort II/III', fiscaal weekblad FED, 1988, no 728, blz. 2300. Tweede Kamer, vergaderjaar 1988-1989, 20 873, no 3 , blz. 25.

14. J. Hoogendoorn, Enkele opmerkingen naar aanleiding van wetsontwerpen "Oort II/III", fiscaal weekblad FED, 1988, no 729, blz. 2300. Zie ook J. Nijstad, Aftrekbare kosten: hinkstapsprong?, Weekblad voor fiscaal recht, 1989, no 5870 , blz. 648. Nijstad stelt verderop in zijn artikel dat 'de fiscale behandeling van de op werknemers drukkende kosten tot verwerving ten opzichte van collega's die daarvoor een vergosding ontvangen, niet alleen verschillend is ten aanzien van uitgaven voorkomend op de "negatieve lijsten", maar voor de kosten in zijn algemeenheid.'

Zie ook de evaluatie van de OORT-wetgeving; bijna $20 \%$ van de ondervraagde particulieren geeft toe dat ze door het beperken of het wegvallen van bepaalde aftrekposten getracht heeft de desbetreffende kosten onder een andere aftrekpost te laten vallen. Eindrapport over de evaluatie OORT-wetgeving, t.a.p., blz. 7.

15. Het CDA formuleert de eisen voor aftrekbaarheid van uitgaven als kosten als volgt:

1. de uitgave moet specifiek voor het beroep zijn gedaan; of

2. de uitgave draagt $\mathrm{bij}$ aan een behoorlijke vervulling van een dienstbetrekking en

a. wijkt qua omvang niet af van wat in het maatschappelijk verkeer is aanvaard;

b. de uitgave zou niet tot een dergelijk bedrag zijn gemaakt door ecn belastingplichtige die qua inkomen, vermogen en gezinsomstandigheden in vergelijkbare omstandigheden verkeert, doch niet qua dienstbetrekking;

c. de uitgave behoort niet te zeer tot de persoonlijke levenssfeer. Hier komen het omvangscriterium (a) en het vergelijkingscriterium (b) om de hoek kijken. Tweede Kamer, vergaderjaar 1988-1989, 20 873, no 7, blz. 19.

16. Tweede Kamer, vergaderjaar 1988-1989, 20873 , no 3, blz. 12. 
Bovendien wordt een onderscheid gemaakt tussen de categorie van gevallen waarin de werknemer door de werkgever wordt betrokken bij het maken van de kosten en de categorie waarin de werknemer zelf de kosten maakt, die al dan niet door de werkgever zullen worden vergoed.

De eerste categorie wordt weer onderscheiden naar gelang van vier situaties:

'a. de werkgever maakt kosten;

b. de werkgever maakt kosten, de werknemer schiet de betaling voor;

c. de werkgever geeft de werknemer opdracht bepaalde kosten te maken en verstrekt hem daartoe de middelen;

d. de werkgever geeft de werknemer opdracht bepaalde kosten te maken welke de werknemer zelf betaalt en vervolgens van de werkgever terugontvangt. ${ }^{17}$

In de gevallen $b$ tot en met $d$ is de werknemer intermediair.

De tweede categorie betreft de eventuele vergoedingen door de werkgever. Indien een werkgever een bepaalde kostenpost vergoedt, kan daaraan het vermoeden worden ontleend dat het om zakelijke kosten gaat.

Het voornaamste argument van de regering om een indeling naar gelang van de verschillende situaties te maken, is dat het niet gaat om gelijke gevallen; de situaties van aftrekbare kosten en vergoedingen zijn niet gelijk. ${ }^{18}$ 'Met betrekking tot de relevante posten is de symmetrie veeleer te vinden in de verhouding intermediairfunctie versus vergoedingen dan in de relatie tussen aftrekbare kosten en vergoedingen daarvan. Onze conclusie is dan ook dat de verschillende behandeling van kosten en vergoedingen daar geoorloofd is en geen ongelijkheid oplevert in de zin van het ongelijk behandelen van gelijke gevallen. ${ }^{19}$

In het merendeel van de gevallen gaat het om vergoedingen in het kader van inkomsten uit dienstbetrekking. Vergoedingen in het kader van niet uit dienstbetrekking verkregen inkomsten kunnen alleen op declaratiebasis belastingvrij worden verstrekt. ${ }^{20}$

\subsection{De parlementaire discussie en de kritiek in de literatuur}

De nadere invulling van de artikelen 35 en 36 Wet IB 1964 gaf een interessante discussie tussen de regering en het parlement. Aanvankelijk stelt de regering slechts voor om de in artikel 35 Wet IB 1964 genoemde posten te beperken. Het parlement geeft een aanvullend criterium: 'Uitgaven die niet uitsluitend en met uitschakeling van alle persoonlijke omstandigheden zijn gedaan tot verwerving,

17. Tweede Kamer, vergaderjaar 1988-1989, 20873 , no 9, blz. 20 en 21.

18. Tweede Kamer, vergaderjaar 1988-1989, 20 873, no 9, blz. 21 en 22. Zie ok Vreugdenhil (CDA), Handelingen Tweede Kamer, vergaderjaar 1988-1989, 20595 enz., blz. 39-2410, mk en rk.

19. Tweede Kamer, vergaderjaar 1988-1989, 20 873, no 9, blz. 23. Een ander citaat: 'Met andere woorden, in die gevallen is de gelijkheid niet zozeer te zoeken bij de situaties van aftrek en vergoeding alswel bij de situaties van rechtstreeks kosten maken voor de werkgever en eerst zelf kosten maken om die door de werkgever vergoed te krijgen'. H. Mobach en L.W. Sillevis, Cursus Belastingrecht, Inkomstenbelasting, 2.3.9.A,c, blz. 1559.

20. Tweede Kamer, vergaderjaar 1988-1989, 20 873, no 5, blz. 41. 
inning en behoud van de inkomsten worden slechts tot de aftrekbare kosten gerekend indien en voor zover:

$1^{\circ}$ de belastingplichtige aannemelijk kan maken dat het (noodzakelijk en) gebruikelijk is voor belastingplichtigen die in zijn omstandigheden verkeren, deze uitgaven daartoe te doen, dan wel

$2^{\circ}$ de belastingplichtige kan aantonen dat het naar algemeen inzicht redelijk (= noodzakelijk) kan worden geacht voor een belastingplichtige die in zijn omstandigheden verkeert, deze uitgaven daartoe te doen' ${ }^{21}$

De regering heeft kritiek op dit criterium. Op de eerste plaats leidt dit criterium tot te veel onzekerheden. Deze onzekerheden zouden pas in de loop van de tijd door jurisprudentie en uitvoering worden opgelost. De doelmatigheid is hiermee niet gediend. Op de tweede plaats zou het bovenstaand criterium een rol kunnen spelen bij de zakelijke uitgaven zodra persoonlijke omstandigheden blijkens de aard en omvang van de uitgaven in het geding zijn. De fiscus moet bij de hantering van het criterium zowel de aard als de omvang van de kosten toetsen. De bewijsproblematiek van hetgeen onder $1^{\circ}$ of $2^{\circ}$ is vermeld, kan wisselen. Dit kan tot veel verwarring leiden indien de problematiek in de uitvoering en niet in een wettekst moet worden opgelost. Ten derde moet bij het toetsen van het persoonlijke motief van de gemengde kosten de vraag worden beantwoord in hoeverre het onderhavige criterium zal leiden tot een aanvullende beperking. Dezelfde problemen als bij de naar aard en omvang zakelijke uitgaven komen hier op. Op de vierde plaats zou het noodzakelijkheidscriterium bij de zakelijke uitgaven die met het persoonlijk leven samenhangen in vele gevallen leiden tot gehele of gedeeltelijke niet-aftrekbaarheid. Onder de huidige wetgeving (regime 1988, MW) zijn deze uitgaven veelal wel aftrekbaar. Op de vijfde plaats zou het noodzakelijkheidscriterium aan de aftrekkant niet tot een belangrijke aanvullende beperking leiden; dit vanwege de concrete beperking in het wetsvoorstel. Ten slotte zou men zich met betrekking tot het noodzakelijkheidscriterium aan de vergoedingenkant moeten afvragen hoe moet worden omgegaan met de verschillen in bewijslast aan de aftrekkant. ${ }^{22}$

Een discussie volgt en de uitkomst is dat het nieuwe artikel 35 Wet IB 1964 een samenvatting en een aanscherping van de jurisprudentie betreft. De aanscherping bestaat uit een omvangs- en een vergelijkingscriterium. Het omvangscriterium houdt in dat per jaar de kosten per kostencategorie niet meer mogen belopen dan hetgeen gebruikelijk is. De aanscherping met betrekking tot het vergelijkingscriterium houdt in dat 'kosten die onder het huidige regime binnen de grenzen der redelijkheid steeds aftrekbaar zijn, te weten, de kosten die met uitschakeling van alle persoonlijke omstandigheden uitsluitend door de aard van de dienstbetrekking worden veroorzaakt en die derhalve moeten worden gemaakt door een ieder die dergelijke werkzaamheden verricht, slechts aanwezig worden

21. Hetgeen tussen haakjes staat is later aangevuld. Een directe relatie met de dienstbetrekking wordt gelegd. Tweede Kamer, vergaderjaar 1988-1989, 20 873, no 5, blz. 43, 44 en no 9, blz. 16. Handelingen Tweede Kamer, vergaderjaar 1988-1989, 20595 enz., blz. 26-51, mk, 39-2459, lk.

22. Tweede Kamer, vergaderjaar 1988-1989, 20 873, no 9, blz. 16, 17 en 18. 
geacht voor zover overigens vergelijkbare personen die kosten niet plegen te maken., ${ }^{23}$

Het verschil tussen het voorgestelde artikel 36 Wet IB 1964 en de huidige (1988, MW) rechtspraak is gelegen in het feit dat minder kosten aftrekbaar zijn dan voorheen. De forfaitaire invulling van het omvangs- en het vergelijkingscriterium van artikel 36 Wet IB 1964 brengt met zich dat de omvang van de na toepassing van die bepaling voor aftrek resterende kosten altijd groter is dan hetgeen gebruikelijk is. Indien aan de voorwaarden van artikel 36 Wet IB 1964 is voldaan, is de vraag of aan beide criteria is voldaan overbodig en ongeoorloofd. Deze criteria komen alleen aan de orde bij kosten die niet onder artikel 36 Wet IB 1964 vallen. ${ }^{24}$

Tijdens de zgn. reparatiewetgeving volgt een nadere uitleg. Het omvangscriterium kan in artikel 36 Wet IB 1964 nog wel een afzonderlijke rol spelen bij het tweede lid, onderdeel $h$, betreffende de post tekstverwerkers e.d. en het tweede lid, onderdeel e, de post huisvesting buiten de woonplaats. ${ }^{25}$

Ingeval beide criteria worden toegepast, wordt eerst getoetst aan het omvangscriterium, vervolgens aan het vergelijkingscriterium. Zowel de toepassing van het omvangscriterium als die van het vergelijkingscriterium dient per kostencategorie plaats te vinden. ${ }^{26}$

De beide criteria komen niet aan de orde in geval van vergoedingen door de werkgever aan de werknemer. De toenmalige staatssecretaris Koning: 'De conclusie is, dat het doortrekken van het criterium van het niet overtreffen hetgeen gebruikelijk is naar de vergoedingenkant niet juist is ....227

23. Het vergelijkingscriterium in de sfeer van de inkomensbesteding is te vergelijken met het voorgestelde. Het omvangscriterium is daarentegen nieuw. Zie onder andere Eerste Kamer, vergaderjaar 1988-1989, 20 873, no 133c, blz. 8 en 9. Handelingen Eerste Kamer, vergaderjaar 19881989, 20595 enz., blz. 26-1005, mk en 27-1084, Ik. De invoering van de tekst van artikel 35 Wet IB 1964 zal een duidelijke verandering zijn ten opzichte van hetgeen in de jurisprudentie als geldend wordt beschouwd. Zie onder andere A.N. Botermans, Aftrekbare kosten en kostenvergoedingen: De klok teruggezet, Maandblad Belastingbeschouwingen, 1989, no 6, blz. 150 e.v.. Het vergelijkingscriterium moet thans ook worden toegepast op zuiver zakelijke uitgaven.

24. A.N. Botermans, Aftrekbare kosten en kostenvergoedingen: De klok teruggezet, Maandblad Belastingbeschouwingen, 1989, no 6, blz. 150 en 151. De auteur heeft het over het teruggaan van de objectivering naar de subjectivering van kosten. A.N. Botermans, t.a.p., blz. 152. Eerste Kamer, vergaderjaar 1988-1989, 20 873, no 133c, blz. 10.

25. Eerste Kamer, vergaderjaar 1989-1990, 21 184, no 60b, blz. 2.

26. Vraag 174, Oort, Vervolgpublicatie van de werkgroep-Oort, V-N, 2 april 1992, no 7, blz. 1149. Zie voor een voorbeeld uit de jurisprudentie betrekking hebbende op de post kleding waarin het omvangs- en vergelijkingscriterium in acht worden genomen, Hof Leeuwarden 22 april 1993, V-N 1993, blz. 2360.

27. De staatssecretaris noemt de volgende redenen: '1. Het zou werkgevers in feite onmogelijk worden gemaakt een werknemer dic hij als voortiekker op een bepaald gebied laat opereren, de daarmee gepaard gaande en naar de omvang ongebruikelijke hoge kosten te vergoeden. 2. Werkgevers die ongebruikelijke dingen waaraan geen prive-elementen zijn verbonden, van hun werknemers verlangen, moeten de mogelijkheid behouden daarvoor onbelaste vergoedingen te geven, bijvoorbeeld de vergoedingen voor het thuis hebben van een faxapparaat. 3 . Er zou een niet goed te motiveren verschil in behandeling ontstaan tussen de werkncmer die zelf een PC 
Hoe dient een aftrekpost te worden getoetst, indien tevens een (gedeeltelijke) vergoeding van de werkgever wordt ontvangen? Eerst moet worden nagegaan of er sprake is van kosten. Vervolgens zijn er de twee beperkingen in de vorm van het omvangs- en het vergelijkingscriterium, al dan niet forfaitair. Indien sprake is van kosten, dient de vergoeding in mindering te komen op de aftrek. ${ }^{28}$

De jurisprudentie inzake het omvangs- en vergelijkingscriterium begint zijn vormen aan te nemen. De twee criteria worden in de rechtspraak uitgekristalliseerd. Ik vrees dat ten aanzien van de vrij detaillistische regelingen de jurisprudentie van voren af aan begint. ${ }^{29}$ Dit betekent dat de rechterlijke macht de komende jaren veel werk zal krijgen. ${ }^{30}$

Wellicht ten overvloede zij hier nog opgemerkt dat de Belastingdienst veel moeite heeft met de toepassing van het omvangs- en het vergelijkingscriterium. ${ }^{31}$

aanschaft en daarvoor een vergoeding krijgt en de werknemer wiens werkgever een PC bij hem thuis zet'. Handelingen Tweede Kamer, vergaderjaar 1988-1989, 20595 enz., blz. 26-52.

Zie echter Arts, die van mening is dat het uit de parlementaire geschiedenis nog niet duidelijk is of, en in hoeverre het omvangs- en het vergelijkingscriterium van toepassing is op kostenvergoedingen. En daarmee is ook niet duidelijk of het verband tussen verwervingskosten en aftrekbare kosten is verbroken, aldus Arts. J.H.M. Arts, De invloed van de loonbelasting op de winst uit onderneming, Weekblad voor fiscaal recht, 1991, no 5965, blz. 824.

28. Vraag 175, Oort. Vervolgpublicatie van de werkgroep-Oort, V-N 1992, blz. 1148. Zie in dezelfde lijn gelegen uitspraak van Hof Arnhem 16 november 1993, V-N 1994, blz. 634.

Zie ook de mondelinge uitspraak van Hof Leeuwarden 29 april 1993, Infobulletin 93/402, waarin de normering van de autokosten van $f 0,44$ (tekst 1990), als een invulling van het vergelijkingscriterium wordt gezien. Op dit bedrag moct de kilometervergoeding in mindering worden gebracht.

29. Enige voorbeelden Hof 's-Gravenhage 2 februari 1993, V-N 1993, blz. 1964 (beperking in artikel 36 , lid 2, onderdeel $g$ is een invulling van het onvangs- en vergelijkingscriterium), Hof Arnhem 11 januari 1994, Infobulletin 94/220 (omvangscriterium) en Hof Leeuwarden 4 januari 1994, Infobulletin 94/221 (kosten congres).

Vergelijk de cijfers van vór OORT. Toen had $10,8 \%$ van de uitspraken van de belastingkamers van de Gerechtshoven betrekking op aftrekbare kosten die verband houden met arbeidsinkomen en $11,6 \%$ op de autokostenfictie. Zicht op eenvoud, t.a.p., bijlage 10, blz. 173. Het zou thans aardig zijn de cijfers met de huidige te vergelijken.

Zie ook de uitspraak van Hof Amsterdan 25 mei 1993, BNB 1994/160, V-N 1993, blz. 2716. In tegenstelling tot de afschrijving moet de drempel van de kosten van de personal computer niet naar tijdsgelang worden berekend.

30. Notabene niet alieen de rechterlijke macht. Ook de uitvoerende macht vult het omvangs- en vergelijkingscriterium nader in. Zie inzake de aftrekbare kosten en buitengewone lasten van een personal computer de Resolutic van 19 juni 1991, nr. DGM91-450, zoals deze is gewijzigd bij Resolutic van 27 mci 1993, nr. CA93/100 betreffende artikel 35, ecrste lid, artikel 36, tweede lid, onderdeel $2 \mathrm{~h}$, cn artikel 46 Wet IB 1964, BNB 1993/251. Naar aanleiding van het arrest van HR 31 maart 1993, V-N 1993, blz. 1247, moest het beleid ten aanzien van de aftrek van de pc als buitengewone lasten worden veranderd.

Zie ook de uitspraak van Hof Leeuwarden 26 mei 1993, Infobulletin 93/467, waarin de inspecteur onderzoeken waarin het omvangs- en vergelijkingscriterium van kleding van sportleraren is vastgesteld overlegt.

31. Tweede Kamer, vergaderjaar 1992-1993, 22 374, no 2, blz. 6. Evaluatie OORT-wetgeving, Deelproject Inkomstenbelasting Particulieren, Ervaring van de belastingdienst, J.M. Haring-Lohman, oktober 1992, rapportnr. 26, blz. 5 en 20. Met name de aftrekpost vakliteratuur levert in dit ver- 
De kritiek van de meeste, zo niet alle fiscale auteurs, op OORT-II is in het algemeen negatief.

Als laatste zou ik graag het volgende voor zichzelf sprekende citaat opnemen. 'En alsof het allemaal nog niet erg genoeg was, gaf de staatssecretaris in de schriftelijke voorbereiding herhaaldelijk volmondig toe, dat de voorstellen voor de gemengde kosten gebaseerd zijn op pragmatische, doch uiteraard arbitraire keuzen. ${ }^{32}$

\subsubsection{Wetgevingsbeginsel(en)}

Een eerste opmerking zou ik willen maken over de tijdsdruk. Net als bij de behandeling en invoering van het wetsvoorstel OORT-I is nu ook de tijdsdruk groot. Illustratief is dat het wetsvoorstel OORT-II in tegenstelling tot OORT-I niet is voorgelegd aan de Commissie voor de Toetsing van wetgevingsprojecten. ${ }^{33}$ De redenen hiervoor moeten worden gezocht in het feit dat de Commissie daar niet om heeft verzocht en in het feit dat de Minister van Justitie het niet nodig heeft gevonden. Waarom wordt niet echt duidelijk, maar de factor tijd heeft wel een belangrijke rol gespeeld. ${ }^{34}$ Deze factor speelt de laatste jaren wel een grote rol. Over de toenemende tijdsdruk kan men zich mijns inziens zorgen maken.

band veel problemen op. Evaluatie OORT-wetgeving, Deelproject Inkomstenbelasting Particulieren, t.a.p., blz. 21.

Voorbeelden met betrekking tot het vergelijkingscriterium: Hof Lecuwarden 4 september 1992, nr. 984/91, V-N 1993, blz. 1366, HR 31 maart 1993, V-N 1993, biz. 1247 e.v. Hof Amsterdam 3 februari 1993, Infobulletin 93/277 en Hof Amsterdam 8 september 1993, V-N 1994, blz. 165. En met betrekking tot het omvangscriterium: Hof Leeuwarden 14 februari 1992, nr. 792/91, V-N 1992, blz. 782 en Hof Amsterdam 21 oktober 1992, nr. 92/0162, V-N 1993, blz. 1301 e.v..

Opmerkelijk hierbij is dat het Hof Leeuwarden de bewijslast bij de inspecteur legt; dit in tegenstelling tot de werkgroep-Oort.

Zie ook Hof Leeuwarden 30 juni 1993, BNB 1994/118. In casu had een plaatsvervangend hoofd van de belastingdienst een bedrag van $f 4.656$ literatuurkosten. De inspecteur vergeleek de aftrekbare kosten inzake literatuur van 23 andere plaatsvervangende hoofden van dienst en/of teamleiders en accepteerde op basis van het onvangscriterium slechts $f 1.000$ als aftrekbare kosten. Het hof gaf de inspecteur gelijk, doch legt de bewijslast inzake het uitgaan van de kosten boven hetgeen gebruikelijk is op de inspecteur. Zwemmer concludeert dat de regeling onuitvoerbaar is. J.W. Zwemmer, Friesland op zijn smalst, Weekblad voor fiscaal recht, Column, 1993, no 6073, blz. 1475.

En zie het eindrapport over de evaluatie OORT-wetgeving: 'De toepassing van het omvangsen vergelijkingscriterium in inkomstenbelasting voor particulieren was voor $75 \%$ van de inspecties/eenheden vaak tot vrijwel vaak een probleem.' Eindrapport over de evaluatie OORT-wetgeving, t.a.p., blz. 8 en 9.

32. Engwirda (D66), Handelingen Tweede Kamer, vergaderjaar 1988-1989, 20595 enz., blz. 39-2450, rk.

33. Tweede Kamer, vergaderjaar 1988-1989, 20 873, no B, blz. 10.

34. Tweede Kamer, vergaderjaar 1988-1989, 20 873, no B, blz. 2 en 3, no 4, blz. 7, no 9, blz. 8, 9 en no 5, blz. 33. 
Een volgende opmerking betreft het motiveringsbeginsel. De Raad van State is van mening dat de memorie van toelichting geen duidelijk beeld geeft van de fiscale beginselen en overwegingen. Tekenend is dan ook dat de memorie van toelichting na het advies van de Raad van State op vele punten is aangevuld. ${ }^{35}$ Een aspect waarbij het motiveringsbeginsel een grote rol speelt, is de vereenvoudiging. De vereenvoudiging is de dragende grond voor de hele Oort-operatie, althans voor OORT-I. De wetsvoorstellen OORT-II en OORT-III passen echter niet in het streven om de wetsvoorstellen in generieke eenvoud te presenteren. Met generieke eenvoud wordt bedoeld, 'dat voor het maatschappelijk verkeer algemeen gebruikelijke situaties heldere en beknopte wettelijke bepalingen dienen te gelden, een stelregel waarvan slechts in uitzonderingsgevallen zou mogen worden afgeweken' ${ }^{36}$ In uitzonderingssituaties zou pas gebruik mogen worden gemaakt van complexe wetgeving. Voor een uitzonderingssituatie zullen goede redenen moeten worden aangevoerd. Met andere woorden, het motiveringsbeginsel stelt extra eisen. ${ }^{37}$ De uitzonderingssituatie is met de invoering van OORT-II blijkbaar snel gevonden. De Oort-operatie doet de wetgeving uitdijen en maakt haar aanzienlijk complexer. Toename van wetgeving leidt tot minder kennis, en inherent daaraan, minder acceptatie van de wetgeving. En een niet door een ieder aanvaarde wetgeving leidt tot een lagere belastingopbrengst, want degene die de belastingheffing niet aanvaardt, zal minder geneigd zijn de belasting te betalen. De aanvaarding van een wetgevingsprodukt verloopt sneller als de wetgeving duidelijk en helder is. ${ }^{38}$

Een volgend aspect waarbij het motiveringsbeginsel een rol speelt, is de introductie van de asymmetrie tussen niet aftrekbare kosten en de onbelaste vergoedingen. Uit de literatuur en het parlement komt de kritiek dat de motivering om de symmetrie los te laten niet deugdelijk is. ${ }^{39}$

35. Een voorbeeld is de gevraagde nadere motivering van artikel 36 , eerste lid, onderdeel e Wet IB 1964. Tweede Kamer, vergaderjaar 1988-1989, 20 873, no B, blz. 24. Zie ook de kritiek van onder andere de PPR op de motivering van de verlaging van de tarieven en de regeling van aftrek van gemengde kosten. Tweede Kamer, vergaderjaar 1988-1989, 20 873, no 5, blz. 9.

Feteris en Brouwer verwoorden de motiveringseis aldus: 'Dit betekent dat er een dragende motivering aan de hervormingsmaatregelen ten grondslag moet liggen, die duidelijk maakt waarom na afweging van verschillende alternatieven de keuze nu juist op deze regeling is gevallen.' M.W.C. Feteris, J.Th.L. Brouwer, De vereenvoudiging ontspOort (2), fiscaal weekblad FED, 1988, no 714, blz. 2235.

36. H.P.A.M. van Arendonk, Belastingfraude en oneigenlijk gebruik na de belastingherziening 'Oort', Maandblad Belastingbeschouwingen, 1989, no 11, blz. 321, noemt drie sleutelwoorden: kenbaarheid, hanteerbaarheid en aanvaardbaarheid.

37. P. Kavelaars, De kern van de zaak, Weekblad voor fiscaal recht, 1988, no 5844, blz. 1439.

38. Vergelijk H.P.A.M. van Arendonk, Belastingfraude en oneigenlijk gebruik na de belastingherziening 'Oort', Maandblad Belastingbeschouwingen, 1989, no 11, blz. 321.

39. Feteris en Brouwer karakteriseren de wetsvoorstellen als volgt: '... de meest voorkomende kosten .... Het zijn precies deze kosten waarin wordt geschrapt. Geen leidende beginselen dus, maar het beleid van de struikrover: pakken waar je het meeste kan halen.' M.W.C. Feteris, J.Th.L. Brouwer, De vereenvoudiging ontspOort (2), fiscaal weekblad FED, 1988, no 714, blz. 2237. 
Een ander beginsel dat in het geding is, is het rechtszekerheidsbeginsel. Het rechtszekerheidsbeginsel komt bij de afschaffing of beperking van de aftrekbare kosten en de regeling van de (on)belaste kostenvergoedingen in het gedrang. De regeling zou duidelijker in de wettekst moeten worden omschreven. ${ }^{40}$ Een duidelijke wettekst bevordert de rechtszekerheid.

Een met het rechtszekerheidsbeginsel samenhangende eis is die van consistentie. De opsomming van de beperking van de aftrekbare kosten wordt vanuit de Kamer en de fiscale literatuur weinig consistent geacht. ${ }^{41}$ Van regeringszijde wordt toegegeven dat een theoretische discussie niet aanwezig is. ${ }^{42}$ Dit is opmerkelijk, want eerder in de memorie van antwoord heeft de regering nog toegezegd verbeteringen met betrekking tot een eenvoudiger stelsel, dat gebaseerd is op heldere, consistente en wetstechnische juiste uitgangspunten, in de uiteindelijke beschouwingen te betrekken.

In geval van mankementen ten aanzien van die uitgangspunten zou vooral met het opleggen van lasten aan de burgers voorzichtig moeten worden omgesprongen. Burgers verwachten een rechtvaardiging voor het opleggen van lasten. Zeker dient gewaakt te worden voor het achteraf theoretisch onderbouwen van een maatregel; dit ondermijnt mijns inziens de belastingmoraal.

Een laatste opmerking betreft het gelijkheidsbeginsel. Het gelijkheidsbeginsel wordt in een zodanige mate geschonden dat geen sprake meer is van een behoorlijke wetgeving, aldus enige fiscale auteurs. ${ }^{43}$ De kritiek betreft voorname-

40. Tweede Kamer, vergaderjaar 1988-1989, 20 873, no 4, blz. 2, no 5, blz. 2 en no 7, blz. 15. Idem met betrekking tot verduidelijking van de intermediairfunctie van de werknemer in de wettekst (PvdA). Tweede Kamer, vergaderjaar 1988-1989, 20 873, no 9, blz. 18. Zie ook de kritiek van M.W.C. Feteris, J.Th.L. Brouwer, De vereenvoudiging ontspOort (2), fiscaal weekblad FED, 1988, no 714, blz. 2235. Zie ook Van Arendonk, die stelt dat blijkbaar door voordrachten van de staatssecretaris de wettekst duidelijk moet worden. Hierdoor komt de rechtsbescherming van de burger in het gedrang. H.P.A.M. van Arendonk, Belastingfraude en oneigenlijk gebruik na de belastingherziening 'Oort', Maandblad Belastingbeschouwingen, 1989, no 11, blz. 321.

41. Zie onder andere Tweede Kamer, vergaderjaar 1988-1989, 20 873, no 4, blz. 10. Handelingen Tweede Kamer, vergaderjaar 1988-1989, 20595 enz., blz. 39-2458, mk. J.E.A.M. van Dijck, Gemengde kosten, Weekblad voor fiscaal recht, 1988, no 5844, blz. 1415 en M.W.C. Feteris, J.Th.L. Brouwer, De vereenvoudiging ontspOort(2), fiscaal weekblad FED, 1988, no 714, blz. 2236.

42. Tweede Kamer, vergaderjaar 1988-1989, 20 873, no S, blz. 6 en 7.

43. H.P.A.M. van Arendonk, De operatie Oort: de vereenvoudiging weggesneden? Maandblad Belastingbeschouwingen, 1988, no 11, blz. 301 en J.E.A.M. van Dijck, Gemengde Kosten, Weekblad voor fiscaal recht, 1988, no 5844 , blz. 1420. In iets andere bewoordingen, maar met dezelfde strekking, P.E. Keekstra, Vereenvoudiging tussen droom en daad: gemengde gevoelens, Weekblad voor fiscaal recht, 1988, no 5844, blz. 1451. Van Ballegooijen pleit voor een herstel van de symmetrie, behalve voor representatiekosten; dit herstel is goed voor de kenbaarheid van het recht. C.W.M. van Ballegooijen, Naar een herziening van het regime van de gemengde kosten, Weekblad voor fiscaal recht, 1992, no 6025, blz. 1307.

Niessen vertaalt het aldus, dat uitgaande van de vaststelling van het inkomen per individu, het geheel of gedeeltelijk nict meer aftrekbaar zijn van daadwerkclijke zakelijke kosten leidt tot een gelijke belastingdruk voor belastingplichtigen met een verschillend besteedbaar inkomen. R.E.C.M. Niessen, Honderd jaar brede herwaardering en het gelijkhcidsbeginsel, Weekblad voor 
lijk de niet in de wetssystematiek passende voorgestelde asymmetrie tussen de niet-aftrekbare kosten en de onbelaste vergoedingen. ${ }^{44}$

Het bovenstaande overziende concludeer ik dat op de toepassing van de wetgevingsbeginselen in OORT-II het een en ander valt aan te merken.

\subsubsection{Het draagkrachtbeginsel}

De Raad van State meent dat het voorstel inzake de tariefopbouw zich nauwelijks verdraagt met de werking van het draagkrachtbeginsel. Vooral de overgang van 10\% in de eerste schijf naar 55\% in de tweede schijf getuigt nauwelijks dat de draagkrachtgedachte in acht wordt genomen, aldus de Raad van State. 'Naar het oordeel van de Raad moet worden geconcludeerd dat de uitvoering van het rapport van de Commissie Oort aan het belastingtarief een opzet naar draagkracht gedeeltelijk ontneemt. ${ }^{45}$ De regering ontkent. ${ }^{46}$ Zowel de gemiddelde als de marginale druk wijzigt, maar de totaaldruk blijft hetzelfde. Feitelijk kan worden geconstateerd dat de verdeling van de belastingdruk wordt gewijzigd. ${ }^{47}$ De Kamer vraagt welke inkomenspolitieke doelstellingen van de regering aan deze wijzigingen ten grondslag liggen. ${ }^{48}$ Een duidelijk antwoord wordt hierop niet gegeven. Mogen we hieruit concluderen dat het waarschijnlijk is dat de nieuwe drukverdeling min of meer toevallig is?

Ik kan me niet aan de indruk onttrekken dat de regering in deze materie gebruik maakt van doelredeneringen. Ter illustratie: '... is er weliswaar geen sprake van een zwaarder accent voor «draagkracht» als bepalende factor .... ... de draagkrachtnoties zoals die in het tarief tot uitdrukking komen [veranderen] niet wezenlijk van gewicht. ${ }^{, 49}$ Blijkbaar blijft het van belang dat het draagkrachtbeginsel als leidende gedachte van de Wet IB 1964 wordt gezien. Dat de werking en de inhoud van het draagkrachtbeginsel langzamerhand worden beperkt, doet niet ter zake.

Deze stelling wordt ook gesteund door hetgeen de regering zegt over de totstandkoming van feitelijke tariefstructuren. De totstandkoming moet als een uit-

fiscaal recht, 1992, no 6026 , blz. 1366.

44. In de literatuur zijn enkele voorstellen gedaan om de symmetric te herstellen. Zie onder andere C.W.M. van Ballegooijen, t.a.p., blz. 1304-1309, J.W. Bellingwout, Vereenvoudiging van het regime van de gemengde kosten, Weekblad voor fiscaal recht, 1992, no 6025, blz. 1310-1315.

45. Tweede Kamer, vergaderjaar 1988-1989, 20 873, no B, blz. 3. Enige tijd later kent de ecrste schijf een percentage van 7, de tweede een percentage van 50 .

46. Tweede Kamer, vergaderjaar 1988-1989, 20 873, no B, blz. 4.

47. Duidelijk is dat de internationale tendens om te tarieven te verlagen een belangrijke factor is. Tweede Kamer, vergaderjaar 1988-1989, 20 873, B, blz. S.

48. Tweede Kamer, vergaderjaar 1988-1989, 20873 , no 4, blz. 4, 10 en no 5, blz. 3.

49. Tweede Kamer, vergaderjaar 1988-1989, 20 873, no B, blz. 4 en no 3, blz. 6. Wel dient de draagkrachtgedachte betrokken te worden bij de premieheffing. Dit standpunt wordt nogmaals herhaald in de memorie van antwoord. Tweede Kamer, vergaderjaar 1988-1989, 20 873, no 5, blz. 24. 
vloeisel van politieke keuzen worden beschouwd. ${ }^{50}$ De regering: 'Het zou een misverstand zijn te denken dat er een theoretische draagkrachtconceptie is die zou kunnen leiden tot een eenduidige, als het ware wetenschappelijk af te leiden tariefstructuur., ${ }^{51}$ Met andere woorden, de vraag hoe wetenschappelijk gezien het tarief volgens de draagkrachttheorie moet zijn, is niet zo belangrijk als het oordeel over de concrete inhoud van het tarief inclusief de inkomenseffecten. ${ }^{52}$ Hier wordt een groot gewicht aan de inkomenseffecten toegekend. ${ }^{33}$ De Raad van State maakt een interessante opmerking over de zogenaamde 'koopkrachtplaatjes'. De relativering van de mogelijke inkomensgevolgen wordt te groot geacht. ${ }^{54} \mathrm{Bij}$ dit alles moet in beschouwing worden genomen dat het vaststellen van de exacte gevolgen voor de individuele belastingplichtige enigszins problematisch is. 55

Bij een andere gelegenheid laat de regering in het midden of de tariefstructuren al dan niet theoretisch onderbouwd zijn. 'Hiermee is echter geenszins gezegd dat de tariefstructuur niet langer mede zou worden bepaald door fiscaal-theoretische uitgangspunten. ${ }^{.56}$ Werden ze dat, gezien het bovenstaande, dan wel? Duidelijk is in ieder geval dat de gedachten over de fiscaal-theoretische uitgangspunten niet consequent zijn. Politieke argumenten spelen een grote rol. ${ }^{57}$ Onder poli-

50. Tweede Kamer, vergaderjaar 1988-1989, 20 873, no 4, blz. 4, 5, no 5, blz. 24 en 25 en Minister van Financiën, Ruding, Handelingen Tweede Kamer, vergaderjaar 1988-1989, 20595 enz., blz. 28-12. OORT-II heeft een breed politiek draagvlak nodig en heeft dat ook, aldus minister van Financiën, Ruding. Handelingen Tweede Kamer, vergaderjaar 1988-1989, 20 873, blz. 40-2507, lk.

51. Tweede Kamer, vergaderjaar 1988-1989, 20 874, no 3, blz. 7 en no 5, blz. 41.

52. Tweede Kamer, vergaderjaar 1988-1989, 20 873, no 9, blz. 52.

53. Handelingen Tweede Kamer, vergaderjaar 1988-1989, 20595 enz., blz. 39-2424.

54. Tweede Kamer, vergaderjaar 1988-1989, 20 873, no B, blz. 17.

55. Tweede Kamer, vergaderjaar 1988-1989, 20 873, no 4, blz. 32 en no 5, blz. 48. Hier gaat het weliswaar om een verschil in bedragen aan aftrekposten, die kunnen verschillen per belastingplichtige, niet alleen bij verschillende inkonensniveaus, maar ook bij een gelijk inkomensniveau. Bovendien kunnen de effecten van de Dekker-voorstellen niet in de berekening worden meegenomen. Tweede Kamer, vergaderjaar 1988-1989, 20 873, no 7, blz. 21. Handelingen Tweede Kamer, vergaderjaar 1988-1989, 20595 enz., blz. 40-2502, mk en rk en 40-2503.

56. Tweede Kamer, vergaderjaar 1988-1989, 20 873, no 9, blz. 9 en 51. Even later zegt de regering (blz. 51 en 52): 'Wij hebben tot uitdrukking willen brengen dat het tarief zoals dat tot stand komt niet, dan wel niet zonder grote moeilijkheden is af te leiden uit een zuiver theoretisch concept'.

57. Bij voorbeeld in de Tweede Kamer rijst de vraag hoe het uiteindelijke tarief is vastgesteld. Buiten het parlement verschenen berichten dat de heer De Vries (CDA) een aandeel in de vaststelling heeft gehad. Tweede Kamer, vergaderjaar 1988-1989, 20 873, no 4, blz. 9 en 17.

Met betrekking tot het onderscheid fiscale en politieke overwegingen haal ik minister van Financiën Ruding aan: 'Wij beoordelen die (amendementen, $M W$ ) op inhoudelijke gronden. $U$ kent de criteria als fiscale aspecten, budgettaire consequenties en menskracht. Wij gebruiken daarbij geen partijpoliticke overwegingen.' Er is blijkbaar een verschil tussen fiscale overwegingen en politieke overwegingen. Handelingen Tweede Kamer, vergaderjaar 1988-1989, 20873, blz. 26-61. Zie ook Hoogendoorn: 'Deze prijsbepaling (systcembreuk voor tariefsverlaging, $M W$ ) is een politieke keuze, een politieke beslissing met vele (ook internationale) sociale en economische aspecten.' J. Hoogendoorn, Enkele opmerkingen naar aanleiding van wetsontwerpen 'Oort II/III', fiscaal weekblad FED, 1988, no 729, blz. 2299. 
tiek versta ik onder andere de haalbaarheid van een voorstel, het mogelijke aantal te behalen stemmen bij verkiezingen en partijpolitieke ideeën.

\section{OORT-II}

De geïntroduceerde asymmetrie is een onderwerp waarbij zowel het draagkrachtbeginsel ${ }^{58}$ als het gelijkheidsbeginsel is betrokken.

Een werknemer krijgt voor het maken van bepaalde kosten een onbelaste vergoeding van de werkgever. Een andere werknemer maakt dezelfde kosten, maar krijgt geen vergoeding en kan deze kosten niet aftrekken. Hoe het begrip draagkracht ook moet of kan worden omschreven, in deze situatie wordt mijns inziens een verschil in draagkracht met betrekking tot het object waarover belasting wordt geheven gecreëerd. Het draagkrachtbeginsel komt niet volledig tot zijn recht. Een ongelijke behandeling van bepaalde kosten heeft als gevolg dat eerst-genoemde werknemer uiteindelijk meer inkomen ter beschikking heeft dan de tweedegenoemde; hij 'houdt' als het ware meer draagkracht 'over'.

Het door de regering voorgestelde systeem werkt als volgt. Indien een werkgever een vergoeding geeft, is daarmee ook het zakelijke karakter van de uitgave objectief vastgesteld. Daar de objectieve vaststelling van de uitgave niet meer door de overheid, maar door de werkgever geschiedt, verwijdert de regering hiermee een draagkrachtelement uit de Wet IB 1964. Laat ik dit toelichten. Er bestaat een verschil in draagkracht tussen de werknemer die de kosten niet kan aftrekken en voor deze kosten geen vergoeding krijgt, en de werknemer die voor dezelfde kosten een onbelaste vergoeding krijgt. De werkgever bepaalt of een onbelaste vergoeding wordt gegeven of niet. De wetgever houdt met de mogelijkheid dat de werkgever geen vergoeding geeft geen rekening. Het verschil in draagkracht dat in geval van het niet geven van een vergoeding door de werkgever ontstaat, is voor rekening van de werknemer die de kosten niet kan aftrekken. Hierdoor wordt geen rekening gehouden met het verschil in draagkracht dat kan ontstaan.

Interessant in dit verband is de volgende opmerking in de memorie van antwoord: '... in het algemeen kan worden gesteld dat zij een zakelijk karakter kunnen hebben, los van de vraag of een werkgever bereid is hiervoor een vergoeding te verstrekken. ${ }^{60}$ Moet ik hieruit afleiden dat de werkgever toch niet de zakelijkheid kan bepalen?

In de literatuur hoort men ook dat de voorgestelde asymmetrie niets meer te maken heeft met draagkracht. Door de asymmetrie wordt het draagkrachtbegin-

58. In de parlementaire geschiedenis van het onderhavige wetsvoorstel wordt af en toe gesproken van een rechtvaardigheidsbeginsel in plaats van een draagkrachtbeginsel. Ter illustratie: '... dat beperking van aftrekposten het rechtvaardigheidsbeginsel, dat ten grondslag ligt aan een gedifferentieerde benadering van belastingplichtigen, niet mag worden geschaad.' Mijns inziens wordt hier het draagkrachtbeginsel bedoeld. Tweede Kamer, vergade rjaar 1988-1989, 20 873, no 4, blz. 28 (RPF).

59. Vergelijk Tweede Kamer, vergaderjaar 1988-1989, 20 873, no 4, blz. 19. Zie ook Vermeend (PvdA), Handelingen Tweede Kamer, vergaderjaar 1988-1989, 20595 enz., blz. 39-2435, mk en rk. Vergelijk Van Dijck, die stelt dat de asymmctric niets met draagkracht te maken heeft.

60. Tweede Kamer, vergaderjaar 1988-1989, 20 873, no 5, blz. 59. 
sel alsmaar minder sterk. ${ }^{61}$ Van Dijck spreekt over de aftrekbaarheid van kosten als een essentieel element van een inkomstenbelasting die zich naar de draagkracht richt. ${ }^{62}$ Enige Kamerleden zijn van mening dat bij een herbezinning op aftrekposten onder andere een betere benadering van draagkracht nodig is. ${ }^{63}$ Mijns inziens moet eerst goed duidelijk worden wat onder het object van draagkracht moet worden verstaan, het zgn. zoeken naar een communis opinio. Vervolgens zal moeten worden gekeken naar de gevolgen van het al dan niet beperken van de aftrekposten voor de inhoud van het begrip draagkracht enerzijds en het al dan niet onbelastbaar laten van vergoedingen anderzijds.

\section{Het draagkrachtbeginsel en de samenlevingsvorm}

Het grootste voordeel van de OORT-operatie ligt bij de tweeverdieners. ${ }^{64} \mathrm{De}$ wetsvoorstellen maken niet duidelijk of er, wat het draagkrachtprincipe betreft, een verbetering ten opzichte van de Tweeverdienerswetgeving wordt gebracht. ${ }^{65}$

Doordat de basisaftrek wordt toegekend aan ieder van de partners en in alleenverdienerssituaties de basisaftrek kan worden overgedragen, wordt naar de mening van de regering voldoende rekening gehouden met de draagkrachtverschillen tussen de éen- en de meerpersoonshuishoudens. ${ }^{66}$ Hieruit leid ik af dat een meerpersoonshuishouden draagkrachtverminderende werking heeft.

61. Zie onder andere J.E.A.M. van Dijck, Kostenvergoedingen, Column, Weekblad voor fiscaal recht, 1988 , no 5837 , blz. 1137 .

62. J.E.A.M. van Dijck, Gemengde kosten, Weekblad voor fiscaal recht, 1988, no 5844, blz. 1413 en zie Vermeend (PvdA) die stelt dat op basis van het draagkrachtprincipe een andere oplossing gekozen had kunnen worden in geval van de beperking of de afschaffing van de aftrekposten. Handelingen Tweede Kamer, vergaderjaar 1988-1989, 20595 enz., blz. 42-2593.

63. Tweede Kamer, vergaderjaar 1988-1989, 20 873, no 4, blz. 7 (D66). De Grave (VVD) beschrijft de aftrekpost als een uitgave die buiten de meting van draagkracht wordt geplaatst. Ingeval dat een belastingplichtige veel verdient, zal deze meer netto-voordeel hebben. Dit is een gevolg van de progressic. Handelingen Tweede Kamer, vergaderjaar 1988-1989, 20595 enz., blz. 42-2592.

64. Tweede Kamer, vergaderjaar 1988-1989, 20873 , no 4, blz. 3 en 29, no S, blz. 49, waarin geconstateerd wordt dat de marginale druk van belasting en premies voor een alleenverdiener hoger is dan in het regime van vo6́r 1989. Handelingen Eerste Kamer, vergaderjaar 1988-1989, 20595 enz., blz. 27-1072, mk.

Een gedeelte van de doelstelling van de Tweeverdienerswetgeving wordt op deze wijze teniet gedaan. Zie ook Tweede Kamer, vergaderjaar 1988-1989, 20 873, no 9, bijlage 9.

Door de invoering van de OORT-wetgeving is voor de zgn. 'grote' tweeverdieners een grotere inkomensvooruitgang opgetreden dan voor andere inkomensgroepen. De berekeningen van de koopkrachtplaatjes blijken niet altijd te kloppen. Uit het parlement, Weekblad voor fiscaal recht, 1991, no 5944, blz. 38 en 39.

65. Vergelijk het standpunt van de SGP-fractie. Tweede Kamer, vergaderjaar 1988-1989, 20873 , no 7, blz. 8. Voorgesteld wordt om de alleenverdieners een extra aftrek te geven, zodat de draagkrachtverhoudingen tussen de alleen- en tweeverdieners worden verbeterd, aldus de SGP. Tweede Kamer, vergaderjaar 1988-1989, 20 873, no 7, blz. 25. Opmerkelijk is dat de SGP-fractie blijft vasthouden aan de gezinsdraagkracht, maar niet wil erkennen dat een niet-huwelijkse samenlevingsvorm een draagkrachtverhogende werking heeft.

66. Tweede Kamer, vergaderjaar 1988-1989, 20 873, no 5, blz. 8. 
Uit de volgende stellingname in de memorie van antwoord voor de Eerste Kamer kan hetzelfde worden afgeleid. 'De verhouding van het netto inkomen van een werknemer die als alleenverdiener een gezin moet onderhouden tot het netto inkomen van zijn collega die hetzelfde bruto inkomen verdient maar daarvan als alleenstaande moet rond komen, is een heel redelijke vanuit een oogpunt van draagkracht. ${ }^{67}$ Deze verhouding is op het niveau van het minimumloon 100:92. ${ }^{68}$ Hieruit kan worden afgeleid dat de draagkracht van een subject blijkbaar toch exact te berekenen is.

Indien het wetsvoorstel inzake de geleidelijke afschaffing van de overdracht van de basisaftrek wet wordt, betekent dit mijns inziens dat er een andere manier moet worden gevonden om rekening te houden met de draagkrachtverschillen tussen eén- en tweeverdieners.

\section{Het tax-creditsysteem}

Een laatste opmerking met betrekking tot het draagkrachtbeginsel betreft het in de kamerstukken vaak te berde gebrachte zogenaamde tax-creditsysteem. ${ }^{\phi \theta}$ De regering oppert dat de draagkrachtmutaties alleen in de huidige systematiek een gelijke behandeling krijgen. Het tax-creditsysteem is volgens de regering niet interessant omdat het stelsel bestaat uit het toepassen van een tarief op een belastbaar inkomen; het belastbaar inkomen wordt voor iedere belastingplichtige op dezelfde manier bepaald. Indien het tax-creditsysteem wordt toegepast, zou strijdigheid met dat uitgangspunt optreden. Bovendien leidt een tax-creditsysteem tot een steilere progressie. ${ }^{70}$ Enige kamerleden zijn het daar niet mee eens, en stellen zich op het standpunt dat het draagkrachtbeginsel ook goed tot zijn recht kan komen in een tax-creditsysteem. ${ }^{71}$ Het probleem is mijns inziens wederom wat precies onder draagkracht moet worden verstaan. ${ }^{72}$

Het geheel overziende concludeer ik dat de definitie van het object waaraan de draagkracht moet worden ontleend en het subject van draagkracht op zijn minst onduidelijk zijn. De tweede conclusie is dat de werking van het draagkrachtbeginsel onder andere door invoering van de asymmetrie minder sterk geworden is. $^{\text {T3 }}$

67. Eerste Kamer, vergaderjaar 1988-1989, 20873 , no 133c, blz. 5 en 6.

68. Zie onder andere Handelingen Tweede Kamer, vergaderjaar 1989-1990, 20595 enz., blz. 40-2514, lk.

69. Vooral D66 is voorstander van het tax-creditsystecm. Zic over de definitie van het tax-creditsysteem hoofdstuk 4.

70. Tweede Kamer, vergaderjaar 1988-1989, 20 595, no 8, blz. 40.

71. Tweede Kamer, vergaderjaar 1988-1989, 20873 , no 7, blz. 10 en no 9, blz. 12.

72. Stevens acht het tax-creditsysteen in de sfeer van de aftrekposten ongewenst. In de tariefsfeer niet, aangezien het daar niet gaat om de formulering van het inkomensbegrip als maatstaf van draagkracht. L.G.M. Stevens, Eenvoudig belasten is lastig, Weekblad voor fiscaal recht, 1988, no 5844 , blz. 1395.

73. Vergelijk hetgeen $\mathrm{Dc}$ Grave (VVD) opmerkt ten aanzien van de verlaging van de tarieven: een minder fijnmazige meting van de draagkracht is voldoende. Zie ook Van Amelsvoort (CDA), Handelingen Tweede Kamer, vergaderjaar 1988-1989, 20595 enz., blz. 39-2384, rk, 39-2396, rk, 
Met de invoering van het wetsvoorstel OORT-II, wordt de al eerdere genoemde asymmetrie een feit. Er kunnen zich drie soorten asymmetrie voordoen, t.w.:

1. de kosten zijn voor de werknemer niet aftrekbaar en de desbetreffende vergoeding is voor de werknemer onbelast;

2. de vergoedingen voor kosten zijn (volledig) aftrekbaar als loonkosten en de vergoeding is onbelast bij de werknemer; ${ }^{74}$

3. er vindt belastingheffing bij de genieter plaats en de vergoedingen zijn niet geheel aftrekbaar bij de werkgever. ${ }^{75}$

Het onderstaande handelt over de eerstgenoemde asymmetrie.

De eerste gedachte die bij het woord asymmetrie opkomt, is strijd met het gelijkheidsbeginsel. Zowel in de literatuur als in de parlementaire geschiedenis zijn vragen over de asymmetrie en artikel 26 BuPo gerezen. ${ }^{76}$

In eerste instantie denkt een kamermeerderheid dat de geïntroduceerde asymmetrie strijd met het gelijkheidsbeginsel oplevert. ${ }^{n}$ Bijna alle politieke partijen waren tegen de voorgestelde asymmetrie. In dit kader zijn de opmerkingen van de VVD opmerkelijk. Eerst stelt ze zich op het standpunt dat de regering een gedegen argumentatie heeft ten aanzien van de asymmetrie, maar gezien de jurisprudentie ware het toch beter om het zekere voor het onzekere te kiezen en toch een aftrekbaarheid van gemengde kosten in de privé-sfeer toe te staan. ${ }^{78}$

en 39-2397, lk.

74. Voorbeelden zijn: vakliteratuur, werkkleding, gereedschap, muziekinstrumenten etc., tekstverwerkers etc., vakcursussen etc. N. Bink, E. Wasch, Aftrekbare kosten en vergoedingen, KJuwer, Belastingwijzers 7 , vierde herziene druk, 1991, blz. 59. Ook kan sprake zijn van onbelaste vergoedingen en 3/4 aftrek. Voorbeelden daarvan zijn: voedsel, drank en genotmiddelen, representatiekosten en congressen etc. Als laatste kan nog worden aangevoerd dat de vergoeding tot bepaalde grenzen onbelast is en dat er volledige aftrek plaatsvindt bij de werkgever. Voorbeelden zijn: het kostenforfait voor het woon-werkverkeer, het zakelijk gebruik van de privé-auto met een maximum van f 0,49 (tekst 1992), de kosten van verhuizing, en de kosten van huisvesting buiten de woonplaats met een maximum van 2 jaar. N. Bink, E. Wasch, t.a.p., blz. 60.

75. Een voorbeeld is de post kleding. De vergocding is volledig belast en er vindt $3 / 4$ aftrek plaats. N. Bink, E. Wasch, Aftrekbare kosten en vergoedingen, Kluwer, Belastingwijzers 7 , vierde herziene druk, 1991, blz. 61.

76. Tweede Kamer, vergaderjaar 1988-1989, 20 873, no 4, blz. 7, no 7, blz. 16 (CDA), 17 (VVD), 18 (D66), en no 9, blz. 16. De Eerste Kamer vraagt zich ook af of de asymmetrie niet in strijd is met het gelijkheidsbeginsel. Eerste Kamer, vergaderjaar 1988-1989, 20 873, no 133b, blz. 8 en 10. Zie bij voorbeeld C.J. Visser, Haast geboden?, Weekblad voor fiscaal recht, 1988, no 5844, blz. 1456, A.J.M. van Elk, Commentaar van de Nederlandse Orde van belastingadviseurs op wetsvoorstel 'Oort II', Weekblad voor fiscaal recht, 1988, no 5844, blz. 1459.

77. Tweede Kamer, vergaderjaar 1988-1989, 20 873, no 4, blz. 7 (D66), 19 en 20 (CDA), no 5, blz. 37 (CDA, PVDA, D66, SGP en PPR).

78. ' ... van oordeel waren dat de regering op basis van een gedegen argumentatie tot haar keuze is gekomen. Niettenin moet uit de jurisprudentic van de Centrale Raad van Beroep, ook op basis van het BuPo-verdrag, de conclusie worden getrokken dat het non-discriminatiebeginsel zeer rigide wordt toegepast, en afwegingen van de werkgever voor een niet volledig gelijke behandeling vanwege niet gelijke omstandigheden al snel terzijde worden geschoven. ... Derhalve zo, concludeerden deze leden, ware het te overwegen het zekere voor het onzekere te nemen door bij de mogelijkheid van een onbelastbare vergoeding toch aftrek mogelijk te maken van 
De VVD-fractie komt tot het oordeel dat de voorgestelde asymmetrie niet in strijd is met het gelijkheidsbeginsel. De fractie noemt drie redenen, t.w.:

1. De Raad van State vindt asymmetrie geoorloofd mits deze is vastgelegd in een formele wet en gebaseerd op doelmatigheidsredenen; ook het Europese Hof van de Rechten van de Mens laat voor dat geval een zeker onderscheid toe.

2. Er bestaat een verschil tussen de aftrek en de vergoeding van bepaalde kosten. Dit verschil wordt gebaseerd op het feit dat een derde partij in het geding is, $\mathbf{n l}$. de werkgever.

3. De Hoge Raad heeft in een aantal uitspraken bevestigd dat een ongelijke behandeling geoorloofd is, mits op gronden van doelmatigheid. ${ }^{79}$

De regering ontkent strijd met het gelijkheidsbeginsel en wel om de volgende redenen. Niet onder alle omstandigheden dient een symmetrie te bestaan tussen de aftrek- en de vergoedingenkant. Bovendien heeft de Hoge Raad een ongelijke behandeling tussen de aftrek- en de vergoedingenkant toegestaan. De regering zegt dat op zijn minst kan worden betwijfeld of bij aftrekbare kosten en vergoedingen sprake is van gelijke gevallen. ${ }^{80}$ Gelijk zijn de gevallen waarin de werknemer als intermediair optreedt en de gevallen waarin de werknemer een vergoeding krijgt. In geval van een belaste vergoeding is een intermediairfunctie niet goed mogelijk, aldus de regering. ${ }^{81}$ De toenmalige staatssecretaris verwoordt het aldus: 'Immers, de werknemer die kosten maakt en daarvoor een vergoeding ontvangt, staat meer op gelijke voet met een werknemer die - om het zo maar eens te zeggen - de kosten van zijn werkgever aan het maken is, dan met een werknemer die zijn eigen kosten maakt en daarvoor geen vergoeding ontvangt'. ${ }^{82} \mathrm{Er}$ worden mijns inziens door de staatssecretaris niet twee maar drie situaties beschreven. De eerste twee situaties zijn volgens de staatssecretaris synoniemen en worden gebruikt om naar een beoogd resultaat toe te redeneren. ${ }^{\circledR}$

Feteris en Brouwer merken op: 'Wij achten het dan ook zeker niet denkbeeldig dat de rechter de voorgestelde asymmetrie in strijd zal verklaren met het discriminatieverbod van artikel 26 van het BuPo-verdrag, waardoor een deel van de

gemengde kosten in de niet-winstsfeer.' Tweede Kamer, vergaderjaar 1988-1989, 20 873, no 7, blz. 17 .

79. Handelingen Tweede Kamer, vergaderjaar 1988-1989, 20595 enz., blz. 39-2385, rk en 39-2386, lk en mk. Zie voor een voorbeeld HR 22 maart 1994, BNB 1994/112, waarin de Hoge Raad oordeelt dat om redenen van uitvoerbaarheid en controleerbaarheid de wetgever ervoor heeft gekozen om het verhoogde reiskostenforfait uitsluitend toe te kennen aan degenen die een openbaar-vervoerverklaring kunnen overleggen.

80. De toenmalige staatssecretaris Koning benaderde deze materie uit twee invalshoeken, t.w.: 1 . moeten gelijke gevallen onder alle omstandigheden gelijk worden behandeld en 2 . is wel sprake van gelijke gevallen? Handelingen Tweede Kamer, vergaderjaar 1988-1989, 20595 enz., blz. 402518, $\mathrm{mk}$.

81. Zie noot 18.

82. Handelingen Tweede Kamer, vergaderjaar 1988-1989, 20595 enz., blz. 40-2518.

83. Engwirda (D66) stelt dat de staatssecretaris met betrekking tot de gemengde kosten $180^{\circ}$ gedraaid is. Handelingen Tweede Kamer, vergaderjaar 1988-1989, 20595 enz., blz. 39-2451. 
financiering van de vereenvoudigingsoperatie jaren later op drijfzand blijkt te rusten. ${ }^{84}$

De overheid behandelt belastingplichtigen die in gelijke omstandigheden verkeren ongelijk. De werkgever dient te bepalen of hij een vergoeding geeft of niet. Indien de werkgever een vergoeding geeft, kan daaraan het vermoeden worden ontleend dat de vergoeding ziet op een behoorlijke vervulling van de dienstbetrekking. Maar stel dat de werkgever van mening is dat de uitgave ter behoorlijke vervulling van de dienstbetrekking moet worden gedaan, maar desondanks geen vergoeding geeft. In dit geval behandelt de werkgever de belastingplichtigen ongelijk. ${ }^{85}$

Mijns inziens worden in het ene geval de kosten van de werkgever gemaakt, en in de andere twee gevallen kosten in het kader van de dienstbetrekking. Deze laatste kosten zijn naar mijn mening van een andere aard dan eerstgenoemde. Kosten gemaakt in het kader van de dienstbetrekking houden verband met de bron inkomsten uit arbeid, terwijl kosten gemaakt voor de werkgever dat niet hoeven te doen.

Een volgend element dat het gelijkheidsbeginsel betreft, is het tarief van de eerste schijf voor de niet-ingezetenen van Nederland. Dit tarief bedraagt voor de eerste schijf $25 \%$. De verschillen tussen het inkomen dat onderworpen is aan het $25 \%$-tarief en het ander inkomen, zijn van zodanige aard dat geen sprake is van gelijke gevallen, aldus de regering. ${ }^{86}$ Redeneer dat het in casu niet om gelijke gevallen gaat en het gelijkheidsbeginsel komt niet aan de orde.

Ten slotte nog een opmerking over de behandeling van gehuwden en ongehuwd samenlevenden. De regering merkt hierover op: '... staat enerzijds haaks op het streven naar verdere individualisering, schept anderzijds een voor de belastingplichtigen financieel aantrekkelijke situatie in verband met mogelijke tariefverschillen en leidt daarnaast tot een verschil in behandeling tussen echtgenoten en

84. 'Een wet waarin (vrijwel) gelijke gevallen ongelijk worden behandeld, wordt maatschappelijk moeilijk aanvaard, stimuleert het ontgaan van belasting en leidt daarmee tot een ongezonde fiscalisering van de samenleving.' M.W.C. Feteris, J.Th.L. Brouwer, De vereenvoudiging ontspOort(2), fiscaal weekblad FED, 1988, no 714, blz. 2235 en 2236.

Staatssecretaris Van Amelsvoort is van mening dat de in de wet neergelegde asymmetrie - en daarmee is blijkbaar ook de rechtvaardigingsgrond voor de ongelijke behandeling gegeven - niet zal lciden tot strijd met het gelijkheidsbeginsel. Uit het parlement, Weekblad voor fiscaal recht, 1991, no 5985, blz. 1703.

85. C.J. Visser, Haast geboden? Weckblad voor fiscaal recht, 1988, no 5844 , blz. 1456 en H.P.A.M. van Arendonk, De operatie-Oort: dc vereenvoudiging weggesneden?, Maandblad Belastingbeschouwingen, 1988, no 11, blz. 302 en Handelingen Tweede Kamer, vergaderjaar 1988-1989, 20 595 enz., blz. 42-2599.

86. Eerste Kamer, vergaderjaar 1988-1989, 20 873, no 133c, blz. 4 en staatssecretaris Koning, die stelt dat de verdragen de binnenlandse en de buitenlandse belastingplichtigen ook niet als gelijk willen beschouwen. Handelingen Tweede Kamer, vergaderjaar 1988-1989, 20595 enz., blz. 28-13, Ik en mk. Zie ook L.G.M. Stevens, De vereenvoudiging wordt duur betaald, Weekblad voor fiscaal recht, 1989, no 5857, blz. 213. 
ongehuwd samenwonende partners. ${ }^{, 87}$ Vergeleken met de Tweeverdienerswetgeving wordt de doelstelling om de gehuwden en de ongehuwd samenlevenden gelijk te behandelen niet meer nagestreefd. ${ }^{88}$

Relevante jurisprudentie met betrekking tot de aftrekbaarheid van gemaakte kosten in relatie tot het gelijkheidsbeginsel

\section{Het Koffiegeld-arrest}

Ik ga nu nader in op het in hoofdstuk 4 vermelde Koffiegeld-arrest. Het arrest betreft twee elementen; ten eerste de onbelastbaarheid van koffiegeldvergoedingen en ten tweede het verschil in aftrek en vergoedingen van reiskosten.

Voor zover het betreft de koffiegeldvergoedingen gaat het hier om uitvoeringsbeleid. Bij resolutie zijn de koffiegeldvergoedingen onbelast verklaard. Een gevolg hiervan is, aldus de Hoge Raad, dat indien geen vergoeding wordt gegeven de gemaakte kosten aftrekbaar zijn, ondanks dat deze uitgaven volgens vaste rechtspraak niet tot de aftrekbare kosten worden gerekend. ${ }^{89}$

De A-G Van Soest is een andere mening toegedaan. 'Als voornaamste verschil zie ik, dat bij de belastingheffing of vrijstelling van vergoedingen drie partijen betrokken zijn en bij de aftrek van kosten slechts twee. Indien de vergoedingen verstrekt worden, dan is daarover - vanuit in beginsel tegengestelde belangen - overeenstemming bereikt tussen de werkgever en de werknemer (onder omstandigheden hun belangenbehartigers) en moet vervolgens de fiscus zijn standpunt bepalen. Laatstgenoemde kan zich dan in beginsel gemakkelijker bij de bereikte overeenstemming neerleggen dan wanneer hij de situatie ten gronde moet beoordelen in zijn relatie uitsluitend tegenover de belastingplichtige werknemer.' Bovendien leidt het toestaan van de aftrekbaarheid van zulke geringe bedragen

87. Tweede Kamer, vergaderjaar 1988-1989, 20873 , no 9, blz. 29. Een ander punt van gelijke behandeling betreft de giftenregeling. De ongehuwd samenlevenden worden individueel in de belastingheffing betrokken. Het gevolg kan zijn dat verschillen optreden die ten gunste van die zowel ten gunste van de ongehuwd samenlevenden als de gehuwden zijn. Tweede Kamer, vergaderjaar 1988-1989, 20 873, no 5 , blz. 50 en 51.

88. In de notitie Leefvormen, Tweede Kamer, vergaderjaar 1985-1986, 19262 , geeft de regering het volgende antwoord op de vraag of een ongelijke behandeling tussen de gehuwden en ongehuwd samenlevenden geoorloofd is: 'Deze en in de vraag genoemde verschillen (duur, kans van scheiding, verwachting, bereidheid tot wederzijdse economische bijstand) rechtvaardigen echter naar de stellige overtuiging van het kabinet geen verschil in behandeling van gehuwden en ongehuwd samenwonenden in het kader van de minimumbehoeftenregelingen. ... Het zij in dit verband nogmaais gesteld dat naar onze mening een verschil in behoefte en draagkracht niet voortvloeit uit de formalisering van een samenlevingsverband door middel van een huwelijk, maar uit het samenleven zelf.' Uit: Tj. Gcrbranda, M. Kroes, Grondrechten evaluatie-onderzoek, Documentatie-rapport (1), NJCM, Leiden, 1991, blz. 1-179 en 1-180. Zie echter A.J.M. van Elk, die voorstander is van een algehele gelijke behandeling. A.J.M. van Elk, Commentaar van de Nederlandse Orde van Belastingadviseurs op wetsvoorstel 'OORT-II', Weckblad voor fiscaal recht, 1988, no 5844 , blz. 1459.

89. HR 22 juni 1988, BNB 1988/2S9 m.nt. J.E.A.M. van Dijck. Het betreft in casu een vóórOORTse situatie, de resolutie van 12 juni 1980 , no $280-7154$, maar het arrest is van belang voor de onderhavige materie. V-N 5 juli 1980, blz. 1384. Tweede Kamer, vergaderjaar 1988-1989, 20 595 , no 8 , blz. 38 . 
tot een ondermijning van de doelmatigheid en de maatschappelijke psychologie, aldus de A-G.

Getuige het criterium in de OORT-wetgeving dat de werkgever moet beoordelen of een vergoeding strekt tot een behoorlijke vervulling van de dienstbetrekking, heeft de regering zich aangesloten bij de strekking van het citaat. ${ }^{90} \mathrm{De}$ regel dat wanneer de werkgever de kosten vergoedt daarmee een vermoeden van een behoorlijke vervulling van de dienstbetrekking vaststaat, roept bij de Raad van State vragen met betrekking tot het gelijkheidsbeginsel op. ${ }^{91}$

Inzake het verschil in aftrek en vergoeding van reiskosten wordt in het arrest beslist, dat de wetgever het om redenen van doelmatigheid nodig heeft geacht dat hetgeen in geval van een vergoeding boven het aftrekbedrag uitkomt, vrijgesteld is. Met andere woorden, de aftrekbare kosten mogen lager zijn dan de vrijgestelde vergoedingen. ${ }^{92}$ De wetgever heeft het doelmatig geoordeeld dat vergoedingen ook boven het aftrekbare bedrag worden vrijgesteld en die ongelijkheid is door de formele wetgever bewust en expliciet in de wet vastgelegd, aldus de Hoge Raad. De kritiek van onder andere Van Arendonk houdt in dat een beroep op de doelmatigheid niet ter zake doet, juist omdat de regeling een forfait is. ${ }^{93}$

Zoals gezegd maakt de regering in de wetgeving gebruik van het door de Hoge Raad aangereikte handvat. $\mathrm{Zij}$ kan in het algemeen tot een ongelijke behandeling beslissen, mits de mogelijkheid maar is geregeld in de wet èn de noodzaak voor de ongelijke behandeling is gelegen in redenen van doelmatigheid. ${ }^{94}$ In de literatuur en in de Kamer is twijfel gerezen over het argument van de doelmatigheid. De doelmatigheid moet nader inhoud worden gegeven, anders is er volgens de Tweede Kamer en enige fiscale auteurs strijd met het BuPo-verdrag. ${ }^{95}$

90. De regering is de mening toegedaan dat niet iedere ongelijkheid een strijd met het gelijkheidsbeginsel oplevert. Tweede Kamer, vergaderjaar 1988-1989, 20 873, B, blz. 15.

91. Tweede Kamer, vergaderjaar 1988-1989, 20 873, no B, blz. 13.

92. Het gelijkheidsbeginsel brengt niet mee dat de aftrekbare kosten niet lager mogen zijn dan de vrijgestelde vergoedingen. Zie onder andere HR 16 september 1992, BNB 1993/20, m.nt. J. Brunt.

93. H.P.A.M. van Arendonk, OORT I + OORT II, Vereenvoudiging I - Vereenvoudiging II, Maandblad Belastingbeschouwingen, 1988, no 9, blz. 224.

Zie voor een bevestiging van de gcoorloofde discrepantie tussen de vergoedingen en aftrek van reiskosten de uitspraak van het Hof Arnhem 15 december 1992, V-N 1993, blz. 1789.

94. Ook de Raad van State (30 september 1988) stelt zich op het standpunt dat asymmetrie oirbaar is, mits in formele wet vastgelegd en steunend op de doelmatigheid. Handelingen Tweede Kamer, vergaderjaar 1988-1989, 20595 enz., blz. 39-2386. Dit kan indien de redenen duidelijk in de wet zijn vastgelegd. Tweede Kamer, vergaderjaar 1988-1989, 20 873, B, blz. 14.

95. Tweede Kamer, vergaderjaar 1988-1989, 20 873, no 7, blz. 16 (CDA), Handelingen Tweede Kamer, vergaderjaar 1988-1989, 20595 enz., blz. 42-2599, rk. En zie Zwemmer, die met betrekking tot de doelmatigheid en de voorgestelde regeling inzake de literatuur het volgende stelt. Het verschil tussen het Koffiegeld-arrest en de literatuur zit in het feit dat de reiskosten om wille van de doelmatigheid een forfait kennen en de literatuur niet. Derhalve is met betrekking tot de literatuur sprake van een schending van het gelijkheidsbeginsel. J.W. Zwemmer, Haastige spoed is zelden goed, Weekblad voor fiscaal recht, 1988, no 5844, blz. 1436. 
Het verschil tussen de regeling inzake de reiskostenvergoedingen en die betreffende de koffiegeldvergoedingen is hierin gelegen dat de eerste regeling door de wetgever en de tweede in de uitvoeringssfeer tot stand is gekomen.

In het arrest komt bovendien het vergelijkingscriterium aan de orde: '..., door iemand die niet een dienstbetrekking als die van belanghebbende vervult, doch overigens wat inkomen, vermogen en gezin betreft in dezelfde omstandigheden verkeert, niet zouden zijn gemaakt.' Enige tijd later is dit criterium in de wet gecodificeerd.

Interessant is nog dat het hof in een overweging het draagkrachtbeginsel aan de orde stelt. 'Deze belastingheffing naar individuele draagkracht komt ook tot uiting in de Korte Toelichting op de Wet inkomstenbelasting 1964, .... In de korte toelichting wordt aangegeven dat in de Wet de aard en het wezen van de synthetische inkomstenbelasting welke het totale inkomen, ongeacht de herkomst, onderwerpt aan een belastingheffing naar draagkracht zijn behouden.' Het draagkrachtbeginsel wordt nog steeds als een belangrijke leidraad gezien.

\section{Het Studeerkamer-arrest}

In het Studeerkamer-arrest gaat het om het verschil in behandeling van de aftrekbare kosten ter zake van een studeerkamer in de woning tussen de huurder-bewoner en de eigenaar-bewoner (artikel 35, derde lid Wet IB 1964, tekst 1983).$^{96}$ Dit arrest betreft weliswaar een oude tekst van artikel 35 Wet IB 1964, maar het betreft hier het verschil tussen de huurder-bewoner en de eigenaarbewoner, welk verschil in een later arrest weer van belang is.

In casu wordt een beroep gedaan op artikel $26 \mathrm{BuPo}$. Anders dan de A-G Moltmaker is de Hoge Raad van mening dat het gelijkheidsbeginsel niet geschonden is. De Hoge Raad motiveert de beslissing met een verwijzing naar de wetgever. De wetgever heeft geen gelijke gevallen aanwezig gezien en de aanvankelijke gelijke behandeling van de huurder met de eigenaar beëindigd door middel van een wetswijziging. Er is geen duidelijke aanwijzing dat de bepaling van artikel 35, derde lid Wet IB 1964 met artikel 26 BuPo strijdt. ${ }^{97}$ 'Het voor het

96. HR 8 juli 1988, BNB 1988/302 m.nt. J.P. Scheltens. Zie ook HR 4 mei 1994, V-N 1994, blz. 1682 en BNB 1994/195 (artikel 35, lid 3 Wet IB 1964, tekst 1986), inzake de ongelijke behandeling tussen belastingplichtigen die voor het verwerven van inkomsten uit arbeid niet gebruik maken van een werkkamer in de woning, alle door hen gemaakte kosten mogen aftrekken en belastingplichtigen die ten behoeve van het verwerven van inkomsten uit arbeid daarentegen wel een werkkamer in de woning gebruiken slechts een deel van de werkkamerkosten mogen aftrekken. Bovendien zou er een ongelijke behandeling zijn tussen belastingplichtigen die voor het verwerven van inkomsten uit arbeid gebruik maken van een werkkamer in de eigen woning en belastingplichtigen die ten behoeve van hun onderneming gebruik maken van een werkkamer die tot het vermogen van de onderneming behoort. De Hoge Raad oordeelt in beide gevallen dat geen sprake is van schending van het gelijkheidsbeginsel.

97. Van Soest is van mening dat indien de wetgever de bestaande gelijkheid in een wettelijke regeling wil doorbreken, nog niet zo zeker is dat sprake is van schending van het gelijkheidsbeginsel. A.J. van Socst, Belastingen: inkomstenbelasting, vermogensbelasting, vennootschapsbelasting, achttiende druk, Gouda Quint, 1994, blz. 182 en 183. Zie ook W.E.M. van Nispen tot Sevenaer, De 35\%-regeling en het gelijkheidsbeginsel, Weekblad voor fiscaal recht, 1992, no 6017, blz. 964, noot 16. 
gebruik van een werkkamer in de eigen woning opgeofferde woongenot komt immers niet als een uitgave in geld of in natura in aftrek maar als een voor verwerving van inkomsten opgeofferd bestanddeel van de in het belastbare inkomen begrepen huurwaarde. De wijze waarop die huurwaarde forfaitair in het belastbare inkomen is opgenomen, met inachtneming van zowel een beleggings- als een bestedingsaspect vormt een zo speciale regeling dat niet kan worden gezegd dat de wetgever in redelijkheid niet heeft kunnen oordelen dat die huurwaarde voldoende afwijkt van een door huurder betaalde huur om voor de regeling van de aftrekbare kosten tot een uiteenlopende behandeling aanleiding te geven.'

Zeer interessant is de conclusie van A-G Moltmaker. Volgens Moltmaker eist artikel 26 BuPo geen rechtsgrond van een belasting. De vraag naar de rechtsgrond van een belasting is een gepasseerd station voor artikel $26 \mathrm{BuPo}$. Artikel $26 \mathrm{BuPo}$ doet wel zijn invloed gelden op de wet zelf en de toepassing van de wet. Een ongelijke behandeling van gelijke gevallen kan gerechtvaardigd zijn door een legitieme doelstelling van overheidsbeleid en/of het middel in een redelijke verhouding staat tot de doelstelling.

Een voorbeeld van een legitieme doelstelling van overheidsbeleid is het streven naar doelmatigheid, mits met inachtneming van de eis van proportionaliteit tussen doel en middel. Hierbij kan worden gedacht aan het forfait. Een verschil in behandeling kan niet enkel en alleen door budgettaire gronden worden gerechtvaardigd, aldus Moltmaker.

\section{Het Kinderopvang-arrest}

Naar aanleiding van het Koffiegeld-arrest zijn in de Kamer vragen gesteld met betrekking tot kinderopvangkosten. ${ }^{98}$ De staatssecretaris is van mening dat de Resolutie van 14 april 1988, nr DB88/1836 inzake de kinderopvangkosten niet van dezelfde strekking is als de resolutie inzake de koffiegeldvergoedingen. De laatstgenoemde resolutie betreft een invulling van een beleid gerechtvaardigd door doelmatigheidsoverwegingen, terwijl de eerstgenoemde resolutie een waarderingskwestie betreft. Derhalve is het gelijkheidsbeginsel niet van toepassing, aldus de staatssecretaris.9

Volgens enige kamerleden moet op basis van de bestaande jurisprudentie een (beperkte) aftrekpost worden toegestaan aan belastingplichtigen die van hun werkgever geen vergoeding ontvangen voor de kosten van de kinderopvang. De regering antwoordt hierop dat uiteindelijk de administratieve rechter in belastingzaken hierover moet beslissen. ${ }^{100}$ De vraag rijst: wie is hier de wetgever die verantwoordelijk is voor een rechtvaardig stelsel van belastingheffing?

98. Tweede Kamer, vergaderjaar 1988-1989, 20 873, no 7, blz. 26.

99. Weekblad voor fiscaal recht, 1988, no 5838, blz. 1201 en 1202 . Handelingen Tweede Kamer, vergaderjaar 1988-1989, 20595 enz., blz. 42-2624.

100. Tweede Kamer, vergaderjaar 1988-1989, 20873 , no 9, blz. 33. Sommige kamerleden (onder andere Vermeend, PvdA) vinden dat de regering de jurisprudentie niet moet afwachten. Handelingen Tweede Kamer, vergaderjaar 1988-1989, 20595 enz., blz. 42-2593, rk. 
Of de wetgever nu wel of niets onderneemt, de jurisprudentie heeft niet op zich laten wachten. ${ }^{101}$ Normaal gesproken behoren de kinderopvangkosten niet tot de aftrekbare kosten. In een resolutie is bepaald dat de vergoeding van de werkgever voor de kosten van kinderopvang die worden gemaakt bij een niet gesubsidieerde instelling, onbelast is voor het meerdere van de eigen bijdrage van de werknemer in een gesubsidieerde instelling. De Hoge Raad beslist dat de werknemer die geen vergoeding ontvangt, de kosten voor zover die meer belopen dan de eigen bijdrage, mag aftrekken, tenzij een redelijke grond voor de ongelijke behandeling bestaat. ${ }^{102}$

Dit arrest vertoont sterke verwantschap met het Koffiegeld-arrest. Het verschil zit in de ruimte die aan de uitvoerende instanties wordt gelaten om tot een ongelijke behandeling over te gaan, aldus annotator Den Boer. ${ }^{103}$ In het Koffiegeld-arrest had de uitvoerende instantie de ruimte niet, in het Kinderopvang-ar-

101. HR 12 december 1990, BNB 1991/76. Ministeriële resolutie van 14 april 1988, nr. DB88/1836, onder 3, letter b, BNB 1988/172.

102. In een resolutie bepaalt de staatssecretaris dat het arrest alleen zijn gelding heeft ten aanzien van de kosten gemaakt in dienstbetrekking. 'Het arrest leidt naar mijn mening niet tot aftrek van kosten kinderopvang voor personen met (uitsluitend) winst uit onderneming, andere inkomsten uit arbeid en/of inkonsten uit vroegere arbeid.' Daarnaast gelden nog enige andere voorwaarden. Bovendien wordt in de resolutie een onderscheid gemaakt naar jaren. Resolutie van 31 oktober 1991, nr. DB 91/1259, BNB 1992/19, gewijzigd bij resolutic van 30 januari 1992, nr. DB91/7121, BNB 1992/106. Gewijzigd op 22 januari 1993; resolutic 22 januari 1993, nr. DB93/2, orspronkclijk 31 oktober 1991, nr. DB91/1259, BNB 1993/87, V-N 4 februari 1993, blz. 363.

Met betrekking tot de Resolutie van 31 oktober 1991, nr. DB91/1259 is een uitspraak geweest, waarin het hof beslist dat doelmatigheidsredenen en privacy-aspecten een objectieve en redelijke rechtvaardiging vormen voor het verschil in behandeling van de kosten van kinderopvang in het kader van de heffing van de inkomstenbelasting en in het kader van de heffing van de loonbelasting. Hof 's-Gravenhage 11 november 1992, V-N 1993, blz. 838.

103. Een belangrijk arrest voor de toepassing van het gelijkheidsbeginsel in de beleidssfeer is het arrest van HR 16 juli 1993, Weekblad voor fiscaal recht, 1993, no 6066, biz. 1223, BNB 1993/321 m.nt. P.J. Wattel (artikel 35, tekst 1988). In casu betreft het herinrichtingskosten en dergelijke van een ambtenaar in vergelijking met dezelfde kosten van een werknemer. De toepassing brengt mee dat een werknemer dic geen vergoeding krijgt, de werkelijk gemaakte herinrichtingskosten en dergelijke als aftrekbare kosten in aanmerking mag nemen, tenzij voor de ongelijke behandeling een redelijke grond bestaat. Deze ontbreekt in casu.

De staatssecretaris is van mening dat de gevolgen van dit arrest beperkt blijven tot de periode van v66r 1990, met een beroep op het feit dat het arrest betrekking heeft op het belastingjaar 1988 en het feit dat na 1990 de symmetrie tussen aftrekbare kosten en belastingvrije vergoedingen niet alleen in de wetgeving, maar ook in de beleidssfeer is doorbroken. Weekblad voor fiscaal recht, 1993, no 6074, blz. 1564. Wattel heeft hierop in zijn noot kritiek en stelt 'de asymmetrie van de Oort-wetgeving strikt te beperken tot de expliciet door de Oortwetgeving geregelde gevallen, aangezien zij een duidelijke inbreuk op het algemene rechtsbeginsel van gelijkheid vormt. Het standpunt van de staatssecretaris komt erop neer dat een of andere doelmatigheids- of beleidsgedachtc een fundamenteel rechtsbeginsel opzij zou kunnen zetten zonder dat enige geschreven regel, Jaat staan een formeel-wettelijke regel dat expliciet bepaalt.' BNB 1993/322, blz. 2305. Wattel spreekt zelfs van het invoeren door het Ministerie van Asymmetrie van het ongelijkhcidsbeginsel als fundamenteel rechtsbeginsel. P.J. Wattel, Het ongelijkheidsbeginsel, Weekblad voor fiscaal recht, Column, 1993, no 6079, blz. 1723. 
rest wel; een ongelijke behandeling zou mogelijk zijn indien daarvoor een redelijke grond bestaat. ${ }^{104}$

Thans (1994) is in de Eerste Kamer een wetsvoorstel inzake de aftrek en belastingvrije vergoeding van kosten van kinderopvang in behandeling. ${ }^{105}$ Mede naar aanleiding van bovenstaand arrest wordt voorgesteld de kosten van beroepsmatige kinderopvang voor kinderen van 12 jaar of jonger van belastingplichtigen die buitenshuis meer dan $f 5.925$ verdienen dan wel in aanmerking komen voor de zelfstandigenaftrek maximaal $f 10.000$ als buitengewone last toe te laten; althans voor zover die uitgaven meer belopen dan bij ministeriële regeling vast te stellen bedragen. De regeling wordt uitgebreid tot zelfstandigen. De regeling bevordert de toetreding van vrouwen met kinderen tot de arbeidsmarkt, aldus de regering. ${ }^{106}$

De Raad van State merkt op dat het noemen van het maximum van $f 10.000$ per kind voor de vergoeding van kinderopvangkosten in het voorgestelde artikel 46, lid 10 Wet IB 1964 en het niet noemen van dat maximum in het voorgestelde artikel 11, lid 1, onderdeel n Wet LB 1964 een verschil oplevert. 'Tevens zal, zoals uit de toelichting blijkt, verschil worden gemaakt in de franchises die voor rekening blijven van de werknemer die een vergoeding van de werkgever ontvangt dan wel van de werknemer die de kosten zelf draagt en de zelfstandige, die een beroep doet op de buitengewone lastenregeling.' Het bovenstaande levert een ongelijke behandeling op waarvoor geen redelijke grond aanwezig is. ${ }^{107}$ Als antwoord hierop vult de regering de memorie van toelichting aan met de opmer-

104. Zie voor een vergelijkbaar arrest HR 16 juli 1993, BNB 1993/299, m.nt. J. Brunt (artikel 35, tekst 1988). Brunt merkt in zijn noot op dat de Hoge Raad dan wel en dan niet de zinsnede 'tenzij voor de ongelijke behandeling cen redelijke grond bestaat', toevoegt. HR 16 juli 1993 , BNB 1993/299, blz. 2202.

105. Zie Wijziging van de Wet op de inkomstenbelasting 1964, de Wet op de loonbelasting 1964 en de Coördinatiewet Sociale Verzekering (regelingen met betrekking tot aftrek en belastingvrije vergoeding van kosten van kinderopvang). Eerste Kamer, vergaderjaar 1993-1994, 23 483, no 158. Ten tijde van het drukken van het proefschrift is dit wetsvoorstel wet geworden (Wet van 15 december 1994, Stb. 1994, 930).

Een voorbeeld van een uitspraak waaruit blijkt wat onder kinderopvangkosten moet worden verstaan is Hof 's-Hertogenbosch 13 september 1993, V-N 1994, blz. 1794.

106. Tweede Kamer, vergaderjaar 1993-1994, 23 483, no 3, blz. 7 en no 5, blz. 6 en 8. Dit ondanks de verhoogde eigen bijdragen. Zie ook Tweede Kamer, vergaderjaar 1993-1994, 23 483, no 4, blz. 3 en 8 en Eerste Kamer, vergaderjaar 1993-1994, 23 483, no 158a, blz. 1 en Handelingen Tweede Kamer, vergaderjaar 1993-1994, 23483 etc., blz. 31-2357, rk en 33-2584, rk.

107. Tweede Kamer, vergaderjaar 1993-1994, 23 483, B, blz. 2. Zie ook een opmerking van enige leden van GroenLinks. 'In de voorgestelde regeling zijn kosten pas aftrekbaar bij overschrijding van de $100 \%$ van de door WVC geadviseerde ouderbijdragen, terwijl vergoedingen al bij overschrijding van $75 \%$ van de door WVC geadviseerde ouderbijdragen belastingurij zijn. Komt de voorgestelde regeling daarmee nict in strijd met het door de Hoge Raad gehanteerde gelijkheidsbeginsel?' Tweede Kamer, vergaderjaar 1993-1994, 23 483, no 4, blz. 3. De regering antwoordt dat in casu twee heel verschillende gevallen aan de orde zijn. Tweede Kamer, vergaderjaar 1993-1994, 23 483, no 5, blz. 3.

Zie ook de door de VVD gemaakte opmerkingen inzake de beroepsopvang. Handelingen Tweede Kamer, vergaderjaar 1993-1994, 23 483, blz. 31-2353, mk. 
king dat de situaties van kinderopvang in natura en vergoedingen voor kosten van kinderopvang zeer dicht bij elkaar liggende situaties zijn. Bovendien zou door het niet noemen van een maximum in de vergoedingenkant tot uitdrukking moeten komen dat door het geven van een vergoeding van de werkgever het zakelijk karakter van de uitgave vaststaat. ${ }^{108}$

Overigens wordt in de kamerstukken de opmerking gemaakt dat het wetgevingsproces zeer snel is geweest, met alle gevolgen van dien. ${ }^{109}$

\section{Het Studeerkamer-en koffiegeld-II-arrest}

Op 17 november 1993 heeft de Hoge Raad opnieuw een arrest gewezen met betrekking tot de aftrekbare kosten inzake de kantoorruimte en de kosten van consumptie van koffie. ${ }^{110}$ Gemakshalve noem ik dit arrest het Studeerkameren koffiegeld-II-arrest.

Het betreft in casu de regeling van artikel 36, eerste lid, onderdeel e, en tweede lid, onderdeel f Wet IB 1964 (huidige tekst).

\section{1. kantoorniimte}

Het verschil tussen de huurder-bewoner en de eigenaar-bewoner komt opnieuw aan de orde. Met de invoering van artikel 36, tweede lid, onderdeel $\mathrm{f}$ Wet IB 1964 is een ongelijkheid tussen de eigenaar en de huurder inzake de regeling van de aftrekbare kosten van de kantoorruimte in de woning van de belastingplichti-

108. Tweede Kamer, vergaderjaar 1993-1994, 23 483, B, blz. 2 en 3 en no 3, blz. 10. Opmerkelijk is nog dat de precieze inkomenseffecten niet goed vallen aan te geven. Tweede Kamer, vergaderjaar 1993-1994, 23 483, B, blz. 6 en no 5, blz. 4. Handelingen Tweede Kamer, vergaderjaar 1993-1994, 23 483, blz. 31-2357, rk.

109. Tweede Kamer, vergaderjaar 1993-1994, 23 483, no 4, blz. 1. Naast dit wetsvoorstel is er nog een vrij oud wetsvoorstel ingediend op 13 oktober 1986 door de leden Vermeend en Van Nieuwenhoven betreffende een invoering van een fiscale tegemoetkoming ter bevordering van kinderopvangvoorziening met het oog op het verbeteren van de toegang tot de arbeidsmarkt voor met name (her)intredende vrouwen, Tweede Kamer, vergaderjaar 1986-1987, 19 750. Het laatste kamerstuk van dit wetsvoorstel dateert van 23 november 1989.

Daarnaast wordt in het wetsvoorstel inzake de afschaffing van de overdracht van de basisaftrek ook enige voorstellen met betrekking tot kinderopvang gedaan. Tweede Kamer, vergaderjaar 1993-1994, 23 231. Het is natuurlijk van belang dat de voorstellen op elkaar worden afgestemd.

110. HR 17 november 1993, BNB 1994/36, m.nt. P.J. Wattel en AA 1994, blz. 526, m.nt. J.W. Zwemmer. De staatssecretaris is genoodzaakt geweest een resolutie over de gevolgen van het arrest uit te brengen. De resolutie houdt in dat nog bezien moet worden in hoeverre artikel 36, tweede lid, onderdeel f Wet IB 1964 in overeenstemming moet worden gebracht met artikel $26 \mathrm{BuPo}$. Bij eigen-woning bezitters moet voor de aftrek van de kosten inzake een kantoorruimte worden uitgegaan van de huurwaarde bepaald via artikel 42a, negende lid Wet IB 1964. Resolutie van 5 januari 1994, nr. DB93/5157M, BNB 1994/63. Inzake het koffiegeld wordt bepaald dat voor werknemers die doorgaans nict op vijf dagen per week werken, het aftrekbare bedrag wordt gesteld op $f 1$ per gewerkte dag. Met een beroep op de doclmatigheid acht de staatssecretaris het niet zinvol om bij de uitvoering van het arrest een onderscheid te maken tussen ambulante en niet-ambulante werknemers. Dit is opmerkelijk, daar nu de doelmatigheid een gelijke behandeling mogelijk maakt. Normaal voorkomt de doelmatigheid juist de gelijke behandeling. 
ge ontstaan. Het betreft in casu het verschil in behandeling van de inrichtingskosten e.d.. Artikel 36, tweede lid, onderdeel f Wet IB 1964 normeert de kosten die verband houden met de kantoorruimte; de kosten van inrichting vallen ook daaronder. Hiervoor bestaat geen objectieve en redelijke rechtvaardiging, aldus de Hoge Raad.

De Hoge Raad oordeelt dat artikel 36, tweede lid, onderdeel $\mathrm{f}$ in strijd is met het gelijkheidsbeginsel, zoals dit is neergelegd in artikel $26 \mathrm{BuPo}{ }^{111}$ Het artikel levert een discriminatie op tussen de eigenaar en de huurder. Deze ongelijkheid bestaat ten aanzien van de aftrek van inrichtingskosten; deze kosten zijn niet van aftrek uitgesloten, maar worden 'meegenomen' met het voor kantoorruimte opgeofferde woongenot in éen forfait. ${ }^{112}$

\section{Parlementaire geschiedenis van de kantoorruimte ${ }^{113}$}

'Het begrip kantoorruimte moet voor de onderhavige bepaling worden opgevat als werk- of studeerkamer, als ruimte waarin men zijn arbeid verricht. De kantoorruimte zal in het algemeen worden gekenmerkt door de aanwezigheid van een bureau of schrijftafel en boekenkasten en dergelijke. Onder kantoorruimte valt niet alleen de kamer die speciaal als kantoorruimte is ingericht, maar ook het gedeelte van een kamer dat, of de ruimte die voor de administratieve werkzaamheden van de belastingplichtige is ingericht', aldus de parlementaire geschiedenis. ${ }^{114}$ De Raad van State verwacht een bron van geschillen omtrent het criterium grotendeels in de kantoorruimte thuis verrichten van werkzaamheden. ${ }^{115}$

111. In BNB 1988/302 ging het om een verschil in behandeling tussen de eigenaar-bewoner en de huurder-bewoner betreffende het opgeofferde woongenot. In casu gaat het om aftrek van kosten van inrichting e.d.

112. Zie voor een bespreking van het gelijkheidsbeginsel hoofdstuk 7, § 7.4.2.

113. Een onderscheid dient te worden gemaakt tussen de belastingplichtigen die elders een kantoorruimte hebben en degene die dat niet hebben. In het eerste geval moet de belastingplichtige het merendeel van de inkomsten uit arbeid en winst in de kantoorruimte thuis verdienen, wil hij aanspraak blijven maken op de aftrek. In het tweede geval moet de belastingplichtige voor meer dan de helft de inkomsten kunnen 'toerekenen' aan de kantoorruimte. Tweede Kamer, vergaderjaar 1988-1989, 20 873, no 5, blz. 57 en Eerste Kamer, vergaderjaar 1988-1989, 20595 enz., no 133c, blz. 10. Handelingen Tweede Kamer, vergaderjaar 1988-1989, 20595 enz., biz. $26-55$, $1 \mathrm{k}$.

114. Eerste Kamer, vergaderjaar 1989-1990, 21 184, no 60b, blz. 6. Stel dat een huisarts een groepspraktijk en cen behandelkamer heeft. Zijn de kosten van deze behandelkamer aftrekbaar? De behandelkamer voldoet niet aan de gegeven omschrijving en derhalve zijn de kosten van die kamer aftrekbaar, aldus de staatssecretaris. Zie ook de mededeling van de Directic Particulieren, Infobulletin 91/639, V-N 1992, blz. 70.

$\mathrm{Zie}$ voor een voorbeeld uit de jurisprudentic waarin beoordecld wordt of een werkkamer een kantoorruimte is Hof 's-Gravenhage 14 december 1993, V-N 1994, blz. 1503. Zie ook mededeling van de Directie Particulieren, Infobulletin 92/441, V-N 1992, blz. 2418.

115. Tweede Kamer, vergaderjaar 1988-1989, 20 873, B, blz. 22. De regering merkt hierover op dat de belastingplichtige het voldoen aan het criterium aannemelijk moet maken 'door een globale opgave te doen met betrekking tot de omvang van het gebruik van de kantoorruimte in relatie tot de buiten die kantoorruimte verrichte activiteiten. Tweede Kaner, vergaderjaar 1988-1989, $20873, \mathrm{~B}$, blz. 23. 
De door de Raad van State verwachte jurisprudentie heeft niet lang op zich laten wachten. ${ }^{116}$ Opmerkelijk zijn de uitspraken van met name het Hof 's-Gravenhage. ${ }^{117}$ Indien een belastingplichtige meer dan $50 \%$ van de gewerkte uren kan toerekenen aan de studeerkamer, zijn de kosten volgens het hof aftrekbaar. De door een leraar in de studeerkamer gewerkte uren worden even zwaar beoordeeld als uren gewerkt op school. Dit is in strijd met de tekst en de parlementaire geschiedenis van de wetsbepaling artikel 36 , lid 1 , onderdeel b, ten eerste Wet IB 1964, aldus staatssecretaris Van Amelsvoort. ${ }^{118}$ In dit verband is ook de beleidspublicatie van de staatssecretaris van belang. 'Het begrip 'grotendeels verwerven' wordt opgevat in die zin dat de prestaties waarvoor wordt betaald grotendeels in (of vanuit) die ruimte worden verricht. Meestal zullen aard (en centrum) van de werkzaamheden een belangrijke indicatie geven. In de situatie waarin de verdeling van de prestaties moeilijk is toe te rekenen aan thuis dan wel elders, kan een tijdscriterium worden gehanteerd. ${ }^{119}$

De Hoge Raad heeft onlangs een belangrijk arrest gewezen naar aanleiding van de uitspraak van Hof 's-Gravenhage van 11 september 1992 inzake de kantoorruimte. De Hoge Raad overweegt in 3.4.: 'Uit deze wetsgeschiedenis moet worden afgeleid dat naar de bedoeling van de wetgever bij de toerekening van de inkomsten uit arbeid en winst uit onderneming aan de in de kantoorruimte in de woning verrichte werkzaamheden eerst moet worden bezien of splitsing van die arbeidsinkomsten of winst mogelijk is doordat bepaalde opbrengsten concreet tegenover bepaalde werkzaamheden staan. Indien - zoals in het onderhavige geval - echter een splitsing op basis van de concreet tegenover bepaalde werkzaamheden staande opbrengsten niet mogelijk is omdat uit eén dienstbetrekking inkomsten worden genoten welke in hun geheel staan zowel tegenover in de kantoorruimte verrichte werkzaamheden als tegenover elders verrichte werkzaamheden moet worden aangenomen dat een toerekening aan de hand van de feitelijke duur van de werkzaamheden in de kantoorruimte en elders het meest beantwoordt aan de bedoeling van de wetgever. Voor een toerekening waarbij aan bepaalde binnen die dienstbetrekking verrichte werkzaamheden meer gewicht wordt gegeven dan aan andere, is dan, anders dan in het middel betoogd geen

116. Zie over het criterium 'grotendeels' onder andere de uitspraken van het Hof Leeuwarden 28 april 1992, V-N 1992, blz. 2016, 24 september 1992, V-N 1993, blz. 490, Hof 's-Gravenhage 3 november 1992, V-N 1993, blz. 365 (genieten van inkomsten uit vroegere arbeid naast inkomsten in de sfeer van artikel 22, eerste lid, onderdeel b Wet IB 1964), 29 januari 1993, V-N 1993, blz. 1185 en 25 maart 1993, V-N 1993, blz. 2487, 5 oktober 1993, Infobulletin 93/748 en Hof Amsterdam, 3 februari 1993, V-N 1993, blz. 1962.

117. In de uitspraak van Hof 's-Gravenhage 1 oktober 1993, Infobulletin $94 / 127$ wordt naast het inkomenscriterium het tijdscriterium toegepast en kan de belanghebbende een aftrek claimen daar deze meer uren thuis dan op school had gewerkt. Zie ook Hof 's-Gravenhage 11 september 1992, Infobulletin 93/28 en Hof Arnhem 9 februari 1993, V-N 1993, blz. 3523.

118. Weekblad voor fiscaal recht, 1993, no 6052, blz. 665 .

119. V-N 1992, blz. 2418. In de uitspraak van Hof Amsterdam 27 januari 1994, Infobulletin 94/291 hanteert het hof het inkomenscriterium zoals dat is neergelegd in de parlementaire geschiedenis. Zie Tweede Kamer, vergaderjaar 1988-1989, 20 873, no 5, blz. 56-58. 
plaats. ${ }^{120}$ Bij éen arbeidsbron dient volgens de Hoge Raad het tijdscriterium te worden gehanteerd. ${ }^{121}$

\section{2. koffiegeld}

Een tweede punt dat in het Studeerkamer- en Koffiegeld-II-arrest aan de orde komt, is de symmetrische behandeling van niet-aftrekbare kosten en belaste vergoedingen. De wetgever heeft de symmetrische behandeling van niet-aftrekbare kosten en belaste vergoedingen voor niet-ambulante werknemers gehandhaafd. In casu gaat het om bestuur. Voor de niet-ambulante werknemers wordt een begunstigend beleid gevoerd ten aanzien van de vergoeding. Naar het oordeel van de Hoge Raad brengt het gelijkheidsbeginsel met zich dat die begunstigende behandeling zich dan ook dient uit te strekken tot de niet-ambulante werknemers die de kosten tijdens werktijd zelf dragen. ${ }^{122}$

Een asymmetrische wetgeving geeft nog geen fiat aan de uitvoerende instanties om een asymmetrisch beleid te voeren, aldus annotator Wattel. ${ }^{123}$

\subsubsection{Het vereenvoudigingsstreven}

Vereenvoudiging is het kernwoord van de commissie-Oort. Hoe staat het met het vereenvoudigingsstreven in het wetsvoorstel OORT-II?

De Raad van State is van mening dat de mede uit budgettaire overwegingen gedane voorstellen met betrekking tot de gemengde kosten niet de vereenvoudigingsgedachte dienen. ${ }^{124}$ De bewindslieden merken daarentegen op: '... dat de voorgestelde maatregelen ten aanzien van de aftrekbaarheid van gemengde kosten naar hun oordeel passen in het streven naar een eenvoudiger belastingsysteem. $\mathrm{Zij}$ voegen daaraan toe dat zij er zich van bewust zijn dat de voorstellen onvermijdelijk leiden tot een uitgebreider regelgeving op het punt van de aftrekbare kosten'. ${ }^{125}$ Even later wordt het een en ander wel duidelijker; het gaat om een budgettaire dekking. ${ }^{126} \mathrm{De}$ regering geeft toe dat de keuze van de gemeng-

120. HR 27 april 1994, V-N 1994, blz. 1585, Weekblad voor fiscaal recht, 1994, no 6104, blz. 770 en BNB 1994/193 en m.nt. Van Dijck. Zie ook HR 27 april 1994, V-N 1994, blz. 1588, Weekblad voor fiscaal recht, 1994, no 6104, blz. 771 en BNB 1994/194 m.nt. Van Dijck.

121. Bij meerdere bronnen van arbeidsinkomen is splitsing van het arbeidsinkomen mogelijk. 'In dat geval zal moeten worden nagegaan welke opbrengst aan actief arbeidskinkomen aan de uren in de werkkamer kan worden toegerekend. Als dat meer is dan de helft van de totale arbeidsopbrengsten, is de werkkameraftrek verzekerd.' J.W. Zwemmer, De werkkamer als aftrekpost, Weekblad voor fiscaal recht, 1994, no 6113, blz. 1126.

Zwemmer merkt nog op: 'De proceduregevoeligheid van de regeling is evident, .... De beste oplossing lijkt nog om de werkkameraftrek maar helemaal af te schaffen. ... De prijs van de eenvoud is hoog.' J.W. Zwemmer, t.a.p., blz. 1127.

122. Zie Stevens: 'Mijns inziens een onwelwillend enge interpretatie, waarmee een merkwaardige ongelijkheid tussen ambulante en niet-ambulante, werknemers wordt geïntroduceerd.' L.G.M. Stevens, Verongelijkt, Column, Weckblad voor fiscaal recht, 1993, no 6082, blz. 1834.

123. P.J. Wattel, t.a.p., blz. 280 en 281.

124. Tweede Kamer, vergaderjaar 1988-1989, 20 873, B, blz. 7.

125. Tweede Kamer, vergaderjaar 1988-1989, 20 873, no B, blz. 7, no 4, blz. 27, no 7, blz. 7 en 13.

126. Tweede Kamer, vergaderjaar 1988-1989, 20 873, no B, blz. 7. 
de kosten enigszins arbitrair is. ${ }^{127}$ Dit is natuurlijk niet de juiste manier van wetgeven. Over eenvoudig gesproken!

Uit de kamerstukken blijkt duidelijk dat de concreet genoemde posten aanleiding geven tot discussies, niettegenstaande het feit dat de regering van mening is dat de concreet genoemde posten zo duidelijk zullen zijn dat deze niet zo veel uitvoeringsproblematiek en inherent daaraan veel jurisprudentie met zich brengen. ${ }^{128}$ De regering is van mening dat concrete beperkingen minder uitvoeringsproblemen zullen opleveren dan algemene formuleringen. ${ }^{129}$ De regering verwacht dat de tendens zal zijn dat eerder minder dan meer vergoedingen zullen worden gegeven. De literatuur vreest echter dat de negatieve lijst zeker tot feitelijke afbakeningsproblemen zal leiden. Bovendien zal sprake zijn van een wildgroei in de secundaire arbeidsvoorwaarden. ${ }^{130}$

Door de afname van het aantal aftrekposten en de behoefte aan aftrekposten zal zowel voor de belastingplichtigen als voor de belastingdienst een vereenvoudiging in de uitvoering optreden, aldus de regering. ${ }^{131}$ Hierover is terecht twijfel gere-

127. Tweede Kamer, vergaderjaar 1988-1989, 20 873, no B, blz. 11, no 3, blz. 12, no 7, blz. 6 en 7 . Tweede Kamer, vergaderjaar 1988-1989, 20 874, no 6, blz. 6. De regering stelt dat de keuze weliswaar arbitrair is, maar de uitgangspunten worden geacht door de brede lagen van de bevolking te worden onderschreven.

De concurrentiepositie is een enorm belangrijk element waarmee rekening moet worden gehouden. Handelingen Eerste Kamer, vergaderjaar 1988-1989, 20595 enz., blz. 26-1008. Dit is om verschillende moverende redenen niet juist, aldus Feteris en Brouwer. M.W.C. Feteris, J.Th.L. Brouwers, De vereenvoudiging ontspOORT(1), fiscaal weekblad FED, 1988, no 706, blz. 2189.

128. Zie de bespreking van de artikelen bij Tweede Kamer, vergaderjaar 1988-1989, 20873 , no 3, 4, 5,7 en 9. Handelingen Tweede Kamer, vergaderjaar 1988-1989, 20595 enz., blz. 39-2388, lk, 39-2446, rk, 39-2451, lk, 39-2458, mk en 42-2599, rk.

129. Eerste Kamer, vergaderjaar 1988-1989, 20 595, no 190a, blz. 10 en Tweede Kamer, vergaderjaar 1988-1989, 20 873, no 5, blz. 30 en 41 en ook het CDA is deze mening toegedaan. Tweede Kamer, vergaderjaar 1988-1989, 20 873, no 7, blz. 12. De regering is hier wel tegenstrijdig. 'Wij zullen overigens niet ontkennen dat de andere elementen van de in de memorie van antwoord gegeven nadere uitwerking van een - aangescherpt - kostenbegrip nieuwe vragen oproept die veelal pas door de rechter zullen kunnen worden beantwoord aan de hand van omstandigheden van het concrete geval.' 'Tweede Kamer, vergaderjaar 1988-1989, 20 873, no 9, blz. 15. Ook het kamerlid De Grave (VVD) is van mening dat het gedetailleerde karakter van artikelen 35 en 36 Wet IB 1964 de taak van de rechter zal verlichten. Handelingen Tweede Kamer, vergaderjaar 1988-1989, 20595 enz., blz. 26-54. Zie echter ook de zgn. reparatiewetgeving, waarin de vragen over en de problemen van de uitvoering van de concrete posten veelvuldig zijn. Tweede Kamer, vergaderjaar 1989-1990, no 7, blz. 1. Zie Van Dijck die voorstander is van het noemen van concrete posten, maar daarnaast opteert voor een algemene regel. J.E.A.M. van Dijck, Gemengde kosten, Weekblad voor fiscaal recht, 1988, no 5844, blz. 1415.

130. L.G.M. Stevens, Eenvoudig belasten is lastig, Weekblad voor fiscaal recht, 1988, no 5844, blz. 1411. M.W.C. Feteris, J.Th.L Brouwer, De vereenvoudiging ontspOort (2), fiscaal weekblad FED, 1988, no 714, blz. 2236. Vergelijk ook Tweede Kamer, vergaderjaar 1988-1989, 20 873, no 5, blz. 31, no 9, blz. 25. Tweede Kamer, vergaderjaar 1988-1989, 20 874, no 5, blz. 1 en 12.

131. Tweede Kamer, vergaderjaar 1988-1989, 20 873, no 5, blz. 32, no 9, blz. 26. De invoering van OORT-II levert een besparing op van 75 manjaren. Handelingen Eerste Kamer, vergaderjaar 1988-1989, 20595 enz., blz. 26-993, lk. 
zen. In de Tweede Kamer wordt verwacht wordt dat de wetsvoorstellen OORTII en OORT-III tot uitvoeringsproblemen zullen leiden, welke uiteindelijk de elders beoogde vereenvoudiging te niet doen. ${ }^{132}$ In ieder geval is de verwachte afname van het aantal aangiftebiljetten niet gerealiseerd. ${ }^{133}$ De voorstellen zullen tot een verzwaring van de uitvoeringslast leiden, zowel voor de belastingdienst als de inhoudingsplichtigen en de belastingplichtigen. ${ }^{134}$

De literatuur denkt er ook zo over; zowel voor de belastingplichtigen, de inhoudingsplichtigen als voor de belastingdienst treedt geen vereenvoudiging op. ${ }^{135}$ De praktijk wijst het verder uit; voor de belastingplichtigen en de inhoudingsplichtigen is in het algemeen geen vereenvoudiging opgetreden. ${ }^{136}$

De wens tot algehele vereenvoudiging die door de commissie-Oort is voorgestaan, blijkt slechts in bepaalde opzichten gerealiseerd te zijn of te worden. De bevordering van de uitvoerbaarheid is een element van vereenvoudiging. ${ }^{137} \mathrm{De}$ rechtvaardigheid is zeker niet gediend met de indiening van de wetsvoorstellen

132. Zie onder andere Tweede Kamer, vergaderjaar 1988-1989, 20 873, no 7, blz. 7 (D66), no 9, blz. 27. Zo is $30 \%$ van de inhoudingsplichtigen niet in staat on alle beperkte aftrekbare kosten van de volledig aftrekbare kosten te onderscheiden. Tweede Kamer, vergaderjaar 1992-1993, 22 374, no 2, blz. 5. OORT en de inhoudingsplichtigen, De Tweede Meting, Verslag van een onderzoek door het Erasmus Centre for sociolegal tax research, Faculteit der Rechtsgeleerdheid Erasmus Universiteit, in opdracht van het Ministerie van Financiën, A.M. Eling, oktober 1992, blz. 14 en 35.

133. Aanvankelijk wordt de afname van het aantal aangiftebiljetten op 600.000 geschat. Maar door de verruining van de mogelijkheid om T-biljetten in te dienen (175.000) en de wijziging in de buitengewone lastenregeling (120.000), loopt de verwachte afname terug tot 305.000 ! Eerste Kamer, vergaderjaar 1988-1989, 20 873, no 133c, blz. 3. Zie ook hoofdstuk 4, noot 212.

134. Tweede Kamer, vergaderjaar 1988-1989, 20 873, no B, blz. 7, no 9, blz. 27.

135. Zie A.J.M. van Elk, Commentaar van de Nederlandse Orde van Belastingadviseurs op wetsvoorstel 'OORT-II', Weekblad voor fiscaal recht, 1988, no 5844, blz. 1458, H.P.A.M. van Arendonk, De operatie-Oort: de vereenvoudiging weggesneden?, Maandblad Belastingbeschouwingen, 1988, no 11, blz. 303 en C.J. Visser, Haast geboden?, Weekblad voor fiscaal recht, 1988, no 5844, blz. 1455 en A.J.M. van Elk, OORT-II, Weekblad voor fiscaal recht, 1988, no 5844, blz. 1457, en Handelingen Eerste Kamer, vergaderjaar 1988-1989, 20595 enz., blz. 261011. Zie ook Brouwer en Feteris, die spreken van een vereenvoudiging in naam en het in de lade stoppen van het rapport 'Heerendiensten'. J.Th.L. Brouwer, M.W.C. Feteris, De vereenvoudiging ontspOort (5), fiscaal weekblad FED, 1988, no 764, blz. 2421 en 2422.

De tweede tussenrapportage van de Oort-evaluatie geeft het volgende beeld. $81 \%$ van de $\mathrm{VpB}$-ondernemingen en $70 \%$ van de overige inhoudingsplichtigen vinden de vereenvoudiging ver te zoeken. Deze percentages waren bij de cerste tussenrapportage lager! $75 \%$ van de $\mathrm{Be}$ lastingdienst is van mening dat het stelsel vereenvoudigd is, zij het dat het niveau waarop niet erg hoog is. Tweede Kamer, vergaderjaar 1992-1993, 22 374, no 2, blz. 5 en Evaluatie OORTwetgeving, Deelproject Inkomstenbelasting Particulieren, t.a.p., blz. 7.

136. De tweede tussenrapportage van de Oort-evaluatie leert dat de belastingplichtigen minder positief zijn gaan denken over de uitruil van aftrekposten tegen tariefverlaging. Tweede Kamer, vergaderjaar 1992-1993, no 22 374, no 2, blz. 4.

137. Aldus cok de regering, Tweede Kamer, vergaderjaar 1988-1989, 20 873, no B, blz. 22. 
OORT-II en OORT-III. ${ }^{138}$ Met betrekking tot de doelmatigheid kan hetzelfde worden opgemerkt.

De uitvoeringskosten bedragen 39,5 miljoen gulden. ${ }^{139}$ De menskrachtbesparing van de gehele OORT-operatie, dat wil zeggen, OORT-I, OORT-II en OORT-III, bedraagt voor de belastingdienst 1.140 mensjaren ${ }^{140}$ Zoals al eerder aan de orde is geweest, is de parameter van vereenvoudiging het aantal mensen dat werkzaam is bij de belastingdienst. Dit is wel eenvoudig gesteld, daar vereenvoudiging ook een positieve uitwerking moet hebben voor de belastingplichtigen en inhoudingsplichtigen.

Ten aanzien van de uitvoering komt ook de mate van fraudegevoeligheid aan de orde. De Eerste Kamer is van mening dat de $75 \%$ of $100 \%$ aftrekbaarheid van bepaalde kosten een zekere fraudegevoeligheid heeft en daarmee komt het vereenvoudigingsstreven nog verder op de tocht te staan. ${ }^{141}$ Immers de regelingen dienen ten gevolge van de fraude weer aangepast te worden. Dit is zeker niet doelmatig. ${ }^{142}$ Kortom, de vereenvoudiging is ver te zoeken. ${ }^{143}$

138. C.C.H.J. Driessen, Verecnvoudiging in rechtvaardig perspectief, Weekblad voor fiscaal recht, 1998, no 5844, blz. 1472. J.E.A.M. van Dijck, Gemengde kosten, Weekblad voor fiscaal recht, 1988, no 5844, blz. 1413. Menig Tweede Kamerlid denkt er ook zo over. Zie bij voorbeeld Schutte (RPF). Handelingen Tweede Kamer, vergaderjaar 1988-1989, 20595 enz., blz. 2603. De Eerste Kamer is ook van mening dat niet een stelsel, maar de opbrengst van de wetsvoorstellen bepalend is voor de inhoud van de wetsvoorstellen inzake de gemengde kosten. Handelingen Eerste Kamer, vergaderjaar 1988-1989, 20595 enz., blz. 26-1017.

139. Tweede Kamer, vergaderjaar 1988-1989, 20 873, no B, blz. 16.

140. Aanvankelijk levert OORT-I een besparing op van 1.610 mensjaren(+); OORT-II cen besparing van 80 mensjaren $(+)$. De belastingheffing over het privégebruik van de auto van de werkgever kost 85 mensjaren(-). En OORT-III kost 150 mensjaren(-). De controle van de gemengde kosten kost 70 mensjaren. Tweede Kaner, vergaderjaar 1988-1989, 20873 , no 3, blz. 15, no 5, blz. 51. Handelingen Tweede Kamer, vergaderjaar 1988-1989, 20595 enz., blz. 40-2517.

In de tweede tussenrapportage van de Oort-cvaluatie constatecrt de belastingdienst een afname van de controleerbaarheid als gevolg van de invoering van het omvangs- en het vergelijkingscriterium. Tweede Kamer, vergaderjaar 1992-1993, 22 374, no 2, blz. 17. Evaluatie OORTwetgeving, Deelproject Inkomstenbelasting Particulieren, t.a.p., blz. 6 en 21. Eind-rapport over de evaluatic OORT-wetgeving, Ministerie van Financiën, Directoraat-Generaal der Belastingen, Directoraat-Generaal voor Fiscale Zaken, juli 1994, blz. 12.

De evaluatie leert dat uiteindelijk een besparing van 1.140 mensjaren is gerealiseerd. Zie hoofdstuk 4, noot 222.

141. Eerste Kamer, vergaderjaar 1988-1989, 20 873, no 133b, blz. 7 en 8.

142. In de praktijk blijkt dat de regeling voor werknemers en ondernemers ingewikkeld en hier en daar fraudegevoelig is. C.W.M. van Ballegooijen, t.a.p., blz. 1305. De tweede tussenrapportage van de Oort-evaluatie leert dat de belastingconsulenten van mening zijn dat de fraudegevoeligheid toegenomen is. De niet-commerciële hulpverleningsinstanties daarentegen zijn van mening dat voor belastingplichtigen uit hun doelgroep (in het algemeen de lagere inkomens) de fraudegevoeligheid niet is toegenomen. Tweede Kamer, vergaderjaar 1992-1993, 22 374, no 2, blz. 13 en 14. Evaluatie OORT-wetgeving, Deelonderzoek, Belastingconsulenten, W. van Dijk, mei 1992, rapportnr. 19, blz. 5.

143. Zie ook de speciale uitgave van de werkgroep-Oort, Praktijkvragen Werkgroep Oort, april 1990 , waarin vragen en antwoorden over Oort zijn opgenomen (vraag $1 \mathrm{t} / \mathrm{m} \mathrm{166)}$. V-N 22 mei 1990 , no 22, blz. 1607-1671. In december 1991 is de werkgrocp ontbonden. Daarna zijn nog enige vragen en antwoorden verschenen. V-N 23 april 1992, no 7, blz. 1147-1153. (vraag 167 $\mathrm{t} / \mathrm{m} 185$, loon- en inkomstenbelasting niet-winst) V.N 27 augustus 1992, no 5, biz. 2411-2414 
Ongeveer 5,55 miljard wordt besteed aan lastenverlichting. De hoogte van het bedrag is een politieke keuze. ${ }^{144}$ Hoe hebben de budgettaire overwegingen concrete zaken bepaald? De lengte van de eerste schijf is door puur budgettaire redenen bepaald, evenals de verhoging van het huurwaardeforfait. ${ }^{145}$

Als één ding duidelijk wordt bij de bestudering van het onderhavige wetsvoorstel, dan is het wel dat de budgettaire redenen een prominente, zo niet de enige, rol hebben gespeeld. De Raad van State heeft daarop kritiek. ${ }^{146}$ De Raad van State legt een te zwaar accent op de budgettaire redenen, aldus de regering. ${ }^{147}$ Anderzijds geeft de regering toe dat hoofdzakelijk budgettaire redenen de doorslag hebben gegeven voor het wetsvoorstel. ${ }^{148}$

Ik geef enige relevante citaten.

(vraag $186 \mathrm{t} / \mathrm{m} \mathrm{192,} \mathrm{loon-en} \mathrm{inkomstenbelasting} \mathrm{winst).} \mathrm{De} \mathrm{algemene} \mathrm{indruk} \mathrm{is} \mathrm{dat} \mathrm{de} \mathrm{OORT-}$ wetgeving niet de vereenvoudiging heeft gediend.

144. Er is 1,25 nurd. reserve voor koopkrachtreparatie; één miljard is voor de lastenverlichting aangewend. Het overige deel van de 1,25 mrd. wordt aangewend voor kinderopvang en maatregelen naar aanleiding van de Stichtingsvariant. De overige $4,3 \mathrm{mrd}$. worden gefinancierd uit de belastingmeevaller, de beperking van de gemengde kosten en de Brede Herwaardering. Persbericht Financiën, 21 juli 1988, nr. 88/183, blz. 4.

De opbrengst van OORT-II wordt gecalculeerd op $f 675$ miljoen per jaar. Zie J.Th.L. Brouwer, M.W.C. Feteris, De vereenvoudiging ontspOort(1), fiscaal weekblad FED, 1988, no 706 , blz. 2189. De opbrengst bedraagt in de niet-winstsfeer $f 675$ miljoen (Tweede Kamer, vergaderjaar 1988-1989, 20 873, no 3, blz. 49) en de opbrengst bedraagt in de winstsfeer $f 600$ miljoen (Tweede Kamer, vergaderjaar 1988-1989, 20 874, no 3, blz. 5). OORT-II wordt gefinancierd door de beperking van de aftrekposten en de belastingmeevallers. Handelingen Tweede Kamer, vergaderjaar 1988-1989, 20595 enz., blz. 40-2505, mk.

Zie verder noot 3 en hoofdstuk 4, noot 227.

145. Handelingen Eerste Kamer, vergaderjaar 1988-1989, 20595 enz., blz. 27-1077. Zie ook het buitenland-lek dat wordt gedicht door het percentage van $25 \%$. Het dichten leidt tot een opbrengst van $15 \mathrm{mln}$.. Schutte (RPF) vraagt of deze opbrengst de regering heeft doen inzien dat het een lek betrof. Handelingen Tweede Kamer, vergaderjaar 1988-1989, 20595 enz., blz. 42-2612, Ik. Tweede Kamer, vergaderjaar 1988-1989, 20 873, no 4, blz. 10.

Ten aanzien van de verhoging van het huurwaardeforfait stelt de regering dat de verhoging moet worden gezocht in het gegeven dat het forfait te laag is. Tweede Kamer, vergaderjaar 1988-1989, 20 873, B, blz. 26.

146. Tweede Kamer, vergaderjaar 1988-1989, 20873 , no B, blz. 12. Zie ook Tweede Kamer, vergaderjaar 1988-1989, 20 873, no 7, blz. 7.

147. Tweede Kamer, vergaderjaar 1988-1989, 20873 , no B, blz. 7 en 12. Minister van Financiën Ruding stelt dat de drie voorstellen gebaseerd zijn op èn politieke, èn fiscale, èn budgettaire overwegingen. Handelingen Eerste Kamer, vergaderjaar 1988-1989, 20595 enz., blz. 27-1031.

148. Zie onder andere Tweede Kamer, vergaderjaar 1988-1989, 20 873, no 4, blz. 27. Handelingen Eerste Kamer, vergaderjaar 1988-1989, 20595 enz., blz. 26-1004 en 26-1016. In geval van de asymmetrische effecten is geen sprake van een stelselbelejd, maar is de opbrengst bepalend. Zie ook A.J.M. van Elk, Commentaar van de Nederlandse orde van belastingadviseurs op wetsvoorstel 'OORT-II', Weekblad voor fiscaal recht, 1988, no 5844, blz. 1457 en 1461 . Het kameriid De Grave (VVD) wil wel doen geloven dat het gaat om een afweging met betrekking tot het vereenvoudigingsaspect en niet het budgettaire, maar hij draagt geen argumenten aan om zijn stelling te staven. Handelingen Tweede Kamer, vergaderjaar 1988-1989, 20595 enz., blz. 39-2379, 40-2519, mk. 
1. Minister van Financiën Ruding: 'Naast nobele fiscale principes, zat er een heel practisch standpunt bij: er moest voldoende geld worden gevonden'. ${ }^{149}$

2. 'Naast het inhoudelijke aspect dat op zich zelf al de conclusie rechtvaardigt dat op het terrein van de gemengde kosten mogelijkheden tot vereenvoudiging aanwezig zijn, komen zo ook middelen beschikbaar die kunnen worden ingezet om te komen tot een verlaging van het tarief. ${ }^{150}$

3. '... terwijl tevens de voorziene opbrengst van de beperking van de gemengde kosten in gevaar zou komen. ${ }^{.151}$

Uit deze citaten wordt duidelijk dat het binnenhalen van geld de voornaamste rol heeft gespeeld. De kritiek uit de literatuur betreft dan ook het te zware accent op de budgettaire overwegingen.

\subsubsection{De rol van pressiegroepen}

Is het bij OORT-I al zo dat de pressiegroepen een rol speelden, bij OORT-II is dit nog duidelijker het geval. Ik noem enige voorbeelden.

1. Onder druk van de sociale partners zijn de reiskostenvergoedingen niet verlaagd. ${ }^{152}$ Aanvankelijk wilde de Kamer de vergoedingen gelijkstellen aan de forfaits. ${ }^{153}$

2. Buiten het parlement om is het uiteindelijke tarief vastgesteld. De Kamer vraagt naar een verklaring. ${ }^{154}$ Enige kamerleden beweren dat de pressiegroepen, met name die van het bedrijfsleven, verantwoordelijk zijn voor de tariefsverlaging met beperking van de aftrekposten. Het alternatief zou zijn een geringere tariefsverlaging met een geringere beperking van aftrekposten. ${ }^{155}$ Uiteindelijk is gekozen voor de eerstgenoemde mogelijkheid.

3. De uitvoering van de OORT-wetgeving wordt in onderling overleg gedaan met de werkgeversorganisaties. Er kan dan mijns inziens niet aan de indruk worden ontkomen dat de te bespreken bepalingen in dat geval enigszins in het belang van de belangenorganisaties zullen worden uitgelegd. ${ }^{156}$

149. Handelingen Eerste Kamer, vergaderjaar 1988-1989, 20595 enz., blz. 27-1079.

150. Tweede Kamer, vergaderjaar 1988-1989, 20 873, no 3, blz. 12. Kamerlid Ingwerda (D66) verwoordt het budgettaire belang als volgt: '... dat zelfs het budgettaire argument niet opgaat om dit soort gedetailleerde onzin (regeling inzake de actentas, $M W$ ) in de fiscale wetgeving op te nemen.' Handelingen Tweede Kamer, vergaderjaar 1988-1989, 20595 enz., blz. 26-56, lk.

151. Aldus de regering. Zie Tweede Kamer, vergaderjaar 1988-1989, 20 873, no 9, blz. 15.

152. H.P.A.M. van Arendonk, De operatie-Oort: vercenvoudiging weggesneden?, Maandblad Belastingbeschouwingen, 1988, no 11, biz. 302. Tweede Kamer, vergaderjaar 1988-1989, 20 873, no 9, blz. 33.

153. Handelingen Tweede Kamer, vergaderjaar 1988-1989, 20595 enz., blz. 26-43.

154. Tweede Kamer, vergaderjaar 1988-1989, 20 873, no 4, blz. 9 (SGP).

155. Van Arendonk is het er niet mee eens en stelt zich op het standpunt dat de politici het zelf hebben gewild en de ellende van OORT-II en OORT-III aan zichzelf hebben te danken. H.P.A.M. van Arendonk, Belastingfraude en oneigenlijk gebruik na de belastingherziening 'Oort', Maandblad Belastingbeschouwingen, 1989, no 11, blz. 319.

156. A. Timmermans, Oort en de ondernemer ofwel de caravan en de kroket, Maandblad Belastingbeschouwingen, 1990, no 10, blz. 255. Van Arendonk vindt juist dat de werkgevers-en de werknemersorganisaties in tegenstelling tot de bruteringsoperatie zich met betrekking tot de 
Het zal van de druk van de sociale partners afhangen hoe de uiteindelijke invulling van de OORT-wetgeving door de praktijk zal geschieden.

\subsubsection{Andere beginselen}

In de kamerstukken en de literatuur worden nog enige andere 'elementen' als beginsel bestempeld. Het eerste beginsel houdt in dat een belastingplichtige naar zijn zuiver inkomen wordt belast. Dat wil zeggen, het zuiver inkomen is een optelsom van de inkomsten minus de uitgaven. Dit beginsel is een nadere uitwerking van het draagkrachtbeginsel. ${ }^{157}$

Het tweede beginsel heeft te maken met het draagkrachtbeginsel en inherent daaraan het gelijkheidsbeginsel. 'Het beginsel dat vergoedingen, objectief beschouwd, in redelijke verhouding dienen te staan tot het doel waarvoor zij worden toegekend, betreft vergoedingen voor kosten van werknemers die behoren tot een groep van werknemers die uit oogpunt van in verband met hun dienstbetrekking te maken noodzakelijke kosten in gelijke omstandigheden verkeren. ${ }^{.158}$ Het zakelijke karakter van de vergoedingen staat in dit beginsel voorop. De aanwezigheid van de zakelijkheid dient door de werkgever te worden bepaald. Eveneens verwant met het draagkracht- en het gelijkheidsbeginsel is het beginsel dat indien bepaalde posten in de sfeer van inkomsten uit arbeid tot aftrekbare kosten kunnen worden gerekend, de vergoedingen onbelast dienen te zijn. ${ }^{159}$ Dit is de zgn. symmetrie. Het moge duidelijk zijn dat dit beginsel door de invoering van wetsvoorstel OORT-II in belangrijke mate opzij is gezet.

Het vierde genoemde beginsel houdt in dat de fiscus niet treedt in het beleid van de ondernemer. Met dit laatste wordt bedoeld de inbreuk op het fiscale winstbegrip door de beperking van de aftrekbaarheid van kosten. Over de vraag of al dan niet een inbreuk plaats vindt op het winstbegrip, lopen de meningen nogal uiteen. ${ }^{160}$ Afhankelijk of al dan niet een inbreuk van het winstbegrip kan worden geconstateerd, is het beginsel al dan niet opzij gezet.

gemengde kosten zeer soepel hebben opgesteld. H.P.A.M. van Arendonk, Belastingfraude en oneigenlijk gebruik na de belastingherziening 'Oort', Maandblad Belastingbeschouwingen, 1989, no 11, blz. 319.

157. J.E.A.M. van Dijck, Gemengde kosten, Weekblad voor fiscaal recht, 1988, no 5844, blz. 1413.

158. Tweede Kamer, vergaderjaar 1988-1989, 20 873, no 5, blz. 38, no 9, blz. 24.

159. Zie Vermeend (PvdA), Handelingen Tweede Kamer, vergaderjaar 1988-1989, 20595 enz., blz. 39-2435.

160. Zie onder andere A.J.M. van Elk, Commentaar van de Nederlandse Orde van Belastingadviseurs op wetsvoorstel 'OORT-II', Weekblad voor fiscaal recht, 1988, no 5844, blz. 1462. Zie ook Handelingen Eerste Kamer, vergaderjaar 1988-1989, 20595 enz., blz. 27-1071, lk. De meeste auteurs menen dat sprake is van een inbreuk. Er zijn auteurs die er een andere mening op na houden. Zie C. Zegers, De werkelijke gedachte achter de aftrekbeperking van de gemengde kosten, Weekblad voor fiscaal recht, 1990, no 5898, blz. 78. Hetzelfde kan worden gezegd over het inkomensbegrip. Zie verder over dit onderwerp § 5.5.1. 


\subsection{Het wetsvoorstel OORT-III}

Het wetsvoorstel OORT-III beoogt de aftrek van de in de winstsfeer gemaakte kosten te beperken of af te schaffen. Onderscheiden moet worden tussen de gemengde kosten in het algemeen en de gemengde kosten die de ondernemer zelf maakt.

De gemengde kosten in het algemeen betreffen kosten van degenen die bij de ondernemer in dienst zijn en kosten van degenen met wie hij zakelijke contacten onderhoudt. De datum van inwerkingtreding van dit gedeelte van het wetsvoorstel is 1 juli 1989. De reden voor deze datum is dat de budgettaire opbrengst van OORT-III een rol speelt in het kader van de Vpb-WIR-AKW-operatie, aldus de regering. De datum kan niet worden verschoven naar 1 januari $1990 .{ }^{161} \mathrm{De}$ regeling van de gemengde kosten betrekking hebbende op de ondernemer zelf is op 1 januari 1990 in werking getreden.

Het wetsvoorstel betreft de introductie van artikel $8 \mathrm{a}$, eerste tot en met derde lid, en artikel 8b, eerste tot en met vierde lid Wet IB $1964 .{ }^{162}$ De wettelijke systematiek is dat artikel 8b Wet IB 1964 een aanvulling is op artikel 8a Wet IB 1964. Artikel 8a, eerste lid, gaat voor op artikel 8a, tweede lid. Bovendien gaat de specifieke bepaling voor de algemene, hetgeen gebruikelijk is.

De samenhang met OORT-II bestaat hierin dat indien een vergoeding van een niet langer aftrekbare uitgave bij een werknemer belastingvrij is, de aftrekbaarheid van de uitgave bij de werkgever beperkt is, een enkele uitzondering daargelaten. Deze maatregel is nodig om te voorkomen dat belastbaar loon in onbelaste vergoedingen wordt omgezet. ${ }^{163}$ Hier wordt een discrepantie geconstateerd tussen de theorie en de maatschappelijke werkelijkheid wat betreft het inkomensbegrip. ${ }^{164}$

Hoe ingewikkeld de materie is, blijkt wel uit het volgende. Een tijd lang hebben enkele kamerleden ten onrechte gemeend dat de volgende stelling waar was. Wanneer een vergoeding bij de werknemer belast is, kan dezelfde vergoeding bij de werkgever in de winstsfeer tot $75 \%$ aftrek worden beperkt. Integendeel, de vergoeding kan als loon tot $100 \%$ ten laste van de winst worden gebracht. ${ }^{165}$ De volgende stelling is wel waar. Ingeval een werkgever aan zijn werknemer een onbelaste kostenvergoeding verstrekt, kan de aftrekbaarheid van de vergoeding in de winstsfeer zijn beperkt. ${ }^{160}$

161. Handelingen Tweede Kamer, vergaderjaar 1988-1989, 20595 enz., blz. 40-2504, lk, 40-2514, rk, 40-2515, lk, Handelingen Eerste Kamer, vergaderjaar 1988-1989, 20595 enz., blz. 27-1050, mk en rk.

162. Artikel 8, ecrste lid Wet $\mathrm{VpB} 1969$ wordt aangepast.

163. Persbericht Financiën, 21 juli 1988, 88/184.

164. Tweede Kamer, vergaderjaar 1988-1989, 20874 , no 6, blz. 8.

165. Eerste Kamer, vergaderjaar 1988-1989, 20 873, no 133c, blz. 11.

166. Eerste Kamer, vergaderjaar 1988-1989, 20873 , no 133c, blz. 16. Een anderc illustratie dat de materie ingewikkeld is, is de volgende. ' $\mathrm{l} k \mathrm{heb}$ de indruk dat er nu antwoorden gegeven zijn die afwijken van wat eerder is gezegd of geschreven. Dat draagt bij aan de verwarring die op dit terrein (artt. 35 en 36 Wet IB 1964, MW) bestaat.' Christiaanse (CDA), Handelingen Eers- 


\subsection{De parlementaire discussie en de kritiek in de literatuur}

Gezien de samenhang met OORT-II kan hetgeen in het bovenstaande is geconstateerd mede van toepassing worden verklaard op OORT-III en vice versa; de parlementaire discussie en de kritiek in de literatuur van OORT-III vallen grotendeels samen met hetgeen aan de orde is geweest onder $\$ 5.3$. Om enige overlapping te voorkomen, worden enkele sub-paragrafen bij de behandeling van OORT-III buiten beschouwing gelaten. Slechts aanvullende opmerkingen worden gemaakt.

\subsubsection{Wetgevingsbeginsel(en)}

Een wetsvoorstel behoeft een goede toelichting. Een goede toelichting op het wetsvoorstel OORT-III heeft enerzijds met het motiveringsbeginsel, anderzijds met fiscale beginselen te maken. Wat het motiveringsbeginsel betreft, merk ik op dat dit niet of slechts marginaal in acht is genomen. De overwegingen van de Raad van State getuigen daar ook van. De Raad van State heeft geen duidelijk beeld van de overwegingen en/of beginselen welke in het wetsvoorstel aan de orde zouden kunnen zijn bij de bepaling van de fiscale winst respectievelijk bij de gedachten dat bepaalde uitgaven niet langer aftrekbaar zijn. 'Het gevaar van wil-lekeur dreigt indien leidende beginselen en consistente gedachtengangen komen te ontbreken'. ${ }^{167}$ Deze worden niet genoemd, dus zijn ze niet aanwezig. Even verderop zegt de Raad van State: 'Naar het oordeel van de Raad ligt de oorzaak hiervan in het ontbreken van een in de fiscale systematiek gewortelde dragende gedachte. ${ }^{168}$

Een volgend voorbeeld met dezelfde strekking als het bovenstaande is de gebrekkige motivering van de inbreuk op het inkomens- en het winstbegrip. De Raad van State plaatst de nodige vraagtekens. ${ }^{169}$

Een ander aspect waarbij het motiveringsbeginsel is betrokken, is het percentage van 75. De Raad van State vindt het percentage enigszins willekeurig en vraagt

te Kamer, vergaderjaar 1988-1989, 20595 enz., blz. 27-1068, rk. Zie ook C. Zegers, De werkelijke gedachte achter de aftrekbeperking van gemengde kosten, Weekblad voor fiscaal recht, 1990, no 5898, blz. 71 .

167. Tweede Kamer, vergaderjaar 1988-1989, 20 874, no B, blz. 2 en 3 en Tweede Kamer, vergaderjaar 1988-1989, 20 873, B, blz. 11. De regering antwoordt dat de bepalingen enigszins arbitrair zijn, maar dat deze toch niet als willekeur moeten worden aangemerkt. Tweede Kamer, vergaderjaar 1988-1989, 20 873, B, blz. 11.

168. Tweede Kamer, vergaderjaar 1988-1989, 20 874, no B, blz. 4.

169. De fraudegevoeligheid inzake de regeling van de gemengde kosten is ook niet of nauwelijks gemotiveerd. Tweede Kamer, vergaderjaar 1988-1989, 20 874, no B, blz. 2 en 12. Zo ook de PvdA-fractie in de Tweede Kamer. Tweede Kamer, vergaderjaar 1988-1989, 20 874, no 5, blz. 1. De regering is van mening dat geen inbreuk plaatsvindt op het inkomens- en winstbegrip. Zie bij voorbeeld Handelingen Eerste Kamer, vergaderjaar 1988-1989, 20595 enz., blz. 27. 1050 , rk. 
zich af of de regering zich louter heeft laten leiden door budgettaire overwegingen. $^{170}$

\subsubsection{Het draagkrachtbeginsel}

In het wetsvoorstel OORT-III gaat het met name om een veronderstelde inbreuk op het fiscale winstbegrip. ${ }^{171}$ Hierover verschillen de meningen. Zowel in de Eerste als in de Tweede Kamer zijn enige kamerleden ervan overtuigd dat sprake is van een inbreuk op het inkomens- en het winstbegrip. Het inkomensbegrip is een praktisch, empirisch inkomensbegrip dat ten behoeve van de belastingheffing naar draagkracht is gevormd. Indien een inbreuk op dit begrip plaatsvindt, kan worden gesproken van een indirecte inbreuk van het draagkrachtbeginsel. ${ }^{172}$ Voorbeelden die door enige fiscale auteurs ter illustratie van een inbreuk op het inkomensbegrip naar voren zijn gebracht, zijn: de kosten van literatuur, het hebben van een werkkamer en het bijwonen van een congres. ${ }^{173}$ Van regeringszijde wordt ontkend dat sprake is van een inbreuk; hoogstens een 'bijstelling'. ${ }^{174}$

De discussie rondom de vermeende inbreuk op het fiscale winstbegrip heeft wat weg van een welles-nietes-spelletje. In het parlement en in de literatuur wordt geopperd dat sprake is van een inbreuk en van regeringszijde wordt bij herhaling gezegd dat geen sprake is van een inbreuk.

Een volgende opmerking die ik over het draagkrachtbeginsel wil maken, houdt verband met het percentage van 75 ; de aftrek van de door de werkgever gegeven vergoeding wordt beperkt tot $75 \%$ vanwege het privé-element. Dit percentage wordt zowel door de Raad van State als door de literatuur niet begrepen. ${ }^{175} \mathrm{De}$ regering antwoordt dat de hoogte van $75 \%$ enigszins arbitrair is, maar wel een

170. Tweede kamer, vergaderjaar 1988-1989, 20874 , no B, blz. 6. De regering antwoordt dat het percentage, zij het enigszins willekeurig, is gedaan in navolging van de internationale tendens. Tweede Kamer, vergaderjaar 1988-1989, 20 874, no B, blz. 6.

171. Tweede Kamer, vergaderjaar 1988-1989, 20 874, no 5, blz. 4. Zie verder de noten 160 en 169.

172. Vergelijk bij voorbeeld Vreugdenhil (CDA), Handelingen Tweede Kamer, vergaderjaar 19881989, 20595 enz., blz. 39-2403 en 39-2409 en Handelingen Eerste Kamer, vergaderjaar 19881989, 20595 enz., blz. 27-1071. Tweede Kamer, vergaderjaar 1988-1989, 20 874, no 5, blz. 1 en 2 , no 8, blz. 2 en 3.

173. Deze kosten zijn in de niet-winstsfeer niet meer aftrekbaar. Zie onder andere J.Th.L. Brouwer, M.W.C. Feteris, De vereenvoudiging ontspOort(4), fiscaal weekblad FED, 1988, no 748 , blz. 2364. Zie ook Van Elk, die spreekt van een aantasting van het winstbegrip. A.J.M. van Elk, Commentaar van de Nederlandse Orde van Belastingadviseurs op wetsvoorstel 'Oort Il', Weekblad voor fiscaal recht, 1988, no 5844, blz. 1461 en 1462.

174. Tweede Kamer, vergaderjaar 1988-1989, 20 874, no 6, blz. 2 en no 9, blz. 3.

175. Tweede Kamer, vergaderjaar 1988-1989, 20874 , no B, blz. 6. M.W.C. Feteris, J.Th.L. Brouwer, De vereenvoudiging ontspOort(2), fiscaal weckblad FED, 1988, no 714, blz. 2238 en J. Hoogendoorn, Enkele opmerkingen naar aanleiding van wetsontwerpen 'Oort II/III, fiscaal weekblad FED, 1988, no 728, blz. 2298 en 2299. Van Ballegooijen optecrt voor een percentage van 50. C.W.M. van Ballegooijen, t.a.p., blz. 1307. 
remfunctie heeft. De rem heeft als doel te voorkomen dat loon in onbelaste vergoedingen wordt omgezet. ${ }^{176}$

Een arbitrair element bepaalt de draagkracht die na aftrek overblijft. Weliswaar is dat inherent aan een forfait, maar indien veel gebruik gemaakt wordt van arbitraire elementen, wordt naar mijn mening de werking van het draagkrachtbeginsel onzeker.

\subsubsection{Het gelijkheidsbeginsel}

Het voorgestelde artikel 8b Wet IB 1964 beoogt de gemengde kosten van de ondernemer op dezelfde wijze te behandelen als die van degene die in loondienst is. Opmerkelijk hierbij is dat de kosten van het woon-werkverkeer tot 10 kilometer niet aftrekbaar zijn voor de werknemer en dat deze wel aftrekbaar zijn bij de ondernemer-natuurlijk persoon. De kosten voor voedsel, drank en genotmiddelen en representatiekosten zijn voor de werknemer niet aftrekbaar maar voor de IBondernemer althans tot $75 \%$. Hetzelfde kan gezegd worden met betrekking tot de kosten van verblijf buiten de woonplaats en de kosten voor congressen e.d.. Kosten gemaakt voor tekstverwerkers e.d. zijn voor de werknemer niet meer aftrekbaar, terwijl deze wel volledig aftrekbaar blijven voor een ondernemer-natuurlijk persoon, mits de apparatuur tot zijn ondernemingsvermogen behoort. Hetzelfde geldt voor het gereedschap. ${ }^{17}$

Met de invoering van de voorgestelde wetgeving wordt een vlucht in de BV-vorm verwacht. ${ }^{172} 2$ Hierop zegt de regering dat de beperking van aftrekposten slechts een marginale invloed heeft op de keuze van de rechtsvorm. ${ }^{17}$ De voordelen voor een directeur/grootaandeelhouder ten opzichte van een IB-ondernemer zijn miniem; de voordelen betreffen onder andere de kosten met betrekking tot kle-

176. Tweede Kamer, vergaderjaar 1988-1989, 20 874, no 3, blz. 3. Eerste Kamer, vergaderjaar 19881989, 20874 , no 173a, blz. 1. Van Arendonk c.s. stellen dat vanwege budgettaire overwegingen de regelgeving inzake de onbelaste vergoedingen-beperkte winstaftrek hebben bepaald. H.P.A.M. van Arendonk, P. Kavelaars, L.G.M. Stevens, Eenvoud in praktijk, 2e herziene druk, 1991, blz. 169.

177. J.W. Zwemmer, Haastige spoed is zelden goed, Weckblad voor fiscaal recht, 1988, no 5844, blz. 1436-1438.

Indien de ondernemer cen kantoorruimte heeft die tot het ondernemingsvermogen behoort, wordt de aftrek niet beperkt door artikel 8b, lid 1, onderdeel a, ten eerste Wet IB 1964. Vraag 191, Oort. Vervolgpublicatic van de werkgroep-Oort, V-N 1992, blz. 2414.

178. L.G.M. Stevens, Eenvoudig belasten is lastig, Weekblad voor fiscaal recht, 1988, no 5844, blz. 1410. M.W.C. Feteris, J.Th.L Brouwer, De vereenvoudiging ontspOort (2), fiscaal weekblad FED, 1988, no 714, blz. 2236. H.P.A.M. van Arendonk, OORT I + OORT II, Vereenvoudiging I - Vereenvoudiging II, Maandblad Belastingbeschouwingen, 1988, no 9, blz. 228. Vergelijk ook Tweede Kamer, vergaderjaar 1988-1989, 20 873, no 5, blz. 31, no 9, blz. 25. Tweede Kamer, vergaderjaar 1988-1989, 20874 , no 5 , blz. 1 en 12.

179. Eerste Kamer, vergaderjaar 1988-1989, 20 595, no 190a, blz. 9 en Tweede Kamer, vergaderjaar 1988-1989, 20 874, B, blz. 10. Weekblad voor fiscaal recht, 1989, no 5864, blz. 472 en 473 . Zie echter Feteris en Brouwer, die ook aantonen dat er een vlucht naar de BV-vorm zal voordoen, omdat daar meer mogelijkheden om kosten af te trekken zijn. M.C.W. Feteris, J.Th.L. Brouwer, De vereenvoudiging ontspOort(2), fiscaal weekblad FED, 1988, no 714, blz. 2236. 
ding, literatuur, persoonlijke verzorging en tot het prive-vermogen behorende apparatuur.

In het algemeen wordt de wijze van beperken van bepaalde aftrekposten in strijd met het gelijkheidsbeginsel geacht. Hier wordt onder andere de voorgestelde asymmetrie bedoeld. ${ }^{180}$ Uit de kamerstukken van dit wetsvoorstel wordt duidelijk dat er nog steeds vragen zijn met betrekking tot het gelijkheidsbeginsel in relatie tot het Koffiegeld-arrest. Dit betreft het onderscheid natuurlijk persoon-ondernemer versus de directeur-grootaandeelhouder ${ }^{181}$ Het antwoord van de regering luidt dat de twee genoemde belastingplichtigen niet gelijk zijn. ${ }^{182} \mathrm{De}$ regering stelt dat het gelijkheidsbeginsel ziet op personen en niet op zaken. ${ }^{183}$ Hier ziet men weer dat twee gevallen niet als gelijk worden beschouwd, zodat men niet meer toekomt aan toetsing van het gelijkheidsbeginsel.

\subsubsection{Het vereenvoudigingsstreven}

Onder vereenvoudiging kan mede de bevordering van de uitvoering worden verstaan. ${ }^{184}$ De invoering van OORT-III kost 135 manjaren. ${ }^{185}$ De toename van uitvoeringskosten kan niet als een vereenvoudiging worden gezien.

Enige concrete elementen uit het wetsvoorstel voldoen niet aan de wens tot vereenvoudiging. Ten aanzien van de $75 \%$ aftrekbeperking in de winstsfeer stelt de Raad van State zich op het standpunt dat de doeltreffendheid hier niet in acht is genomen. ${ }^{186}$ Een hoge mate van doeltreffendheid gaat hand in hand met het

180. J.W. Zwemmer, Haastige spoed is zelden goed, Weekblad voor fiscaal recht, 1988, no 5844, blz. 1429. Eerste Kamer, vergaderjaar 1988-1989, 20 874, no 173, blz. 6.

181. In het parlement vraagt men (CDA) zich af of het verschil in behandeling tussen ondernemer IB-sfeer en ondernemer $\mathrm{VpB}$-sfeer, mede gezien het Koffiegeld-arrest, kan blijven bestaan. Tweede Kamer, vergaderjaar 1988-1989, 20874 , no 6, blz. 5, no 8, blz. 1. De regering antwoordt dat de twee gevallen niet gelijk zijn. Tweede Kamer, vergaderjaar 1988-1989, 20874 , no 9, blz. 3. Hetzelfde kan worden gezegd van een werknemer en een ondernemer-natuurlijk persoon. Eerste Kamer, vergaderjaar 1988-1989, 20 874, no 173a, blz. 6. Tweede Kamer, vergaderjaar 1988-1989, 20 874, no 8, blz. 1.

182. Tweede Kamer, vergaderjaar 1988-1989, 20 874, no 9, blz. 2 en 3.

183. Tweede Kamer, vergaderjaar 1988-1989, 20 874, no 9, blz. 7.

184. Tweede Kamer, vergaderjaar 1988-1989, 20873 , no B, blz. 22.

185. Handelingen Eerste Kamer, vergaderjaar 1988-1989, 20595 enz., blz. 26-993, Ik.

186. Tweede Kamer, vergaderjaar 1988-1989, 20873 , no B, blz. 11. In het parlement rijzen ook vragen met betrekking tot de fraudegevoeligheid van de 75\%-structuur. Zie onder andere de RPF-fractie. Handelingen Tweede Kamer, vergaderjaar 1988-1989, 20595 enz., blz. 39-2447, mk.

Zie ook het artikel van Arts over de samenhang tussen artikel 8a Wet IB 1964 en artikel 11, eerste lid, onderdeel $j$ Wet LB 1964. Uit dat artikel blijkt dat het nog niet zo eenvoudig is het zgn. prive-element, aanwezig in vergoedingen van de werkgever aan de werknemer of kosten gemaakt door de werkgever voor de werknemer, te belasten. De auteur geeft vijf interpretaties van de samenhang weer. Uiteindelijk kiest hij voor de volgende interpretatie: '... heffing van loonbelasting van de werknemer en toepassing van art. 8a Wet IB 1964 bij de werkgever aldus, dat het gedcelte van de uitgave dat op grond van art. 8a Wet IB 1964 niet aftrekbaar zou zijn, wordt verminderd met het bedrag dat bij de werknemer als loon in aanmerking wordt geno- 
vereenvoudigingsstreven. Derhalve leidt het niet in acht nemen van de doeltreffendheid tot een frustratie van het vereenvoudigingsstreven. De Eerste Kamer is van mening dat met betrekking tot de bedoelde asymmetrie de vereenvoudiging ver te zoeken is. ${ }^{187}$

De wetsvoorstellen OORT-II en OORT-III frustreren het vereenvoudigingsstreven, aldus Brouwer en Feteris. ${ }^{188}$ De grote vraag bij de vereenvoudiging is: voor wie treedt deze op? Is dat voor de inhoudingsplichtigen, de belastingplichtigen of voor de fiscus? Voor de inhoudingsplichtigen in ieder geval niet. Dezen zitten met een hogere administratieve last, aldus enige fiscale auteurs. In het parlement is men deze mening ook toegedaan. ${ }^{189}$ Van regeringszijde wordt gezegd dat het mee zal vallen. ${ }^{190}$

Voor de belastingplichtigen leveren de wetsvoorstellen OORT-II en OORT-II ook niet de gewenste vereenvoudiging op. Uiteindelijk levert de gehele OORToperatie een vermindering van 200.000 aanslagen op; de voorstellen van de commissie-Oort moesten een vermindering van 600.000 aanslagen opleveren. ${ }^{191}$

Het parlement is eveneens van mening dat de gewenste vereenvoudiging niet optimaal is gerealiseerd. ${ }^{192}$ Met name de mogelijkheid tot fraude is een punt van

men ninus het bedrag dat bij de werknemer als loon in aanmerking moet worden genomen, groter dan het gedeelte van de uitgave dat op grond van art. 8a Wet IB 1964 niet aftrekbaar zou zijn, dan is de uitgave bij de werkgever in haar geheel aftrekbaar'. J.H.M. Arts, t.a.p., blz. 828 en 829.

Zie ook het Eindrapport over de evaluatie OORT-wetgeving, t.a.p., blz. 9.

187. Eerste Kamer, vergaderjaar 1988-1989, 20 874, no 173, blz. 6.

188. J.Th.L. Brouwer, M.W.C. Feteris, De vereenvoudiging ontspOort(5), fiscaal weekblad FED, 1988, no 764, blz. 2425. De meeste inhoudingsplichtigen zijn nict gehecl te spreken over OORT-III; zij vinden de beperkingen moeilijk, onoverzichtelijk en slecht. Zie de eerste tussenrapportage van de OORT-evaluatie, Tweede Kamer, vergaderjaar 1991-1992, 22 374, no 1, blz. 14. Evaluatie OORT-wetgeving, Deelonderzoek, Belastingconsulenten, t.a.p., blz. 5 .

189. Vreugdenhil (CDA) spreekt over de maatschappelijke druk waaronder het wetsvoorstel staat. Handelingen Tweede Kamer, vergaderjaar 1988-1989, 20595 enz., blz. 39-2409, lk. Zie onder andere Handelingen Eerste Kamer, vergaderjaar 1988-1989, 20595 enz., blz. 27-1067, mk, 27 1072, mk. Er wordt hier ook een zekere mate van inconsistentie geconstateerd. Ik citeer. '... maar het lijkt mij niet juist om aan de ene kant vergoelijkend te praten over de werkdruk die uit deze maatregelen voortvloeit en aan de andere kant die werkdruk te gebruiken om zaken die in de senaat spelen van de hand te wijzen.' De vraag rijst of hier gebruik wordt gemaakt van een doelredenering? Dat lijkt me wel. Zie ook C.J. Visser, Haast geboden?, Weekblad voor fiscaal recht, 1988, no 5844, blz. 1455.

190. Tweede Kamer, vergaderjaar 1988-1989, 20 874, no 9, blz. 2.

191. H.P.A.M. van Arendonk, Belastingfraude en oneigenlijk gebruik na de belastingherziening 'Oort', Maandblad Belastingbeschouwingen, 1989, no 11, blz. 318. Zie hoofdstuk 4, noot 212.

192. Tweede Kamer, vergaderjaar 1988-1989, 20874 , no S, blz. 3, 5 en no 6, blz. 4. Eerste Kamer, vergaderjaar 1988-1989, 20874 , no 173, blz. 6. Handelingen Tweede Kamer, vergaderjaar 19881989, 20595 enz., blz. 42-2596, mk, Handelingen Eerste Kamer, vergaderjaar 1988-1989, 20595 enz., blz. 26-998, rk, 26-1011, lk en mk, blz. 26-1018, lk. Zie ook Tweede Kamer, vergaderjaar 1988-1989, 20 874, no B, biz. 7. 
zorg. De regering doet ook dit punt af met de stelling dat het allemaal mee zal vallen. ${ }^{193}$

In de literatuur komt men tot de conclusie dat de vereenvoudiging uiteindelijk alleen voor de fiscus is geslaagd. ${ }^{194}$

Dit blijkt ook uit de tweede tussenrapportage van de Oort-evaluatie. Deze wijst uit dat de inhoudingsplichtigen en de belastingplichtigen in tegenstelling tot de belastingdienst van mening zijn dat het belastingstelsel er in het algemeen niet eenvoudiger op geworden is. ${ }^{195}$

Ook de eindrapportage leert dat eenheden Ondernemingen, Grote Ondernemingen en Particulieren/Ondernemingen van mening zijn dat de uitvoerbaarheid niet is verbeterd. 'Met betrekking tot de gemengde kosten in de winstsfeer is vaak opgemerkt, dat de toegenomen controle-inspanning in geen verhouding staat tot het geringe financiële belang. ${ }^{196}$

\subsubsection{Budgettaire overwegingen}

De opbrengst van OORT-III is geraamd op $f 600$ miljoen per jaar. ${ }^{197}$ De budgettaire overwegingen hebben zeker in het wetsvoorstel OORT-III de hoofdrol gespeeld. ${ }^{198}$ De totale opbrengst van inkomstenbelasting en vennootschapsbelasting wordt geraamd op $f 775$ miljoen $(250+525$ miljoen $)$, in plaats van de oorspronkelijke $f 600$ miljoen. ${ }^{199}$

193. Tweede Kamer, vergaderjaar 1988-1989, 20 874, no 3, blz. 4, no 6, blz. 2 en 3. Zie bij voorbeeld C.J. Visser, Haast geboden?, Weckblad voor fiscaal recht, 1988, no 5844, blz. 1455.

194. H.P.A.M. van Arendonk, Belastingfraude en oneigenlijk gebruik na dc belastingherziening 'Oort', Maandblad Belastingbeschouwingen, 1989, no 11, blz. 319.

195. Tweede Kamer, vergaderjaar 1992-1993, 22 374, no 2, blz. 4 en 5 . In de eerste tussenrapportage van de OORT-evaluatie was de Belastingdienst van mening dat van een stroomlijning van de aftrekposten en andere OORT-wetgeving vooralsnog geen sprake leek te zijn. Bovendien was de tijd te kort. Als redenen werden aangevoerd: de complexe wetgeving, het ontbreken van goede begripsomschrijvingen en eenduidige interpretatievoorschriften en het plaatsvinden van wijzigingen in de uitvoeringsgregelingen tussen aanname en invoering van de wetgeving, aldus de dienst. Rapport, OORT-wetgeving in de loonbelasting. Een verslag van de ervaringen van de inspecties/eenheden van de Belastingdienst met de Oort-wetgeving in de sfeer van de loonbelasting, oktober 1991, rapportnr. 15, blz. 6.

196. Eindrapport over de OORT-evaluatic, t.a.p., blz. 9.

197. Zie J.Th.L. Brouwer, M.W.C. Feteris, De vereenvoudiging ontspOort(1), fiscaal Weekblad FED 24 november 1988, blz. 2189. Aanvankelijk bedraagt de opbrengst in de niet-winstsfeer $f 675$ miljoen en in de winstsfeer $f 600$ miljoen, 400 miljoen in de sfeer van de vennootschapsbelasting, 200 miljoen in de inkomstenbelastingsfeer. Tweede Kamer, vergaderjaar 1988-1989, 20 873, no 3, blz. 49 en Tweede Kamer, vergaderjaar 1988-1989, 20 874, no 3, blz. 5.

198. Zie onder andere Tweede Kamer, vergaderjaar 1988-1989, 20 874, no 5, blz. 6 en B, blz. 12. Handelingen Tweede Kamer, vergaderjaar 1988-1989, 20595 enz., blz. 40-2519, mk. Handelingen Eerste Kamer, vergaderjaar 1988-1989, 20595 enz., blz. 26-1004, lk en 26-1016. Zie ook de discussie omtrent de invoering van het amendement-Vreugdenhil, no 22; het budgettaire beslag is te groot, aldus staatssecretaris Koning. Handelingen Tweede Kamer, vergaderjaar 1988-1989, 20595 enz., blz. 28-18, mk.

199. Tweede Kamer, vergaderjaar 1988-1989, 20 874, no 16, blz. 2. Zie voor de uiteindelijke opbrengst hoofdstuk 4 , noot 227. 
Over het percentage van de aftrek van 75 vraagt de Raad van State zich af of budgettaire overwegingen de hoofdrol hebben gespeeld. ${ }^{200}$ Zoals gezegd moeten de redenen voor invoering op 1 juli 1989 worden gezocht in budgettaire overwegingen. ${ }^{201}$ De budgettaire opbrengst van OORT-III is al verwerkt als gevolg van de $\mathrm{VpB} / \mathrm{WIR} / \mathrm{AKW}$-operatie. Door de snelle invoering wordt de voorbereidingsperiode voor de belastingplichtigen wel erg kort. ${ }^{202}$

Naar aanleiding van vragen over de opbrengst van bepaalde kostensoorten in de winstsfeer antwoordt de regering dat ze niet kan antwoorden, daar op korte termijn de gevraagde gegevens niet uitgesplitst kunnen worden ${ }^{203}$ Kan dit dan wel op langere termijn? Gezien de grote rol die budgettaire overwegingen spelen, is het enigszins bevreemdend dat de budgettaire gegevens aanvankelijk niet verstrekt kunnen worden. ${ }^{204}$ Enige tijd later gebeurt dit wel. De grote gevolgen van de vaststelling van de gegevens in acht nemend is het volgende citaat uit de notitie van de toenmalige minister van Financiën, Ruding, opmerkelijk: 'Benadrukt moet worden dat de resultaten van het onderzoek, gelet op de noodzakelijkerwijs beperkte omvang van de steekproef en gezien ook het feit dat het gaat om een onderzoek naar tot op heden fiscaal niet-relevante aspecten, met ruime onzekerheidsmarges zijn omgeven' ${ }^{205}$ Verder wordt geopperd dat de elementen van de optelsom niet zeker zijn, maar dat de uitkomst vaststaat. ${ }^{206}$

\subsection{Samenvatting en conclusies}

\section{Algemeen}

De invoering van de wetsvoorstellen OORT-II en OORT-III is een feit. Voor de grote OORT-operatie was geld nodig dat grotendeels werd gevonden in de beperking of afschaffing van de aftrekposten. Budgettaire overwegingen zijn van uitermate groot belang geweest.

In het parlement en in de literatuur hebben de wetsvoorstellen grote weerstand ondervonden. Met de invoering van de asymmetrie komt met name de schending

200. Tweede Kamer, vergaderjaar 1988-1989, 20 874, no B, blz. 6.

201. Handelingen Eerste Kamer, vergaderjaar 1988-1989, 20595 enz., blz. 26-1004. Het later invoeren zou op een verlies van 300 miljoen komen te staan. Eerste Kamer, vergaderjaar 1988-1989, 20874 , no 173a, blz. 9. Zie ook J.W. Zwemmer, die stelt dat een budgettaire reden op zich geen reden kan zijn voor een vervroegde inwerkingtreding. J.W. Zwemmer, Haastige spoed is zelden goed, Weekblad voor fiscaal recht, 1988, no 5844 , blz. 1435.

202. Tweede Kamer, vergaderjaar 1988-1989, 20 874, no S, blz. 6 (VVD).

203. Tweede Kamer, vergaderjaar $1988-1989,20873$, no 5, blz. 51. Ook ten tijde van de behandeling van het wetsvoorstel OORT-III zijn de gegevens nog niet bekend. Tweede Kamer, vergaderjaar 1988-1989, 20 874, no 9, blz. 5.

204. Zie ook het RPF-lid. Tweede Kamer, vergaderjaar 1988-1989, 20 874, no S, blz. 5,6 en no 9, blz. 2. Zie voor nadere informatie over de budgettaire aspecten Tweede Kamer, vergaderjaar 1988-1989, 20874 , no 16.

205. Tweede Kancr, vergaderjaar 1988-1989, 20 874, no 16, blz. 2.

206. Tweede Kamer, vergaderjaar 1988-1989, 20 874, no 16, blz. 2. 
van het draagkrachtbeginsel en inherent daaraan het gelijkheidsbeginsel veelvuldig aan de orde.

Eén algemene conclusie kan mijns inziens zonder tegenspraak worden getrokken. De beoogde vereenvoudiging is door de invoering van de wetsvoorstellen OORTII en OORT-III enigszins tenietgedaan.

\section{Wetgevingsbeginsel(en)}

De wetgevingsbeginselen zijn niet optimaal in acht genomen. Met name de toenemende tijdsdruk waarmee de regering de wetsvoorstellen door het parlement jaagt, baart enige zorgen; zeker gezien de enorme omvang van de wetgevingsoperatie.

Daarnaast wordt niet altijd het motiveringsbeginsel in acht genomen. De Raad van State eist enkele malen een nadere motivering in de memorie van toelichting.

\section{Het draagkrachtbeginsel}

De werking van het draagkrachtbeginsel is door de invoering van OORT-II en OORT-III wederom afgenomen of althans onduidelijker geworden. De werking van het draagkrachtbeginsel is, al dan niet gerechtvaardigd, hetzij via een beroep op de vereenvoudiging, hetzij via een beroep op budgettaire overwegingen meer malen opzij gezet. De bij OORT-I gerezen vraag of het draagkrachtbeginsel nog enige betekenis heeft in de Wet IB 1964, neemt na invoering van de wetvoorstellen OORT-II en OORT-III in belang toe.

Duidelijk zal zijn dat er een nader onderzoek over de invulling van het inkomensen winstbegrip zal moeten komen.

\section{Het gelijkheidsbeginsel}

De werking van het gelijkheidsbeginsel heeft bij de invoering van OORT-II en OORT-III wel aan een zekere druk bloot gestaan. Hier moet met name worden gedacht aan de invoering van de asymmetrie tussen de niet-aftrekbaarheid van kosten van bepaalde posten enerzijds en de onbelaste vergoedingen van dezelfde posten anderzijds. Het gelijkheidsbeginsel wordt meer malen door een beroep op het vereenvoudigingsstreven opzij gezet.

Getuige de stroom van jurisprudentie die op dit moment op gang komt, zal de rechter in casu een aanzienlijke rol spelen.

Inherent aan het draagkracht- en het gelijkheidsbeginsel is het beginsel dat vergoedingen onbelast zijn indien bepaalde posten tot de aftrekbare kosten kunnen worden gerekend. Met de invoering van de asymmetrie is de werking van dit beginsel in belangrijke mate tenietgedaan.

\section{Het vereenvoudigingsstreven}

Met betrekking tot het vereenvoudigingsstreven merk ik op dat het streven met de invoering van de wetsvoorstellen OORT-II en OORT-III zeker niet wordt gediend. De regelingen zijn zeer detaillistisch van aard. Bovendien is de parameter van vereenvoudiging, nl. de vermindering van het aantal mensjaren bij de belas- 
tingdienst, te beperkt van aard. Het streven naar vereenvoudiging moet voor alle betrokkenen, t.w. de belastingdienst, de belastingwetgever en niet in de laatste plaats voor de belastingplichtigen en de inhoudingsplichtigen een zekere positieve uitwerking hebben.

\section{Budgettaire overwegingen}

Budgettaire overwegingen zijn de leidende gedachten geweest van de invoering van de wetsvoorstellen OORT-II en OORT-III.

De vraag rijst of de lasten die de invoering met zich brengt volgens een verdelingsbeginsel, zo men wil het draagkrachtbeginsel, worden verdeeld over de belastingplichtigen. De verdeling van de lasten opgelegd door de belastingheffer mag niet uitsluitend door budgettaire overwegingen worden bepaald. De reden waarom belastingplichtigen belasting moeten betalen liggen in het budgettaire, maar dat wil nog niet zeggen dat de verdeling van lasten ook enkel en alleen door budgettaire overwegingen kan worden bepaald.

Mijns inziens kan voorzichtig de stelling worden geopperd dat vanwege budgettaire overwegingen inbreuken worden gepleegd op het draagkrachtbeginsel. Het draagkrachtbeginsel wordt in dat geval als volgt uitgelegd: 'Bij die belastingplichtigen zijn de meeste financiële middelen aanwezig, dus daar worden de lasten opgelegd.'

\section{De rol van pressiegroepen}

In de totstandkoming van de onderhavige wetsvoorstellen hebben ook de pressiegroepen een rol gespeeld. Wederom dient gewaakt te worden voor een te ondoorzichtige rol van bepaalde pressiegroepen. 


\section{Deel II}

Theorie inzake de beginselen van een rechtvaardige inkomstenbelasting 



\title{
De totstandkoming van belastingwetgeving
}

\begin{abstract}
'Gedurende de laatste decennia heeft de gedachte veld gewonnen dat de verdeling van de belastingdruk niet het resultaat is van een consequente toepassing van belastingbeginselen, maar dat zij in feite in belangrijke mate tot stand komt onder invloed van politieke machtsverhoudingen en de pressie van belangengroepen."
\end{abstract}

\subsection{Inleiding}

Het praktijk-georiënteerde gedeelte van mijn onderzoek is thans afgesloten. Bij de bespreking van de Tweeverdienerswetgeving met de daaraan voorafgaande geschiedenis van de fiscale positie van de vrouw en de Oort-wetgeving stonden de volgende vragen centraal: Welke beginselen noemt de fiscale wetgever en hoe gaat hij met deze beginselen om; hebben zij een consequente werking of niet? In dit hoofdstuk bespreek ik enige elementen, die hun invloed bij de totstandkoming van een belastingwet doen gelden. Het geheel van beslissingen over de overheidsinkomsten en -uitgaven van de Tweeverdieners-wetgeving en de OORTwetgeving komt aan de orde.

De overheid is een samenspel van ministers, parlementariërs, fracties, kamercommissies, pressiegroepen en ambtenaren, die ieder hun eigen belangen en machtsposities hebben. ${ }^{2}$ Zowel de burgers als het bedrijfsleven kunnen in een pressiegroep hun wensen met betrekking tot overheidsinkomsten en -uitgaven kenbaar maken. Een alternatief voor overheidsuitgaven zijn de zgn. belastinguit-

1. L. Koopmans, A.H.E.M. Wellink, H.J. Woltjer en C.A. de Kam, Overheidsfinanciën, zevende geheel herziene druk, Stenfert Kroese, 1991, blz. 164.

2. L. Koopmans c.s., t.a.p., blz. 6, 29 en 84 . Het tekort aan informatie over de gewenste omvang en de samenstelling van de overheidsuitgaven heeft tot gevolg dat belangengroepen kunnen optreden. $\mathcal{L}$. Koopmans, c.s., t.a.p., blz. 5 . koopmans c.s. nocmen nog enige andere redenen waarom belangengroepen kunnen optreden:

1. In het algemeen zijn degenen die over een uitgave beslissen, degenen die van die uitgave genieten en degenen die voor die uitgave moeten betalen, niet dezelfde personen. Er is een scheiding tussen beslissen, genieten en betalen. Deze scheiding zou, aldus Koopmans c.s. leiden tot een toegang creëren voor belangengroepen. L. Koopmans c.s., t.a.p., blz. 73.

2. Bovendien kan het voor politieke partijen aantrekkelijk zijn om zich te richten op bepaaide groepen omdat bij een meerpartijensysteem de uitkomst van een te nemen beslissing niet van te voren duidelijk is. L. Koopmans c.s., t.a.p., blz. 80.

3. Door de dominerende rol van de vaste kamercommissie wordt de invloed van de belangengroepen vergroot. L. Koopmans c.s., t.a.p., blz. 82. 
gaven ${ }^{3}$, bij voorbeeld aftrekposten. ${ }^{4}$ Bij de belastinguitgaven is de invloed die een pressiegroep kan uitoefenen van een bijzonder groot belang.

Ten tijde van de invoering van de OORT-wetgeving verwoordde de toenmalige staatssecretaris van Financiën Koning het aldus: ' $\mathrm{l} k$ wil hier niet ingaan op de vraag waarom de wetgeving zo ingewikkeld is geworden maar én van de factoren is dat allerlei groeperingen ernaar hebben gestreefd hun eigen regelingen in de wetgeving terug te vinden. ${ }^{.5}$ Kortom, de vrees dat pressiegroepen de materie krachtig (kunnen) beïnvloeden, is in sterke mate aanwezig. De vraag is, in hoeverre deze wensen in de praktijk van de wetgeving tot uiting komen.

\section{Wetsevaluatie}

De praktijk van het onderzoek van wetgeving heeft geleid tot verschillende soorten wetsevaluaties. ${ }^{6}$ Snellen bij voorbeeld maakt onderscheid tussen vier soorten wetsevaluaties, t.w.:

1. de juridische wetsevaluatie;

2. de technisch-wetenschappelijke ofwel de beleidsmatige wetsevaluatie;

3. de 'economische' wetsevaluatie;

4. de politieke wetsevaluatie.?

3. Zie voor de definitie van belastinguitgaven hoofdstuk 1 , noot 26 . De overheidsuitgaven zijn niet alleen de uitgaven die nodig zijn voor de werking van de overheid, maar ook de zgn. belastinguitgaven. Dc opbouw van de verzorgingsstaat heeft de groei van de overheidsuitgaven bevorderd. L. Koopmans c.s., t.a.p., blz. 31.

4. Economen zien meer aftrekposten in de inkomsten- en vennootschapsbelasting als belastinguitgave dan fiscalisten. L. Koopmans c.s., t.a.p., blz. 13.

5. Inleiding Staatssecretaris H.E. Koning ter gelegenheid van het congres 'Eenvoud in zicht', Eenvoud in zicht, Weekblad voor fiscaal recht, 1986, no 5750, blz. 1434. Een ander voorbeeld komt van Stevens, de latere voorzitter van de commissie-Stevens. Stevens uitte tijdens de behandeling van de OORT-wetgeving de vrees dat politiek belangrijke groeperingen, zoals de alleenstaanden, met een door hen gewenste invoering van een toeslag het vereenvoudigingsstreven zouden frustreren. W.F.C. Stevens, Snel voort met Oort!, Weekblad voor fiscaal recht, 1987, no 5796, blz. 1334.

6. Wetsevaluatie is een vorm van beleidsevaluatie, aldus Snellen. I.Th.M. Snellen, Wetsevaluatie tussen wetenschap en beleid, onder redactie van J.H.T.H. Andriessen, J.M.J. Baaijens, E.M.H. Hirsch Ballin en I.Th.M. Snellen, W.E.J. Tjeenk Willink, 1987, blz. 49. Volgens Winter '[is] wetsevaluatie een nuttig instrument met het oog op verwezenlijking van enkele eisen die in de rechtsstaat worden gesteld aan de totstandkoming en werking van wetgeving.' $H . B$. Winter, Wetgeving en wetsevaluatie; een siamese tweeling?, In: De rechtsstaat herdacht, W.E.J. Tjeenk Willink, 1989, blz. 230.

7. 1. De juridische wetsevaluatie.

De juridische wetsevaluatie heeft betrekking op de formele en/of materiële gelding van rechtsregels. Bij de formele gelding moet bij voorbeeld aan de tocdeling van bevoegdheden worden gedacht; bij materiële gelding bij voorbeeld aan de mate van naleving van de rechtsregels.

2. De technisch-wetenschappelijke ofwel de beleidsmatige wetsevaluatie.

Zowel de wetenschappelijke als de economische houdbaarheid zijn elementen van de technischwetenschappelijke evaluatie. De wetenschappelijke houdbaarheid betreft de vraag naar een deugdelijke beleidstheorie, de zgn. doelbereiking of effectiviteit; de economische houdbaarheid betreft de vraag naar de verhouding van lasten en opbrengsten.

3. De 'economische' wetsevaluatie. 
Interessant is dat de regering zowel voor de Tweeverdienerswetgeving als voor de OORT-wetgeving een wetsevaluatie heeft toegezegd. ${ }^{8}$

Niet alleen de soort wetsevaluatie, ook vanuit welke invalshoek de wet wordt bekeken, is in dit kader belangrijk. ${ }^{9}$ Vanuit de optiek van de waarborgfunctie wordt nagegaan of de invoering van de wet de gewenste rechtszekerheid, de gelijkheid en de democratie dient; vanuit de optiek van de instrumentfunctie wordt nagegaan of en in hoeverre de wet een bepaalde doelstelling bereikt. ${ }^{10}$ Aangezien de Wet IB 1964 pretendeert een belastingheffing naar draagkracht te zijn, is het onderzoek naar de werking van het draagkrachtbeginsel een onderzoek naar de toepassing van de waarborgfunctie. Het draagkrachtbeginsel is immers een nadere invulling van het gelijkheidsbeginsel. De Wet IB 1964 is ook een instrument van herverdeling. Dat men geen juist onderscheid maakt tussen de verschillende functies verklaart mijns inziens dat men onder draagkracht ook de herverdeling verstaat.

De kosten/baten-analyse ofwel de efficiency-criteria spelen bij de economische wetsevaluatie een rol. De meest vergaande vorm van deze evaluatie houdt in dat de doelbereikings-, effectiviteits- en efficiency-criteria een rol spelen èn dat elk effect in beginsel zijn eigen beoordelingsmaatstaven heeft.

4. De politieke wetsevaluatic.

In de politieke wetsevaluatic wordt de wet als produkt van de politieke verhoudingen gezien. In moeizaam tot standgekomen wetten, waar veelal sprake is van compromissen, komt verhullend spraakgebruik veelvuldig voor. I.Th.M. Snellen, t.a.p., blz. 50-54. Dit geldt zeker voor de belastingwetten, waar de verdeling van inkomens als een compromissoir element wordt gezien. Vergelijk H.B. Winter, M. Scheltema, M. Herweijer, Evaluatie van wetgeving, Kluwer, 1990, blz. 102.

Oosting onderscheidt de evaluaties naar gelang van de tijdsfase waarin zij geschieden. Ten aanzien van de ex post evaluatie zijn er drie stadia, t.w.:

1. de analyse en de beoordeling van de wettekst;

2. het onderzoek naar de werking van de wet;

3. de beoordeling zelf en eventueel de advisering. In: H. van de Graaf, R. Hoppe, Beleid en politiek, een inleiding tot de beleidswetenschap en de beleidskunde, Coutinho, 1992, tweede druk, blz. 172 en 173.

8. Polak zegt over georganiseerde wetsevaluaties het volgende. 'Tot georganiseerde wetsevaluatie wordt steeds besloten als er geen consensus bestaat.' Dit is mijns inziens van toepassing op belastingwetten. A.M. Polak, Wetsevaluatie tussen wetenschap en beleid, t.a.p., blz. 6.

Een bezwaar van een evaluatie achteraf is echter dat pressiegroepen veelal belang kunnen hebben bij de voortzetting van een wet. A.F.A. Korsten, Wetsevaluatie tussen wetenschap en beleid, t.a.p., blz. 22. Hier geldt zeer zeker het adagium 'Oude belastingen, goede belastingen, nieuwe belastingen, slechte belastingen'. Ontleend aan D.A. Albregtse, De commissie-Oort en de aftrekposten: Vereenvoudigen én bezuinigen!, Maandblad Belastingbeschouwingen, 1986, no 9 , blz. 221.

9. Zie voor het onderscheid waarborgfunctie en instrumentele functie o.a. Stout. 'De wet als beleidsinstrument, waarbij het gaat om het formuleren van beleidsdoelen, de doelhiërachie, de middelen en de controle op de effectuering ervan, staat in haar verhouding tot bestuursbeleio gelijk aan alle andere bestuursbesiuiten, bij voorbeeld plannen ...' H.D. Stout, Doelmatige bestuurlijke belangenafweging: een speciaal terrein. In: De rechtsstaat herdacht, W.E.J. Tjeenk Willink, 1989, blz. 245.

10. Vergelijk H.B. Winter, M. Scheltema, M. Herweijer, t.a.p., blz. 13 en 14. 
Ik bekijk de Wet IB 1964 grotendeels vanuit de optiek van de waarborgfunctie. Hier en daar komt de instrumentele functie van de wet zijdelings aan de orde. Het voeren van een bepaald beleid kan vorderen dat de wet een instrumentele functie heeft. Hiermee wil ik niet zeggen dat het voeren van een bepaald beleid niet de waarborgfunctie kan dienen. Het bevorderen van de gelijkheid kan het voeren van een beleid zijn en daarmee een toepassing van de waarborgfunctie. Maar mijns inziens moet het voeren van een bepaald beleid grotendeels aan de instrumentele functie worden gekoppeld. Het beleid kan verschillend van aard zijn. Te denken valt aan budgettaire overwegingen, schoner-milieu-overwegingen en inkomenspolitiek. ${ }^{11}$

In dit hoofdstuk bespreek ik de 'sfeer' waarin de wetgevingsprodukten tot stand komen, en haar invloed op de werking van de (verdelings)beginselen.

Ik heb getracht de wetgevingsprodukten op een manier te bekijken die het beste aansluit op de door de fiscale wetgever geopperde wetgevings- en (verdelings)beginselen of, om minder zware bewoordingen te gebruiken, door de fiscale wetgever geopperde leidende gedachten. ${ }^{12}$ Hierbij stel ik de volgende vragen. Zijn de door de regering en de parlementariërs geopperde gedachten consequent of niet? Spelen partijpolitieke belangen of andersoortige belangen, zoals belangen van pressiegroepen, een rol? Het antwoord op deze vragen is zeker niet gemakkelijk te achterhalen, maar de parlementaire stukken en de fiscale literatuur geven enige aanwijzingen. Door middel van deze aanwijzingen moet de achtergrond, de context, waarin de (verdelings)beginselen tot uiting of juist niet tot uiting komen, duidelijk worden.

Naar aanleiding van de Wet IB 1964 rijst dan de volgende vraag: Zijn de (verdelings)beginselen meer dan een invulling van een bepaalde politieke machtsverhouding op een bepaalde tijd op een bepaalde plaats? Met andere woorden, is een (verdelings)beginsel ter rechtvaardiging van de belastingheffing meer dan het resultaat van de werking van het maatschappelijk mechanisme; het bereiken van de grootste gemene deler?

11. De interessante vraag rijst hoe de relatie van het recht ten opzichte van het beleid moet worden gezien. Verscheidene visies zijn mogelijk. De twee uiterste zijn: of het recht kan als middel ter realisering van het beleid worden gezien, òf het beleid kan als concretisering van het recht worden gezien. Tussen deze twee opvattingen zijn nog vele andere mogelijk. Het is duidelijk dat in de eerste visie het recht, onder andere bestaande uit de (verdelings)beginselen, van een andere orde is dan het beleid. In de tweede visie zijn het recht en het beleid van dezelfde orde. Zie ook H. van de Graaf, R. Hoppe, t.a.p., blz. 164 en 165.

Zie ook Mincke, die spreekt van een onderscheid in werkzaamheden van juristen tussen 'sturen van de samenleving' en 'het stellen van beperkingen en het trekken van grenzen'. G.W. Mincke, Privaatrecht en pluralisme, rede, Kluwer, 1992, blz. 4 en 5.

12. Vergelijk Hirsch Ballin, die onder wetsevaluatie het volgende verstaat: 'het evalueren van de eigenlijke taakvervulling door de wetgever, d.i. het afwegen van belangen die betrokken zijn bij besluitvorming van de overheid in de vorm van algemeen verbindende voorschriften'. E.M.H. Hirsch Ballin, Rechtsstaat en beleid, W.E.J. Tjeenk Willink, Zwolle, 1991, blz. 401. 
Een voorlopig antwoord op deze vraag luidt dat er een verschil is tussen de theorie en de praktijk inzake de belastingheffing. Het verschil wordt juist veroorzaakt door budgettaire, economische en politieke elementen, zoals partij-politieke belangen en ideeën en ook de invloeden van de verscheidene pressiegroepen. ${ }^{13}$

Let wel, het ligt niet in mijn bedoeling om een uitputtende opsomming van de genoemde elementen weer te geven. Het handelt om niet meer dan het geven van een indicatie. De indicatie is wel belangrijk voor het uiteindelijke antwoord op de vraag of de in de veelal oude literatuur geopperde belastingtheorieën en/of (verdelings)beginselen (nog) enigszins in de wetgeving tot uiting (kunnen) komen. Deze vraag komt in hoofdstuk 7 aan de orde.

\subsection{Het belang van budgettaire, economische en politieke elementen}

Ik begin deze paragraaf met een veelzeggend citaat van Hofstra. 'De uitspraak dat 'op bijna geen onderdeel van het rechtsgebied zo vernuftig met gekunstelde rechtsgronden het feitelijk ongerechtvaardigde (werd en wordt) verdedigd (als bij het belastingrecht)', dateert van meer dan een halve eeuw geleden, maar sindsdien zijn de verhoudingen er eerder slechter dan beter op geworden. ${ }^{14}$ Hofstra bedoelt dat de rechtsgronden die aan het belastingrecht worden toegedicht niet de eigenlijke (rechts)gronden zijn, maar een verdoezeling van een aantal redenen van budgettaire, economische of van politieke aard.

In dit verband speelt ook de verwevenheid van het rechtsgebied met andere gebieden, zoals dat van de economie. De vraag rijst of in dat geval de (verdelings)beginselen nog een functie van betekenis kunnen vervullen. ${ }^{15}$ Is het belastingrecht een beleidsinstrument net zoals alle andere en spelen derhalve extra, aparte beginselen geen rol?

Budgettaire, economische en politieke elementen spelen een cruciale rol inzake het wetgevingsproces van de belastingheffing. $\mathrm{Zij}$ hebben effect op de werking van de zgn. (verdelings)beginselen. Een voorbeeld: indien de wetgever met de wensen van pressiegroepen hetzij bij de totstandkoming, hetzij bij de uitvoering van de wet rekening houdt, dan zal dit tot uiting komen bij de verdeling van de belastingdruk.

13. Wat onder politick moet worden verstaan is mocilijk weer te geven, aldus Baaijens. J.M.J. Baaijens, Beleidsnetwerken in actie, Monografieën sociaal recht, KJuwer, 1988, no 5, blz. 137 en 138.

14. Hofstra haalt Kranenburg, 1928, blz. 124 aan. H.J. Hofstra m.m.v. C. van Raad, Inleiding tot het Nederlands bclastingrecht, Fiscale hand- en studieboeken, no 1, zevende druk, Kluwer, 1992, blz. 87 en noot 49.

15. Dit is de bekende discussie met Van den Tempel. Deze stclt zich op het standpunt dat de belastingheffing een instrument is ter bevordering van een bepaald economisch of sociaal be-leid. A.J. van den Tempel, Het einde van de belastingbeginselen, Weckblad voor fiscaal recht, 1979, no 5411 , blz. 703 . 
Wellicht is onvermijdelijk dat de (verdelings)beginselen een zekere politieke lading hebben, maar ik ben de mening toegedaan dat juist een onderscheid moet worden gemaakt tussen het bedrijven van politiek en het nader invullen van de (verdelings)beginselen. ${ }^{16}$ Het onderscheid is al in hoofdstuk 1 aan de orde geweest, maar gezien het cruciale belang zou ik het onderscheid hier graag nog eens nader toelichten. De politieke meningen kunnen een nadere invulling geven aan de beginselen, maar een beginsel heeft een werking die enigszins onafhankelijk is van politieke meningsverschillen. Enigszins onafhankelijk, omdat de politiek en de invulling van de (verdelings)beginselen in elkaar overvloeien. Het gevaar bestaat dat onder het mom van het toepassen van de (verdelings)beginselen de inhoud van de (verdelings)beginselen gelijk is aan het bedrijven van politiek. De rechtvaardiging van de belastingheffing blijkt in dat geval niet meer te zijn dan een uitvloeisel van bepaalde politieke machtsverhoudingen. ${ }^{17}$ Het belastingstelsel verwordt dan tot de optelsom van een aantal deelbelangen zonder dat het wordt gedragen door een meer algemeen, de gehele bevolking betreffend, idee omtrent rechtvaardige lastenverdeling. ${ }^{18}$

Met het onderscheid dat ik maak tussen het bedrijven van politiek en het toepassen van de (verdelings)beginselen in het achterhoofd, stel ik de vraag of de invloed van de budgettaire, de economische en de politieke elementen een zodanige is dat de werking van de (verdelings)beginselen zwakker is dan men gewoonlijk toegeeft.

\subsection{Budgettaire en economische elementen}

Met name in de bespreking van de OORT-operatie hebben we gezien dat budgettaire overwegingen een zeer belangrijke rol speelden. Vanzelfsprekend is de overheid gehouden aan budgettaire randvoorwaarden. Dat wil zeggen, dat ideeën niet tegen iedere prijs kunnen worden uitgevoerd. Het voeren van een bepaald beleid is daarom aan grenzen gebonden. Een van de grenzen is de budgettaire ruimte. ${ }^{19}$ Begrotingspolitiek heeft ook invloed op de belastingpolitiek. ${ }^{20}$

16. Ik vind voor deze stelling steun in de literatuur. Vergelijk Nobel: 'Hier komt bij, dat ik de indruk heb dat de laatste jaren politieke overwegingen nog meer dan vroeger een rol zijn gaan spelen, ook bij de belastingwetgeving. Die politieke overwegingen, die op zichzelf geenszins laakbaar zijn, hebben echter ook een sterk negatieve invloed gehad op de technische kwaliteit van de wetgeving.' N. Nobel, Belastingadviseur en wetgever. Hoe eerbiedwaardig is de wet?, Kluwer, 1983 , blz. 14.

17. Vermeend omschreef het aldus: 'Belastingheffing is de spiegel van de democratie.' In: J.H. Elfers, H. Velthuizen, Fiscale kwaliteitszorg(en)?, Weekblad voor fiscaal recht, 1993, no 6056, blz. 811 .

'In de belastingwetgeving worden politieke voorkeuren en maatschappelijke belangen en ontwikkelingen weerspiegeld.' J.H. Elfers, H. Velthuizen, t.a.p., blz. 811.

18. Vergelijk J.A.G. van der Geld, Zicht op fiscale wetgeving, Tilburg University Press, 1991, blz. 17 en 19.

19. Reuvers noemt de herverdelende en de economisch sturende doelen naast het budgettaire doel. M.R. Reuvers, Belasting, politick en strategie, FED, 1986, blz. 23 en vergelijk J.W. Zwemmer, Haalt de inkomstenbelasting het jaar 2092?, Weekblad voor fiscaal recht, 1992, no 6026, blz. 


\section{Budgettaire overwegingen}

Onder budgettaire elementen zou ik willen verstaan: al hetgeen betrekking heeft op de besluitvorming ten aanzien van de omvang van de onder andere door middel van belastingheffing te verkrijgen middelen. De keuze van de belastingheffing als financieringsmiddel is van geheel andere orde dan de vraag welke maatstaf moet worden gehanteerd voor de verdeling van de opgelegde lasten. De kwestie hoe en waar de benodigde middelen moeten worden geheven, heeft niets met de budgettaire elementen te maken; deze kwestie komt pas aan de orde na de vaststelling van het budget.

Het mag niet zo zijn dat de budgettaire overwegingen de rol van verdelingsbeginsel gaan overnemen. Dat de vrees hiervoor niet geheel irreëel is, blijkt uit het volgende citaat: 'En hoe lang zal het nog duren totdat de rechter een belastingwet onverbindend verklaart, omdat de louter budgettaire beweegredenen van de overheid te zeer in strijd zijn met de algemene rechtsbeginselen? ${ }^{21}$

Natuurlijk kan de rechtvaardigheid niet geheel ten koste gaan van de budgettaire overwegingen en vice versa, maar er zal een compromis tussen beide begrippen gevonden moeten worden. Een compromis dat recht doet aan zowel de rechtvaardigheidseisen als de budgettaire eisen. ${ }^{22}$

\section{Economische overwegingen}

Naast de budgettaire overwegingen doen de economische overwegingen eveneens hun invloed gelden.

Onder economische elementen zou ik het geheel van besluitvormingsprocessen en beslissingen die de economische politiek van de overheid betreffen, willen verstaan. Economische overwegingen kunnen van invloed zijn op de keuze van het belastingmiddel. Het belastingmiddel kan variëren van persoonlijke en zakelijke belastingen tot bijzondere heffingen.

Economische overwegingen betreffen bij voorbeeld de bevordering van de werkgelegenheid in een bepaalde branche. Denk bij voorbeeld aan de in het verleden bestaande aftrek van groot onderhoud en schilderwerk; de werkgelegenheid in die branche werd bevorderd. ${ }^{23}$

Bovendien kan belastingheffing als een instrument ter bevordering van een economisch beleid worden gebruikt. De belastingheffing kan bepaalde faciliteiten bieden. Hierbij valt te denken aan de WIR. Degenen die gebruik kunnen maken van de faciliteiten worden bevoordeeld ten opzichte van die belastingplichtigen die dat niet kunnen.

1334.

20. Tussen de begrotings- en de belastingpolitiek bestaat een wisselwerking. J.A.J. de Vries, Het belastingpolitieke systeem, Elsevier, 1980, blz. 131.

21. Ch.P.A. Geppaart, Rondom het empirische begrip inkomen, Weekblad voor fiscaal recht, 1992, no 6026 , blz. 1379.

22. Zie voor een interessante uiteenzetting van de verhouding tussen financiële normen en rechtsnormen, Brenninkmijer. Deze stelt dat de financiële normen minder goed ontwikkeld zijn dan rechtsnormen. A.F.M. Brenninkmeijer, Financiële normen en rechtsnormen, Nederlands juristenblad 1988, afl. 32, blz. 1166.

23. Zie cok de discussie omtrent de aftrek onderhoud eigen huis. 
Bijzondere maatregelen en bepaalde faciliteiten zijn slechts enige voorbeelden van het gebruik van de belastingheffing als sturingsmechanisme. Daarnaast moet ook aan het leggen van accenten op exporterende of importerende, arbeids- of kapitaalintensieve sectoren et cetera, et cetera worden gedacht.

Evenals de budgettaire overwegingen hebben de economische overwegingen hun beperkende invloed op de werking van de (verdelings)beginselen. ${ }^{24}$ Het voeren van een economisch beleid door middel van het instrument van de belastingheffing verzwakt de basis van het heffen naar draagkracht. ${ }^{25}$ Met andere woorden, het economisch beleid maakt een inbreuk op de verdeling van de lastendruk. Verdelingsbeginselen, moeten ondanks de mogelijkheid van beïnvloeding door economische overwegingen op het belastingrecht, hun werking kunnen behouden. $\mathrm{Er}$ zal een rechtvaardige verdeling van de lasten plaats dienen te vinden. Smeets vertaalde het in 1967 als volgt: 'Reeds hier kan ik opmerken, dat het moderne belastingbeleid niet uitsluitend berust op economische leerstellingen; het heeft de oude inslag van heffen naar draagkracht niet verloren. Integendeel, deze sociale basis geldt nog steeds, al hebben het dienstbetoon aan het economische beleid alsmede de eisen van uitvoerbaarheid van hetgeen 'gelijke druk voor allen' meebrengt, genoopt tot wettelijke constructies die in bepaalde situaties meermalen niet voldoen aan min of meer stringente eisen van rechtvaardigheid. ${ }^{26}$

Resumerend kan worden gezegd, dat budgettaire en economische overwegingen de werking van de (verdelings)beginselen afgrenzen, de inhoud als het ware een omlijsting geven. Op zichzelf is dat niet bezwaarlijk. Het wordt voor de werking van (verdelings)beginselen bezwaarlijk indien budgettaire en economische overwegingen de verdeling van de belastingdruk op beslissende wijze gaan bepalen.

\subsection{Politieke elementen}

Naast budgettaire en economische overwegingen spelen politieke overwegingen een rol. Het bedrijven van politiek vindt altijd plaats met inachtneming van subjectieve en partijpolitieke inzichten. ${ }^{27}$ Daarin ligt een oorzaak van het feit dat politieke beslissingen vaak van compromissoire aard zijn.

24. Vergelijk M.P. van Overbeeke, Inkomstenbelasting: einde of nieuw begin?, Weekblad voor fiscaal recht, 1992, no 6026, blz. 1356.

25. Smeets noemt het heffen naar draagkracht het sociale element van het belastingbeleid. M.J.H. Smeets, Economisch beleid en belastingrecht, rede, 1967, blz. 6, 16 en 17.

26. M.J.H. Smeets, t.a.p., blz. 6.

27. Vergelijk J.A. Schumpeter, Kapitalisme, socialisme en democratie, Hilversum, 1963, blz. 240 en 241. J.A. Ponsioen S.C.J., Sociologie van het economisch-politieke denken, In: Economische wetenschap en economische politiek, 1952, blz. 60 . 
Niet alleen zijn de beslissingen van compromissoire aard, ook kunnen de bij die beslissingen betrokken partijen heel heterogeen zijn, bij voorbeeld het kabinet. ${ }^{28}$ Hierbij komt dat de door een politieke partij uitgesproken voorkeur niet gelijk hoeft te zijn aan de werkelijke voorkeur. Dit is wat Koopmans c.s. stemmenhandel ofwel 'vote-trading' noemen. De ene partij geeft in een bepaalde materie steun aan de andere partij in ruil voor steun in een andere materie. Dit kan zowel uitdrukkelijk als stilzwijgend geschieden. ${ }^{29}$ Bovendien handelt een politieke partij op basis van stemmenmaximalisatie. De minst impopulaire maatregelen zullen worden genomen, daar anders het stemmenverlies te groot is. ${ }^{30}$

Ten aanzien van de belastingwetten betekent het compromissoir karakter van zowel de beslissingen als de betrokken partijen dat de invulling van de (verdelings)beginselen onder andere afhankelijk is van hetgeen in gegeven omstandigheden politiek 'haalbaar' is. Hirsch Ballin: 'De uitdrukking dat de overheid in een rechtsstaat 'gebonden' is aan het recht mag niet worden verschraald tot de gedachte dat formele vereisten in acht moeten worden genomen en de overheid voor het overige haar gang mag gaan, al naar gelang wat politiek wenselijk wordt gevonden. De beginselen van de democratische en sociale rechtsstaat normeren ook het politieke handelen. ${ }^{31}$

Zeker de laatste jaren hebben politieke overwegingen de belastingwetgeving steeds meer beïnvloed. ${ }^{32}$ Afhankelijk van de uitwerkingen van het voeren van politiek hoeft dit niet erg te zijn voor belastingbeginselen. Het wordt wel ernstig indien belastingbeginselen worden gekoppeld aan het voeren van een bepaalde politiek, die niets uitstaande heeft met die belastingbeginselen.

Het voeren van een bepaalde politiek is van een andere orde dan het in acht nemen van belastingbeginselen. Belastingbeginselen impliceren een wetenschappelijke achtergrond. Politiek en wetenschap kunnen goed samengaan, maar dat is niet noodzakelijk het geval.

In het algemeen echter worden het voeren van politiek en belastingbeginselen onder dezelfde noemer geschaard. In de literatuur vind ik steun voor deze gedachtengang. ${ }^{33}$ Tekenend in dit verband is hetgeen De Kam in een interview voor Tribuut heeft gezegd: 'Ik ben het er wel mee eens dat zodra er belastingbe-

28. L. Koopmans c.s., t.a.p., blz. 84 e.v..

29. 'Op de markt is ieder gedwongen zijn werkelijke voorkeur te onthullen. In de politiek behoeft de getoonde voorkeur niet samen te vallen met de werkelijke voorkeur.' L. Koopmans c.s., t.a.p., blz. 76 en 77. Vergelijk ook J.A. Schumpeter, t.a.p., blz. 242.

30. P.B. Boorsma, Belastinghervorming in Nederland, ESB, 1986, blz. 80.

31. E.M.H. Hirsch Ballin, Rechtsstaat en beleid, t.a.p., blz. vi.

32. W. Buis, Toetsing fiscale wetgeving. In: Recht van spreken, Meering-bundel, Kluwer, 1984, blz. 68. Vergelijk Van der Geld: 'De bezinning op de essentiële uitgangspunten van een inkomstenbelasting, is vooral een politieke kwestie.' J.A.G. van der Geld, De honderdjarige inkomstenbelasting, wat moeten we ermee?, Weekblad voor fiscaal recht, 1992, no 6026, blz. 1382.

33. Een al eerder aangehaald voorbeeld: de opvoering van het tarief van de inkomstenbelasting is door politieke overwegingen ingegeven en niet door de belastingtechniek. G. Slot, Verpolitiekte inkomstenbelasting. In: Recht van spreken, Meering-bundel, Kluwer, 1984, blz. 90. 
ginselen worden aangeroepen, men niet meer wetenschappelijk bezig is, maar normatief, of, zo u wilt, politiek. ${ }^{34}$

Politiek en economie beïnvloeden elkaar wederzijds. Onder economie versta ik hier zowel de economische toestand als een economische analyse. Door middel van het voeren van een economisch beleid wordt de politieke visie op de economische toestand duidelijk. Andersom noopt de economische toestand tot bepaalde maatregelen, die in de politiek moeten worden genomen.

Oort verwoordt het verschil tussen de economische analyse en politiek als volgt: 'De economie (economische analyse, MW) als zodanig kan immers geen uitspraak doen over de vraag of veranderingen in de inkomensverdeling, die het gevolg zijn van bepaalde beleidsvoorstellen, al dan niet aanvaardbaar zijn. Dat moet de politiek uitmaken. ${ }^{35}$

De complexiteit van de economische orde is zo groot dat men geen énnduidige visie kan verwachten. Tussen twee extreme visies liggen vaak vele wegen van de waarheid. Het bewandelen van de weg van de waarheid wordt vaak ook nog bemoeilijkt doordat van gegevens moet worden uitgegaan, die niet met honderd procent zekerheid zijn vast te stellen. Hierbij kan men bij voorbeeld aan de zgn. 'koopkrachtplaatjes' denken.

Niet alleen moet economie van politiek, maar ook van rechtvaardigheid worden onderscheiden. 'Wat macro-economisch verantwoord is en maatschappelijk nut zou zijn kan niettemin afstuiten ..., op de eisen die een rechtvaardige verdeling van de belastingdruk stelt .....36

Maar ook hier geldt dat een eenduidige visie niet mogelijk is. '... dat bij de vi-sie van juristen op de economie het doel-middelspoor (d.w.z. aspecten van efficiency en effectiviteit van de toe te passen instrumenten en procedures), het invloedspoor (in de dubbele betekenis van invloed via inspraak en via feitelijk handelen) en het rechtsspoor (in de zin van aspecten van rechtmatigheid en rechtvaardigheid), al naar gelang de concrete functie van de betrokken juris-ten in uiteenlopende opvattingen een rol spelen. ${ }^{37}$

34. C.A. de Kam, Belasting betalen is emotie, Tribuut, december 1992, blz. 18.

Zie ook Hoefnagels, die op zijn beurt Vermeend citeert: 'Als hoogleraar zit ik er voor de burger, en in de Kamer zit ik voor de overheid.' G.P. Hoefnagels, Over belastingfraude, criminologie en democratic, Weekblad voor fiscaal recht, 1992, no 6027, blz. 1400.

35. C.J. Oort, Belastinghervorming, Weekblad voor fiscaal recht, 1988, no 5808, blz. 151. En Schumpeter: 'Op die manier zouden de politici in de regering, en in het bijzonder de politicus die aan het hoofd staat van het ministerie van productie, ongetwijfeld de invloed van het politieke element laten gelden, zowel door hun wetgevende maatregelen over de algemene beginselen volgens welke het economische apparaat moet functioneren als door hun benoemingsbevoegdheid die noch geheel afwezig noch geheel formeel zou kunnen zijn.' J.A. Schumpeter, t.a.p., blz. 255.

36. H.J. Hofstra m.m.w. C. van Raad, Inleiding, t.a.p., blz. 73.

37. P. Verloren van Themaat, Economie, gezien door juristen, Academie van wetenschappen, 1988, blz. 234. 
Economie, recht en politiek zijn drie verschillende onderdelen van een maatschappelijke orde, die in onderlinge relatie met elkaar staan. Een scherp onderscheid tussen de verschillende onderdelen is niet of nauwelijks te maken. Dit maakt het moeilijk om in concrete kwesties scherp te kunnen oordelen.

Politiek getint is ook de nadere invulling van (verdelings)beginselen. Hier zijn wederom verscheidene visies mogelijk. De (verdelings)beginselen komen in hoofdstuk 7 uitgebreid aan de orde, daar zij een puur fiscaal karakter hebben. Met puur fiscaal karakter bedoel ik te zeggen dat (verdelings)beginselen enkel en alleen bij het belastingrecht zijn betrokken. Dit geldt niet voor de nader te noemen elementen.

Derhalve wil ik in dit hoofdstuk twee andere elementen, die niet een puur fiscaal karakter hebben, de revue laten passeren, t.w.: het voeren van beleid en de invloed van pressiegroepen. Zowel het voeren van beleid als de aanwezigheid van pressiegroepen hebben een invloed op de werking van de (verdelings)beginselen. ${ }^{38}$

\section{Het voeren van beleid}

Beleid kan worden omschreven als een plan met een doel-middelstructuur. ${ }^{39}$ Beleid is het gehele proces dat moet worden gevolgd van de erkenning van het bestaan van een probleem tot een oplossing van dat probleem en de uitvoering daarvan. Beleid ontstaat derhalve niet van de ene op de andere dag. Vóor de vaststelling van beleid moeten beslissingen worden genomen. ${ }^{40}$ In geval van beleid kan de instrumentfunctie van de wet een prominente rol spelen. De wet is het middel ter realisering van een bepaald doel, het beleid. Beleid brengt recht tot gelding. ${ }^{41}$

Beleid is het voeren van politiek, zij het dat bepaalde eisen van recht in acht moeten worden genomen. "Toch is ook over de belangenafweging in fundamentele beslissingen van wetgevingsbeleid, al mag men het politiek moment daarvan niet bagatelliseren, uit juridisch oogpunt, het een ander te zeggen, bij voorbeeld aan de hand van het rechtsbeginsel dat evenredigheid van middelen en doeleinden eist. ${ }^{42}$

38. Vergelijk Reuvers, die stelt dat de rechtsgronden van de fiscale wetgeving soms in het gedrang komen door het gedrag van pressiegroepen. M.R. Reuvers, t.a.p., blz. 36.

39. H. van de Graaf, R. Hoppe, t.a.p., blz. 163. Hirsch Ballin geeft de volgende kenmerken van beleid: 'de overheidsactviteiten als min of meer consistent geheel; gerichtheid daarvan op doeleinden; bepaling van de middelen ter realisering van die doeleinden.' E.M.H. Hirsch Ballin, Rechtsstaat en beleid, t.a.p., blz. 1.

40. J.G.A. van Mierlo, Tax Reform, Economic Emancipation of Women, and Public Policy Formation in the Netherlands 1980-1992: A Public Choice Approach, Journal of Economic Studies 1991, 18, 5/6, blz. 99. Zie ook Van Mierlo voor een schema van de totstandkoming van beleid. J.G.A. van Mierlo, Pressiegroepen in de Nederlandse politick, Stichting Maatschappij en Onderneming, 1988.

41. E.M.H. Hirsch Ballin, Rechtsstaat en beleid, t.a.p., blz. 15.

42. E.M.H. Hirsch Ballin, Rechtsstaat en beleid, t.a.p., blz. 401. Reuvers noemt rechtsgronden politiek gekleurd. 'Een rechtsgrond is het motief dat op het moment van het instellen en invoeren 
In dit verband is ook het volgende citaat van belang. 'Zulks leidt ertoe dat dat deel van de wetgevende macht dat onafhankelijk van het bestuur over wetgeving heeft te oordelen - het parlement - in toenemende mate de neiging vertoont de wetgeving vanuit het bestuursbelang te benaderen. Wetten worden daardoor, aldus Scheltema, vooral op hun betekenis voor het regeringsbeleid beoordeeld, welke tendens wordt versterkt door het grote overwicht van de regering ten opzichte van het parlement op het terrein van de legislatieve deskundigheid. ${ }^{.43}$ De afstand tussen besturen en wetgeven is kleiner geworden; de wet is de sturende factor geworden.

Een belangrijke vorm van beleid is de inkomenspolitiek. Albeda en Galan omschrijven inkomenspolitiek als dat deel van het beleid '[dat zich] rechtstreeks en met dat doel [bezig houdt] met de vorming en verdeling van inkomen'. 'Inkomenspolitiek is immers politiek; op basis van feiten, verbanden, voorwaarden en mogelijkheden spelen inzichten en voorkeuren een rol. ${ }^{.44}$ Inkomensvorming is afhankelijk van de economische orde. De invulling van de verdeling van inkomen is het bedrijven van politiek. Hier komt de verwevenheid van politiek en economie duidelijk naar voren.

Een andere belangrijke vorm van beleid is het nastreven van een optimale realisering van nevendoeleinden. In de belastingheffing is vele malen geprobeerd nevendoeleinden in de wetgeving te verweven. Denk bij voorbeeld aan de introductie van het schoner-milieubelang inzake de regeling van het reiskostenforfait in de Wet IB 1964 in 1991. Het schoner-milieubelang is thans een belang dat in de maatschappij een hoge prioriteit kent.

Het op een bepaald moment in de maatschappij belangrijk geachte belang bepaalt de werking van (verdelings)beginselen. De waardering voor dat belang kan zo ver gaan dat de (verdelings)beginselen opzij worden gezet. Deswege is het belangrijk dat men zich goed realiseert welke invloed het gebruik van nevendoeleinden op de werking van (verdelings)beginselen kan hebben. Indien de uitwerking van het nevendoeleinde in een belastingwet desastreus is voor de werking van (verdelings)beginselen, moet men zich afvragen of het niet beter zou zijn het nevendoeleinde door middel van een andersoortige maatregel te realiseren.

van de belasting wordt gebruikt om die invoering te ondersteunen.' M.R. Reuvers, t.a.p., blz. 22. Zie ook Verloren van Themaat die stelt dat een bepaald beleid aan wettelijke procedurele en inhoudelijke criteria moct worden getoetst. P. Verloren van Themaat, t.a.p., blz. 246.

43. Zie Sillevis en De Vries, die Scheltema, 1984, aanhalen. L.W. Sillevis, N.H. de Vries, Universiteit, belastingbeginselen en samenleving, Weekblad voor fiscaal recht, 1990, no 5943, biz. 1890 en 1891 , noot 44.

44. W. Albeda, C. de Galan, Inkomen, vorming, verdeling, beleid, Wolters-Noordhoff, Groningen, 1970, blz. 24 en 238 . Vergelijk Van den Tempel: '.. en dat hetgeen wij nog gewend zijn de 'fiscale verdeling van lasten' te noemen, niet anders kan zijn dan een onderdeel van die politiek.' A.J. van den Tempel, Het einde van de belastingbeginselen, Weekblad voor fiscaal recht, 1979, no 5411 , blz. 702 . 
In het algemeen kan men zeggen dat het aantal pressiegroepen en de invloed van die pressiegroepen in het parlement zijn toegenomen. Dit heeft onder andere te maken met de toenemende specialisatie van kamerleden. ${ }^{45}$ Een andere factor is de verhoogde invloed van de overheid op het maatschappelijk leven. In het politiek proces kunnen pressiegroepen hun wensen kenbaar maken. ${ }^{46}$ Interessant is de visie van Van Mierlo op de commissie-Oort. Zo'n commissie wordt volgens hem in het leven geroepen vanwege de deskundigheid en de maatschappelijke ervaring. Maar door middel van deze commissie krijgen ondernemers een unieke mogelijkheid om invloed uit te oefenen op het overheidsbeleid. $^{47}$

Het fenomeen pressiegroepen roept vele vragen op. Het is bij voorbeeld onduidelijk hoeveel pressiegroepen aanwezig zijn en hoe groot hun macht is. ${ }^{48} \mathrm{Het}$ woord 'pressie' heeft een negatieve bijklank. Hebben pressiegroepen daadwerkelijk negatieve aspecten? Zo ja, in welk opzicht? Over de antwoorden kan verschillend worden gedacht.

Allereerst geef ik de definities van pressiegroepen van enige auteurs weer. Het ligt echter zeker niet in de bedoeling om uitputtend over het fenomeen pressiegroepen te berichten. Volgens Van Doorn zijn pressiegroepen 'belangengroepen die zich ongenodigd in de politieke arena begeven om aldaar op de besluitvor-

45. L. Koopmans c.s., t.a.p., blz. 82. De ambtenaren vormen ook een groep die in dit verband niet te vergeten is. L. Koopmans c.s., t.a.p., blz. 88. Zie ook Sillevis en De Vries, die spreken van een ontbreken van overlegst ructuur tussen de politiek en de beleidsmakers en de onafhankelijke wetenschapsbeoefenaars. L.W. Sillevis, N.H. de Vries, t.a.p., blz. 1886. Zie ook Van den Berg en Molleman, die spreken van een dualisme; het generalisme tegenover het specialisme; generalistische parlementariërs en de tegenover de machtige vertegenwoordigers van belangen, die ook in het parlement zitting hebben. J.Th.J. van den Berg en H.A.A. Molleman, Crisis in de Nederlandse politiek, 2e druk, Sanson, 1980, blz. 37.

46. L. Koopmans c.s., t.a.p., blz. 30. L.W. Sillevis, N.H. de Vries, t.a.p., biz. 1886. Stevens verwoordt het als volgt: 'Dit stelsel (stelsel van waarden en normen in een veronderstelde gesloten totaliteit, MW) richt zich op de rechtvaardiging, c.q. de handhaving van een bepaalde machtsstructuur binnen de maatschappij of binnen maatschappelijke groeperingen, door een overdraagbare verklaring van een bepaalde mens- en maatschappijvisie op te stellen.' L.G.M. Stevens, Belasting naar draagkracht, Kluwer, 1980, blz. 51, noot 42 . Stevens maakt een onderscheid tussen waarden en belangen. Hij constateert dat de staat een strijdtoneel wordt waar de belangengroepen om de voorrang strijden. L.G.M. Stevens, t.a.p., blz. 137.

De regering is voornemens een wetsvoorstel Vorderingsrecht belangenorganisaties in te dienen. Tweede Kamer, vergaderjaar 1991-1992, no 5, blz. 28.

47. J.G.A. van Mierlo, Pressiegroepen, t.a.p., blz. 109 en 110.

48. Er is de overtuiging dat de pressiegroepen een verschijnsel vormen van de laatste tijd. Dit is niet waar, $\infty \mathrm{k}$ in de vorige eeuw berustte de macht niet alleen bij de regering en het parlement. Zie J.J. de Jong, Pressiegroepen, de invloed der georganisecrde groepen op het maatschappelijk en politiek leven, Mens en medemens, aspecten der sociale werkelijkheid, 1959, blz. 14 en A.G.J. Haselbekke, Profijtbeginsel en politieke besluitvorming, Stenfert Kroese, 1987, blz. 76.

Hoe moeilijk dat te verrichten onderzoek is, blijkt uit het artikel van M. Brouwer, Enkele opmerkingen over de empirische studie van pressie en publiek, In: Pressiegroepen, J.J. de Jong, 1959, blz. 40. Zie ook Van Mierlo, die stelt dat empirisch en normatief onderzoek naar pressiegroepen vaak twijfelachtig en niet exact is. J.G.A. van Mierlo, Pressiegroepen, t.a.p., blz. 179. 
ming druk uit te oefenen. ${ }^{49}$ Stevens omschrijft een pressiegroep als volgt. 'Het begrip 'pressiegroep' kan een groot aantal organisaties van zeer uiteenlopend karakter omvatten, en is daarom rijkelijk vaag; haar werkzaamheden voltrekken zich voor een deel in de vertrouwelijke sfeer van persoon tot persoon. De pressiegroepen verschillen daarom principieel van de politieke partijen, op welker bestaan onze vorm van parlementaire democratie steunt. ${ }^{50}$ Van Mierlo definieert pressiegroepen als 'organisaties die pogen een bepaald aspect of onderdeel van het overheidsbeleid te beïnvloeden zonder deel uit te maken van de overheid, dat wil zeggen de formele politieke instituties van de parlementaire democratie., 51

Mijns inziens vertegenwoordigen pressiegroepen een bepaald gedeelte van de bevolking of het bedrijfsleven, en behartigen zij een specifiek belang, zonder het geheel waarin dat belang moet passen, in ogenschouw te (willen) nemen. Het volgend citaat van Hirsch Ballin gaat weliswaar over een versnippering van beleidsterreinen, maar kan mijns inziens worden toegepast op het bestaan van pressiegroepen, indien voor 'algemene wetten en wetboeken' de Wet IB 1964 en voor 'specifieke beleidsopvattingen' de eisen van pressiegroepen wordt gelezen. 'Algemene wetten en wetboeken zijn - zoals daar wordt betoogd - een waarborg tegen wat Van Eijkeren het 'particularisme in de wetgeving' noemde. Daarmee doelde bij op het - op grond van voor een bepaalde sector specifieke beleidsopvattingen - tot stand brengen van regels die zich slecht verdragen met dat waar het ons in de wetgeving toch eigenlijk om moet gaan: een binnen de rechtsorde als geheel consistente belangenafweging uit algemene gezichtspunten. ${ }^{52}$

In de definities is veelal een negatieve ondertoon met betrekking tot het pressiegroepen waar te nemen; de negatieve ondertoon betreft het gebrek aan democratische legitimatie van pressiegroepen.

Pressiegroepen worden vaak in relatie gebracht met politieke partijen. Beide behartigen bepaalde belangen in een organisatiestructuur. Er zijn overeenkomsten, maar ook verschillen. Pressiegroepen hebben met de politieke partijen gemeen dat ze een pendelfunctie vervullen tussen de burger en de overheid en trachten het overheidsbeleid te beïnvloeden. Pressiegroepen verschillen van politieke partijen doordat ze niet langs de officiële, formele weg mensen kandi-

49. J.A.A. van Doorn, Pressiegroepen: correctie of corruptie? In: Pressiegroepen, J.J. de Jong, 1959, blz. 64 .

50. L.G.M. Stevens, Belasting naar draagkracht, Kluwer, 1980, blz. 104.

51. J.G.A. van Mierlo, t.a.p., blz. 59. Ponsioen noemt vijf factoren die de economische politiek van cen economische macro-groep bepalen, t.w.: de geestesstromingen, de feitelijke economische situatie van de macro-groep, de regeringskringen, de wereldbeschouwelijke groepen en belangengroepen. Dit is beweerd in 1952, maar mijns inziens bepalen belangengroepen ook hedendaags grotendeels de econonische politiek. J.A. Ponsioen S.C.J., sociologie van het economischpolitieke denken, In: Economische wctenschap en cconomische politiek, 1952, blz. 75 en 76.

52. E.M.H. Hirsch Ballin, Rechtsstaat en beleid, t.a.p., blz. 360 . 
daat stellen voor de overheidslichamen. ${ }^{53}$ Met name dit verschil roept vragen op met betrekking tot de gewenste legitimatie van pressiegroepen.

Alhoewel niet met zekerheid is vast te stellen hoe groot de invloed van pressiegroepen is, is het natuurlijk niet zo dat pressiegroepen onbeperkt hun invloed kunnen doen gelden. Net zoals bij het beleid het geval is, voorkomen wettelijke procedurele en inhoudelijke criteria dat bepaalde belangen hun enorme invloed kunnen doen gelden. ${ }^{54}$

\section{Democratische verantwoording}

In het bovenstaande wordt al duidelijk dat het een interessante vraag is hoe het bestaan van de belangengroeperingen democratisch is te verantwoorden. Met name is deze vraag van toepassing op pressiegroepen welke hun eigen belang behartigen. De vraagt rijst ten koste van wie deze belangen worden behartigd. ${ }^{35}$ Degenen ten koste van wie de belangen worden behartigd, kunnen zich niet via de democratische weg verdedigen. Een oplossing zou kunnen zijn ook een pressiegroep te vormen.

De vraag rijst of pressiegroepen al dan niet in een maatschappij aanwezig moeten zijn. Voorstanders van hun aanwezigheid zeggen dat ze de democratie bevorderen en derhalve niet in strijd behoeven te zijn met het democratiebe-

53. J.G.A. van Mierlo, Pressiegroepen, t.a.p., blz. 57. Pressiegroepen hebben niet altijd de gewenste invloed. Vergelijk de tegenvallende invloed die de vrouwen hebben gehad in de sociale en fiscale politiek. Dit ligt onder andere aan de structuur van beleidsbeslissingen nemen. J.G.A. van Mierlo, Tax Reform, Economic Emancipation of Women, and Public Policy Formation in the Netherlands 1980-1992: A Public Choice Approach, Journal of Economic Studies 1991, Vol. 18, No. 5/6, blz. 94 e.v.. Zie ook Vansina. Vrouwenorganisaties zijn moeilijk te vinden en deswege is er ook geen lobby. Y. Vansina, A Schumpeterian Approach to Emancipatory Economics, Journal of Economic Studies 1991, Vol. 18, No. 5/6, blz. 74.

54. P. Verloren van Themaat, t.a.p., blz. 246. Interessant is de visie van Hirsch Ballin. Deze bekijkt de materie vanuit de belangenbescherming. Hirsch Ballin ziet een drievoudige bescherming van de belangen van de burgers. Let hierbij vooral het onder b genoemde. 'De rechtsstatelijke gestalte van het sociaal contract geeft aan de wezenlijke belangen van de rechtsgenoten een drievoudig verankerde bescherming, namelijk niet slcchts door [a] die bescherming als staatstaak te aanvaarden, maar ook door [b] de besluitvorming daarover via het democratische principe en de openbaarheidsregels te relateren aan de belangen en inzichten van de rechtsgenoten, en door [c] in het constitutionele recht, dat als het ware de basis van overeenstemming over het sociaal contract definieert, in de vorm van grondrechten bepaalde belangen een versterkte bescherming te bieden.' E.M.H. Hirsch Ballin, Rechtsstaat en beleid, t.a.p., blz. 405.

Kalma ziet het toekennen van meer macht en meer verantwoordelijkheid aan de belangengroepen als éen van de grondslagen van de democratie. P. Kalma, De illusie van de 'democratische staat', Kluwer, 1982, blz. 69.

55. 'In de volksvertegenwoordiging hebben de spitsen van belangengroepen zitting genomen. $\mathrm{Z}_{\mathrm{ij}}$ zijn door hun deskundigheid veelal de sectorspecialisten van de fracties, en houden dikwijls nog steeds voeling met de belangenorganisaties waaraan zij vroeger waren verbonden. De uitbreiding van het aantal leden van de Tweede Kamer (in 1956) van 100 tot 150 werkte de specialisatie op deelbelangen in de hand en heeft de penetratie van belangengroepen in de het parlement vergemakkelijkt.' L. Koopmans c.s., t.a.p., blz. 82. 
ginsel. ${ }^{56}$ Een citaat ter ondersteuning: ' $\mathrm{Zij}$ zijn wezenlijk democratisch, inzoverre zij vaak - niet altijd - het klinkend bewijs zijn van de interesse der burgers bij de publieke zaak. $Z_{\mathrm{ij}}$ zijn de rem bij uitstek op de apathie die vooral de moderne massademocratie zo gemakkelijk aantast. Bovendien: zij zijn de consequentie van het zeer democratische recht van vrijheid van meningsuiting en van vereniging. ${ }^{57}$

Tegenstanders beweren stellig dat de pressiegroepen de democratie ondermijnen. 'Pressiegroepen zijn bij uitstek ondemocratisch, wanneer onder democratie wordt verstaan de realisering van de gelijke rechten van alle burgers, niet alleen voor de wet, maar ook in omstandigheden die niet wettelijk zijn vastgelegd. Democratie is meerderheidsmacht, pressie is minderheidsmacht. ${ }^{58}$ 'Blijven de politieke partijen zich echter als doorgeefluik van particuliere deelbelangen gedragen en blijven zij falen in de vervulling van hun makelaarsfunctie, dan is dat niet alleen jammer voor de kiezers en schadelijk voor de democratie. ${ }^{.59}$

Pressiegroepen kunnen enerzijds een gevaar zijn voor de democratie, anderzijds zijn ze nodig in een dynamische maatschappij. Een overheid kan niet los van de maatschappij haar besluiten vaststellen. Voor deze besluiten moet een maatschappelijk draagvlak aanwezig zijn. ${ }^{60}$ Door middel van pressiegroepen wordt duidelijk of de besluiten al niet in goede aarde vallen.

De visie op pressiegroepen hangt samen met de visie op de staat. Stel dat de staat wordt gezien als instituut waarmee een contract kan worden gesloten. Ieder individu heeft een contract met de staat; hetzelfde geldt voor pressiegroepen. Voortdurend vinden er tussen de staat, de overheid en de burgers interacties plaats. In deze interacties worden ieders belangen over en weer duidelijk gemaakt en wordt er over de belangen onderhandeld. In deze visie kan een pressiegroep ook zijn belangen verdedigen en daarmee is het aanwezig zijn van een pressiegroep in een staat volkomen gerechtvaardigd. 'Een ruilrelatie in de vorm van een contract veronderstelt altijd verschillende belangen. Deze belangen kunnen gelegen zijn in het niveau waarop de belangen gedefinieerd zijn: individuele belangen; groepsbelangen; klassen; hele samenlevingen in de zin van algemeen belang; als ook in de aard; materieel, immaterieel. Het gaat ons bij een contract om verschillende belangen. ${ }^{.61}$

\section{Pressiegroepen en belastingrecht}

Toegespitst op de belastingheffing valt het volgende te zeggen over pressiegroepen. De beslissingen die de financiële middelen betreffen, kennen vaak een grote

56. Zie Van Mierlo, die een aantal voor- en tegenstanders opsomt. J.G.A. van Mierlo, Pressiegroepen, t.a.p., blz. 54 en 55 . Zie voor de voor- en nadelen van de pressiegroepen voor het democratisch functioneren, J.G.A. van Mierlo, Pressiegroepen, t.a.p., blz. 180-183.

57. J.A.A. van Doorn, t.a.p., blz. 82.

S8. J.A.A. van Doorn, t.a.p., blz. 82. Het democratiegehalte is niet de enige maatstaf waarop pressiegroepen kunnen worden beoordeeld. Daarnaast kunnen pressiegroepen worden beoordeeld met behulp van economiemaatstaven. J.G.A. van Mierlo, Pressiegroepen, t.a.p., blz. 187 en 188.

59. J.G.A. van Mierlo, Pressiegroepen, t.a.p., blz. 126.

60. J.M.J. Baaijens, Beleidsnetwerken in actie, t.a.p., blz. 193.

61. J.M.J. Baaijens, Beleidsnetwerken in actie, t.a.p., blz. 188. 
mate van beïnvloeding door pressiegroepen ${ }^{62}$; zeker bij de verdelingsproblemen zijn de pressiegroepen betrokken. ${ }^{63}$ Pressiegroepen spelen ook een rol in de afwenteling van belastingen. Grote en goed georganiseerde pressiegroepen kunnen de belasting afwentelen door middel van strenge looneisen. Koopmans c.s.: 'Er zijn duidelijke aanwijzingen dat de vakbonden er in de jaren zestig en zeventig in zijn geslaagd een belangrijk deel van de toen sterk stijgende premielast af te wentelen op de ontvangers van het overig inkomen (winsten, rente en huuropbrengsten). ${ }^{64}$ In het laatste citaat komt een door Wicksel aangetoonde paradox naar voren; nl. een botsing van een individueel belang en een collectief belang. Het blijkt zo te zijn dat burgers die zo min mogelijk belasting voor zichzelf willen betalen, toch instemmen met een belastingverhoging voor iedereen. ${ }^{65}$

Als de financiële specialisten in het parlement zich als pressiegroep voor de belastingbetaler gaan opstellen wordt het evenwicht van de pressiegroepen verstoord, aldus Pen. Het evenwicht wordt verstoord omdat de overheidsuitgaven blijven toenemen, terwijl de genegenheid om belasting te betalen niet evenredig

62. De Vries spreekt over normen in het belastingpolitieke systeem. Deze zijn de verwachtingen van de leden over de wijze waarop eisen in beslissingen worden omgezet. J.A.J. de Vries, t.a.p., blz. 92.

Normen zijn de geldende (on)geschreven spelregels, die behoren tor de gebruiken, die men kan vertrouwen. Tot de geschreven spelregels behoren de normen betreffende het formele belastingpolitieke proces. De ongeschreven spelregels worden gevonden via een empirisch onderzoek naar het informele belastingpolitieke proces.

Met de normen die gelden in het belastingpolitieke systeem, worden geheel andere normen bedoeld dan de normen die gelden voor het belastingpolitieke systeem. De normen voor het belastingpolitieke systeem zijn de doelstellingen van het belastingpoliticke systeem. Met normen die gelden in het belastingpolitieke systeem worden bedoeld de geschreven en ongeschreven spelregels die worden gehanteerd ter realisering van het belastingpolitieke proces. De geschreven regels staan in het staats-, en bestuursrecht omschreven. De ongeschreven regels zijn gebruiken, die door middel van empirisch onderzoek naar voren komen. J.A.J. de Vries, t.a.p., blz. 129 en 130.

63. J. Pen, Het verstoorde evenwicht der pressiegroepen. In: Pressiegroepen, J.J. de Jong, 1959, blz. 89, J.A. Ponsioen S.C.J., t.a.p., blz. 78. Vergelijk De Vries. De Vries spreekt van een belastingpolitieke gemeenschap. Deze bestaat uit alle leden, die bijdragen in een belasting die wordt geheven in het politieke systeem waartoe zij behoren. Allen hebben belastingbelangen en belastingideeën.

Het belastingbelang van de leden bestaat hieruit, dat een zo'n gering mogelijk aandeel in de belastingheffing wordt bijgedragen en dat een zo'n groot mogelijk voordeel wordt genoten. Hiertegenover moeten de vele algemene belangen worden geplaatst. De politiek moet trachten een compromis tot stand te brengen. J.A.J. de Vries, t.a.p., blz. 49, 51 en 52. Het antwoord op de vraag wat gebeurt met nieuwe door de leden opgeroepen belangen, hangt af van de steun die zo'n nieuw belang krijgt, van de resistentie van de oude belangen, van de verhouding tussen het politieke en het belastingpolitieke systeem en van de steun aan het belastingregime en belastingautoriteiten. J.A.J. de Vries, t.a.p., blz. 71.

64. L. Koopmans c.s., t.a.p., blz. 190.

65. De verplichte belastingbetaling door en aan de burgers van een staat is een voorbeeld van een democratische aanvaarding van dwang, aldus Wicksel. Ontleend aan Van Mierlo. J.G.A. van Mierlo, Pressiegroepen, t.a.p., blz. 38. 
toeneemt. ${ }^{66}$ Pen noemt de paradox niet, maar de strekking van zijn stelling is mijns inziens dezelfde.

Pressiegroepen kunnen derhalve een aanzienlijke rol spelen bij de nadere invulling van de belastingheffing. In ieder geval mag hun rol niet worden onderschat. Op zich is het voor de aanvaarding van de belastingheffing evident dat een bepaalde maatschappelijke groepering haar goedkeuring geeft aan de vorm waarin de belastingheffing is gegoten. Hierbij moeten dan wel de grootte en de samenstelling van die maatschappelijke groepering in acht worden genomen. Het mag niet uitmonden in een dictatuur van een groepering.

De rol van pressiegroepen hangt samen met de fiscaliteitsfunctie. Ziet men als functie van de fiscaliteit enkel en alleen de financiering van de overheidsuitgaven, dan is geen rol voor pressiegroepen weggelegd. De fiscaliteit is dan niet het juiste instrument voor pressiegroepen. Ingeval de fiscaliteitsfunctie ruimer is dan die van financiering van de uitgaven, kunnen pressiegroepen bij de concretisering van de belastingplichten hun wensen c.q. eisen kenbaar maken. De fiscale wetgever kan door middel van wettelijke voorschriften met de wensen c.q. eisen rekening houden. In dat geval is de fiscaliteit wel een juist instrument voor pressiegroepen.

Interessant in dit verband is de visie van Schumpeter. Schumpeter beschouwt de belastingheffing als een gevolg en een afspiegeling van een bepaalde maatschappij. Voldoet een belastingstelsel niet meer aan de ideeën in de maatschappij, dan moet het belastingstelsel zich aanpassen. ${ }^{67}$

Welke zijn de signalen waaruit blijkt dat het belastingstelsel niet meer conform de ideeën van de maatschappij is? Mijns inziens kan de aanwezigheid van pressiegroepen een signaal zijn. Indien pressiegroepen in een maatschappij structureel aanwezig zijn, beantwoordt het hedendaags gebeuren niet meer helemaal aan de theorieën van de staat en de overheid. ${ }^{68}$ Derhalve moet de belastingheffing zich op den duur aanpassen. Wel moeten enige eisen in acht worden genomen. Deze eisen hangen samen met de legitimatie van pressiegroepen. De invloed van een pressiegroep moet gelegitimeerd zijn, wil hij kunnen 'meedenken' over een nadere invulling van de belastingheffing door middel van belastingwetgeving. De besluitvorming zou onder meer door een verklaring van de identiteit van deelnemende partijen gelegitimeerd moeten zijn.

66. J. Pen, t.a.p., blz. 94.

67. Y. Vansina, t.a.p., blz. 69.

68. Zie ook de eis die Schumpeter stelt aan belangengroepen: '... dat een democratische regering alleen dan tot volle tevredenheid zal functioneren, indien alle belangengroepen waarom het gaat eenstemmig zijn niet alleen in hun trouw aan het land maar ook in hun trouw aan de structurele beginselen van de bestaande maatschappij.' J.A. Schumpeter, t.a.p., blz. 250. 


\subsection{Samenvatting en conclusies}

Belastingheffing is een complex geheel. Bijna alle facetten van het maatschappelijk leven ondergaan de invloed van belastingheffing. En de belastingheffing past zich op haar beurt weer aan aan de maatschappelijke orde. De grote verwevenheid van de belastingheffing met de maatschappelijke orde maakt het moeilijk om concrete, eenduidige uitspraken met betrekking tot (verdelings)beginselen te doen. De uitspraken moeten in een breder perspectief geplaatst worden. Het perspectief betreft elementen die een prominente rol spelen in de totstandkoming van de belastingwetgeving.

Elementen, die een prominente rol spelen, zijn van budgettaire, economische en politieke aard.

Budgettaire elementen kunnen als randvoorwaarden van de omvang van de belastingheffing worden beschouwd. Economische elementen bepalen de nadere inhoud van de belastingheffing. Politieke elementen zijn nader te verdelen in het voeren van beleid en de rol van pressiegroepen. Alhoewel niet exact is vast te stellen hoe groot de rol van pressiegroepen is, is deze in elk geval aanzienlijk te noemen.

Bovengenoemde elementen zijn dermate dominant aanwezig dat de vraag rijst of er nog wel sprake kan zijn van een goede en zelfstandige werking van (verdelings)beginselen.

Vooropgesteld zij dat een ieder een rechtvaardige samenleving wil, waarin een ieder gelijk wordt behandeld. Desalniettemin trek ik de volgende, voorzichtige conclusie. De inhoud van de (verdelings)beginselen is gebaseerd op dit rechtvaardigheidsverlangen. Daarnaast zijn de (verdelings)beginselen een nadere invulling van een machtsverhouding op een bepaalde plaats op een bepaald moment. 



\section{Rechtvaardigheidsbeginselen tegenover doelmatig- heid(sbeginsel(en))}

'Het bleek echter, zelfs tot op de dag van vandaag, uitermate gecompliceerd [het draagkrachtbeginsel] in theoretisch opzicht gestalte te geven, laat staan het in de fiscale praktijk blijvend tot zijn recht de laten komen. Die pelgrimstocht naar het draagkrachtbeginsel ontaardde dan ook niet zelden in een ware martelgang."

\subsection{Inleiding}

Tot nu toe zijn enige wijzigingswetten van de Wet IB 1964, enige voorbeelden uit de praktijk van de belastingwetgeving, en de 'sfeer' waarin deze wetgeving tot stand komt aan de orde geweest. Bij de verdeling van de opgelegde lasten over de burgers blijken vele belangen een rol te spelen, die de uiteindelijke verdeling van de lasten beïnvloeden.

In de (oude) literatuur komen bij de kwestie van de verdeling van de lasten veelal de zgn. verdelingsbeginselen aan de orde. De overheid heft belasting en als hoofdregel geldt hierbij dat de lasten zo rechtvaardig mogelijk over de burgers moeten worden verdeeld. ${ }^{2}$

De verdelingsbeginselen zijn onder te verdelen in het draagkrachtbeginsel en het profijtbeginsel. ${ }^{3}$ Het draagkrachtbeginsel is het meest genoemde en belangrijkste verdelingsbeginsel. ${ }^{4} \mathrm{De}$ verdelingsbeginselen kunnen als een nadere invulling van het gelijkheidsbeginsel worden gezien. Belangrijk is dat de verdelingsbeginselen juist worden gedefinieerd en gehanteerd, zij het dat een invulling naar tijd en plaats onvermijdelijk is:

Tegenover de verdelingsbeginselen als rechtvaardigingsbeginselen kan de eis van doelmatigheid worden geplaatst. Doelmatigheid is de laatste tijd sterk in opmars

1. F.H.M. Grapperhaus, De pelgrimstocht naar het draagkrachtbeginsel, Kluwer, 1993, blz. 62.

2. Al vanaf de zestiende eeuw bestaat er een discussie over een rechtvaardige verdeling van de belastingdruk. F.H.M. Grapperhaus, t.a.p., blz. 59. Grapperhaus geeft een ontwikkeling in de geschiedenis van de belastingheffing en uiteindelijk de inkomstenbelasting en het draagkrachtbeginsel weer.

3. De Langen noemt het beginsel van de bevoorrechte verkrijging ook een verdelingsbeginsel. Zie \$7.2. Hartogh noemt het profijt- en het draagkrachtbeginsel verdelingsbeginselen van een speciaal type. Hij geeft ze de vorm 'Ieder naar zijn x', waarbij voor ' $x$ ' een bepaald persoonskenmerk kan worden ingevuld. G.A. den Hartogh, Fiscale moraal en de moraal van de fiscus, Weekblad voor fiscaal recht, 1987, no 5772 , blz. 545 .

4. Zie Nederstigt, die concludeert dat soms het draagkrachtbeginsel vrijwel identiek wordt geacht aan een rechtvaardige verdeling van de belastingdruk. W.F. Nederstigt, Rechtvaardigheid en doelmatigheid van belastingheffing naar draagkracht, Smeetsbundel, 1967, blz. 261. 
en kan de werking van de rechtvaardigheidsbeginselen beperken. ${ }^{5}$ Onder doelmatigheid kunnen zowel de efficiency en de effectiviteit als het gebruik van de belastingheffing voor nevendoeleinden worden verstaan. Ook met betrekking tot de eis van doelmatigheid is het belangrijk dat deze juist wordt gedefinieerd. De vraag of de eis van doelmatigheid als een beginsel moet worden beschouwd of niet, is een cruciaal element in de vaststelling van een definitie van de eis van doelmatigheid.

De rode draad van het onderzoek is een nadere beschrijving te geven van het compromis tussen rechtvaardigheid en doelmatigheid inzake enige wijzigingswetten van de Wet IB 1964.

In de praktijk van de belastingwetgeving komt het compromis tussen rechtvaardigheid en doelmatigheid duidelijk tot uiting. In de totstandkoming van deze wetgeving kan vaak niet anders dan met een compromis worden gewerkt. Dit wordt onder andere veroorzaakt door de verscheidenheid van partijen die bij de totstandkoming van de belastingwetgeving zijn betrokken. Naast ambtenaren en politici hebben pressiegroepen een invloed op het wetgevingsprodukt; belastingplichtigen of groepen van belastingplichtigen pogen hun belangen via ambtenaren en politici zo gunstig mogelijk in de wetgeving vast te leggen. De wet is niet anders dan een afspiegeling van het uiteindelijke resultaat van onderhandelen tussen verschillende partijen. ${ }^{6}$ De overwegingen van rechtvaardigheid en doelmatigheid ter motivering van een wetgevingsprodukt, die al dan niet terecht zijn gegeven, zijn in het eerste gedeelte van het onderzoek naar voren gekomen.

Ter afsluiting van het onderzoek wil ik de zgn. 'theorie' inzake het compromis tussen rechtvaardigheid en doelmatigheid bespreken. ${ }^{7}$

5. Al in 1980 constateert Stevens dat doelmatigheid in toenemende mate de belastingheffing bepaalt. L.G.M. Stevens, Belasting naar draagkracht, Kluwer, 1980, blz. 138.

6. Slagter spreekt hier van een compromis binnen de doelmatigheid, waar rechtvaardigheid geen rol speelt. W.J. Slagter, Rechtvaardigheid en doelmatigheid, rede, Rotterdam, 1961, blz. 5 .

7. Rechtvaardigheid is de maatstaf van het recht, doelmatigheid het doel; samen bepalen zij de inhoud van het recht. W.J. Slagter, t.a.p., blz. 9. Is een goed onderscheid mogelijk tussen rechtvaardigheid en doelmatigheid? Of moet je zeggen dat rechtvaardigheid ook doelmatigheid impliceert? Ik maak een onderscheid tussen rechtvaardigheid en doelmatigheid. Vergelijk Hofstra, die goed recht ook doelmatig recht vindt. Zic hoofdstuk 4, noot 53 en zie M.R. Reuvers, Belasting, politiek en strategie, FED, 1986, blz. 68, M.R. Reuvers, Mythen en de belastingheffing. In: Fantasic en durf, FED, 1991, blz. 86. Slagter geeft het volgende beeld van een compromis: 'Een compromis tussen rechtvaardigheid en doelmatigheid betekent, dat noch het ideaal van de rechtvaardigheid noch dat van de doelmatigheid ten volle kan worden bereikt; ter wille van het compromis moet men een deel van de verwerkelijking van zijn ideaal prijsgeven, in de poging dit te bereiken blijven steken.' Een vereniging van beide begrippen is volgens hem niet mogelijk, daar ze te verschillend zijn. W.J. Slagter, t.a.p., blz. 13. Grapperhaus omschrijft het compromis tussen rechtvaardigheid en doelmatigheid als een dilemma voor de belastingheffer: '... rekening houdend met zijn schaarse middelen en met de noodzaak die economisch, effectief en efficiënt aan te wenden, moet [de belastingheffer] een antwoord geven op de vraag van de vereenvoudiging van de belastingwetgeving tegenover de rechtvaardigheid die eist dat met relevante verschillen rekening wordt gehouden en voorts tegenover de introductie in het fiscale recht van niet-fiscale doeleinden.' F.H.M. Grapperhaus, Vereenvoudiging van de belastingheffing een vraagstuk voor managers, Weekblad voor fiscaal recht, 1986, no 5750, blz. 1436. 
Waaruit bestaat in de belastingheffing rechtvaardigheid? Hofstra spreekt van fiscale rechtsbeginselen ${ }^{8}$ die moeten passen in een gerechtigheidsconceptie, die aan de maatschappij ten grondslag ligt.' Wil de werking, van beginselen van belastingheffing duidelijk worden, dan moet eerst de rechtsgrond van de belasting worden vastgesteld. Onder de rechtsgrond van de belasting wordt yèrstaan: 'de motivering waarom, op overwegingen van rechtvaardigheid en doelmatigheid, een bepaalde belasting een plaats mag of moet innemen als onderdeel van een als een samenhangend geheel te beschouwen samenstel van belastingen (belastingstelsel)..$^{10}$ Met overwegingen van rechtvaardigheid ${ }^{11}$ en doelmatigheid wordt naar mijn mening het genoemde compromis bedoeld. ${ }^{12}$

8. Zie wat over de term 'fiscale rechtsbeginselen' is gezegd hoofdstuk 4, paragraaf 4.3.3.2.

9. H.J. Hofstra, Het fiscale wetgevingspröes, Weekblad voor fiscaal recht, 1985, no 5672, blz. 255 en H.J. Hofstra, De toekomst van de inkomstenbelasting, Weekblad voor fiscaal recht, 1975, no 5248, blz. 1035.

10. H.J. Hofstra en L.G.M. Stevens, Inkomstenbelasting, Fiscale hand- en studieboeken, no 2, Kluwer, 1994, vierde druk, blz. 7. Zie ook Reuvers, die stelt dat een rechtsgrond politiek gekleurd is; de rechtsgrond wordt geput uit de bestaande rechtsbeginselen. M.R. Reuvers, Belasting, politiek en strategie, FED, 1986, biz. 22.

Christiaanse maakt een onderscheid tussen rechtsgrond en strekking. 'Met de rechtsgrond bedoelen wij de motivering, het fundament van de regeling; onder de strekking verstaan wij daarentegen de doeleinden die in 'cencreto met de regeling lijken te worden nagestreefd.' J.H. Christiaanse, Belastingaftrek voor de gehuwde vrouw, derde druk, Kluwer, 1961, blz. 17.

11. Interessant is bij voorbeeld de vraag aan belastingplichtigen of de OORT-wetgeving rechtvaardig is, zonder daarbij de definitie van rechtvaardigheid te geven. Uit de OORT-evaluatie blijkt dat het merendeel van de particulieren en de inhoudingsplichtigen neutraal reageert op de vraag of het belastingstelsel rechtvaardiger is geworden. Een grote minderheid van de inhoudingsplichtigen vond het stelsel onrechtvaardiger geworden. De niet-commerciële hulpverleningsorganisaties vonden het stelsel eveneens onrechtvaardiger geworden. Eindrapport over de evaluatie OORT-wetgeving, Ministerie van Financiën, Directoraat-Generaal der Belastingen, DirectoraatGeneraal voor Fiscale Zaken, juli 1994, blz. 4.

12. Schendstok maakt een onderscheid tussen de eisen van de belastingtechniek, inhoudende de eis van een redelijke druk van bijkomende verplichtingen en de eis dat een wettelijke regeling op fiscaal gebied vatbaar dient te zijn om op een rechtvaardige wijze te worden uitgevoerd, enerzijds, en de eisen der gerechtigheid, de overige eisen, anderzijds. B. Schendstok, Ontwikkelingsfactoren van het belastingrecht, 1946, blz. 5 en 6.

Zie $\infty$ k het interessante onderzoek van De Vries. De economie en het recht kunnen niet de grondslagen voor de doelmatigheid en de rechtvaardigheid van de bclastingheffing leveren, aldus De Vries. J.A.J. de Vries, Het belastingpolitieke systeem, Elsevier, 1970, blz. 27. Derhalve probeert De Vries via een andere weg deze grondslagen wel te vinden, nl. via een politieke theorie. JA.J. de Vries, t.a.p., blz. 27. Roos noemt de theorie van De Vries een empirische politieke theorie. Een politieke theorie van de belasting kan normatief of empirisch iets zeggen over de politieke doeleinden en/of aspecten van de belastingen. N.H.M. Roos, Enkele rechtstheoretische kanttekeningen bij een belastingtheoretische discussie, Nederlands Juristenblad, 1980, afl. 12 , blz. 261. Hij tracht kwalitatieve en kwantitatieve verbanden te leggen. Het leggen van kwalitatieve verbanden houdt in, dat aangetoond wordt dat het belastingpolitieke systeem is opgebouwd uit een veelheid van belastingpolitieke sub-systemen. Het leggen van kwantitatieve verbanden houdt in dat een concreet onderzoek naar een sub-systeem wordt verricht. Uit de resultaten van dit onderzoek kan getracht worden een algemeen geldende belastingtheorie op te stellen. J.A.J. de Vries, t.a.p., biz. 45. 
In de huidige tijd wordt nog steeds over de eis van een rechtvaardige verdeling van de lasten gesproken. Het draagkrachtbeginsel heeft nog steeds een magische uitstraling. Bij de bespreking van de wetgevingsprodukten rees de vraag, of ondanks het veelvuldige beroep op het draagkrachtbeginsel de werking van het beginsel in de huidige tijd nog voldoende wordt of kan worden gerealiseerd. Ik heb de indruk dat de conclusie dat de verdelingsbeginselen een ondergeschikte rol spelen en dat andere 'beginselen' de overhand hebben gekregen, gerechtvaardigd is. Mochten andere 'beginselen' de overhand hebben gekregen, dan is tevens aangetoond dat de werking en de nadere invulling van beginselen van plaats en tijd afhankelijk zijn. ${ }^{13}$ De rechtvaardiging van een wetgevingsprodukt kan blijkbaar steeds een andere inhoud krijgen. Mijns inziens behoeven rechtvaardigingsgronden van een wet niet dezelfde inhoud als rechtvaardigheidsbeginselen te hebben. ${ }^{14}$, Welke zijn de rechtvaardigheidsbeginselen van het belastingrecht?

\section{Beginselen}

Een definitie van een rechtsbeginsel is: '... een gedachte waaraan een volk waarde is gaan hechten, een gedachte die, omdat zij zelve niet is rechtsregel, niet als zodanig mag worden gehanteerd en 'toegepast' naar het heet, doch die telkens weer in die toepassing wordt erkend. ${ }^{15}$ Scholten reduceert bepaalde rechtsregels tot regels met een algemenere strekking en deze regels worden op hun beurt weer gereduceerd tot nog algemenere et cetera. Ten slotte is daar het rechtsbeginsel, dat niet meer voor directe toepassing vatbaar is, doch uiterst belangrijk. ${ }^{16}$

De Waard omschrijft het begrip als volgt: '[Beginselen] hebben dikwijls een zeer algemene betekenis en zijn dan ook dikwijls tamelijk vaag. Niet alle beginselen pretenderen universele geldigheid. $\mathrm{Zij}$ mogen niet geschonden worden, maar behoeven anderzijds niet in alle gevallen geheel verwezenlijkt te worden om hun waarde te behouden. ${ }^{17}$.

Hofstra spreekt over het 'beginsel van het hoogste niveau', waarin de deelgebieden van het recht moeten wortelen. ${ }^{18}$ Volgens Hofstra hebben beginselen een

13. Zie ook M.P. van Overbeeke, Inkomstenbelasting: einde of nieuw begin?, Weekblad voor fiscaal recht, 1992, no 6026, biz. 1358.

14. Vergelijk Geppaart: 'Een belasting wordt niet rechtvaardig door haar in een andere juridische vorm te gieten.' Ch.P.A. Geppaart, Wie is eigenlijk de belastingplichtige?, Column, Weekblad voor fiscaal recht, 1994, no 6102, blz. 668. Of in andere bewoordingen door dezelfde persoon: 'Daarbij (terugbetaling van de belastingmeevaller, $\mathrm{MW}$ ) werd uit het oog verloren dat belasting uit kracht van wet wordt geheven en niet uit kracht van begroting.' R.H.M.J. Offermans, Belastingfraude en belastingmoraal, verslag van de belastingadviseursdag 1994, Weekblad voor fiscaal recht, 1994, no 6104, blz. 759.

ii 15. P. Scholten, Recht en Gerechtigheid, Verzamelde Geschriften deel I, Tjeenk Willink, 1980, blz. 304. Ontleend aan J.G. Detiger, Belastingbeginselen, Smeetsbundel, 1967, blz. 88, die cursiveert.

16. Ontleend aan J.G. Detiger, t.a.p., blz. 87. G.J. Scholten, Rechtsbeginselen en rechtsregeis, scheiden schaadt, W.E.J. Tjeenk Willink, 1983, blz. 3.

17. B.W.N. de Waard, Beginselen van burgerlijke rechtspleging, met name in het administratief procesrecht, Zwolle, 1987, blz. 78. De Waard is overigens van mening dat geen scherp onderscheid gemaakt kan worden tussen rechtsbeginsel en rechtsregel. B.W.N. de Waard, t.a.p., bjz. 81.

18. H.J. Hofstra, Over belastingbeginselen, Weekblad voor fiscaal recht, 1979, no 5427, blz. 1217. 
Onder rechtvaardigheid kunnen naar mijn mening onder andere gelijkheid redelijkheid en billijkheid worden geschaard. Redelijkheid en billijkheid zijn termen, die veelvuldig in het privaatrecht worden gebruikt, maar zij kunnen mijns inziens ook in het belastingrecht toepassing vinden.

Rechtvaardigheid kan mijns inziens als een 'hoger' begrip dan rechtmatigheid worden beschouwd, daar de redelijkheid en billijkheid niet evident onder rechtmatigheid behoeven te vallen. Met 'hoger' begrip bedoel ik dat de redelijkheid en billijkheid de rechtvaardigheid als het ware boven de rechtmatigheid plaatsen. Rechtvaardigheid is een morele categorie die zich laat vertalen in de genoemde eisen. Indien de wet aan deze eisen voldoet, dan is de rechtmatigheid van de wet gelijk aan de rechtvaardigheid van de wet. ${ }^{21}$

Toegespitst op belastingheffing betekent dit dat de beginselen van een rechtvaardige verdeling van lasten in gelijkheid, redelijkheid en billijkheid kunnen worden gevonden.

Zoals gezegd moeten rechtvaardigheidsbeginselen ook worden onderscheiden van rechtvaardigingsgronden van een wet. Rechtvaardigheidsbeginselen zijn van een andere orde dan de gronden ter rechtvaardiging. De gronden ter rechtvaardiging van een wetgevingsprodukt worden gevonden in de parlementaire geschiedenis en in de overwegingen van een wet. Deze behoeven niets met rechtvaardigheid te maken hebben.

Volgens Slagter kan een onderscheid worden gemaakt tussen vergeldende rechtvaardigheid (justitia commutativa) en verdelende rechtvaardigheid (justitia distributiva). Vergeldende rechtvaardigheid heeft betrekking op de eis van gelijkheid én verdelende rechtvaardigheid heeft betrekking op de eis van evenredigheid. De inhoud van de rechtvaardigheid wordt bepaald door de gelijkheid en de evenredigheid. ${ }^{2}$ Derhalve wordt een onderscheid gemaakt tussen het gelijkheidsen het evenredigheidsbeginsel. Andere auteurs zijn een andere mening toegedaan. Deze stellen dat onder het gelijkheidsbeginsel tevens de eis van de evenredigheid valt. De evenredigheidseis komt tot uitdrukking in de volgende omschrijving van het gelijkheidsbeginsel: gelijke gevallen dienen gelijk te worden behandeld en ongelijke gevallen naar de mate van evenredigheid van ongelijkheid. ${ }^{23}$

21. Vergelijk L.G.M. Stevens: 'De wet mag echter niet worden vereenzelvigd met het recht omdat dit een zekere meerwaarde bezit. Het recht wordt ingevuld met beginselen, waarbij de wet tot uitgangspunt wordt genomen. Stevens onderscheidt hier drie niveaus, waartussen een zekere spanning bestaat: ethiek, recht en wet'. Uit: R.H.M.J. Offermans, t.a.p., blz. 764.

22. W.J. Slagter, t.a.p., blz. 18. Kaptein maakt een soortgelijk onderscheid; distributieve (verdelende) en retributieve (wederkerige) rechtvaardigheid. De wederkerige rechtvaardigheid heeft minder politieke elementen dan de verdelende. H.J.R. Kaptein, Integriteit en het tekort van doelmatigheid en rechtvaardigheid. In: C.W. Maris c.s., Recht, Rechtvaardigheid en Doelmatigheid, Kluwer, 1990, blz. 349. Het onderscheid gaat terug tot Aristoteles.

23. Zie bij voorbeeld W.J. de Langen, De grondbeginselen van het Nederlandse belastingrecht, deel I, Samson, 1954, blz. 6. De definitie wordt sinds Aristoteles gehanteerd. Hieruit valt af te leiden dat het zeer moeilijk is om een goede definitie te geven van het gelijkheidsbeginsel. Dit is inherent aan de moeilijke toepassing van het beginsel. In de moderne subjectivistische belastingthẹorie betekent evenredigheid: een ieder moet zoveel belașting betalen dat het totale genot 
Voor het belastingrecht zijn vergeldende rechtvaardigheid en verdelende rechtvaardigheid van het grootste belang. In het hiernavolgende wordt uitgegaan.van de zogenaamde ruime omschrijving van het gelijkheidsbeginsel, nl. inclusief de eis van evenredigheid. Kan het gelijkheidsbeginsel onbeperkt worden toegepast in het belastingrecht? Nee, een grens wordt onder andere gevonden in de eis van doelmatigheid.

\section{Afwenteling}

Ten slotte verdient in deze inleiding de mogelijkheid tot afwenteling aandacht. In dit hoofdstuk komen de theoretische grondslagen van de verdelingsbeginselen aan de orde. Een onderscheid dient te worden gemaakt tussen de richtlijnen de werking van de beginselen - die de fiscale wetgever hanteert of dient te hanteren voor de vaststelling van de lasten voor de belastingplichtigen en het uiteindelijk dragen van de lasten door belastingplichtigen, de mogelijkheid tot afwenteling. Het eerstgenoemde aspect wordt in dit hoofdstuk besproken, het tweede niet. De redenen hiervoor moeten worden gezocht in de noodzakelijke afbakening van het onderzoek en de moeilijkheid om de juiste gegevens inzake de afwenteling te achterhalen. Hoe de lasten in werkelijkheid op de belastingplichtigen drukken is derhalve, behoudens een enkele opmerking, niet of nauwelijks in dit onderzoek behandeld en komt ook in het hiernavolgende niet aan de orde.

Bij de bestudering van de parlementaire geschiedenis blijkt niet of nauwelijks dat de wetgever rekening houdt met de mogelijkheid tot afwenteling, terwijl het naar mijn mening voor de fiscale wetgever wel degelijk van belang is dat hij bij. de vaststelling van de lasten rekening houdt met die mogelijkheid.

In het vervolg van dit hoofdstuk geef ik een kort historisch overzicht van hetgeen door enige van de meest vooraanstaande (fiscaalrechtelijke) auteurs over de door hen genoemde beginselen te berde is gebracht ( $\$ 7.2$ ). Vervolgens bespreek ik de verdelingsbeginselen afzonderlijk, t.w.: het draagkrachtbeginsel ( $\S$ 7.3.1) en het profijtbeginsel (\$7.3.2).

Daar rechtvaardigheid vaak met gelijkheid wordt geïdentificeerd, bespreek ik het gelijkheidsbeginsel als 'overkoepelend' beginsel van de verdelingsbeginselen. $\mathrm{Na}$ een weergave van het gelijkheidsbeginsel in het algemeen (\$ 7.4.1), ga ik na of, en in hoeverre, het gelijkheidsbeginsel van betekenis kan zijn in het belastingrecht (\$ 7.4.2).

In $\S 7.5$ volgt een beschrijving van doelmatigheid. In $\S 7.6$ toets ik de onderzochte wetgeving aan de genoemde beginselen. In $\S 7.7$ volgen een samenvatting en conclusies.

voor allen in dezelfde verhouding (= evenredig) zal worden verminderd. A.C. Rijkers, Naar een proportioneel inkomstenbelastingtarief in de 21e eeuw, rede, Kluwer, 1991, blz. 7. 
In de loop van de geschiedenis zijn de beginselen van belastingheffing al veelvuldig aan onderzoek onderworpen. De verschillende onderzoeken geven een aardige indicatie van de verscheidenheid van beginselen; ieder onderzoek geeft weer andere beginselen. Daarnaast tonen de onderzoeken aan dat er een breed verlangen naar een rechtvaardiging van de belastingheffing bestaat. Derhalve is het interessant om de opvattingen van enige auteurs weer te geven.

Verscheidene (fiscaalrechtelijke) auteurs hebben met behulp van verschillende onderzoeksmethoden een poging ondernomen om de beginselen van belastingheffing te vinden en te ordenen. De probleemstelling van de verschillende onderzoeken luidt in het algemeen: $\mathrm{Zijn}$ belastingbeginselen aanwezig en, zo ja, welke inhoud hebben zij?

Ik geef alleen de kernpunten van opvattingen en/of theorieën beknopt weer. Tevens vermeld ik de door de auteurs gebruikte onderzoeksmethoden; deze geven een nadere indicatie over de gevonden beginselen. Ik heb bij het geven van dit historisch overzicht zeker niet de pretentie volledig te willen zijn. Voor een weergave van de visie van Hofstra en de door hem genoemde beginselen volsta ik met een verwijzing naar hoofdstuk $1, \S 1.3$. Specifieke opmerkingen over de verdelingsbeginselen geef $i k$ in de desbetreffende paragrafen weer (§ 7.3.1-7.3.2).

\section{Van den Berge}

Van den Berge is van mening dat de belastingheffing geen neutraal verschijnsel is. Het verschijnsel heeft bedoelde en onbedoelde sociale en economische gevolgen. ${ }^{24}$ Bovendien heeft de belastingheffing een zekere mate van relativiteit, die wordt veroorzaakt door de rechtsovertuiging van een volk, het volkskarakter, het stadium van ontwikkeling van het volk en economische omstandigheden. De belastingheffing kan variëren, zowel naar tijd als naar plaats. ${ }^{25}$

\section{Gebruikte methode}

Via een inductieve methode probeert Van den Berge de beginselen, de regels van materiële inhoud te vinden. Er moet een zekere gemeenschappelijkheid zijn, die bestaat 'in het gezamenlijk behoren, in de twintigste eeuw, tot een volk met democratische instellingen, weliswaar door ons veelal op verschillende wijze geïnterpreteerd, maar toch een macht, die ons allen, bewust of onbewust, op fundamentele wijze beheerst. ${ }^{26} \mathrm{Hij}$ heeft als vertrekpunt voor het vinden van de beginselen het concrete rechtsbewustzijn, dat aanwezig is in de volksgemeenschap. Het concrete rechtsbewustzijn dat aan tijd en plaats gebonden is, vindt zijn grondslag in de absolute Idee der gerechtigheid. ${ }^{27}$ Van den Berge komt via

24. W.H. van den Berge, Beginselen van de belastingheffing, Geschriften van de Vereniging voor Belastingwetenschap, no 68, Samson, 1949, blz. 87.

25. W.H. van den Berge, t.a.p., blz. 40 en 41.

26. W.H. van den Berge, t.a.p., blz. 8.

27. W.H. van den Berge, t.a.p., blz. 47. 
een beschrijving van het begrip beginselen naar de concrete beginselen van de belastingheffing. Beginselen zijn volgens Van den Berge: 'algemene regels welke behoren te worden gevolgd en [die] op een bepaald nivèau kunnen worden onderscheiden van de bijzondere regelen, welke afgeleid uit die beginselen, bij de uitwerking van die beginselen worden gevolgd ${ }^{28} \mathrm{Er}$ is een zekere hiërarchie tussen de beginselen aanwezig en aan dezè hiërarchie wordt door Van den Berge een groot belang toegekend, daar het anders niet mogelijk is een zinnige uitspraak over deze beginselen te doen. De beginselen kenmerken zich onder andere doordat een beginsel op een bepaald niveau een nadere concrete inhoud geeft aan een hoger, abstracter beginsel. ${ }^{29}$

\section{Gevonden beginselen}

Van den Berge maakt een onderscheid tussen het financieel, economisch, belastingtechnisch en rechtfilosofisch aspect. De eerste drie aspecten zijn nuttigheidsregelen en hebben een technisch karakter; het laatste aspect kan als normatief worden gekwalificeerd. ${ }^{30}$ De aspecten kunnen op de gehele belastingheffing of op een afzonderlijke belasting betrekking hebben.

Financiële beginselen zijn die beginselen die betrekking hebben op de algemene eisen van financieel-technische aard. Deze beginselen moeten worden onderscheiden van de eisen van financiële politiek. 'Als een gezond beginsel van financiële politiek moet ook worden aangemerkt de eis dat de opbrengst van de belastingen zowel een element van stabiliteit, als een element van beweeglijkheid in zich draagt. ${ }^{31} \mathrm{De}$ eisen van financiële politiek hebben daarentegen invloed op de structuur van de belastingheffing. ${ }^{32}$

Een voorbeeld van een financieel beginsel is dat het financiële grensnut van de belastingheffing niet mag worden overschreden. Met andere woorden, de belastingheffing heeft zijn grenzen. ${ }^{33}$. Dit is een toepassing van nutsmaximalisatie; een algemene regel, die niet alleen voor het belastingrecht geldt. Het hier opperen van de eis van het niet overschrijden van het financiële grensnut met betrekking tot belastingheffing is als het ware een open deur intrappen.

In dit kader moet aan de belastingvlucht, het ontgaan en het ontduiken van de belastingen worden gedacht. De eis dat de verhouding tussen de opbrengst van

28. W.H. van den Berge, t.a.p., blz. 3.

29. W.H. van den Berge, t.a.p., blz. 3.

30. P.J.A. Adriani, Het belastingrecht, Deel I, 1954, blz. 196.

31. Zowel een stabiel als een beweeglijk facet moeten in de structuur van de belastingheffing tot gelding worden gebracht. Een stabiel facet wordt beheerst door de eis dat opbrengst van de belastingen zeker moet zijn. Dit wordt bewerkstelligd door een complex van belastingen. Een beweeglijk facet wordt beheerst door de budgettaire noodzaak de variabele uitgaven te dekken èn door de economische conjunctuurpolitiek. W.H. van den Berge, t.a.p., blz. 51.

32. W.H. van den Berge, t.a.p., blz. 51-53.

33. Of, om met de woorden van Van den Berge te spreken, dat men niet de kip met de gouden eieren slacht. W.H. van den Berge, t.a.p., blz. 56 en 57. 
de belasting en de directe perceptiekosten ${ }^{34}$ zo gunstig mogelijk moet zijn, wordt door Van den Berge niet als een financieel beginsel gezien. Hetzelfde geldt voor de eis dat de lasten die de belasting voor de belastingplichtige met zich brengt, zo gering mogelijk moeten zijn. ${ }^{35}$

Ten tweede komt het economische aspect aan de orde. Wat verstaat Van den Berge onder economie? Economie is de wetenschap diē zich bezighoudt met 'de vraag op welke wijze produktie en consumptie van de volksgemeenschap zodanig georganiseerd kunnen worden dat zij zoveel mogelijk bestaande behoeften bevredigen'. ${ }^{36}$ Met deze definitie wordt het probleem van de rechtvaardige verdeling van de inkomens en vermogens buiten de wetenschap van de economie gehouden.

Het proces van de fiscaliteit kan economisch worden gezien als het onttrekken van koopkracht van particuliere produktie- en verbruikshuishoudingen èn het toevoegen van koopkracht aan particuliere produktie- en verbruikshuishoudingen. Van den Berge heeft in zijn onderzoek naar de beginselen van belastingheffing alleen het eerste gedeelte in zijn onderzoek betrokken, nl. het onttrekken van de koopkracht.

Een voorbeeld van een economisch beginsel is dat het proces van het onttrekken van koopkracht aan de particuliere huishoudingen en produktiehuishoudingen per saldo de welvaart moet vergroten. ${ }^{37}$ Dit beginsel bestaat ten eerste uit een negatieve eis yan 'zo weinig mogelijk nadeel toebrengen' en ten tweede uit de positieve eis van 'nut' genereren. ${ }^{38}$ De vigerende maatschappelijke situatie, onder andere hierin bestaande dat de particuliere huishoudingen zijn gericht op het behalen van winst, moet ten behoeve van het algemeen belang niet terzijde

34. Onder directe perceptiekosten moeten worden verstaan die kosten die het heffen en het invorderen van belastingen met zich brengen voor de overheid. Indirecte perceptiekosten zijn de kosten en de lasten die de belastingheffing voor de belastingplichtigen met zich brengt. Zie W.H. van den Berge, t.a.p., blz. 112.

35. W.H. van den Berge, t.a.p., blz. 58 en 59.

36. W.H. van den Berge, t.a.p., blz. 63. Voor het nader preciseren van het economische aspect hanteert Van den Berge het volgende schema:

'I. De belastingheffing moet zo' weinig mogelijk belemmeren - en, voor zover zulks mogelijk is, bevorderen - dat ten behoeve van de productie een voldoende hoeveelheid nuttige kapitaalgoederen ter beschikking komt.

II. De belastingheffing moet zo weinig mogelijk belemmeren - en, voor zover zulks mogelijk is, bevorderen - dat van de beschikbare kapitaalgoederen en arbeidskrachten een zo efficiënt mogelijk gebruik wordt gemaakt.

III. De belastingheffing moet worden afgestemd op - en, voor zover zulks mogelijk is, dienstbaar worden gemaakt aan - de algemene economische politiek, welke zich ten doel stelt de 'welvaart' te bevorderen en in het bijzonder storingen in de gelijkmatige gang van het maatschappelijk leven te voorkomen of te matigen.' W.H. van den Berge, t.a.p., blz. 69 en 70.

Ten aanzien van I en II geldt het uitgangspunt dat het bevorderen van de welvaart een toenemende consumptie met zich brengt. Vooropgesteld zij in dat geval dat een grote en efficiënte produktie noodzakelijk is. W.H. van den Berge, t.a.p., blz. 75 .

37. W.H. van den Berge, t.a.p., blz. 62.

38. W.H. van den Berge, t.a.p., blz. 68. 
worden geschoven. De economie en de belastingpolitiek moeten met dit gegeven rekening houden ${ }^{39}$

Het economisch aspect is belangrijk. De tegenstellingen die economische overwegingen, hetzij onderling, hetzij met de andere aspecten, oproepen, dienen in concreto en niet in abstracto tegen elkaar te worden afgewogen. ${ }^{40}$

Als derde noemt Van den Berge het belastingtechnische aspect. Belastingtechnische factoren toetsen de wensen, die op het gebied van het belastingrecht bestaan, aan de concrete mogelijkheden. Voordat tot de beschouwing van de belastingtechnische factoren kan worden overgegaan, moet eerst de vraag zijn beantwoord of de belastingheffing wel nuttig is als instrument. Een voorbeeld van een belastingtechnische eis is 'dat de belastingheffing op systematische, duidelijke, efficiënte en, voor zover zulks mogelijk is, eenvoudige wijze in de wettelijke regeling is belichaamd.41 Het belastingreecht dient uitvoerbaar te zijn en moet ook daadwerkelijk deugdelijk worden uitgevoerd. ${ }^{42}$ De belastingheffing dient daarbij tẹvens zo veel mogelijk gecodificeerd te zijn, zodat daarmẹde ook de autonomie van het belastingrecht ten opzichte van andere rechtsgebieden wordt bevorderd. ${ }^{43}$

Als laatste aspect behandelt Van den Berge het rechtsfilosofische aspect. Het algemeen rechtsbewustzijn evolueert met de ontwikkeling van cultuur en de wijziging van de economische en sociale verhoudingen. ${ }^{44}$ Het democratisch stelsel beïnvloedt het algemeen rechtsbewustzijn positief. ${ }^{45} \mathrm{Het}$ algemeen rechtsbewustzijn is niet gelijk te stellen met de sociale gerechtigheidsidee of met de psychologie van het volk. Hiermede is niet gezegd dat de belastingheffing geen rekening dient te houden met psychologische factoren. ${ }^{46}$

De verschillende factoren, zoals onder andere financiële, economische, sociale en belastingtechnische, moeten op hun betekenis worden gewogen in het rechtsbewustzijn voor de volksgemeenschap, voor de onderlinge verhoudingen tussen de groepen en de leden van de volksgemeenschap en voor de verhouding van die groepen en leden tot die volksgemeenschap. Het algemeen rechtsbewustzijn is zeer complex en dient nader geanalyseerd te worden. Dit analyseren geschiedt door een onderzoek naar de verschijnselen en de daarop betrekking hebbende regelen. ${ }^{47}$

39. W.H. van den Berge, t.a.p., blz. 67.

40. W.H. van den Berge, t.a.p., blz. 102.

41. W.H. van den Berge, t.a.p., blz. 104.

42. W.H. van den Berge, t.a.p., blz. 110.

43. Delegatie in de belastingwetgeving is belangrijk omdat daarmee vooral de economische eisen van beweeglijkheid en specialisatie kunnen worden gediend. W.H. van den Berge, t.a.p., blz. 106.

44. W.H. van den Berge, t.a.p., blz. 115.

45. W.y. van den Berge, t.a.p., blz. 127.

46. W.H. van den Berge, t.a.p., blz. 130. Vergelijk Stevens, die stelt dat mensen een bepaaide levensovertuiging hebben, waaraan enige grondbeginselen ontspringen. Het draagkrachtbeginsel heeft ook te maken met deze levenșovertuiging. L.G.M. Stevens, Belasting naar draagkracht, Kluwer, 1980, blz. 34.

47. W.H. van den Berge, t.a.p., blz. 133. 
Van den Berge probeert aan te tonen wat de inhoud van het algemeen rechtsbewustzijn is. ${ }^{48} \mathrm{De}$ veelvuldig gebruikte begrippen 'gelijkheid' en 'algemeenheid' kunnen als een bepaald facet van het algemeen rechtsbewustzijn fungeren. ${ }^{49}$ Het begrip 'gelijk' houdt in dat gelijke gevallen gelijk en ongelijke gevallen ongelijk dienen te worden behandeld. In het kader van de belastingheffing richt dit begrip zich tegen willekeur. Het begrip 'algemeenheid' houdt in dat het maken van een uitzondering of bijzondere regels voor een bepaalde belastingplichtige niet kan worden aanvaard..$^{50}$

Een volgende eis die aan de belastingheffing kan worden gesteld, is dat deze zeker dient te zijn en een bepaaldheid dient te bezitten. Het belastbare feit dient nauwkeurig beschreven te zijn. Bovendien dient de belastingheffing wettelijk, in het algemeen zonder terugwerkende kracht, te zijn geregeld. ${ }^{51}$

\section{De Langen}

\section{Gebruikte methode}

De Langen probeert met behulp van de zogenaamde rechtsoordelen de beginselen te vinden. Deze rechtsoordelen zijn de rechtsgevoel-oordelen over bepaalde onderwerpen van individuen in een bepaalde gemeenschap. Het kenmerkende van een rechtsgevoel tegenover andere gevoelens is, dat altijd door het subject de volgende eis in het geding wordt gebracht, ook zonder dat zijn wil daarop is gericht: 'gelijke gevallen moeten gelijk worden behandeld, en verschillende in evenredigheid van het verschil'. Dit is de zogenaamde objectiviteitseis. De Langen is van mening dat deze eis nader gespecificeerd dient te worden: gelijke belangen moeten even zwaar worden gewogen en gelijk worden behandeld en verschillende in een bepaalde relatie tot het verschil. ${ }^{52}$

De rechtsoordelen zijn onder te verdelen in individuele en gezaghebbende rechtsoordelen: Individuele rechtsoordelen zijn op hun beurt weer onder te verdelen in primaire rechtsoordelen, dat wil zeggen, de weergave van een duidelijke reactie van het rechtsgevoel bij een gemakkelijke belangenafweging, en gecompliceerde rechtsoordelen, waarbij de belangenafweging niet zo gemäkkelijk geschiedt. De Langen noemt twee voorbeelden van primaire rechtsoordelen met betrekking tot het belastingrecht t.w.: 'laat ieder belasting betalen in verhouding tot zijn draagkracht' en 'laat ieder belaśting betalen in verhouding tot de diensten die hij van overheidswege geniet.'.

48. Hij komt onder andere tot de conclusie dat de gedachte 'loon naar werken' bij verscheidene belastingen aanwezig is. W.H. van den Berge, t.a.p., blz. 145.

49. Vergelijk ook F.H.M. Grapperhaus, De pelgrimstocht naar het draagkrachtbeginsel, Kluwer, 1993, blz. 36.

50. W.H. van den Berge, t.a.p., blz. 148. Zie ook H.J.W. Klein Wassink, De ideologie van het belastingrecht, 1975, blz. 96. In: Cijns en Dijns, Hofstra-bundel, 1975.

51. W.H. van đen Berge, t.a.p., blz. 151-153.

52. W.J. de Langen, t.a.p., blz. 6.

53. W.J. de Langen, t.a.p., blz. 7. 
Een gezaghebbend rechtsoordeel is dat 'oordeel, dat naar verwacht wordt, door de wetgever van dat land zou worden aanvaard (of opnieuw zou worden aanvaard wanneer het recht in het positieve recht werd opgenomen), indien deze alle voor een volledige beoordeling benodigde tijd en aandacht onmiddellijk beschikbaar zou stellen en een beslissing zou nemen. ${ }^{\text {s4 }}$ Het rechtsbewustzijn van een volk is de som van alle rechtsoordelen welke op dat moment geacht worden gezag, autoriteit in dat volk te bezitten. Dit rechtsbewustzijn is op zijn beurt de som van de voor de wetgever aanvaardbare rechtsoordelen. ${ }^{55}$ Gezaghebbende rechtsoordelen kunnen ook primair of gecompliceerd zijn. ${ }^{56} \mathrm{Uit}$ deze gezaghebbende rechtsoordelen wordt getracht de 'algemene wetmatigheid' te vinden. ${ }^{57}$

Om deze rechtsoordelen op te sporen is gebruik gemaakt van de empirischanalytische methode. Met deze methode wordt niet het onderzoek in volle omvang bedoeld; de methode vormt de voortdurende grondslag van het onderzoek. Het onderzoek is generaliserend van aard. De empirisch-analytische methode is niet de enige methode, die in het onderzoek wordt gebruikt. Naast deze methode zijn deductie, fantasie en analogie met andere takken van wetenschap onontbeerlijk. ${ }^{58}$ De Langen onderzoekt eerst de verschijnselen; vanuit deze verschijnselen worden de gezaghebbende rechtsoordelen via bepaalde hypothesen onderzocht.

\section{Gevonden beginselen}

De Langen gebruikt het begrip 'grondbeginselen'. Grondbeginselen zijn ongeschreven zeer algemene regels, welke ten grondslag liggen aan de door de wetgever gegeven voorschriften. Grondbeginselen komen in de wettelijke voorschriften voor. In bepaalde voorschriften kunnen meer beginselen voorkomen. Het kan een keer gebeuren dat de beginselen onderling botsen. In dat geval moet een afweging van de betreffende beginselen plaatsvinden. Maar men behoeft niet altijd zelf de waarden aan de verschillende doeleinden toe te kennen. Dit moet echter soms wel gedaan worden, omdat er anders geen oplossing in het verschiet ligt, aldus De Langen..$^{9}$

De Langen vindt dat er zes grondbeginselen zijn: drie verdelingsbeginselen en drie andere. ${ }^{60} \mathrm{De}$ drie verdelingsbeginselen zijn beginselen van het belasting-

54. W.J. de Langen, t.a.p., blz. 11.

55. W.J. de Langen, t.a.p., blz. 11.

56. W.J. de Langen, t.a.p., blz. 13.

57. W.J. de Langen, t.a.p., blz. 16.

58. W.J. de Langen, t.a.p., blz. 18 en 19.

59. W.J. de Langen, t.a.p., blz. 41.

60. W.J. de Langen, t.a.p., blz. 38-40. In zijn rede (1950) had De Lafigen nog een beginsel meer, $\mathrm{nl}$. het gelijkheidsbeginsel. W.J. de Langen, Grondbéginselen van ons belastingstelsel, rede, Kluwer, 1950 , blz. 3. Het gelijkheidsbeginsel geldt mijns inziens voor alle rechtsgebieden. Later, in zijn onderzoek, realiseert De Langen zich dat ook en stelt hij zich op het standpunt dat het gelijkheidsbeginsel voor alle recht geldt. 
recht, terwijl de andere drie beginselen voor het gehele recht gelden. Sommige grondbeginselen kunnen nog in een aantal onderbeginselen worden onderscheiden.

De zes grondbeginselen zijn: 1 . het draagkrachtbeginsel ${ }^{61} ; 2$. het beginsel van de bevoorrechte verkrijging; 3 . het profijtbeginse ${ }^{62} ; 4$. het welvaartbeginsel; 5 . het beginsel van de minste pijn; 6. het beginsel van de geoorloofde realisatie. De laatste drie beginselen hebben met doelmatigheid te maken. Het profijtbeginsel, het welvaartbeginsel, het beginsel van de minste pijn en het beginsel van de geoorloofde realisatie kunnen ook een rol spelen buiten het gebied van het belastingrecht. ${ }^{63}$

De drie verdelingsbeginselen beheersen in hoofdzaak de verdeling van de totale last over de individuele belastingplichtigen. Het draagkrachtbeginsel, het beginsel van de bevoorrechte verkrijging en het profijtbeginse $\left.\right|^{64}$ zijn beginselen die een alternatieve toepassingsmogelijkheid aan de wetgever biedeñ. Dit wil zeggen, dat de wetgever het beginsel mag toepassen. Hiermee is niet gezegd, dat een belasting maar één verdelingsbeginsel kan bevatten.

Aangezien De Langen de enige van de hier opgesomde auteurs is die het beginsel van de bevoorrechte verkrijging expliciet noemt, volgt hier een bespreking daarvan.

Wanneer bij het verkrijgen van een bate de verkrijger in een bevoorrechte positie verkeert in vergelijking met anderen, mag een speciale belasting die verband houdt met de grootte van die bate worden geheven. ${ }^{65}$ Het beginsel van de bevoorrechte verkrijging is aan het profijtbeginsel verwant. ${ }^{66} \mathrm{Het}$ beginsel heeft slechts betrekking op 'bepaalde baten' en niet op het gehele inkomen. Bovendien ziet het beginsel op 'de wijze van verkrijging van geldelijke of geldswaardige baten'; het draagkrachtbeginsel daarentegen op de besteding. ${ }^{67}$ Een kritiek punt is dat het veelal onmogelijk is de juiste grootte van de bevoorrechte baten te bepalen. ${ }^{68}$ Toepassing van het beginsel van de bevoorrechte verkrijging wordt door uitvoeringsmoeilijkheden beïnvloed.

61. Als onderbeginselen van het draagkrachtbeginsel kunnen het beginsel van het noodzakelijk levensonderhoud, de idee van het evenredig nutsoffer en het tegenslagbeginsel worden gezien. De idee van het evenredige nutsoffer dient als de leidende gedachte in het belastingrecht te fungeren. W.J. de Langen, t.a.p., blz. 145.

62. Als onderbeginselen van het profijtbeginsel gelden het rembeginsel en het (subjectieve) belangenbeginsel. Het rembeginsel houdt in dat onaanvaardbare verkwisting dient te worden voorkomen. W.J. de Langen, t.a.p., blz. 216.

63. W.J. de Langen, t.a.p., blz. 38.

64. Het draagkracht- en het profijtbeginsel worden in de desbetreffende paragrafen behandeld.

65. W.J. de Langen, t.a.p., blz. 146. Het beginsel van de bevoorrechte verkrijging wordt ook wel het buitenkansbeginsel genoemd. H.J. Hofstra m.m.v. C. van Raad, Inleiding t.a.p., blz. 81 .

66. Een profijtbeginsel heeft alleen betrekking op een gedeelte van inkomen of vermogen. W.J. de Langen, t.a.p., blz. 172.

67. W.J. de Langen, t.a.p., blz. 39 en W.J. de Langen, Grondbeginselen van ons belastingstelsel, rede, Kluwer, 1950, biz. 8.

68. W.J. de Langen, t.a.p., blz. 172 en 178. 
De zware progressie wordt door De Langen als een toepassing van het beginsel van de bevoorrechte verkrijging gezien. ${ }^{\Theta}$ De herverdeling van inkomens door middel van het verhogen van het tarief voor hogere inkomens is mijns inziens van een andere orde dan het toepassen van een belastingbeginsel. ${ }^{70}$

Het beginsel zou volgens De Langen ook toepassing moeten krijgen bij het belasten van de zgn. 'capital gains'. Decennia lang bestaat er al een discussie over de vraag of de waardevermeerderingen van bepaalde bronnen wel of niet moeten worden belast. ${ }^{\text {ji }}$. Heden ten dage zijn deze baten in de Wet IB 1964 onbelast. Thans gaan stemmen op de 'capital gains' in de belastingheffing te betrekken.

Het tegenovergestelde van een bevoorrechte verkrijging is een moeizame verkrijging van bepaalde baten. Als spiegelbeeld van het beginsel van de bevoorrechte verkrijging zou in dat geval een lastenverlichting moeten worden toegepast. Een voorbeeld zou het toepassen van het arbeidskostenforfait kunnèn zijn.

\section{Van den Tempel}

Van den Tempel is in de jaren zeventig in een interessante discussie gewikkeld geweest met Hofstra over het al dan niet bestaan van belastingbeginselen.

\section{Gebruikte methode}

Van den Tempel komt via een eigen visie op belastingheffing tot zijn spraakmakende conclusies. De belastingheffing is volgens Van den Tempel ingeweven in het maatschappelijke leven en maakt deel uit van de gehele rechtsorde. $\mathrm{De}$ belastingheffing dient een specifiek doel, namelijk een sociaal-economisch doel. In dit laatste wordt een extra rechtvaardiging gevonden voor het bestaan van de belastingheffing. ${ }^{72}$ Onder specifiek doel wordt in dat geval niet een rechtvaardige verdeling van de belastingdruk verstaan. 'Een gevolg van dit alles is dat de instrumentele band (het karakter van belastingmaatregel) geleidelijk op de achtergrond raakt tegenover de samenhang van belastingmaatregelen met andere maatregelen van dezelfde strekking, maar genomen met een ander instrument. $^{\text {.73 }}$

69. W.J. de Langen, t.a.p., blz. 159. Een bekend voorbeeld waarin het beginsel van de bevoorrechte verkrijging een eminente rol speelde, was de vermogensaanwasbelasting.

70. Zie echter Stevens: 'Daarbij wordt evenwel over het hoofd gezien, dat de omstandigheid dat de definitie van het draagkrachtbeginsel en de toepassing van de leer van het evenredige nutsoffer de herverdelingselementen buitensluit, niet behoeft te impliceren dat daarom ook de herverdeling van het inkomen buiten discussie wordt geplaatst. De definitie heeft slechts een onderscheidende functie.' Zie L.G.M. Stevens, Belasting naar draagkracht, KJuwer, 1980, blz. 160.

71. De Langen vermeldt deze discussie al; $e r$ is in de jaren twintig een wetsontwerp ingediend om een belasting te heffen op de waardevermeerdering van onroerende zaken. Dit wetsontwerp heeft het niet gehaald. W.J. de Langen, t.a.p., blz. 151 en 157. Na de oorlog is wel een tijd lang de vermogensaanwasbelasting geheven.

72. A.J. van den Tempel, Het einde van de belastingbeginselen, Weekblad voor fiscaal recht, 1979, no 5411, blz. 699.

73. A.J. van den Tempel, t.a.p., blz. 700. 
Het antwoord op de vraag welk instrument voor een bepaald probleem of verschijnsel het beste is, kan niet in abstracto worden bepaald. ${ }^{74}$

\section{Gevonden beginselen}

De belastingheffing is als overheidsinstrument ter bevordering van een bepaald economisch of sociaal beleid complementair. ${ }^{75}$ Dat wil zeggen, de belastingheffing is een instrument, net als elk ander. ${ }^{76}$ Deswege kunnen geen specifieke belastingbeginselen gelden; de voor het algemeen recht geldende beginselen zijn ook de beginselen voor het belastingrecht.

Ondanks het niet-bestaan van de beginselen van de belastingheffing, is Van den Tempel de mening toegedaan dat de begrippen 'draagkracht' en 'profijt ${ }^{7}$ een rol spelen en ook behoren te spelen in de belastingheffing. Deze begrippen vormen de maatstaf voor de inkomenspolitiek. Deze inkomenspolitiek maakt op haar beurt weer deel uit van de sociaal-economische politiek.

Hofstra is daarentegen de mening toegedaan dat belastingbeginselen een rol moeten spelen. Sillevis en De Vries herleiden de discussie tot een controverse tussen belastingbeginselen (Hofstra) en algemene rechtsbeginselen (Van den Tempel). Daardoor blijken de verschillen tussen beide auteurs volgens Sillevis en De Vries overigens niet zo groot te zijn als wordt aangenomen. Op de eerste plaats hebben de belastingbeginselen en algemene rechtsbeginselen invloed op elkaar. Op de tweede plaats gaan beide auteurs uit van een gemeenschappelijk uitgangspunt, nl. dat er sprake is van vórwetenschappelijke fundamentele waarden. ${ }^{78}$

Algemene conclusies opvattingen en/of theorieën

1. Met uitzondering van Van den Tempel spelen bij elk van de auteurs beginselen een evidente rol. ${ }^{79}$ Indien de beginselen genoemd door de auteurs bij

74. A.J. van den Tempel, t.a.p., blz. 705.

75. De Vries vertaalt het als volgt. Voor het maken van enige zinnige opmerkingen over het belastingpolitieke systeem is het noodzakelijk dat er een gedegen kennis aanwezig is van de politieke, sociale en economische omstandigheden van het betreffende land. J.A.J. de Vries, t.a.p., blz. 196. Het politicke en economische systeem bepaalt het belastingpolitieke systeem. Twee begrippen spelen hierbij een belangrijke rol, nl. de sociale en de economische vooruitgang. Deze twee begrippen zijn echter in grote mate onbepaald. Hierdoor ontstaat een zekere mate van onrust in het belastingpolitieke systeem. J.A.J. de Vries, t.a.p., blz. 211 en 213.

76. A.J. van den Tempel, t.a.p., blz. 703.

77. 'Profijt' wordt omschreven als datgene dat ten gevolge van een overheidsvoorziening is genoten. A.J. van den Tempel, t.a.p., blz. 703 en 704.

78. L.W. Sillevis en N.H: de Vries, Universiteit, belastingbeginselen en samenleving, Weekblad voor fiscaal recht, 1990, no 5943, blz. 1889 en 1890.

79. Enigzins afwijkend in vergelijking met de voorgaande onderzoeken, zowel in onderzoeksmethode als in gevonden beginselen, maar daarom niet minder interessant, is het onderzoek van De Vries, 'Het belastingpolitieke systeem'. Werken de economen vanuit doelmatigheid en de juristen vanuit rechtvaardigheid, De Vries daarentegen beziet belastingheffing vanuit het 'belastingpolitieke systeem'. 'Belastingheffing in de zin van 'belastingpolitiek systeem' is het geheel van politieke gedragingen, die gericht zijn op de gezaghebbende toewijzing van waarden voor de maatschappij door middel van belastingen'. J.A.J. de Vries, t.a.p., biz. 41. 
elkaar worden geplaatst, ontstaat het volgende schema.

AUTEUR

1. W.H. van den Berge METHODE

theoretisch; inductiemethode

2. W.J. de Langen

empirisch-analytisch deductiè,' analogie en fantasie

3. A.J. van den Tempel theoretische redenering

4. H.J. Hofstra theoretische redenering

\section{BEGINSELEN}

1. het financiële aspect 2. het economische aspect 3 . het belastingtechnische aspect 4 . het rechtsfilosofische aspect 1. het draagkrachtbeginsel 2. het beginsel van de bevoorrechte verkrijging 3. het profijtbeginsel 4. het welvaartsbeginsel 5 . het beginsel van de ongeoorloofde realisatie 6 . het beginsel van de minste pijn

beginselen der belastingheffing zijn niet (meer) aanwezig beginselen zijn aanwezig o.a. het beginsel van gelijkheid en het beginsel van algemeenheid.

2. De theorieën bezitten alle een bepaalde mate van subjectiviteit. De vraag is of dit onvermijdelijk is, waarschijnlijk wel. Maar de subjectiviteit maakt die theorieën en opvattingen nog niet onbruikbaar voor het onderzoek. ${ }^{80}$

Enige voorbeelden van de subjectiviteit ter illustratie.

a. Van den Berge en De Langen stellen, dat de belastingheffing in overeenstemming moet zijn met het rechtsbewustzijn van een volksgemeenschap. Bij Van den Berge vindt het rechtsbewustzijn zijn grondslag in de Idee der gerechtigheid. Twee vragen rijzen: 1. Wat is het rechtsbewustzijn en hoe wordt-dit geanalyseerd? 2. Wat is de definitie van een volksgemeenschap? Mijns inziens behoeven de antwoorden niet eensluidend te zijn. Van den Berge geeft zelf toe dat het analyseren van het rechtsbewustzijn zeer moeilijk is, maar het is wel een zaak

\footnotetext{
Wat is een 'politiek systeem'? Een politiek systeem is de verzameling van politieke gedragingen. Aan politieke gedragingen zijn de volgende eisen te stellen: waarden dienen toebedeeld te worden; deze toedeling moet gezaghebbend zijn; deze toedeling moet gezaghebbend voor een maatschappij zijn.

De Vries gebruikt een empirische methode om tot enige beschouwingen over belastingheffing te komen. Een aantal variabelen zoals belastingbelangen, belastingideologieën, belastingwaarden, belastingnormen en belastingautoriteiten wordt onderzocht. J.A.J. de Vries, t.a.p., blz. 39 en 44. Het onderzoek is op drie niveaus verricht, t.w.:
}

1. Op het niveau van de belastingpolitieke gemeenschap; met dit niveau worden de belastingbelangen en belastingideologieën bedoeld.

2. Op het niveau van het belastingpolitieke regime; onder deze categorie vallen de belastingwaarden van en belastingnormen in het belastingpolitieke systeem.

3. Op het niveau van de belastingpolitieke autoriteiten; hieronder valt de belastingbureaucratie. J.A.J. de Vries, t.a.p., blz. 216.

80. Zie ook M.P. van Overbeeke, Het begin der belastingbeginselen, rede, KJuwer, 1982, blz. 11. 
van essentieel belang, daar het rechtsbewustzijn in zijn theorie immers een toetsingsinstrument is voor de belastingheffing.

b. Een volgend element dat niet geheel ontbloot is van subjectiviteit, is de hiërarchie van de desbetreffende beginselen. Zowel Van den Berge als De Langen geven niet aan hoe deze hiërarchie wordt bepaald. $\mathrm{Zij}$ stellen dat in concreto moet worden bepaald welk beginsel voorrang heeft. De vraag is natuurlijk of het wel mogelijk is om beginselen in abstracto tegenover elkaar af te wegen, maar indien de afweging in concreto dient plaats te vinden, wat is dan het afwegingsmechanisme? De afweging kan mijns inziens niet anders dan subjectief worden gemaakt. ${ }^{81}$

c. De Langen heeft een empirisch onderzoek verricht. In een empirisch onderzoek naar theoretische elementen - in casu essentiële beginselen van belastingheffing - schuilt het gevaar dat de werkelijkheid met die theoretische elementen wordt vermengd. Er worden als het ware elementen van de voorgestelde theorie in de werkelijkheid 'ingelezen'. Met dit 'inlezen' sluipen subjectieve inzichten in de theorie. ${ }^{82}$

Hetgeen in het bovenstaande is opgemerkt ten aanzien van het vermengen van theoretische elementen met werkelijke feiten, kan ook worden opgemerkt ten aanzien van de door De Langen in het onderzoek gebruikte methoden van analogie met andere takken van wetenschap en het gebruik van fantasie.

3. 'Algemeenheid' en 'gelijkhẹid' zijn twee vaak voorkomende eisen in de door de auteurs weergegeven opvattingen en/of theorieën. Deze eisen kunnen mijns inziens aan het gehele recht en dus ook aan het belastingrecht worden gesteld. Daarmee zijn de twee eisen geen specifieke eisen voor het belastingrecht. Specifieke eisen van het belastingrecht betreffen de verdeling van de door de belastingwetgever opgelegde lasten.

4. Sociale en economische factoren spelen bij elk van de vier auteurs een rol. Het economisch en sociaal leven speelt een belangrijke rol in de belastingheffing. Andersom heeft de belastingheffing op haar beurt invloed op het economische en het sociale leven. De belastingheffing is zo verweven met het maatschappelijk leven, dat het mijns inziens nauwelijks meer gesproken kan worden van een op zichzelf staand belastingrecht, met eigen beginselen.

81. Hofstra heeft kritiek op de theorie van De Langen. De theorie is cen bonte verzameling van beginselen en onderbeginselen. Overwegingen van uiteenlopende aard worden lukraak naast elkaar gesteld. Een rangorde tussen deze overwegingen wordt echter niet gegeven. De opsomming van De Langen biedt noch voor de theorie, noch voor de praktijk, maar enig houvast, aldus Hofstra. H.J. Hofstra m.m.v. C. van Raad, Inleiding, t.a.p., blz. 81 en zie ook J.A.J. de Vries, die stelde dat de theorie van De Langen een wereldvreende theorie is. J.A.J. de Vries, t.a.p., blz. 25 .

82. Vergelijk ook M.R. Reuvers, Mythen en de belastingheffing. In: Fantasie en durf, FED, 1991, blz. 83. 
5. Wat is het belang van de theorieën voor het onderhavige onderzoek? Deze theorieën hebben alle gepoogd een rechtvaardiging te vinden voor de verdeling van lasten opgelegd door de fiscale wetgever. In al deze theorieën zitten kernen van waarheden, die gebruikt kunnen worden voor de verdere ontwikkeling van de (verdelings)beginselen. Bovengenoemde auteurs, hun onderzoeksmethoden en hun beginselen zijn zowel bejubeld als bekritiseerd. Enigszins nostalgisch wordt naar de verdelingsbeginselen verwezen. De moeilijk te beantwoorden vraag blijft of de beginselen op een juiste manier worden gebruikt. Anders gezegd, het is goed mogelijk dat een onjuist etiket op een stelling wordt geplakt ter rechtvaardiging van een bepaalde maatregel.

Vele malen wordt een beroep gedaan op het draagkrachtbeginsel. Dit is niet het enige beginsel dat in belastingheffing een rol speelt. Via een onderzoek van de wetgeving betreffende de inkomstenbelasting is duidelijk geworden welke belangen de wetgever als beginsel wil beschouwen en hoe de onderlinge rangorde van beginselen en/of belangen min of meer wordt bepaald. Naar mijn mening spelen het gelijkheidsbeginsel als een algemeen beginsel en het specifieke draagkrachtbeginsel in de inkomstenbebelasting een rol. Hiertegenover kan de eis van de doelmatigheid worden geplaatst.

\subsection{Verdelingsbeginselen}

\subsubsection{Het draagkrachtbeginsel}

De gedachte dat de totale belastingdruk naar draagkracht over de belastingplichtigen moet worden verdeeld - de zgn. draagkrachttheorie - heeft vrijwel algemene erkenning gehad in het eerste kwartaal van de $20 \mathrm{e}$ eeuw. Nog steeds leeft de gedachte dat het draagkrachtbeginsel het leidende beginsel is of moet zijn in de inkomstenbelasting. ${ }^{83}$ Deze gedachte vindt echter steeds minder aanhangers ${ }^{84}$

83. Het draagkrachtbeginsel dateert al vanaf de 11e eeuw. Grapperhaus noemt een geschrift uit 1070 waarin het draagkrachtbeginsel min of meer wordt genoemd. F.H.M. Grapperhaus, De pelgrimstocht naar het draagkrachtbeginsel, Kluwer, 1993, blz. 63. 'De steeds weer wijkende horizonten van dat beginsel ontslaan fiscalisten echter niet van de plicht de weg er naar toe gewetensvol te blijven betreden om zo metgezel te zijn van al diegenen die in de eeuwen voor ons hebben getracht de pelgrimstocht naar het draagkrachtbeginsel te volbrengen ...' F.H.M. Grapperhaus, t.a.p., blz. 76 en 77.

Zie ook E.J.J.M. KJimman, Fiscaliteit en ethiek, toegespitst op de belastingheffing. Uit: R.H.M.J. Offermans, t.a.p., blz. 762 en 763.

84. Enige voorbeelden volgen. Zwemmer vindt het idee van het synthetische inkomensbegrip als maatstaf van draagkracht achterhaald. Hijstelteen analytische inkomstenbelasting minder manipuleerbaar is. J.W. Zwemmer, Haalt de inkomstenbelasting het jaar 2092?, Weekblad voor fiscaal recht, 1992, no 6026, blz. 1335.

Kogels stelt voor het draagkrachtbeginsel voor een deel los te laten. H.A. Kogels, Op weg naar een geharmoniseerde inkomstenbelasting?, Weekblad voor fiscaal recht, 1992, no 6026, blz. 1370 en 1371. 
Vooropgesteld zij dat een onderzoek naar verdelingseffecten zeer moeilijk is. Dit is onder andere een gevolg van de onmogelijke opgave om een sluitende definitie van de verdelingsbeginselen te geven. Een voorbeeld is de niet eensluidende definiëring van het inkomensbegrip. ${ }^{85}$ Het is moeilijk om een goede maatstaf van draagkracht te vinden. De draagkrachttheorie is al eerder een theorie genoemd, die zoekt naar feiten ter staving van de theorie. ${ }^{86}$ Dit is nog steeds zo.

Een gevolg van de onduidelijkheid is dat subjectieve inzichten een nadrukkelijke rol gaan spelen.

\section{Definitie}

Gelijkheid van de belastingdruk werd in de $18 \mathrm{e}$ eeuw een steeds groter verlangen. Adam Smith formuleerde het aldus, dat de overheid haar neutraliteit tegenover de particuliere sector slechts kan handhaven door de belastingdruk 'in proportion of the revenue' te verdelen. 'Revenue' betekent (objectief) inkomen. ${ }^{87}$

Grapperhaus heeft het over de moeilijke toepassing van het draagkrachtbeginsel, maar wil het beginsel nog niet overboord zetten. F.H.M. Grapperhaus, Van hoepelrok naar petticoat, Weekblad voor fiscaal recht, 1992, no 6026, blz. 1377.

Niessen daarentegen gelooft in een belasting naar draagkracht. R.E.C.M. Niessen, Honderd jaar brede herwaardering en het gelijkheidsbeginsel, Weekblad voor fiscaal recht, 1992, no 6026, blz. 1365. Zo ook H.P.A.M. van Arendonk, De inkomstenbelasting in Nederland: een monumentaal bouwwerk, Maandblad Belastingbeschouwingen, 1993, no 6, blz. 155.

85. Vergelijk Haselbekke. Deze noemt drie probleemcategorieën, nl. 1. problemen van conceptuele aard; 2. problemen die samenhangen met ontoereikende theoretische inzichten; 3. problemen die betrekking hebben op het datamateriaal. A.G.J. Haselbekke, Profijtbeginsel en politieke besluitvorming, blz. 205 en 206.

Hofstra stelt dat tot een een goed inkomensbegrip moet worden gekomen, wil een werkelijke vereenvoudiging plaatsvinden. 'Begrippen als 'rechtvaardigheid' en 'rechtsgelijkheid' raken in het belastingrecht op de achtergrond, terwijl deze beginselen juist daarin moeten blijven doordringen.' W.H.C. Zuidgeest, Afscheio Hofstra, Weekblad voor fiscaal recht, 1994, no 6110, blz. 974.

86. H.J.W. Klein Wassink, t.a.p., blz. 102. Of zoals Hofstra het formuleert: 'In een naar draagkracht te heffen en op een herverdeling gerichte inkomstenbelasting dient immers de maatstaf van het individuele inkomen niet door de afzonderlijke inkomensbestanddelen, doch door het individuele inkomen in zijn totaliteit. Het type inkomestenbelating dat aan deze eis voldoet wordt een synthetische inkomstenbelasting genoemd.' H.J. Hofstra en L.G.M. Stevens, Inkomstenbelasting, t.a.p., blz. 15.

Al in vroeger tijden bleek het onmogelijk om de draagkracht goed te kunnen meten en te controleren. F.H.M. Grapperhaus, De pelgrimstocht naar het draagkrachtbeginsel, Kluwer, 1993, blz. 58.

In de literatuur wordt steeds meer getwijfeld aan (het synthetisch inkomensbegrip als) de maatstaf van draagkracht. Zie onder andere Zwemmer, Haalt de inkomstenbelasting het jaar 2092?, Weekblad voor fiscaal recht, 1992, no 6026, blz. 1335. En A.C. Rijkers, Besmet bloed, Weekblad voor fiscaal recht, 1992, no 6026, biz. 1351.

87. Het draagkrachtbeginsel van Smith is afgeleid van het profijtbeginsel. Het genoten inkomen is maatstaf van profijt. A.G. Jaliens, Fiscale ethiek: Rechtvaardigheid en rechtvaardiging van de fiscus, Maandblad Belastingbeschouwingen, 1987, no 6, blz. 158. 
Draagkracht is het element dat toonaangevend is bij de verdeling van de totale belastingdruk over de belastingplichtigen. Hierbij speelt het gelijkheidsbeginsel als een richtinggevend begrip. De lasten dienen zo gelijk mogelijk te worden verdeeld en het is belangrijk een criterium daarvoor te vinden. Het criterium wordt gevonden in het begrip draagkracht. Het is zoals Adam Smith het verwoordde, ieders 'ability to pay'.

De meest gebruikte en geciteerde definitie van het draagkrachtbeginsel is de definitie van De Langen. Het draagkrachtbeginsel houdt volgens De Langen in, 'dat belasting mag worden geheven in relatie tot de omvang van ieders niet voor levensonderhoud noodzakelijke, bereikbare behoeftenbevrediging en wel in de ethisch meest bevredigende relatie; deze wordt door het evenredige nutsoffer gerealiseerd. ${ }^{89}$ Het draagkrachtbeginsel heeft betrekking op het gehele inkomen, vermogen en gezinssamenstelling, aldus De Langen. ${ }^{90}$ Hierbij moet in acht worden genomen dat het voor het levensonderhoud noodzakelijke bedrag op het gehele inkomen en het vermogen in mindering komt.

Wat is draagkracht? Ondanks vele pogingen de draagkracht te definiëren, blijft het een vaag begrip. ${ }^{91}$ Ter illustratie: '... ieder zal ten behoeve van de overheidsfinanciën voor een evenredig deel afstand moeten doen van zijn mogelijkheden tot behoeftenbevrediging, voor zover die de voorziening in noodzakelijk levensonderhoud te boven gaat. ${ }^{.92}$ Dit citaat bevat een aardige doelstelling, maar hoe die doelstelling moet worden ingevuld, wordt niet aangegeven. In het verleden zijn vele theorieën ter rechtvaardiging van het draagkrachtbeginsel ontwikkeld. De draagkrachttheorieën beogen de belastingdruk te verdelen naar de individuele draagkrachten van de afzonderlijke belastingplichtigen.

Deze draagkrachttheorieën zijn onder te verdelen in drie categorieën:

1. De theorieën die de bestaande verdeling.van volksinkomen en -vermogen onjuist achten. De belastingheffing is een instrument om de verdeling rechtvaardiger te laten verlopen:

2. De leer van de absolute belastingplicht. Deze leer gaat uit van de opvatting dat de Staat een orgaan is dat boven alle individuen staat, met als doel verwezenlijking van het recht. De Staat heeft een eigen recht op de goederen

88. H.J. Hofstra en L.G.M. Stevens, Inkomstenbelasting, t.a.p., blz. 7 en 8.

89. W.J. de Langen, t.a.p., blz. 38. Zie J. van Soeșt, De grondbeginselen van de vermogensbelasting. Smeetsbundel, 1967, blz. 320.

90. W.J. de Langen, t.a.p., blz. 57 en 142.

91. Van Soest constateert dit $\infty \mathrm{k}$ en stelt tevens vast dat het draagkrachtbeginsel zo waarschijnlijk is, dat algemeen wordt aangenomen dat het door een matige progressie het best tot uiting komt. J. van Soest, Belastingbeginselen. In: Honderd jaar rechtsleven: Nederlandse Juristen-Vereniging, 1870-1970, Tjeenk Willink, blz. 336. C. Goedhart, Enkele facetten van belastingprogressie. In: Fiscaal-economische opstellen, Schendstok-bundel, 1966, blz. 98.

Zie voor een pleidooi voor het draagkrachtbeginsèl, Individualisering en draagkracht, Rapport CDA-werkgroep, mei 1991, blz: 17.

92. W.F. Nederstigt, t.a.p., blz. 261. 
van de burgers. Zijn doel in acht genomen, moet de Staat de belastingheffing gelijkmatig opleggen. Uit deze laatste eis volgt het draagkrachtbeginsel.

3. Moderne prestatietheorieën; de grondgedachte van de oude belangentheorie wordt verbonden met de resultaten van de moderne waardenleer. Bij deze theorieën komt eveneens het draagkrachtbeginsel als ideaal beginsel naar voren. 'En dan is er tenslotte als derde groep die van de moderne prestatietheorieën, welker aanhangers de grondgedachte van de oude belangentheorie verbinden met de resultaten van de moderne waardenleer en aldus den eisch van belasting naar draagkracht tot dien van een progressieve belasting uitbouwen. ${ }^{93}$

Hofstra heeft kritiek op deze theorieën, omdat deze uitgaan van een individualistische maatschappijvorm van het 'zuivere kapitalisme', terwijl de maatschappij is veranderd. Bovendien hebben deze draagkrachttheorieën als onderliggend uitgangspunt dat de werking van de vrije concurrentie in de maatschappij een eerlijke en rechtvaardige inkomstenverdeling waarborgt. Maar ook in een vrije concurrentie kunnen zich onbillijkheden voordoen, aldus Hofstra. De conclusie dat de draagkrachttheorie verouderd is, is zijns inziens dan ook gerechtvaardigd. $^{94}$

\section{Draagkrachtvermeerderende en -verminderende factoren}

Draagkracht kan worden onderscheiden in gezinsdraagkracht en individuele draagkracht. De politieke gezindheid bepaalt welke draagkracht als de juiste wordt gezien. 95

Naast dit onderscheid komen bij de bespreking van draagkracht altijd de draagkrachtvermeerderende en -verminderende factoren aan de orde.

Een voorbeeld van een draagkrachtvermeerderend element is het gehuwd zijn. 'De inkomstenbelasting is naar haar vorm een individuele belasting. Ze wordt geheven van natuurlijke personen. Dit geldt ook ten aanzien van combinaties van natuurlijke personen die een gezamenlijke huishouding voeren; zij moeten ieder

93. Het verschil tussen de oude (proportionele heffing) en de moderne (progressieve heffing) belangentheorie is dat de oude theorie uitging van een onjuiste waardeleer. H.J. Hofstra, Het einde van de draagkrachttheorie, Weekblad voor fiscaal recht, 1939. In: Tributen aan het Recht, 100 jaar Weekblad voor fiscaal recht, 1971, blz. 54-56.

94. H.J. Hofstra, Het einde van de draagkrachtthcorie, Weekblad voor fiscaal recht, 1939. In: Tributen aan het Recht, 100 jaar Weekblad voor fiscaal recht, 1971, blz. 56, 59, 60 en 61. Zie ook Rijkers, die van mening is dat er geen draagkrachtmotieven kunnen worden aangevoerd voor de basisaftrek en de toeslagen. Deswege kan worden omgezien naar een proportionele belasting, waardoor het verschil tussen de gezinsdraagkracht en de individuele draagkracht verdwijnt. A.C. Rijkers, Naar een proportioneel inkomstenbelastingtarief in de 21e eeuw, Rede, KJuwer, 1991, blz. 16 en 17. Vergelijk ook F.H.M. Grapperhaus, De pelgrinstocht naar het draagkrachtbeginsel, Kluwer, 1993, blz. 76.

95. Zie bij voorbeeld een CDA-werkgrocp, die een onderscheid maakt tussen gezinsdraagkracht, individuele draagkracht en gematigde individuele draagkracht. Individualisering en draagkracht, Rapport CDA-werkgroep, mei 1991, blz. 9 en 33.

Rijkers is voorstander van een algehele individualisering ten einde intermenselijke relaties van fiscale dimensies te ontdoen. A.C. Rijkers, Besmet bloed, Weekblad voor fiscaal recht, 1992, no 6026, blz. 1351. 
hun eigen belastbare inkomen vaststellen. Er is echter én samenlevingsverband dat een in dit opzicht bijzonder karakter heeft, $\mathrm{nl}$. dat tussen gehuwde personen en hun minderjarige kinderen.96

De draagkracht van het door het echtpaar gevormde gezin wordt bepaald door het gezamenlijke inkomen.

Volgens Hofstra kan een bevredigende regeling van de belastingheffing van gehuwde personen slechts worden bereikt indien zij op een duidelijk uitgangspunt steunt. Hiermee wordt bedoeld dat gekozen moet worden voor een gezamenlijk opleggen van een aanslag of juist het individueel betrekken van iedere belastingplichtige in de belastingheffing.

Indien twee personen van een inkomen moeten leven, dan is dat een draagkrachtverminderende factor. Echter aan de andere kant is het zo, dat de gehuwden in vergelijking met de ongehuwde een aantal besparingen (materiële en immateriële behoeften) hebben, die de ongehuwde moet ontberen. Deze voordelen liggen buiten het economische verkeer, maar kunnen bij de bepaling van 'de betalingscapaciteit niet buiten beschouwing worden gelaten. ${ }^{97}$

Enige decennia geleden was het gezin op de grondslag van een huwelijk vrijwel de enige vorm van samenleving. Tegenwoordig komen andere vormen vaker voor. ${ }^{98}$ Het traditionele gezinsconcept wordt op twee manieren doorbroken, nl. door het individualiseringsproces en door toepassing van het neutraliteitsprincipe. Het al dan niet samenleven is in het individualiseringsproces niet en bij de toepassing van het neutraliteitsprincipe wel een relevante factor voor de bepaling van de draagkracht. Het neutraliteitsprincipe behandelt alle samenlevingsvormen gelijk. De nadruk komt te liggen op het onderscheid 'alleenstaande'/'samenlever'. Echter aan de gelijkstelling van de samenlevingsvormen zijn uitvoeringstechnische problemen verbonden. Een registratieplicht van de samenlevingsvorm zou deze problemen grotendeels kunnen oplossen. ${ }^{99}$ Met het invoeren van deze registratieplicht komt de eis van de doelmatigheid aan de orde.

Met het oog op deze eis gaan steeds meer stemmen op een ieder individueel in de belastingheffing te betrekken. ${ }^{100}$

96. H.J. Hofstra en L.G.M. Stevens, Inkomstenbelasting, t.a.p., blz. 80.

97. H.J. Hofstra en L.G.M. Stevens, Inkomstenbelasting, t.a.p., blz. 81.

98. Met name in de laatste twee decennia kent men een sterke opkomst van niet-huwelijkse samenlevingsvormen. Zie onder andere Tweede Kamer, vergaderjaar 1992-1993, 22 700, no 3 , blz. 2.

99. H.J. Hofstra en L.G.M. Stevens, Inkomstenbelasting, t.a.p., blz. 87 en 88 . Zie ook het advies van de Commissic voor de toetsing van wetgevingsprojecten, die een registratie van samenlevingsvormen (formeel criterium) in plaats van het aantonen van een gezamenlijke huishouding (materieel criterium) voorstaat. Tweede Kamer, vergadcrjaar 1991-1992, 22 700, no 1 , blz. 2.

Zie verder over dit onderwerp $\$$ 7.4.2.

100. Zie onder andere $T$. Blokland, Inkomstenbelasting, naar gezin of naar persoon, Weekblad voor fiscaal recht, 1992, no 6026, blz. 1391. Dit heeft ook als consequentie de gehuwden gelijk te behandelen met de ongehuwden. 
Het wetsvoorstel inzake de geleidelijke afschaffing van de mogelijkheid tot overdracht van de basisaftrek van de VVD-kamerleden De Korte en Van Rey is een illustratie van de verschuiving van de gezinsdraagkracht naar de individuele draagkracht. ${ }^{101}$

Buitengewone lasten worden als een draagkrachtverminderende factor gezien. Hofstra omschrijft de buitengewone lasten als volgt. 'Buitengewone lasten zijn vormen van inkomstenbesteding, die theoretisch met het inkomensbegrip niets te maken hebben, maar die een zodanig draagkrachtverminderend effect hebben dat het redelijk is ze in de draagkrachtbelasting, die de inkomstenbelasting is, niet buiten aanmerking te laten. $\mathrm{Zij}$ komen in tal van variaties voor. De wet beperkt echter de aftrekbaarheid tot enkele duidelijk omschreven categorieën, terwijl het 'buitengewone' karakter van de in aftrek te brengen uitgaven tot uitdrukking wordt gebracht door de voor elke categorie afzonderlijk geldende 'drempels". ${ }^{102}$ Albregtse is de mening toegedaan dat de buitengewone lasten een essentieel onderdeel vormen van een belasting naar draagkracht. Hij motiveert dit door mijns inziens impliciet te verwijzen naar het gelijkheidsbeginsel. ${ }^{103}$

Over de buitengewone lasten bestaat veel jurisprudentie. Willen buitengewone lasten aftrekbaar zijn, dan moeten zij 'buitengewoon' zijn, dat wil zeggen: niet

101. De volledige titel van het wetsvoorstel is: Wetsvoorstel inzake de beperkingen van de mo-gelijkheden tot overdracht van de basisaftrek in het kader van het streven naar een verder-gaande individualisering. Tweede Kamer, vergaderjaar 1993-1994, 23 231, nrs. 1-2. Naast enige andere voorgestejde wetswijzigingen wordt aan artikel S5 Wet IB 1964 een lid toegevoegd:

a. de in Nederland wonende belastingplichtige die is geboren na 31 december 1976 en die, ongehuwd zijnde, in het kalenderjaar meer dan zes maanden een huishouding heeft ge-voerd met geen andere dan eigen kinderen, stiefkinderen of pleegkinderen die bij de aan-vang van het kalenderjaar de leeftijd van 27 jaar niet hebben bereikt;

b. de gehuwden indien een van beiden of beide ouders na 31 december 1976 zijn geboren;

c. de ongehuwd samenwonenden indien een van beiden of beiden zijn geboren na 31 december 1976.

Eenzelfde wetswijziging vindt in de Wet op de loonbelasting 1964 plaats.

De vrijkomende middelen worden gebruikt voor de kinderopvang.

Volgens Gelauff en Graafland wordt het arbeidsaanbod door de afschaffing gestimuleerd. De toename van het arbeidsaanbod zal voornamelijk bestaan uit kleine banen van onge-veer een dag per week. G.M.M. Gelauff en J.J. Graafland, Individualisering in sociale ze-kerheid en belastingen, Economisch statistische berichten, 1992, no 3881, blz. 1005.

102. H.J. Hofstra en L.G.M. Stevens, Inkomstenbelasting, t.a.p., blz. 486.

103. 'Uitgaven, die de belastingplichtige in tegenstelling tot andere belastingplichtigen in een vergelijkbare positie gedwongen is te doen, beïnvloeden ongetwijfeld zijn draagkracht ten opzichte van die van andere belastingplichtigen.' D.A. Albregtse, Buitengewone lasten, fiscale brochures FED, 1992, blz. 78. De buitengewone lastenregeling moet gehandhaafd blijven, aldus Albregtse. De eerste reden ligt in het principe van een belastingheffing naar draagkracht. De tweede reden ligt in de belastingmoraal en de aanvaardbaarheid van de belastingheffing door de belastingplichtigen. De auteur is van mening dat belastingplichtigen door de regeling zich betrokken voelen bij de inkomstenbelasting. D.A. Albregtse, t.a.p., blz. 78 en 79 . 
tot het normale bestedingspatroon behoren van personen die in gelijke omstandigheden verkeren. ${ }^{104} \mathrm{Dit}$ kan als een bijzondere uitwerking van het gelijkheidsbeginsel worden gezien.

Een volgende categorie uitgaven die als draagkrachtverminderend worden beschouwd, is de categorie van aftrekbare giften. Met de toelaatbaarheid van de aftrekbare giften is een niet-fiscaal doeleinde in de wet geintroduceerd. ${ }^{105}$

\section{Het draagkrachtbeginsel als leider?}

In het bovenstaande wordt een aantal draagkrachtvermeerderende en -verminderende factoren genoemd, maar is het draagkrachtbeginsel het leidende beginsel voor de inkomstenbelasting?

Een auteur die een belangrijk onderzoek naar de werking van het draagkrachtbeginsel heeft gedaan, is Stevens. Stevens stelt dat het draagkrachtbeginsel als belangrijkste verdelingsbeginsel geldt voor de loon- en inkomstenbelasting. Niet alleen het inkomen, maar ook het gebruik kan volgens hem tot maatstaf van draagkracht leiden. Stevens denkt dat een ontwikkeling naar een consumptiebelasting denkbaar is. 'Het verteerbare inkomen wordt hoe langer hoe meer tot maatstaf van draagkracht genomen. ${ }^{106}$

Het draagkrachtbeginsel houdt in dat de belasting wordt geheven naar rato van de draagkracht. De draagkracht wordt bepaald door het inkomen. Aan dit beginsel ligt primair het gelijkheidsbeginsel ten grondslag. De rechtsgelijkheid is een dwingende eis voor het recht. Het gelijkheidsbeginsel houdt in dat personen met een zelfde. inkomen een gelijk bedrag aan belasting dragen. De vraag is natuurlijk indien personen niet hetzelfde inkomen hebben, in hoeverre deze ongelijkheid haar weerslag moet vinden in het te betalen bedrag aan belasting? Dit is een kwestie voor de politiek. ${ }^{107}$

Het draagkrachtbeginsel kan op twee wijzen worden ingevuld, t.w.: de inko: mensvariant en de consumptievariant. Het evenredige nutsoffer is de gemeenschappelijke'component. In het eerste geval wordt deze verbonden aan het inkomen en in het tweede geval aan de consumptie. ${ }^{108}$

Hofstra stelt al in 1939 vast dat het draagkrachtbeginsel zijn eindc kent. Hiervoor voert hij twee redenen aan. De eerste is dat de draagkracht in concreto niet vast te stellen is, omdat er zoveel subjectieve factoren een rol spelen bij de vaststelling van de draagkracht en het tarief. Ten tweede omdat het niet duidelijk is,

104. H.J. Hofstra en L.G.M. Stevens, Inkomstenbelasting, t.a.p., blz. 488.

105. H.J. Hofstra en L.G.M. Stevens, Inkomstenbelasting, t.a.p., blz. 499. Zie voor een uitgebreider overzicht van de draagkrachtvermeerderende en -verminderende factoren, hoofdstuk 3.

106. L.G.M. Stevens, Belasting naar draagkracht, Kluwer, 1980, blz. 168 en 166.

107. 'De politieke doelstellingen worden verwoord in termen als 'streven naar een 'redelijke', 'rechtvaardige', 'eerlijke' inkomensverdeling'.' L.G.M. Stevens, Belasting naar draagkracht, ' KJuwer, 1980, blz. 113 en W.P. Erasmus; t.a.p., blz. 495. Stevens en Ermasus bedoelen kennelijk dat voor de formulering van het draagkrachtbeginsel nooit een geheel objectieve definitie kan worden gegeven.

108. L.G.M. Stevens, Belasting naar draagkracht, KJuwer, 1980, blz. 182 en 183. 
waar en hoe de belastingen uiteindelijk drukken. Zijn conclusie luidt dat het draagkrachtbeginsel niet meer is dan een leuze. ${ }^{105}$

Maar als het draagkrachtbeginsel aan zware druk bloot staat, welk uitgangspunt moet dan worden genomen om van een rechtvaardige belastingheffing te kunnen spreken?

Hofstra stelt dat de volgende drie punten als richtsnoer dienen te worden genomen bij de bepaling van een beginsel voor het hedendaagse belastingrecht, t.w.:

1. Nooit de gerechtigheid van het belastingrecht op zichzelf te beoordelen, doch met inachtneming van de rechtsorde als één geheel;

2. Nooit de sociaal-economische gevolgen afzonderlijk te beschouwen, doch als een onderdeel van het economisch en sociaal beleid in haar geheel;

3. Ook andere doeleinden dan de zuivere fiscale kunnen met behulp van de belastingheffing worden nagestreefd. ${ }^{110}$

\section{Toepassingsmogelijkheden en beperkingen}

De toepassing van fret draagkrachtbeginsel verloopt niet geheel vlekkeloos. Ten eerste ligt in de definièring van draagkracht al een beperking van het beginsel besloten; nl. dak over de individuele draagkracht geen eenstemmigheid bestaat. ${ }^{11}$ Hierbij speelt ook nog dat de draagkracht van een individu niet dezelfde omvang heeft als die van een ander. De verschillen in draagkracht worden weerspiegeld in een bijzonder matig progressief tarief, met een aftrek voor noodzakelijk levensonderhoud, en met bijzondere tegemoetkomingen wegens bepaalde buiten het inkomen liggende negatieve draagkrachtfactoren, zoals de gezinssamenstelling. ${ }^{1 \overline{1} \overline{2}}$.

109. H.J. Hofstra, Het einde van de draagkrachttheorie, Weekblad voor fiscaal recht, 1939. In: Tributen aan het recht, 100 jaar Weekblad voor fiscaal recht, 1971, blz. 51.

110. Hofstra formuleert het kader waarin hèt belastingbeginsel zich moet ontwikkelen. 'De belastingwetenschap dient, anders dan tot dusver, de belastingheffing te zien als een onscheidbaar geheel van het organische geheel dat de rechtsorde vornt; zij dient niet alleen te vragen naar de rechtvaardigheid van het belastingstelsel, doch zij dient deze te beschouwen in verband met de rechtvaardigheid van de gehele rechtsorde; de overheid dient niet te aarzelen, ook de belastingheffing zo nodig te gebruiken als een middel tot vervulling van haar sociaal-economische taak.' H.J. Hofstra, Het einde van de draagkrachttheorie, Weekblad voor fiscaal recht, 1939. In: Tributen aan het Recht, 100 jaar Weekblad voor fiscaal recht, 1971 , blz. 63 en 64 .

111. 'Ondanks tal van pogingen is er echter tot dusver niemand in geslaagd een verantwoorde maatstaf voor het meten van individuele draagkrachtverschillen aan te geven.' Bovendien zijn de tekortkomingen van het inkomensbegrip ernstig, aldus Hofstra. H.J. Hofstra en L.G.M. Stevens, Inkomstenbelasting, t.a.p., blz. 571.

112. H.J. Hofstra en L.G.M. Stevens, Inkomstenbelasting, t.a.p., blz. 8. Zie ook Van Schie, die vindt dat het draagkrachtbeginsel gebaseerd is op twee achterhaalde uitgangspunten, t.w.: het individualistisch uitgangspunt en de geïsolcerde benadering van de belastingheffing als 'lastenverdeling'. P.M. van Schie, De gebonden ratio, Vier kanttekeningen bij doel en strekking van de inkomstenbelastingwet, Tolvrije gedachten, Groninger Fiscaliteiten, Doedensbundel, Kluwer 1980, blz. 26. 
tot het normale bestedingspatroon behoren van personen die in gelijke omstandigheden verkeren. ${ }^{104}$ Dit kan als een bijzondere uitwerking van het gelijkheidsbeginsel worden gezien.

Een volgende categorie uitgaven die als draagkrachtverminderend worden beschouwd, is de categorie van aftrekbare giften. Met de toelaatbaarheid van de aftrekbare giften is een niet-fiscaal doeleinde in de wet geintroduceerd. ${ }^{105}$

\section{Het draagkrachtbeginsel als leider?}

In het bovenstaande wordt een aantal draagkrachtvermeerderende en -verminderende factoren genoemd, maar is het draagkrachtbeginsel het leidende beginsel voor de inkomstenbelasting?

Een auteur die een belangrijk onderzoek naar de werking van het draagkrachtbeginsel heeft gedaan, is Stevens. 'Stevens stelt dat het draagkrachtbeginsel als belangrijkste verdelingsbeginsel geldt voor de loon- en inkomstenbelasting. Niet alleen het inkomen, maar ook het gebruik kan volgens hem tot maatstaf van draagkracht leiden. Stevens denkt dat een ontwikkeling naar een consumptiebelasting denkbaar is. 'Het verteerbare inkomen wordt hoe langer hoe meer tot maatstaf van draagkracht genomen. ${ }^{106}$

Het draagkrachtbeginsel houdt in dat de belasting wordt geheven naar rato van de draagkracht. De draagkracht wordt bepaald door het inkomen. Aan dit beginsel ligt primair het gelijkheidsbeginsel ten grondslag. De rechtsgelijkheid is een dwingende eis voor het recht. Het gelijkheidsbeginsel houdt in dat personen met een zelfde inkomen een gelijk bedrag aan belasting dragen. De vraag is natuurlijk indien personen niet hetzelfde inkomen hebben, in hoeverre deze ongelijkheid haar weerslag moet vinden in het te betalen bedrag aan belasting? "Dit is een kwestie voor de politiek. ${ }^{107}$

Het draagkrachtbeginsel kan op twee wijzen worden ingevuld, t.w.: de inkomensvariant en de consumptievariant. Het evenredige nutsoffer is de gemeenschappelijke component. In het eerste geval wordt deze verbonden aan het inkomen en in het tweede geval aan de consumptie. ${ }^{108}$

Hofstra stelt al in 1939 vast dat het draagkrachtbeginsel zijn einde kent. Hiervoor voert hij twee redenen aan. De eerste is dat de draagkracht in concreto niet vast te stellen is, omdat er zoveel subjectieve factoren een rol spelen bij de vaststelling van de draagkracht en het tarief. Ten tweede omdat het niet duidelijk is,

104. H.J. Hofstra en L.G.M. Stevens, Inkomstenbelasting, t.a.p., blz. 488.

105. H.J. Hofstra en L.G.M. Stevens, Inkomstenbelasting, t.a.p., blz. 499. Zie voor een uitgebreider overzicht van de draagkrachtvermeerderende en -verminderende factoren, hoofdstuk 3.

106. L.G.M. Stevens, Belasting naar draagkracht, Kluwer, 1980, biz. 168 en 166.

107. 'De politieke doelstellingen worden verwoord in termen als 'streven naar een 'redelijke', 'rechtvaardige', 'eerlijke' inkomensverdeling'.' L.G.M. Stevens, Belasting naar draagkracht, Kluwer, 1980, blz. 113 en W.P. Erasmus, t.a.p., blz. 495. Stevens en Ermasus bedoclen kennelijk dat voor de formulering van het draagkrachtbeginsel nooit een geheel objectieve definitie kan worden gegeven.

108. L.G.M. Stevens, Belasting naar draagkracht, Kluwer, 1980, biz. 182 en 183. 
waar en hoe de belastingen uiteindelijk drukken. Zijn conclusie luidt dat het draagkrachtbeginsel niet meer is dan een leuze. ${ }^{105}$

Maar als het draagkrachtbeginsel aan zware druk bloot staat, welk uitgangspunt moet dan worden genomen om van een rechtvaardige belastingheffing te kunnen spreken?

Hofstra stelt dat de volgende drie punten als richtsnoer dienen te worden genomen bij de bepaling van een beginsel voor het hedendaagse belastingrecht, t.w.:

1. Nooit de gerechtigheid van het belastingrecht op zichzelf te beoordelen, doch met inachtneming van de rechtsorde als eén geheel;

2. Nooit de sociaal-economische gevolgen afzonderlijk te beschouwen, doch als een onderdeel van het economisch en sociaal beleid in haar geheel;

3. Ook andere doeleinden dan de zuivere fiscale kunnen met behulp van de belastingheffing worden nagestreefd. ${ }^{110}$

\section{Toepassingsmogelijkheden en beperkingen}

De toepassing van tret draagkrachtbeginsel verloopt niet geheel vlekkeloos. Ten eerste ligt in de-definièring van draagkracht al een beperking van het beginsel besloten; $n l$. dak over de individuele draagkracht geen eenstemmigheid bestaat. ${ }^{111}$ Hierbij speelt ook nog dat de draagkracht van een individu niet dezelfde omvang heeft als die van een ander. De verschillen in draagkracht worden weerspiegeld in een bijzonder matig progressief tarief, met een aftrek voor noodzakelijk levensonderhoud, en met bijzondere tegemoetkomingen wegens bepaalde buiten het inkomen liggende negatieve draagkrachtfactoren zoals de gezinssamenstelling. ${ }^{112}$

109. H.J. Hofstra, Het einde van de draagkrachttheorie, Weekblad voor fiscaal recht, 1939. In: Tributen aan het recht, 100 jaar Weckblad voor fiscaal recht, 1971, blz. 51.

110. Hofstra formuleert het kader waarin hèt belastingbeginsel zich moet ontwikkelen. 'De belastingwetenschap dient, anders dan tot dusver, de belastingheffing te zien als een onscheidbaar geheel van het organische geheel dat de rechtsorde vormt; zij dient niet alleen te vragen naar de rechtvaardigheid van het belastingstelsel, doch zij dient deze te beschouwen in verband met de rechtvaardigheid van de gehele rechtsorde; de overheid dient niet te aarzelen, ook de belastingheffing zo nodig te gebruiken als cen middel tot vervulling van haar sociaal-economische taak.' H.J. Hofstra, Het einde van de draagkrachttheorie, Weekblad voor fiscaal recht, 1939. In: Tributen aan het Recht, 100 jaar Weekblad voor fiscaal recht, 1971, blz. 63 en 64 .

111. 'Ondanks tal van pogingen is er echter tot dusver niemand in geslaagd een verantwoorde maatstaf voor het meten van individuele draagkrachtverschillen aan te geven.' Bovendien zijn de tekortkomingen van het inkomensbegrip ernstig, aldus Hofstra. H.J. Hofstra en L.G.M. Stcvens, Inkomstenbelasting, t.a.p., blz. 571.

112. H.J. Hofstra en L.G.M. Stevens, Inkomstenbelasting, t.a.p., blz. 8. Zie ook Van Schie, dic vindt dat het draagkrachtbeginsel gebaseerd is op twce achterhaalde uitgangspunten, t.w.: het individualistisch uitgangspunt en de geisolcerde benadering van de belastingheffing als 'lastenverdeling'. P.M. van Schie, De gebonden ratio, Vier kanttekeningen bij doel en strekking van de inkomstenbelastingwet, Tolvrije gedachten, Groninger Fiscaliteiten, Doedensbundel, Kluwer 1980, blz. 26. 
Ten tweede hangt de ingewikkelde toepassing van het draagkrachtbeginsel samen met het feit dat de belastingheffing niet alleen een budgettaire functie heeft. De overheid heeft verantwoordelijkheid voor de maatschappelijke verhoudingen en ontwikkelingen, zowel met betrekking tot een stabiele en groeiende economie als met betrekking tot redelijke inkomensverhoudingen. ${ }^{113}$

Het sociale beleid en de economische doeleinden hebben hun eigen karakteristieke kenmerken en bepalen als het ware voor een deel het fiscale beleid en daarmede de inhoud van de draagkrachtgedachte. In het eerste geval wordt de draagkrachtgedachte wel toegepast, maar met een correctie naar de hogere inkomens toe; deze worden zwaarder belast. ${ }^{114}$ In het tweede geval hebben nevendoeleinden - met andere woorden, de eis van doelmatigheid - veelal de overhand. Deze kunnen in botsing komen met de rechtvaardigheidseis van de draagkrachtgedachte. ${ }^{115}$

Samengevat blijkt uit het bovenstaande dat het niet eenvoudig is de draagkracht als leidraad te nemen. ${ }^{116}$ In de literatuur is daarom naar alternatieven gezocht. Als alternatief voor een draagkrachtbelasting wordt wel eens een verteringsbelasting genoemd. Dit is geen juiste keuze, aldus onder andere Hofstra, daar de belastingdruk in tijd wordt verplaatst, die noch door enig rechtvaardigheidsprincipe, noch door enig vooroordeel kan worden gerechtvaardigd. ${ }^{117}$

In dit verband is ook illustratief hetgeen Creusen c.s. voorstaan. Creusen c.s. zijn eveneens van mening dat de inkomstenbelasting niet langer door de draagkrachtgedachte wordt gedragen. $\mathrm{Zij}$ vragen zich af of het inkomensbegrip nog voldoet aan de eisen van de draagkrachtgedachte en werken vervolgens een concept uit voor een aangepaste vermogensvergelijkingstheorie. ${ }^{118}$

113. H.J. Hofstra m.m.v. C. van Raad, Inleiding, t.a.p., blz. 73.

114. Hierbij moet worden gedacht aan de herverdeling van inkomens. Het draagkrachtbeginsel en de herverdeling van inkomens zijn twee verschillende elementen in een belastingheffing.

115. H.J. Hofstra en L.G.M. Stevens, Inkomstenbelasting, t.a.p., blz. e.v.. Dezelfde mening is Stevens toegedaan in zijn bijdrage aan de Belastingadviseursdag 1994. Uit: R.H.M.J. Offermans, t.a.p., blz. 764.

116. Vergelijk onder andere enige prognoses van De Vries: De verworvenheden die thans met de individualistische belastingheffing verbonden zijn, zoals onder andere het element van de draagkracht, zullen in de loop van de tijd verdwijnen. In de loop van de tijd zal een ander vrijheidsbegrip ontstaan. De individualistische belastingheffing betreft een negatief begrip, terwijl de functionele belastingheffing een positief begrip in houdt. De waarden en normen blijken onder invloed van het E.E.G.-recht niet zo resistent tc zijn, waardoor er de neiging is dat de individualistische belastingheffing verschuift naar een functionele. J.A.J. de Vries, t.a.p., blz. 217, 220-222.

117. H.J. Hofstra en L.G.M. Stevens, Inkomstenbelasting, t.a.p., blz. 10. Hofstra verwijst naar Goode. Deze wijst er op dat ontsparing plaats vindt bij oudere mensen en besparing vindt plaats tijdens perioden waarin sprake is van een relatief hoog inkomen. Bovendien is de heffingsgrondslag heel smal, waardoor de marginale tarieven heel hoog zijn. H.J. Hofstra en L.G.M. Stevens, Inkomstenbelasting, t.a.p., blz. 9.

118. E.M.G. Creusen, D. Booij, P.M. van Schie, Naar cen breder inkomensbegrip? Weekblad voor fiscaal recht, 1979, no 5406, blz. 553 e.v.. 
Aan de bronnentheorie kleeft een aantal bezwaren. Ten eerste blijft een aantal factoren van draagkrachtvermeerdering buiten beschouwing. Ten tweede slaagt de praktijk er in om in beginsel belaste draagkrachtvermeerderingen ten overstaan van de belastingdienst in een onbelaste vorm te gieten. Ten derde is niet duidelijk wat onder 'bron' moet worden verstaan. Ten vierde staat de wijze van bepaling van de opprengsten uit de bron niet eenduidig vast. Ten slotte kan de theorie in een moderne economische samenleving niet goed meer functione-
ren. ${ }^{119}$

Derhalve gaat Creusen's voorkeur uit naar een andere theorie, nl. de vermogensvergelijkingstheorie. In deze theorie dient iedere reële draagkrachtvermeerdering te worden belast. Iedere vermogenstoename wordt door Creusen c.s. als inkomen gezien. Onder vermogenstoename worden niet alleen winsten op vermogensbestanddelen verstaan, maar ook alle vormen van wat in het spraakgebruik 'inkomen' wordt genoemd. De constatering van de vermogens-toename is voldoende voor de toename van de koopkracht en derhalve is sprake van inkomen in fiscale zin. ${ }^{120}$

Deze theorie vangt in ieder geval de bezwaren genoemd onder het derde, het vierde en het vijfde punt op. Elk stelsel dat uitgaat van de bronnentheorie, maar voordelen belast die niet uit enige bron voortvloeien, of het aantal bronnen uitbreidt, beweegt zich in de richting van de vermogensvergelijkingstheorie. Het inkomen wordt niet bepaald door de vermogensvergelijking, maar dit neemt niet weg, dat toch gesproken kan worden van een vermogensvergelijkingstheorie, daar het resultaat hetzelfde is. ${ }^{121}$

Brüll is de mening toegedaan dat de toepassing van het draagkrachtbeginsel beperkt moet blijven tot de financiering van de traditionele overheidstaak. Voor de collectieve behoeftenbevrediging is het draagkrachtbeginsel niet geschikt. ${ }^{122}$ Het probleem hierbij lijkt me dat de nadere definities van de traditionele overheidstaak en de collectieve behoeftenbevrediging niet geheel te scheiden zijn. Volgens Nederstigt motiveert Brüll hier belastingheffing naar draagkracht als 'een verondersteld 'evenredig belang bij alle burgers', waardoor het onderscheid tussen naar draagkracht en heffing naar (fictief) profijt vervalt'. De draagkracht is slechts de maatstaf voor het profijt. ${ }^{123}$

Stel dat moet worden aangenomen dat iedere burger een gelijk belang bij de overheidsmaatregelen heeft. In dat geval neemt het profijt niet evenredig aan de draagkracht toe. 'Voor zover het draagkrachtbeginsel niet samenvalt met het profijtbeginsel bewerkt belastingheffing naar draagkracht derhalve, evenals belastingheffing volgens het buitenkansbeginsel een herverdeling van de inkomens. ${ }^{.124}$

119. E.M.G. Creusen c.s., t.a.p., blz. 555 en 557.

120. E.M.G. Creusen c.s., t.a.p., blz. 555.

121. E.M.G. Creusen c.s., t.a.p., blz. 562.

122. D. Brüll, Rechtsnorm en overheidsbudget, Openbare les, 1967, blz. 9 en 10. Zie ook W.F. Nederstigt, t.a.p., blz. 262.

123. W.F. Nederstigt, t.a.p., biz. 262.

124. W.F. Nederstigt, t.a.p., blz. 262 en 263. 
Een probleem bij de herverdeling van de inkomens is dat de belastingheffing zijn invloed al doet gelden bij de vorming van het primaire inkomen. ${ }^{125}$ Bovendien moet de onzekere factor van de mogelijkheid van afwenteling van de belastingheffing in acht worden genomen. ${ }^{126}$

In het verleden heeft het draagkrachtbeginsel in de inkomstenbelasting een zeer belangrijke rol gespeeld. De vooronderstellingen van de inkomstenbelasting zijn eenvoudig, echter de uitwerking van de inkomstenbelasting blijkt gecompliceerd. ${ }^{127}$ Zowel de functionele als de budgettaire functie van de belastingheffing heeft geleid tot een ingewikkelde belastingheffing. De hoge belastingdruk wordt veroorzaakt door een omvangrijke collectieve sector.

Mede als gevolg van de ingewikkeldheid wil de fiscale wetgever, en ten dele heeft hij dat ook gedaan, overgaan tot de zgn. belastinghervormingen. De belastinghervormingen reiken in de meeste gevallen niet verder dan tariefverlagingen, al dan niet gepaard gaande met verbreding van de heffingsgrondslag. In Nederland is sprake van een verbreding van een heffingsgrondslag. Voor een theoretische discussie zijn de uitgangspunten die bij de verbreding van de heffingsgrondslag zijn aangevoerd van groot belang.

\section{Toekomst draagkrachtbeginsel}

Wat kan in de huidige tijd van het draagkachtbeginsel worden gezegd?

Het is moeilijk om een goede èn bruikbare omschrijving van het begrip draagkracht te hebben en daarmee de draagkracht te bepalen, die voor de vaststelling. van het belastbaar inkomen van belang wordt geacht.

Indien over het draagkrachtbeginsel wordt gesproken, moet het duidelijk zijn waarop het beginsel van toepassing is. Daarbij valt te onderscheiden tussen het subject, het object en het tarief. Kortom, het begrip draagkracht dient duidelijk omschreven te zijn; zo niet, dan komt de discussie over de rechtsgrond van de belastingheffing in de lucht te hangen. ${ }^{128}$

Bovendien moet duidelijk zijn op welk moment het draagkrachtbeginsel zijn werking heeft of moet hebben. Is dat het moment waarop de lastenverdeling door vastlegging van subject, object en tarief in een wet haar uitvoering krijgt of is dat het moment na heffing van belasting: In het ecrste geval wordt uitgegaan van een bruto-lastenverdeling en in het tweede geval van een netto-uitkomst. Het laatste

125. W.F. Nederstigt, t.a.p., blz. 263.

126. Ook Detiger is de mening toegedaan dat de realisatie van het draagkrachtbeginsel door middel van de inkomstenbelasting een utopie moet worden geacht. Andere maatregelen, zoals bij voorbeeid sociale maatregelen, zullen het gewenste resultaat eerder bereiken, aldus Detiger.

Rechtvaardigheid met betrekking tot de bclastingheffing is overigens niet identiek aan een rechtvaardige verdeling van de belastingdruk. W.F. Nederstigt, t.a.p., blz. 267.

127. H.J. Hofstra en L.G.M. Stevens, Inkomstenbelasting, t.a.p., blz. 571.

128. Hofstra constateerde al in 1939 dat draagkracht op verschillende manieren wordt gebruikt. Dit komt mede door de vage inhoud van het begrip. Zie H.J. Hofstra, Het einde van de draagkrachttheorie, Weekblad voor fiscaal recht, 1939. In: Tributen aan het Recht, 100 jaar Weekblad voor fiscaal recht, 1971, blz. 65 . 
hangt onder andere samen met de koopkrachtplaatjes. ${ }^{129}$ Deze koopkrachtplaatjes worden te pas en te onpas ten tonele gevoerd. ${ }^{130}$ Met deze koopkrachtplaatjes wordt onder andere in de belastingwetgeving veelvuldig gewerkt. ${ }^{131}$ In de literatuur wordt, onder andere door de voorzitter Oort, zelfs gesproken van een dictatuur van de koopkrachtplaatjes. ${ }^{132}$

Hierbij spelen enkele problemen, nl. ten eerste wordt de status quo verondersteld rechtvaardig te zijn en, ten tweede, zegt de vergelijking van netto-uitkomsten niets over de vraag of bruto-inkomsten op rechtvaardige wijze worden belast.

Een nadeel van het gebruik van de koopkrachtplaatjes is dat veel factoren buiten beschouwing worden gelaten. Hierdoor zijn uitspraken over bepaalde situaties

129. Zie De Kam en Sturm: 'De effectieve drukverdeling van publieke heffingen kan niet worden bepaald met de gebruikelijke, veelgesmade koopkrachtoverzichten .... Zulke overzichten blijven een (zeer ruwe) benadering van de veelvormige werkelijkheid.' De auteurs wensen gebruik te maken van statistische gegevens. C.A. de Kam en J.E. Sturm, De effectieve druk van inkomensheffingen en vermogensbelasting, voor en na de operatie-'OORT', Weekblad voor fiscaal recht, 1994, no 6117, blz. 1261.

130. Of zoals een topambtenaar van Financiën het zegt: 'In Engeland zijn de inkomensstatistieken ontoereikend. In Frankrijk maakt men er zich gewoon minder druk om. En in de Verenigde Staten kijkt men alleen of de onderste en de hoogste inkomensgroep globaal hetzelfde overhouden. Verder is er geen discussie. Maar in Nederland worden de effecten van de belastingverlaging voor elke groep tot op een kwartje nagerekend.' $H$. Buddingh, Het grote rekenen kan beginnen, NRC Handelsblad, supplement Mens en Bedrijf, 3 augustus 1988, blz. 3 .

131. Dat inkomenseffecten niet altijd de boventoon voeren, blijkt uit het volgende citaat. 'Daarbij hebben de voordelen van eenvoud de doorslag gegeven boven volledige inkomensneutraliteit, omdat partners zelf een inkomensneutrale oplossing kunnen realiseren en omdat de inkomenseffecten ook bij én percentage beperkt konden blijven.' Tweede Kamer, vergaderjaar 1992-1993, 23 269, no 7, blz. 4.

132. Zie onder andere W.F.C. Stevens, Heeft eenvoud toekomst?, Weekblad voor fiscaal recht, 1989, no 5855, blz. 138. Zie ook de discussie over de effecten van de voorstellen die plaatsgevonden heeft tussen minister Ruding en de heer Kombrink (PvdA) en de heer Engwirda (D66). Handelingen Tweede Kamer, vergaderjaar 1988-1989, 20595 enz., blz. 40-2502, 402503. Handelingen Eerste Kamer, vergaderjaar 1988-1989, 20595 enz., blz. 26-993. Handelingen Eerste Kamer, vergaderjaar 1988-1989, 20595 enz., blz. 27-1035, rk.

Sommige kamerleden (CDA) realiseren zich dat koopkrachtverschillen niet tot achter de komma kunnen worden geregeld. Tweede Kamer, vergaderjaar 1992-1993, 23 269, no 4, blz. 1.

Schutte, GPV, formuleert bij dc bespreking van het Belastingplan 1994 het gebruik van het koopkrachtplaatje aldus: 'I $\mathrm{k}$ zal dat $0 \mathrm{k}$ niet ontkennen, maar het overheersende beeld is toch wel dat het er vooral om is gegaan om een evenwichtig koopkrachtplaatje te kunnen presenteren. Uiteraard hecht ook ik aan een evenwichtige verdeling van lasten, maar de vraag is of de overheid met haar fiscale instrumentarium, nog voldoende mogelijkheden heeft om dat te kunnen bewerkstelligen.' Handelingen Tweede Kamer, vergaderjaar 19931994, blz. 31-2359, lk.

Zie ook J.A.G. van der Geld, Zicht op fiscale wetgeving, Tilburg University Press, 1991, blz. 13. Zie ook L. Koopmans, A.H.E.M. Wellink, H.J. Woltjer, C.A. de Kam, Overheidsfinanciën, zevende geheel herziene druk, Stenfert Kroese, 1991, blz. 213. 
niet met zekerheid te geven. Een alternatief voor de koopkrachtplaatjes is de zgn. microsimulatie. ${ }^{133}$

Ik ga er vanuit dat het draagkrachtbeginsel in zijn zuiverste vorm - en dat is naar mijn mening ook de oorspronkelijke vorm - alleen van toepassing kan zijn in het eerstgenoemde geval. In het tweede geval kan niet meer worden gesproken van enkel en alleen een lastenverdeling, daar vele andere elementen een rol spelen. Het draagkrachtbeginsel is naar mijn mening onder zware druk komen te staan, aangezien andere invloeden - zoals die van de nevendoeleinden - (te) sterk zijn geworden. ${ }^{134}$

\subsection{2}

Het profijtbeginsel

Het profijtbeginsel ${ }^{135}$ is een tweede beginsel dat een rechtvaardige verdeling van de lasten dient te bewerkstelligen. De toepassing van het beginsel vindt vooral plaats bij de kostprijsverhogende belastingen. Het profijtbeginsel kent . echter ook een toepassing in de Wet IB 1964. Denk bij voorbeeld aan de introductie van het schoner-milieubelang in het reiskostenforfait; degene die het milieu belast, moet daarvoor betalen. ${ }^{136}$ Wat is de definitie van het profijtbeginsel en welke zijn de toepassingsmogelijkheden en beperkingen van het beginsel?

133. Een uitgebreid micromodel simuleert de inkomensgevolgen van overheidsmaatregelen. Hierbij wordt gebruik gemaakt van een voor de gehele Ncderlandse bevolking representatief gegevensbestand. L. Koopmans c.s., t.a.p., blz. 213.

'Koopkrachtoverzichten zijn niet bruikbaar om de inkomensgevolgen weer te geven van maatregelen die raken aan elementen buiten het gestandariseerde bruto-netto traject.' Zicht op eenvoud, Rapport van de commissie tot vereenvoudiging van de loonbelasting en inkomstenbelasting, Sdu, 1991, blz. 116. Zie verder \$ 4.2.7.

134. Vergelijk F.H.M. Grapperhaus, Fiscale geschiedenis in 2094, Column, Weekblad voor fiscaal recht, 1994, no 6108, blz. 865 en 866.

135. Aanvankelijk was de economische band met de prestatie van de overheid sterk. In de loop van de tijden is de relatie met het profijtbeginsel terug te voeren in het algemeen belang dat de burgers bij overheidsvoorzieningen hebben. De belastingplichtige heeft profijt van het overheidsoptreden; hoe groter het vermogen, hoe meer belang. Het idee van de draagkracht, welke de grondslag is voor de belastingheffing, is gelegen in de hoogte van het vermogen. ' $V$ ia het profijt dat de belastingbetaler heeft van het overheidsoptreden komen we zo paradoxaal genoeg uit bij het draagkrachtpincipe.' F.H.M. Grapperhaus, De pelgrimstocht naar het draagkrachtbeginsel, Rluwer, 1993, blz. 20 en 66.

136. Wet van 4 juli 1990 tot wijziging van de inkomstenbelasting en de loonbelasting (aftopping reiskostenforfait), Stb. 1990, 355. Boorsma vindt het principe van 'de vervuiler betaalt' complementair aan het profijtbeginsel. Bovendien is het belang van het profijtbeginsel de laatste jaren toegenomen. P.B. Boorsma, Belastinghervorming in Nederiand, Economisch sociaal blad, 1986, blz. 84. Zie ook L. Koopmans c.s., t.a.p., blz. 94 en 95. Koopmans c.s. spreken van een herstel van het prijsmechanisme.

Overigens blijkt het gebruik van de fiscale carpoolregeling, een gewenst element van bovengenoemde wet, tegen te vallen. Handelingen Tweede Kamer, vergaderjaar 1993-1994, blz. 31-2343, lk. 


\section{Definitie}

De meest gebruikelijke definitie van profijtbeginsel is, 'dat aan elk individu afzonderlijk naar profijt de kosten worden toegerekend van een verzameling goederen, die de overheid ter beschikking stelt aan de gemeenschap'. ${ }^{137}$ In andere bewoordingen, het profijtbeginsel houdt in, 'dat belasting mag worden geheven in relatie tot de mate waarin ieder diensten van de overheid geniet'. ${ }^{138}$ Stevens formuleert het profijtbeginsel als volgt: '... dat belasting wordt geheven naar de mate waarin het individu profijt heeft getrokken uit de door de overheid gefinancierde voorzieningen. ${ }^{139}$

Hofstra onderscheidt bij de vraag welke plaats en vorm het profijtbeginsel kan hebben drie stadia. De stadia zijn in chronologische volgorde weergegeven. Het eerste stadium betreft de zgn. 'groepsbelastingen'. Groepsbelastingen zijn belastingen waarmee de kosten van bepaalde voorzieningen, waarbij een speciale bevolkingsgroep geacht wordt een bijzonder belang te hebben, geheel of gedeeltelijk over de groep worden omgeslagen. Bepaalde belastingplichtigen kunnen zijn bevoordeeld, waardoor een ongelijkheid met andere belastingplichtigen ontstaat. De ongelijkheid moet worden rechtgetrokken. Deze belastingen passen niet in de draagkrachttheorie.

Een tweede stadium bestaat uit een uitbreiding van het belangenbeginsel, t.w.: kosten van overheidsactiviteiten worden omgeslagen over degenen die daarvan profijt hebben. Het derde stadium betreft een nog ruimere strekking van het belangenbeginsel. De voorwaarde is dat de overheidshuishouding in haar geheel als een produktiehuishouding wordt gezien. Hier moet een onderscheid worden gemaakt tussen de produktie- en de opbrengstbelastingen. De eerstgenoemde hebben betrekking op het beslag dat op de produktiefactoren wordt gelegd; de tweede op de opbrengsten van de produktiefactoren. ${ }^{140}$

\section{Toepassingsmogelijkheden en beperkingen}

Het profijtbeginsel toepassen 'impliceert, dat een exacte band wordt gelegd tussen het feitelijke gebruik van collectieve voorzieningen en het bedrag dat

137. J.R Abbing, Economie en cultuur: de subsidieproblematiek in de economische theorie, alsmede aanzetten tot een economie van de kunsten, Staatsuitgeverij, 's-Gravenhage, 1978, blz. 212. Volgens Abbing zijn er vele definities van het profijtbcginsel. '... vele verschillende toepassingen van de profijtgedachte - met uitzondering dan van dat ene, algemeen bekend geworden profijtbeginsel dat goed beschouwd geen echte toepassing van de profijtgedachte is.' J.R. Abbing, t.a.p., blz. 214.

138. W.J. de Langen, t.a.p., blz. 39.

139. L.G.M. Stevens, Belasting naar draagkracht, Kluwer, 1980, blz. 163. Stevens ziet liever dat het profijtbeginsel 'vergoedingsbeginsel' wordt genoemd, met een onderverdeling in het profijt- en het schadevergoedingsbeginsel. Inzake het profijtbeginsel is een burger werkelijk gebaat en inzake het schadevergoedingsbeginsel is de overheid door toedoen van burgers geschaad doordat extra uitgaven moeten worden gedaan. L.G.M. Stevens, Elementair belastingrecht voor economen en bedrijfsjuristen, Kluwer, 11e herziene druk, 1993, blz. 7 en 8 .

140. H.J. Hofstra m.m.v. C. van Raad, Inlciding, t.a.p., blz. 119 en 120. 
daarvoor moet worden betaald', aldus Haselbekke. ${ }^{141}$ Het profijtbeginsel heeft zich ontwikkeld als een verdelingsbeginsel en als een middel tot bevordering van een efficiënte allocatie. ${ }^{142}$ De functie van verdelingsbeginsel is het oudst. 'Op welke wijze kan worden gekomen tot een rechtvaardige verdeling van de last die voortvloeit uit de bekostiging van publieke uitgaven? ${ }^{143}$ De functie van middel tot bevordering van een efficiënte allocatie kan invloed hebben op de andere functie, die van de rechtvaardige verdeling. ${ }^{144}$ De twee functies zijn niet te scheiden; de inkomensverdeling kan bij een analyse van de beheersbaarheid van de overheidsuitgaven niet buiten beschouwing worden gelaten. Bovendien zijn de functies niet waardevrij. ${ }^{145}$ Belangrijk is dat doeleinden en instrumenten niet worden verward. ${ }^{146}$

Het draagkrachtbeginsel wordt toegepast op een gegeven omvang van uitgaven en ontvangsten; het profijtbeginsel juist niet. ${ }^{147}$ Met andere woorden, in tegenstelling tot het draagkrachtbeginsel is de toepassing van het profijtbeginsel onafhankelijk van het inkomen en heeft dit niets met draagkracht te maken. Dit blijkt ook uit de meeste omschrijvingen van het profijtbeginsel. ${ }^{148}$

141. A.G.J. Hasclbekke, Het profijtbeginsel en de beheersing van de collectieve sector. In: Naar een beheersbare collectieve sector, Serie geschriften van het Fiscaal-economisch Instituut van de Erasmus Universiteit Rotterdam, 1981, blz. 127.

142. A.G.J. Haselbekke, Het profijtbeginsel en de beheersing van de collecticve sector, 1981, blz. 131 en 148. Vergelijk ook Van den Tempel, 'Profijt duidt dan aan wat ten gevolge van een overheidsvoorziening genoten is; profijt kan echter ook een aanwijzing zijn dat bij voorbeeld verspilling dreigt (allocatiegcbreken).' A.J. van den Tempel, Het einde van de belastingbeginselen, Weekblad voor fiscaal recht, 1979, no 5411, blz. 704. Boorsma beschouwt de keuze voor het profijtbeginsel op basis van de allocatie-functie als een beperkende waarde van het beginsel. P.B. Boorsma, t.a.p., blz. 83. Zic ook Wolfson, die onder allocatie verstaat een 'optimale omvang en samenstelling van een pakket van dingen, van goederen en diensten, terwijl het verdelingsvraagstuk nagaat welke mensen over die dingen beschikkingsmacht uitoefenen'. D.J. Wolfson, Inkomensverdeling en beheersbaarheid. In: Naar een beheersbare collectieve sector, A.G.J. Haselbekke c.s., Serie geschriften van het Fiscaal-economisch Instituut van de Erasmus Universiteit Rotterdam, 1981, blz. 190.

143. A.G.J. Haselbekke, Profijtbeginsel en politieke besluitvorming, Stenfert Kroese, 1987, blz. 14.

144. A.G.J. Haselbekke, Profijtbeginsel en politieke besluitvorming, Stenfert Kroese, 1987, blz. 247.

145. D.J. Wolfson, t.a.p., blz. 201.

146. Zo zijn volgens Wolfson belastingen en overheidsuitgaven geen doel op zichzelf maar een middel ter financiering van overheidsactiviteiten. D.J. Wolfson, t.a.p., blz. 219.

147. A.G.J. Haselbekke, Het profijtbeginsel en de beheersing van de collectieve sector, 1981, blz. 148.

148. Andere opvattingen zijn mogelijk. Het kan zijn dat de toepassing afhankelijk is van het inkomen, maar in dat geval gaat de eis van doelmatigheid een rol spelen. Het profijtbeginsel kan volgens de PrdA en DS'70 (1974) toepassing vinden op gebieden die niet essentieel zijn voor het levensonderhoud. J.Th.J. van den Berg, H.A.A. Molleman, De crisis in de Nederlandse politiek, Samson, 2e druk, 1980, blz. 207.

Voorzichtigheid moet worden betracht met betrekking tot het vragen van een inkomensafhankelijke prijs in het kader van de toepassing van het profijtbeginsel. A.G.J. Haselbekke, Profijtbeginsel en politieke besluitvorming, Stenfert Kroese, 1987, blz. 250. 
In het algemeen zal een ieder aan een geleverde dienst hetzelfde profijt ontlenen, tenzij men moet aannemen dat in geval van het genieten van meer geleverde diensten hetzij sprake is van een afnemend grensnut, hetzij van juist meer profijt ${ }^{149}$. In geval het profijt gelijk blijft, kan per geleverde dienst hetzelfde bedrag worden betaald, tenzij ervan uit gegaan moet worden dat een zekere progressie op zijn plaats is. Met de overige situaties kan op de volgende wijze rekening worden gehouden. Indien rekening wordt gehouden met het afnemende grensnut, wordt gemiddeld per geleverde dienst minder betaald. Indien rekening wordt gehouden met meer profijt, kan een progressie worden toegepast. Al deze situaties variëren naar de mate waarin de toepassing van het profijtbeginsel afhankelijk is gesteld van het inkomen.

Heeft het profijtbeginsel toepassingsmogelijkheden? Ja, aldus Haselbekke. Haselbekke vindt het profijtbeginsel een goede mogelijkheid om een betere informatievoorziening te krijgen tussen burger en overheid en om het afwegingsproces tussen voorzieningen en kosten daarvan te verbeteren. ${ }^{150}$ Het profijtbeginsel verbetert de doelmatigheid en de doeltreffendheid van publieke voorzieningen. ${ }^{151}$ Indien het beginsel aldus begrepen moet worden, herbergt het een element van rechtvaardigheid èn een element van doelmatigheid.

Toepassing van het profijtbeginsel levert een aantal problemen op. Een eerste moeilijkheid is gelegen in de definiëring en berekening van 'profijt'. Het is moeilijk goed functionerende maatstaven te formuleren. Een van de auteurs die geprobeerd heeft maatstaven te ontwikkelen, is De Langen. De Langen onderscheidt twee maatstaven t.w.: de kostprijs van de overheidsprestatie en het belang van de prestatie voor de contribuabele. De eerste maatstaf is in tegenstelling tot de tweede te berekenen, aldus De Langen. Het belang van de prestatie voor de contribuabele is onder te verdelen in een subjectieve en een objectieve maatstaf. De subjectieve maatstaf is ieders belang bij het genoten profijt; de objectieve maatstaf houdt in dat het profijt voor een ieder op een gelijke waarde wordt gewaardeerd. ${ }^{152}$

Een tweede moeilijkheid is gelegen in de mogelijkheid tot identificeren van de personen die geacht worden profijt te hebben. Hier komt de relatie met doelmatigheid aan de orde. ${ }^{153}$

Indien men uitgaat van de ongebruikelijke koppeling van het profijtbeginsel aan het inkomen, dan treedt een derde moeilijkheid op. Deze is dan gelegen in het

149. Meer profijt kan bij voorbecld worden aangenomen bij milieu-belastende diensten. Degene die meer gebruik makkt van het milieu, dient evenredig meer te betalen.

150. A.G.J. Haselbekke, Profijtbeginsel en politieke besluitvorming, Stenfert Kroese, 1987, blz. 191.

151. A.G.J. Haselbekke, Profijtbeginsel en politieke besluitvorming, Stenfert Kroese, 1987, blz. 193.

152. W.J. de Langen, t.a.p., blz. 185. Vergelijk ook Goedhart, die stelt dat het profijtbeginsel in de eigenlijke belastingheffing geen toepassing kan vinden. C. Goedhart, t.a.p., blz. 97.

153. A.G.J. Haselbekke, Het profijtbeginsel en de beheersing van de collectieve sector, 1981, blz. 144. 
gegeven dat niet met zekerheid kan worden gezegd of het tarief degressief, proportioneel of progressief moet verlopen, aldus Haselbekke. ${ }^{154}$ Aangezien de zekerheid ontbreekt, zal indien gekozen wordt voor een belasting met toepassing van het profijtbeginsel, de keuze voor het uiteindelijke verloop van het tarief een politieke zijn.

Stel dat aangenomen moet worden dat iemand met een hoger inkomen meer diensten afneemt, dan kan voor de berekening van het af te dragen bedrag een progressief tarief worden aangenomen. In dat geval worden mijns inziens twee verdelingsbeginselen gebruikt, nl. het profijt- èn het draagkrachtbeginsel, eventueel versterkt met de wens tot herverdeling.

Een beperking van het profijtbeginsel is dat het beginsel volgens sommige auteurs alleen toepasbaar is indien de inkomens van de belastingplichtigen niet al te onevenredig zijn verdeeld. Zo niet, dan treedt strijd met het gelijkheidsbeginsel op; de toepassing van het profijtbeginsel kan in dat geval een denivellerende werking hebben. ${ }^{155}$

De auteurs geven geen nadere uitleg, maar als ik ze goed begrijp, gaan zij uit van een toepassing van het profijtbeginsel onafhankelijk van het inkomen.

Het bovenstaande leert dat de problemen van het profijtbeginsel van soortgelijke aard zijn als bij het draagkrachtbeginsel. De definiëring van het begrip profijt is niet eenduidig en niet makkelijk te maken.

Hierdoor kunnen partijpolitieke voorkeuren een eigen invulling aan het begrip geven.

\subsection{Het gelijkheidsbeginsel}

\section{Definitie}

Het gelijkheidsbeginsel oefent een enorme aantrekkingskracht uit. Maar het is geen absoluut geldend beginsel. Het gelijkheidsbeginsel is een beginsel dat afgewogen dient te worden tegenover andere beginselen. Veelal wordt het gelijkheidsbeginsel als rechtvaardigheidsbeginsel tegenover doelmatigheid geplaatst. ${ }^{156}$ De vraag is hoe doelmatigheid zich verhoudt tot rechtvaardigheidsbeginselen. Wat gebeurt ingeval doelmatigheid en rechtvaardigheid met elkaar in botsing komen?

154. A.G.J. Hasselbekke, Profijtbeginsel en politicke besluitvorming, Stenfert Kroese, 1987, blz. 14. J.R. Abbing, t.a.p., blz. 213.

155. J.Th.J. van den Berg, H.A.A. Molleman, De crisis in de Nederlandse politiek, Samson, $2 e$ druk, 1980, blz. 207. Of er een denivellerende werking is, is afhankelijk van de tariefstelling en het feitelijk gebruik van de collectieve voorzieningen. A.G.J. Haselbekke, Het profijtbeginsel en de beheersing van de collectieve sector, 1981, blz. 134.

156. Vergelijk L.G.M. Stevens, Belasting naar draagkracht, Kluwer, 1980, blz. 144. 
Een element in de belastingheffing waarin de afweging tussen doelmatigheid en gelijkheidsbeginsel ten gunste van eerstgenoemde uitvalt, is het $\mathrm{zgn}$. forfait. Het gelijkheidsbeginsel is een geheel andere constitutionele norm dan de andere rechtsnormen: 'het stelt eisen aan de belangenafwegingen die aan die andere rechtsnormen ten grondslag liggen, en hanteert daarbij als aangrijpingspunt de differentiatiecriteria waarin die belangenafwegingen tot uitdrukking komen'. ${ }^{157}$ Het gelijkheidsbeginsel is een beginsel, ten aanzien waarvan een ieder het eens is met de omschrijving, maar als het op de nadere uitwerking van dit beginsel aankomt, lopen de meningen uiteen. Daarom wordt heden ten dage nog altijd uitgegaan van de formele omschrijving van Aristoteles. De omschrijving luidt als volgt: 'Gelijke gevallen dienen gelijk te worden behandeld en ongelijke gevallen naar de mate van de onevenredigheid'. ${ }^{158}$

$\widetilde{B}$ elangrijk bij het gelijkheidsbeginsel is de vraag voor wie het geldt. De belastingwetgever moet het gelijkheidsbeginsel ten aanzien van de belastingplichtigen bij de verdeling van de door hem opgelegde lasten in acht nemen. Hierbij. is het nodig te weten welke gevallen gelijk en welke ongelijk zijn.

\section{Realisatie}

$\mathrm{Na}$ het geven van de omschrjiving van het gelijkheidsbeginsel, rijst de vraag hoe, en op welk niveau, de werking van het gelijkheidsbeginsel gerealiseerd kan worden?

In de Staatscommissie van advies inzake de Grondwet en de Kieșet van 1969 (de zgn. commissie Cals-Donner) waren de meningen omtrent de werking van het gelijkheidsbeginsel verdeeld. De meerderheid stelde zich op het standpunt dat het gelijkheidsbeginsel slechts als toetssteen kan worden gebruikt voor de rechtstoepassing. De wetgever moet het gelijkheidsbeginsel in acht nemen, maar slechts de wetgever.komt het oordeel toe in welke mate en onder welke omstandigheden dit inachtnemen dient te geschiedeñ. ${ }^{159}$

Een minderheid echter, was de mening toegedaan dat ook de wetgever het beginsel in acht dient te nemen, en dat een rechter dienaangaande een toetsingsmogelijkheid dient te bezitten ${ }^{160}$ Uiteindelijk luidt artikel $120 \mathrm{GW}$ : 'De rechter treedt niet in de beoordeling van de grondwettigheid van wetten en verdragen.' De discussie is in de loop van de tijden actueel gebleven. Bij tijd en wijle hoort

157. E.M.H. Hirsch Ballin, Staatsrecht en bestuursrecht: Artikel 1 van de Grondwet als fundamentele constitutionele norm. In: Gelijkheid en recht, C.W. Maris, Zwolle, 1988, blz. 153.

158. R.H. Happé, Gelijkheidsbeginsel in ethisch perspectief, Geschriften voor de belastingwetenschap, no 178, Kluwer, 1989, biz. 13. Vergelijk L. Mulder, die stelt dat thans het gelijkheidsbeginsel uit de volgende elementen bestaat:

'1. er kan sprake zijn van een ongerechtvaardigd onderscheid;

2. er kan sprake zijn van een ongerechtvaardigde gelijkstelling.' L. Mulder, Over gelijkheid, onderscheid en diskriminatie, Recht en kritiek, 1985; no 11, blz. 81.

159. Volgens Mulder heeft de wetgever oorspronkelijk een groter bereikingsgebied van het gelijkheidsbeginsel in gedachte gehad. Deze vergroting bestaat uit 'strijdigheid met de emancipatoire stelling van de bepaling. L. Mulder, t.a.p., blz. 81 .

160. M.C. Burkens, Gelijke behandeling, Grondrechten, commentaar op hoofdstuk 1 van de herziene Grondwet. In: Jeukensbundel, 1982, blz. 51. 
men de roep om een controlerend orgaan voor de door de wetgever vervaardigde produkten. ${ }^{161}$

In de literatuur zijn de meeste auteurs de mening toegedaan dat het gelijkheidsbeginsel een beginsel is, dat op alle fronten zijn gelding heeft. ${ }^{162}$ Zowel de rechter, de wetgever, als het bestuur, moeten het gelijkheidsbeginsel in .acht nemen. Deze staatsorganen moeten ten aanzien van hun handelen de belangen uit algemene gezichtspunten afwegen. Het gelijkheidsbeginsel voor de wetgever houdt in dat zoveel mogelijk wordt gestreefd naar geldend recht dat aan gelijkheid een prioriteit toekent. ${ }^{163}$. Maar hiermee wordt niet gezegd waar de grens ligt bij het al dan niet toepassen van het gelijkheidsbeginsel.

Volgens Happe moet het gelijkheidsbeginsel vanuit een bepaald perspectief worden bezien. Hierdoor krijgt het gelijkheidsbeginsel een inhoudelijk aspect. Ingeval de rechter een beslissing moet nemen, dient de wettelijke regeling te worden bekeken. ${ }^{164}$ Voor de wetgever geldt dat op grond van het ethische gelijkheidsbeginsel ruimte wordt gegeven om terwille van het algemene belang ongelijkheden in het leven te roepen. ${ }^{165}$

Het recht moet worden gezien als een eenheid, waarin de aan die eenheid ten grondslag liggende rechtsbeginselen dienen te worden afgestemd. Een van die rechtsbeginselen is het gelijkheidsbeginsel. De overheid moet de belangen van een belastingplichtige op dezelfde wijze' afwegen als die van een andere belastingplichtige.

Het legaliteitsbeginsel en het doelmatigheidsbeginsel spelen hierbij een voorname rol, aldus Happe.' Deze opmerking moet vooral gezien worden in het licht van de onderlinge strijdigheid van de rechtsbeginselen. Nu eens gaat het legaliteitșbeginsel voor en dan weer het doelmatigheidsbeginsel. Maar de grote vraag

161. Zie F.A.M. Stroink, De plaats van de rechter in het staatsbestel, rede, W.E.J. Tjeenk Willink, 1990. Wat betekent dit voor de wetgever? Wat betreft de wetgeving in formele zin, kan de rechter niet in de grondwettigheid van de wetgeving treden. Met andere woorden, de rechter is niet bevoegd de wetgeving in formcle zin te toetsen op het gelijkheidsbeginsel. Hiermee is nog niet gezegd dat de bedoelde toetsing niet gewenst zou zijn.

Zie ook Van der Geld, die een Raad voor fiscaal-theoretische vraagstukken zou willen instellen om gevraagd en ongevraagd advies uit te brengen aan regering en parlement. J.A.G. yan der Geld, Zicht op fiscale wetgeving, Tilburg University Press, 1991, blz. 37.

162. Vergelijk G.E. Langemeyer: 'Een beginsel is er,'dat alle rechtsleer als minimum van juist recht erkent: objectiviteit, de eis dat gelijke gevallen gelijk moeten worden behandeld, en verschillende in evenredigheid van het verschil.' G.E. Langemeyer, Ons oordeel over wat recht moet zijn, Tjeenk Willink, 1950, 2e druk, blz. 6.

163. Zie onder andere H. Smit, De opmars van het gelijkheidsbeginsel. In: Van wet naar recht, Scheltens-bundel, Kluwer, 1984, blz. 192.

164. R.H.Happé, Gelijkheidsbeginsel in ethisch perspectief, Geschriften voor de belastingwetenschap, no 178, Kluwer, 1989, blz. 16.

165. R.H. Happe, Gelijkheidsbeginsel in ethisch perspectief, Geschriften voor de belastingwetenschap, no 178, KJuwer, 1989, blz. 18. 
is wat het afwegingsmechanisme - dat een nadere rangorde tussen de beginselen moet aangeven - in concrete gevallen inhoudt? ${ }^{160}$

Echter bij het formuleren van een gelijkheidsbeginsel voor de wetgever loopt men de kans in een cirkelredenering terecht te komen. Burkens: 'De wetgever moet gelijke gevallen gelijk behandelen. De wetgever treft een regeling waarin hij bepaalde gevallen als onderling gelijk aanmerkt; deze worden dan naar rechtsgevolg gelijk behandeld. Waarom meent de wetgever, dat hij de desbetreffende gevallen als gelijk moet aanmerken? Omdat hij meent, dat deze gevallen gelijk dienen te worden behandeld. Voor de wetgever zijn derhalve gelijk de gevallen, die zijns inziens gelijk moeten worden behandeld. Ergo: het recht moet gelijke gevallen gelijk behandelen; en gelijk zijn.de gevallen, die gelijk behandeld dienen te worden'. ${ }^{167}$

Dit citaat is een illustratie van een beschrijving van het gelijkheidsbeginsel vanuit de distributieve rechtvaardigheid. De hier geopperde gedachtengang kan ik volledig onderschrijven, maar naar mijn mening moet de vraag naar het waarom, naar de motieven,'van de wetgever om de naar zijn mening gelijke gevallen gelijk te behandelen worden gesteld. Deze worden veelal duidelijk na bestudering van de parlementaire geschiedenis. Pas indien zo'n onderzoek naar de motieven van de wetgever is gedaan, kan een oordeel over het in acht nemen of het juist niet in acht nemen van het gelijkheidsbeginsel door de wetgever worden gegeven. Een laatste opmerking rest hier nog. Het gelijkheidsbeginsel is in feite het beginsel van de fundamentele rechtsgelijkheid. Het is een beginsel van de communatieve rechtvaardigheid. De eis gelijke gevallen gelijk te behandelen is een distributieve rechtvaardigheid waarover niets op theoretisch niveau te zeggen valt. ${ }^{168} \mathrm{De}$ meeste auteurs beschrijven het gelijkheidsbeginsel vanuit de distributieve rechtvaardigheid, maar kunnen geen enkel criterium aangeven, waardoor uit de cirkelredenering kan worden gekomen.

\section{Waar is het gelijkheidsbeginsel omschreven?}

Ten eerste in de Grondwet. Artikel $1 \mathrm{GW}$ luidt: 'Allen die zich in Nederland bevinden, worden in gelijke gevallen gelijk behandeld. Discriminatie wegens godsdienst, levensovertuiging, politieke gezindheid, ras, geslacht of op welke grond dan ook, is niet toegestaan.' Met de plaats van het artikel in de Grondwet

166. R.H. Happé, Gelijkheidsbeginsel in ethisch perspectief, Geschriften voor de belastingwetenschap, no 178, Kluwer, 1989, blz. 18.

167. C. Burkens, t.a.p., blz. 59.

168. 'Het gaat bij deze discussies over de invulling van het juridische gelijkheidsbeginsel vaak om de aanvaardbare mate van maatschappelijke en juridische ongelijkheid.' 'Het gaat niet meer om formele gelijkheid voor de wat ten einde 'vrijheid om...' te bereiken, maar om materiëlc gelijkheid door de wet, tencinde 'vrijheid van...' te bereiken.' R. Holtmaat, Met zorg eea recht? een analyse van het politick-juridisch vertoog over bijstandsrecht, W.E.J. Tjeenk Willink, 1992, blz. 272 en noten 37 en 39. 
is overigens niet gezegd dat dit in een grondrecht vastgelegd beginsel een hogere prioriteit dient te worden toegekend dan de andere grondrechten. ${ }^{169}$

Het gelijkheidsbeginsel is behalve in de Grondwet ook in verscheidene verdragen omschreven. Door de rechter is aan deze bepalingen directe werking toegekend.

Bij voorbeeld artikel 26 van het zogenaamde BuPo-verdrag ${ }^{170}$ : ‘Allen zijn gelijk voor de'wet en hebben zonder discriminatie aanspraak op gelijke bescherming door de wet. In dit verband verbiedt de wet discriminatie van welke aard ook en garandeert een ieder gelijke en doelmatige bescherming tegen discriminatie op welke grond ook, zoals ras, huidskleur, geslacht, taal, godsdienst, politieke of andere overtuiging, nationale of maatschappelijke afkomst, eigendom, geboorte of ander- status.' Het verdrag heeft rechtstreekse werking in het Nederlandse rechtsstelsel. ${ }^{171}$ Artikel $26 \mathrm{BuPo}$ geeft een norm voor de toepassing van wettelijke voorschriften en voor de inhoud van die voorschriften. ${ }^{172}$

Op grond van genoemd verdrag moet de fundamentele gelijkwaardigheid van ieder individu ten allen tijde in acht worden genomen. Op geen enkele grond valt een inbreuk op deze gelijkwaardigheid te rechtvaardigen. ${ }^{173}$ In de Wet IB 1964. mag soms op gronden een ongelijke behandeling worden voorgestaan met als motief de doelmatigheid. ${ }^{174}$.

Een verdràgsartikel met dezelfde strekking is te vinden in het.Europees Verdrag tot bescherming van de rechten 'van de mens en de fundamentele vrijheden (verder te noemen: EVRM). Het verdragsartikel betreffende het gelijkheidsbeginsel is artikel 14 EVRM: 'Het genot van de rechten en vrijheden, welke in dit Verdrag zijn vermeld, is verzekerd zonder enig onderscheid op welke grond ook,

169. Vergelijk J.J. Oostenbrink, Vlagincidenten rondom artikel 1 van de Grondwet. In: Burger en overheid, Steenbeaktbundel, 1984, blz. 171.

170. Internationaal Verdrag inzake Burgerrechten en politieke rechten, New York, 19 december 1966, Trb. 1969, 99, Nederlandse vertaling: Trb. 1978, 177.

171. In het arrest van 8 juli 1988, BNB 1988/302 (het Studeerkamer-arrest) is artikel 26 BuPoverdrag voor het eerst in het Nederlandse belastingrecht toegepast. J.A. Smit, Over het verdrag van New York, het non-discriminatiebeginsel en de werkkameraftrek, Weekblad voor fiscaal recht, 1989, no 5853, blz. 93. Zie ook hoofdstuk 5, § 5.3.3.

$\mathrm{Zie}$ voor een gehonoreerd peroep op op.discriminatie als bedoeld in artikel 26 IVBPR met betrekking tot het belastingrecht HR 17 november 1993, BNB 1994/36. Zie ook noot van Brunt bij HR 11 november 1992, BNB 1993/62 inzake artikel 5, eerste lid Wet.IB 1964, tekst 1986 en HR 21 oktober 1992, BNB 1993/28, m.nt. Zwemmer (artikel 67, letter a, Wet IB 1964, tekst $1984 \mathrm{t} / \mathrm{m} 1986$ ).

172. Hetzelfde geldt voor art. $1 \mathrm{GW}$. Echter het oordeel of een wet in formele zin in overeenstemming is met art. $1 \mathrm{GW}$ is niet ter nadere beoordeling van de rechter. Gelijk in de praktijk, Rapport van de interdepartementale juridische werkgroep gelijkheidsbeginsel (IWEG), Uitgave van het Ministerie van Justitie, Stafafdeling Algemeen Wetgevingsbeleid, Den Haag, 1990, blz. 42 en 49. R.H. Happé, Gelijkheid: een kwestie van standpunt, Weekblad voor fiscaal recht 1991, no 5951, biz. 299.

173. Vergelijk de conclusie van A.G. Moltmaker bij het arrest van HR 8 juli 1988, BNB 1988/302, blz. 2008.

174. Een voorbeeld van een beslissing van de Hoge Raad waarin een grond, in casu discriminatie naar woonplaats, uit het oogpunt van doelnatigheid rechtvaardig wordt geacht, is het arrest van HR 19 december 1990, BNB 1991/78. in casu ging het om de alleenverdienerstoeslag. 
zoals geslacht, ras, kleur, taal, godsdienst, politieke of andere overtuiging, nationale of maatschappelijke afkomst, behoren tot een nationale minderheid, vermogen, geboorte of andere status. ${ }^{175}$

Artikel 14 EVRM levert geen zelfstandige grond voor een procedure op. Het artikel dient altijd in samenhang met een ander artikel van het Europese verdrag van de rechten van de mens te worden ingeroepen. Artikel 14 EVRM koppelt de inroepbaarheid van het gelijkheidsbeginsel aan het genot van de rechten en vrijheden die in het verdrag zijn neergelegd. ${ }^{176}$ Echter in de praktijk hebben zowel het Hof als de Commissie aan artikel 14 EVRM een vergaande verzelfstandiging toegekend. ${ }^{17}$

\section{iCriteria}

In hoeverre is de bovenstaande definitie van het gelijkheidsbeginsel bruikbaar? De definitie geeft namelijk geen nadere criteria. Wanneer zijn twee gevallen gelijk en onder welke omstandigheden dienen criteria hun gelding te hebben en te blijven houden? Welke criteria dient de wetgever in acht te nemen?

Vooropgesteld zij dat toepassing van het gelijkheidsbeginsel in tegenstelling tot andere grondrechten een belangenafweging inhoudt, Het beginsel stelt de eis dat er differentiatiecriteria àanwezig moeten zijn. De differentiatiecriteria, die door grondrechten beschermde rechten treffen, zijn discriminatoir. In de andere gevallen dient de belangenafweging, die tot de keuze van een bepaald criterium heeft geleid, afzonderlijk te worden beoordeeld. Dit laatste houdt de zgn. doelmiddel-toetsing in. Dat wil zeggen, beoordeéld wordt of het gemaakte onderscheid nuttig en nodig is ter verwezenlijking van het te bereiken doel. Bovendien dient een redelijke verhouding te bestaan 'tussen' de beoogde gevolgen voor de te dienen belangen enerzijds, en de nadelige gevolgen voor de andere mee te wegen belangen anderzijds. ${ }^{178}$.

Deze toetsing heeft veel overeenkomsten met de toetsing van het willekeurverbod en het evenredigheidsbeginsel. Deze twee laatste beginselen zijn belangrijk

175. Inzake belastingheffing heeft het Europese Hof voor de rechten van de Mens met betrekking tot artikel 14 EVRM onder andere het volgende geoordeeld. In de zaak Gudmundsson versus IJsland, Yearbook III (1960), (424) wordt duidelijk dat hat oordeel over de progressie in de belastingwetgeving een nationale aangelegenheid is en dat derhalve de rechter zeer marginaal op de redelijkheid toetst.

176. A.W. Heringa, Sociale grondrechten, T.M.C. Asser Instituut, 1989, blz. 304.

177. ' P. van Dijk, G.J.H. van Hoof, De Europese conventie in theorie en praktijk, Ars Aequi Libri, Rechten van de mens, 2 e druk, 1988, blz. 450 en 451 . Zie ook de Wet van 2 maart 1994, houdende algemene regels ter bescherming tegen discriminatie op grond van godsdienst, levensovertuiging, politieke gezindheid, ras, geslacht, nationaliteit, hetero- of homoseksuele gerichtheid of burgerlijke staat (Algemene wet gelijke behandeling), Stb. 1994, 230. In deze wet wordt een direct en indirect onderscheid op basis van genoemde kenmerken verboden. Zie echter ook artikel 4, onder $c$, inhoudende dat de wet onverlet laat het 'onderscheid dat gemaakt wordt bij of krachtens enige andere wet, welke voorafgaand aan deze wet in werking is getreden'. Overigens heeft de wet een beperkt toepassingsgebied (zie artikel 5).

178. E.M.H. Hirsch Ballin, t.a.p., blz. 145 en 146. 
'1. De rechter doet niets omdat een keuze moet worden gemaakt die niet binnen de rechtsvormende taak van de rechter valt;

2. De rechter doet niets omdat de discriminatoire wettelijke regeling inmiddels is gewijzigd of binnenkort zal worden gewijzigd;

3. De rechter laat de wettelijke bepaling buiten toepassing ${ }^{185}$;

4. De rechter legt de wettelijke regeling verdragsconform uit.

De rechterlijke toetsing komt niet verder dan de beantwoording van de vraag of het onderscheid in casu redelijk is of niet. ${ }^{187}$

In BNB 1994/36 waarin artikel 36, lid 2, onderdeel f Wet IB 1964 (tekst 1990) in strijd met artikel 26 BuPo wordt geacht, stelt de Hoge Raad de volgende denkbare oplossingen voor.

1. Het geheel buiten toepassing laten van de bepaling. 'Dit resultaat zou echter ernstig te kort doen aan de door de wetgever met de Wet van 27 april 1989, Stb. 1989, 123, beoogde beperking van de aftrekbaarheid van en vereenvoudiging van de wetstoepassing bij kosten als die welke verbonden zijn aan de kantoorruimte in de woning van de belastingplichtige, en verder gaan dan nodig is om de gesignaleerde ongelijkheid op te heffen.' (overweging 3.6.)

2. De bepaling buiten toepassing laten voor uitsluitend de inrichtingskosten e.d. ... 'Echter dan doet het resultaat, zij het in mindere mate, te kort aan de beoogde vereenvoudiging.' (overweging 3.7.)

3. 'Zolang een heroverweging als bedoeld in 3.7. (ten aanzien van het gewraakte artikel, MW) niet heeft plaatsgevonden, zal de Hoge Raad, ten einde de geconstateerde ongelijkheid ten aanzien van de inrichtingskosten e.d. ... zoveel als in zijn vermogen ligt, op te heffen alsmede toch zoveel als mogelijk tegemoet te komen aan de wens van de wetgever te komen tot vereenvoudiging en normering van de aftrek van kosten ..., bepalen dat in geval van een kantoorruimte in een eigen woning de in artikel 36 , lid 2, letter $\mathrm{f}$ van de Wet bedoelde huurwaarde wordt bepaald op het in artikel 42a, lid 9, van de Wet als huurwaarde aangeduide bedrag.'

185. Een voorbeeld waarin de rechter de bepaling buiten toepassing had kunnen laten, maar hij dat niet heeft gedaan doordat er een wetswijziging heeft plaatsgevonden, is het arrest HR 8 mei 1991, BNB 1991/196 m.nt. P. den Boer. In casu ging het om een verschil in behandeling bij toepassing van het autokostenforfait ingevolge de Wet IB 1964 en de Wet LB 1964. Een ander voorbeeld waarin de Hoge Raad oordeelt dat geen sprake is van een ongelijke behandeling, maar waarin tevens sprake is van een gewijzigde wet is HR 11 december 1991, BNB 1992/129 m.nt. Sinnighe Damsté.

186. R.H. Happé, Artikel 26 BuPo-verdrag, ofwel hoe het belastingrecht de maat wordt genomen, Weekblad voor fiscaal recht, 1990, no 5907, blz. 401. Happé toont het verschil aan met de besfissingen van de Centrale Raad van Beroep. Dit, zo stelt hij, omdat het sociaal verzekeringsrecht nauwe verwantschap vertoont met het belastingrecht. De Centrale Raad van Beroep blijkt de rechtsvormende taak veel ruimer op te vatten dan de Hoge Raad. Hiermee zou de rechtsbescherming van de burger meer gebaat zijn.

Vergelijk ook A.W. Heringa, die de volgende mogelijkheden van de rechter opsomt: 'vernietiging', 'buitentoepassing verklaring', 'zelf regelend optreden'. A.W. Heringa, t.a.p., blz. 185.

187. J. Mulder, t.a.p., blz. 81. 
Opmerkelijk is dat de Hoge Raad verder gaat dan de vier bovengenoemde mogelijkheden. De Hoge Raad is volgens Wattel in casu op de stoel van de wetgever gaan zitten. Het rechtscollege had het bij de constatering dat er sprake is van een schending van het gelijkheidsbeginsel moeten laten. ${ }^{188}$ Zwemmer kan zich niet aan de indruk onttrekken dat 'het gebrek aan overtuigingskracht van de argumentatie door de sterkte van de gebruikte bewoordingen moet worden gemaskeerd'. ${ }^{189}$

In geval van strijd met artikel 14 EVRM en artikel 26 BuPo is de staat aansprakelijk. Deze moet dan passende maatregelen nemen. Het is de vraag hoeveel tijd de wetgever mag nemen voor het nemen van de desbetreffende maatregelen. Eerst dient naar het verdrag zelf te worden gekeken. Mocht dit geen uitkomst bieden, dan is redelijkheid hẹt criterium. ${ }^{190}$.

\subsection{2}

Het gelijkheidsbeginsel in het belastingrecht.

Het gelijkheidsbeginsel speelt een belangrijke rol in de wetgeving in het algemeen, maar speelt dit beginsel eveneens een belangrijke rol in de belastingwetgeving?

Discriminatie in het fiscale recht vindt veelal plaats omwille van budgettaire overwegingen. Financiële randwoorwaarden bepalen uiteindelijk de ruimte waarin een regeling tot stand kan worden gebracht en uitgevoerd. ${ }^{191}$ Dit lijkt me reden om extra allert te zijn op een juíste toepassing van het gelijkheidsbeginsel. Veelal wordt de nadruk gelegd op het gebruik van het gelijkheidsbeginsel inclusief het evenredigheidsbeginsel. De lasten opgelegd door de belastingheffer dienen zo evenredig mogelijk te worden verdeeld.

Is in de Grondwet een regeling van een rechtvaardige verdeling getroffen? De oude Grondwet omschreef een belangrijke eis voor de belastingheffing. Het van belang zijnde artikel in de oude Grondwet was artikel $189 \mathrm{GW}$ : 'Geene priviliegen kunnen in het stuk van belastingen worden verleend'.

188. De wetgever kan een asymmetrische behandeling niet afdoen net een simpel beroep op 'doelmatigheid', aldus Wattel. P.J. Wattel in zijn noot bij HR 17 november 1993, BNB 1994/36, blz. 280 en 281.

189. J.W. Zwemmer in zijn noot bij HR 17 november 1993, AA 1994, blz. 533. De annotator vraagt zich af of de door de Hoge Raad gegeven oplossing binnen de rechtsvormende taak van de rechter valt. J.W. Zwemmer, t.a.p., blz. 534.

190. A.W. Heringa, t.a.p., blz. 187 en 188.

191. Tj. Gerbranda, M. Kroes, Grondrechten evaluatieonderzoek, Documentatierapport (1), N.J.C.M., 1991, blz. 1-314. Volgens A-G Moltmaker mag de wetgever budgettaire overwegingen geen uitsluitende rol laten spelen bij de beoordeling of een verschil in behandeling gerechtvaardigd is. Deze vraag moet worden onderscheiden of de rechter een niet te rechtvaardigen verschil in behandeling mag nalaten te corrigeren op basis van budgettaire overwegingen. BNB 1988/302, blz. 2008 en 2009. Zie ook J.A.G. van der Geld, t.a.p., blz. 27 en 28. 
Volgens W. Scholten is een privilege: 'iedere begunstiging van een bepaalde contribuabele of groep van contribuabelen met de enkele bedoeling van deze belastingplichtige(n) met voorbij gaan van alle anderen en met voorbij gaan van het algemeen belang te bevoordelen. Het doel van de fiscale begunstiging is dus van groot gewicht. ${ }^{192} \mathrm{Bij}$ het privilege gaat het om ongelijkheid in plaats van gelijkheid. Deswege is een maatregel welke gelijkheid van recht beoogt geen privilege scheppende maatregel. W. Scholten zag artikel $189 \mathrm{GW}$ als een getuigenis van een rechtsbeginsel. ${ }^{193}$ Thans is dit artikel afgeschaft.

Het voor dit moment van belang zijnde artikel in de Grondwet is artikel 104 GW: 'Belastingen van het Rijk worden geheven uit kracht van een wet. Andere heffingen van het Rijk worden bij wet geregeld.' In dit artikel is niets meer van het gelijkheidsbeginsel te vinden. Betekent dit dat het gelijkheidsbeginsel geen werking heeft? Zeer zeker niet, immers artikel 1 van de Grondwet, betreffende het gelijkheidsbeginsel geldt evenzeer voor de belastingwetgever. ${ }^{194}$

Het gelijkheidsbeginsel speelt zeker een belangrijke rol in de belastingwetgeving, daar het voor de aanvaarding van de belastingheffing zeer belangrijk is dat er een gelijkheid van de burger voor de belastingwet is. ${ }^{195}$ Met het opleggen van de lasten dient de belastingwetgever het gelijkheidsbeginsel in acht te nemen. Vanwege deze gelijkheid kent de Nederlandse inkomstenbelasting geen echte subjectieve vrijstellingen.

Sinds het Studeerkamer-arrest (HR 8 juli 1988, BNB 1988/302) is de toepasselijkheid van artikel 26 BuPo vastgesteld. Een strijd met artikel 26 BuPo kan een vorm zijn van een inbreuk op het draagkrachtbeginsel; bij voorbeeld indien de noodzakelijke minimumbehoeftenvoorziening door een regeling wordt aangetast. $^{196}$

Wanneer over het gelijkheidsbeginsel wordt gesproken, is er altijd sprake van een bepaalde relatie: een instantie of persoon is de mening toegedaan een geval gelijk of ongelijk te behandelen. Bepaalde criteria worden gebruikt om al dan niet een onderscheid te maken. Van Overbeeke stelt - net als Happé - dat de hier bedoelde relaties worden gezien vanuit verschillende gezichtspunten. In geval van het belastingrecht is dat vanuit het gezichtspunt van de overheid èn vanuit het gezichtspunt van de belastingplichtigen. ${ }^{197}$ Het gelijkheidsbeginsel

192. W. Scholten, Geen privilegiën in het stuk der b̧elastingen, Weekblad voor fiscaal recht, 1958, no 4414, blz. 702 en 703.

193. W. Scholten, t.a.p., blz. 703.

194. Zie onder andere C. Burkens, t.a.p., blz. 58 e.v..

195. H. Smit, t.a.p., blz. 192. Vergelijk ook M.P. van Overbeeke, t.a.p., blz. 66, die stelt, dat de belastingheffing objectief gelijkmatig dient te zijn.

196. R.H. Happé, Artikel 26 BuPo-verdrag, ofwel hoe het belastingrecht de maat wordt genomen, Weekblad voor fiscaal recht, 1990, no 5907, bł 321 en 322. R.H. Happé, Gelijkheidsbeginsel in ethisch perspectief, Geschriften voor de belastingwetenschap, no 178, Kluwer, 1989, blz. 17.

197. De fiscus heeft de plicht de Einzelfallgerechtigkeit te verheffen tot Normgerechtigkeit; een concreet geval tot een algemene regel te maken. R.H. Happé, Gelijkheidsbeginsel in ethisch perspectief, Geschriften voor de belastingwetenschap, no 178, Kluwer, 1989, blz. 12. Detiger: 
heeft betrekking op de inhoud van een wettelijke regeling. Hierboven is al aangetoond dat het gelijkheidsbeginsel alleen kan worden toegepast met behulp van verifieerbare criteria. Welke zijn de criteria van het gelijkheidsbeginsel in het kader van de belastingheffing?

Het is moeilijk twee gelijke gevallen te constateren. Niet alle criteria zijn relevant. Een eerste selectie wordt gemaakt door de wettelijke regeling zelf. De tekst van de regeling kan wellicht een aanknopingspunt zijn, zij het dat dat met betrekking tot het gelijkheidsbeginsel vaak niet veel zal opleveren. Een tweede selectie wordt gemaakt door het doel van de wettelijke regeling. Dit doel kan uit de wetsgeschiedenis en toepassingen van de wet duidelijk worden. ${ }^{198} \mathrm{Om}$ het doel van de wet te achterhalen, dienen derhalve niet alleen de wijzigingswetten, doch de gehele achterliggende geschiedenis van de desbetreffende fiscale wetgeving te worden onderzocht. Voor afwijking van de bestaande wetgeving dienen zwaarwegende motieven te worden aangevoerd.

Hiermee is nog niet gezegd, dat het doel makkelijk te achterhalen is. Be bestudering van de wetsgeschiedenis kan niet al te veel problemen opleveren, maar het achterhalen van de maatschappelijke ontwikkelingen des te meer. Bovendien is het mogelijk dat de maatschappelijke ontwikkelingen en de ontwikkelingen in de politiek - die uiteindelijk toch een van de belangrijkste elementen is bij het proces van de belastingwetgeving - niet geheel op elkaar aansluiten. Het laatste is van een geheel complex van moeilijk te doorgronden factoren afhankelijk. Hierdoor krijgt het gelijkheidsbeginsel een relatieve waarde; het gelijkheidsbeginsel is niet absoluut geldend.

Daarnaast wordt het beginsel begrensd door het algemeen belang ${ }^{199}$ en andere beginselen zoals het vertrouwensbeginsel, het rechtszekerheidsbeginsel, de gerechtigheid, het legaliteitsbeginsel en de doelmatigheid.

Ter illustratie: het toepassen van het rechtszekerheidsbeginsel kan leiden tot een inbrepuk op het gelijkheidsbeginsel. Een rechtsstaat accepteert de op de wet gebaseerde ongelijkheid van het verleden en neemt deze ongelijkheid voor de toekomst weg. De rechtszekerheid bestaat in dat geval uit het accepteren van de

'... is er voor recht, gedragen door een gemeenschappelijke overtuiging, slechts één gemeenschappelijke maatstaf, het gelijkheidsbeginsel dat zich verschillend openbaart naar gelang van de situatie - in casu de relatie tussen staat en individu - waarin het tot gelding moet worden gebracht.' J.G. Detiger, Belastingbeginselen, Smeetsbundel, 1967, blz. 107.

198. R.H. Happé, Artikel 26 BuPo-verdrag, ofwel hoe het belastingrecht de maat wordt genomen, Weekblad voor fiscaal recht, 1990, no 5907, blz. 392.

199. - R.H. Happé, Gelijkheidsbeginsel in ethisch perspectief, Geschriften voor de belastingwetenschap, no 178, Kluwer, 1989, blz. 17. 
in de verleden voorkomende ongelijkheden. ${ }^{200}$ Aldus heeft het gelijkheidsbeginsel een relatieve waarde. ${ }^{201}$

Geppaart heeft de betrekkelijkheid van het gelijkheidsbeginsel aardig weergegeven. De betrekkelijkheid is ten eerste hierin gelegen dat men niet kan zeggen wạnneer gevallen gelijk zijn en, ten tweede hierin dat toepassing van het gelijkheidsbeginsel nog niet impliceert dat het toe te passen recht goed is. Ten derde mag toepassing van het gelijkheidsbeginsel niet leiden tot grote vrijheidsbeperkingen, aldus Geppaart. ${ }^{202}$

\section{Het gelijkheidsbeginsel in de jurisprudentie}

Wat betekent het gelijkheidsbeginsel in concreto voor het belastingrecht? De (recente) jurisprudentie levert het volgende beeld.

1. Een belangrijk arrest inzake de gelijke behandeling van de gehuwde man met de gehuwde vrouw en van gehuwden met ongehuwd samenlevenden is het Tandartsvrouw-arrest (HR 27 september 1989, BNB 1990/61, inzake artikelen 23 en 26 AWR, artikel 5, eerste en tweede lid Wet IB 1964 (tekst 1981)).

Vooropgesteld zij dat de man als belastingplichtige werd aangewezen. De Hoge Raad beslist in casu dat niet iedere ongelijke behandeling van gelijke gevallen een schending oplevert van artikel $26 \mathrm{BuPo} .{ }^{203} \mathrm{Er}$ dient dan wel een objectieve

200. Vergelijk J.W. Zwemmer, De rechtsongelijkheid van de rechtsstaat. In: Quod Licet Jovi, PED, 1983, blz. 29. Het ontgaan van de belastingen moet volgens hem geoorloofd zijn. Zie in geval van een botsing van het legaliteits- met het gelijkheidsbeginsel, Happe. In sommige gevallen is niet de formele gelijkheid c.q. het legaliteitsbeginsel van belang, maar de materiële gelijkheid. R.H. Happé, Gelijkheidsbeginsel in ethisch perspectief, Geschriften voor de belastingwetenschap, no 178, Kluwer, 1989, blz. 11 en 12.

201. M.P. van Overbeeke, Enige opmerkingen over discriminatie en belastingrecht. In: Gelijkheid, gelijkwaardigheid, discriminatie en het recht, P.L. Dijk, Rede VU, 1985, blz. 66.

Vergelijk ook de mening van A:W. Heringa en van R.E. de Winter, omtrent de gelding van het gelijkheidsbeginsel. De Winter en Heringa zijn van mening dat het gelijkheidsbeginsel een relatieve waarde heeft, omdat het nu eenmaal niet mogelijk is om alles door de overheid te laten controleren. Een zekere schaarste is in de samenleving aanwezig en derhalve kan het gelijkheidsbeginsel niet geheel uit de verf komen; vandaar de term relatieve waarde. A.W. Heringa, R.E. de Winter, De relaticve waarde van het gelijkheidsbeginsel, Tijdschrift voor Openbaar bestuur, 1982, no 17, blz. 509.

202. Ch.P.A. Geppaart, De betrekkelijke waarde van het gelijkheidsbeginsel. In: Quod Licet Jovi, 1983, blz. 10-13. Geppaart noemt nog een vierde element, nl.: het toetsingverbod van artikel $120 \mathrm{GW}$. Dit kan worden onzeild door de werking van artikel $26 \mathrm{BuPo}$.

203. Een ander voorbeeld van toetsing van artikel $26 \mathrm{BuPo}$ is de uitspraak van Hof 's-Hertogenbosch 5 februari 1991, BNB 1992/254 (artikel S, lid 5 Wet IB 1964, tekst 1984), waarin werd beslist dat een onderscheid tussen eigenaren/huurders die in Frankrijk wonen met in Nederland woonachtige eigenaren/huurders objectief en redelijk is. Interessant is de toepassing van artikel $26 \mathrm{BuPo}$ in geval van buitenlandse belastingplichtigen. Dezen missen veelal bepaalde faciliteiten. Vergelijk P. den Boer in zijn annotatie van het arrest van HR 19 december 1990, BNB 1991/78.

De Hoge Raad heeft een uitspraak van het Hof van Justitie van de Europese Gemeenschappen te Luxemburg ex artikel 177 EEG-verdrag gevraagd omtrent de eventuele strijdigheid van artikel S3b Wet IB 1964 met artikel 48 Verdrag tot oprichting van de EG. HR 23 maart 1994, BNB 1994/154, V-N 1994, blz. 1381. 
en redelijke rechtvaardiging te bestaan voor het bestaan van de ongelijke behandeling. De ongelijke behandeling van de gehuwde vrouw en haar man inzake de samenvoeging van inkomens is een objectief en gerechtvaardigd onderscheid. De wetgever mocht ter wille van de eenvoud en de praktische uitvoerbaarheid de man als belastingplichtige aanwijzen. Daarnaast rechtvaardigt zulks het feit dat in het overgrote deel van de huwelijken het stelsel van de algemene gemeenschap van goederen wordt gehanteerd en in dat geval maakt het niet uit bij wie de inkomensbestanddelen worden belast.

De Hoge Raad overweegt verder dat 'voor zover belanghebbende bedoelt te betogen dat het bepaalde in artikel 5, leden 1 en 2 (tekst 1981) van de Wet in verband met het in de artikelen 14 EVRM en 26 IVBPR neergelegde gelijkheidsbeginsel strijdig is met artikel 1 van meergenoemd Protocol (Eerste Protocol bij het EVRM, MW), mist dit betoog zelfstandige betekenis, naast belanghebbendes beroep op artikel 26 IVBPR.'

De bepaling dat in tegenstelling tot de gehuwde man de gehuwde vrouw niet een recht van bezwaar en beroep heeft, levert een niet te rechtvaardigen onderscheid op, aldus de Hoge Raad. ${ }^{204}$ 
2. In dit kader is een uitspraak van het Hof 's-Gravenhage ${ }^{205}$ belangrijk. In casu gaat het om een aftrek van een hypothecaire lening van een gehuwde vrouw, die aan de man wordt toegerekend. Deze toerekening geschiedt ook bij de premieheffing volksverzekeringen. De berekening van het premie-inkomen op basis van artikel 5, lid 1 Wet IB 1964 wordt in strijd geacht met het gelijkheidsbeginsel, nl. een ongelijke behandeling van man en vrouw. De vraag is of de berekening van de AOW-premie in strijd is met de Derde EG-richtlijn en of de berekening van de AWW-premie in strijd is met artikel $26 \mathrm{BuPo}$. Het hof oordeelt van niet, daar er weliswaar sprake is van gelijke gevallen, doch een objectieve rechtvaardigingsgrond aanwezig is. De rechtvaardigheidsgrond wordt gevonden in een doelmatige heffing.

3. De gelijke behandeling van ongehuwd samenlevenden met gehuwden levert in de praktijk de meeste problemen op. ${ }^{206}$ Niet duidelijk is of, en wanneer, de

205. Hof 's-Gravenhage 6 mei 1991, NJCM-bulietin, 1992, no 17-8, blz. 874 e.v.. Zie ook HR 11 november 1992, BNB 1993/62, m.nt. Brunt. In dit arrest ging het om artikel 5, eerste lid Wet IB 1964 (tekst 1986). Ook ingeval dat gehuwden buiten gemeenschap van goederen zijn gehuwd, wordt samenvoeging geoorloofd geacht. Overwegingen van doelmatigheid vormen cok hier een objectieve en redelijke rechtvaardiging voor de onderhavige ongelijkheid. Burgerrechtelijk hebben partijen gekozen voor een uitsluiting, fiscaalrechtelijk moet de man de belasting van de vrouw betalen. De Hoge Raad is van oordeel dat in de memorie van toelichting bij de tweede fase van de Tweeverdienerswet (Wet van 30 december 1983, Stb. $690)$ de overwegingen met betrekking tot doelmatigheid voldoende zijn om tot een objectieve en redelijke rechtvaardiging voor de ongelijkheid te kunnen concluderen.

Andere voorbeelden waarin niet tot een ongelijke behandeling wordt beslist, omdat een objectieve en redelijke rechtvaardiging aanwezig is, zijn HR 16 september 1992, BNB 1993/21, m.nt. Brunt en HR 21 oktober 1992, BNB 1993/28, m.nt. Zwemmer.

Aparte vermelding verdient het arrest van de Hoge Raad van 4 november 1992, BNB 1993/102 inzake artikel 37, tweede lid AOW, artikel 41, tweede lid AWW jo artikel 4, eerste lid Richtlijn van 19 december 1978, nr. 79/7/EEG en artikel 5, eerste lid Wet IB 1964 (premieheffing volksverzekeringen 1988). De Hoge Raad overweegt in 3.6.: 'Het vorenoverwogene brengt mee dat niet kan worden gezegd dat de bestreden regeling, ook indien het daaruit voor belanghebbende voortvloeiende nadeel, onder overigens gelijke onstandigheden, aanzienlijk meer vrouwen dan mannen zou treffen een niet geoorloofde onderlinge ongelijke behandeling van mannen en vrouwen oplevert.' Het motief inzake de eenvoudige afleiding van de premieheffing van het inkomen levert geen ongeoorloofde ongelijke behandeling tussen mannen en vrouwen op, aldus de Hoge Raad. Vergelijk de noot van W.A. Sinninghe Damsté, die van mening is dat de Hoge Raad gelijk heeft, daar anders het gehele stelsel van de premieheffing op losse schrocven zou worden gezet. (Zie voor een soortgelijke redenering de conclusic van A-G Moltmaker bij het arrest van de HR 27 september 1989, BNB 1990/61). HR 4 november 1992, BNB 1993/102, blz. 793 en 794. Sinninghe Damsté stelt dat zolang het draagkrachtbeginsel aanwezig is, er een spanning tussen dat beginsel en het gelijkheidsbeginsel zal blijven bestaan. W.A. Sinninghe Damsté, t.a.p., blz. 794.

206. Een vrij recent arrest dat weliswaar de vermogensbelasting betreft, maar dat gezien de samenhang tussen vermogens- en inkomstenbelasting van belang is, is het arrest van de Hoge Raad van 15 september 1993 betreffende artikel 5 VB 1964 (tekst 1982), FED 1993/827 m.nt. J.A. Smit, BNB 1993/344, m.nt. J.W. Zwemmer. Het vermogen wordt toegerekend aan de belastingplichtige aan wie de inkomsten uit vermogen worden toegerekend. De Hoge Raad oordeelt dat er geen strijd is met artikel $26 \mathrm{BuPo}$, daar een objectieve en en redelijke rechtvaardigingsgrond voor de ongelijke behandeling aanwezig is. De objectieve en redelijke 
ongehuwd samenlevenden met de gehuwden moeten worden gelijkgesteld. De wetgever en rechter hinken hier op twee gedachten; het ene moment worden zij wel en het het andere moment worden zij niet gelijkgesteld. In het Tandartsvrouw-arrest is de ongelijke behandeling van gehuwden met ongehuwd samenlevenden geoorloofd omdat het huwelijk een hechtere economische band voorstelt dan de ongehuwde samenleving. ${ }^{207}$

Belangrijk in dit verband is het rapport Leefvormen van de Commissie voor de Toetsing van wetgevingsprojecten. Er bestaat een verscheidenheid aan regelingen en behandelingen van ongehuwd samenlevenden. Een algehele individualisering wordt afgewezen. De commissie kiest voor een formeel criterium, een registratie, in plaats van een materieel, de aanwezigheid, van een gezamenlijke huishou-

rechtvaardigingsgrond wordt gevonden in de het feit de gehuwde man en vrouw in fiscaal opzicht een economische eenheid vormen; de wetgever mag ter wille van de eenvoud en de uitvoerbaarheid van de wet in redelijkheid één van hen aanwijzen als belastingplichtige. Hier wordt uitgegaan van de gezamenlijke draagkracht die gehuwden hebben, $\infty$ indien sprake is van een buiten gemeenschap van goederen gesloten huwelijk. In het laatste geval wijkt het streven naar individualisering voor doelmatigheid. Smit constateert een spanning tussen het privaatrecht en belastingrecht. Zie Smit in zijn noot, FED 1993/827.

Hetzelfde wordt gecordecld over artikel 5 Wet VB 1964, huidige tekst, HR 15 september 1993, BNB 1994/7.

Zie ook het arrest HR 19 mei 1Q93, BNB 1993/241, m.nt. J.W. Zwemmer inzake artikel 24 Successiewet 1956 (tekst 1981). In dat arrest wordt geconcludeerd dat er geen ongelijke behandeling van gehuwden en ongehuwd samenlevenden is, daar er een redelijke en objectieve rechtvaardigingsgrond is. Deze grond wordt gevonden in redenen van uitvoerbaarheid.

207. R.H. Happé, Artikel 26 BuPo-verdrag, bfwel hoe het belastingrecht de maat wordt genomen, Weekblad voor fiscaal recht, 1990, no 5907, blz. 389-390. Let wel, dat de regels inzake de samenvoeging met ingang van 1984 zijn gewijzigd. Zie voor een al dan niet gelijke behandeling van gehuwden met ongehuwde samenlevenden de volgende twee uitspraken. Hof 's-Gravenhage 16 oktober 1986, KG 1987, 15: '... Ook als is sprake van een duurzame relatie en van samenleven in gezinsverband, dat neemt niet weg dat het samenleven in een dergelijke relatie niet alleen in juridisch opzicht (...). wezenlijk verschilt van het huwelijk, doch ook in brede maatschappelijke kringen zowel in Nederland als daarbuiten als wezenlijk anders dan een huwelijk wordt beschouwd.' Zie echter de uitspraak van de CRvB van 13 november 1986, TAR 1987, 13, waarin sprake is van een notarieel samenlevingscontract: '.... dat de rechtsontwikkeling op het onderhavige terrein zover is voortgeschreden dat ten aanzien van de in dit geding aan de orde zijnde voorzieningen de gehuwden enerzijos en de op basis van een notariecl samenlevingscontract in een gemeenschappelijke huishouding samenwonenden anderzijds niet meer als ongelijke gevallen kunnen worden aangemerkt ...' 
Samengevat: de gehuwden vormen in fiscaal opzicht een economische eenheid, ongeacht of zij buiten gemeenschap van goederen zijn gehuwd of niet. Een beroep op een gelijke behandeling via artikel 26 BuPo en artikel 14 EVRM is tot nu toe niet gehonoreerd. Ter wille van de eenvoud kan de belastingwetgever éen belastingplichtige aanwijzen. Daarvoor is een objectieve en redelijke rechtvaardigingsgrond aanwezig.

4. In een vrij recent arrest waarbij het gelijkheidsbeginsel en het draagkrachtbeginsel betrokken zijn, wordt door de Hoge Raad beslist dat het niet meer honoreren van de alleenstaandetoeslag door de fiscale wetgever geen strijd oplevert met artikel $26 \mathrm{BuPo}^{210} \mathrm{De}$ ongelijke behandeling tussen de alleenstaandetoeslag en de toeslagen voor alleenstaande verzorgende ouders en alleenverdieners is gerechtvaardigd daar, bij de groep alleenstaanden in tegenstelling tot de twee andere groepen geen financiële lasten meebrengende gezinsleden aanwezig zijn. 'Op grond hiervan kon de wetgever in redelijkheid oordelen dat uit oogpunt van draagkracht een verschil in belastingvrije sommen gerechtvaardigd is.'

In vergelijking met de tweeverdieners krijgen de alleenstaanden dezelfde belastingurije som. De draagkracht van beide groepen is echter verschillend. De

208. Twee opties zijn mogelijk, een zgn. 'lichte' en een zgn. 'zware' registratie. Een 'lichte' registratie houdt in dat er een Gemeentelijke basisadministratic persoonsgegevens plaatsvindt, met vooral publiekrechtelijke rechtsgevolgen; een 'zware' houdt in een registratie in de burgerlijke stand met ook privaatrechtelijke rechtsgevolgen. Tweede Kamer, vergaderjaar 19911992, 22 700, no 1, blz. 2. Tweede Kamer, vergaderjaar 1991-1992, 22 700, no 1, blz. 6.

De regering wil eerst een uitgebreid onderzock van de fraudegevoeligheid, de financiële consequenties en de benadering van de werkelijklieid door de registratie alvorens tot besluitvorming over te gaan. Dit onderzoek is er geweest. De regering is niet voor een 'lichte' registratie. Zie onder andere Tweede Kamer, vergaderjaar 1992-1993, 22 700, no 3, blz. 5. De beste mogelijkheid voor registratie is een met behulp van de Gemeentelijke basisadministratie persoonsgegevens (GBA) rechtstreckse gegevensuitwisseling tussen betrokken uitvoeringsorganen over de leefvorm. Tweede Kamer, vergaderjaar 1993-1994, 22 700, no 4, blz. 2.

De registratie dient alleen open te staan voor mensen 'tussen wie een huwelijksbelemmering bestaat, hetzij op grond van bloedverwantschap, hetzij omdat zij van hetzelfde gesiacht zijn', aldus de regering. Tweede Kamer, vergaderjaar 1992-1993, 22 700, no 3, blz. 5. Een gevolg voor de inkomstenbebelasting is dat de toerekening van niet-persoonlijke inkomensbestanddelen - die thans slechts bij gehuwden plaatsvindt, ook bij de geregristreerde personen plaatsvindt. Tweede Kamer, vergaderjaar 1992-1993, 22 700, no 3, blz. 7.

Thans is, mits voldaan aan een aantal cisen cen gelijkstelling van een geregistreerd samenlevingsverband met een huwelijk mogelijk. De rechtsgevolgen van de registratie en huwelijk zijn in publiekrechtelijk opzicht, zoals bij voorbeeld voor belastingen, volledig dezelfde. Mededeling in Staatscourant 11 oktober 1993, nr 194, blz. 1, V-N 1993, blz. 3157.

209. Tweede Kamer, vergaderjaar 1992-1993, 22 700, no 3, blz. 4.

210. In casu gaat het om artikel 54 Wet IB 1964, tekst 1990. HR 21 oktober 1992, BNB 1993/29, m.nt. J.W. Zwemmer. 
Hoge Raad: 'Voor zover als gevolg van die keuze uit een oogpunt van draagkracht sprake is van een gelijke behandeling van ongelijke gevallen, heeft de wetgever in redelijkheid kunnen oordelen dat voor die behandeling de uitvoerbaarheid van de wetgeving een objectieve en redelijke rechtvaardiging biedt.'

5. Als laatste wordt de asymmetrie tussen niet-aftrekbare kosten en onbelaste vergoedingen besproken (Het Koffiegeld-arrest, BNB 1988/259 en het Kinderopvang-arrest, BNB 1991/76). Ingeval de werkgever een onkostenvergoeding aan de werknemer geeft, staat de zakelijkheid van de gemaakte onkosten vast. Hier zou men kunnen spreken van een horizontale werking van grondrechten, maar dan wel van een horizontale werking met een extra accent. Er heeft nl. een verplaatsing van de toepassing van het gelijkheidsbeginsel plaatsgevonden van wetgever, een overheidsorgaan, naar een particulier, een werkgever. Het gelijkheidsbeginsel moet zowel door de werkgever als door de wetgever in acht worden genomen. Voor het overige verwijs naar de opmerkingen gemaakt in $\S$ 5.3.1-5.3.3.

De relatie van het gelijkheidsbeginsel met de verdelingsbeginselen

Het gelijkheidsbeginsel kan mijns inziens worden gezien als een 'overkoepelend' beginsel van de verdelingsbeginselen. ${ }^{211}$ Het gelijkheidsbeginsel impliceert een bepaalde mate van rechtvaardigheid, een gelijke verdeling van rechten èn verplichtingen. De verdelingsbeginselen impliceren dat de lasten zo rechtvaardig mogelijk - in de meeste gevallen betekent dat door middel van een juiste maatstaf gelijk - over de burgers worden verdeeld. ${ }^{212}$

De relatie van het gelijkheidsbeginsel met het draagkrachtbeginsel is als volgt. Het gelijkheidsbeginsel impliceert voor iedere belastingplichtige gelijkheid van belastingdruk. De gelijkheid van belastingdruk wordt bewerkstelligd door een maatstaf te kiezen die zo rechtvaardig mogelijk is. Deze maatstaf wordt gevonden in 'draagkracht'. Indien iedere belastingplichtige naar draagkracht in de lasten bijdraagt, is sprake van een gelijke behandeling van gevallen. Immers de draagkracht van een ieder levert hetzelfde resultaat op, nl. een gelijke belasting-

211. De volgende hiërarchische ladder van beginselen kan worden geschetst:

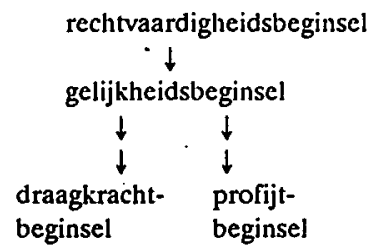

212. Vergelijk Dreesman, die stelt dat een verdelende rechtvaardigheid een toepassing is van het gelijkheidsbeginsel, terwijl doelmatigheid vaak ongelijkheid met zich brengt. A.C.R. Dreesman, gelijkheid en doelnatigheid: aspecten van een afruil. In: Maatschappelijke ongelijkheid; de overheid, een zorg, Nederlands Gesprekscentrum, 1987, blz. 13. 
druk. Heffing naar ieders draagkracht levert, in theorie, een voor ieder gelijke belastingdruk op.

Het ontgaan en afwentelen van belastingen is in dit verband belangrijk. Dit leidt tot rechtsongelijkheid, daar een belastingplichtige die zijn belastingschuld niet voldoet een grotere draagkracht 'overhoudt' dan degene die dat wel doet. De gelijkheid moet door de belastingwetgever in acht worden genomen, zij het niet als een voor alle tijden en plaatsen geldende norm. ${ }^{213}$

De relatie van het gelijkheidsbeginsel met het profijtbeginsel is als volgt. Stel: een individu heeft het genot van een bepaalde overheidsdienst. In vergelijking met iemand die het genot niet heeft, geniet het desbetreffende individu een voordeel. Wil sprake zijn van een gelijke behandeling van individuen door de overheid, dan moet het bevoordeelde individu het genot betalen. Voorwaarde is dat het genot in geldeenheden is uit te drukken. Het gelijkheidsbeginsel impliceert dat de burger moet betalen voor een door de overheid aan hem geleverde dienst. Met andere woorden, het bevoorrecht zijn of het belang dat de burger bij de geleverde dienst heeft, kent een prijs.

Bij het bovenstaande moet in acht worden genomen dat het gelijkheidsbeginsel vaak een sterke werking krijgt toegeschreven. De relatieve waarde van het gelijkheidsbeginsel mag niet uit het oog worden verloren.

\subsection{Doelmatigheid}

Tegenover rechtvaardigheid staat doelmatigheid. In het recht bestaat tussen rechtvaardigheid en doelmatigheid een compromis. ${ }^{214}$

Doelmatigheid kan worden omschreven als een verzameling van vele respectabele belangen. ${ }^{215}$ Doelmatigheid dient door de wetgever in acht te worden genomen, wil de belastingheffing enige mate van succes kennen. ${ }^{216} \mathrm{Hofstra}$ : $\mathrm{Te}$ vaak wordt vergeten dat de verantwoordelijkheid voor de doeltreffende uitvoering van een wettelijk systeem primair ligt bij de wetgever, die de belanghebbenden en

213. W.F. Nederstigt, t.a.p., blz. 269.

214. L.G.M. Stevens stelt het aldus: 'Voor de realisatie van een rechtvaardige belastingwetgeving is het noodzakelijk dat de economische ruilrechtvaardigheid en de verdeelrechtvaardigheid van het recht met elkaar in overeenstemming worden gebracht.' Uit: R.H.M.J. Offermans, t.a.p., blz. 764.

215. Slagter verstaat onder doelmatigheid onder andere rechtseenvoud en budgettaire overwegingen. W.J. Slagter, t.a.p., blz. 11.

216. H.J. Hofstra m.m.v. C. van Raad, Inieiding, t.a.p., blz. 184. Stevens stelt zowel aan de rechtvaardigheid als de docimatigheid de eisen van gelijkheid, evenredigheid en objectiviteit. L.G.M. Stevens, Belasting naar draagkracht, Kluwer, 1980, blz. 144. 
de uitvoerende organen niet mag opzadelen met wetteksten waaraan de doorsnee-burger geen touw meer kan vastknopen. ${ }^{217}$

Doelmatigheid in belastingheffing moet in verband met de zgn. 'excess burden' worden gezien. ${ }^{218}$ 'Excess burden' is het door fiscale verplichtingen verbonden aan economische activiteiten afzien van die activiteiten. De 'excess burden' komt bij belastingen naar winst en vermogen sterker naar voren dan bij kostprijsverhogende belastingen. ${ }^{219}$

In het onderzoek is de centrale vraag die met betrekking tot doelmatigheid speelt: Wordt doelmatigheid consequent gebruikt of wordt het begrip gebruikt naar gelang het desbetreffend belang van de fiscale wetgever daartoe aanleiding geeft? Dit belang kan zowel positief als negatief worden ingevuld.

\section{Definitie}

Welke elementen zijn typerend voor de omschrijving van doelmatigheid? De Langen sprak over doelmatigheid in de vorm van drie beginselen.

1. Het welvaartsbeginsel verlangt dat 'belasting aldus wordt geheven, dat de welvaart van het volk zo weinig mogelijk geschaad en zo veel mogelijk bevorderd wordt'. ${ }^{200} \mathrm{Bij}$ dit beginsel kan het gebruik van' nevendoeleinden worden ondergebracht.

2. Het beginsel van de minste pijn en het beginsel van de geoorloofde realisatie houden de uitvoering van het welvaartsbeginsel in. Het beginsel van de minste pijn houdt in, 'dat belasting aldus wordt geheven, dat het ontnemen van de beschikkingsmacht over zijn geldmiddelen aan de belastingplichtige zo weinig mogelijk pijn veroorzaakt? ${ }^{221}$

3. Het beginsel van de geoorloofde realisatie houdt in dat het streven van de wetgever erop gericht moet zijn, dat de andere vijf beginselen niet verder worden gerealiseerd dan geoorloofd is, en ook voor zover dat geoorloofd is. ${ }^{222}$

Grapperhaus spreekt over doelmatigheid als een noodzaak van drie elementen, t.w.: Economy, Effectiveness en Efficiency. 'Onder 'Economy' is daarbij te

217. H.J. Hofstra en L.G.M. Stevens, Inkomstenbelasting, t.a.p., blz. 575. Bij de behandeling van de Nota-Grapperhaus werd doelmatigheid als volgt omschreven: 'de doelmatigheid, die eist dat de regeling zoveel mogelijk eenvoudig is te begrijpen en gemakkelijk is toe te passen.' Tweede Kamer, vergaderjaar 1969-1970, 10 515, no 2, blz. 18.

218. Due en Friendländer onderscheiden drie soorten excess burden, t.w.:

'1. de 'factor excess burden' via uitstoting van arbeid of kapitaalgoederen;

2. de 'consumers excess burden' via substitutie-effecten in het consumptiepakket en;

3. 'production excess burden' door substitutie-effecten in de produktietechniek.' Ontleend aan L.G.M. Stevens, Belasting naar draagkracht, Kluwer, 1980, blz. 81, noot 60 .

219. W.F. Nederstigt, t.a.p., blz. 269. Cnossen stelt eenvoud gelijk aan doelmatigheid. 'Eenvoud in de fiscalitcit houdt in dat een gegeven opbrengst met een minimum aan kosten wordt gerealiseerd. Die kosten dienen ruim te worden gedefinieerd. $\mathrm{Zij}$ omvatten alle directe en indirecte offers die aan de inning en de naleving van de belastingen zijn verbonden.' $S$. Cnossen, Zicht op echte eenvoud, Weekblad voor fiscaal recht, 1990, no 5901, blz. 168.

220. W.J. de Langen, t.a.p., blz. 39.

221. W.J. de Langen, t.a.p., blz. 39.

222. W.J. de Langen, t.a.p., blz. 39. 
verstaan dat tegen minimale kosten hulpmiddelen worden verworven van een zodanige kwaliteit dat daarmee de gestelde doeleinden op een adequate wijze kunnen worden nagestreefd. 'Effectiveness' is een normatieve maatstaf voor het bereiken van resultaten bij het nastreven van die doeleinden, terwijl 'Efficiency" een normatieve maatstaf vormt voor het benutten van hulpmiddelen bij het streven naar die resultaten.' Eenvoud heeft een ondersteunende functie voor deze drie elementen. ${ }^{223}$

In het algemeen heerst de opvatting dat doelmatigheid een grotere invloed van tijd en plaats ondergaat dan rechtvaardigheid. ${ }^{224}$ Dit heeft mijns inziens te maken met het feit dat de rechtvaardigheidselementen op een hoger, en daarmee op een abstracter, niveau staan dan de doelmatigheidscriteria. Onder doelmatigheid kunnen vele uiteenlopende eisen worden begrepen. Door het uiteenlopen van die eisen lijkt het alsof doelmatigheid 'soepeler' is.

Indien doelmatigheid tegenover rechtvaardigheid staat, kan eveneens worden gezegd dat doelmatigheid tegenover het gelijkheidsbeginsel als een specifieke rechtvaardigheidseis staat.

$\mathrm{Er}$ is betoogd dat het doelmatigheidsbeginsel niet aan het gelijkheidsbeginsel tegengesteld is, maar een aanvulling daarop vormt. Dit wordt gemotiveerd door de eis dat sprake moet zijn van een doelmatig functionerende belastingdienst. Immers een ondoelmatige belastingdienst leidt tot willekeur. ${ }^{225}$

\section{Is doelmatigheid een beginsel?}

Over de vraag of de eis van doelmatigheid als een beginsel moet worden beschouwd, bestaan uitleenlopende meningen. Slagter meent dat de doelmatigheid als een beginsel moet worden gezien. ${ }^{226}$ Happé spreekt van doelmatigheidsbeginselen, zij het dat doelmatigheid een concretisering is van het gelijkheidsbeginsel. In tegenstelling tot het gelijkheidsbeginsel heeft doelmatigheid niet het niveau van de rechtsregel. Het begrip doelmatigheid is een beginsel van een lagere orde. De overheid moet doelmatig met de middelen en mensen, die zij ter beschikking heeft, omgaan. ${ }^{227}$

223. F.H.M. Grapperhaus, Vereenvoudiging van de belastingheffing een vraagstuk voor managers, Wcekblad voor fiscaal recht, 1986, no 5750, blz. 1435 en 1436.

224. Vergelijk W.J. Slagter, t.a.p., blz. 7. Vergelijk ook Van Ovcrbeeke: 'De uit de rechtsbeginselen te ontwikkelen belastingbeginselen zijn echter naar tijd en plaats gebonden aan de maatschappelijke omstandigheden.' M.P. van Overbeeke, Inkomstenlasting: cinde of nieuw begin?, Weckblad voor fiscaal recht, 1992, no 6026, blz. 1358.

225. P.H.J. Essers, in: Het gelijkheidsbeginsel in ethisch perspectief, van R.H. Happé, Geschriften van de Vereniging voor de Belastingwetenschap, no 178,1989 , blz. 30.

226. W.J. Slagter, t.a.p., blz. 11. M.J.H. Smeets, Grondbeginselen van de belastingheffing, 1962, biz. 44. L.G.M. Stevens, Belasting naar draagkracht, Kluwer, 1980, blz. 134.

De Hoge Raad spreekt over het beginsel van de geoorloofde uitvoering (doelmatigheid en eenvoud), HR 19 mei 1993, V-N 1993, blz. 1905 en BNB 1993/242.

227. Happé maakt hier evenals Hirsch Ballin en Van Soest cen onderscheid tussen een rechtsbeginsel en een rechtsregel. Bij een rechtsbeginsel gaat het om fundamentele principes van het recht die niet eenduidig in een concreet geval van toepassing zijn. Bij een rechtsregel kun je dat wel stellen. J. van Soest, De directe werking van rechtsbeginselen in het stelifige 
Hofstra daarentegen is de mening toegedaan dat de doelmatigheid een aspect is waarmee rekening moet worden gehouden, maar het is geen beginsel. De reden ligt voornamelijk in de mate van stabiliteit van de beginselen. Deze stabiliteit zou voor de doelmatigheid minder zijn dan voor de beginselen. De doelmatigheid kan echter wel de gelding van de beginselen beperken. Hofstra maakt een opmerking over het compromis tussen rechtvaardigheid en doelmatigheid. Het compromis kan niet langs rationele manier worden opgelost, aldus Hofstra. Merkwaardig is evenwel dat Hofstra even verderop in zijn boek vaststelt, dat doelmatigheid, ondanks dat deze niet een specifiek belastingrechtbeginsel is, een grotere rol speelt in het gebied van de belastingheffing dan in de overige rechtsgebieden. Hij praat dan over belangen van een hogere orde, zoals het gerechtigheidslement, en belangen van een lagere orde, zoals de doelmatigheid. 228

Samen met de eis van de rechtszekerheid vormt de doelmatigheid een eis voor het gehele recht. ${ }^{229}$ Natuurlijk kan aan alle rechtsgebieden naast een rechtvaardigheidseis een eis van doelmatigheid worden gesteld. Maar de belastingheffing is een gebied met enorme uitvoeringslasten. Bovendien brengt het dwangmatige karakter van de belastingheffing met zich dat de uitvoering zorgvuldig moet geschieden. Deze twee elementen tezamen rechtvaardigen mijns inziens de stelling dat de eis van doelmatigheid in de belastingheffing een meer nadrukkelijke rol moet spelen.

De doelmatigheid komt met name aan de orde bij de instrumentele functie van de wet; het wordt mogelijk om het beleid doeltreffend uit te voeren. ${ }^{230}$ Gezien de plaats die het begrip doelmatigheid in deze tijd inneemt en de werking die aan het begrip wordt toegekend, kan het naar mijn mening als een beginsel worden gezien; het is een algemeen geldende en in het algemeen als belangrijk ervaren eis die aan het recht kan worden gesteld.

\section{Doeltreffendheid en doelnatigheid}

Doelmatigheid kan in rechtseconomische zin worden gebruikt; het onderscheid tussen effectiviteit en efficiëntie. Effectiviteit is de mate waarin de doelstellingen

belastingrecht, 1972. R.H. Happe, Gelijkheidsbeginsel in ethisch perspectief, Geschriften voor de belastingwetenschap, no 178, Kluwer, 1989, blz. 21 en 40, noot 1. Zie ook Roos, die stelt dat er geen principeel verschil is tussen rechtsbeginselen en rechtsregels; alleen het geldingsbereik van rechtsbeginselen is groter. N.H.M. Roos, t.a.p., blz. 260.

228. H.J. Hofstra m.m.v. C. van Raad, Inleiding, t.a.p., blz. 85. Vergelijk ook R.H. Happé, Gelijkheidsbeginsel in ethisch perspectief, Geschriften voor de belastingwetenschap, no 178, Kluwer, 1989, blz. 20 die spreekt over een doelmatigheidsruimte. Onduidelijk is of hier een beginsel of niet wordt bedoeld.

229. H.J. Hofstra m.m.v. C. van Raad, Inleiding, t.a.p., blz. 84.

230. J.H. van Kreveld, De kwaliteit van wetgeving: rechtsstatelijke en bestuurlijke eisen. In: Recht doen door wetgeving, E.H.M. Hirsch Ballin-bundel, 1991, blz. 192.

Hofstra stelt zich op het standpunt dat in de belastingheffing een nevendoeleinde alleen mogelijk is indien de belastingheffing het enige instrument is. Een nevendoeleinde mag worden gehanteerd, indien tevens vaststaat dat de regeling niet aan de uitvoering van de primaire taak van de belastingdienst in de weg staat. H.J. Hofstra, Vereenvoudiging van de inkomstenbelasting concreet bezien. In: Giele-bundel, 1990, Kluwer, blz. 247. 
van de belastingheffing worden gerealiseerd. De overheid dient zich bij het stellen van bepaalde doeleinden af te vragen, op welke wijze en met welke middelen de gestelde doelen het best kunnen worden bereikt. ${ }^{231}$ Effectiviteit komt aan de orde in geval van verwezenlijking van nevendoeleinden in de belastingheffing. ${ }^{232}$

Efficiëntie is de mate waarin de overheid erin slaagt de doelstellingen tegen zo laag mogelijke kosten te realiseren. ${ }^{233}$ Hierbij wordt in termen van tijd, geld en mankracht gedacht. De door de wetgeving veroorzaakte lasten moeten zo licht mogelijk zijn. ${ }^{23}$

Het efficiëntieçriterium staat onverschillig tegenover distrubitieve effecten. ${ }^{235}$ Voor distributieve effecten kunnen mijn inziens onder andere de effecten van de verdelingsbeginselen worden gelezen. Het recht kan mijns inziens niet enkel en alleen worden beschouwd als instrument om maatschappelijke doelen te verwezenlijken. ${ }^{236}$

Effectiviteit en efficiëntie kunnen tegen elkaar botsen. In dat geval moet een middenweg worden gezocht. Deze begrippen spelen door de drie niveaus van Montesquieu heen, maar worden in het kader van dit onderzoek beperkt tot het wetgevende niveau.

Volgens Caanen en Essers heeft de wetgever een aantal keuzemogelijkheden ten aanzien van de wettelijke basis van de belastingheffing, t.w.:

'1. systeembenadering versus partiële benadering;

2. wetgeving met uitgebreide of beperkte delegatiemogelijkheden;

3. het hanteren van vage versus strikt geëxpliciteerde normen;

4. het in meer'of mindere mate hanteren van forfaitaire regelingen'. ${ }^{237}$

ad 1: Een systeembenadering is de benadering door de wetgever van de wetgeving in het geheel. De grondslagen e.d. komen hier aan de orde. Een partiële benadering daarentegen houdt in dat de effectiviteit en de efficiëntie worden beoordeeld vanuit een bepaalde invalshoek.

ad 2: Het gevaar van een uitgebreide delegatiewetgeving is hierin gelegen dat de wetgever de grenzen van de overgedragen bevoegdheden niet voldoende vaststelt,

231. Zie noot bij H.D. Stout, Doelmatige en bestuurlijke belangenafweging: een speciaal terrein. In: De rechtsstaat herdacht, W.E.J. Tjeenk Willink, 1989, blz. 238 die J.L.M. Hakvoort, Territoriale decentralisatie, Van Gorcum, 1980, blz. 24 aanhaalt.

232. H.J. Hofstra, Het fiscale wetgevingsproces, Weekblad voor fiscaal recht, 1985, no 5672, blz. 256.

233. Ch. Caanen, P.H.J. Essers, Rechtseconomie en belastingrecht. In: Rechtseconomie, Ars Aequi, oktober 1990 , blz. 75 .

234. J.H. van Kreveld, t.a.p., blz. 197 en 198.

235. A.M. Hol, Instrumentalisme en recht. Enkele rechtstheoretische kanttekeningen. In: Gielebundel, Kluwer, 1990, blz. 273.

236. A.M. Hol, t.a.p., blz. 275.

237. Ch. Caanen, P.H.J. Essers, t.a.p., blz. 75. 
waardoor de rechtszekerheid afneemt en hiermee ook de efficiëntie en de effectiviteit. Een middenweg dient te worden gevonden.

ad 3: Hetgeen onder 2 is beweerd ten aanzien van uitgebreide delegatiewetgeving, kan ook worden gezegd over het hanteren van vage normen. Met het hanteren van vage normen is de rechtszekerheid niet gediend, echter er kan wel worden ingesprongen op nieuwe maatschappelijke ontwikkelingen. In geval van een te grote detaillering van de wettelijke regeling is de rechtszekerheid wel gediend, maar of de regeling dan ook effectief en efficiënt is, is nog maar de vraag. Ook hier geldt dat een middenweg dient te worden gevonden.

ad 4: Forfaitaire regelingen zijn onderwerpen in de belastingheffing waar de rechtvaardigheid en de doelmatigheid elkaar op een concreet niveau ontmoeten. Zowel in de opbrengsten- als in de'kostensfeer bestaan forfaits. De meest bekende in de Wet op de inkomstenbelasting zijn: het reiskostenforfait (artikel 36, lid 1, onderdeel a en lid 2, onderdeel a Wet IB 1964) ${ }^{238}$, het arbeidskostenforfait (artikel 37 Wet IB 1964) ${ }^{239}$, het huurwaardeforfait (artikel 42a Wet IB 1964) en de $15 \%$ afschrijving van woonhuizen (artikel 7 Uitvoeringsregeling IB $1990)^{240}$.

Volgens Stevens kunnen forfaits omschreven worden als regelingen 'waarbij voor soortgelijke of althans bij elkaar behorende grootheden vaste bedragen worden vastgesteld indien het bepalen van de werkelijke bedragen overwegende bezwaren oplevert' ${ }^{241}$ Hofstra formuleert hêt forfait als volgt: 'Een forfaitaire rege-' ling houdt in dat voor soortgelijke, of althans dicht bij elkaar liggende, figuren, waar de vaststelling van de exacte bedragen waarom het gaat bezwaren oplevert, vaste bedragen worden vastgesteld.242.

De motieven voor een forfaitaire regeling worden vaak gevonden ip de belastingtechniek. Met het toepassen van een forfaitaire regeling zoù de fratide dienen te worden voorkomen. De forfaitering zou als een legalisering van de fraude tot

238. De resultaten van de aftopping van het reiskostenforfait zijn betrekkelijk gering. De milieueffecten zijn verwaasloosbaar gebleken. Tweede Kamer, vergaderjaar 1992-1993, 22 833, no 21, blz. 9 en 10. Mijns inziens kan geconcludeerd worden dat het streven naar het nevendoeleinde van een schoner milieu met behulp van de belastingheffing niet optimaal is.

239. Thans zijn er twee wetsvoorstellen om het arbeidskostenforfait te verhogen naar 8 resp. 10\%. De regering stelt voor het forfait te verhogen van 5 naar $8 \%$. Het tweede wetsvoorstel is van de VVD-leden De Korte en Van Rey inhoudende een wijziging van de Wet op de inkomstenbelasting 1964 en de Wet op de loonbelasting 1964 met het oog op een verhoging van het arbeidskostenforfait in het kader van het werkgelegenheids- en inkomensbeleid, Tweede Kamer, vergaderjaar 1993-1994, 23138.

Verwacht wordt dat het wetsvoorstel een gunstige uitwerking heeft op de arbeidsparticipatie van deeltijdwerkers. Handelingen Tweede Kamcr, vergaderjaar 1993-1994, blz. 31-2342, mk. Hierbij zij aangetekend dat de loon-en inkomstenbelasting als herverdelend instrument niet moet worden overschat. Advies belastingvercenvoudiging, Sociaal-Economische Raad, $87 / 17,16$ oktober 1987, blz. 39.

240. H.J. Holstra m.m.v. C. van Raad, Inleiding, t.a.p., blz. 198 en 199.

241. L.G.M. Stevens, Belasting naar draagkracht, Kluwer, 1980, blz. 380.

242. HJ. Hofstra m.m.v. C. van Raad, Inleiding, t.a.p., blz. 198. 
aan de grens van het in het forfait genoemde bedrag kunnen worden beschouwd. ${ }^{243}$

In het kader van de doelmatigheid zijn forfaitaire regelingen een voorbeeld van efficiënte wetgeving. ${ }^{24}$ De effectiviteit is minder gediend, omdat in individuele gevallen afbreuk wordt gedaan aan de eis van een rechtvaardige belastingheffing. $245 . .$.

Doelmatigheid heeft alles te maken met de uitwerkingen van de belastingheffing. In de Wet IB 1964 betreft de uitwerking vooral de hoogte en de opbouw van het tarief, de ingewikkeldheid van de belasting, de weerstand tegen de belasting en de economische gevolgen. ${ }^{246}$ Hierbij moet tevens worden bedacht dat pressiegroepen in hun eigen voordeel invloed trachten uit te oefenen op de uitwerkingen van de belastingheffing. Denk in geval van pressiegroepen aan de kwestie van het reiskostenforfait, het huurwaardeforfait, de aftrekbaarheid van de gemengde kosten en, recentelijk, de pleziervaartuigenbelasting. ${ }^{247}$

Een ander belangrijk aspect dat bij de doelmatigheid in acht moet worden genomen, is het aspect van de belastingvermijding, al dan niet legaal. Het is in strijd met de doelmatigheid - zowel effectiviteit en efficiëntie - als belastingvermijding plaatsvindt. $\mathrm{Zij}$ houdt in, dat afgezien wordt van economische activiteiten in verband met de daaraan verbonden fiscale verplichtingen. ${ }^{248}$ Belastingvermijding wordt onder andere veroorzaakt door de (ingewikkelde) inkomstenbelasting. Dit wil echter niet zeggen, dat belastingvermijding niet bewust kan worden nagestreefd door de overheid ter wille van de beïnvloeding van het economisch handelen. ${ }^{249}$

Uit het voorgaande volgt dat doelmatigheid een ruim begrip is. Doelmatigheid kan worden onderverdeeld in effectiviteit en efficiëntie. Doelmatigheid wordt in het parlement en in de literatuur vaker dan voorheen als een beginsel gekarakteriseerd.

Doelmatigheid is in ieder geval de laatste tijd sterk in opmars en het vermoeden bestaat dat het begrip voor meer doeleinden dan alleen de realisering van de eis van doelmatigheid gebruikt.

243. H.J. Hofstra m.m.v. C. van Raad, Inleiding, t.a.p., blz. 194.

244. Ch. Caanen, P.H.J. Essers, t.a.p., blz. 77.

245. Ch. Caanen, P.H.J. Essers, t.a.p., blz. 76 en 77.

246. H.J. Hofstra en L.G.M. Stevens, Inkomstenbelasting, t.a.p., blz. 572 en 573.

247. Of zoals Hofstra het stelt: '..., doch sindsdien een illussie gebleken euforie die sommige kamerfracties telkens weer doet zoeken naar nieuwe groepen van belastingplichtigen - tevens kiezers! - die wellicht eveneens op een fiscale tegemoetkoming aanspraak zouden kunnen maken, zonder zich om andere urgente problemen en om beginselen en wetstructuren te bekommeren: een detaillistische benadering, die de wezenlijke problemen miskent.' W.H.C. Zuidgeest, t.a.p., blz. 974 en 975.

248. J.G. Detiger, t.a.p., blz. 269.

249. J.G. Detiger, t.a.p., blz. 270 en 271. 


\subsection{De wetgeving getoetst aan rechtvaardigheid en doelmatigheid}

\subsubsection{De Tweeverdienerswetgeving}

\section{Rechtvaardigheid}

In de Tweeverdienerswetgeving is een compromis bewerkstelligd tussen twee 'soorten' draagkracht. Ten eerste is dat de gezinsdraagkracht die tot uiting komt in het samenvoegingsstelsel. In het samenvoegingsstelsel wordt rekening gehouden met de draagkracht die voortvloeit uit de samenwoning van de partners. Ten tweede is dat de individuele draagkracht, die tot uiting komt in het individuele stelsel. In dit stelsel wordt een ieder individueel in de belastingheffing betrokken en wordt geen rekening gehouden met de draagkracht die voortvloeit uit de samenlevingsvorm.

In de Tweeverdienerswetgeving is geprobeerd zowel aan de gezinsdraagkracht als aan de individuele draagkracht tegemoet te komen.

Duidelijk is dat in de maatschappelijke ontwikkeling de positie van de (gehuwde) vrouw steeds zelfstandiger wordt. Hierdoor wordt het moeilijker om een samenvoegingsstelsel te hanteren. Steeds meer stemmen gaan op om het individuele stelsel te hanteren.

De Tweeverdienerswetgeving heeft de positie van de gehuwde vrouw ten opzichte van haar man willen verbeteren. Bovendien is beoogd de ongehuwd samenlevenden in een gelijke positie te brengen met de gehuwden. Dit laatste is niet helemaal gelukt, waarbij budgettaire overwegingen een cruciale rol hebben gespeeld. Hetzelfde geldt voor de reparatiewetgeving die ten tijde van de totstandkoming van de Tweeverdienerswetgeving nodig bleek te zijn. ${ }^{250}$ De grens van deze reparatiewetgeving werd gevonden in de budgettaire ruimte.

\section{Doelmatigheid}

Wat de doelmatigheid betreft, kan met betrekking tot de Tweeverdienerswetge- . ving worden geconcludeerd dat deze niet gediend is. Zeker niet als men de reparatiewetgeving in ogenschouw neemt.

\section{Het compromis}

Wetgeving is een produkt van het compromis van rechtvaardigheid en doelmatigheid. In de Tweeverdienerswetgeving is er een compromis gevonden tussen de gezinsdraagkracht en de individuele draagkracht. Ik ben de mening toegedaan dat indien het rechtvaardigheidselement niet eenduidig is, dit geen gunstige uitwerking heeft op het doelmatigheidselement. De uitwerking van de wet wordt daardoor bijzonder ingewikkeld en dat is met betrekking tot de Tweeverdienerswetgeving ook wel gebleken.

Eén conclusie is in ieder geval evident. Het draagkrachtbeginsel is, voor zover van een werking daarvan nog sprake is, aan invloed van tijd en plaats onderhe- 
' vig; wellicht meer dan wordt verondersteld. De maatschappij en haar machtsverhoudingen zijn bepalend. ${ }^{251}$

\subsubsection{OORT-I}

\section{Rechtvaardigheid}

Vooropgesteld zij dat het niet in de bedoeling van de commissie-Oort lag om aandacht te schenken aan de grondslagen van de inkomstenbelasting. Ook in het daaropvolgende wetsvoorstel wordt niet veel aandacht gegeven aan de grondslagen. Het draagkrachtbeginsel heeft een ondergeschikte rol gespeeld in de totstandkoming van de OORT-wetgeving. In de regering en in het parlement is de toepassing van het draagkrachtbeginsel niet altijd even duidelijk geweest. Dit heeft naar alle waarschijnlijk te maken met de niet geheel te vermijden invulling van het draagkrachtbeginsel door partijpolitieke ideeën.

Koopkrachtplaatjes daarentegen zijn wel uitdrukkelijk aan de orde gekomen. Hierdoor is de rechtvaardigheid tot in de kleinste details uitgewerkt; althans dat is de achterliggende gedachte van de koopkrachtplaatjes.

Deze rechtvaardigheid is echter van een andere orde dan de eerstgenoemde. De rechtvaardige verdeling van lasten ziet op de bruto-opbrengst; de koopkrachtplaatjes betreffen de netto-opbrengst.

\section{Doelmatigheid}

Doelmatigheid wordt in de OORT-wetgeving gevonden in het vereenvoudigingsstreven. Wat daarvan uiteindelijk terecht is gekomen, is door de invoering van vele amendementen minder dan beoogd. Hierbij moet ook worden bedacht dat pressiegroepen een aandeel in de totstandkoming van de wetgeving hebben gehad.

Naast het vereenvoudigingsstreven werd een tariefverlaging voorgesteld. Opmerkelijk is dat bij de eerste tussentijdse evaluatie bleek dat heel veel belastingplichtigen niet hadden onderkend dat de tariefverlaging een belangrijk element in de OORT-wetgeving is geweest. In het kader van de doelmatigheid kan mijns inziens voorzichtig worden geconcludeerd dat de informatievoorziening in dat geval niet goed heeft gefunctioneerd.

Voor een goed resultaat van de beoogde doelstellingen van de OORT-wetgeving is het van belang hoe de betrokkenen - de belastingplichtigen, de inhoudingsplichtigen en de Belastingdienst over de vereenvoudiging denken. Een vergelijking van de eerste met de tweede tussentijdse OORT-evaluatie leert dat met name meer inhoudingsplichtigen van mening zijn dat de belastingheffing eenvoudiger is geworden.

251. Bovendien bcstaat er een wisselwerking tussen het belastingrecht en de politieke bewegingen. F.H.M. Grapperhaus, De pelgrimstocht naar het draagkrachtbeginsel, Kluwer, 1993, blz. 64 . 


\section{Het compromis}

Het compromis van rechtvaardigheid en doelmatigheid op OORT-I toegepast, wil ik het volgende opmerken. De Wet IB 1964 was(!) te ingewikkeld geworden en deswege werd een commissie ingesteld. Deze commissie moest met enige vereenvoudigingsvoorstellen komen. Dit heeft de commissie ook gedaan. De vereenvoudigingsvoorstellen zouden de doelmatigheid dienen. Ervan uitgaande dat de wet een compromis is van rechtvaardigheid en doelmatigheid, kan het niet anders zijn dan dat sleutelen aan het doelmatigheidselement invloed heeft op het rechtvaardigheidselement. Of wellicht moet je zeggen dat het rechtvaardigheidselement verschraald is tot een vereenvoudigingsstreven en een tariefverlaging.

\section{Rechtvaardigheid}

De rechtvaardiging van de invoering van OORT-II en OORT-III wordt grotendeels gevonden in budgettaire overwegingen. Het draagkrachtbeginsel wordt, hetzij door deze budgettaire overwegingen, hetzij door het vereenvoudigingsstreven opzij gezet. Het gelijkheidsbeginsel is met de ingevoerde asymmetrie enigszins geweld aangedaan. Kortom, met de rechtvaardigheid ts het niet zo goed gesteld in OORT-II en OORT-III.

\section{Doelmatigheid}

Het vereenvoudigingsstreven is ver te zoeken. Eveneens hebben pressiegroepen bij de totstandkoming van zich laten spreken. Het uiteindelijke resultaat is verre van eenvoudig.

De doelmatigheid is niet optimaal gediend.

\section{Het compromis}

De beoordeling van het compromis tussen rechtvaardigheid en doelmatigheid kan niet anders dan kritisch zijn. Zowel ten aanzien van het rechtvaardigheidselement als ten aanzien van het doelmatigheidselement is kritiek mogelijk. Het compromis kan mijns inziens derhalve niet anders dan negatief worden beoordeeld.

\subsection{Samenvatting en conclusies}

De stelling dat de beginselen een algemene strekking hebben en invloed van tijd en plaats ondergaan, wordt in dit hoofdstuk nog eens bevestigd. Het draagkrachtbeginsel dat lange tijd zeer populair is geweest en waarop bijna elke zichzelf respecterende fiscalist zich beroept, staat onder druk. De wil te heffen naar draagkracht is aanwezig, maar de nadere invulling van het draagkrachtbeginsel is niet zo helder als wordt verondersteld. 
Een eerste mogelijke oorzaak is het subjectieve element dat eigen is aan de definitie van 'draagkracht'. Het draagkrachtbeginsel wordt vaak genoemd. ${ }^{252}$ Waarom? Een reden zou kunnen zijn dat men bang is dat het anders met de moraliteit van de belastingplichtigen en dientengevolge de belastingopbrengst slechter zou zijn gesteld dan nu het geval is.

Een tweede mogelijke oorzaak is dat naast het draagkrachtbeginsel andere belangen en/of beginselen steeds meer aan de orde komen. Welke die belangen en/of beginselen zijn, is aan de hand van de studie naar de wetgevingsprodukten duidelijk geworden. Van belang hierbij is de vraag naar de redenen van de fiscale wetgever om bepaalde fiscale maatregelen te nemen. Aan welke belangen betekenis wordt toegekend in de vorm van een beginsel, hangt af van de omstandigheden die op een bepaalde tijd en/of plaats zich doen gelden.

Een van de beginselen welker werking de laatste tijd sterk in opmars is, is het doelmatigheidsbeginsel. De conclusie is mijns inziens gerechtvaardigd dat aan het begrip doelmatigheid de kwaliteit van beginsel kan worden verleend.

Het draagkrachtbeginsel als rechtvaardigingsgrond van de Wet IB 1964 blijkt steeds moeilijker te handhaven. Doelmatigheid is een begrip dat ten koste van de rechtvaardigheid wordt ingevoerd. Of heeft de rechtvaardigheid de laatste decennia te veel aandacht gekregen en worden de zaken thans weer gelijk getrokken?

Het vinden van een juist compromis is een moeilijke afweging, maar indien het beroep op doelmatigheid wordt overdreven, wordt het gelijkheidsbeginsel in het algemeen en daarmede het draagkrachtbeginsel in het bijzonder, steeds verder uitgehold. Immers een te groot beroep op doelmatigheid impliceert een vergroting van ongelijkheid. ..:

Het compromis van rechtvaardigheid en doelmatigheid is voortdurend in beweging: Tijd en plaats zijn twee niet te verwaarlozen elementen in het uiteindelijke compromis. De in de maatschappij heersende opvattingen bepalen uiteindelijk de nadere inhoud van een beginsel. De kwalificatie 'heersend' is onder andere afhankelijk van de invloed van bepaalde pressiegroepen. Hetzelfde kan worden gezegd over de rangorde van beginselen. Belangrijk in dit kader is de vraag waarom bepaalde belangen en/of beginselen een dominante rol krijgen toebedeeld of toebedeeld zullen krijgen.

De redenen hiervoor liggen in de al dan niet verander(en)de opvattingen in de maatschappij en in de mate ván invloed die een bepaalde groep belastingplichtigen kan uitoefenen. Indien die groep en de invloed die die groep heeft groot genoeg is, kunnen deze opvattingen in belangen en/of beginselen resulteren, waarmee de fiscale wetgever rekening houdt. Met andere woorden, de in de

252. 'Hoewel thans wel wordt ingezien dat sommige aanhangers van de draagkrachtgedachte aan overdrijving en oppervlakkigheden niet wisten te ontkomen leeft de gedachte zelf nog stecds zo sterk in het algemene rechisbewustzijn, dat zij ook thans nog een krachtig argument ten gunste van de inkomstenbelasting als belastingtype pleegt op te leveren.' H.J. Hofstra en L.G.M. Stevens, Inkomstenbelasting, t.a.p., blz. 8. 
maatschappij bestaande opvattingen komen mits voldoende ondersteund, in het belastingrecht tot uiting.

Hierin schuilt een dilemma; enerzijds moet een goed functionerend belastingstelsel rekening houden met de samenleving, anderzijds moet het niet zover gaan dat pressiegroepen het belastingstelsel nader gaan invullen. Het gevaar bestaat dan dat het overzicht. wordt verloren en dat het eigen belang boven de rechtvaardige verdeling van lasten wordt geplaatst.

Het bovenstaande indiceert dat de motieven van de fiscale wetgever kritisch moeten worden bekeken.

Door het minder sterk worden van de werking van het draagkrachtbeginsel, wordt het beroep op het toepassen van het gelijkheidsbeginsel sterker. Het probleem bij het gelijkheidsbeginsel is echter van soortgelijke aard als bij het draagkrachtbeginsel. Een ieder is het wel erover eens dat het gelijkheidsbeginsel moet worden toegepast, maar de concrete toepassing daarvan brengt grote moeilijheden mee.

Het lijkt of te veel principes in eén begrip moeten worden gevat. Er zullen keuzen moeten worden gemaakt. Die keuzen zullen niet altijd 'beginselmatig' kunnen geschieden. Partijpolitieke ideeën en het feit dat politieke compromissen worden gesloten, kunnen blijkbaar niet worden genegeerd. Of moet gezegd worden dat het nastreven van bepaalde beginselen per definitie politiek bedrijven is? Weliswaar moet het beleid van de fiscale wetgever consistent, betrouwbaar, geloofwaardig zijn en met de maatschappelijke ontwikkelingen rekening houden, maar bij het bedrijven van politiek spelen vaak andere factoren een rol, zoals partijpolitieke belangen. Een voorbeeld is het in stand houden van een coalitie. In dat geval. kunnen de beginselen mijns inziens gemakkelijk het onderspit delven. .

Duidelijk wordt dat nagedacht moet worden over de rechtvaardigingsgrond van de Wet IB 1964; een eerste stap zou zijn het inkomensbegrip aan een nadere theoretische beschouwing te onderwerpen. ${ }^{253}$

\section{Algemene conclusies}

Aannemende dat de werking van de verdelingsbeginselen heeft beștaan of zelfs nog bestaat, kan niet anders gezegd worden dan dat vervaging van de fiscale beginselen, althans het draagkrachtbeginsel, een element van deze tijd is.

Gezien het bovenstaande zijn de in de inleiding getrokken voorlopige conclusies voor het grootste deel waar. Deze conclusies luiden:

1. In vergelijking met voorgaande jaren kan aan bepaalde geldende beginselen een geringere werking worden toegekend en aan andere een grotere.

253. H.J. Hofstra en L.G.M. Stevens, Inkomstenbelasting, t.a.p., blz. 571. Hofstra stelt verder een diepgaande herbezinning over de inkomstenbelasting voor: ' $\mathrm{Zij}$ moet zich richten op twee vragen: in de eerste plaats op de principiële vraag welke plaats de inkomstenbelasting in ons belastingstelsel moet innemen, en in de tweede plaats op die naar de uitwerking die aan haar moet worden gegeven.' H.J. Hofstra en L.G.M. Stevens, Inkomstenbelasting, t.a.p., blz. 573 en 574. 
2. Een bepaald belang wordt in tegenstelling tot voorheen de werking van een beginsel toegekend, met andere woorden, het 'etiket' van beginsel opgeplakt. Getuige de kamerstukken wordt op de doelmatigheid het 'etiket' van beginsel geplakt. Voorheen was dit niet zo. Het is een begrip dat de werking van - de beginselen kon en kan beperken, maar de doelmatigheid werd in het al= gemeen niet tot de beginselen gerekend. De doelmatigheid wordt thans naast de beginselen geplaatst; hierdoor kan de-doelmatigheid de werking van de andere beginselen beperken. Wellicht ten overvloede zij nog opgemerkt dat, het niet altijd even duidelijk is wat onder doelmatigheid moet worden verstaan.

3. Budgettaire overwegingen spelen een steeds grotere rol. Gelet op deze wetenschap moet voorzichtigheid worden betracht bij het al dan niet in-voeren van bepaalde fiscale maatregelen. Het draagkrachtbeginsel wordt door budgettaire overwegingen ingeperkt.

4. De rol van de pressiegroepen mag niet worden onderschat. Zeker dient gewaakt te worden voor een dominantie van deelbelangen in een wetsvoorstel.

5. De vijfde conclusie hangt samen met de vorige. Het belang van het bedrijven van politiek mag ook zeker niet worden onderschat. Hierbij moet onder andere worden gedacht aan het sluiten van compromissen. Het gevaar bestaat dat termen zoals fiscale beginselen, budgettaire overwegingen en overwegingen van (partij)politieke aard door elkaar worden gebruikt.

In ieder geval moet mijns inziens ten behoeve van de geloofwaardigheid van de fiscale wetgever het gevaar van het gebruik maken van 'doelredeneringen' worden ontweken.

Het bovenstaande in acht nemende wil ik met de woorden die Hofstra al in 1979 heeft geschreven eindigen. 'De onderschatting van het gerechtigheidsmotief, die vele doelmatigheidsoverwegingen kenmerkt, leidt echter veelal tot een verschuiving van de aandacht van de fiscale beginselen (de-rechtvaardigheid) naar een doelmatig (sociaal) economiseh beleid, tot een verwarring met betrekking tot het begrip belastingbeginsel, en tot miskenning van het 'eigen recht' van de belastingheffing als afgerond - zij het niet geïsoleerd doch geïntegreerd zijn in de totale Iechtsorde-rechtsstelsel. ${ }^{254}$ Mijns inziens is er tot op de huidige dag nog niet zo veel veranderd. Of met de woorden van Stevens: ‘Het draagkrachtbeginsel dreigt steeds door dergelijke machtsfactoren te worden uitgehold en te worden yervormd tot een machtsondersteunend surrogaatbeginsel. ${ }^{.255}$

254. H.J. Hofstra, Over belastingbeginselen, Weekblad voor fiscaal recht, 1979, no 5427, blz. 1220. Hofstra is van mening dat opgepast moet worden voor het verstard vasthouden aan bepaalde opvattingen. '... door de opgewekte wijze, waarop nog steeds in de parlementaire debatten getracht wordt de meest uiteenlopende, en dikwijls volst rekt tegenstrijdige, wensen met het twee eeuwen oude draagkrachtcriterium te motiveren.' H.J. Hofstra, De toekomst van de inkomstenbelasting, Weekblad voor fiscaal recht, 1975, no 5248, blz. 1043.

255. L.G.M. Stevens, Belasting naar draagkracht, Kluwer, 1980, blz. 555. Overigens behoeft volgens hem een belastingheffing naar draagkracht niet te impliceren dat daadwerkelijk naar draagkracht wordt belast. L.G.M. Stevens, t.a.p., blz. 556. 


\section{Conclusies}

Bij het opleggen van belastingen dient een rechtvaardige verdeling te worden nagestreefd. Belastingen kennen een subject, object, en tarief. In de loop van de tijd kunnen deze variëren. In de inkomstenbelasting kan met name de nadere definiëring van object en tarief als een probleem worden gezien, daar in die elementen in het bijzonder de lastenverdelingsproblematiek tot uiting komt. Ieder wetgevingsprodukt berust op een compromis van rechtvaardigheid en doelmatigheid. Voor de inkomstenbelasting kan voor rechtvaardigheid onder andere het draagkrachtbeginsel worden ingevuld. De vraag rijst op welke wijze de bij de wetgeving betrokken instanties met rechtvaardigheid en doelmatigheid omgaan.

De nadere invulling van het draagkrachtbeginsel is niet altijd dezelfde. Door de jaren heen worden in dit beginsel verschillende factoren onderkend, waaraan een verschillend gewicht kan worden toegekend. De draagkrachtvermeerderende en verminderende factoren variëren naàr gelang van tijd en plaats. Zo blijkt aan de draagkrachtverminderende factor van het buitenshuis werken van de gehuwde vrouw niet steeds hetzelfde gewicht te worden toegeschreven. In de jaren zestig was het een factor van belang, thans niet meer (hoofdstuk 2). Ik concludeer dat met betrekking tot het draagkrachtbeginsel het accent verschuift van de gezinsdraagkrácht naar de individuele draagkracht.

In de roemruchte Tweeverdienerswetgeving (hoofdstuk 3) worden eveneens de verschillende draagkrachtvermeerderende en verminderende factoren afgewogen. In deze wetgeving werd een compromis tot stand gebracht tussen de gezinsdraagkracht en de individuele draagkracht. Dit is een van de redenen waardoor deze wetgeving onuitvoerbaar bleek.

Met betrekking tot het gelijkheidsbeginsel kan worden geconcludeerd dat dit niet geheel werd nageleefd. Ongehuwde samenlevers konden niet geheel worden gelijk gesteld met de gehuwden. Een reden hiervoor werd gevonden in budgettaire overwegingen.

Naar aanleiding van de steeds ingewikkelder geworden wetgeving werd een commissie ingesteld, die naar de naam van de voorzitter, de commissie-OORT werd genoemd. Deze commissie heeft enige vereenvoudigingsvoorstellen gedaan. Mijns inziens kan onder vereenvoudiging niet alleen de vereenvoudiging van het aangiftebiljet worden verstaan. Een vereenvoudiging van het aangiftebiljet kan niet geheel zonder vereenvoudiging van de belastingheffing. 
De voorstellen van de commissie zijn niet alle ingevoerd. Dit heeft onder andere te maken met de rol die pressiegroepen spelen. Denk met name aan de geschiedenis rond de bruteringsoperatie (hoofdstuk 4). Daarnaast zijn budgettaire overwegingen van belang geweest. Hierbij moet aan de afschaffing van de alleenstaande-toeslag worden gedacht.

De OORT-wetgeving diende gefinancierd te worden door middel van beperking of afschaffing van de aftrekposten, zowel in de winst- als in de niet-winstsfeer. Ten onrechte werden hier aan de namen van OORT-II en OORT-II verbonden (hoofdstuk 5).

Duidelijk werd in ieder geval dat de symmetrie tussen aftrekbare kosten en onbelaste vergoedingen werd doorbroken. Het gelijkheidsbeginsel is derhalve ook hier niet ten volle aan zijn trekken gekomen. Daarnaast komt thans een stroom van nieuwe jurisprudentie los, hetgeen een aanwijzing kan zijn dat de wetgeving niet geheel duidelijk is.

Uit het bovenstaande blijkt dat belastingheffing een complex geheel is. Budgettaire, economische en politieke factoren doen hun invloed gelden op het uiteindelijke wetgevingsprodukt. Met name andere dan puur fiscale beleidsoverwegingen en de rol die pressiegroepen kunnen spelen, zijn mede-bepalend voor het uiteindelijke produkt (hoofdstuk 6).

Bestudering van hetgeen in de oude literatuur te berde wordt gebracht over beginselen en het toetsen van de Tweeverdieners- en OORT-wetgeving aan het compromis van rechtvaardigheid en doelmatigheid, leert dat het compromis voortdurend in beweging is. Het wetgevingsprodukt is het resultaat van de machtsverhoudingen van een bepaald moment (hoofdstuk 7). 


\section{Samenvatting}

\section{Inleiding}

Belastingheffing veronderstelt gedwongen overdrachten van burgers aan de overheid, en grijpt dus diep in in het leven en de beurs van de burgers. Het is dan ook begrijpelijk dat over de rechtvaardiging van belastingheffing altijd veel is gesproken en geschreven. Nu neem ik in dit onderzoek het bestaan van staat, overheid en belasting als gegeven aan en richt ik mij op de vormgeving van de belastingheffing. Belastingen kunnen immers naar object, subject en tarief verschillen, en kennen zodoende een grote mate van verscheidenheid. Bovendien kunnen bestaande heffingen worden gewijzigd of plaats maken voor andere.

Mijn onderzoek heeft betrekking op de besluitvorming aangaande belastingheffing. Deze wordt in beginsel door de regering en het parlement neergelegd in wetgeving. Volkomen doorzichtig is dit proces echter niet, enerzijds omdat afwenteling van de ene op de andere burger plaatsvindt en de wetgever bovendien naast de wens om middelen te verzamelen tevens nevendoeleinden nastreeft, anderzijds omdat in de besluitvorming de politieke context een belangrijke rol speelt. Daarmee doel ik met name op het compromissoire karakter van politieke beslissingen en de rol van pressiegroepen.

De vraag hoe de belastingheffing op rechtvaardige wijze kan geschieden, heeft vele hoofdbrekens gekost. Vele theorieën en beginselen ter rechtvaardiging van een verdeling van de lasten zijn in de loop van de tijd bedacht. Enkele theorieën en beginselen sprongen eruit en hebben voor een tijdje als leidraad gefungeerd voor de belastingheffer. Deze dacht met behulp van deze theorieën en beginselen een in de samenleving aanvaarde belastingheffing tot stand te kunnen brengen. Eén van die beginselen is het draagkrachtbeginsel. Vanuit de wens een heffing naar draagkracht te realiseren, werd de inkomstenbelasting geintroduceerd. Beknopt gezegd komt het erop neer dat sinds het einde van de vorige eeuw het draagkrachtbeginsel als het leidende beginsel van de inkomstenbelasting wordt beschouwd. De vraag is of het draagkrachtbeginsel heden ten dage nog voldoende opgeld kan doen om te spreken van een inkomstenbelasting gebaseerd op het draagkrachtbeginsel. Bovendien is het niet altijd helder en duidelijk waarover men spreekt; soms is bij voorbeeld niet duidelijk of men draagkracht in relatie tot een subject of tot een object bedoelt. 
Daarnaast is het begrip doelmatigheid een factor die de werking van het draagkrachtbeginsel kan beperken. Dit komt tot uiting in het compromis van rechtvaardigheid en doelmatigheid.

De inkomstenbelasting is mijn object van onderzoek geweest. Ik heb aan de hand van de parlementaire geschiedenis en de literatuur de volgende vragen onderzocht:

1. Welke beginselen worden in de Wet IB 1964 en in enige van haar wijzigingswetten gebruikt? Zijn deze beginselen inherent aan het belastingrecht, of niet?

2. Hoe gaan de personen en instanties die bij het wetgevingsproces zijn betrokken met de beginselen om? $\mathrm{Zijn}$ dezen consequent in het omgaan met de beginselen of niet?

Met name is hierbij van belang of de zgn. oude beginselen nog een rol van betekenis spelen.

De studie naar de rechtvaardigingsgronden van de Wet IB 1964 omvat een meer praktische en een meer theoretische benadering.

\section{Praktijk inzake de inkomstenbelasting}

De bespreking van de praktijk van de wetgeving valt in drie gedeelten uiteen. Het eerste gedeelte betreft de ontwikkeling van de fiscale positie van de gehuwde vrouw; het tweede gedeelte de Tweeverdienerswetgeving en het derde de OORT-wetgeving. Het commentaar op de wetgeving is opgesplitst in algemene opmerkingen, opmerkingen betreffende wetgevingsbeginselen, het draagkrachtbeginsel, het gelijkheidsbeginsel, doelmatigheid en budgettaire overwegingen. Met betrekking tot de OORT-wetgeving maak ik ook opmerkingen over het vereenvoudigingsstreven.

In hoofdstuk 2 staat de ontwikkeling van de fiscale positie van de gehuwde vrouw centraal. Eén draagkrachtbeïnvloedend element valt met name op, nl. het buitenshuis werken van de gehuwde vrouw.

In de jaren zestig gaan steeds meer vrouwen buitenshuis werken. Aanvankelijk wordt met het draagkrachtverminderend effect van het buitenshuis werken van de gehuwde vrouw fiscaal rekening gehouden, naderhand niet meer.

De maatschappelijke ontwikkeling van de gehuwde vrouw is de leidraad geweest voor de nadere invulling van de belastingheffing. De belastingheffing past zich als het ware aan de maatschappelijke ontwikkeling aan. Hierdoor verandert de invulling van het draagkrachtbeginsel. Een meer individuele draagkracht komt in plaats van de gezinsdraagkrachi. Alhoewel de maatschappelijke ontwikkeling de belastingheffing nader invult, blijft het draagkrachtbeginsel de leidende gedachte.

In de latere Tweeverdienerswetgeving, hoofdstuk 3, wordt meer rekening gehouden met de verdere verzelfstandiging van de positie van de (gehuwde) vrouw. Het proces van aanpassing van de belastingheffing aan de maatschappij gaat voort. In deze wetgeving wordt een synthese gevonden tussen de gezinsdraagkracht en de individuele draagkracht. 
In vergelijking met de periode voorafgaand aan de Tweeverdienerswetgeving komt de gezinsdraagkracht onder grotere spanning te staan. In deze periode blijkt dat het toekennen van gewicht aan draagkrachtbeïnvloedende factoren een moeilijke zaak is.

Bovendien komen ongehuwde samenlevingsvormen steeds meer voor. In de Tweeverdienerswetgeving vindt een gelijkstelling plaats van de gehuwden naar de ongehuwd samenlevenden en omgekeerd. Echter een volledige gelijkstelling wordt niet mogelijk geacht vanwege de uitvoeringsaspecten en budgettaire overwegingen. De rechtvaardigheid vindt zodoende haar begrenzing in de uitvoering en het budget.

De reparatiewetgeving van de Tweeverdienerswetgeving maakt duidelijk dat de ingewikkeldheid van de wetgeving buiten alle proporties is.

In hoofdstuk 4 worden de commissie-OORT en de daaropvolgende OORTwetgeving behandeld, waarvan een beperking van de complexiteit werd verwacht. De geschiedenis van de instelling van de commissie-Oort toont aan dat een onderscheid moet worden gemaakt tussen de wens tot vereenvoudiging op abstract niveau en de wens tot vereenvoudiging op concreet niveau. Op abstract niveau stemt een ieder in met de wens tot vereenvoudiging, op concreet niveau wordt dat moeilijker.

Onder vereenvoudiging wordt verstaan een vermindering van de administratieve problemen voor de burger, een toevloeien van de collectieve lasten naar de staatskas met zo min mogelijk maatschappelijke kosten en een beperking op menskracht bij de belastingdienst.

In 1986 heeft de commissie-OORT vereenvoudigingsvoorstellen gedaan. $\mathrm{Na}$ een enthousiaste ontvangst van deze voorstellen bleef door de vele amendementen in de uiteindelijke wet weinig van de vereenvoudiging overeind. Geconcludeerd kan worden dat de roep om vereenvoudiging wel heeft bestaan, maar dat deze sterk aan kracht heeft ingeboet.

Een van de redenen hiervoor is gelegen in het succesvol optreden van pressiegroepen. Een voorbeeld hiervan is de introductie van de overhevelingstoeslag.

Met betrekking tot het draagkrachtbeginsel merk ik hier slechts op dat de alleenstaande-toeslag om doelmatigheidsredenen èn budgettaire overwegingen is afgeschaft.

Wat de gelijkstelling van de ongehuwd samenlevenden ten opzichte van de gehuwden betreft, lag het aanvankelijk in de bedoeling om deze terug te draaien. De ongehuwd samenlevenden dienden volledig individueel in de belastingheffing te worden betrokken. Het uiteindelijke wetgevingsprodukt is min of meer in een handhaving van de bestaande wetgeving met een aantal optieregelingen geresulteerd.

Verder leert de parlementaire geschiedenis van OORT-I dat de eis van doelmatigheid in opmars is. Er wordt zelfs gesproken van een beginsel van doelmatigheid. De verhouding tussen rechtvaardigheid en doelmatigheid moet ten gunste van de doelmatigheid worden bijgesteld. 
Onder de eis van doelmatigheid moet hier in ieder geval een vereenvoudigingsstreven worden verstaan. Naast de eis van doelmatigheid hebben budgettaire overwegingen een beduidende rol in de totstandkoming van OORT-I gespeeld.

De algemene conclusie die voortvloeit uit de bestudering van de parlementaire geschiedenis en de literatuur betreffende OORT-I, luidt dat de werking van beginselen onderhevig is aan tijd en plaats.

In hoofdstuk 5 komen OORT-II en OORT-III aan de orde. OORT-II betreft de aanpassing van de tariefstructuur en de afschaffing of beperking van de in de niet-winstfeer gemaakte kosten en OORT-III de afschaffing of beperking van aftrekbare kosten in de winstsfeer. Het algemene artikel inzake de aftrekbaarheid van kosten is aangescherpt.

De afschaffing of beperking van de aftrekposten heeft samen met de afschaffing van de alleenstaande-toeslag in het parlement en in de literatuur veel stof doen opwaaien. Daarnaast werd de symmetrie tussen aftrekbaarheid van kosten en onbelaste vergoedingen doorbroken.

De voornaamste reden voor OORT-II en OORT-III is gelegen in budgettaire overwegingen. De lastenverlichting die door de invoering van OORT-I in het verschiet was gesteld, moest worden betaald.

$\mathrm{Nu}$ kan gezegd worden dat budgettaire overwegingen altijd een rol spelen in de belastingheffing, maar het moet natuurlijk niet zo zijn dat deze overwegingen de rol van 'verdelingsbeginsel' toebedeeld krijgen. De belastingwetgever legt lasten op, en deze lasten moeten volgens een rechtvaardig principe worden verdeeld. De belastingwetgever mag zich hierbij niet de vraag stellen waar het meeste geld te halen is. In dat geval is niet meer het draagkrachtbeginsel, maar zijn budgettaire overwegingen het 'verdelingsprincipe'. Budgettaire overwegingen kunnen aan de tot stand gebrachte lastenverdeling een deel van de daaraan toegedachte rechtvaardiging ontnemen.

Een conclusie die met betrekking tot de gehele OORT-wetgeving kan worden getrokken, is dat de vereenvoudiging uiteindelijk ver te zoeken is.

\section{Theorie inzake de beginselen van een rechtvaardige inkonstenbelasting}

In het bovenstaande heb ik de zgn. praktijk beschreven. Ik heb twee grote wetgevingsoperaties via een onderzoek van de wetsgeschiedenis en een literatuurstudie bekeken. Tijdens het onderzoek rees de vraag hoe de beginselen van belastingheffing zich uitkristalliseren. Met andere woorden, wat is de achtergrond, waarin de beginselen van belastingheffing hun gelding verkrijgen?

Het is duidelijk dat de belastingheffing verweven is met de maatschappelijke orde. Budgettaire, economische en politieke overwegingen spelen een belangrijke rol bij de totstandkoming van de wetgeving. In een overgangshoofdstuk, hoofdstuk 6 , bespreek ik deze overwegingen.

Bij de politieke overwegingen maak ik een onderscheid tussen het voeren van een bepaald beleid en het bestaan van pressiegroepen. Pressiegroepen spelen een aanzienlijke rol bij de totstandkoming van de belastingwetgeving. In het 
bestaan van pressiegroepen zit een paradox: enerzijds zijn ze nodig om bepaalde maatschappelijke problemen aan het licht te brengen en anderzijds is er een probleem van democratische verantwoording.

Het bestaan van pressiegroepen en hun invloed vormen een reden te meer om te veronderstellen dat de invulling van het draagkrachtbeginsel zeer gebonden is aan tijd en plaats.

$\mathrm{Na}$ dit overgangshoofdstuk bespreek ik in hoofdstuk 7 de theorie, zoals deze in de literatuur is gepresenteerd. In deze theorie komt voornamelijk de totstandkoming van het compromis tussen rechtvaardigheid en doelmatigheid aan de orde.

De belastingheffing kent al sinds lange tijd een behoefte aan een rechtvaardiging. $\mathrm{Na}$ de bespreking van enige werken van fiscale auteurs ga ik aan de hand van twee verdelingsbeginselen, t.w. het draagkracht- en het profijtbeginsel, na of deze enige gelding in het belastingrecht hebben. Het blijkt dat de twee beginselen toepassingsmogelijkheden en beperkingen kennen.

Vervolgens komt het gelijkheidsbeginsel aan de orde. Het beginsel kan als 'overkoepelend' beginsel van de verdelingsbeginselen worden gezien. Een onderscheid wordt gemaakt tussen het gelijkheidsbeginsel in het algemeen en het gelijkheidsbeginsel in het belastingrecht. De werking van het gelijkheidsbeginsel in het belastingrecht komt met name in de jurisprudentie tot uiting. Het beginsel kent echter een relatieve waarde; onder andere de eis van doelmatigheid beperkt de werking van het beginsel.

De eis van doelmatigheid staat tegenover die van de rechtvaardigheid. Deze eis van doelmatigheid is mijns inziens door zijn werking als een beginsel te beschouwen; de eis kan de werking van de rechtvaardigheid beperken. Onder doelmatigheid kunnen veel belangen worden geschaard.

Uiteindelijk heb ik de onderzochte wetgevingsprodukten aan de beginselen en het compromis van rechtvaardigheid en doelmatigheid getoetst.

In de Tweeverdienerswetgeving is de rechtvaadigheidseis ver doorgevoerd. De prijs hiervoor is dat de doelmatigheid ver te zoeken is. De ingewikkeldheid resulteert in een roep om vereenvoudiging.

Om aan deze roep te voldoen, wordt een commissie ingesteld. De commissieOort komt met vergaande vereenvoudigingsvoorstellen. Deze voorstellen worden niet helemaal in wetgeving omgezet. De wil is wel aanwezig geweest, echter vele amendementen hebben de wetgeving ingewikkelder gemaakt. In deze hebben pressiegroepen een rol gespeeld. De toepassing van de eis van doelmatigheid in de vorm van een vereenvoudigingsstreven is niet gerealiseerd.

OORT-I heeft een tariefverlaging bewerkstelligd en deze moet betaald worden. De opbrengst wordt gevonden in de afschaffing of beperking van bepaalde aftrekposten (OORT-II en OORT-III).

Budgettaire overwegingen bepalen het rechtvaardigheidsgehalte van OORT-II en OORT-III. Bovendien wordt in OORT-II en OORT-III een asymmetrie in- 
gevoerd. Bepaalde kosten zijn niet (meer) aftrekbaar, terwijl vergoedingen daarvoor onbelast zijn. Dit is in strijd met het gelijkheidsbeginsel.

Het gedetailleerde karakter van de voorstellen en de verzwaring van de uitvoering van de wetgeving voor alle betrokken partijen maken dat de doelmatigheid ver te zoeken is.

Resumerend kan worden gezegd dat het compromis tussen rechtvaardigheid en doelmatigheid voortdurend in beweging is.

Ik kom terug op de probleemstelling. Het antwoord op de eerste vraag: Welke beginselen gebruikt de belastingwetgever?, luidt: het draagkrachtbeginsel, het gelijkheidsbeginsel en het doelmatigheidsbeginsel. Deze beginselen blijken voor de wetgever veelvuldig als leidraad te dienen. Daarnaast worden meer terloops gebruikte beginselen en de motieven, die op een bepaald tijdstip als dringend worden ervaren in acht genomen.

De tweede vraag, inhoudende of de personen en de instanties die bij het wetgevingsproces zijn betrokken, de beginselen c.q. de motieven consequent gebruiken, moet ontkennend worden beantwoord. Toepassing en invulling van de beginselen zijn afhankelijk van tijd en plaats. De maatschappelijke verhoudingen bepalen de nadere invulling van de belastingheffing.

Bovendien spelen politieke belangen een rol. Hierbij valt bij voorbeeld te denken aan de noodzaak compromissen te sluiten.

Wellicht geldt dit niet alleen voor het belastingrecht, doch voor het gehele recht. De afhankelijkheid van tijd en plaats geeft een zekere mate van flexibiliteit aan het recht.

Hiermee kom ik tot aan de algemene conclusie van het onderzoek. De roep om een rechtvaardiging van de inkomstenbelasting blijft bestaan. Deze rechtvaardiging wordt gevonden in het draagkrachtbeginsel. Alhoewel het beginsel zeer vaag is en een eensluidende, nauwkeurige beschrijving niet kan worden gegeven, is het blijkbaar belangrijk dat de Wet IB 1964 is gebaseerd op het draagkrachtbeginsel. Dit geldt te meer daar een redelijk alternatief voor het draagkrachtbeginsel (nog) niet is gevonden. 


\section{Summary}

Principles and practice of income taxation

\section{Introduction}

Taxation presupposes imposed transfers of money by citizens to the state. This deeply affects people's lives and pocketbooks. The fact that there has always been a lot of discussion about the justification of taxation needs no further explanation. In my dissertation, where the existence of state, public authority and taxes are assumed to be given facts, I have concentrated on the form of taxation. Taxes may differ according their object (type of tax), their subject (type of tax payer) and their rate, which creates a great variety in taxation. In addition, existing taxes can be amended or replaced by others.

My study focuses on the decision-making process in taxation. In principle, the results of this process are laid down by government and parliament in statutes. This process is not entirely transparent. First of all, the one taxpayer may transfer his burden to another and the legislator has other objectives in addition to the wish to raise state capital. And second, the political framework plays an important part in decision-making. The latter refers in particular to the 'art of the possible' character of political decisions and the role of pressure groups.

Many have wrestled with the question of how to justify taxation. A substantial number of theories and principles serving to justify a distribution of the tax burden has been formulated over the years. Some theories and principles have come to the foreground and have served for a while as a guideline to the tax collector, who assumed that with the aid of these theories and principles a system could be devised capable of rendering taxation acceptable to society. One of these principles is the principle of taxation according to the ability to pay, which I shall call here the 'means principle'.

As a result of the desire to bring about a taxation system based on means, income tax was introduced. Briefly stated, since the end of the last century the leading principle underlying income taxation has been the means principle. The question, however, is whether this principle is still valid in today's world and whether income taxation continues to be based on this principle. Furthermore, it is not always clear what is meant by the means principle, for example, when applied in relation to the object of taxation or when applied in relation to the subject. Another factor which may limit the operation of the means principle is 
the notion of expediency. This is manifested in the compromise between a just tax and an appropriate tax in terms of expediency.

The object of my study is income taxation. On the basis of legislative history and doctrinal writings, I have studied the following questions:

1 What principles were used in the Dutch Income Tax Act 1964 and its Amendment Acts? Are these principles inherent in tax law, or not?

2. How do the individuals and bodies involved in the legislative process handle these principles? Are they consistent in dealing with them?

Of particular importance here is whether the 'old' principles continue to have an impact. The study of the grounds justifying the Income Tax Act 1964 is carried out from both a practical and a more theoretical angle.

\section{The practice of income taxation}

The discussion of the Act's practice is divided in three parts: the development of the fiscal position of the married woman; fiscal legislation regulating the income tax duties of double income earners and, thirdly, the OORT-legislation. The comment on the legislation is organized as follows: general remarks, comments on principles of legislation, the means principle, the principle of equality, the requirement of expediency and budgetary considerations. In connection with the OORT-legislation, I also discuss the simplification efforts.

In Chapter 2, the development of the fiscal position of the married woman is the central focusing point. One element influencing the means element becomes immediately visible: the married woman's entering the job market. In the sixties, more and more women are finding work outside the home. Initially, the negative effect of this on the family's means is taken into account, later this consideration is abandoned.

The social development of the married woman has been the guiding principle for the way in which taxes were imposed. The legislator adapts himself, as it were, to social changes, which automatically changes the definition of the means principle. An ability to pay which focuses more on the individual takes the place of 'family means'. Although social changes define the way in which taxes are imposed, the means principle nevertheless remains the leading principle.

In the subsequent Double Income Acts, discussed in chapter 3, the continuing emancipation of the (married) woman is taken into account. The process of adapting the taxation system to societal changes stays intact. In these Acts, a synthesis is found between family means and individual means.

In comparison to the period preceding the Double Income legislation, the family's ability to pay comes under a lot of strain. In this period, it becomes evident that giving weight to factors which have an impact on the ability to pay is a difficult issue. In addition, more and more forms of cohabitation emerge. In the Double Income Acts, cohabitants are treated on a somewhat equal basis with married couples. Full equality is deemed not feasible for budgetary reasons and for reasons of implementation. The element of being 'just' is therefore restrained by the elements of 'implementation' and 'budget'. 
The legislation introduced to redeem the flaws of the Double Income Acts shows that the Acts were disproportionately complex.

In Chapter 4, the OORT Commission and the resulting OORT-legislation are discussed. It was anticipated that the OORT-legislation would reduce the complexity of fiscal legislation. The history of the introduction of the OORT Commission demonstrates that a distinction must be made between the desire to come to a simplification at an abstract level and the wish for an effective simplification. At an abstract level, there is a consensus, difficulties are encountered at a concrete level.

Simplification should be understood as: fewer administrative problems for taxpayers, a flow of the collective tax and social security charges to the treasury with the least possible cost to society and less manpower for the revenue office.

In 1986, the OORT Commission came with proposals to simplify the system. Although these were met with enthusiasm, the resulting Act did not constitute a major simplification due to the large number of amendments. It can be concluded that the initial strong call for simplification was getting increasingly feeble. This was partly the result of the success of pressure groups. A case in point is the introduction of the premium transfer allowance (overhevelingstoeslag), a shifting of the burden from the employer, or social security office, to the employee, or benefit claimant.

With regard to the means principle, I merely note in this chapter that the additional exemption for single householders has been abolished for both budgetary reasons and reasons of expediency. Originally, it was planned to do away with the equal treatment of cohabitants vis-à-vis married couples. The idea behind this was that cohabitants should be taxed on an individual basis only. In the eventual legislative product, the existing legislation was kept intact, but was complimented by a number of optional arrangements.

A study of the legislative history of OORT-I shows that the expediency requirement is gaining ground. There is even talk of an expediency principle. The balance between just taxation and expedient taxation should be tipped in favour of expediency. The expediency requirement consists at least of the simplification effort. Apart from the expediency requirement, budgetary considerations have played an important role in the realization of OORT-I. The general conclusion to be drawn from studying the legislative history and the scholarly literature on OORT-I is that the operation of principles is affected by time and place.

In chapter 5, OORT-II and OORT-III are discussed. OORT-II deals with the adaptation of the rate structure and the abolition, or restriction, of the deductibility of costs incurred in non-profit situations, whereas OORT-III deals with the abolition or restriction of the deductibility of costs incurred by businesses. The general article on the deductibility of costs has been tightened. The abolition or restriction of deductions in conjunction with the abolition of the additional tax exemption for single householders has stirred a lot of dust both 
in parliament and among doctrinal writers. In addition, the symmetry between deductibility of costs and tax-exempt cost allowances has been broken.

The principal considerations leading to OORT-II and OORT-III were of a budgetary nature. The tax relief which had been promised by OORT-I needed to be funded. Although it is conceded that budgetary considerations always play a role in taxation, they should nevertheless not be given the function of 'distribution principle'. The fiscal legislator imposes tax duties and this burden should be distributed fairly. He should not base his decision on how to obtain maximum revenue. If he does, it is no longer the means principle, but budgetary considerations which function as a 'distribution principle'. Budgetary considerations can take away part of the justification earmarked for the distribution of the burden. The conclusion to be drawn on the basis of the entire OORT-legislation is that, in the end, the intended simplification did not materialize.

The theory of the principles underlying a just incone tax system

In the preceding section, I have described the taxation practice. I have investigated two major legislative operations by studying its legislative history and the writings of fiscal scholars. In the course of my research, the question arose as to how the principles of taxation come about. In other words, what gives them validity?

It is clear that taxation is closely connected with the social order. Budgetary, economic and political motives play an important role in the creation of fiscal laws. In an intermediate chapter, chapter 6 , these motives are discussed. When discussing political motives, I draw a distinction between conducting a certain policy and the existence of pressure groups. The latter substantially influence the creation of fiscal legislation. The phenomenon of pressure groups harbours a paradox: on the one hand they are needed to bring out certain social problems and on the other hand there is the problem of democratic legitimation. The existence of pressure groups and their influence are all the more reason for assuming that the definition of the means principle is determined by time and place.

Following the intermediate chapter, chapter 7 features the theory of taxation as presented in doctrinal writing, which mainly deals with the creation of the compromise between just and expedient taxation. For a long time, taxation has been in need of justification. After discussing a number of works by authors on fiscal matters, I investigate whether the two distribution principles, i.e. the means principle and the direct-profit principle, have any validity in fiscal law. The outcome is that the two principles are applicable, but not without restriction.

Subsequently, the principle of equality is discussed. This principle can be considered an overall principle under which the distribution principles can be ranged. A distinction is made between the general principle of equality and the principle of equality as applied in fiscal law. The operation of the principle of equality in fiscal law can be derived from case law. The merit of the principle, however, is relative; its operation is restricted by, among other things, the 
requirement of expediency. This requirement is counterbalanced by the requirement of just taxation. Because of its operation, the expediency requirement, in my view, can be considered a principle. It may limit the operation of the principle of just taxation. Many interests are dressed up as reasons of expediency.

Finally, I test the products of legislation I have investigated against the principles and the compromise between justice and expediency. In the Double Income Acts, the requirement of just taxation has been too severely applied, leaving little or no room for expediency. Its complicated structure calls for simplification. In order to meet this problem, a commission, the OORT Commission, was installed. This commission proposed far-reaching simplification measures. Their proposals have not been converted into legislation in their entirety. There was a will to do so, but the many amendments complicated the proposed legislation. Pressure groups were active here. The application of the requirement of expediency in the form of a simplification effort has not been realized.

Oort-I has brought about lower rates, which called for financial compensation. Such compensation was found in the abolition or restriction of the deductions for certain costs (OORT-II and OORT-III). Budgetary considerations determine the 'justice value' of OORT-II and OORT-III, which also introduced asymmetry between (no longer) deductible business costs and tax-exempt cost allowances. Certain business costs are no longer deductible, whereas cost allowances are taxexempt. This is in violation of the principle of equality.

The degree of detail in the proposals and the higher demands with regard to the implementation of the legislation for all parties involved cause the expediency element to be almost non-existent. In sum, it can be said that the compromise between justice and expediency is in a constant state of flux.

To return to the central problem of the thesis: the answer to the first question as to which principles are used by the tax legislator is: the means principle, the principle of equality and the principle of expediency. These are the principles the legislator often uses as guidelines. In addition to those, some ad hoc principles and motives are taken into account if they are considered pressing at a certain point in time.

The second question as to whether the principles, or the motives, as the case may be, are applied consistently by the individuals and bodies involved in the legislative process must be answered in the negative. Their application and definition are determined by time and place. Social relations are responsible for a more detailed definition of taxation. Furthermore, political interests play an important role, for instance, the necessity to compromise. This, perhaps, holds true for all types of law, not just tax law. A dependence on time and place makes the law flexible to some degree.

The study ends with a general conclusion. The call for a justification of income tax remains. Such justification is found in the means principle. Although this principle is rather vague and lacks a precise, unequivocal definition, it is apparently important that the Income Tax Act 1964 is based on the means 
principle. The more so, since a suitable alternative for this principle has not yet been found.

translated bij Louise Rayar 


\section{Literatuurlijst}

\section{E. Aardema,}

Rapport van de commissie-Oort; een voorlopig oordeel, Weekblad voor fiscaal recht, 1986, no 5733, blz. 761-765.

J.R. Abbing,

Economie en cultuur: de subsidieproblematiek en de economische theorie, alsmede aanzetten tot een economie van de kunsten, Staatsuitgeverij, 's-Gravenhage, 1978.

P.J.A. Adriani,

Het belastingrecht, deel I, Samson, 1954.

L. Adringa,

Van gezinsdraagkracht naar individuele draagkracht, De tweeverdienerswet: evaluatie en alternatieven, Nemisis, 1987, blz. 171-180.

Advies,

Belastingvereenvoudiging, Advies inzake het rapport van de commissie-OORT, Raad voor het Midden-en Kleinbedrijf, 1986.

Advies,

Emancipatieraad, Advies eenvoud in de loon- en inkomstenbelasting, juni 1987, nr. II $/ 38 / 87$.

Advies Belastingvereenvoudiging,

Advies vereenvoudiging belastingheffing en premieheffing volksverzekeringen, Sociaal-Economische Raad, 87/17, 16 oktober 1987.

W. Albeda, C. de Galan,

Inkomen, vorming, verdeling, beleid, Wolters-Noordhoff, Groningen, 1970.

D.A. Albregtse,

De commissie-Oort en de aftrekposten: Vereenvoudigen èn bezuinigen!, Maandblad Belastingbeschouwingen, 1986, no 9, blz. 221-226.

D.A. Albregtse,

Oort-I + II en de aftrekposten: minder eenvoud en meer bezuiniging, Maandblad Belastingbeschouwingen, 1988, no 11, blz. 322-325.

D.A. Albregtse,

Buitengewone lasten, Fed Fiscale brochures, 1992. 
P.J. van Amersfoort, D.J. van den Hoeven,

De Wet tweeverdieners, Weekblad voor fiscaal recht, 1984, no 5625, blz. 189-200.

J.H.T.H. Andriessen, J.M.J. Baaijens, E.M.H. Hirsch Ballin, I.Th.M. Snellen, Wetsevaluatie tussen wetenschap en beleid, W.E.J. Tjeenk Willink, 1987.

J.A.M. van Angeren,

Beginselen van behoorlijke wetgeving. In: Kracht van wet, Van Eykerenbundel, W.E.J. Tjeenk Willink, 1984, blz. 63-74.

K.V. Antal,

Eenvoud in het belastingrecht in Nederland, Openbare les, Leiden, 1947.

H.P.A.M. van Arendonk,

De Tweeverdienersregeling, Maandblad Belastingbeschouwingen, 1986, no 6, blz. 158-162.

H.P.A.M. van Arendonk,

Zicht op eenvoud gloort en er is bereidheid tot verandering, Maandblad Belastingbeschouwingen, 1988, no 1, blz. 1-4.

H.P.A.M. van Arendonk,

OORT-I + OORT-II, Vereenvoudiging I - Vereenvoudiging II, Maandblad Belastingbeschouwingen, 1988, no 9, blz. 221-229.

H.P.A.M. van Arendonk,

De operatie Oort: de vereenvoudiging weggesneden?, Maandblad Belastingbeschouwingen, 1988, no 11, blz. 301-304.

H.P.A.M. van Arendonk,

De Eerste Kamer en de Vereenvoudigingsvoorstellen-Oort, Maandblad Belastingbeschouwingen, 1989, no 6, blz. 141-147.

H.P.A.M. van Arendonk,

Belastingfraude en oneigenlijk gebruik na de belastingherziening 'Oort', Maandblad Belastingbeschouwingen, 1989, no 11, blz. 318-321.

H.P.A.M. van Arendonk,

1990?, Maandblad Belastingbeschouwingen, 1990, no 1, blz. 1-2.

H.P.A.M. van Arendonk,

'Oort en de ondernemer, de ecrste ervaringen', Maandblad Belastingbeschouwingen, 1990, no 10, blz. 245-249.

H.P.A.M. van Arendonk, P. Kavelaars, L.G.M. Stevens,

Eenvoud in praktijk, OORT wetgeving, tweede herziene druk, Kluwer, 1991.

H.P.A.M. van Arendonk,

De inkomstenbelasting in Nederland: een monumentaal bouwwerk, Maandblad Belastingbeschouwingen, 1993, no 6, blz. 155-169.

J.H.M. Arts,

De invloed van de loonbelasting op de winst uit onderneming, Weekblad voor fiscaal recht, 1991, no 5965, blz. 819-829.

J.M.J. Baaijens,

Beleidsnetwerken in actie, Monografieën sociaal recht, no 5, Kluwer, 1988. 


\section{C.P.A. Bakker,}

Gehuwde tweeverdieners: ondoelmatige ingreep, Weekblad voor fiscaal recht, 1983, no 5594, blz. 684-686.

\section{C.P.A. Bakker,}

Wetsontwerp tweeverdieners tweede fase: een kapitale misgreep. Weekblad voor fiscaal recht, 1983, no 5612, blz. 1417-1420.

C.P.A. Bakker,

Leven met Tweeverdieners 2, Weekblad voor fiscaal recht, 1984, no 5624, blz. 161-166.

C.P.A. Bakker,

Tweeverdieners derde fase: kruidenierspolitiek, Weekblad voor fiscaal recht, 1984, no 5657, blz. 1352-1355.

C.P.A. Bakker,

Herziening loon- en inkomstenbelasting, Weekblad voor fiscaal recht, 1987, no 5779, blz. 771-774.

\section{C.P.A. Bakker,}

Weerstanden tegen vereenvoudiging, Weekblad voor fiscaal recht, 1988, no 5843, blz. 1372-1376.

C.P.A. Bakker,

Nogmaals: de oortse tariefgroepen en het splitsingsstelsel, Weekblad voor fiscaal recht, 1991, no 5949, blz. 224-228.

C.W.M. van Ballegooijen,

Naar een herziening van het regime van de gemengde kosten, Weekblad voor fiscaal recht, 1992, no 6025, blz. 1304-1309.

J.W. Bellingwout,

Vereenvoudiging van het regime van de gemengde kosten, Weekblad voor fiscaal recht, 1992, no 6025, blz. 1310-1315.

J.Th.J. van den Berg, H.A.A. Molleman,

De crisis in de Nederlandse politiek, tweede druk, Samson, 1980.

W.H. van den Berge,

Beginselen van de belastingheffing, Geschriften van de Vereniging voor Belastingwetenschap, no 68, Samson, 1949.

W.H. van den Berge,

De structuur van het belastingrecht, rede, 1951. In: Tributen aan het recht, 100 jaar Weekblad voor fiscaal recht, 1971, blz. 74-91.

N. Bink, E. Wasch,

Aftrekbare kosten en vergoedingen, Kluwer belastingwijzers 7, vierde herziene druk, 1991.

T. Blokland,

Inkomstenbelasting, naar gezin of naar persoon, Weekblad voor fiscaal recht, 1992, no 6026, blz. 1390-1392.

A.J. Bok,

Rechter contra wetgever: toetsing van geschreven aan ongeschreven recht. In: De rechtsstaat herdacht, W.E.J. Tjeenk Willink, 1989, blz. 267-281. 


\section{P.B. Boorsma,}

Belastinghervorming in Nederland, ESB, 1986, blz. 80-85.

A.N. Boternans,

Aftrekbare kosten en kostenvergoedingen: De klok teruggezet, Maandblad Belastingbeschouwingen, 1989, no 6, blz. 148-152.

A.F.M. Brenninkmeijer,

Financiële normen en rechtsnomen, Nederlands juristenblad 1988, afl. 32, blz. 1164-1166.

M. Brouwer,

Enkele opmerkingen over de empirische studie van pressie en publiek. In: Pressiegroepen. J.J. de Jong, 1959, blz. 25-62.

J.Th.L. Brouwer, M.W.C. Feteris,

De vereenvoudiging ontspOort(1), Fiscaal Weekblad FED 24 november 1988, blz. 2187-2190.

J.Th.L. Brouwer, M.W.C. Feteris,

De vereenvoudiging ontspOort(4), fiscaal weekblad FED, 1988, no 748, blz. 23612364.

J.Th.L. Brouwer, M.W.C. Feteris,

De vereenvoudiging ontspOort(5), fiscaal weekblad FED, 1988, no 764, blz. 24212425.

D. Brïll,

Rechtsnorm en overheidsbudget, Openbare Les, 1967.

H. Buddingh,

Het grote rekenen kan beginnen, NRC Handelsblad, supplement Mens en Bedrijf, 3 augustus 1988, blz. 3.

W. Buis,

Toetsing van fiscale wetgeving, In: Recht van spreken, Meering-bundel, Kluwer, 1984, blz. 67-72.

Gr. van der Burght,

Vergoeding voor huishoudelijke arbeid?, Weekblad voor fiscaal recht, 1993, no 6043, blz. 212-220.

M.C. Burkens,

Gelijke behandeling. In: Grondrechten, commentaar op hoofdstuk 1 van de herziene Grondwet, Jeukens-bundel, 1982, blz. 49-65.

Ch. Caanen, P.H.J. Essers,

Rechtseconomie en belastingrecht. In: Rechtseconomie, Ars Aequi, oktober 1990, blz. 75-79.

Ch. Caanen,

Ceterum censeo non esse dividendum of de oortse tariefgroepen en het splitsingsstelsel, Weekblad voor fiscaal recht, 1990, no 5913, blz. 648-652.

J.H. Christiaanse,

Belastingaftrek voor de gehuwde vrouw, derde druk, Kluwer, 1961. 


\section{J.H. Christiaanse,}

Deel 2. De fiscale behandeling van de gehuwde vrouw. In: Belastingbeschouwingen, Christiaanse-bundel, Kluwer, 1989, blz. 61-65.

S. Cnossen,

Zicht op echte eenvoud, Weekblad voor fiscaal recht, 1990, no 5901, blz. 168-171.

E.M.G. Creusen, D. Booij, P.M. van Schie,

Naar een breder inkomensbegrip?, Weekblad voor fiscaal recht, 1979, no 5406, blz. 553-562.

A.H.R.M. Denie,

De overheid in de omzetbelasting, Fiscale monografieën, no 43, Kluwer, 1987.

J.E.A.M. van Dijck,

De tariefopbouw in het rapport-Oort, Maandblad Belastingenbeschouwingen, 1986, no 9, blz. 209-211.

J.E.A.M. van Dijck,

Kostenvergoedingen, Column, Weekblad voor fiscaal recht, 1988, no 5837, blz. 1137-1138.

J.E.A.M. van Dijck,

Gemengde kosten, Weekblad voor fiscaal recht, 1988, no 5844, blz. 1413-1429.

P. van Dijk, G.J.H van Hoof,

De Europese conventie in theorie en praktijk, Ars Aequi Libri, Rechten van de mens, tweede druk, 1988.

J.A.A. van Doom,

Pressiegroepen: correctie of corruptie? In: Pressiegroepen, J.J. de Jong, 1959, blz. 64-85.

A.C.R. Dreesman,

Gelijkheid en doelmatigheid: aspecten van een afruil. In: Maatschappelijke ongelijkheid; de overheid een zorg, Nederlands Gesprekscentrum, 1987, blz. 1221.

C.C.H.J. Driessen,

Vereenvoudiging in rechtvaardig perspectief, Weekblad voor fiscaal recht, 1988, no 5844 , blz. $1472-1477$.

A.J.M. van Elk,

Commentaar van de Nederlandse Orde van Belastingadviseurs op wetsvoorstel "Oort-II", Weekblad voor fiscaal recht, 1988, no 5844, blz. 1457-1463.

W.P. Erasmus,

De directe werking van beginselen in het stellige belastingrecht, Belastingconsulentendag, 1972.

W.P. Erasmus,

De directe werking van beginselen in het stellige belastingrecht, Weekblad voor fiscaal recht, 1972, no 5089, blz. 494-499.

M.W.C. Feteris, J.Th.L. Brouwer,

De vereenvoudiging ontspOort(2), fiscaal weekblad FED, 1988, no 714, blz. 22352238. 


\section{Fiscale wetgeving,}

Belastingmaatregel voor gehuwde tweeverdieners, Weekblad voor fiscaal recht, 1983, no 5584 , blz. 382.

G.M.M. Gelauff en J.J. Graafland,

Individualisering in sociale zekerheid en belastingen, Economisch statistische berichten, 1992, no 3881, blz. 1001-1005.

JA.G. van der Geld,

Zicht op fiscale wetgeving, Tilburg University Press, 1991.

J.A.G. van der Geld,

De honderdjarige inkomstenbelasting, wat moeten we ermee?, Weekblad voor fiscaal recht, 1992, no 6026, blz. 1381-1382.

Gelijk in de praktijk,

Rapport van de interdepartementale juridische werkgroep gelijkheidsbeginsel (IWEG), Uitgave van het Ministerie van Justitie, Stafafdeling Algemeen Wetgevingsbeleid, Den Haag, 1990.

Ch.P.A. Geppaart,

Rondom het empirische begrip inkomen, Weekblad voor fiscaal recht, 1992, no 6026, blz. 1379-1380.

Ch.P.A. Geppaart,

Wie is eigenlijk de belastingplichtige?, Column, Weekblad voor fiscaal recht, 1994, no 6102, blz. 667-668.

Tj. Gerbranda, M. Kroes,

Grondrechten evaluatie-onderzoek, Documentatie-rapport (1), NJCM, Leiden, 1991.

J.F.M. Giele,

Het fiscale rechtstekort, Kluwer, 1977.

J.F.M. Giele,

De problematiek van de tweeverdieners, Fed Nederlandse Federatie van belastingconsulenten, 1986.

J.F.M. Giele,

Enige gezichtspunten bij toerekening aan echtelieden van inkomensbestanddelen, in het bijzonder aan de gehuwde vrouw. In: Belastingbeschouwingen, Christiaanse-bundel, Kluwer, 1989, blz. 81-96.

C. Goedhart,

Enkele facetten van belastingprogressie. In: Fiscaal-economsiche opstellen, Schendstok-bundel, Samson, 1966, blz. 95-106.

H.P.J. Goossen,

Eenvoud kan niet méér, Symposiumverslag, Weekblad voor fiscaal recht, 1986, no 5733 , blz. 811.

H. van de Graaf, R. Hoppe,

Beleid en politiek, een inleiding tot de beleidswetenschap en de beleidskunde, Coutinho, 1992.

Graag of niet,

rapport van de Commissie-Stevens, Sdu, 1991. 
F.H.M. Grapperhaus,

Weekblad voor fiscaal recht, Column, 1985, no 5705, blz. 1505-1506.

F.H.M. Grapperhaus,

Vereenvoudiging van de belastingheffing een vraagstuk voor managers, Weekblad voor fiscaal recht, 1986 , no 5750 , blz. 1435-1446.

F.H.M. Grapperhaus,

Van hoepelrok naar petticoat?, Weekblad voor fiscaal recht, 1992, no 6026, blz. 1377-1379.

F.H.M. Grapperhaus,

De pelgrimstocht naar het draagkrachtbeginsel, Kluwer, 1993.

F.H.M. Grapperhaus,

Fiscale geschiedenis in 2094, Column, Weekblad voor fiscaal recht, 1994, no 6108, blz. 865-866.

R.H. Happé,

Het gelijkheidsbeginsel in ethisch perspectief, Geschriften van de Vereniging voor Belastingwetenschap, no 178, Kluwer, 1989.

R.H. Happé,

Artikel 26IVBPR-verdrag, ofwel hoe het belastingrecht de maat wordt genomen, Weekblad voor fiscaal Recht, 1990, no 5907, blz. 387-402.

R.H. Happé,

De opmars van het gelijkheidsbeginsel voltooid?, Weekblad voor fiscaal recht, 1993, no 6042, blz. 145-158.

A. Hartman,

De 'Oortse' tariefgroepen en het splitsingsstelsel, Weekblad voor fiscaal recht, 1990, no 5934, blz. 1497-1501.

G.A. den Hartogh,

Fiscale moraal en de moraal van de fiscus, Weekblad voor fiscaal recht, 1987, no 5772, blz. 541-553.

A.G.J. Haselbekke,

Profijtbeginsel en politieke besluitvorming, Stenfert Kroese, 1987.

A.G.J. Haselbekke,

Het profijtbeginsel en de beheersing van de collectieve sector. In: Naar een

beheersbare collectieve sector, Fiscaal Economisch Instituut, Rotterdam, 1981, blz. 125-155.

H.J. Hellema,

De belastingwetenschap neutraal? In: Cijns en Dijns, Hofstra-bundel, Kluwer, 1975, blz. 63-72.

A.W. Heringa, R.E. de Winter,

De relatieve waarde van het gelijkheidsbeginsel, Tijdschrift voor Openbaar Bestuur, 1982, no 17, blz. 508-511.

A.W. Heringa,

Sociale grondrechten, T.M.C. Asser Instituut, 1989. 
F.G. van Herwaarden, C.A. de Kam,

De fiscale behandeling van leefvormen, 1970-1990, Weekblad voor fiscaal recht, 1990, no 5905, blz. 321-328.

E.M.H. Hirsch Ballin,

Rechtsbeginselen en algemene beginselen van behoorlijk bestuur, Tijdschrift voor Rechtsfilosofic en Rechtstheorie, 1982, blz. 105-111.

E.M.H. Hirsch Ballin,

Staatsrecht en bestuursrecht: Artikel 1 van de Grondwet als fundamentele constitutionele norm. In: Gelijkheid en recht, C.W. Maris, Zwolle, 1988.

E.M.H. Hirsch Ballin,

Rechtsstaat en beleid, W.E.J. Tjeenk Willink, 1991.

G.P. Hoefnagels,

Over belastingfraude, criminologie en democratie, Weekblad voor fiscaal recht, 1992, no 6027, blz. 1399-1400.

D. van den Hoeven,

Nog wat vraagpunten bij de toepassing van de wet tweeverdieners, Weekblad voor fiscaal recht, 1985 , no 5692, blz. 971-978.

H.J. Hofstra,

Socialistische belastingpolitiek, De Arbeiderspers, 1946.

H.J. Hofstra,

Plaats en taak van de belastingwetenschap, Kluwer, 1966.

H.J. Hofstra,

Het einde van de draagkrachttheorie, Weekblad voor fiscaal recht, 1939. In:

Tributen aan het recht, 100 jaar Weekblad voor fiscaal recht, 1971, blz. 51-66.

H.J. Hofstra,

De toekomst van de inkomstenbelasting, Weekblad voor fiscaal recht, 1975, no 5248, blz. 1033-1045.

H.J. Hofstra,

Over belastingbeginselen, Weekblad voor fiscaal recht, 1979, no 5427, blz. 12131220.

H.J. Hofstra,

Van recht naar wet. In: Van wet naar recht, Scheltens-bundel Kluwer, 1984, blz. 53-63.

H.J. Hofstra,

Het fiscale wetgevingsproces, Weekblad voor fiscaal recht, 1985 , no 5672 , blz. 253-256.

H.J. Hofstra,

Vereenvoudiging van de inkomstenbelasting concreet bezien. In: Giele-bundel, 1990, Kluwer, blz. 245-256.

H.J. Hofstra,

De lof van de Tweeverdienersregeling. In: Mobach-bundel, Leids Fiscaal Jaarboek, Gouda Quint, 1985, blz. 39-42. 
H.J. Hofstra, L.G.M. Stevens,

Inkomstenbelasting, Fiscale hand- en studieboeken, no 2, vierde druk, Kluwer, 1994.

H.J. Hofstra,

Het splitsingsstelsel. In: Belastingbeschouwingen, Christiaanse-bundel, Kluwer, 1989, blz. 67-80.

H.J. Hofstra m.m.v. C. van Raad,

Inleiding tot het Nederlands belastingrecht, Fiscale hand- en studieboeken, no 1, zevende druk, Kluwer, 1992.

A.M. Hol,

Instrumentalisme en recht. Enkele rechtstheoretische kanttekeningen. In: Gielebundel, Kluwer, 1990, blz. 257-276.

\section{R. Holtmaat,}

Met zorg een recht?, een analyse van het politiek-juridisch vertoog over bijstandsrecht, W.E.J. Tjeenk Willink, 1992.

\section{J. Hoogendoom,}

Enkele opmerkingen naar aanleiding van wetsontwerpen 'Oort II/III', fiscaal weekblad FED, 1988, no 728, blz. 2298-2301.

Individualisering en draagkracht,

Rapport CDA-werkgroep, mei 1991.

D. Juch,

Architecten gevraagd, Weekblad voor fiscaal recht, 1992, no 6026, blz. 1374-1376. Het kabinetsstandpunt inzake de voorstellen van de commissie-Oort, Weekblad voor fiscaal recht, 1987, no 5758, blz. 67-81.

P. Kalma,

De illusie van de 'democratische' staat, Kluwer, 1982.

C.A. de Kam,

Big rat is eating you!, Weekblad voor fiscaal recht, 1986, no 5750, blz. 1461-1472. C.A. de Kam,

Tax reform in a welfare state: the case of the Netherlands, 1960-1987, Den Haag, 1988.

CA. de Kam, F.G. van Herwaarden,

Belastingherziening in Nederland: problemen en perspectieven, Preadviezen van de Koninklijke Vereniging voor de Staathuishoudkunde, 1988.

C.A. de Kam, J.E. Stum,

De effectieve druk van inkomensheffingen en vermogensbelasting, voor en na de operatie-'OORT', Weekblad voor fiscaal recht, 1994, no 6117, blz. 1261-1275.

\section{M.K. Kamperman,}

Enige beschouwingen over de opbouw van het tarief der inkomstenbelasting. In: Fiscaal-economische opstellen, Schendstok-bundel, Samson, 1966, blz. 136-151. H.J.R. Kaptein,

Integriteit en het tekort van doelmatigheid en rechtvaardigheid. In: C.W. Maris c.s., Recht, Rechtvaardigheid en Doelmatigheid, Kluwer, 1990, blz. 348-358. 
P. Kavelaars, L.G.M. Stevens, L.Opheikens,

Tweeverdieners 1984-1985: Fiscaal- en sociaalrechtelijke aspecten, Kluwer, tweede druk, 1985.

$P$. Kavelaars,

Tweeverdieners: laatste fase?, Weekblad voor fiscaal recht, 1985, no 5707, blz. 1596-1607.

\section{P. Kavelaars,}

De kern van de zaak, Weekblad voor fiscaal recht, 1988, no 5844, blz. 1439-1448. P. Kavelaars,

Alleenstaande samenwoners of samenwonende alleenstaanden?, Weekblad voor fiscaal recht, 1990, no 5920, blz. 955-960.

P.E. Keekstra,

Vereenvoudiging: het moet, het kan!, Weekblad voor fiscaal recht, 1986, no 5733, blz. 798-799.

P.E. Keekstra,

Gemengde gevoelens, Weekblad voor fiscaal recht, 1988, no 5844, blz. 1449-1451. E.N. Kertzman,

Belastingheffing van gehuwden en ongehuwden, Fiscale monografieën, no 32, Kluwer, 1979.

E. van Kessel, M. Kuperis, H. Pott-Buter,

Hoezo gelijk belast?, Invloed van arbeid, belasting- en premieheffing op het leven van vrouwen, 1986.

H.J.W. Klein Wassink,

De ideologie van het belastingrecht, 1975, blz. 96. In: Cijns en Dijns, Hofstrabundel, 1975, blz. 91-113.

H.A. Kogels,

Op weg naar een geharmoniseerde inkomstenbelasting?, Weekblad voor fiscaal recht, 1992, no 6026, blz. 1368-1371.

H. Kombrink,

De progressieve druk van H. Mobach, Mobach-bundel, Leids Fiscaal Jaarboek, Gouda Quint, 1985, blz. 77-80.

H.E. Koning,

Inleiding ter gelegenheid van het congres 'Eenvoud in zicht', Eenvoud in zicht, Weekblad voor fiscaal recht, 1986, no 5750, blz. 1433-1434.

L. Koopmans, Overheidsfinanciën, Stenfert Kroese, derde druk, 1975, blz. 51-59, 89-131.

L. Koopmans, A.H.E.M. Wellink, H.J. Woltjer, CA. de Kam,

Overheidsfinanciën, zevende druk, Stenfert Kroese, 1991.

T. Koopmans,

Compendium van het Nederlandse staatsrecht, Zwolle, vijfde druk, 1987.

J.H. van Kreveld,

De kwaliteit van wetgeving: rechtsstatelijke en bestuurlijke eisen. In: Recht doen door wetgeving, E.M.M. Hisch Ballin-bundel, 1991, blz. 189-202. 


\section{G.E. Langemeyer,}

Ons oordeel over wat recht moet zijn, Tjeenk Willink, rede, 1950, tweede druk. WJ. de Langen,

Grondbeginselen van ons belastingstelsel, rede, Kluwer, 1950.

W.J. de Langen,

De grondslagen van het Nederlands belastingrecht, Deel I, Samson, 1954.

D.A.M. Meeles,

De nevendoeleinden van de de belastingheffing, In: Van Dijck-bundel, Fed, 1988, blz. 243-262.

J.G.A. van Mierlo,

Pressiegroepen in de Nederlandse politiek, Stichting Maatschappij en Onderneming, 1988.

J.GA. van Mierlo,

Tax Reform, Economic Emancipation of Women, and Public Policy Formation in the Netherlands 1980-1992: A Public Choice Approach, Journal of Economic Studies, Vol. 18, No. 5/6, 1991, page 87-104.

\section{G.W. Mincke,}

Privaatrecht en pluralisme, rede, Kluwer, 1992.

H. Mobach,

Solidair of solitair: een versluierend dilemma. In: Fiscale rechtsbescherming, Leids fiscaal jaarboek, Gouda Quint, 1985, blz. 105-113.

H. Mobach,

Belastingrecht en zorg, Lezing werkgroep Vrouw en Recht, 10 september 1991.

D. Molenaar,

Artiesten en vereenvoudigen, Weekblad voor fiscaal recht, 1988, blz. 1478-1480.

Mondeling overleg over de behandeling van de Nota Op weg,

Weekblad voor fiscaal recht, 1983, no 5596, blz. 785-786.

J.P.H. de Monté Verloren, J.E. Spruit,

Hoofdlijnen uit de ontwikkeling der rechterlijke organisatie in de Noordelijke Nederlanden tot de Bataafse omwenteling, zesde druk, Kluwer, 1982.

L. Mulder,

Over gelijkheid, onderscheid en diskriminatie, Recht en kritiek, 1985, no 11.

W.F. Nederstigt,

Rechtvaardigheid en doelmatigheid van belastingheffing naar draagkracht. In:

Smeetsbundel, Kluwer, 1967, blz. 261-271.

R.E.C.M. Niessen,

Voordeel beogen en voordeel verwachten, Fed-bundel Fantasie en Durf, 1991, blz. 75-80.

R.E.C.M. Niessen,

Honderd jaar brede herwaardering en het gelijkheidsbeginsel, Weekblad voor fiscaal recht, 1992, no 6026, blz. 1364-1366.

R.E.C.M. Niessen,

Belastingbeginselen, belastingvlucht en het initiatief-wetsvoorstel van het duo $\mathrm{V}$ en V, Column, Forfaitair, 1993, no 34, blz. 62-63. 


\section{J. Nijstad,}

Aftrekbare kosten: hinkstapsprong?, Weekblad voor fiscaal recht, 1989, no 5870, blz. 646-652.

W.E.M. van Nispen tot Sevenaer,

De 35\%-regeling en het gelijkheidsbeginsel, Weekblad voor fiscaal recht, 1992, no 6017 , blz. 961-964.

\section{R.H.M.J. Offermans,}

Belastingfraude en belastingmoraal, verslag van de belastingadviseursdag 1994, Weekblad voor fiscaal recht, 1994, no 6104, blz. 758-766.

C.J. Oort,

Belastinghervorming, rede 5 februari 1988, Weekblad voor fiscaal recht, 1988, no 5808, blz. 151-158.

C.J. Oort,

Belastingherziening in de jaren negentig, Maandblad Belasting Beschouwingen 1990, no 10, blz. 262-264.

J.J. Oostenbrink,

Vlagincidenten rondom artikel 1 van de Grondwet. In: Burger en overheid, Steenbeek-bundel, 1984, blz. 169-181.

A.J. Ouweneel,

Vereenvoudiging niet voor de werkgever, Maandblad Bclastingbeschouwingen, 1988, no 11, blz. 317-320.

A.J. Ouweneel,

Oort Herziening belasting- en premieheffing en gevolgen voor arbeidsvoorwaarden, sociale verzekeringen en pensioenen, 1989.

M.P. van Overbeeke,

Enige opmerkingen over discriminatie en belastingrecht. In: Gelijkheid, gelijkwaardigheid, discriminatie en het recht, P.L. Dijk, rede VU, 1985.

M.P. van Overbeeke,

Inkomstenbelasting: einde of nieuw begin?, Weekblad voor fiscaal recht, 1992, no 6026, blz. 1356-1358.

J. Pen,

Het verstoorde evenwicht de pressiegroepen, In: Pressiegroepen. J.J. de Jong, 1959, blz. 86-103.

J.A. Ponsioen S.C.J.,

Sociologie van het economisch-politieke denken, In: Economische wetenschap en economische politiek, Stenfert Kroese, 1952, blz. 59-80.

H. Prast,

Belastingadviseur en vereenvoudiging van de wetgeving, Pre-advies no. 6 en debat voor de drieëndertigste jaarvergadering van de Nederlandse Orde van Belastingadviseurs, Kluwer, 1987.

Rapport van de Commissie ter bestudering van de fiscale aspecten van samenlevingsvormen,

Geschriften van de Vereniging voor Belastingwetenschap, Kluwer, 1984, no 162. 
Bespreking van het rapport van de Commissie ter bestudering van de fiscale aspecten van samenlevingsvormen,

Geschriften van de Vereniging voor Belastingwetenschap, Kluwer, 1984, no 163. J. Rensema,

De tweeverdienerswet heeft tenminste kwaliteit, Weekblad voor fiscaal recht, 1985, no 5676, blz. 416-417.

J. Reugebrink,

Directe en indirecte belastingen: een achterhaalde classificatie? In: Cijns en Dijns, Hofstra-bundel, Kluwer, 1975, blz. 131-150.

M.R. Reuvers,

Belasting, politiek en strategie, Fed, 1986.

M.R. Reuvers,

Mythen en de belastingheffing, Fed-bundel Fantasie en durf, 1991, blz. 81-87.

A.C. Rijkers,

Tweeverdieners-III, Een nabeschouwende vooruitblik, Weekblad voor fiscaal recht, 1984, no 5636, blz. 517-533.

A.C. Rijkers,

Naar een proportioneel inkomstenbelastingtarief in de 21e eeuw, rede, Kluwer, 1991.

A.C. Rijkers,

Besmet bloed, Weekblad voor fiscaal recht, 1992, no 6026, blz. 1350-1352.

N.H.M. Roos,

Enkele rechtstheoretische kanttekeningen bij een belastingtheoretische discussie, Nederlands Juristenblad 1980, aflevering 12, blz. 255-261.

J.P. Scheltens,

De directe werking van rechtsbeginselen in het stellige belastingrecht, bespreking van W.P. Erasmus van de belastingconsulentendag 1972, Weekblad voor fiscaal recht, 1972 , no 5089, blz. 494-499.

D.F. Scheltens,

Rechtsbeginselen, Tjeenk Willink, 1983.

B. Schendstok,

Ontwikkelingsfactoren van het belastingrecht, rede 16 mei 1946, Samsom, 1946.

W. Scholten,

Geen privilegiën in het stuk der belastingen, Weekblad voor fiscaal recht, 1958, no 4414 , blz. $699-70$ B.

G.J. Scholten,

Rechtsbeginselen en rechtsregels, scheiden schaadt. G.J. Scholten, D.F. Scheltens, H.J. Eikema Hommes. In: Rechtsbeginselen, tweede druk, Tjeenk Willink, 1983.

H.M.N. Schonis,

Inkomstenbelasting: ingrijpende verbouwing noodzakelijk, Weekblad voor fiscaal recht, 1992, no 6026, blz,. 1348-1350.

J.A. Schumpeter,

Kapitalisme, socialisme en democratie, Sterrenserie, no 9, Hilversum, 1963. 
$K$ Schuyt, R. van Veen,

De verdeelde samenleving, Stenfert Kroese, 1990.

L.W. Sillevis,

De opmars van de samenwoners in de inkomstenbelasting. In: Mobach-bundel, Leids Fiscaal Jaarboek, Gouda Quint, 1985, blz. 161-176.

L.W. Sillevis, N.H. de Vries,

Universiteit, belastingbeginselen en samenleving, Weekblad voor fiscaal recht, 1990, no 5943, blz. 1882-1893.

W.J. Slagter,

Rechtvaardigheid en doelmatigheid, Enige beschouwingen over het compromiskarakter van het recht, rede, Kluwer, 1961

G. Slot,

Verpolitiekte inkomstenbelasting. In: Recht van spreken, Meering-bundel, Kluwer, 1984, blz. 87-90.

M.J.H. Smeets,

De economische betekenis van de belastingen, Amsterdam, tweede druk, 1954. M.J.H. Smeets,

Economisch beleid en belastingrecht, rede, Amsterdam, 1967.

H. Snijders-Borst,

Belasting en leefeenheid, Weekblad voor fiscaal recht, 1983, no 5578, blz. 191207.

H. Snijders-Borst,

Lof en blaam, Weekblad voor fiscaal recht, 1983, no 5618, blz. 1603-1625.

J. van Soest,

De grondbeginselen van de vermogensbelasting. Smeetsbundel, 1967, blz. 319326.

J. van Soest,

Belastingbeginselen. In: Honderd jaar rechtsleven, Nederlandse Juristen-Vereniging, 1870-1970, Tjeenk Willink, blz. 333-340.

J. van Soest,

De directe werking van rechtsbeginselen in het stellige belastingrecht, Nederlandse Federatie van Belastingconsulenten, 1973.

A.J. van Soest,

Belastingen: inkomstenbelasting, vermogensbelasting, vennootschapsbelasting, Gouda Quint, achttiende druk, 1994.

H. Smit,

De opmars van het gelijkheidsbeginsel. In: Van wet naar recht, Scheltens-bundel, Kluwer, 1984.

J.A. Smit,

Over het verdrag van New York, het non-discriminatiebeginsel en de werkkameraftrek, Weekblad voor fiscaal recht, 1989, no 5853, blz. 93-97.

Th.D.F. Somsen,

Ein mädchen für alles?, Weekblad voor fiscaal recht, 1985, no 5672, blz. 262-263. 
H. van de Staat,

Weg met het fiscale huwelijk, Intermediair, 1990, no 25, blz. 13-17.

L.G.M. Stevens,

Belasting naar draagkracht, Kluwer, 1980.

L.G.M. Stevens,

Wetsontwerp Tweeverdieners, Weekblad voor fiscaal recht, 1983, no 5591, blz. 573-585.

L.G.M. Stevens,

Wetsontwerp Tweeverdieners II: schutterputjeswetgeving, Weekblad voor fiscaal recht, 1983, no 5612, blz. 1401-1417.

L.G.M. Stevens,

Nota Tweeverdieners derde fase, Weekblad voor fiscaal recht, 1984, no 5645, blz. 801-817.

L.G.M. Stevens,

Wetsontwerp Tweeverdieners, derde fase (nr 18 519), Weekblad voor fiscaal recht, 1984, no 5655, blz. 1225-1243.

L.G.M. Stevens,

Kritiek op kritiek, Weekblad voor fiscaal recht, 1985, no 5671, blz. 213-214.

L.G.M. Stevens,

Gezicht op eenvoud, Weekblad voor fiscaal recht, 1986, no 5733, blz. 780-787.

L.G.M. Stevens,

Solidair en solitair: de relevantie van de leefvorm voor het inkomensbeleid, rede, Kluwer, 1986.

L.G.M. Stevens,

Vereenvoudigen is niet eenvoudig, Weekblad voor fiscaal recht, 1988, no 5833, blz. 993-1015.

L.G.M. Stevens,

Eenvoudig belasten is lastig, Weekblad voor fiscaal recht, 1988, no 5844, blz. 1395-1412.

L.G.M. Stevens,

De vereenvoudiging wordt duur betaald, Weekblad voor fiscaal recht, 1989, no 5857, blz. 205-216.

L.G.M. Stevens,

Ondergang van een draagkrachtheffing in de Europese ruimte, Weekblad voor fiscaal recht, 1992, no 6026, blz. 1342-1344.

L.G.M. Stevens,

Elementair belastingrecht voor economen en bedrijfsjuristen, elfde herziene druk, Kluwer, 1993.

L.G.M. Stevens,

Verongelijkt, Column, Weekblad voor fiscaal recht, 1993, no 6082, blz. 1833-1834.

W.F.C. Stevens,

Zicht op eenvoud!, Weekblad voor fiscaal recht, 1986, no 5733, blz. 800-806.

W.F.C. Stevens,

Snel voort met Oort!, Weekblad voor fiscaal recht, 1987, no 5796, blz. 1333-1334. 
W.F.C. Stevens,

OORT-II Démasqué, Weekblad voor fiscaal recht, 1988, no 5844, blz. 1393-1394. W.F.C. Stevens,

Heeft eenvoud toekomst?, Weekblad voor fiscaal recht, 1989, no 5855, blz. 137138.

H.D. Stout,

Doelmatige en bestuurlijke belangenafweging: een speciaal terrein. In: De rechtsstaat herdacht, W.E.J. Tjeenk Willink, 1989, blz. 237-254.

F.A.M. Stroink,

De plaats van de rechter in het staatsbestel, rede, W.E.J. Tjeenk Willink, 1990.

Tarieven inkomstenbelasting voor gehuwden en ongehuwden,

Geschriften van de Vereniging voor Belastingwetenschap, Samson, 1958, no 95.

A.J. van den Tempel,

De belasting als instrument der economische politick, Samson, 1945.

A.J. van den Tempel,

Het einde van de belastingbeginselen, Weekblad voor fiscaal recht, 1979, no 5411, blz. 697-706.

J.R. Thorbecke, bewerkt door J.P. Duyvernan,

Staatsinrigting en staatsbestuur, Gouda Quint, 1968.

W. Timmer,

Belastingadviseur en de vereenvoudiging van de uitvoering, Weekblad voor fiscaal recht, 1988 , no 5827 , blz. 739-746.

A. Timmermans,

Oort en de ondernemer ofwel de caravan en de kroket, Maandblad Belastingbeschouwingen, 1990, no 10, blz. 253-256.

'Tweeverdienersmaatregel' voor gehuwden treedt 1 oktober in werking,

Weekblad voor fiscaal recht, 1983, no 5600, blz. 958-959.

Uitgangspunten voor de derde fase tweeverdieners,

Weekblad voor fiscaal recht, 1984, no 5642, blz. 698-706.

Y. Vansina,

A Schumpeterian Approach to Emancipatory Economics, Journal of Economic Studies, Vol. 18, No. 5/6 1991, page 66-76.

$P$. Verloren van Themaat,

Economie, gezien door juristen, Koninklijke Nederlandse acadamie van wetenschappen, 1988.

W.A. Verneend,

Het wordt wat stiller rond de inkomstenbelasting, Weekblad voor fiscaal recht, 1992, no 6026, blz. 1340-1341.

Verslag forumdiscussie,

Weekblad voor fiscaal recht, 1986, no 5750, blz. 1473-1482.

C.J. Visser,

Haast geboden?, Weekblad voor fiscaal recht, 1988, no 5844, blz. 1452-1456. 
I.J.F.A. Vijfeijken,

De tweeverdienersregeling, Weekblad voor fiscaal recht, 1986, no 5727, blz. 561566.

I.C. van der Vlies,

Handboek wetgeving, tweede herziene druk, W.E.J. Tjeenk Willink, 1991.

J.A.J. de Vries,

Het belastingpolitieke systeem, Elsevier, 1970.

B.W.N. de Waard,

Beginselen van burgerlijke rechtspleging, met name in het administratief procesrecht, Zwolle, 1987.

E.P.J. Wasch,

Tweeverdienersregeling: gezamenlijke huishouding commerciële relatie en enkele praktijkproblemen, Weekblad voor fiscaal recht, 1986, no 5742, blz. 1157-1168.

E. Wasch, N. Bink,

Aftrekbare kosten en vergoedingen, Kluwer belastingwijzers 7, vierde herziene druk, 1991.

P.J. Wattel,

Het ongelijkheidsbeginsel, Weekblad voor fiscaal recht, Column, 1993, no 6079,

blz. 1723-1724.

G.J. Wiarda,

Drie typen van rechtsvinding, Zwolle, 1988.

F.C. Wijle,

Belastingen en gezinseenheid, Een kritische beschouwing inzake verbanden tussen gezinsconnecties en subjectieve belastingheffing, Fiscaal-Economisch Instituut, Samson, Rotterdam, no 3, 1972.

H.B. Winter,

Wetgeving en wetsevaluatie; een siamese tweeling?, In: De rechtsstaat herdacht, W.E.J. Tjeenk Willink, 1989, blz. 223-235.

H.B. Winter, M. Scheltema, M. Herweijer,

Evaluatie van wetgeving, Kluwer, 1990.

D.J. Wolfson,

Inkomensverdeling en beheersbaarheid. In: Naar een beheersbare collectieve sector, A.G.J. Haselbekke c.s., Serie geschriften van het Fiscaal-economisch Instituut van de Erasmus Universiteit Rotterdam, 1981, blz. 189-223.

C. Zegers,

De werkelijke gedachte achter de aftrekbeperking van de gemengde kosten,

Weekblad voor fiscaal recht, 1990 , no 5898, blz. 71-74.

W.H.C. Zuidgeest,

Afscheid Hofstra, Weekblad voor fiscaal recht, 1994, no 6110, blz. 972-975.

J.W. Zwemmer,

De ongelijkheid van de rechtsstaat. In: Quod Licet Jovi, Brüll-bundel, W.E.J. Tjeenk Willink, 1983, blz. 27-30. 
J.W. Zwemmer,

Haastige spoed is zelden goed, Weekblad voor fiscaal recht, 1988, no 5844, blz. 1429-1439.

J.W. Zwemmer,

Deregulering en afslanking, Weekblad voor fiscaal recht, 1988, no 5848, blz. 1581-1582.

J.W. Zwemmer,

Toerekening van inkomen en vermogen aan gehuwden. In: Giele-bundel, Kluwer, 1990, blz. 719-735.

J.W. Zwemmer,

Haalt de inkomstenbelasting het jaar 2092?, Weekblad voor fiscaal recht, 1992, no 6026 , blz. 1333-1335.

J.W. Zwemmer,

Friesland op zijn smalst, Weekblad voor fiscaal recht, Column, 1993, no 6073, blz. 1475-1476.

J.W. Zwemmer,

De werkkamer als aftrekpost, Weekblad voor fiscaal recht, 1994, no 6113, blz. 1124-1127. 


\section{Curriculum vitae}

Marjon Weerepas werd geboren op 29 mei 1963 te Gennep. In 1981 haalde zij het VWO-diploma aan het Elzendaalcollege te Boxmeer. Van 1981 tot 1987 studeerde zij Nederlands Recht aan de Katholieke Universiteit Nijmegen. Van 1 september 1988 tot 1 maart 1993 werd zij aangesteld bij de Rijksuniversiteit Limburg als assistente in opleiding.

Sinds 1993 werkt zij als universitair docent belastingrecht bij de vakgroep Belastingrecht van de Rijksuniversiteit Limburg. 